\title{
Karol Żakowski
}

\section{WEWNĄTRZPARTYJNE UWARUNKOWANIA POLITYKI JAPOŃSKIEJ PARTII LIBERALNO-DEMOKRATYCZNEJ WOBEC CHIN W LATACH 1955-2006}

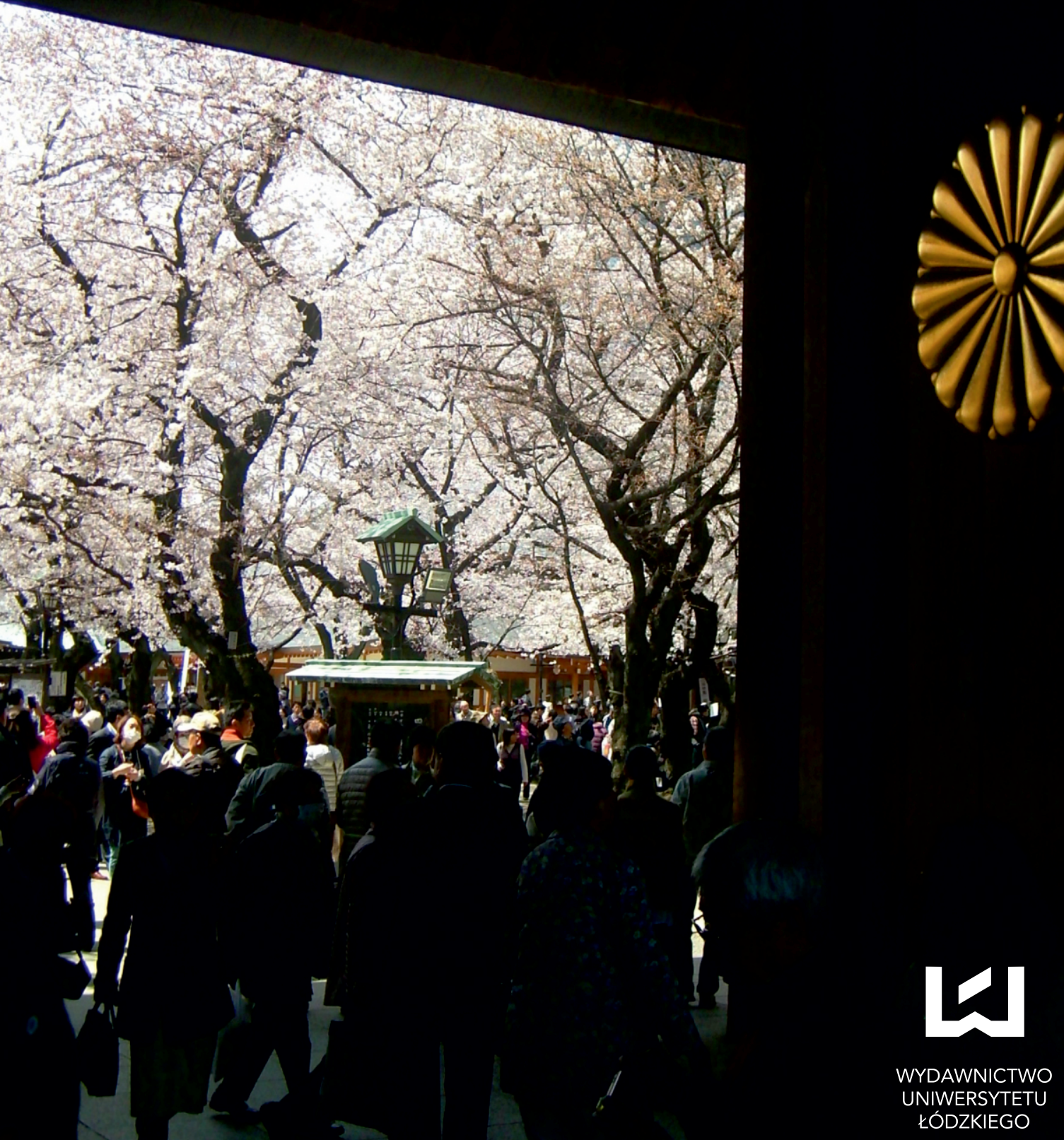




\section{Karol Żakowski}

WEWNĄTRZPARTYJNE UWARUNKOWANIA POLITYKI JAPOŃSKIEJ PARTII LIBERALNO-DEMOKRATYCZNEJ WOBEC CHIN W LATACH 1955-2006

ŁÓDZKIEGO

ŁÓDŹ 2012 
Karol Żakowski - Zakład Azji Wschodniej, Wydział Studiów Międzynarodowych i Politologicznych Uniwersytet Łódzki, 90-131 Łódź, ul. Narutowicza 59a

\title{
RECENZENT
}

Jan Rowiński

\section{OPRACOWANIE EDYTORSKIE}

Karol Żakowski

\section{PROJEKT OKŁADKI \\ Karol Żakowski}

Wydrukowano z gotowych materiałów dostarczonych do Wydawnictwa UŁ

(C) Copyright by Uniwersytet Łódzki, Łódź 2012

Wydane przez Wydawnictwo Uniwersytetu Łódzkiego

Wydanie I. 6005/2012

ISBN 978-83-7525-757-1

https://doi.org/10.18778/7525-757-1

\author{
Wydawnictwo Uniwersytetu Łódzkiego \\ 90-131 Łódź, ul. Lindleya 8 \\ www.wydawnictwo.uni.lodz.pl \\ e-mail: ksiegarnia@uni.lodz.pl \\ tel. (42) 66558 63, faks (42) 6655862
}


Najbliższym 



\section{SPIS TREŚCI}

WSTĘP 9

\section{ROZDZIAL I}

PARTIA LIBERALNO-DEMOKRATYCZNA I PODZIALY WŚRÓD JEJ CZLONKÓW 23

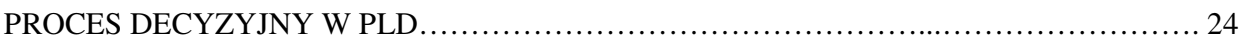

Organy władzy ustawodawczej i wykonawczej w Japonii................................ 24

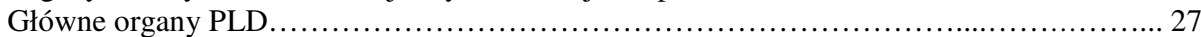

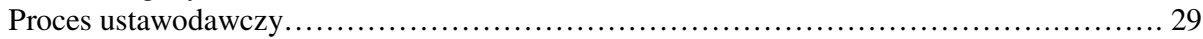

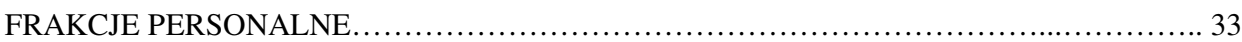

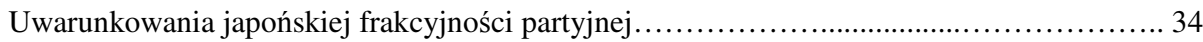

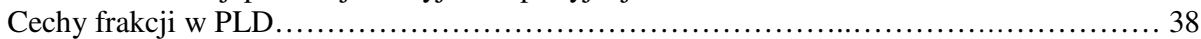

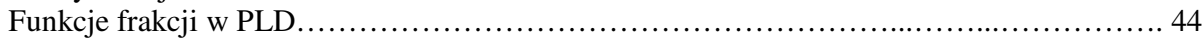

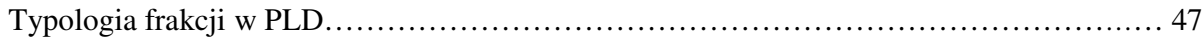

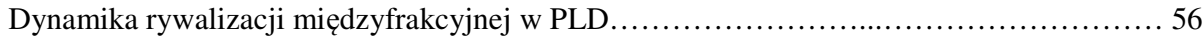

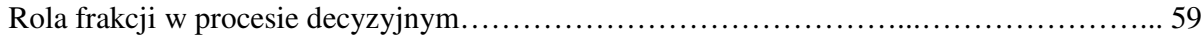

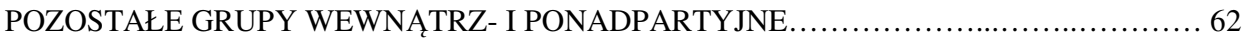

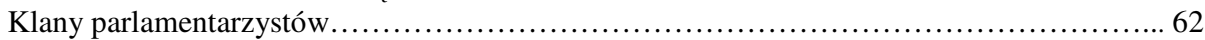

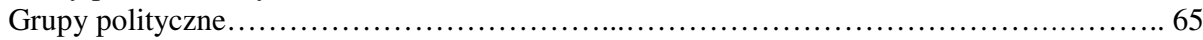

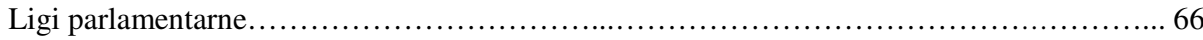

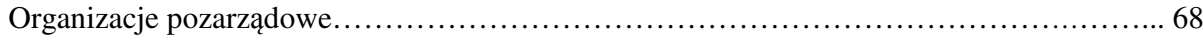

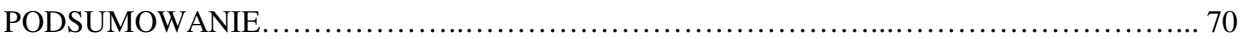

ROZDZIAŁ II

SPÓR PIERWSZEGO POKOLENIA PRZYWÓDCÓW FRAKCJI O POLITYKĘ WOBEC CHIN

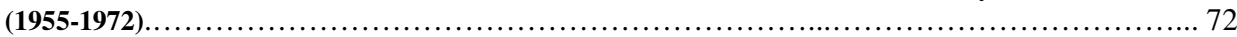

HATOYAMA ICHIRŌ I ISHIBASHI TANZAN (1955-1957) …............................. 76

Rządy Hatoyamy Ichirō i jego wizja stosunków z Chinami................................. 76

Stracona okazja do zbliżenia z ChRL za rządów Ishibashiego Tanzana...................... 82

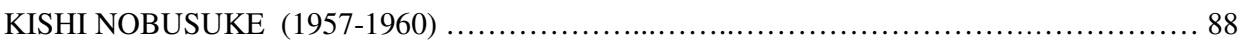

„Główny nurt” Kishiego Nobusuke i źródła jego protajwańskości.......................... 88

Ku zamrożeniu kontaktów z ChRL ................................................. 91

Ku nowemu sojuszowi ze Stanami Zjednoczonymi................................... 97

IKEDA HAYATO (1960-1964) ........................................................ 103

Hamowane odprężenie w stosunkach japońsko-chińskich.................................. 103

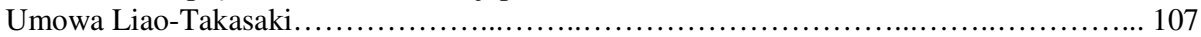

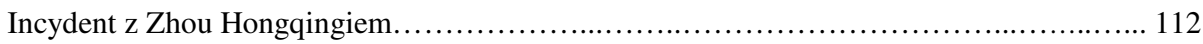

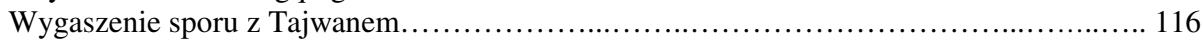

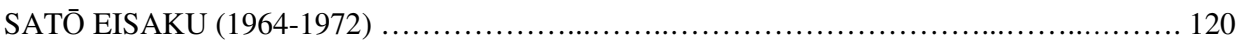

Umiarkowana protajwańskość ,głównego nurtu” Satō Eisaku................................ 121 
Powrót do „logiki zimnej wojny" ...................................................... 126

Kulminacja napięcia w relacjach z ChRL.............................................. 129

„Szok Nixona” i spóźnione próby zbliżenia z ChRL..................................... 135

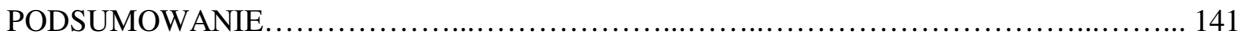

\section{ROZDZIAŁ III}

SPRAWA CHIŃSKA NA TLE „WOJNY KAKU-FUKU” (1972-1980)......................... 143

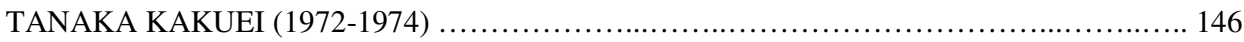

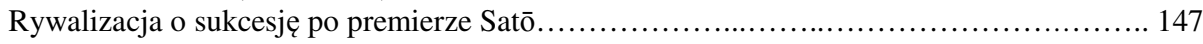

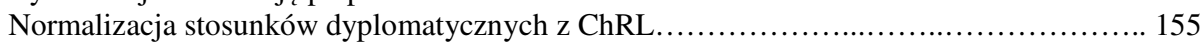

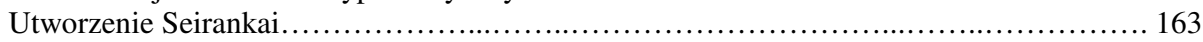

Opór obozu protajwańskiego wobec umowy lotniczej z ChRL.............................. 166

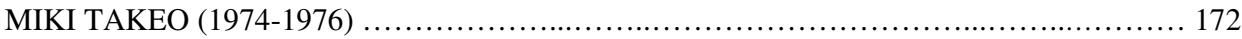

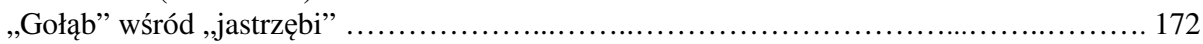

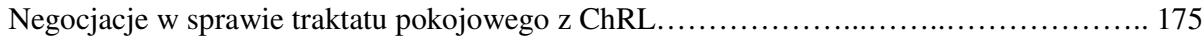

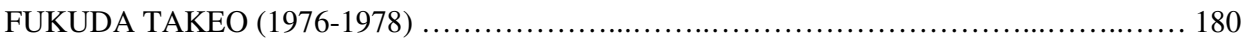

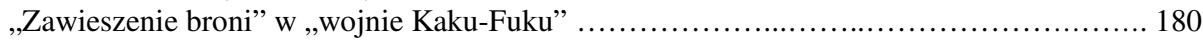

Droga do zawarcia Traktatu o pokoju i przyjaźni z ChRL .............................. 182

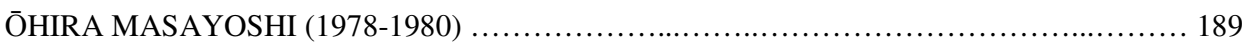

Wznowienie wojny „Kaku-Fuku” .................................................... 190

Sprawa chińska na tle „starcia czterdziestodniowego” i „,wyborów happeningowych”....... 193

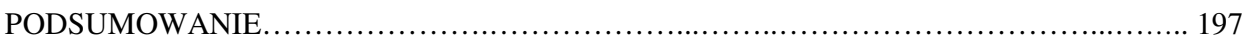

\section{ROZDZIAL IV \\ POLITYKA PLD WOBEC CHIN W OKRESIE „OGÓLNEGO GLÓWNEGO NURTU”}

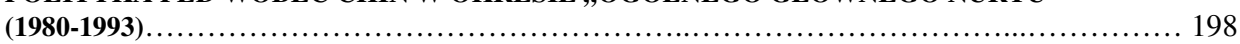

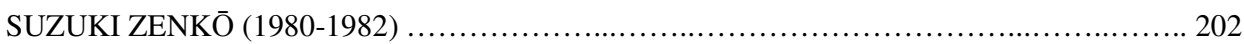

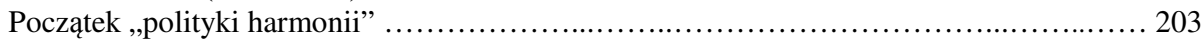

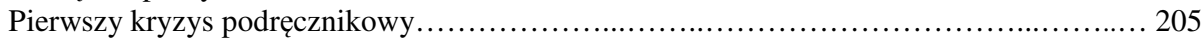

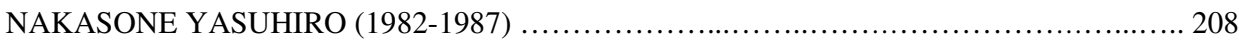

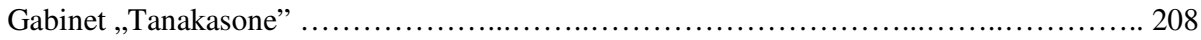

Problem wizyty w świątyni Yasukuni i drugi kryzys podręcznikowy $\ldots \ldots \ldots \ldots \ldots \ldots \ldots \ldots \ldots . \ldots \ldots 212$

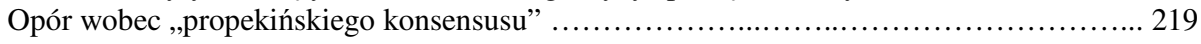

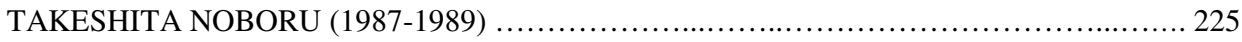

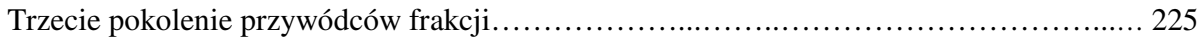

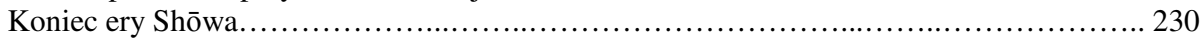

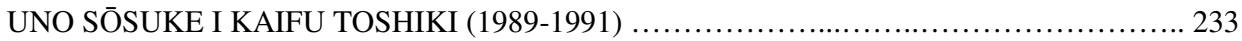

„Główny nurt” Uno Sōsuke i reakcja Japonii na masakrę na placu Tiananmen................ 233

„Główny nurt” Kaifu Toshikiego i problem zniesienia sankcji wobec ChRL................ 236

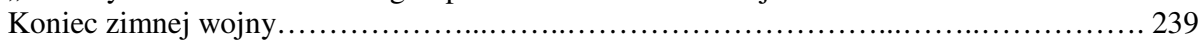




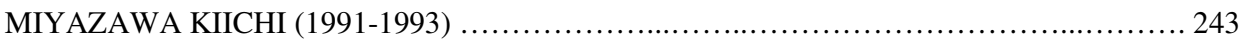

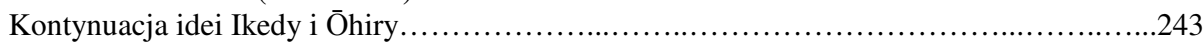

Problem „kobiet pocieszycielek” i wizyta pary cesarskiej w ChRL .......................... 246

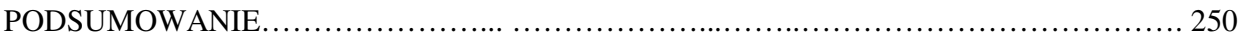

ROZDZIAŁ V

STOSUNKI JAPOŃSKO-CHIŃSKIE W DOBIE DEREGULACJI SYSTEMU FRAKCYJNEGO W

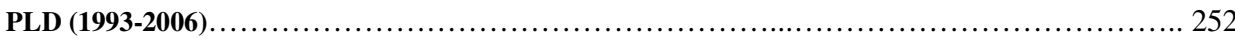

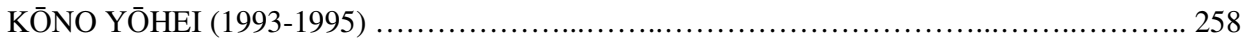

Postawa polityczna Kōno Yōheia i reforma wewnątrzpartyjna.............................. 258

Problem wizyty Li Denghuia i przeprosin za zbrodnie wojenne .......................... 261

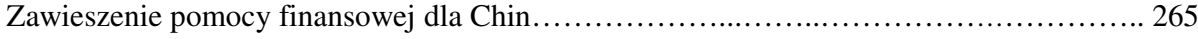

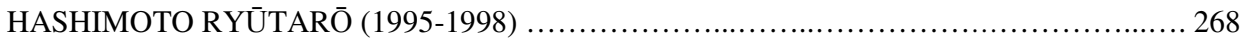

Nastawienie Hashimoto Ryūtarō wobec Chin i historii Japonii............................ 268

Dalsza eskalacja napięcia w relacjach japońsko-chińskich............................... 270

Kwestia nowych wytycznych sojuszu japońsko-amerykańskiego.......................... 276

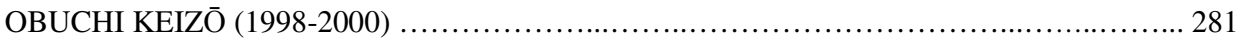

Wewnątrzpartyjne uwarunkowania polityki Obuchiego Keizō wobec Chin.................. 281

20. rocznica podpisania Traktatu o pokoju i przyjaźni z ChRL ........................... 283

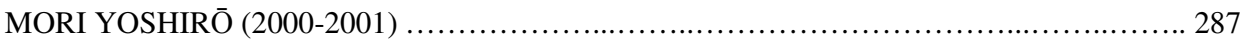

Mori Yoshirō i jego postawa wobec Chin................................................ 287

Problem wizyty Li Denghuia i chińskich statków badawczych.............................. 290

„Bunt Katō” i dalsze osłabienie obozu propekińskiego..................................... 292

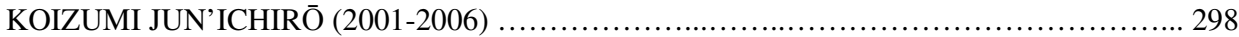

Poglądy polityczne Koizumiego Jun'ichirō i plany reformy strukturalnej................... 298

Stosunki japońsko-chińskie w cieniu wizyt w świątyni Yasukuni.............................. 303

Kryzys 2005 roku i zakończenie pomocy rozwojowej dla Chin............................ 310

Obóz protajwański i propekiński za kadencji Koizumiego............................... 315

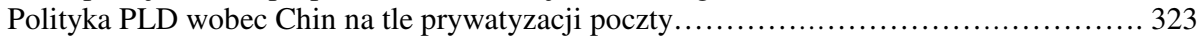

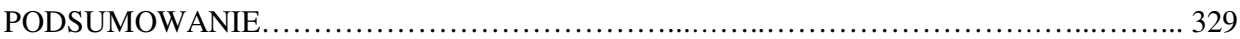



Ideologiczne, osobowościowe i personalne uwarunkowania polityki PLD wobec Chin....... 331

Sprawa chińska jako narzędzie rywalizacji wewnątrzpartyjnej............................. 341

Wpływ ewolucji systemu wewnątrzpartyjnego na politykę PLD wobec Chin................ 345

Model kształtowania stanowiska PLD wobec Chin ................................... 351

INDEKS WYBRANYCH POLITYKÓW PLD ..................................... 355

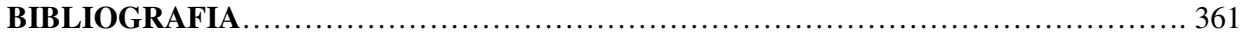

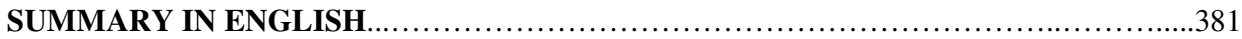





\section{WSTĘP}

Stosunki pomiędzy Japonią a Chinami były jednymi z najważniejszych relacji bilateralnych wpływających na kształt systemu międzynarodowego w regionie Azji Wschodniej. W 1952 roku Japonia oficjalnie uznała rząd Republiki Chińskiej na Tajwanie, utrzymując jedynie pozarządowe kontakty z Chińską Republiką Ludową. Relacje z władzami w Tajpej lub Pekinie, podobnie jak spory na temat kształtu polityki wobec Stanów Zjednoczonych czy Związku Radzieckiego, stały się przedmiotem zażartej debaty na japońskiej scenie politycznej. W 1972 roku rząd w Tokio dokonał normalizacji stosunków dyplomatycznych z Chinami komunistycznymi. W ten sposób zlikwidowano główną przeszkodę $\mathrm{w}$ kontaktach japońsko-chińskich, jednak od lat 80. XX wieku nasiliły się problemy związane $\mathrm{z}$ pamięcią o japońskich zbrodniach popełnionych na narodzie chińskim w czasie II wojny światowej. Zarówno fakt istnienia dwóch rządów pretendujących do reprezentowania całych Chin, jak i problemy historyczne, sprawiały, że polityka wobec Chin budziła duże kontrowersje pośród parlamentarzystów japońskiego obozu konserwatywnego, skupionego w ramach Partii Liberalno-Demokratycznej.

\section{Cel badań i struktura pracy}

Badania podjęte $\mathrm{w}$ niniejszej pracy koncentrują się na analizie wewnątrzpartyjnych uwarunkowań polityki Partii Liberalno-Demokratycznej wobec Chin w latach 1955-2006. W okresie powojennym Partia Liberalno-Demokratyczna (PLD) niemal nieprzerwanie rządziła Japonią, więc decyzje przez nią podejmowane prawie automatycznie stawały się oficjalną polityką rządu w Tokio ${ }^{1}$. Z kolei stosunki z Chinami, jako relacje z potężnym krajem sąsiednim, zawsze zajmowały szczególne miejsce $\mathrm{w}$ japońskiej dyplomacji. Cezurą początkową pracy jest moment powstania PLD w 1955 roku, granicę końcową zaś wyznacza kadencja Koizumiego Jun'ichirō (2001-2006), ostatniego premiera z czwartego pokolenia liderów PLD. Autor nie bada polityki wobec Chin piątego pokolenia przywódców PLD, ponieważ ich rządy zaczęły się niedawno i nie stanowią jeszcze zamkniętego okresu. Długi, ponad 50-letni, zakres czasowy pracy wynika $\mathrm{z}$ jednego $\mathrm{z}$ głównych celów badawczych, jakim jest prześledzenie ewolucji uwarunkowań polityki PLD wobec Chin w czterech okresach.

Termin „sprawa chińska” w znaczeniu użytym w książce oznacza całokształt problemów związanych ze stosunkami Japonii z Chinami, które stały się kwestią sporną wewnątrz PLD. W szczególności dotyczy kwestii istnienia dwóch

\footnotetext{
${ }^{1} \mathrm{~W}$ okresie omawianym w pracy PLD utraciła władzę jedynie na niecały rok na przełomie $1993 \mathrm{i}$ 1994 roku. Zmiana władzy w wyniku wyborów z sierpnia 2009 roku nie mieści się w chronologicznych ramach książki.
} 
rządów, podających się za prawowitych reprezentantów państwa chińskiego. Chociaż wojnę domową wygrała w 1949 roku strona komunistyczna, nie była w stanie objąć kontroli nad całością terytorium $\mathrm{Chin}^{2}$. Reżim Guomindangu (Partii Narodowej) z Jiang Jieshim (Czang Kaj-szekiem) na czele utrzymał władzę na Tajwanie i okolicznych wysepkach ${ }^{3}$. Pod koniec lat 70. XX wieku ChRL rozpoczęła reformy zmierzające do przyjęcia systemu wolnorynkowego, zaś na przełomie lat 80 . i 90. XX wieku na Tajwanie został wprowadzony ustrój demokratyczny. W przypadku braku dodatkowych określeń termin „Tajwan” w znaczeniu użytym przez autora wskazuje na Republikę Chińską (na Tajwanie), zaś termin „Chiny” na Chińską Republikę Ludową ${ }^{4}$.

Podstawowym celem niniejszej pracy jest zbadanie, w jaki sposób czynniki wewnątrzpartyjne wpływały w omawianym okresie na formułowanie przez PLD polityki wobec Chin. Należy jednak zwrócić uwagę, iż także czynniki zewnętrzne (zwłaszcza dyplomacja USA oraz sytuacja w ChRL i na Tajwanie) powodowały ewolucję uwarunkowań wewnątrzpartyjnych i w ograniczonym zakresie również one muszą stać się przedmiotem analizy. Z drugiej strony, celem badań nie są same polityczne czy gospodarcze stosunki między Japonią a Chinami, tylko sytuacja panująca w PLD i jej wpływ na politykę wobec Chin. Główne tezy pracy są następujące:

1. Uwarunkowania ideologiczne i osobowościowe oraz powiązania personalne członków PLD były jednym z czynników wpływających na kształt polityki partii wobec Chin, jak też na stan stosunków japońsko-chińskich.

2. Sprawa chińska stanowiła jeden $\mathrm{z}$ instrumentów rywalizacji politycznej wewnątrz PLD.

3. Sposób formułowania polityki wobec Chin ewoluował wraz ze zmianami systemu wewnątrzpartyjnego oraz międzynarodowego otoczenia Japonii.

Jak widać, pierwsze dwie tezy wzajemnie się uzupełniają. $\mathrm{Z}$ jednej strony poglądy, osobowości i powiązania personalne pierwszoplanowych działaczy

\footnotetext{
${ }^{2}$ Komunistyczna Partia Chin (Zhongguo Gongchandang) powstała w 1921 roku. W latach 19241927 utworzyła wspólny front z Guomindangiem w wojnie o zjednoczenie Chin, który został zerwany przez Jiang Jieshiego. W latach 30 . i 40. XX wieku organizowała partyzantkę przeciw japońskim najeźdźcom. W 1949 roku KPCh z Mao Zedongiem na czele proklamowała powstanie Chińskiej Republiki Ludowej. Szerzej na ten temat: Edward Kajdański, Chiny - Leksykon, Książka i Wiedza, Warszawa 2005, s., 113-114.

${ }^{3}$ Guomindang (Kuomintang) została założona w 1912 roku. Po śmierci Sun Wena (Sun Zhongshana, Sun Yat-sena) w 1925 roku przywództwo w partii przejął Jiang Jieshi, który ustanowił w Chinach rządy autorytarne. W 1937 roku Guomindang utworzyła drugi wspólny front $\mathrm{z}$ komunistami w celu przeciwstawienia się inwazji japońskiej. Wojna domowa $\mathrm{z}$ KPCh rozpoczęła się ponownie w 1946 roku, doprowadzając do ucieczki wojsk Jiang Jieshiego na Tajwan w 1949 roku. Szerzej na ten temat: ibidem, s. 124-125.

${ }^{4}$ Jest to jedynie uproszczenie językowe, które nie implikuje sympatii politycznych autora. W przypadku terminu nikka (chiń. Ri-Hua) użyte jest tłumaczenie japońsko-tajwański. Chociaż znak $k a$ (chiń. hua) ma ogólniejsze znaczenie i odnosi się do całości świata chińskiego, w japońskim nazewnictwie przyjęło się jego stosowanie w odniesieniu do Republiki Chińskiej na Tajwanie.
} 
PLD odgrywały pewną rolę w kształtowaniu polityki wobec Chin, z drugiej zaś trudno jest powiedzieć, by stanowiły główny czynnik w tym procesie. Interes polityczny, czyli chęć dojścia i utrzymania się u władzy, a także racja stanu, często wymagały osiągania kompromisów wewnątrz partii i adaptacji do zmieniającej się sytuacji. W tym ujęciu sprawa chińska była traktowana zarówno podmiotowo, jak i przedmiotowo.

Teza trzecia służy spojrzeniu na historię wewnątrzpartyjnych uwarunkowań polityki PLD wobec Chin w sposób całościowy. Zarówno otoczenie międzynarodowe Japonii, jak i struktura wewnętrzna partii rządzącej tym krajem, podlegały ciągłej ewolucji. Wszystkie te przemiany wywierały także niemały wpływ na sposób formułowania przez partię polityki wobec Chin. Poglądy parlamentarzystów, choćby były wyraźnie sprecyzowane, często ulegały modyfikacji w wyniku ewolucji sytuacji międzynarodowej lub zmiany systemu wewnątrzpartyjnego. Zależnie od elastyczności ideologicznej ${ }^{5}$, jednym politykom przychodziło to łatwiej, drugim zaś trudniej. W ten sposób uwarunkowania ideologiczne były trwale sprzężone z czynnikami zewnętrznymi. Nawet jeśli bodziec do zmiany polityki PLD wobec Chin pochodził z otoczenia międzynarodowego, przekładał się na konkretne działanie dopiero po „przefiltrowaniu” przez wewnątrzpartyjne procesy decyzyjne i mechanizmy rywalizacji międzyfrakcyjnej.

Praca jest podzielona na pięć rozdziałów. W pierwszym rozdziale wprowadzony został aparat pojęciowy i szczegóły metodologii zastosowanej w dalszej części pracy. Nacisk położono zwłaszcza na opis procesu decyzyjnego w PLD oraz analizę zjawiska frakcyjności w tej partii. W następnych czterech rozdziałach przeprowadzono analizę wewnątrzpartyjnych uwarunkowań polityki PLD wobec Chin w kolejnych okresach. Periodyzacji dokonano biorąc pod uwage momenty kluczowe z punktu widzenia walki o władzę w partii (uformowanie się dwóch „osi władzy”, „ogólnego głównego nurtu” oraz proces osłabienia frakcyjności), które niemal pokrywały się $\mathrm{z}$ wydarzeniami przełomowymi dla stosunków chińsko-japońskich. Na początku każdego z czterech rozdziałów zawarta jest krótka charakterystyka sytuacji międzynarodowej i wewnątrzpartyjnej $\mathrm{w}$ opisywanych latach. Podrozdziały zostały wydzielone zgodnie $\mathrm{z}$ kadencjami kolejnych przewodniczących PLD. Jest to związane $\mathrm{z}$ faktem, że przyjęta metoda badawcza polega przede wszystkim na analizie ewolucji polityki partii wobec Chin w związku ze zmianą władzy pomiędzy „głównymi

\footnotetext{
${ }^{5}$ Przez „elastyczność ideologiczną” autor rozumie łatwość podejmowania decyzji niezależnie od własnych przekonań, także $\mathrm{w}$ wyniku braku wyraźnie określonego stanowiska w kwestiach ideologicznych. Jest to cecha niemierzalna za pomocą danych ilościowych, ale większość czołowych japońskich polityków można scharakteryzować pod względem elastyczności ideologicznej za pomocą analizy danych jakościowych, np. pamiętników, wywiadów i książek programowych.
} 
nurtami”, które zazwyczaj formowały się przy okazji wyborów na stanowisko przewodniczącego PLD.

W podsumowaniu przedstawione zostały wnioski $\mathrm{z}$ całości badań, uporządkowane według trzech tez przyjętych we wstępie pracy. Na samym końcu sformułowano uproszczony model kształtowania stanowiska PLD wobec Chin. Dla ułatwienia lektury do pracy dołączony został indeks wybranych polityków japońskich, zawierający krótkie opisy powiązań rodzinnych, przynależności frakcyjnej oraz istotniejszych urzędów państwowych i partyjnych sprawowanych przez poszczególnych parlamentarzystów (także w okresie wykraczającym poza czasowe ramy pracy, czyli po 2006 roku).

\section{Teorie, metody i techniki badawcze}

$\mathrm{Na}$ gruncie teorii stosunków międzynarodowych kwestia wpływu czynników wewnątrzpaństwowych na dyplomację kraju traktowana jest różnorodnie. W niniejszej pracy autor nawiązuje do trzech popularnych nurtów: liberalizmu, realizmu/neorealizmu oraz konstruktywizmu. Ponieważ każda teoria kładzie nacisk na inne aspekty rzeczywistości, dopiero odniesienie się do kilku z nich umożliwia w miarę pełną interpretację wewnątrzpartyjnych uwarunkowań polityki PLD wobec Chin. Chociaż autorowi bliska jest liberalna i w pewnym stopniu konstruktywistyczna wizja stosunków międzynarodowych, nie odrzuca także teorii realistycznej. Jeśli rzeczywistość międzynarodową traktować w dużym uproszczeniu, realizm trafnie charakteryzuje prawa rządzące polityką zagraniczną.

W skład teorii liberalizmu wchodzi wiele nurtów, ale ich wspólną cechą jest podkreślanie wpływu czynników wewnątrzpaństwowych na dyplomację. Według Josepha Nye'a tradycyjny podział na politykę wewnętrzną i zagraniczną staje się coraz mniej wyraźny ${ }^{6}$. Jak podkreśla Andrew Moravcsik: „Według liberałów społeczeństwo składa się z pojedynczych aktorów ludzkich o niezależnych interesach i tożsamościach, którzy dążą do zawiązania prywatnych grup, organizacji i porozumień, aby promować swoje cele społeczne i polityczne. Porządek społeczny i polityczny wynika z sumy interakcji takich jednostek, często działających nieświadomie"7. Inaczej mówiąc, w ujęciu liberalnym: „Wszystkie państwa są stanowione przez społeczeństwo obywatelskie, zaś ich polityka odzwierciedla interesy jednej lub większej ilości grup społeczeństwa krajowego. Preferencje państw są więc preferencjami dominujących grup wewnętrznych. Wobec tego polityka zagraniczna nie może po prostu automatycznie wynikać z zewnętrznych oszacowań co do pozycji i równowagi sił $\mathrm{w}$ systemie. Nawet ograniczenia i zagrożenia $\mathrm{z}$ zewnątrz są

\footnotetext{
${ }^{6}$ Joseph Nye, Independence and Interdependence, ,Foreign Policy” 1976, no. 22, s. 137-148.

${ }^{7}$ Andrew Moravcsik, Liberalism and International Relations Theory, Center for International Affairs, Harvard University, Working Paper, no. 92-6, s. 7; dostępne na stronie internetowej: http://www.princeton.edu/ amoravcs/library/liberalism_working.pdf, uzyskane 16 XI 2009.
} 
postrzegane i filtrowane przez wewnętrzne procesy polityczne oraz struktury, które w istotny sposób kształtują efekty polityki"».

Jak widać, przedstawiciele liberalnej wizji stosunków międzynarodowych wiele miejsca poświęcają badaniom poglądów politycznych, ideologii czy powiązań personalnych poszczególnych decydentów lub grup interesu, mających wpływ na dyplomację danego kraju. Niektórzy posuwają się nawet do analizy cech charakteru czy osobowości przywódców państw, by dowieść ich znaczenia $\mathrm{w}$ procesie decyzyjnym ${ }^{9}$. Państwo jest postrzegane jako skomplikowana zbiorowość określonych jednostek, grup interesu i obozów ideologicznych, zaś polityka zagraniczna jako wypadkowa nieustannej rywalizacji między nimi. Stanowisko bliskie tej wizji zajmuje m.in. Iwanaga Kenkichirō. Zwraca on uwagę na wpływ irracjonalnych czynników na podejmowanie decyzji w sferze polityki zagranicznej, jak np. ambicja jednostki czy inne „niskie pobudki" kierujące mężami stanu ${ }^{10}$.

Na drugim biegunie znajdują się zwolennicy teorii realizmu, którzy przedkładają analizę interesu politycznego oraz racji stanu nad przekonania polityków rządzących krajem. W ujęciu realistycznym państwo jest monolitem, a nie złożoną zbiorowością jednostek i grup interesu. Hans J. Morgenthau podkreślał, że polityka zagraniczna poszczególnych krajów pozostaje racjonalna i niezależna „od rozmaitych motywów, preferencji oraz intelektualnych bądź moralnych zalet kolejnych mężów stanu. Realistyczna teoria stosunków międzynarodowych pozwoli uniknąć dwóch najczęstszych błędów: zbytniego zaaferowania motywami oraz preferencjami ideologicznymi. Szukanie klucza do polityki zagranicznej wyłącznie w motywach mężów stanu jest równie daremne, jak zwodnicze. Daremne, ponieważ motywy to najbardziej złudne dane psychologiczne, nierzadko radykalnie zniekształcone przez interesy i emocje zarówno aktorów, jak i obserwatorów. Czy naprawdę znamy własne motywy? Co wiemy o motywach innych ludzi?"'11. Według Morgenthau'a, przy analizie stosunków międzynarodowych należy abstrahować od takich irracjonalnych czynników, jak „filozoficzne lub polityczne sympatie mężów stanu” i skupić się na badaniu uwarunkowań obiektywnych, czyli ,interesu zdefiniowanego w kategoriach potęgi”. Co prawda politycy mogą prezentować swoje przedsięwzięcia jako

\footnotetext{
${ }^{8}$ Martha Finnemore, National Interests in International Society, Cornell University Press, Ithaca London 1996, s. 143-144.

${ }^{9}$ Stephen Benedict Dyson, Thomas Preston, Individual Characteristics of Political Leaders and the Use of Analogy in Foreign Policy Decision Making, „Political Psychology” 2006, vol. 27, no. 2 , s. 265-284.

${ }^{10}$ Iwanaga Kenkichirō, Sengo Nihon no seitō to gaikō, Tōkyō Daigaku Shuppankai, Tokio 1985, s. 6.

${ }^{11}$ Hans J. Morgenthau, Polityka między narodami. Walka o potęgę i pokój, Difin, Warszawa 2010, s. 21.
} 
wynikające $\mathrm{z}$ własnych przekonań politycznych, ale tak naprawdę jest to tylko środek do zdobycia poparcia społecznego ${ }^{12}$.

Neorealizm rozwinął myśl realizmu politycznego. Kładzie się w nim nacisk na bezosobową „strukturę systemu międzynarodowego”, która niezależnie od uwarunkowań wewnętrznych wymusza na poszczególnych państwach określone zachowania. Kenneth N. Waltz podzielał zdanie Morgenthau'a, że teoria stosunków międzynarodowych powinna być daleko idącym uproszczeniem rzeczywistości, ale przeniósł zainteresowanie badawcze z elementów składowych systemu międzynarodowego, czyli suwerennych państw, na samą strukturę systemu. Według Waltza: „Struktura międzynarodowa bierze się z interakcji państw, a potem powstrzymuje je od podejmowania pewnych działań, jednocześnie skłaniając je ku innym" ${ }^{13}$. Podobnie jak w realizmie klasycznym, w neorealizmie nie ma miejsca na analizę poglądów politycznych czy ideologii wyznawanych przez poszczególnych decydentów w polityce zagranicznej. Waltz był zdania, iż: „Rozważania na temat siły dominują nad rozważaniami na temat ideologii. W teorii strukturalnej państwa mają różną pozycję pod względem siły, zaś różnice w pozycjonowaniu pozwalają wyjaśnić zarówno ich zachowanie, jak i ich losy" "14. Ponieważ system międzynarodowy charakteryzuje się anarchicznością, czyli brakiem władzy naczelnej, zachowaniem poszczególnych krajów musi kierować swoisty egoizm. Dążąc do zwiększenia swojej siły i bezpieczeństwa, państwa mają bardzo ograniczoną liczbę możliwych wyborów. Jak widać, w ujęciu realistycznym i neorealistycznym wewnątrzpartyjne czy nawet wewnątrzpaństwowe uwarunkowania nie są na tyle istotne, by w ogóle brać je pod uwagę przy analizie polityki zagranicznej danego kraju.

Trzecia z przywołanych teorii stosunków międzynarodowych, konstruktywizm, kładzie nacisk na badanie wpływu na politykę zagraniczną norm, kultur, tożsamości oraz ról pełnionych przez dany kraj na arenie międzynarodowej. Podobnie jak liberałowie, konstruktywiści postrzegają ,państwa jako osadzone

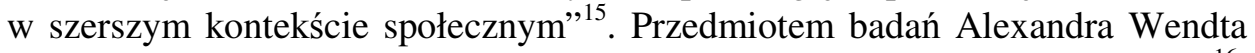
jest ,intersubiektywnie tworzona struktura tożsamości i interesów w systemie"16. Poprzez wzajemną interakcję państwa tworzą pojęcia ,,jaźni” i „innego”. W tym ujęciu mogą pełnić rolę wroga, rywala lub przyjaciela w zależności od poziomu zaufania, jakim siebie darzą. Jak podkreśla Wendt: „Jako samospełniająca się przepowiednia kultura przejawia naturalne tendencje homeostatyczne, a są one tym silniejsze, im jest ona głębiej zinternalizowana przez aktorów. (...) W toku

\footnotetext{
${ }^{12}$ Ibidem, s. 21-22.

${ }^{13}$ Kenneth N. Waltz, Realist Thought and Neorealist Theory, „Journal of International Affairs” 1990, vol. 44, no. 1, s. 29.

${ }^{14}$ Ibidem, s. 31.

${ }^{15}$ Martha Finnemore, op.cit., s. 144.

${ }^{16}$ Alexander Wendt, Anarchy is what States Make of it: The Social Construction of Power Politics, „International Organization” 1992, vol. 46, no. 2, s. 401.
} 
interakcji państwa nie tylko próbują dostać to, czego pragną, ale próbują podtrzymać pojęcia «jaźni» i «innego», które są źródłem tych pragnień. Agenci sami są nieustającymi efektami interakcji, są zarówno przyczynowo uwarunkowani, jak i stanowieni przez nią" ${ }^{17}$. Według Wendta państwa mogą zmienić swoją tożsamość, ale jest to powolny proces. Niemniej jednak: „Nawet jeśli na początku były egoistyczne powody, proces współpracy skłania do redefinicji tych powodów poprzez ponowne formułowanie tożsamości i interesów zgodnie z nowymi intersubiektywnymi rozumieniami i zobowiązaniami"18.

Podejście konstruktywistów do wewnątrzpaństwowych uwarunkowań polityki zagranicznej jest różnorodne. O ile Peter Katzenstein poświęca im dużo uwagi, Martha Finnemore skupia się raczej na analizie norm na poziomie społeczności międzynarodowej ${ }^{19}$. Co ciekawe, Katzenstein wybrał za obiekt badań Japonię. Według niego sytuacja wewnętrzna, jak też przeszłość geopolityczna, wywarły duży wpływ na powstanie norm społecznych w tym kraju. Normami można nazwać „,fakty społeczne, których efekty w kształtowaniu polityki są potencjalnie tak samo ważne, jak surowa siła czy racjonalna kalkulacja. Normy zazwyczaj informują, jak aktorzy polityczni definiują to, co chcą osiągnąć. Normy pomagają koordynować konflikty polityczne (normy regulatywne), jak też kształtują polityczne spory o tożsamość (normy konstytutywne). Lekceważenie norm i uważanie interesów aktorów za dane jest więc pomijaniem ważnego aspektu polityki oraz polityki bezpieczeństwa narodowego" ${ }^{20}$. Jak twierdzi Katzenstein: „Międzynarodowa równowaga sił i czynniki sytuacyjne definiujące koszty względne miały mniejsze znaczenie dla japońskiej polityki bezpieczeństwa niż wewnętrzne walki polityczne i kontestowane normy"21. Jak widać, w podejściu do wewnątrzpaństwowych uwarunkowań polityki zagranicznej Katzenstein jest bliższy wizji liberalnej niż realistycznej. Uzupełnia ją jednak o rolę tożsamości społecznej pod postacią norm, które stanowią istotne tło dla rywalizacji pomiędzy przeciwstawnymi obozami ideologicznymi. W ujęciu konstruktywistycznym kluczowym problemem staje się stwierdzenie, czy określone idee, interakcje lub praktyki zostały już na tyle zinternalizowane przez ogół społeczeństwa lub przynajmniej przez elity polityczne, by można je było nazwać „,normami” w rozumieniu Katzensteina, bądź też by uformowały nową „tożsamość” czy „rolę” w interpretacji Wendta.

Autor przyjął metodę analizy wewnątrzpartyjnych uwarunkowań polityki PLD wobec Chin poprzez zbadanie składu kolejnych „głównych nurtów” oraz

17 Idem, Społeczna teoria stosunków międzynarodowych, Wydawnictwo Naukowe Scholar, Warszawa 2008, s. 290-291.

${ }^{18}$ Idem, Anarchy is..., s. 417.

19 John M. Hobson, The State and International Relations, Cambridge University Press, Cambridge 2000, s. 154- 166.

${ }^{20}$ Peter J. Katzenstein, Cultural Norms and National Security. Police and Military in Postwar Japan, Cornell University Press, Ithaca - London 1998, s. ix-x.

${ }^{21}$ Ibidem, s. 197. 
ewolucji systemu wewnątrzpartyjnego. Systemem można nazwać „uporządkowany wewnętrznie w całość układ elementów mających określoną strukturę"22. Pojęcie systemu wewnątrzpartyjnego (frakcyjnego) w znaczeniu użytym w pracy odnosi się do zasady uporządkowania podstawowych elementów składowych PLD, którymi przynajmniej do 1993 roku były frakcje personalne. Ponieważ przyjętej metody badawczej nie da się opisać bez uprzedniego wprowadzenia podstawowych informacji na temat procesu decyzyjnego i frakcyjności w tym ugrupowaniu, jej szczegóły zostały przedstawione w pierwszym rozdziale. Metodę tę zastosowano do opisu sytuacji wewnątrzpartyjnej w trzech pierwszych okresach (lata 1955-1993). W piątym rozdziale, przy badaniu czwartego okresu (lata 1993-2006), analiza poprzez „główne nurty" straciła walory badawcze ze względu na osłabienie frakcyjności w PLD. Do opisu sytuacji w latach 90. XX wieku i na początku XXI wieku posłużyło natomiast zbadanie skutków wzrostu popularności poglądów nacjonalistycznych wśród polityków PLD oraz wpływu deregulacji systemu frakcyjnego w partii na jej politykę wobec Chin.

Przy analizie składu „głównych nurtów” dużą rolę odegrały dane ilościowe, gdyż mierzona była wielkość poszczególnych obozów ideologicznych w ramach wewnątrzpartyjnych koalicji. Z kolei w ostatnim z rozdziałów nacisk został położony niemal wyłącznie na dane jakościowe, zwłaszcza na analizę nastawienia wobec Chin kolejnych przewodniczących PLD. W dysertacji zastosowano elementy takich powszechnie spotykanych metod badawczych, jak analiza systemowa (ukazanie relacji pomiędzy frakcjami jako elementami systemu wewnątrzpartyjnego, opis konfliktowych oddziaływań „głównego” i „przeciwnego nurtu” oraz ich wpływu na politykę PLD wobec Chin), metoda decyzyjna (analiza formalnych i nieformalnych mechanizmów funkcjonowania PLD oraz ich wpływu na podejmowanie decyzji w sprawie chińskiej) czy metoda historyczna ${ }^{23}$.

Przy badaniu składu „głównych nurtów” w PLD ważną rolę odgrywa przedstawiona $\mathrm{w}$ pierwszym rozdziale typologia frakcji, zwłaszcza podział członków PLD na obóz propekiński i protajwański oraz na ,jastrzębi” i „gołębi”. „Typologia może być zdefiniowana jako konceptualne ramy, w których zjawiska są klasyfikowane pod względem cech wspólnych z innymi zjawiskami" ${ }^{24}$. Typy idealne istnieją jedynie jako punkty odniesienia dla obserwowanych zjawisk, zaś ,żaden typ nie jest dokładną reprodukcją wszystkich cech zjawiska" ${ }^{\text {,25 }}$. W tym świetle typologię należy traktować jako daleko idące uproszczenie opisywanej

22 Andrzej Jan Chodubski, Wstęp do badań politologicznych, Wydawnictwo Uniwersytetu Gdańskiego, Gdańsk 2006, s., s. 119.

${ }^{23}$ Ibidem, s. 119-131.

${ }^{24}$ Johann Mouton, HC Marais, Basic Concepts in the Methodology of Social Sciences, HSRC Publishers, Pretoria 1996, s. 137.

${ }^{25}$ Ibidem. 
rzeczywistości. Także przyporządkowanie poszczególnych polityków i frakcji PLD do danych obozów ideologicznych zostało dokonane w celu bardziej przejrzystego ukazania niezwykle skomplikowanej sytuacji panującej $\mathrm{w}$ partii. W trakcie wywiadów z japońskimi parlamentarzystami autor odniósł wrażenie, że żaden polityk nie lubi być jednoznacznie „szufladkowany” jako członek konkretnego stronnictwa. Niemniej jednak poprzez analizę danych jakościowych (poglądy zapisane w pamiętnikach i książkach programowych, członkostwo w organizacjach, konkretne działania w polityce wewnętrznej i zagranicznej) możliwe jest przypisanie większości kluczowych polityków do poszczególnych obozów ideologicznych.

Na podstawie przeprowadzonych badań sformułowany został model kształtowania stanowiska PLD wobec Chin. Modelem można nazwać „bardziej precyzyjną i schematyczną [od teorii - przyp. aut.] prezentację relacji pomiędzy dwoma lub większą ilością elementów"26. O ile typologia jest jedynie „statycznym obrazem" badanej rzeczywistości, o tyle model stanowi próbę przedstawienia dynamiki analizowanego zjawiska. W tym celu pomija się najmniej istotne elementy, wyolbrzymiając znaczenie tych czynników i relacji, które na podstawie badań zostały uznane za najważniejsze dla przedstawienia konkretnego procesu ${ }^{27}$. Także model zaproponowany przez autora stanowi celowe zniekształcenie rzeczywistości w celu zwrócenia uwagi na elementy kluczowe dla zrozumienia wewnątrzpartyjnych uwarunkowań polityki PLD wobec Chin.

Najważniejszą techniką badawczą zastosowaną w pracy była analiza treści źródeł pierwotnych i wtórnych, przeprowadzona m.in. w Archiwum Dyplomatycznym Ministerstwa Spraw Zagranicznych w Tokio oraz w Internecie. Oprócz prac japońskojęzycznych autor odwołuje się do publikacji w języku chińskim, koreańskim oraz językach europejskich. Ważny element badań stanowiły wywiady naukowe i rozmowy z japońskimi politologami, politykami oraz ich sekretarzami, przeprowadzone $\mathrm{w}$ trakcie stażów autora na Wydziale Prawa Uniwersytetu Kwansei Gakuin w Nishinomiyi (IX 2008 - III 2009), jak też w Izbie Reprezentantów Parlamentu Japonii i siedzibie PLD w Tokio (III 2009). Ze względu na stosunkowo małą jeszcze ilość wyczerpujących analiz naukowych czy pamiętników dotyczących kadencji ostatnich premierów, wywiady były bardzo ważne szczególnie w przypadku opisu sytuacji wewnątrzpartyjnej w czwartym z omawianych okresów (1993-2006). Wywiady z politykami, zapisane na nośniku fonograficznym, miały charakter ustny, indywidualny oraz nieautoryzowany. W doborze respondentów autor położył nacisk na aspekt jakościowy, a nie ilościowy - znalazły się wśród nich najważniejsze postacie obozu propekińskiego (Kōno Yōhei, Katō Kōichi) oraz

\footnotetext{
${ }^{26}$ Erik Stavnsager Rasmussen, Per Østergaard, Suzanne C. Beckmann, Essentials of Social Science Research Methodology, University Press of Southern Denmark, Odense 2006, s. 49.

${ }^{27}$ Johann Mouton, HC Marais , op.cit., s. 140-141.
} 
protajwańskiego (Hiranuma Takeo). W przypadku wywiadów, zwłaszcza z politykami, zawsze istnieje ryzyko daleko posuniętego subiektywizmu respondentów, których wypowiedzi czasami trudno poddać dogłębnej krytyce. Niemniej jednak rozmowy z parlamentarzystami PLD były cennym źródłem opinii na temat sytuacji panującej w tym ugrupowaniu oraz jego polityki wobec Chin.

Należy pamiętać, że każda teoria, typologia czy model upraszczają i zniekształcają rzeczywistość, dążąc do prostoty i przejrzystości. Nie inaczej jest z niniejszą pracą. Ponieważ celem książki jest ukazanie wewnątrzpartyjnych uwarunkowań polityki PLD wobec Chin, wszystkie inne czynniki siłą rzeczy zeszły w niej na dalszy plan. Nie oznacza to jednak, by były mniej ważne czy drugoplanowe. Wręcz przeciwnie, bez uwzględnienia chociażby ewolucji otoczenia międzynarodowego Japonii nie sposób zrozumieć zmian, jakie zachodziły w polityce PLD wobec Chin.

\section{Dotychczasowy stan badań i opis literatury}

Zarówno problematyka rywalizacji politycznej wewnątrz PLD, jak i stosunków japońsko-chińskich, doczekała się olbrzymiej literatury, w szczególności japońskojęzycznej. Jak do tej pory brak było jednak wyczerpującej monografii, która by połączyła te dwa tematy. Nieliczne publikacje, które są bezpośrednio związane $\mathrm{z}$ problematyką rozprawy, albo dotyczą bardziej ograniczonego zakresu czasowego, albo ujmują problematykę uwarunkowań japońskiej polityki wobec Chin z perspektywy szerszej niż wewnątrzpartyjna. Autor nie spotkał się natomiast z publikacją, która ukazywałaby proces formułowania polityki PLD wobec Chin na tle rywalizacji międzyfrakcyjnej w ramach partii od lat 50. XX wieku po początek XXI wieku. Pod tym względem niniejsza praca może stanowić istotne uzupełnienie dotychczasowych badań.

Bardzo ważną rolę $w$ rozprawie odgrywają pamiętniki oraz książki programowe japońskich polityków. Autor w szczególności próbował dotrzeć do wszystkich publikacji napisanych przez liderów frakcji oraz przewodniczących PLD. Jest to ściśle związane z przyjętą metodą badawczą, w której nacisk został położony na analizę osobistych przekonań i uwarunkowań personalnych głównych twórców polityki partyjnej, a także ich ewolucji pod wpływem czynników wewnątrz- i pozapartyjnych. Na szczęście większość premierów i liderów frakcji pozostawiła po sobie bogatą literaturę (np. sześciotomowe dzienniki Satō Eisaku czy czterotomowe pamiętniki Yoshidy Shigeru). Spośród szefów rządu wyczerpujących pamiętników nie pozostawili po sobie przede wszystkim ci, którzy zmarli przedwcześnie (Ikeda Hayato, Ōhira Masayoshi, Obuchi Keizō), zostali oskarżeni o korupcję (Tanaka Kakuei, Hashimoto Ryūtarō), rządzili bardzo krótko (Uno Sōsuke), bądź jeszcze nie zdążyli ich napisać (Koizumi Jun'ichirō). Nawet oni jednak zazwyczaj wydali przynajmniej jedną książkę zawierającą swój program polityczny. Oczywiście w przypadku pamiętników z założenia należy się liczyć z subiektywizmem autorów, jakże 
często widocznym w przypadku różnych opisów i ocen tego samego wydarzenia przez reprezentantów przeciwstawnych obozów politycznych. Celem pracy jest właśnie ukazanie tych różnic zdań i zbadanie ich wpływu na formułowanie polityki PLD wobec Chin. Oprócz pamiętników polityków, w pracy wykorzystane zostały książki zawierające wspomnienia tłumaczy, biurokratów, sekretarzy oraz członków rodzin parlamentarzystów. Istotnym źródłem informacji na temat nastawienia poszczególnych polityków wobec Chin są również dokumenty z Archiwum Dyplomatycznego Ministerstwa Spraw Zagranicznych w Tokio oraz zapisy obrad Parlamentu Japonii dostępne na stronie internetowej Biblioteki Parlamentarnej w Tokio.

Z naturalnych względów tematyką japońskiej sceny politycznej i samej PLD zajmowali się przede wszystkim sami Japończycy. Pośród prac naukowych na szczególną uwagę zasługują monografie Fukuia Haruhiro (Jiȳ Minshutō to seisaku kettei, Fukumura Shuppan, Tokio 1969), Iyasu Tadashiego (Seitō habatsu no shakaigaku. Taishū minshusei no nihonteki tenkai, Sekai Shisōsha, Kioto 1983), Kitaoki Shin'ichiego, (Jimintō - Seikentō no 38 nen, Chūō Kōron Shinsha, Tokio 2008), Murakawy Ichirō (Seisaku kettei katei, Shinzansha, Tokio 2000), Ishikawy Masumiego i Hirose Michisady (Jimintō - Chōki shihai no kōzō, Iwanami Shoten, Tokio 1989) czy Satō Seizaburō i Matsuzakiego Tetsuhisy (Jimintō seiken, Chūō Kōronsha, Tokio 1986). Znacznie mniej liczne są książki na temat japońskiej polityki publikowane poza Japonią, przede wszystkim w Azji, Stanach Zjednoczonych i Europie. Zwykle dotyczą tylko ogólnych procesów rządzących sprawowaniem władzy w tym kraju lub formułowaniem polityki zagranicznej. Spośród ważniejszych prac należy wspomnieć o publikacjach Wang Zhensuo (Zhanhou Riben zhengdang zhengzhi, Renmin Chubanshe, Pekin 2001), Geralda Curtisa (The Japanese Way of Politics, Columbia University Press, New York 1988; The Logic of Japanese Politics. Leaders, Institutions, and the Limits of Change, Columbia University Press, New York 1999), Michaela Jonathana Greena (Japan's Reluctant Realism. Foreign Policy Challenges in an Era of Uncertain Power, Palgrave Macmillian, New York 2003) czy Tomohito Shinody (Leading Japan. The Role of the Prime Minister, Praeger Publishers, Westport 2000).

Cenne źródło opisów relacji panujących pomiędzy politykami PLD stanowią także książki reporterów politycznych. Japońska scena polityczna jest bardzo przejrzysta, zaś dziennikarze stosunkowo łatwo uzyskują informacje dotyczące zakulisowych spotkań, potajemnych rozmów czy stosunków interpersonalnych panujących pomiędzy parlamentarzystami. Warte uwagi są szczególnie książki reporterów specjalizujących się w problematyce danej frakcji w PLD bądź nawet w działalności określonego wpływowego polityka (tzw. bankisha). Dziennikarze tacy są co prawda ograniczeni w swoich działaniach pewnymi więzami lojalności z opisywanymi grupami lub jednostkami, jednak mając z nimi stały kontakt potrafią uzyskać cenne informacje niedostępne dla osób z zewnątrz. Nie 
sposób nie wymienić takich komentatorów, jak były sekretarz premiera Ikedy Hayato, Itō Masaya, czy były sekretarz premiera Tanaki Kakueia, Hayasaka Shigezō. Pozostali dziennikarze polityczni często przywoływani w pracy to m.in. Eguchi Nobuyuki, Honzawa Jirō, Inoue Yoshihisa, Iseri Hirofumi, Itagaki Eiken, Kikuchi Hisashi, Tsuchiya Shigeru, Tominomori Eiji oraz Uchida Kenzō. Oprócz książek publicystycznych w pracy wykorzystano artykuły prasowe, zwłaszcza z takich popularnych dzienników, jak „Asahi Shinbun” i „Yomiuri Shinbun".

Również problematyka stosunków japońsko-chińskich była przedmiotem badań licznych azjatyckich, amerykańskich i europejskich uczonych. Warto wspomnieć o monografiach Tanaki Akihiko (Nitchū kankei 1945-1990, Tōkyō Daigaku Shuppankai, Tokio 1996), Shimady Masao i Tian Jianonga (Sengo nitchū kankei 50 nen - Nitchū sōhō no kadai wa hatasaretaka, Tōhō Shoten, Tokio 1997), Caroline Rose (Sino-Japanese Relations. Facing The Past. Looking to The Future?, Routledge Curzon, London - New York 2005), Mōri Kazuko (Nitchū kankei: Sengo kara shinjidai e, Iwanami Shoten, Tokio 2006), Tamury Shigenobu, Tomashimy Norio i Koedy Yoshito (Nikka dankō to nitchū kokkō seijōka, Nansōsha, Tokio 2000), Soeyi Yoshihide (Japan's Economic Diplomacy with China, 1945-1978, Clarendon Press, Oxford 1998) czy pracach zbiorczych pod red. Jin Xide (21 shiji de Zhong-Ri guanxi, Chongqing Chubanshe, Chongqing 2007) i Xu Zhixiana (Zhong-Ri guanxi 30 nian 19722002, Shishi Chubanshe, Pekin 2002). Spośród polskich publikacji można wymienić m.in. monografię Roberta Jakimowicza (Stosunki japońsko-chińskie w latach 1949-2002. Aspekty polityczne i gospodarcze, Wydawnictwo Akademii Ekonomicznej w Krakowie, Kraków 2004) oraz prace Jana Rowińskiego (Morze Wschodniochińskie: region potencjalnego konfliktu $w$ Azji, PISM, Warszawa 1990; Problem wysp Senkaku (Tiaoyi Liedao) w stosunkach chińsko-japońskich, PISM, Warszawa 1982). Wśród książek poświęconych tematyce relacji japońsko-tajwańskich na szczególną uwagę zasługuje monografia Lin Jinjinga (Ume to sakura - Sengo no nikka kankei, Sankei Shuppan, Tokio - Osaka 1984). Jej autor był przedstawicielem Republiki Chińskiej w Japonii, więc w sferze komentarzy praca nie jest obiektywna, jednak pod względem faktograficznym stanowi wyczerpujące źródło informacji na temat kontaktów pomiędzy rządem w Tokio a reżimem Guomindangu od zakończenia II wojny światowej po lata 80. XX wieku. Należy także wspomnieć o obszernej publikacji wydanej przez Zaidan Hōjin Kazankai (Nitchū kankei kihon shiryōshū 1949 nen - 1997 nen, Zaidan Hōjin Kazankai, Tokio 1998), która zawiera niemal kompletny zbiór najważniejszych dokumentów dotyczących relacji japońsko-chińskich po II wojnie światowej.

Do monografii, które są najbardziej bezpośrednio związane z problematyką poruszaną w niniejszej dysertacji można zaliczyć prace Zhao Quanshenga (Nitchū kankei to Nihon no seiji, Iwanami Shoten, Tokio 1999, tłumaczenie na 
język japoński książki Japanese Policymaking: The Politics Behind Politics. Informal Mechanisms and the Making of China Policy, Oxford University Press/Praeger, New York - Hong Kong 1993), Huang Dahuia (Riben dui-Hua zhengce yu guonei zhengzhi-Zhong-Ri fujiao zhengzhi guocheng fenxi, Dangdai Shijie Chubanshe, Pekin 2006) oraz Honzawy Jirō (Taiwan robī, Dētahausu, Tokio 1998). Zhao Quansheng opisuje, w jaki sposób charakterystyczne dla Japonii mechanizmy sprawowania władzy wpływały na politykę tego kraju wobec Chin. Książka stanowi doskonałe kompendium wiedzy na temat nieformalnych procesów decyzyjnych w PLD, ale jest tylko zbiorem czterech studiów przypadku, a nie przeglądową interpretacją wewnątrzpartyjnych uwarunkowań polityki tego ugrupowania wobec Chin. Z kolei Huang Dahui bardzo dogłębnie analizuje czynniki wpływające na politykę Japonii wobec Chin, w tym sytuację w PLD, jednakże przedmiotem jego badań jest jedynie proces normalizacji japońsko-chińskich stosunków dyplomatycznych w 1972 roku. Ostatni z trzech autorów, Honzawa Jirō, opisuje skład i ewolucję tajwańskiego lobby w PLD. Jak podkreśla, jego publikacja jest pierwszą pracą poświęconą w całości temu zagadnieniu. Chociaż książka wiele wnosi do badań podjętych $\mathrm{w}$ niniejszej rozprawie, została napisana ze $\mathrm{z}$ góry przyjętą tezą o szkodliwości działań posłów protajwańskich i nie spełnia wymogów naukowego obiektywizmu (Honzawa Jirō jest komentatorem politycznym o skrajnie pacyfistycznych i wyraźnie propekińskich przekonaniach). Żaden z wyżej wymienionych autorów nie stosuje też metodyki przyjętej w niniejszej pracy, czyli badania polityki PLD wobec Chin poprzez analizę składu „głównych nurtów" w partii.

\section{Uwagi techniczne}

Do zapisu nazw własnych i terminów japońskich w pracy została zastosowana transkrypcja Jamesa Curtisa Hepburna, bez zamiany zgłoskotwórczego „n” na „m” przed spółgłoskami „,b”, „,p”, „,m”. Z kolei do transkrypcji nazw własnych i terminów chińskich użyty został obowiązujący w ChRL system pinyin, z pominięciem zapisu tonów. W pracy jest on stosowany konsekwentnie również do transkrypcji nazwisk i imion Tajwańczyków. Do zapisu terminów koreańskich użyto latynizacji poprawionej, obowiązującej w Korei Południowej. Wyjątkiem od stosowania powyższych transkrypcji są niektóre słowa, które już zadomowiły się w języku polskim, jak Tokio, Kioto, Nagoja, gejsza, Pekin, Tajpej itp. Oprócz nazwisk, imion, nazw geograficznych oraz nazw organizacji i instytucji wyrazy obcego pochodzenia pisane są kursywą.

Wschodnioazjatyckie nazwiska i imiona podane są w kolejności stosowanej w Japonii, Chinach czy Korei, czyli nazwisko poprzedza imię. Wyjątkiem są nazwiska autorów prac w językach europejskich, w przypadku których został pozostawiony zapis użyty $\mathrm{w}$ danej publikacji. Autor odmienia nazwiska i imiona 
Azjatów przez przypadki zgodnie z zasadami języka polskiego ${ }^{28}$. Niektóre nazwy własne, których pisownia w formie oryginalnej przyjęła się w językach europejskich (np. Nihon Izokukai, Kōmeitō, Seirankai), zostały przetłumaczone na język polski, jeśli to w ogóle możliwe, tylko za pierwszym razem w nawiasie. Tytuły publikacji japońskich i chińskich $\mathrm{w}$ przypisach podane są jedynie $\mathrm{w}$ transkrypcji. Dopiero w bibliografii pojawiają się razem z tłumaczeniem. Dla ułatwienia lektury, tylko najczęściej używane złożone nazwy własne podane są w wersji skróconej (PLD: Partia Liberalno-Demokratyczna, ChRL: Chińska Republika Ludowa, KPCh: Komunistyczna Partia Chin).

\section{Podziękowania}

Niniejsza książka jest uzupełnioną i zmodyfikowaną wersją pracy doktorskiej obronionej w 2010 roku na Wydziale Studiów Międzynarodowych i Politologicznych Uniwersytetu Łódzkiego. Autor pragnie podziękować promotor pracy Profesor Małgorzacie Pietrasiak oraz pozostałym członkom Zakładu Azji Wschodniej za inspirujące dyskusje na temat badań podjętych w niniejszej dysertacji. Wyrazy wdzięczności należą się recenzentom: Profesorowi Janowi Rowińskiemu oraz Profesorowi Andrzejowi Sepkowskiemu za bezcenne uwagi i wskazówki dotyczące modyfikacji niezbędnych przed publikacją. Dziękuję również kadrze naukowej uniwersytetów Kwansei Gakuin i Kansai Daigaku za rady na temat metodologii badań i całokształtu przyjętych założeń badawczych, udzielone w trakcie wykładów gościnnych na tych uczelniach. Szczególną wdzięczność odczuwam wobec posła PLD Kōno Tarō i jego sekretarzy za nieocenioną pomoc $\mathrm{w}$ badaniach podczas stażu w Parlamencie Japonii. Specjalne podziękowania należą się mojej Rodzinie za udzielone mi wsparcie i motywację do pracy.

\footnotetext{
${ }^{28}$ Odmieniane są zarówno imiona, jak i nazwiska japońskie, z wyjątkiem tych kończących się na „e”, „o” oraz „,u”. Ze względu na jednosylabową budowę nie są odmieniane nazwiska chińskie, chyba że występują bez imienia (np. „Z Jiang Jieshim” lub „Z Jiangiem”). Szerzej na temat odmiany nazwisk i imion obcego pochodzenia: Jan Grzenia, Stownik nazw własnych, Wydawnictwo Naukowe PWN, Warszawa 2002, s. 60-72.
} 


\section{Rozdział I}

\section{PARTIA LIBERALNO-DEMOKRATYCZNA I PODZIALY WŚRÓD JEJ CZŁONKÓW}

W celu analizy ewolucji wewnątrzpartyjnych uwarunkowań polityki PLD wobec Chin należy najpierw przedstawić proces decyzyjny w ramach partii oraz strukturę organizacyjną badanego ugrupowania. Ponieważ w latach 1955-2006 PLD niemal nieprzerwanie sprawowała władzę w Japonii, reguły i nieformalne zwyczaje wewnątrzpartyjne nierozerwalnie sprzęgły się z procesem decyzyjnym na poziomie oficjalnych instytucji państwowych, w tym tych odpowiedzialnych za kreowanie japońskiej polityki zagranicznej.

PLD powstała w listopadzie 1955 roku z połączenia dwóch dużych ugrupowań: Japońskiej Partii Demokratycznej i Partii Liberalnej. Po raz pierwszy w historii Japonii wszyscy wpływowi politycy konserwatywni stali się wówczas członkami jednej partii. Ponieważ w tym samym roku zjednoczeniu uległo także lewe i prawe skrzydło Japońskiej Partii Socjalistycznej (Nihon Shakaitō), w japońskiej politologii używa się terminu ,system 1955 roku” (1955 nen taisei) na określenie sytuacji politycznej w latach 1955-1993/1994. System ten charakteryzował się bardzo stabilnym poparciem społecznym dla dwóch głównych ugrupowań. Przez 38 lat PLD bezwzględnie dominowała na japońskiej scenie politycznej, uzyskując $w$ kolejnych wyborach ponad połowę mandatów w Izbie Reprezentantów ${ }^{1}$. Tylko raz, w latach 1983-1986, zawarła koalicję z inną partią, Nowym Klubem Liberalnym². Japońska Partia Socjalistyczna była skazana na rolę „wiecznej opozycji”, uzyskując co najwyżej jedną trzecią mandatów w izbie niższej ${ }^{3}$. Za datę końca „systemu 1955 roku” uznaje się rok 1993, gdy PLD została odsunięta od władzy przez koalicję Japońskiej

\footnotetext{
${ }^{1} \mathrm{~W}$ latach 70. XX wieku liczba mandatów uzyskanych przez PLD spadła poniżej 50 proc., ale ugrupowanie zdołało utrzymać władzę, rekrutując do swoich szeregów posłów bezpartyjnych. Szerzej na ten temat: Nagatachō kenbunroku pod red. Watanabe Tsuneo, Tōyō Keizai Shinpōsha, Tokio 1980, s. 24-26; Muramatsu Michio, Itō Mitsutoshi, Tsujinaka Yutaka, Nihon no seiji, Yūhikaku, Tokio 1999, s. 80-154.

${ }^{2}$ Ze względu na bardzo małe rozmiary Nowego Klubu Liberalnego (kilku parlamentarzystów), nie wywarł on zauważalnego wpływu na rządy.

${ }^{3}$ Skostnienie systemu partyjnego wynikało z wielu czynników, m.in. z charakteru japońskiej ordynacji wyborczej, frakcyjności w PLD, podziałów ideologicznych w okresie zimnowojennym czy wsparcia finansowego, udzielanego PLD przez przedsiębiorców. Szerzej na ten temat: Ishikawa Masumi, Hirose Michisada, Jimintō - Chōki shihai no kōzō, Iwanami Shoten, Tokio 1989, s. 3-203; Kong Uisik, Ilbon hyeondae jeongchi-ui ihae, Sejong Chulpansa, Busan 2003 , s. $127-155$.
} 
Partii Socjalistycznej z mniejszymi ugrupowaniami, bądź rok 1994, gdy socjaliści zawarli umowę koalicyjną z PLD. W latach 1994-2006 PLD utrzymała status największego ugrupowania w parlamencie, ale była zmuszona do dzielenia się władzą z innymi partiami.

W PLD da się zauważyć liczne rodzaje grup zrzeszających jej członków. Były one także w mniejszym lub większym stopniu związane $\mathrm{z}$ kształtowaniem polityki partii wobec Chin. Są to zarówno tzw. klany (zoku) polityków, specjalizujących się w określonej dziedzinie ustawodawstwa, jak i grupy polityczne, oparte na wspólnie podzielanych poglądach. Pewne znaczenie miały także niektóre platformy ponad- czy pozapartyjne, których członkami byli m.in. parlamentarzyści PLD. Spełniały one funkcję mobilizacji poparcia dla określonych idei wśród opozycji lub całego społeczeństwa, stając się tym samym jednym z narzędzi wewnątrzpartyjnej rywalizacji politycznej. Niemniej jednak najważniejszą linią podziału w ramach PLD był tradycyjnie podział na frakcje personalne. To właśnie te grupy najbardziej kojarzyło się $\mathrm{z}$ walką o władzę w partii, zaś wszystkie inne rodzaje zrzeszeń pozostawały w dużym stopniu podrzędne $\mathrm{w}$ stosunku do frakcyjności. Wpływ frakcji na proces decyzyjny jest sprawą budzącą wiele kontrowersji, ale nie da się zaprzeczyć, że ramy rywalizacji pomiędzy tymi grupami determinowały personalny skład rządu i głównych organów partyjnych. Z tego powodu analiza kolejnych „głównych nurtów”, czyli wewnątrzpartyjnych koalicji, pod kątem tworzących je frakcji stała się podstawą metody badawczej przyjętej w niniejszej pracy.

\section{PROCES DECYZYJNY W PLD}

Ponieważ przez kilkadziesiąt lat rządów PLD proces decyzyjny w ramach tej partii prawie nierozerwalnie zlał się $\mathrm{z}$ zasadami funkcjonowania oficjalnych organów państwowych, stał się niemal tożsamy z procesem ustawodawczym. Co więcej, parlament został tu zepchnięty do drugorzędnej roli „maszynki do głosowania" ustaw, których treść była tak naprawdę ustalana na poziomie partyjnym. Najważniejszą rolę w procesie decyzyjnym odgrywał przewodniczący partii, który na dodatek niemal zawsze pełnił funkcję premiera Japonii. Łączenie tych dwóch stanowisk dawało liderom PLD olbrzymią władzę. Z drugiej strony, nie należy nie doceniać nieoficjalnych ograniczeń, jakie napotykali przewodniczący tego ugrupowania, jeśli chcieli siłą narzucać partii niepopularne decyzje.

\section{Organy władzy ustawodawczej i wykonawczej w Japonii}

Japonia jest monarchią konstytucyjną o systemie demokracji parlamentarnej (gikaisei minshushugi). Cesarz (tennō) spełnia jedynie funkcje reprezentacyjne i rytualne, takie jak przyjmowanie listów uwierzytelniających od ambasadorów, podpisywanie dokumentów ratyfikacyjnych czy przyznawanie odznaczeń. Zgodnie z artykułem 1 Konstytucji Japonii jest tylko „symbolem jedności 
narodu japońskiego" (Nihon kokumin tōgō no shōchō) ${ }^{4}$ i nie ma żadnego wpływu na proces decyzyjny. Jakiekolwiek działania cesarza wymagają „rady i aprobaty rządu",.

Parlament Japonii (Nihon Kokkai) jest jedynym organem ustawodawczym państwa. Posiada dwie izby, których członkowie wybierani są w wyborach powszechnych. Izba wyższa (Izba Radców, Sangiin) zrzesza około 250 osób (obecnie 242, liczba ta zmieniała się w czasie), z których połowa jest wybierana co 3 lata na sześcioletnią kadencję. Większą rolę odgrywa izba niższa (Izba Reprezentantów, Shūgiin), zrzeszająca obecnie 480 posłów wybieranych na czteroletnią kadencję. W przypadku odrzucenia ustawy przez Izbę Radców, Izba Reprezentantów może ją przegłosować większością dwóch trzecich głosów. W razie braku zgody pomiędzy obiema izbami w sprawie budżetu, decyzja Izby Reprezentantów jest uważana za decyzję całego parlamentu ${ }^{6}$. W obu izbach funkcjonują komisje odpowiedzialne za poszczególne dziedziny ustawodawstwa. Decyzje są w nich podejmowane zwykłą większością głosów ${ }^{7}$.

Premier Japonii jest wybierany przez parlament. W przypadku rozbieżnego wyboru w izbie wyższej i niższej przeważa decyzja Izby Reprezentantów. Premier dysponuje bardzo rozległymi uprawnieniami. Sprawuje nadzór nad wszystkimi gałęziami administracji państwowej. Japońska konstytucja daje prezesom Rady Ministrów prawo do swobodnego powoływania i odwoływania ministrów $^{8}$, jak też rozwiązywania izby niższej ${ }^{9}$. Jako reprezentant gabinetu premier składa do parlamentu ustawy oraz raporty na temat ogólnych spraw państwowych i stosunków międzynarodowych ${ }^{10}$. Jest również wodzem naczelnym Sił Samoobrony ${ }^{11}$.

W skład rządu wchodzi kilkunastu ministrów (maksymalnie 20). Ważną rolę odgrywa też sekretarz gabinetu (naikaku kanbōchōkan), wspomagający premiera w jego obowiązkach. Ze względu na tradycję częstych, corocznych rekonstrukcji rządu, ministrowie rzadko pełnili swoją funkcję przez dłuższy okres. $\mathrm{Z}$ tego powodu zwykle nie mieli dość czasu, by zdobyć doświadczenie w kierowaniu

\footnotetext{
${ }^{4}$ Nihonkoku Kenpō o yomu, Kashiwa Shobō, Tokio 1996, s. 13.

${ }^{5}$ Krzysztof Karolczak, System konstytucyjny Japonii, Wydawnictwo Sejmowe, Warszawa 1999, s. 19.

${ }^{6}$ Nihonkoku Kenpō..., s. 54.

${ }^{7}$ Krzysztof Karolczak, op.cit., s. 31.

${ }^{8}$ Mimo to w czasie rządów PLD wykształcił się zwyczaj, że premier nie dymisjonuje swoich ministrów, aby pozwolić im na „zachowanie twarzy”. W razie konieczności ministrowie są zmuszani do podania się do dymisji. Szerzej na ten temat: Tomohito Shinoda, Leading Japan. The Role of the Prime Minister, Praeger Publishers, Westport 2000, s. 61-62.

${ }^{9}$ Prawo premiera do rozwiązania Izby Reprezentantów nie jest sformułowane explicite w konstytucji, ale wywiedziono je z treści artykułów 69 i 7. Wszystkie Izby Reprezentantów oprócz tej z lat 1972-1976 zostały rozwiązane przed upływem kadencji. Szerzej na ten temat: ibidem, s. 63-71.

${ }^{10}$ Nihonkoku Kenpō..., s. 63.

${ }^{11}$ Tomohito Shinoda, op.cit., s. 57.
} 
resortem, co pogłębiało ich zależność od biurokratów. Japońskie ministerstwa cechował silny sekcjonalizm. Urzędnicy słynęli z przedkładania interesów własnego resortu nad rację stanu, zaś brak koordynacji i zaciekła konkurencja pomiędzy poszczególnymi ministerstwami były charakterystycznymi cechami japońskiego rządu ${ }^{12}$. Wyraźniejsze zmiany nastąpiły dopiero niedawno, po utworzeniu w 2001 roku Biura Gabinetu (Naikakufu), mającego koordynować działania wszystkich ministerstw ${ }^{13}$. Wzmocniono wówczas władzę prezesa Rady Ministrów, co wykorzystał premier Koizumi Jun'ichirō (2001-2006) do narzucania swojej woli partii w stopniu niespotykanym wcześniej ${ }^{14}$.

W przypadku polityki rządu Japonii wobec Chin należy odróżnić rutynowe decyzje małej wagi od decyzji o charakterze przełomowym. Decyzje rutynowe podejmowane były oddolnie przez biurokratów z Wydziału Chin Ministerstwa Spraw Zagranicznych (Gaimushō Chūgokuka) i zatwierdzane oraz modyfikowane przez kolejne wyższe organy: Departament Azji (Ajiakyoku), wiceministra, ministra spraw zagranicznych i premiera. Sprawa wyglądała zupełnie inaczej w przypadku najważniejszych decyzji, ustalających kierunek japońskiej dyplomacji. Wówczas inicjatywa wychodziła od partii rządzącej ${ }^{15}$, a zwłaszcza od samego premiera, który powierzał opracowanie szczegółów niższym organom. Również ministrowie spraw zagranicznych nieraz prowadzili z własnej inicjatywy bardzo aktywną dyplomację wobec Chin, np. Ōhira Masayoshi w rządzie Tanaki Kakueia w latach 1972-1974. Z drugiej strony, jak podkreśla Tanaka Akihiko, ostateczna decyzja zawsze należała do prezesa Rady Ministrów i bez jego wsparcia niemożliwe było podjęcie żadnej ważnej decyzji w sprawie Chin ${ }^{16}$. Z powodu ograniczonej liczby głównych decydentów w państwie, ich cechy charakteru, wyznawane przez nich wartości, jak też interesy, którymi się kierowali, odgrywały istotną rolę w formułowaniu ogólnych ram japońskiej polityki ${ }^{17}$.

Jak widać, Japonia to państwo demokratyczne, w którym cesarz nie odgrywa żadnej roli $\mathrm{w}$ polityce, zaś władza skupiona jest $\mathrm{w}$ rękach wybieranego przez parlament premiera. Uregulowania konstytucyjne czy silna pozycja biurokracji nie wyjaśniają jednak w pełni mechanizmów rządzących procesem decyzyjnym w japońskiej polityce. Wieloletnia hegemonia PLD na scenie politycznej stała się przyczyną wytworzenia organicznych powiązań pomiędzy oficjalnymi

\footnotetext{
${ }^{12}$ Harold R. Kerbo, John A. McKinstry, Who Rules Japan? The Inner Circles of Economic and Political Power, Praeger Publishers, Westport 1995, s. 88-90; Tomohito Shinoda, op.cit., s. 5-7.

${ }^{13}$ Ibidem, s. 215-217

${ }^{14}$ Szerzej na ten temat w piątym rozdziale.

${ }^{15}$ Murakawa Ichirō, Fukuoka Masayuki et al., Gendai no seiji katei, Gakuyō Shobō, Tokio 1982, s. $72-73$.

${ }^{16}$ Tanaka Akihiko, Nitchū kankei 1945-1990, Tōkyō Daigaku Shuppankai, Tokio 1996, s. 190196.

${ }^{17}$ Huang Dahui, Riben dui-Hua zhengce yu guonei zhengzhi - Zhong-Ri fujiao zhengzhi guocheng fenxi, Dangdai Shijie Chubanshe, Pekin 2006, s. 22.
} 
instytucjami władzy państwowej a organami tej partii. Im bardziej upolityczniony stawał się problem w polityce zagranicznej, tym większy wpływ na jego rozwiązanie wywierała dyskusja $\mathrm{w}$ ramach $\mathrm{PLD}^{18}$. Również $\mathrm{w}$ przypadku decyzji związanych z ideologią inicjatywa przechodziła w ręce polityków partii rządzącej ${ }^{19}$.

\section{Główne organy PLD}

Przewodniczący (sōsai) jest najważniejszą osobą w PLD. Zgodnie z artykułem 4 statutu PLD: „Przewodniczący jest najwyższym pełnomocnikiem Partii, reprezentuje Partię i zarządza nią jako całością"20. O znaczeniu tego stanowiska świadczy także fakt, że w latach 1955-2006 jedynie jeden przewodniczący PLD, Kōno Yōhei (1993-1995), nie został premierem Japonii. Teoretycznie szefowie PLD dysponują olbrzymią władzą w ugrupowaniu. Fukui Haruhiro podkreśla, iż tak naprawdę statut partii nie zabrania przewodniczącemu nawet samowolnej modyfikacji czy odrzucania postanowień Rady Generalnej PLD. Niemniej jednak w praktyce uprawnienia przewodniczącego podlegały licznym nieformalnym ograniczeniom. Można do nich zaliczyć specyficzny sposób wyboru na to stanowisko, krótką, dwuletnią (od 2003 roku trzyletnią) kadencję ${ }^{21}$ oraz konieczność dbania o równowagę pomiędzy frakcjami w partii ${ }^{22}$.

Przewodniczący mógł mianować wiceprzewodniczącego partii (fukusōsai). Zwykle było to bardziej stanowisko honorowe niż wiążące się $\mathrm{z}$ realnymi uprawnieniami. Wiceprzewodniczący zajmował się np. dbaniem o zachowanie harmonii wewnątrzpartyjnej $\mathrm{w}$ razie nasilenia się rywalizacji pomiędzy frakcjami ${ }^{23}$. Następnymi wysokimi urzędami w ugrupowaniu, tzw. „trzema urzędami partyjnymi” (tō san yaku), byli: sekretarz generalny (kanjichō), przewodniczący Rady Generalnej oraz przewodniczący Rady Badań Politycznych. Razem z przewodniczącym i wiceprzewodniczącym partii oraz innymi urzędnikami ugrupowania tworzyli oni tzw. zarząd (yakuinkai) PLD, który nieraz odgrywał ważną rolę w procesie decyzyjnym. Jego skład ulegał zmianie w czasie, ale należały do niego osoby piastujące takie stanowiska, jak: przewodniczący Komisji Organizacji Ogólnopaństwowej, przewodniczący Komisji Strategii Parlamentarnej, przewodniczący Komisji Dyscypliny Partyjnej

\footnotetext{
${ }^{18}$ Ibidem, s. 19.

${ }^{19}$ Inoguchi Takashi, Gendai Nihon seiji no kisō, NTT Shuppan, Tokio 2002, 130.

${ }^{20}$ Jiyū Minshutō tōsoku, Jiyū Minshutō, Tokio 2009, s. 3.

${ }^{21}$ Na przełomie lat 60. i 70. XX wieku kadencja została wydłużona do 3 lat, ale za rządów Fukudy Takeo (1976-1978) ponownie skrócono ją do 2 lat. Dopiero przy okazji reelekcji Koizumiego Jun'ichirō w 2003 roku znów ustalono ją na 3 lata. Krótki czas trwania kadencji sprawiał, że szefowie PLD praktycznie bez przerwy musieli zabiegać o wpływy wśród frakcji personalnych w partii. Szerzej na temat sposobu wyboru przewodniczących i praw rządzących dynamiką rywalizacji międzyfrakcyjnej w dalszej części rozdziału.

${ }^{22}$ Fukui Haruhiro, Jiȳ Minshutō to seisaku kettei, Fukumura Shuppan, Tokio 1969, s. 111-112.

${ }^{23}$ Kikuchi Hisashi, Jimintō habatsu ura no ura ga wakaru hon, Piipurusha, Tokio 1987, s. 83.
} 
czy przewodniczący Komisji Spraw Finansowych ${ }^{24}$. Obecnie w skład zarządu oprócz przewodniczącego, wiceprzewodniczącego i ,trzech urzędów partyjnych" wchodzi przewodniczący Komisji Strategii Wyborczej, przewodniczący Zgromadzenia Parlamentarzystów z Izby Radców i sekretarz generalny Izby Radców. Zarząd PLD koordynuje działalność wszystkich organów partyjnych, ustala ogólną strategię partii oraz ,podejmuje decyzje w ważnych kwestiach dotyczących wykonywania spraw partyjnych,25.

Wykres 1.1 Uproszczona struktura organizacyjna PLD.

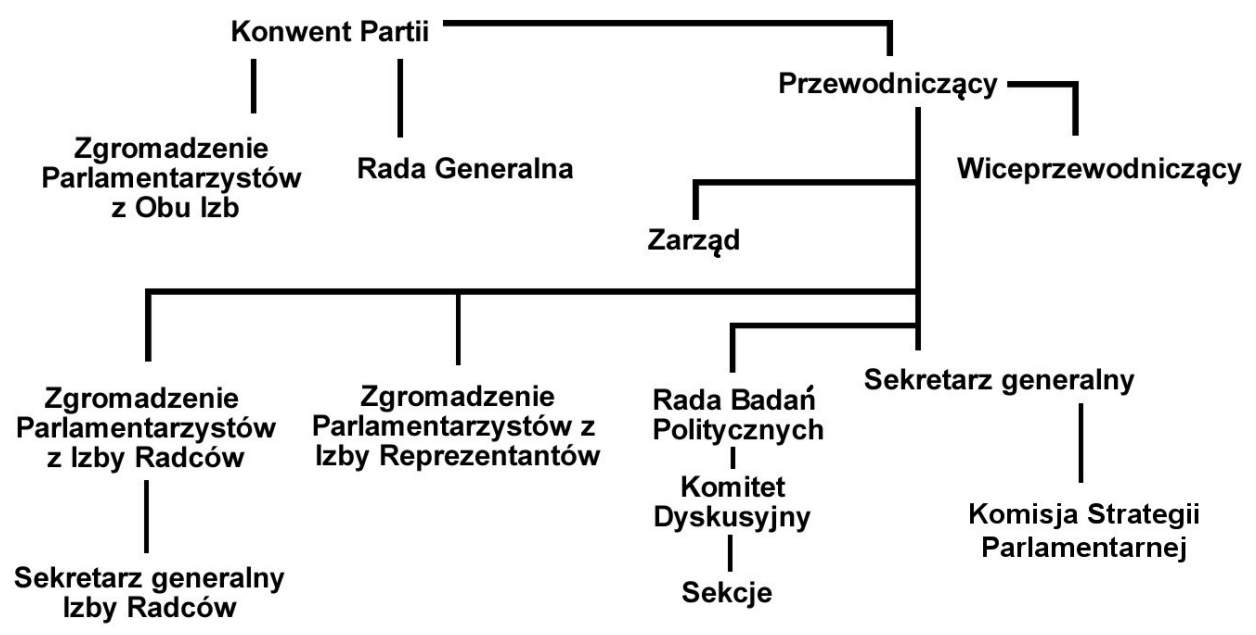

Opracowanie własne na podstawie: Jiyū Minshutō tōsoku, s. 74-75.

Nie ma potrzeby dokładnego omawiania wszystkich organów PLD, gdyż jedynie kilka $\mathrm{z}$ nich odgrywało znaczącą rolę $\mathrm{w}$ procesie decyzyjnym $\mathrm{w}$ partii. Sekretarz generalny był drugą osobą w ugrupowaniu. Piastowanie tej funkcji długo traktowano jako ważne doświadczenie w drodze do stanowiska przewodniczącego PLD. Artykuł 7 statutu partii stypuluje: „Sekretarz generalny wspomaga przewodniczącego, zarządzając sprawami partyjnymi”"26. Ponieważ jego rola sprowadzała się do administrowania funduszami ugrupowania i kwestiami personalnymi, skutecznie działając miał duże możliwości zwiększenia swoich wpływów w PLD. Do lat 70 . XX wieku przewodniczący partii niemal zawsze mianował na to stanowisko członka własnej frakcji. Dopiero za kadencji Mikiego Takeo (1974-1976) złamano ten obyczaj i odtąd regułą stał się

\footnotetext{
${ }^{24}$ Murakawa Ichirō, Seisaku kettei katei, Shinzansha, Tokio 2000, s. 27.

${ }^{25}$ Jiyū Minshutō tōsoku, s. 11.

${ }^{26}$ Ibidem, s. 4.
} 
wybór sekretarza generalnego spośród polityków z innych grup niż frakcja premiera $^{27}$.

Teoretycznie najwyższym organem partyjnym jest Konwent Partii (Tō Taikai), zwoływany raz do roku i zrzeszający parlamentarzystów PLD oraz reprezentantów regionalnych oddziałów partii ${ }^{28}$. W praktyce jednak znacznie większą rolę odgrywała zawsze Rada Generalna (Sōmukai), zbierająca się znacznie częściej i zajmująca się wszelkimi sprawami partyjnymi. Dopiero po uzyskaniu aprobaty Rady Generalnej projekt ustawy mógł być uważany za „decyzję partyjną" (tógi kettei). Urząd przewodniczącego Rady Generalnej należał do najbardziej prestiżowych stanowisk w ugrupowaniu i był zazwyczaj przydzielany reprezentantowi jednej z dużych frakcji. Ilość członków Rady Generalnej ulegała zmianie w czasie. Obecnie należy do niej 14 polityków wybranych spośród posłów izby niższej, $6 \mathrm{z}$ izby wyższej oraz 11 mianowanych przez przewodniczącego partii ${ }^{29}$.

Rada Badań Politycznych (Seimu Chōsakai) to następny ważny organ PLD, pod wieloma względami będący wręcz głównym ośrodkiem w procesie decyzyjnym w partii. Zgodnie ze statutem PLD: „Ustawy, które mają być przyjęte jako polityka partii, muszą zostać poddane dyskusji w Radzie Badań Politycznych"30. W skład tego organu wchodzą parlamentarzyści PLD oraz ewentualnie uczeni wyznaczeni przez przewodniczącego partii. W jego ramach działa Komitet Dyskusyjny (Shingikai), do którego należy przewodniczący Rady Badań Politycznych, wyznaczeni przez niego wiceprzewodniczący oraz maksymalnie 20 innych członków. W celu prowadzenia badań i dyskusji nad ustawami w Radzie funkcjonuje kilkanaście sekcji (bukai), odpowiadających poszczególnym ministerstwom, jak też kilkadziesiąt specjalnych komisji (tokubetsu iinkai) i komitetów badań (tokubetsu chōsakai), zajmujących się bardziej szczegółowymi dziedzinami ustawodawstwa ${ }^{31}$.

\section{Proces ustawodawczy}

Chociaż inicjatywę ustawodawczą w Japonii posiada także grupa 20 członków Izby Reprezentantów lub 10 członków Izby Radców ${ }^{32}$, zdecydowana większość ustaw jest autorstwa rządu ${ }^{33}$. Projekty były zazwyczaj wstępnie przygotowywane przez biurokratów poszczególnych ministerstw. Przed złożeniem ustawy do parlamentu rząd musiał uzyskać na nią zgodę partii. Już w trakcie wstępnych rozmów pomiędzy biurokratami z ministerstw, których dotyczyła nowa ustawa,

\footnotetext{
${ }^{27}$ Murakawa Ichirō, op.cit., s. 34-41.

${ }^{28}$ Jiyū Minshutō tōsoku, s. 12.

${ }^{29}$ Ibidem, s. 14.

${ }^{30}$ Ibidem, s. 15.

${ }^{31}$ Wang Zhensuo, Zhanhou Riben zhengdang zhengzhi, Renmin Chubanshe, Pekin 2001, s. 303304; Jiyū Minshutō tōsoku, s. 15-17.

${ }^{32}$ Krzysztof Karolczak, op.cit., s. 34.

${ }^{33}$ Murakawa Ichirō, Fukuoka Masayuki et al., op.cit., s. 53.
} 
urzędnicy tłumaczyli jej treść najbardziej wpływowym członkom zainteresowanych $z o k u^{34} \mathrm{w} \mathrm{PLD}^{35}$. Jak już zostało wcześniej podkreślone, wpływ biurokracji na proces ustawodawczy był olbrzymi, ale dotyczył przede wszystkim rutynowych decyzji w ramach ogólnych wytycznych polityki Japonii. W przypadku decyzji przełomowych z punktu widzenia polityki zagranicznej państwa, a przede wszystkim takie są przedmiotem analizy w niniejszej pracy, zdecydowanie widać przewodnią rolę polityków PLD ${ }^{36}$. Biurokraci spełniali tu tylko funkcję wykonawców woli władz tej partii.

Po wstępnych rozmowach na poziomie ministerstw pierwsza wersja projektu ustawy trafiała do odpowiednich sekcji bądź, w przypadku problemów dotyczących kilku resortów, do powoływanych ad hoc specjalnych komisji czy komitetów badań Rady Badań Politycznych. W trakcie ich obrad biurokraci oraz zaproszeni uczeni odpowiadali na pytania i wątpliwości parlamentarzystów z PLD. Rada Badań Politycznych była areną lobbingu poszczególnych przedsiębiorstw, środowisk biznesowych i organizacji pozarządowych, które poprzez zaprzyjaźnionych parlamentarzystów z PLD starały się wpłynąć na proces decyzyjny. W przeciwieństwie do komisji parlamentarnych, w których decyzje podejmowano zwykłą większością głosów, w poszczególnych sekcjach Rady Badań Politycznych PLD zwyczajowo obowiązywała zasada jednomyślności. W razie wystąpienia różnicy zdań dochodziło do licznych negocjacji i zakulisowych układów w celu osiągnięcia konsensusu. Ponieważ dyskusje w ramach sekcji były niejawne ${ }^{37}$, ich atmosfera sprzyjała perswazji i zawieraniu potajemnych porozumieñ ${ }^{38}$. Jeżeli nie udało się dojść do kompromisu, uciekano się do powierzenia decyzji przewodniczącemu danej sekcji czy specjalnej komisji. Będący w mniejszości przeciwnicy projektu często wychodzili wcześniej z sali. W ten sposób „zachowywali twarz”, jednocześnie umożliwiając jednomyślne powierzenie decyzji przewodniczącemu. Zazwyczaj zmieniał on tekst kontrowersyjnej uchwały czy ustawy tak, by nadać mu bardziej niejasny, dwuznaczny charakter ${ }^{39}$. W przypadku wyjątkowo ważnej decyzji, wobec której istniał duży opór członków PLD, przewodniczący sekcji mógł także czasowo zawiesić dyskusję nad nią lub odesłać sprawę do organu wyższego. Wszelkie

\footnotetext{
${ }^{34}$ Szerzej na temat zoku (klanów parlamentarzystów) w dalszej części rozdziału.

${ }^{35}$ Iio Jun, Nihon no tōchi kōzō, Chūō Kōron Shinsha, Tokio 2008, s. 84.

${ }^{36}$ Gerald L. Curtis, The Japanese Way of Politics, Columbia University Press, New York 1988, s. $106-107$.

${ }^{37}$ W trakcie stażu w Parlamencie Japonii autor wielokrotnie uczestniczył w posiedzeniach poszczególnych sekcji Rady Badań Politycznych w siedzibie głównej PLD w Tokio, ale jedynie w tych, na których odbywały się prezentacje opinii specjalistów na temat poszczególnych ustaw. Wstęp na obrady sekcji, na których toczyły się zakulisowe rozmowy i zapadały konkretne decyzje (uchiawasekai) mieli tylko określeni politycy.

${ }^{38}$ Yuasa Hiroshi, Kokkai „giin zoku” - Jimintō „Seichō” to Kasumigaseki, Kyōikusha, Tokio 1986, s. 31-32.

${ }^{39}$ Iio Jun, op.cit., s. 85-86.
} 
decyzje podjęte przez sekcje, specjalne komisje bądź komitety badań w ramach Rady Badań Politycznych musiały później uzyskać aprobatę jej Komitetu Dyskusyjnego ${ }^{40}$.

Projekty ustaw były odsyłane z Rady Badań Politycznych do Rady Generalnej. W większości przypadków właściwe decyzje zapadały już na poziomie Rady Badań Politycznych i Rada Generalna jedynie je automatycznie zatwierdzała jako „decyzje partyjne” (tōgi kettei). W przypadku kwestii budzących duże kontrowersje wśród części członków partii, Rada Generalna mogła jednak stać się miejscem zażartych wystąpień posłów, którzy wiedzieli, iż jest to ostatnia szansa na protest przed oficjalnym zatwierdzeniem danej ustawy. Chociaż liczba członków Rady Generalnej była ograniczona i zwykle organ ten składał się z doświadczonych polityków, prawo do uczestniczenia w obradach i zabierania głosu miał każdy parlamentarzysta z PLD ${ }^{41}$. Co więcej, w przypadku decyzji o znaczeniu ogólnopaństwowym, Rada Generalna często stawała się ważniejszym forum dyskusyjnym niż sekcje Rady Badań Politycznych, które wszakże skupiały się na wąskich interesach poszczególnych resortów ${ }^{42}$. Tak było też z niektórymi istotnymi decyzjami dotyczącymi polityki PLD wobec Chin, jak postanowienie o wizycie cesarza w ChRL w 1992 roku.

Chociaż zgodnie ze statutem PLD decyzje w Radzie Generalnej podejmowano większością głosów, w praktyce przyjęta była zasada jednomyślności. Nie oznacza to jednak, by pojedynczy parlamentarzysta mógł zablokować prace nad daną ustawą. Jeśli tylko sprzeciwu nie zgłaszało więcej członków Rady Generalnej, stosowano strategię umożliwiającą „zachowanie twarzy” przez osobę zgłaszającą veto. Pozwalano jej na wygłoszenie krytycznej opinii na kilku posiedzeniach Rady Generalnej, odkładając termin głosowania na później. Kiedy jednak minęło wystarczająco dużo czasu, przewodniczący Rady Generalnej dawał znak, że trzeba podjąć decyzję. Protestujący parlamentarzysta opuszczał wówczas na chwilę obrady, np. wychodząc do toalety. Gdy wracał, było już po głosowaniu. Dzięki tej niepisanej procedurze mógł tłumaczyć się przed grupami interesu, które reprezentował, iż decyzję podjęto pod jego nieobecność ${ }^{43}$.

Fukui Haruhiro zwraca uwagę na rolę w procesie decyzyjnym jeszcze jednego organu PLD, zarządu. Podkreśla, że w przypadku zbytniego upolitycznienia dyskusji nad daną kwestią i „rozwodnienia” treści ustawy czy uchwały w wyniku ostrego sprzeciwu części parlamentarzystów, zarząd był uprawniony do samodzielnego wydania decyzji partyjnej. Rada Badań Politycznych i Rada Generalna składały się z dużej liczby członków, więc siłą rzeczy w organach

\footnotetext{
${ }^{40}$ Murakawa Ichirō, op.cit., s. 171-175.

${ }^{41}$ Fukui Haruhiro, op.cit., s. 105.

${ }^{42}$ Murakawa Ichirō, op.cit., s. 55.

${ }^{43}$ Ishikawa Masumi, Hirose Michisada, op.cit., s. 222.
} 
tych zasiadali także liczni członkowie frakcji ,,przeciwnego nurtu”44. Z kolei około dwie trzecie członków zarządu było wybieranych przez samego przewodniczącego PLD lub przez mianowanego przez niego sekretarza generalnego, co zapewniało zupełną dominację frakcji ,głównego nurtu” w tym ciele. Oznacza to, że decyzja zarządu partii była swoistym „kołem ratunkowym”, używanym przez premiera w razie zastoju obrad na poziomie Rady Generalnej ${ }^{45}$.

Po zatwierdzeniu ustawy przez Radę Generalną wszystkich parlamentarzystów z PLD obowiązywał przymus głosowania zgodnie z decyzją partyjną (tōgi $k \overline{o s o k u})^{46}$. Pozostawała już tylko automatyczna akceptacja decyzji partii przez rząd jako „decyzji gabinetowej” (kakugi kettei) ${ }^{47}$ i oficjalne przegłosowanie ustawy w parlamencie. Kontaktami z ugrupowaniami opozycyjnymi zajmowali się członkowie Komisji Strategii Parlamentarnej PLD (Jimintō Kokkai Taisaku linkai). Mimo że do 1989 roku partia ta posiadała większość mandatów w obu izbach, w razie tzw. „siłowych głosowań” (kyōkō saiketsu) bez wcześniejszego porozumienia z opozycją, partie opozycyjne mogły zastosować jedną z technik utrudniających przyjęcie danej ustawy, jak sprzeciw w komisji parlamentarnej, blokada drzwi lub mównicy, bojkot bądź przeciąganie obrad, wykradanie ołówków stenografom ${ }^{48}$ czy w ostateczności „krowi chód”49. Aby nie dopuścić do takich sytuacji, które kompromitowały parlament, politycy PLD prowadzili zakulisowe negocjacje z posłami opozycyjnymi. Niejednokrotnie pochłaniały one dużo czasu i pieniędzy. Często też, szanując potrzebę opozycji do

\footnotetext{
${ }^{44}$ Szerzej na temat frakcji „przeciwnego” i „głównego nurtu” w dalszej części rozdziału.

${ }^{45}$ Fukui Haruhiro, op.cit., s. 108-111.

${ }^{46}$ Iio Jun, op.cit., s. 87.

${ }^{47}$ Decyzja była przyjmowana przez gabinet jednogłośnie. Z drugiej strony, w razie sprzeciwu któregoś ministra premier miał prawo go odwołać. Szerzej na ten temat: Murakawa Ichirō, op.cit., s. 182.

${ }^{48}$ Aby uniemożliwić obrady posłowie opozycji kradli ołówki stenografom. PLD wyznaczała wówczas jednego polityka do noszenia kilkudziesięciu zapasowych ołówków. Szerzej na ten temat: Kōno Tarō, Kōno Tarō no kokkai kōryaku hon, Eiji Shuppan, Tokio 2003, s. 45.

${ }^{49} \mathrm{Na}$ powstanie ,taktyki krowiego chodu” (gyūho senjutsu) wywarł wpływ swoisty system głosowania w japońskim parlamencie. O ile w Izbie Radców w latach 90. XX wieku wprowadzono głosowanie przez naciśnięcie guzika, o tyle w Izbie Reprezentantów w przypadku ważnych ustaw (w przypadku mniej ważnych głosuje się poprzez wstanie z miejsca) nadal oddaje się głos za pomocą białych (głos za) i niebieskich (głos przeciw) płytek. Wyczytywane są nazwiska posłów według kolejności, w jakiej zasiadają na sali i podchodzą oni rzędem do mównicy, oddając płytki pracownikom parlamentu, którzy umieszczają je w odpowiednich pojemnikach. Na koniec liczy się ilość płytek danego koloru. Posłowie opozycji niejednokrotnie blokowali głosowanie, podchodząc do mównicy bardzo wolno, nawet przez kilkanaście godzin. Ponieważ sesje parlamentu są krótkie i istnieje obyczaj nieprzenoszenia ustaw z jednej sesji na następną, czasami ten sposób wyrażenia protestu skutkował odrzuceniem ustawy. Z czasem „taktykę krowiego chodu” stosowano coraz rzadziej. Według Miyazawy Kiichiego było to spowodowane dopuszczeniem na salę obrad reporterów telewizyjnych. Szerzej na ten temat: Nagatachō..., s. 172-175; Kikigaki. Miyazawa Kiichi kaikoroku pod red. Mikuriyi Takashiego i Nakamury Takafusy, Iwanami Shoten, Tokio 2007, s. 211-214.
} 
manifestacji przed jej wyborcami sprzeciwu wobec niepopularnej ustawy, działacze Komisji Strategii Parlamentarnej PLD z góry negocjowali, jakie metody protestu będę tolerowane ${ }^{50}$. Niemniej jednak zdarzało się, że ustawa budziła tak silne emocje, iż nawet posłowie PLD wyrażali wobec niej sprzeciw opuszczając głosowanie w parlamencie i narażając się na postępowanie dyscyplinarne.

Od 1994 roku PLD była zmuszona do tworzenia rządów koalicyjnych, więc musiała wziąć pod uwagę także stanowisko mniejszych partii wchodzących w skład koalicji. Powołano do życia nowe organy odpowiedzialne za negocjacje pomiędzy PLD a innymi ugrupowaniami koalicyjnymi na każdym etapie procesu decyzyjnego, np. Radę Przewodniczących Partii (Tōshu Kaigi) czy Radę Kontaktów pomiędzy Partiami Koalicyjnymi a Rządem (Seifu - Yotō Shunō Renraku Kaigi). W ich skład wchodzili najwyżsi rangą przedstawiciele poszczególnych ugrupowań oraz członkowie gabinetu ${ }^{51}$. Konieczność wzięcia pod uwagę stanowiska innych partii w pewnym stopniu wywarła także wpływ na politykę PLD wobec Chin. Zależnie od opcji ideologicznej reprezentowanej przez partnerów koalicyjnych umacniała się pozycja lewego bądź prawego skrzydła tego ugrupowania.

$* \quad * \quad *$

Przez dziesięciolecia rządów PLD proces decyzyjny w tej partii nierozerwalnie zlał się z procesem ustawodawczym. Osoby piastujące jednocześnie stanowisko premiera i przewodniczącego PLD teoretycznie posiadały olbrzymią władzę tak $\mathrm{w}$ państwie, jak w samym ugrupowaniu, ale $\mathrm{w}$ praktyce ich uprawnienia podlegały licznym nieoficjalnym ograniczeniom. Nieformalne powiązania pomiędzy politykami pośrednio wywierały wielki wpływ na procesy decyzyjne w PLD. Osoby piastujące urzędy partyjne i państwowe tak naprawdę były przede wszystkim reprezentantami poszczególnych frakcji personalnych. $\mathrm{Z}$ tego powodu kluczem do zrozumienia decyzji podejmowanych na poziomie całego ugrupowania jest analiza dynamiki rywalizacji pomiędzy grupami wewnątrzpartyjnymi.

\section{FRAKCJE PERSONALNE}

Frakcyjność (habatsushugi), czyli podział partii na mniejsze grupy, jest istotną cechą japońskiej sceny politycznej ${ }^{52}$. Jak zauważył Nagamori Seiichi: „nie da się

\footnotetext{
${ }^{50}$ Ishikawa Masumi, Hirose Michisada, op.cit., s. 40-52; Murakawa Ichirō, Fukuoka Masayuki et al., op.cit., s. 66-67; Nagatachō..., s. 177-179.

${ }^{51}$ Murakawa Ichirō, op.cit., s. 95-108.

${ }^{52} \mathrm{Nie}$ jest to jednak unikalna cecha japońskiego systemu politycznego. Podobne frakcje istniały np. we włoskiej Chrześcijańskiej Demokracji. Szerzej na ten temat: Kim Eric Bettcher, Factions of
} 
opisać japońskiej polityki pominąwszy tematykę frakcji”,53. Frakcją (habatsu) nazywa się „krąg towarzyski związany wspólnym pochodzeniem czy interesem bądź członkostwem w partii lub grupie politycznej" ${ }^{54}$. W tym szerokim rozumieniu można wyróżnić kilka rodzajów frakcji. Jednym $\mathrm{z}$ nich są frakcje ideologiczne, charakterystyczne dla japońskiej lewicy ${ }^{55}$, innym pokoleniowe, skupiające członków o podobnym wieku. Większe znaczenie mają frakcje tematyczne, które zrzeszają polityków o takich samych poglądach, w tym na temat polityki zagranicznej. Do tej kategorii należą głównie stowarzyszenia badawcze (kenkyūkai) i grupy dyskusyjne (kondankai), powoływane ad hoc w celu znalezienia rozwiązania konkretnego problemu ${ }^{56}$. Niektóre $\mathrm{z}$ frakcji w tym szerokim rozumieniu zostały omówione w części poświęconej grupom politycznym.

Na japońskiej scenie politycznej największe piętno odcisnęły jednak frakcje personalne, których członkowie skupiali się wokół osoby lidera. Główną cechą odróżniającą frakcję w tym wąskim znaczeniu od innych typów grup w ramach partii była pełniona przez nie funkcja zarządzania olbrzymimi funduszami ${ }^{57}$. PLD można nazwać bardziej „federacją frakcji” (tōha no rengōtai) ${ }^{58}$ niż ugrupowaniem o ściśle scentralizowanej władzy. Istnienie frakcji w oczywisty sposób osłabiało władzę przewodniczącego partii. Nie miał on bezpośredniego wpływu na wszystkich członków ugrupowania, tylko pełnił raczej rolę osoby starającej się lawirować pomiędzy sprzecznymi interesami poszczególnych grup.

\section{Uwarunkowania japońskiej frakcyjności partyjnej}

Istnieją dwie główne teorie odnośnie do źródeł frakcyjności personalnej w PLD. Pierwsza z nich odwołuje się do kulturowych uwarunkowań społeczeństwa japońskiego, zaś druga podkreśla przede wszystkim wpływ powojennych uwarunkowań instytucjonalnych, w szczególności zaś swoistej ordynacji wyborczej opartej na okręgach wyborczych średniej wielkości ${ }^{59}$. O ile pierwsze $\mathrm{z}$ uwarunkowań podlega tylko powolnej zmianie wraz z kolejnymi pokoleniami, o

Interest in Japan and Italy: The Organizational and Motivational Dimensions of Factionalism, „Party Politics” 2005, vol. 11, no. 3, s. 339-358.

${ }_{53}$ Nagamori Seiichi, Habatsu, Chikuma Shinsho, Saitama 2002, s. 7.

${ }^{54}$ Uchida Kenzō, Habatsu. Seiken kōsō no omote to ura, Kōdansha, Tokio 1983, s. 156.

${ }^{55}$ George O. Totten, Tamio Kawakami, The Functions of Factionalism in Japanese Politics, „Pacific Affairs” 1965, vol. 38, no. 2, s. 121.

${ }^{56}$ Edward A. Olsen, Factionalism and Reform of Japan's Liberal Democratic Party, „World Affairs" Winter 1978/1979, vol. 141, no. 3, s. 258.

${ }^{57}$ Iseri Hirofumi, Habatsu saihensei. Jimintō seiji no omote to ura, Chūō Kōronsha, Tokio 1988, s. 72.

${ }^{58}$ Nagamori Seiichi, op.cit., s. 8.

${ }^{59}$ Cheol Hee Park, Factional Dynamics in Japan's LDP since Political Reform. Continuity and Change, ,Asian Survey” 2001, vol. 41, no. 3, s. 430-431. 
tyle ramy instytucjonalne zostały radykalnie zmienione w 1994 roku, co przyczyniło się do osłabienia frakcyjności w PLD.

Frakcyjność na japońskiej scenie politycznej jest po części następstwem tradycji głęboko zakorzenionych w społeczeństwie. Stosunki pomiędzy jednostkami, czy też między jednostkami a grupami oraz pomiędzy grupami, należą do najmniej podatnych na zmianę czynników tworzących społeczeństwo ${ }^{60}$. W Japonii wykształciło się „,społeczeństwo wertykalne” (tate no shakai), w którym wielką rolę odgrywa hierarchiczne uporządkowanie jednostek. Według Nakane Chie: „kryterium hierarchiczne występuje w każdym społeczeństwie, ale w społeczeństwach innych niż japońskie kryterium to nie spełnia $w$ życiu społecznym aż tak ważnej funkcji, by rządziło wszystkimi relacjami interpersonalnymi" ${ }^{61}$. Zależność między przywódcami frakcji a ich pozostałymi członkami ma się wywodzić z feudalnej sieci powiązań między patronem (oyabun) a klientem (kobun) ${ }^{62}$, która od wieków wpływała na każdą dziedzinę życia Japończyków. Również dzisiaj można zauważyć taką paternalistyczną strukturę wertykalną np. w japońskich firmach bądź sektach religijnych. Jest ona związana z zasadą starszeństwa, gdyż stanowiska rozdziela się zazwyczaj według wieku.

Przejawiająca się w stosunkach patron-klient waga relacji interpersonalnych w dużym stopniu wpłynęła na nowożytną i najnowszą historię Japonii. Przed II wojną światową rdzeń polityki stanowiły frakcje terytorialne (hanbatsu) ${ }^{63}$. Ich członków łączyło pochodzenie z tych samych domen feudalnych (hanów), a nie wspólnie podzielane poglądy. Rywalizujące ze sobą grupy - frakcja marynarki i frakcja sił lądowych - występowały także w mającej bezpośredni wpływ na władzę armii japońskiej. Były to tzw. frakcje wojskowe (gunbatsu $)^{64}$. Uchida Kenzō wylicza również inne przykłady frakcji typowych dla japońskiego społeczeństwa: oparte na wspólnym pochodzeniu uniwersyteckim czy biurokratycznym (gakubatsu i kanbatsu) lub na pokrewieństwie czy powinowactwie $(\text { keibatsu })^{65}$.

Według Yamamoto Shichiheia organizacje w japońskim społeczeństwie mają kształt „kłącza” czy „korzenia”. W organizacjach europejskich lub amerykańskich nie ma problemów z określeniem zakresu uprawnień poszczególnych organów w danej instytucji. W Japonii jednak obok struktury oficjalnej (tatemaejō no soshiki) istnieje także „struktura ukryta” (ura soshiki), która opiera się na nieformalnych stosunkach międzyludzkich. W przypadku japońskiego świata polityki rolę pierwszej z nich odgrywa rząd, zaś drugiej

\footnotetext{
${ }^{60}$ Nakane Chie, Tate shakai no ningen kankei, Kōdansha, Tokio 2007, s. 21.

${ }^{61}$ Ibidem, s. 85.

${ }^{62}$ Ibidem, s. 71.

${ }^{63}$ Uchida Kenzō, Habatsu..., s. 161.

${ }^{64}$ Ibidem, s. 164-167.

${ }^{65}$ Ibidem, s. 169-170.
} 
przede wszystkim frakcje ${ }^{66}$. Oficjalna struktura (tatemae) nie zawsze jest tożsama $\mathrm{z}$ realnym układem sił $\mathrm{w}$ ramach grupy (honne) ${ }^{67}$. Dopiero znajomość nieformalnych powiązań umożliwia pełne zrozumienie procesów decyzyjnych.

Biorąc pod uwagę podłoże kulturowe, nic dziwnego, że skupione wokół wpływowych liderów frakcje istniały w PLD już od chwili jej utworzenia w 1955 roku. Z czasem frakcje jeszcze bardziej się integrowały, przypominając wielkie rodziny. Związek tych grup z tradycjami japońskiej wspólnotowości widać nawet w potocznej nazwie frakcji używanej przez jej członków: wioska $(\text { mura })^{68}$. Nowi członkowie partii wchodzili do świata polityki dzięki protekcji wpływowych parlamentarzystów i mogli liczyć na stopniowy awans w grupie, zupełnie jak pracownicy w typowej japońskiej firmie stosującej zasady dożywotniego zatrudnienia.

Co charakterystyczne, tego typu układy były często dziedziczone. Wynika to zresztą nie tylko z sieci powiązań pomiędzy ludźmi władzy, ale także między politykami a ludnością danego okręgu wyborczego. Aby wytworzyć i ciągle utrzymywać relacje ze swoimi wyborcami, posłowie PLD tworzyli specjalne organizacje zwane ,grupami wsparcia” (kōenkai $)^{69}$. Zajmowały się one pozyskiwaniem zwolenników dla danego polityka, szczególnie lokalnych liderów grup zawodowych, którzy dzięki własnym koneksjom mogli zapewnić dodatkowe wsparcie $^{70}$. W przypadku przejścia na emeryturę bądź śmierci parlamentarzysty ściśle związanego ze swoim okręgiem wyborczym, jego syn bądź córka często przejmowali „W spadku” dane kōenkai razem z wiernym elektoratem. Ważną rolę odgrywało też znane nazwisko oraz środki finansowe, odziedziczone po poprzedniku $^{71}$. W ten sposób dzieci parlamentarzystów otrzymywały szansę wejścia do świata polityki. Najczęściej dokonywało się to w ramach jednej frakcji, petryfikując jej personalny charakter ${ }^{72}$.

Chociaż typowa dla japońskiej kultury sieć zależności wpłynęła na kształt obecnych frakcji, nie da się jednak zaprzeczyć, że do 1994 roku głównie japońska ordynacja wyborcza do Izby Reprezentantów warunkowała frakcyjność w ramach PLD. W okresie tym istniały okręgi wyborcze średnich rozmiarów, w

\footnotetext{
${ }^{66}$ Yamamoto Shichihei, Habatsu. Naze sō naru no ka, Nansōsha, Tokio 1985, s. 21-22.

${ }^{67}$ Bruce Stronach, Beyond the Rising Sun. Nationalism in Contemporary Japan, Praeger Publishers, Westport 1995, s. 85.

${ }^{68}$ Itō Hirotoshi, Kon-Chiku-Shō no kane to kenryoku, Shakai Shinpō, Tokio 1993, s. 51.

${ }^{69} \mathrm{~W}$ marcu 2009 roku autor uczestniczył w uroczystej kolacji kōenkai posła PLD Kōno Tarō w Jokohamie. Byli na nim obecni m.in. pracownicy biur wyborczych, lokalni politycy oraz szeregowi członkowie kōenkai. Podsumowano roczną działalność organizacji, zaś wyborcom najbardziej zaangażowanym w działalność grupy przyznano specjalne nagrody.

${ }^{70}$ Hitoshi Abe, Muneyuki Hindō, Sadafumi Kawato, The Government and Politics of Japan, University of Tokio Press, Tokio 1994, s. 174-175.

${ }^{71}$ Kong Uisik, op.cit., s. 152-154.

${ }^{72}$ Szerzej na temat przyczyn dziedziczenia stanowisk parlamentarnych w Japonii: Matsuzaki Tetsuhisa, Nihongata demokurashī no gyakusetsu - Niseigiin wa naze umareru no ka, Tōjusha, Tokio 1991, s. 9-83.
} 
których wybierano od dwóch do sześciu deputowanych. Taki system sprawiał, że partia pragnąca zdobyć większość w parlamencie była zmuszona do wystawienia w każdym ze 129 okręgów po kilku rywalizujących ze sobą kandydatów. W naturalny sposób poszczególni kandydaci należeli do różnych frakcji w łonie PLD. Można wręcz powiedzieć, że ponieważ oprócz dwóch okręgów sześciomandatowych maksymalnym rozmiarem okręgu było pięć mandatów, ostatecznie uformowało się pięć głównych frakcji ${ }^{73}$.

Chociaż system frakcyjny, jako swoista gwarancja „wewnątrzpartyjnej demokracji" ${ }^{74}$, w pewnym stopniu pozytywnie wpływał na japoński system polityczny, miał również swoje „ciemne strony”, nieustannie podkreślane przez media. Przede wszystkim chodzi tu o związki frakcji z wielkim biznesem, skutkujące m.in. olbrzymią korupcją. Premier Koizumi Jun'ichirō (2001-2006) pragnął wyeliminować frakcyjność w ramach PLD, zaś oznaki osłabienia pozycji frakcji są już widoczne. Z drugiej strony, tego typu hasła nie były niczym nowym. Jak napisał Nagamori Seiichi: „To naturalne, że ktokolwiek by nie został przewodniczącym partii, głosi rozwiązanie frakcji" ${ }^{\text {"75 }}$. Osoby piastujące centralne stanowiska $\mathrm{w}$ partii siłą rzeczy musiały myśleć o swoim ugrupowaniu jako całości i szerzyć hasła, które podobały się wyborcom.

Tak naprawdę, ruch dążący do zniesienia podziału na frakcje pojawił się tuż po utworzeniu samej PLD. Plany tego rodzaju snuli już premierzy Kishi Nobusuke (1957-1960) czy Ikeda Hayato (1960-1964). Innymi zdeklarowanymi przeciwnikami frakcyjności byli w latach 70. XX wieku premierzy Miki Takeo (1974-1976) i Fukuda Takeo (1976-1978). Proponowana przez nich głęboka reforma systemu partyjnego nie doczekała się jednak pełnej realizacji ${ }^{76}$. Głosy o konieczności zniesienia frakcji podnosiły się cyklicznie, szczególnie zaś po przejściowej utracie władzy przez PLD w latach 1993-1994. Paradoksalnie, zazwyczaj były one jedynie elementem rywalizacji międzyfrakcyjnej. Prawdziwe zmiany zostały zapoczątkowane dopiero przez wielopartyjną koalicję, która odsunęła PLD od władzy w 1993 roku $^{77}$.

Reforma ordynacji wyborczej w 1994 roku usunęła najważniejszy czynnik, mający wymuszać frakcyjność wewnątrzpartyjną, czyli okręgi wyborcze średnich rozmiarów. Na ich miejsce wyznaczono 300 okręgów jednomandatowych oraz 11 dużych regionów, z których według zasady proporcjonalności było wybieranych łącznie 200, zaś dzisiaj 180 posłów. Zmiana systemu wyborczego na mieszany miała służyć m.in. likwidacji frakcyjności w PLD. Chociaż reforma

\footnotetext{
${ }^{73}$ Masaru Kohno, Japan's Postwar Party Politics, Princeton University Press, Princeton 1997, s. 107-109; Cheol Hee Park, op.cit., s. 431.

${ }^{74}$ Ibidem, s. 446.

${ }^{75}$ Nagamori Seiichi, op.cit., s. 47.

${ }^{76}$ Edward A. Olsen, op.cit., s. 260-262.

${ }^{77}$ Karol Żakowski, Zniesienie frakcyjności w japońskiej Partii Liberalno-Demokratycznej. Stare zadanie $w$ nowych czasach, „Azja-Pacyfik. Społeczeństwo - Polityka - Gospodarka” 2008, tom 11, s. 26-40.
} 
nie do końca spełniła pokładane w niej nadzieje, frakcje uległy znacznemu osłabieniu. Frakcyjność nadal jest istotnym czynnikiem rywalizacji wewnątrzpartyjnej, ale nie można jej już nazwać dominującą linią podziału między członkami partii. Obecnie frakcje pełnią m.in. funkcje edukacyjne, organizując spotkania dla młodszych posłów, na których mają oni okazję poznać mechanizmy sprawowania władzy ${ }^{78}$. $\mathrm{Z}$ drugiej strony, fakt że frakcje nie zniknęły, a jedynie zmieniły swój charakter, świadczy zarówno o trwałości omówionych wcześniej determinant kulturowych, jak też o istnieniu innych czynników instytucjonalnych, warunkujących frakcyjność w PLD. Już sama wielkość PLD wymuszała pojawienie się pewnych podziałów, umożliwiających sprawniejsze zarządzanie jej członkami. Na kształt frakcyjności w dużym stopniu wpływał także statut partyjny. Istotna była na przykład zmieniająca się w czasie liczba głosów członków parlamentu, wymagana do zgłoszenia kandydatury danej osoby na stanowisko przewodniczącego partii ${ }^{79}$. Dzisiaj wynosi ona 20 i można ją uznać za minimalny rozmiar liczącej się frakcji.

\section{Cechy frakcji w PLD}

Frakcje personalne w PLD miały określone cechy, które stanowiły o ich odmienności od innych grup wewnątrz partii. Były uważane za twory pozbawione konkretnego programu politycznego, oparte natomiast na charakterystycznej dla japońskiego społeczeństwa wertykalnej strukturze społecznej. Przez lata istnienia stały się także grupami wysoce zinstytucjonalizowanymi i niejednokrotnie rozrosły się do imponujących rozmiarów.

Ponieważ japońskie społeczeństwo można nazwać „społeczeństwem wertykalnym", jego charakterystyczne cechy znalazły odzwierciedlenie także we frakcjach PLD. Frakcje zrzeszały osoby połączone silnymi więzami personalnymi, więc przypadki przechodzenia pojedynczych polityków z frakcji do frakcji zdarzały się stosunkowo rzadko ${ }^{80}$. W japońskiej kulturze lojalność jest wysoko ceniona. Politycy zdobywali zaufanie latami nieustannej pracy na rzecz danej frakcji, więc jej opuszczenie wiązałoby się z „degradacją” i koniecznością budowania personalnych więzi w nowym środowisku ${ }^{81}$. Według Nakane Chie cechą charakterystyczną japońskiego społeczeństwa jest zdolność jednostek do pełnego zaangażowania $\mathrm{w}$ działalność tylko jednej organizacji opartej na strukturze wertykalnej. Nawet jeśli Japończyk należy do kilku grup, jedna z nich wyraźnie zajmuje centralne miejsce w jego życiu ${ }^{82}$. W przypadku zdecydowanej

\footnotetext{
${ }^{78}$ Kusano Atsushi, Seiken kōtai no hōsoku, Kadokawa Shoten, Tokio 2008, s. 55.

${ }^{79}$ Patrick Köllner, Factionalism in Japanese Political Parties Revisited or How do Factions in the LDP and the DPJ Differ?, ,Japan Forum”2004, vol. 16, no. 1, s. 92.

${ }^{80}$ Cheol Hee Park, op.cit., s. 442.

${ }^{81}$ Gary W. Cox, Frances McCall Rosenbluth, Michael F. Theis, Electoral Reform and the Fate of Factions: The Case of Japan's Liberal Democratic Party, „British Journal of Political Science” 1999, nr 29, s. 38.

${ }^{82}$ Nakane Chie, op.cit., s. 64-67.
} 
większości parlamentarzystów PLD takimi pierwszorzędnymi organizacjami, z którymi wiązała się kariera polityczna, przynajmniej do lat 90. XX wieku były właśnie frakcje personalne.

Wykres 1.2 Społeczeństwo o strukturze wertykalnej i horyzontalnej.

Spoleczeństwo wertykalne

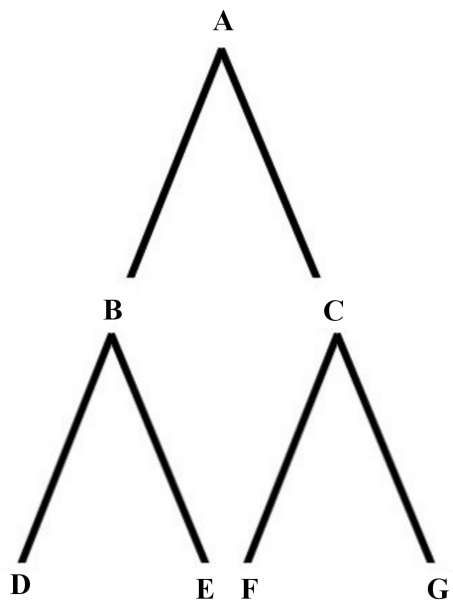

Spoleczeństwo horyzontalne

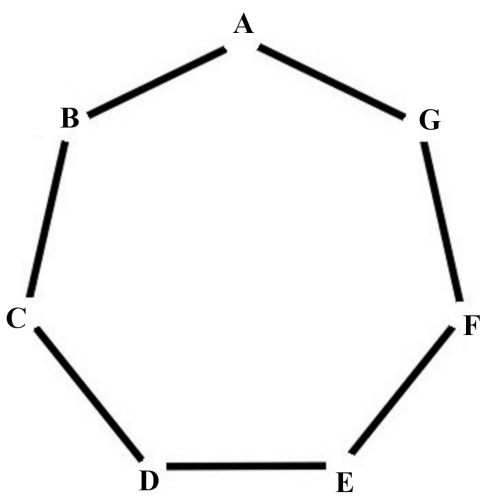

Źródło: Nakane Chie, op.cit., s. 117.

W organizacjach opartych na strukturze wertykalnej zdarzają się rozłamy i fuzje całych grup. Największym zagrożeniem dla jedności frakcji była śmierć lub przejście na emeryturę jej przywódcy. Nawet w przypadku wyznaczenia przez niego następcy, mogło wówczas dojść do walki o władzę. Jeśli tylko ambitny konkurent nowego lidera zdołał pociągnąć za sobą część członków, był $\mathrm{w}$ stanie założyć osobną grupę ${ }^{83}$. Jest to w pełni zgodne $\mathrm{z}$ logiką funkcjonowania organizacji opartych na wertykalnej strukturze zależności interpersonalnych. Z jednej strony mocne są $w$ nich relacje patron-klient, $\mathrm{z}$ drugiej zaś bardzo słabym natężeniem charakteryzują się stosunki horyzontalne pomiędzy osobami znajdującymi się na tym samym szczeblu hierarchii. Jak podkreślała Nakane Chie: „osoby o tej samej klasie i zdolnościach stają się wrogami" ${ }^{84}$. Takimi osobami byli m.in. nieustannie rywalizujący ze sobą szefowie frakcji w PLD. Struktura wertykalna istniała jednak również wewnątrz samych frakcji. Dla jej

\footnotetext{
${ }^{83}$ Eric C. Browne, Sunwoong Kim, Factional Rivals and Electoral Competition in a Dominant Party: Inside Japan's Liberal Democratic Party, 1958-1990, „European Journal of Political Research" 2003, vol. 42, s. 110.

${ }^{84}$ Nakane Chie, op.cit., s. 105.
} 
zobrazowania Nakane Chie stworzyła model odwróconego V, widoczny na wykresie 1.2.

W organizacji opartej na strukturze horyzontalnej do wstąpienia nowego członka wymagana jest zgoda wszystkich dotychczasowych członków. Zazwyczaj sprowadza się ona do automatycznej, domniemanej zgody w przypadku spełnienia przez kandydata jasno określonych kryteriów. Z kolei aby wstąpić do organizacji opartej na strukturze wertykalnej, należy uzyskać zaufanie i poparcie jednego wpływowego członka tej grupy, który wykorzystując własne kontakty wprowadza do organizacji swojego nowego klienta, stającego się odtąd jego lojalnym podwładnym. W ten sposób tworzy się piramida wzajemnych zależności. W obu modelach charakterystyczna jest rola lidera (A). O ile w przypadku struktury horyzontalnej organizacja może przetrwać nawet bez wyraźnie określonego przywódcy, o tyle w drugim modelu lider jest „sworzniem" zapewniającym spójność grupy. Nawet osoby o randze nieco tylko niższej od pozycji przywódcy (B i C) są związane ze sobą jedynie personalnymi więziami $\mathrm{z}$ liderem (A). W razie śmierci przywódcy, na pierwszy plan wysuwa się rywalizacja pomiędzy jego bezpośrednimi klientami (B i C), z których każdy posiada swoich podwładnych. W przypadku zwycięstwa polityka „B”, polityk „C" może dokonać rozłamu, będąc pewnym lojalności polityków „F” i „G”, którzy z kolei pociągną za sobą własnych klientów ${ }^{85}$.

Inną cechą frakcji personalnych w ramach PLD była bezprogramowość ${ }^{86}$. O ile partia jako całość posiadała określony program polityczny, o tyle pozbawione oficjalnego charakteru frakcje działały na zasadzie „kręgów towarzyskich”. W takich opartych na strukturze wertykalnej grupach pierwszorzędne znaczenie miały stosunki emocjonalne, a nie wspólnie podzielane zasady. Jak podkreślała Nakane Chie: „W Japonii, jakkolwiek jednolitej zasady czy idei by nie wyznawała grupa, esencją tej grupy nie jest osobiste bycie wiernym tej właśnie zasadzie (idei), a raczej same stosunki interpersonalne" ${ }^{87}$. Inaczej mówiąc: „Japończycy bardziej cenią uczucia niż logikę ${ }^{\text {"8 }}$. Yamamoto Shichihei dokonał nawet etymologicznej analizy bezprogramowości, podkreślając znaczenie dwóch znaków tworzących wyraz „frakcja” (habatsu). O ile znak batsu (chiń. fa) oznacza grupę o ekskluzywnym członkostwie osób o wspólnym pochodzeniu (np. uniwersyteckim), których nie łączy wspólna ideologia, o tyle znak ha (chiń. pai) odnosi się do grup bardziej inkluzywnych, opartych na wspólnie podzielanych zasadach (np. sekty religijne). Połączenie tych dwóch znaków daje nową jakość, frakcję, która z jednej strony nie skupia się specjalnie na ideologii, z drugiej zaś zrzesza członków na zasadzie dobrowolności, a nie pochodzenia ${ }^{89}$.

\footnotetext{
${ }^{85}$ Ibidem, s. 116-126.

${ }^{86}$ Patrick Köllner, op.cit., s. 93.

${ }^{87}$ Nakane Chie, op.cit., s. 172.

${ }^{88}$ Ibidem, s. 181.

${ }^{89}$ Yamamoto Shichihei, op.cit., s 101-102.
} 
Nie znaczy to jednak, że poszczególne frakcje nie posiadały jakiegokolwiek kolorytu ideologicznego ${ }^{90}$. Obraz całej grupy był często determinowany przez ideologiczne przekonania jej lidera ${ }^{91}$. Według Nakane Chie w organizacjach opartych na strukturze wertykalnej „łatwo szybko osiągnąc jedność poglądów grupy. Dzieje się tak dlatego, że do koordynacji poglądów używana jest hierarchia" ${ }^{92}$. W razie niezgody, stanowisko przywódcy w naturalny sposób przeważało nad poglądami jego podwładnych ${ }^{93}$. Jak twierdzi marszałek Izby Reprezentantów i były przewodniczący PLD, Kōno Yōhei, zasada ta odnosiła się także do frakcji w partii dominującej. Jednocześnie przyznaje on, że po reformie systemu wyborczego w 1994 roku solidarność członków frakcji została znacząco osłabiona, przez co szeregowi politycy nie muszą już w kwestiach ideologicznych podążać za zdaniem własnego oyabuna ${ }^{94}$. Zresztą również i wcześniej zdarzały się secesje z frakcji działaczy niezadowolonych z polityki swojego przywódcy, przy czym nie były one nazbyt częste i występowały tylko w przypadku skrajnych różnic w wyznawanych ideologiach (np. opisane w następnych rozdziałach secesje protajwańskich polityków Nanjō Tokuo i Tamakiego Kazuo z propekińskich frakcji Fujiyamy i Mikiego).

Co ciekawe, zabarwienia ideologiczne frakcji były niejednokrotnie przekazywane z jednej generacji polityków na następną. Wynikało to z faktu, że przez dziesięciolecia lojalnej pracy dla swojego patrona klient zazwyczaj przejmował od niego główną myśl polityczną i w naturalny sposób starał się ją kontynuować po „odziedziczeniu” stanowiska szefa frakcji. Poczucie szacunku dla swojego poprzednika nakazywało zresztą, by nie zbaczać z obranej przez niego drogi. Oczywiście zdarzały się wyjątki, które, co zostanie wykazane w następnych rozdziałach, miały znaczący wpływ na zmianę polityki PLD wobec Chin. Poza tym, jak podkreśla Kōno Yōhei, kolejne pokolenia przewodniczących frakcji w PLD charakteryzowały się coraz mniejszym „,nasyceniem” jakąkolwiek ideologią. O ile bowiem bezpośredni następca założyciela frakcji był zazwyczaj jego najbliższym współpracownikiem, o tyle kolejni szefowie frakcji byli tylko pośrednio związani z pierwszym oyabunem i jego politycznymi poglądami. Do takiej sytuacji dochodziło zwłaszcza, gdy dany polityk został przewodniczącym frakcji dzięki zdolnościom zbierania funduszy wyborczych, a nie ustalania dalekosiężnej wizji politycznej ${ }^{95}$.

\footnotetext{
${ }^{90}$ Fukunaga Fumio, Habatsu kōzō kara mita Kōchikai - Soshiki, jinteki kōsei, rikurūtomento, „Dokkyō Hōgaku” 2005, nr 67, s. 91.

${ }^{91}$ Zagadnienie to zostanie szerzej omówione w części poświęconej typologii frakcji.

${ }^{92}$ Nakane Chie, op.cit., s. 128.

${ }^{93}$ Ibidem, s. $128-129$.

${ }^{94}$ Wywiad autora z Kōno Yōheiem, Rezydencja Marszałka Izby Reprezentantów w Tokio, 13 III 2009.

${ }^{95}$ Ibidem.
} 
W historii PLD istniały zarówno frakcje naprawdę duże, liczące ponad stu parlamentarzystów, jak i małe, skupiające zaledwie kilka osób ${ }^{96}$. Podstawową zasadą rządzącą rozwojem frakcji była jednak „logika liczby” (kazu no ronri), nakazująca jak najbardziej efektywne zwiększanie liczby członków ${ }^{97}$. Chociaż początkowo do frakcji należeli tylko posłowie z Izby Reprezentantów, w latach 60. XX wieku członkostwo rozszerzyło się także na parlamentarzystów z Izby Radców. Mimo że zawsze istniało pewne grono parlamentarzystów bezfrakcyjnych, aż do 2005 roku było ono stosunkowo nieliczne. Zresztą nawet wśród nich wielu posłów nieoficjalnie sympatyzowało z określoną grupą wewnątrzpartyjną.

Największą frakcję w historii PLD stworzył na początku lat 80. XX wieku Tanaka Kakuei, a później Takeshita Noboru. W szczytowym momencie rozwoju w drugiej połowie lat 80. XX wieku liczba jej członków sięgała 140 parlamentarzystów. Długotrwała obserwacja zdaje się jednak potwierdzać spostrzeżenie, że optymalny rozmiar frakcji wynosił mniej więcej od 60 do 80 członków. Poniżej tej liczby frakcja posiadała zbyt małą siłę, aby skutecznie walczyć o istotne stanowiska partyjne czy państwowe. Z kolei zbyt duża grupa, dążąc do hegemonii w partii, mogła skłonić pozostałe frakcje do stworzenia koalicji przeciw niej. Na dodatek po przekroczeniu pewnej liczby członków frakcja stawała się mniej spójna i mogły się w niej pojawić podziały wewnętrzne ${ }^{98}$. Niezadowoleniu $\mathrm{w}$ takiej grupie sprzyjała także niemożność zapewnienia adekwatnych stanowisk dla wszystkich jej zasłużonych członków.

Razem ze wzrostem liczby członków, frakcje stały się tworami wysoce zinstytucjonalizowanymi. Chociaż potocznie określało się je od nazwiska przywódcy, posiadały starannie dobrane nazwy, czasami pochodzące od wyrażeń potocznych, czasami zaś mające dodać grupom poważnego charakteru „stowarzyszeń badawczych”. W niektórych frakcjach nazwy te ulegały zmianie przy okazji ważnych wydarzeń, jak wchłonięcie mniejszej grupy czy zmiana lidera, w niektórych zaś nazwa stanowiła część „etosu” grupy i była przekazywana z pokolenia na pokolenie. Przykładem może być nazwa byłej frakcji Ikedy, Kōchikai, używana od lat 50. XX wieku po dzień dzisiejszy. Dla ułatwienia lektury, frakcje nazywane są w pracy według nazwisk liderów w danym czasie, zaś w przypadku bardziej ogólnych uwag dotyczących poszczególnych nurtów według nazwisk ich założycieli (np. dawna frakcja Ikedy).

\footnotetext{
${ }^{96}$ Można by uszeregować pięć głównych frakcji PLD według wielkości. Największą była zazwyczaj frakcja Satō, następnie dwie duże frakcje Kishiego i Ikedy, średnich rozmiarów frakcja Kōno i najmniejsza z piątki frakcja Mikiego. Wielkość poszczególnych frakcji ewoluowała jednak $\mathrm{z}$ czasem, co zostanie przedstawione $\mathrm{w}$ dalszych rozdziałach pracy.

${ }^{97}$ Iseri Hirofumi, op.cit., s. 87.

${ }^{98}$ Cheol Hee Park, op.cit., s. 443-444.
} 
Frakcje posiadały także własne siedziby z sekretariatami, a nawet wydawały osobne publikacje ${ }^{99}$. Co tydzień w czwartki odbywały się regularne spotkania wszystkich członków ${ }^{100}$. Każdy z nich piastował także stanowisko stosowne do ilości kadencji, które miał za sobą w parlamencie. Na przykład we frakcji Kōmoto w 1987 roku taka struktura organizacyjna składała się z: przewodniczącego, wiceprzewodniczącego, przewodniczącego posiedzeń, członków zarządu, głównego dyrektora i jego asystentów, koordynatorów polityki i całościowego planowania, zastępców koordynatorów, badaczy oraz ich asystentów. O ile przewodniczący mógł się pochwalić piętnastoma kadencjami, zaś wiceprzewodniczący jedenastoma, najniżej usytuowani asystenci badaczy byli parlamentarzystami dopiero pierwszej lub drugiej kadencji ${ }^{101}$. Z drugiej strony, realna pozycja polityków w ramach frakcji Kōmoto nieco odbiegała od oficjalnej hierarchii i wynikała także z indywidualnych predyspozycji polityków, a nie tylko samego starszeństwa ${ }^{102}$.

Instytucjonalizacja osiągała czasami taki poziom, że frakcje spisywały nawet własny statut. Działo się tak szczególnie w przypadku uformowania olbrzymich grup wewnątrzpartyjnych, nad którymi trudno było zapanować. Przykładem może być statut utworzonej w 1987 roku frakcji Takeshity (Keiseikai). Składał się on z siedmiu artykułów, regulujących proces podejmowania decyzji we frakcji i zależności pomiędzy jej poszczególnymi organami, którymi oprócz przewodniczącego i sekretariatu generalnego były np. działy spraw ogólnych czy politycznych ${ }^{103}$. W celu sprawnego kierowania rozrośniętymi frakcjami starano się także tworzyć w ich ramach mniejsze, bardziej spójne grupy. Jednym z kryteriów podziału była ilość kadencji. Tanaka Kauei powołał do życia np. oddzielne stowarzyszenia zrzeszające parlamentarzystów według stażu politycznego (nenji betsu soshiki), zakazując jednocześnie formowania innych grup wewnątrz frakcji. Miało to na celu zapobieżenie rozłamom oraz sprawowanie kontroli nad dystrybucją informacji i wymianą myśli pomiędzy politykami. Podobne zrzeszenia tworzyły również inne frakcje ${ }^{104}$. Oprócz grup samych polityków, Tanaka Kakuei powołał do życia także specjalne organizacje zrzeszające sekretarzy parlamentarzystów należących do frakcji. Łącznie

\footnotetext{
${ }^{99}$ J. A. A. Stockwin, Factionalism in Japanese Political Parties, „Japan Forum” 1989, vol. 1, no. 2 , s. 168 .

${ }^{100} \mathrm{~W}$ marcu 2009 roku autor uczestniczył w spotkaniu frakcji premiera Asō. Dyskusja, jaka się na nim wywiązała, nie dotyczyła przedsięwzięć programowych, a raczej polegała na wymianie informacji na temat relacji interpersonalnych panujących w innych frakcjach.

${ }^{101}$ David M. Morris, The Internal Roles and Functions of Kömoto Faction Liberal Democratic Party Members, ,Japan Forum” 1989, vol. 1, no. 2, s. 152.

102 Ibidem, s. 157.

${ }^{103}$ Iseri Hirofumi, op.cit., s. 33-35.

${ }^{104}$ Ibidem, s. 37-43.
} 
skupiały one ponad 400 osób i stanowiły istotne narzędzie utrzymania dyscypliny frakcyjnej ${ }^{105}$.

Jak widać, frakcje starały się wpływać na każdą sferę działalności swoich członków, jeszcze bardziej umacniając solidarność między nimi. Jak podkreśla Iseri Hirofumi, narastająca od lat 70. XX wieku tendencja do wysokiej instytucjonalizacji działalności frakcji w PLD w wyraźny sposób nadała im charakter „sztucznych partii” (giji seitō $)^{106}$. Z drugiej strony, od czasu reformy 1994 roku widać przeciwną tendencję. Centralne organy partyjne zaczęły dominować nad strukturami organizacyjnymi poszczególnych frakcji, co wpłynęło na dynamikę rywalizacji międzyfrakcyjnej.

\section{Funkcje frakcji w PLD}

Frakcje spełniały trzy podstawowe funkcje: mobilizowały poparcie wyborcze dla własnych członków, pozyskiwały i zarządzały funduszami oraz zajmowały się negocjacjami z pozostałymi grupami, w tym na temat obsadzania stanowisk, zarówno partyjnych, jak i rządowych ${ }^{107}$. Funkcje te uległy zauważalnej zmianie po reformie systemu wyborczego w 1994 roku.

W zamian za lojalność wobec przywódcy frakcji, polityk mógł liczyć na konkretne ułatwienia $\mathrm{w}$ karierze, między innymi na wsparcie w kampanii wyborczej. Frakcje zabiegały o wystawienie własnych kandydatów w poszczególnych okręgach, co nabrało kluczowej wagi, odkąd są one jednomandatowe. Równie istotne stało się zapewnienie członkom danej frakcji odpowiednio wysokich miejsc na listach partyjnych do 11 dużych okręgów. Frakcja, która o to umiejętnie zadbała, mogła liczyć na zwiększenie swoich szeregów w przyszłym parlamencie, a co za tym idzie także wpływu na politykę partyjną. Do 1994 roku najważniejsze było jednak poparcie frakcyjne dla własnych członków na poziomie okręgu wyborczego, gdzie musieli oni konkurować z innymi politykami PLD. Wspierano zwłaszcza najmłodszych kandydatów, którzy nie mieli jeszcze wyrobionych koneksji lokalnych. Pomoc taka polegała chociażby na wygłoszeniu przemowy przez ministra na posiedzeniu kōenkai młodszego kolegi $\mathrm{z}$ frakcji, bądź też na zapewnieniu kontaktów w Tokio, aby początkujący polityk mógł załatwić sprawę, o którą został poproszony przez jakiegoś wpływowego przywódcę opinii z rodzinnego okręgu $^{108}$. Takie budowanie wizerunku i osobistych stosunków z wyborcami poprzez określone środowiska i organizacje nadal odgrywa dużą rolę przy rywalizacji z kandydatami innych partii ${ }^{109}$.

\footnotetext{
${ }^{105}$ Ibidem, s. 76-79.

${ }^{106}$ Ibidem, s. 37.

${ }^{107}$ Cheol Hee Park, op.cit., s. 433.

${ }^{108}$ David M. Morris, op.cit., s. 154.

${ }^{109}$ Ray Christensen, The Effect of Electoral Reforms on Campaign Practices in Japan, „Asian Survey" 1998, vol. 38, no. 10, s. 1003.
} 
$\mathrm{Z}$ drugiej strony, obecnie kandydaci przed wyborami nie podkreślają już tak mocno jak dawniej przynależności frakcyjnej, aby móc łatwiej przyciągnąć głosy wyborców niezwiązanych ściśle $\mathrm{z}$ żadnym środowiskiem ${ }^{110}$. Więzy polityków PLD z tradycyjnymi grupami społecznymi zostały zresztą osłabione za pięcioletniej kadencji Koizumiego Jun’ichirō (2001-2006). Dzięki własnej popularności Koizumi siłą narzucał swoją wolę całej PLD, tępiąc przy tym wewnątrzpartyjną opozycję. Na miejsce buntowników, którzy przeciwstawiali się jego linii politycznej, niejednokrotnie wyznaczał na kandydatów „nowe twarze" ze świata mediów. W ten sposób pokazał, że dzięki reformom z 1994 roku przewodniczący partii może dzięki własnej charyzmie jeszcze bardziej ograniczyć funkcję frakcji związaną z mobilizacją poparcia wyborczego.

Następna funkcja - zarządzanie olbrzymimi pieniędzmi - odróżniała frakcje od innych grup wewnątrzpartyjnych. Związki frakcji ze światem biznesu oraz wszechobecna ,polityka pieniądza” (kinken seiji) zawsze spotykały się jednak z ostrą krytyką opinii publicznej. Funkcja związana $\mathrm{z}$ pozyskiwaniem i rozdzielaniem funduszy uległa zmianie po reformie odpowiedniego ustawodawstwa w 1975 i 1994 roku. Pierwotnie to przywódcy frakcyjni zajmowali się zbieraniem pieniędzy od zamożnych sympatyków, którymi w przypadku PLD były tradycyjnie firmy budowlane, środowiska wiejskie czy organizacje weteranów. Młodzi politycy mogli wówczas liczyć na istotne wsparcie finansowe od swoich patronów. Ciężar pozyskiwania funduszy spadł jednak z czasem także na barki szeregowych członków frakcji.

Za kadencji Mikiego Takeo (1974-1976) wprowadzono ograniczenia w finansowaniu partii, ustanawiając górną granicę datków od pojedynczego przedsiębiorcy na $100 \mathrm{mln}$ jenów rocznie. Politycy dostosowali się jednak do nowej sytuacji. Zamiast przyjmować duże wpłaty od kilku wielkich przedsiębiorstw, zaczęli zabiegać o większą liczbę mniejszych składek od liczniejszej grupy ludzi biznesu ${ }^{111}$. W 1994 roku ostatecznie zakazano dokonywania wpłat na rzecz pojedynczych polityków przez grupy zorganizowane czy firmy, pozwalając im tylko na datki na rzecz partii. Rozpoczęto również subsydiowanie ugrupowań politycznych ze środków państwowych, co zwiększyło kompetencje centralnych władz PLD kosztem jej frakcji. Jednocześnie górną granicę wpłat na rzecz pojedynczych polityków od osób prywatnych ustalono na 1,5 mln jenów rocznie. W wyniku tych zmian finansowa rola frakcji wyraźnie straciła na znaczeniu. Zamiast bezpośrednio wypłacać swoim członkom pieniądze, frakcje zaczęły wymagać od polityków pozyskiwania funduszy w wielkości proporcjonalnej do sprawowanej funkcji. W porównaniu z przeszłością, środki rozdzielane między członków mają dziś charakter symboliczny ${ }^{112}$.

\footnotetext{
${ }^{110}$ Patrick Köllner, op.cit., s. 94.

${ }^{111}$ Iseri Hirofumi, op.cit., s. 74-75.

${ }^{112}$ Cheol Hee Park, op.cit., s. 435-440.
} 
Z drugiej strony, frakcje potrafiły przystosować się do nowych warunków. Chociaż zabronione zostało wpłacanie dużych sum pieniędzy na rzecz pojedynczych polityków, pozostawiono „furtkę” w postaci możliwości finansowego wspierania lokalnych oddziałów PLD. Ponieważ przewodniczącymi takich filii są politycy, regionalne oddziały partii dominującej zaczęły po prostu odgrywać rolę kōenkai poszczególnych kandydatów ${ }^{113}$. Funkcja frakcji została sprowadzona do dystrybucji ,zaufania”, a nie bezpośrednio pieniędzy od przywódcy do szeregowych parlamentarzystów. Lokalne oddziały opanowane przez członków określonej frakcji tworzą swoistą sieć, która dzięki renomie swojego patrona może bardziej skutecznie przyciągać kapitał ${ }^{114}$.

Również znaczenie funkcji rozdziału stanowisk zostało osłabione po reformie 1994 roku, jednak nie w równym stopniu, jak dwóch poprzednich. Do lat 90 . XX wieku proces tworzenia rządu przebiegał w ścisłym gronie przywódców frakcji. Grupy te zachowywały się wręcz jak oddzielne partie, walczące o jak najbardziej korzystne stanowiska dla swoich członków. Ich liderzy sporządzali listy swoich protegowanych, których by najchętniej widzieli w gabinecie. Według tych rekomendacji premier rozdzielał posady rządowe, zachowując równowagę pomiędzy poszczególnymi frakcjami ${ }^{115}$. Polityk chcący zrobić karierę praktycznie musiał należeć do którejś z wewnątrzpartyjnych grup, gdyż bez pomocy wpływowego patrona miał niewielkie szanse na awans. Po przełomie lat 1993-1994 system ten został zachowany, przy czym przy obsadzie stanowisk PLD musiała brać pod uwagę także żądania swoich koalicjantów.

Bardziej widoczne zmiany nastąpiły za rządów ostatniego $\mathrm{z}$ premierów omawianych w niniejszej pracy. Koizumi Jun’ichirō doszedł do władzy głosząc hasła osłabienia czy wręcz zniesienia frakcyjności w PLD. Zapowiadał m.in., że jego rząd będzie gabinetem ludzi kompetentnych, a nie mianowanych według klucza frakcyjnego ${ }^{116}$. W 2001 roku Koizumi rzeczywiście demonstracyjnie nie konsultował $\mathrm{z}$ przywódcami frakcji swoich decyzji w sprawie obsadzenia ministerstw. Z drugiej strony, jego kolejne gabinety siłą rzeczy musiały odzwierciedlać rozkład sił wewnątrz partii. Jak podkreślał przewodniczący Komisji Spraw Zagranicznych Izby Reprezentantów, Kōno Tarō, niższe stanowiska państwowe i partyjne nadal były obsadzane według list przygotowywanych przez szefów frakcji. Co więcej, nawet grupa posłów bezfrakcyjnych stanowiła w tym przypadku swoistą „frakcję", przedstawiając własnych kandydatów poprzez reprezentanta wybranego ze swojego grona ${ }^{117}$.

Odrębnego omówienia wymaga rola frakcji przy wyznaczaniu samego przewodniczącego partii. Można tu wyróżnić trzy metody: wybory (także

\footnotetext{
${ }^{113}$ Tsuchiya Shigeru, Jimintō habatsu kōbōshi, Kadensha, Tokio 2000, s. 72.

${ }^{114}$ Ibidem, s. 79-80.

${ }^{115}$ Iseri Hirofumi, op.cit., s. 129.

${ }^{116}$ Itagaki Eiken, Sengoku Jimintō 50 nen shi - Kenryoku tōsōshi, Kadensha, Tokio 2005, s. 189.

${ }^{117}$ Wywiad autora z Kōno Tarō, Parlament Japonii w Tokio, 10 III 2009.
} 
prawybory), naradę oraz nominację (arbitraż). $\mathrm{Z}$ zasady powinno się organizować wybory pośród członków partii. Do 1978 roku przewodniczący wybierany był na zjazdach partyjnych przez parlamentarzystów z PLD oraz reprezentantów oddziałów partyjnych z każdej prefektury. Później wprowadzono prawybory (yobi senkyo), w których mogli uczestniczyć wszyscy zarejestrowani członkowie PLD, ale ostatecznie przewodniczącego wyznaczali parlamentarzyści spośród dwóch kandydatów, którzy uzyskali najwięcej głosów. Reguły elekcji zmieniały się zresztą kilkakrotnie, zaś jej końcowy wynik zależał przede wszystkim od zakulisowych układów międzyfrakcyjnych. Na dodatek czasami do realnych wyborów w ogóle nie dochodziło. Zdarzało się tak, jeśli panował konsensus co do określonej kandydatury, albo gdy szefowie frakcji po serii zakulisowych rozmów doszli do kompromisu w sprawie przyszłego przewodniczącego PLD. Była to tzw. elekcja przez naradę (hanashiai). Szczególny wariant takiego scenariusza stanowiła nominacja, czyli arbitraż (saitei). Jeżeli szefowie frakcji nie mogli dojść do porozumienia, zaś pragnęli uniknąć wyborów, by nie podgrzewać atmosfery rywalizacji do stanu grożącego rozłamem w partii, powierzali decyzję jednemu z seniorów w ugrupowaniu. Zazwyczaj był nim ustępujący premier bądź wiceprzewodniczący PLD, który arbitralnie wyznaczał nowego lidera ${ }^{118}$. Jak widać, układy pomiędzy frakcjami miały decydujące znaczenie przy elekcji poprzez naradę i wybory, zaś również w przypadku arbitrażu decydent musiał wziąć pod uwagę delikatną równowagę sił w ugrupowaniu.

Po reformie 1994 roku da się jednak zauważyć powolne zmiany, mogące świadczyć o zmniejszeniu roli grup wewnątrzpartyjnych w elekcji przewodniczącego PLD. Osłabienie solidarności członków frakcji sprawiło, że zakulisowe układy między ich przewodniczącymi przestały być decydującym czynnikiem przy wyborze prezesa partii. Znacznie ważniejsze stały się za to popularność i charyzma poszczególnych kandydatów, które mogą pozytywnie wpłynąć na notowania całego ugrupowania.

\section{Typologia frakcji w PLD}

Typologii frakcji personalnych w PLD można dokonać biorąc pod uwagę trzy główne kryteria podziału. Dwa z nich: opozycja ,głównego nurtu konserwatywnego" i „bocznego nurtu konserwatywnego”, jak też „biurokratów” i „ludzi partii”, mają związek z pochodzeniem poszczególnych polityków z różnych środowisk, wobec czego najbardziej widoczne były u zarania PLD. Trzecia $\mathrm{z}$ linii podziału, na ,jastrzębie” i ,gołębie”, odwołuje się do poglądów członków frakcji, w szczególności na temat polityki zagranicznej. Na tle tych trzech opozycji można także zarysować podział na obóz propekiński i protajwański.

\footnotetext{
118 Tanaka Zen'ichirō, Jimintō no duramatsurugī. Sōsai senshutsu to habatsu, Tōkyō Daigaku Shuppankai, Tokio 1986, s. 65-79.
} 
Chociaż w 1955 roku praktycznie wszystkie japońskie partie konserwatywne zjednoczyły się tworząc PLD, animozje z poprzedniego okresu przetrwały w ramach nowego ugrupowania pod postacią rywalizacji międzyfrakcyjnej. Frakcje, które tuż przed powstaniem PLD należały do Partii Liberalnej, zwykło się nazywać „głównym nurtem konserwatywnym” (hoshu honryū ${ }^{119}$, zaś te, które wywodziły się z Japońskiej Partii Demokratycznej, „bocznym nurtem konserwatywnym" (hoshu bōryū). Podział ten z jednej strony odnosi się do dwóch wizji miejsca Japonii w epoce zimnowojennej, $\mathrm{z}$ drugiej zaś był uwarunkowany rywalizacją pomiędzy dwoma politykami o silnej osobowości: Yoshidą Shigeru i Hatoyamą Ichirō.

Twórcą „głównego nurtu konserwatywnego" 120 był Yoshida Shigeru, premier w latach 1946-1947 oraz 1948-1954. Trudno przecenić wpływ, jaki wywarł on na politykę Japonii, jednak szefem rządu został z przypadku. Kiedy w pierwszych powojennych wyborach parlamentarnych w 1946 roku zwyciężyła Japońska Partia Liberalna (Nihon Jiyūtō) ${ }^{121}$, jej przywódca Hatoyama Ichirō razem z dużą grupą przedwojennych polityków otrzymał od amerykańskich władz okupacyjnych zakaz pełnienia funkcji publicznych. Nie mogąc samemu zostać premierem, Hatoyama zdecydował się powierzyć misję stworzenia rządu Yoshidzie Shigeru, ówczesnemu ministrowi spraw zagranicznych. Warunkiem miała być gotowość oddania stanowiska w razie cofnięcia ograniczeń w piastowaniu urzędów przez polityków przedwojennych ${ }^{122}$. W czasie swoich długich rządów Yoshida wprowadził do świata polityki wiele nowych osób, które wypełniły lukę po tymczasowo odciętych od kręgów władzy przedwojennych parlamentarzystach ${ }^{123}$. W naturalny sposób stał się też ich

\footnotetext{
${ }^{119}$ Gotō Motoo, Uchida Kenzō, Ishikawa Masumi, Sengo hoshu seiji no kiseki, t. 2, Iwanami Shoten, Tokio 1994, s. 35; Uchida Kenzō, Sengo saishōron, Bungei Shunjū, Tokio 1994, s. 122; Yayama Tarō, Jimintō Hashimoto-ha no taizai, Fusōsha, Tokio 2004, s. 46; Jin Xide, „Jue-Fu zhanzheng” de neihan, puxi jiqi xin taishi, „Ribenxuekan” 2008, nr 4, s. 40.

${ }^{120}$ Istnieją również inne interpretacje „głównego nurtu konserwatywnego”, np. utożsamiające go z realizmem politycznym, wsparciem dla traktatu sojuszniczego ze Stanami Zjednoczonymi z 1960 roku bądź z odwagą formułowania nowych wizji Japonii. Szerzej na ten temat: Iseri Hirofumi, op.cit., s. 112-116; Kitaoka Shin'ichi, Jimintō - Seikentō no 38 nen, Chūō Kōron Shinsha, Tokio 2008, s. 104-105; Tanaka Rokusuke, Hoshu honryū no chokugen, Chūō Kōronsha, Tokio 1985, s. $118-132$.

${ }^{121}$ Japońska Partia Liberalna powstała w 1945 roku. W 1948 roku zmieniła nazwę na Partię Demokratyczno-Liberalną (Minshu Jiyūtō), zaś w 1950 roku na Partię Liberalną (Jiyūtō). Szerzej na ten temat: Ishikawa Masumi, Sengo seijishi, Iwanami Shoten, Tokio 2004, s. 26-51.

${ }^{122}$ Hatoyama twierdzi, że Yoshida nie tylko wyraził zgodę na ten warunek, ale także podpisał się pod pisemną przysięgą, że odda władzę, jeśli tylko Hatoyama powróci do polityki. Hatoyama Ichirō przyznaje jednak, że później zgubił ten dokument. Z kolei według Yoshidy Shigeru nie było żadnego ustnego ani pisemnego porozumienia w tej sprawie. Szerzej na ten temat: Hatoyama Ichirō, Hatoyama Ichirō kaikoroku, Bungei Shunjū Shinsha, Tokio 1957, s. 55-56; Yoshida Shigeru, Kaisō 10 nen, t. 1, Chūō Kōronsha, Tokio 1998, s. 191.

${ }^{123}$ Tominomori Eiji, Sengo hoshutōshi, Iwanami Shoten, Tokio 2006, s. 64.
} 
oyabunem. Na określenie „głównego nurtu konserwatywnego" używa się wręcz terminu „,szkoła Yoshidy” (Yoshida no gakkōo) ${ }^{124}$.

Oprócz osobistych związków z Yoshidą Shigeru, przynależność do „głównego nurtu konserwatywnego" wiązała się również z przyjęciem określonej linii politycznej, tzw. „doktryny Yoshidy” (Yoshida dokutorin). Polegała ona na odłożeniu na później problemu remilitaryzacji kraju i skupieniu się na odbudowie zniszczonej w czasie II wojny światowej gospodarki Japonii. Aby osiągnąć ten cel w warunkach zimnowojennych konieczne stało się oparcie dyplomacji na sojuszu ze Stanami Zjednoczonymi, który mógłby obronić Japonię przed ewentualnymi atakami z zewnątrz, szczególnie ze strony Związku Radzieckiego ${ }^{125}$. Następcy myśli Yoshidy Shigeru często bardzo ortodoksyjnie traktowali tę doktrynę, nawet gdy uwarunkowania geopolityczne uległy głębokim zmianom ${ }^{126}$. Największymi grupami należącymi do „głównego nurtu konserwatywnego" były frakcje założone przez Satō Eisaku i Ikedę Hayato ${ }^{127}$. Chociaż początkowo istniał silny opór społeczny przeciw „doktrynie Yoshidy”, szczególnie w części dotyczącej stacjonowania amerykańskiego wojska w Japonii, na przełomie lat 60 . i 70. XX wieku została ona zinternalizowana przez szersze kręgi społeczne, a przynajmniej przez większość obozu konserwatywnego ${ }^{128}$.

W opozycji do „głównego nurtu konserwatywnego” uformował się „boczny nurt konserwatywny" Hatoyamy Ichirō, pierwotnie skupiający przede wszystkim polityków przedwojennych. Na początku lat 50 . XX wieku, razem z narastaniem zimnej wojny i wybuchem wojny koreańskiej, zmieniła się polityka Stanów Zjednoczonych wobec Japonii. Władze okupacyjne porzuciły dotychczasową linię zwalczania militaryzmu i zaczęły wręcz zabiegać o ponowne uzbrojenie Japonii jako ważnego sojusznika w walce $\mathrm{z}$ komunizmem. Na przeszkodzie do realizacji tego zadania stała jednak ,doktryna Yoshidy”. Po podpisaniu traktatu pokojowego z San Francisco w 1951 roku zaczęto stopniowo cofać zakaz

\footnotetext{
${ }^{124}$ Iseri Hirofumi, op.cit., s. 112.

${ }^{125}$ Yoshida Shigeru, Kaisō..., t. 4, s. 24-30; Amako Satoshi, Nitchū gaikō hikaku kara mita nitchū kankei [w:] Nitchū kankei o dō kōchiku suru ka. Ajia no kyōsei to kyōryoku o mezashite pod red. Mōri Kazuko i Zhang Yun-linga, Iwanami Shoten, Tokio 2004, s. 30; Norman D.Levin, The Strategic Dimensions of Japanese Foreign Policy [w:] Japan's Foreign Policy After the Cold War. Coping with Change pod red. G. L. Curtisa, M. E. Sharpe, Armonk-London 1993, 202-213.

${ }^{126}$ Sam Yoshida Shigeru był raczej realistą niż pacyfistą. W warunkach powojennych wybrał po prostu najbardziej opłacalną dla Japonii linię dyplomatyczną, nie wykluczając remilitaryzacji w przyszłości. Szerzej na ten temat: Yoshida Shigeru, Kaisō..., t. 2, s. 182-187; idem, Sekai to Nihon, Banchō Shobō, Tokio 1963, s. 202-203.

${ }^{127}$ Fukunaga Fumio, profesor Uniwersytetu Dokkyō w Saitamie, podkreśla, że podział na obozy Yoshidy i Hatoyamy był nie do końca ostry. Np. Ōno Banboku można tak naprawdę nazwać „człowiekiem Hatoyamy”, który pozostał w obozie Yoshidy. Wywiad autora z Fukunagą Fumio, Nishinomiya, 27 XII 2008.

${ }^{128}$ Qingxin Ken Wang, Hegemonic Cooperation and Conflict: Postwar Japan's China Policy and the United States, Praeger Publishers, Westport 2000, s. 265.
} 
sprawowania urzędów publicznych przez polityków przedwojennych. Hatoyama Ichirō liczył, że Yoshida Shigeru spełni obietnicę i odda mu kierownictwo nad partią.

Przedstawiciele „bocznego nurtu konserwatywnego" reprezentowali różne opcje ideologiczne, odzwierciedlające japońską scenę polityczną sprzed 1945 roku. Dominowali wśród nich „rewizjoniści”, dążący do zmiany narzuconej przez Stany Zjednoczone, „upokarzającej” konstytucji uchwalonej w 1946 roku $^{129}$, remilitaryzacji kraju, współpracy z USA na poziomie równego partnerstwa i przywrócenia narodowi japońskiemu ,tradycyjnych wartości”. Należy tu wymienić zwłaszcza frakcje Kishiego Nobusuke i Kōno Ichirō. Z drugiej strony, do „bocznego nurtu konserwatywnego” zaliczali się także pacyfiści, którzy przed 1945 rokiem apelowali o porzucenie ekspansjonistycznej polityki Japonii. Najbardziej prominentne postacie tego grona to Ishibashi Tanzan (został politykiem po wojnie, ale też skazano go na zakaz pełnienia urzędów publicznych), Miki Takeo czy Matsumura Kenzō (środowisko anty-Yoshidowej Partii Reform). Jednych i drugich łączyła głównie chęć odsunięcia od władzy Yoshidy Shigeru i przywrócenia Japonii pełnej niezależności od Stanów Zjednoczonych.

Premier Yoshida odwlekał jednak moment cofnięcia zakazu sprawowania urzędów publicznych przez Hatoyamę Ichirōo ${ }^{130}$. Według Hatoyamy, robił to celowo, obawiając się konkurenta na stanowisko premiera. Ostatecznie Hatoyamie pozwolono powrócić do działalności politycznej w sierpniu 1951 roku ${ }^{131}$. Następne lata były okresem zaciekłej rywalizacji pomiędzy obozem Hatoyamy a Yoshidy. W wyniku licznych sporów tak na tle personalnym, jak i ideologicznym, w Partii Liberalnej (Jiyūtō) doszło do rozłamu. Grupa skupiona wokół Hatoyamy Ichirō opuściła środowisko Yoshidy Shigeru i łącząc się z innym ugrupowaniem konserwatywnym, Partią Reform (Kaishintō), powołała do życia w listopadzie 1954 roku Japońską Partię Demokratyczną (Nihon Minshutō). W wyniku porozumienia z Japońską Partią Socjalistyczną Hatoyama Ichirō obalił gabinet Yoshidy Shigeru i został premierem w grudniu 1954 roku $^{132}$. Aby zbudować stabilną bazę poparcia dla rządu konieczne było jednak zjednoczenie obu nurtów konserwatywnych. Doszło do niego w listopadzie 1955 roku. Z połączenia Partii Liberalnej Ogaty Taketory ${ }^{133}$ i Japońskiej Partii Demokratycznej Hatoyamy Ichirō powstała Partia Liberalno-Demokratyczna (Jiyū Minshutō). Opozycja pomiędzy „głównym nurtem konserwatywnym” i

\footnotetext{
${ }^{129}$ Konstytucja ta weszła w życie 3 maja 1947 roku. W artykule 9 sformułowano zakaz posiadania przez Japonię jakiegokolwiek ,potencjału zbrojnego” (senryoku). Szerzej na ten temat: Kenpō pod red. Kurikiego Hisao i Tonamiego Kōjiego, Seirin Shoin, Tokio 1995, s. 113-118.

${ }^{130}$ Itagaki Eiken, op.cit., s. 33.

${ }^{131}$ Hatoyama Ichirō, op.cit., s. 94-112.

${ }^{132}$ Fukunaga Fumio, Sengo Nihon no saisei - 1945 -1965 nen, Maruzen, Tokio 2004, s. 183-186.

${ }^{133}$ W 1954 roku Yoshida Shigeru przekazał przywództwo w Partii Liberalnej Ogacie Taketorze.
} 
„bocznym nurtem konserwatywnym” pozostała jednak bardzo wyraźna w nowej partii i chociaż z czasem uległa pewnemu zatarciu, w wielu aspektach po dzień dzisiejszy wpływa na dynamikę rywalizacji międzyfrakcyjnej.

Następna $\mathrm{z}$ linii podziału $\mathrm{w}$ ramach PLD przebiegała pomiędzy frakcjami biurokratów (kanryōha) a „ludzi partii” (tōjinha). Obóz dawnych biurokratów był w dużym stopniu tożsamy z „głównym nurtem konserwatywnym”. Yoshida Shigeru, który sam się wywodził z biurokracji Ministerstwa Spraw Zagranicznych, po objęciu urzędu premiera wprowadził do świata polityki wielu wyższych urzędników państwowych, zwłaszcza z Ministerstwa Finansów. Jednakże również w „bocznym nurcie konserwatywnym” jedna $\mathrm{z}$ ważnych frakcji (Kishiego Nobusuke) skupiała wiele osób pochodzących ze środowiska biurokracji. Dawni biurokraci specjalizowali się w formułowaniu polityki i rutynowym administrowaniu krajem, ale brakowało im zdolności pozyskiwania zwolenników dla swoich projektów w partii i w parlamencie ${ }^{134}$.

W przeciwieństwie do biurokratów, obóz „ludzi partii” zrzeszał osoby, które w stosunkowo młodym wieku rozpoczęły karierę polityczną, np. jako partyjni działacze regionalni czy sekretarze posłów, bądź też przeszli do świata polityki z takich zawodów, jak dziennikarstwo. Dominowali wśród nich parlamentarzyści przedwojenni, często czujący niechęć do mających mniejszy staż w świecie polityki dawnych biurokratów. Odwrotnie niż byli biurokraci, zawodowi politycy potrafili mobilizować poparcie dla swoich inicjatyw, jednak mieli gorsze przygotowanie merytoryczne do administrowania krajem. Chociaż podział na frakcje biurokratów i „ludzi partii” odgrywał znaczną rolę w pierwszym z omawianych w pracy okresów, z czasem uległ niemal całkowitemu zatarciu. Obecnie każda z frakcji zrzesza zarówno dawnych biurokratów, jak i „Zawodowych” polityków, często zresztą w drugim czy trzecim pokoleniu ${ }^{135}$.

Trzecia linia podziału pomiędzy frakcjami w największym stopniu dotyka ideologicznych przekonań ich członków. Chociaż stanowiska w sprawie polityki wewnętrznej czy zagranicznej nie mały kluczowego znaczenia przy podziale na frakcje, da się zauważyć pewne stopnie nasilenia bardziej pacyfistycznych lub nacjonalistycznych poglądów wśród członków poszczególnych grup. Parlamentarzystów z frakcji należących do pierwszego obozu można nazwać „gołębiami” (hatoha), zaś do drugiego ,jastrzębiami” (takaha).

Politycy ze skrzydła pacyfistycznego promowali wizję Japonii jako kraju szybko rozwijającego się gospodarczo, który ostatecznie porzucił politykę ekspansjonizmu. Japonia według „gołębi” powinna być mocarstwem gospodarczym, a nie militarnym. Dla części z nich (frakcja Ikedy) zachowanie pacyfistycznego ustroju i skupienie się na ekonomii miał zapewnić Japonii strategiczny sojusz ze Stanami Zjednoczonymi, które wezmą na siebie obowiązek obrony granic swojego partnera. Dla innych (środowisko Ishi-

\footnotetext{
${ }^{134}$ Hoshi Hiroshi, Jimintō to sengo - Seikentō no 50 nen, Kōdansha, Tokio 2005, s. 50-53.

${ }^{135}$ Iseri Hirofumi, op.cit., s. 116.
} 
bashiego, Mikiego i Matsumury) zaś wręcz przeciwnie, gwarancją utrzymania pokoju mogło być uniezależnienie się od USA. Wszakże będąc amerykańskim sojusznikiem Japonia narażała się na konfrontację z obozem komunistycznym. Według tej grupy należało intensywnie szukać porozumienia $\mathrm{z}$ innymi państwami azjatyckimi, niezależnie od zimnowojennych podziałów. Wspólną cechą „gołębi” był ich dystans do sporów ideologicznych, które mogły tylko przeszkadzać w szybkim rozwoju gospodarczym kraju, np. blokując handel z państwami komunistycznymi ${ }^{136}$.

Z kolei nacjonaliści (frakcje Kishiego i Kōno) podkreślali potrzebę powrotu do tradycyjnych wartości, remilitaryzacji i rewizji pacyfistycznej konstytucji z 1946/1947 roku. Miało to być środkiem do uzyskania większej samodzielności na arenie międzynarodowej. Według ,jastrzębi” Japonia powinna być „,normalnym krajem" (futsū no kuni), dysponującym wszystkimi wymiarami potęgi ${ }^{137}$. Nacjonaliści pragnęli bardziej partnerskich stosunków między Japonią a Stanami Zjednoczonymi, jak między dwoma równorzędnymi mocarstwami. Poza tym zwracali dużą uwagę na „patriotyczną” politykę edukacyjną, co mogło nabrać znaczenia międzynarodowego, biorąc pod uwagę pamięć sąsiednich krajów o japońskich podbojach z czasów II wojny światowej. Ponadto nacjonaliści ponad miarę wykazywali zainteresowanie sprawami obronności i bezpieczeństwa, przez co często obsadzali stanowisko dyrektora Agencji Obrony. W przeciwieństwie do „gołębi” przywiązywali dużą wagę do podziałów ideologicznych na świecie i starali się aktywnie zwalczać komunizm ${ }^{138}$.

Opozycja obozów protajwańskiego i propekińskiego była mniej wyraźna niż trzech poprzednich i najbardziej podatna na zmiany. Na poglądy liderów frakcji na temat stosunków z Chinami miały wpływ takie czynniki, jak osobiste kontakty z ludźmi władzy w ChRL bądź na Tajwanie ${ }^{139}$, nastawienie do idei antykomunizmu, azjanizmu ${ }^{140}$ czy pacyfizmu, wizja stosunków ze Stanami

\footnotetext{
${ }^{136}$ Karol Żakowski, Przekonania a rzeczywistość. Podziat Partii Liberalno-Demokratycznej na skrzydto liberalne i konserwatywne a japońska polityka zagraniczna [w:] Meandry japońskiej polityki pod red. Joanny Marszałek-Kawy, Wydawnictwo Adam Marszałek, Toruń 2008, s. 11-12.

${ }^{137}$ Termin „,normalnego kraju” wprowadził do japońskiej politologii dopiero Ozawa Ichirō w latach 90. XX wieku, jednak podstawowe założenia tej teorii były od dawna głoszone przez członków nurtu nacjonalistycznego.

${ }^{138}$ Honzawa Jirō, Jimintō habatsu, Piipurusha, Tokio 1990, s. 112-113.

139 Szczególną rolę w uformowaniu się obozu protajwańskiego odgrywała wdzięczność dla prezydenta Republiki Chińskiej Jiang Jieshiego za jego łaskawą postawę po II wojnie światowej wobec pokonanej Japonii. Jiang szybko odesłał jeńców wojennych do Japonii, był zwolennikiem zachowania systemu cesarskiego, przeciwstawiał się planom podziału Japonii na strefy wpływów i zrzekł się odszkodowań wojennych. Szerzej na ten temat: Ōkubo Denzō, Rekishi no shōgen. Nikka kankei - On o ada de kaeshite yoi no ka, Sankei Shinbunsha Shuppankyoku, Tokio - Osaka 1974, s. 91-150; Huang Dahui, op.cit., s. 38.

${ }^{140}$ Azjanizm to nieostry termin. Odnosi się do teorii głoszącej przynależność Japonii do Azji, potrzebę wspomagania innych krajów azjatyckich, a nawet zawiązania z nimi trwałego sojuszu,
} 
Zjednoczonymi oraz przede wszystkim percepcja przydatności sprawy chińskiej w zdobyciu i utrzymaniu władzy w partii. Jak widać po tej złożonej liście uwarunkowań, duży wpływ na wewnątrzpartyjne uwarunkowania polityki PLD wobec Chin siłą rzeczy musiały mieć czynniki zewnętrzne. Poglądy ideologiczne szefów frakcji były „filtrowane” przez ich przydatność w danym czasie, w zależności od zmieniającej się sytuacji międzynarodowej. Wśród pięciu głównych frakcji można jednak wyróżnić te, które zazwyczaj sprzyjały ChRL oraz te, które miały silne powiązania z reżimem Jiang Jieshiego.

Tabela 1.1 Typologia pięciu dużych frakcji w PLD.

\begin{tabular}{|l|l|l|l|l|}
\hline $\begin{array}{l}\text { Przywódca } \\
\text { frakcji }\end{array}$ & $\begin{array}{l}\text { Rodzaj nurtu } \\
\text { konserwatywnego }\end{array}$ & $\begin{array}{l}\text { Pochodzenie } \\
\text { członków }\end{array}$ & Ideologia & $\begin{array}{l}\text { Nastawienie } \\
\text { wobec Chin }\end{array}$ \\
\hline Miki & Boczny & „Ludzie partii” & „Gołębie” & Propekińskie \\
\hline Ikeda & Główny & Biurokraci & „Gołębie” & Propekińskie \\
\hline Satō & Główny & Biurokraci & \multicolumn{2}{|c|}{ Zmienne } \\
\hline Kishi & Boczny & Biurokraci & „Jastrzębie” & Protajwańskie \\
\hline Kōno & Boczny & „Ludzie partii” & „Jastrzębie” & Mieszane \\
\hline
\end{tabular}

Opracowanie własne.

Najwięcej członków obozu protajwańskiego zrzeszała frakcja Kishiego Nobusuke. Jak widać w tabeli 1.1, w jej skład wchodzili politycy „bocznego nurtu konserwatywnego" i ,jastrzębie”, pragnący zmiany konstytucji oraz remilitaryzacji Japonii. Wielu spośród nich było także zdeklarowanymi antykomunistami, pragnącymi zwycięstwa Guomindangu w chińskiej wojnie domowej. Na prawym skrzydle PLD można również znaleźć frakcję Kōno Ichirō. Pod względem pochodzenia przypominała ona grupę Kishiego, przy czym skupiała „ludzi partii” raczej niż dawnych biurokratów. Jako ,jastrzębie”, członkowie frakcji Kōno, podobnie jak frakcji Kishiego, postulowali remilitaryzację kraju i współodpowiedzialność Japonii razem z USA za utrzymanie bezpieczeństwa w Azji Wschodniej, jednak ich stosunek wobec Chin nieco się różnił. Chociaż było wśród nich także wielu zdeklarowanych członków obozu protajwańskiego, część ,jastrzębi”, razem z samym Kōno, jako środek do zniesienia podległości wobec Stanów Zjednoczonych postrzegała normalizację stosunków dyplomatycznych z ZSRR i ChRL, należąc tym samym do obozu propekińskiego. Było to podejście bliskie ideom Hatoyamy Ichirō. Z tego powodu grupę Kōno można nazwać frakcją o mieszanej ideologii.

W skład obozu propekińskiego wchodzili politycy, którym co prawda daleko było do poglądów marksistowskich, ale potrafili uznać możliwość pokojowej współpracy pomiędzy państwami należącymi do przeciwstawnych bloków

aby zapewnić pokój w regionie. Szerzej na ten temat: Tomoda Seki, Nyūmon - Gendai Nihon gaikō, Chūō Kōronsha, Tokio 1988, s. 208-209. 
ideologicznych ${ }^{141}$. Spośród pięciu dużych frakcji propekińskimi można nazwać grupy Mikiego i Ikedy. Chociaż obie zrzeszały „gołębi”, wywodziły się z zupełnie różnych środowisk. Jak widać w tabeli 1.1, o ile grupa Mikiego Takeo skupiała polityków „bocznego nurtu konserwatywnego”, przede wszystkim „ludzi partii”, frakcja Ikedy Hayato stanowiła rdzeń ,głównego nurtu konserwatywnego" i zrzeszała przede wszystkim dawnych biurokratów wprowadzonych do świata polityki przez Yoshidę Shigeru. Obie grupy były jednak bliskie pod względem ideologii. Mikiego można nazwać zdeklarowanym pacyfistą, przeciwstawiającym się wskrzeszeniu w Japonii militaryzmu, zaś Ikeda starał się kontynuować „doktrynę Yoshidy”, zakładającą zrzucenie ciężaru obrony Japonii na barki USA. Pierwszy postrzegał współpracę z ChRL jako szansę pokojowej stabilizacji stosunków międzynarodowych w Azji Wschodniej i okazję do zadośćuczynienia temu krajowi za krzywdy doznane w czasie japońskiego ekspansjonizmu, drugi zaś pragnął, by korzystne kontakty handlowe z Pekinem przyczyniły się do odbudowy japońskiej gospodarki.

Pomiędzy obozem protajwańskim i propekińskim znajdowała się dawna frakcja Satō. Ta wywodząca się z „głównego nurtu konserwatywnego" i środowiska biurokracji grupa wykazywała umiarkowanie protajwańskie nastawienie pod przewodnictwem Satō Eisaku (1956-1972), zaś w 1972 roku, w okresie rządów Tanaki Kakueia, stała się jedną z frakcji obozu propekińskiego. Tak naprawdę grupa Satō posiadała najmniej wyraźny koloryt ideologiczny spośród wszystkich frakcji w PLD ${ }^{142}$. Jak widać, w tabeli 1.1 zajmuje ona miejsce centralne, pomiędzy „gołębiami” i ,jastrzębiami” oraz między obozem protajwańskim i propekińskim. Parlamentarzyści tej grupy w większym stopniu niż członkowie jakiejkolwiek innej frakcji skupiali się na „polityce pieniądza” i własnej karierze. Poglądy na temat polityki zagranicznej miały dla nich znaczenie drugorzędne jako narzędzie rywalizacji międzyfrakcyjnej. Takie nastawienie tłumaczy, dlaczego to właśnie ta frakcja była zazwyczaj największa w PLD. Młodzi politycy po prostu garnęli się do niej, gdyż zapewniała najlepsze możliwości zrobienia szybkiej kariery. Brak wyraźnego zabarwienia ideologicznego działał na korzyść frakcji Satō przy formowaniu „głównych nurtów”, gdyż najłatwiej jej było dostosować się do nowych potrzeb opinii publicznej, wywołanych przez zmiany sytuacji międzynarodowej. Z tego powodu to właśnie ewolucja polityki wobec Chin tej frakcji miała olbrzymi wpływ na całą PLD i, co za tym idzie, na dyplomację Japonii.

Należy podkreślić, że wszystkie z przedstawionych podziałów były nieostre. Ponieważ frakcje to grupy oparte tak naprawdę na stosunkach interpersonalnych, a nie wspólnym programie, można mówić jedynie o pewnych tendencjach ideologicznych $w$ ich łonie. Im mniejsza frakcja, tym łatwiej o jedność poglądów, zaś największe grupy siłą rzeczy musiały zrzeszać polityków

\footnotetext{
${ }^{141}$ Huang Dahui, op.cit., s. 35.

${ }^{142}$ Iseri Hirofumi, op.cit., s. 152.
} 
reprezentujących różne opcje ideologiczne. W przypadku najważniejszego w pracy podziału według nastawienia wobec Chin, tak naprawdę można by wyróżnić znacznie więcej obozów niż po prostu propekiński, protajwański i mieszany. Najbardziej propekińskie były maleńkie frakcje Matsumury i Ishibashiego. Do następnej grupy można by zaliczyć np. frakcję Fujiyamy. Dopóki zrzeszała ona również licznych polityków protajwańskich, Fujiyama nie mógł jasno zadeklarować się po stronie rządu w Pekinie. Dopiero gdy jego frakcja znacznie zmniejszyła się po secesji najbardziej prawicowych działaczy, stała się równie spójna ideologicznie, jak frakcje Matsumury i Ishibashiego, choć jednocześnie straciła swoje dawne wpływy. Do kolejnej grupy należały frakcje Mikiego i Ikedy. Obie były sporych rozmiarów (choć frakcja Mikiego w latach 70. XX wieku stała się już najmniejszą z pięciu głównych frakcji), dzięki czemu ich przywódcy mieli realne szanse zostania premierami. Wobec tego Miki i Ikeda, jak też ich następcy, chociaż osobiście propekińscy, musieli elastycznie dostosowywać się do sytuacji wewnątrzpartyjnej i międzynarodowej, która nie zawsze sprzyjała kontaktom z ChRL.

Jak już wcześniej wspomniano, najmniej ideologicznie „nasyconą” frakcją była grupa Satō, która najlepiej adoptowała się do „nurtu historii”, zmieniając swoje nastawienie wobec Chin. Z kolei grupą „mieszaną” można nazwać frakcję Kōno, w której dominowali politycy protajwańscy, ale liderzy byli zazwyczaj propekińscy. Kolejne grupy były już mniej lub bardziej protajwańskie. Frakcja Kishiego utrzymywała bliskie relacje $\mathrm{z}$ reżimem Guomindangu, jednak jako jedna $\mathrm{z}$ największych grup siłą rzeczy musiała zrzeszać także sporą liczbę polityków umiarkowanych. Ponieważ zaś jej przywódcy należeli do grona głównych kandydatów na premiera, podobnie jak Miki i Ikeda musieli być w jakimś stopniu elastyczni pod względem ideologii. Podobne ograniczenia dotyczyły sporych frakcji Ōno i Ishiiego w pierwszym okresie jej działalności. Z kolei małe protajwańskie frakcje Mizuty, Shiiny, Nakagawy czy Ishiiego pod koniec jej istnienia i tak nie miały szansy na wybór swojego przywódcy na przewodniczącego PLD, więc mogły zachować spójność ideologiczną porównywalną z frakcjami Ishibashiego i Matsumury na przeciwległym biegunie tej typologii.

Nazywanie poszczególnych frakcji „propekińskimi” lub „protajwańskimi” bez wzięcia pod uwagę stopnia nasilenia tych cech jest dużym uproszczeniem, ale jednocześnie zabiegiem niezbędnym, by móc zbadać zabarwienie ideologiczne kolejnych „głównych nurtów”. W pracy przyjęto zasadę, że do obozu propekińskiego należała frakcja, której przewodniczący oraz dominująca część członków miała poglądy propekińskie, zaś do obozu protajwańskiego frakcja, której przewodniczący oraz znacząca część działaczy miała poglądy protajwańskie. Można było przyjąć tego typu uproszczenie, ponieważ do czasu reformy systemu wyborczego w 1994 roku kariera polityków zależała od ich lojalności wobec frakcji i w kwestiach kluczowych dla stosunków japońsko- 
chińskich ${ }^{143}$ musieli oni postępować zgodnie z decyzjami swojego oyabuna, niezależnie od własnych przekonań. Jeżeli poglądy lidera nie zgadzały się z ideologią dominującą w grupie, można mówić o frakcji „mieszanej”. W takim przypadku przywódca podlegał dużej presji ze strony swoich podwładnych i często nie był $\mathrm{w}$ stanie prowadzić jednoznacznej polityki wobec Chin. W wyniku reformy systemu wyborczego w latach 90. XX wieku znaczenie dotychczasowych typologii frakcji uległo znacznemu zmniejszeniu. Kariera polityków przestała być zależna jedynie od wierności wobec frakcji, co spowodowało osłabienie solidarności ich członków i wzmocnienie podziałów wewnątrzfrakcyjnych. Nawet jeśli we frakcji nadal dominuje określony obóz, mniejszościowi reprezentanci przeciwnej opcji nie muszą już w sprawach ideologii podporządkowywać się decyzji oyabuna.

Podziały związane $\mathrm{z}$ ideologią oraz $\mathrm{z}$ pochodzeniem poszczególnych polityków z określonych środowisk tworzyły w PLD skomplikowaną mozaikę wzajemnych interesów i powiązań personalnych. Dopiero jednak nałożenie jej na zasady rządzące dynamiką rywalizacji międzyfrakcyjnej może dać pełen obraz niezdeterminowanych do końca przez ideologiczne podłoże zachowań szefów frakcji w sprawie polityki wobec Chin.

\section{Dynamika rywalizacji międzyfrakcyjnej w PLD}

Podstawowym celem istnienia frakcji była rywalizacja z pozostałymi grupami. Przy okazji każdych wyborów na stanowisko przewodniczącego PLD frakcje poszukiwały sojuszników, wchodziły w tymczasowe alianse i toczyły zakulisowe negocjacje niczym osobne partie pragnące zawrzeć koalicję. Gra toczyła się o wysoką stawkę, ponieważ grupa, która przeważyła w partii, uzyskiwała także kontrolę nad sterami państwa. Zdaniem Uchidy Kenzō dzieje PLD były niczym innym tylko ciągiem zmiennych sojuszy pomiędzy frakcjami ${ }^{144}$. Przy badaniu dynamiki rywalizacji międzyfrakcyjnej wewnątrz tego ugrupowania należy wyróżnić grupy „głównego nurtu” (shuryūha), poza „głównym nurtem” (hishuryūha), „przeciwnego nurtu” (hanshuryūha) oraz „ogólnego głównego nurtu” (sōshūryūha), jak też „osie władzy” (seiken kijiku).

Frakcjami „głównego nurtu” nazywano te grupy, które w wyborach na przewodniczącego PLD zagłosowały na zwycięzcę, dzięki czemu posiadły pewną przewagę nad pozostałymi frakcjami przy obsadzaniu stanowisk. Była to swoista wewnątrzpartyjna koalicja. Kolejne „główne nurty” formowały się zgodnie z doraźnym interesem liderów frakcji. Czasami dawało się zauważyć pewną solidarność pośród grup należących do poszczególnych obozów ideolo-

\footnotetext{
${ }^{143}$ Ze względu na ponad 50-letni okres badany w pracy z założenia analizowane są jedynie problemy, które wywarły największy wpływ na stosunki japońsko-chińskie. Do lat 70. XX wieku była to głównie kwestia statusu Tajwanu i normalizacji stosunków dyplomatycznych z ChRL, zaś od lat 80. XX wieku także sprawa pamięci historycznej.

${ }^{144}$ Uchida Kenzō, Habatsu..., s. 26.
} 
gicznych, czasami zaś dochodziło do zaskakujących sojuszy między "gołębiami” a ,jastrzębiami”, czy też pomiędzy reprezentantami „głównego” oraz „,bocznego nurtu konserwatywnego”. Polaryzacja np. na ,jastrzębi” i ,gołębi” to wszakże tylko jedno z kryteriów podziału w ramach PLD. Niejednokrotnie silniejsze od wspólnych poglądów okazywały się animozje czy związki rodzinne między szefami frakcji, jak też chłodna kalkulacja, kogo bardziej opłaca się poprzeć, aby uzyskać jak największe wpływy w przyszłym gabinecie.

O ile skład poszczególnych „głównych nurtów” ulegał częstym zmianom w wyniku nieustannej rywalizacji międzyfrakcyjnej, o tyle w pewnych okresach historii PLD da się wyróżnić stałe sojusze pomiędzy wpływowymi politykami partii. Można je nazwać „osiami władzy” (seiken kijiku). Zależnie od posiadanej liczby głosów w parlamencie, taki stały związek dwóch frakcji mógł zupełnie zdominować proces podejmowania decyzji w partii. Chociaż istniało prawdopodobieństwo okresowego odsunięcia „osi władzy” od rządów przez sojusz większości pozostałych szefów frakcji, takie okresy poza "głównym nurtem” były raczej krótkie. W historii PLD można wyróżnić dwie znane „osie władzy”: braterskie przymierze Kishiego Nobusuke z Satō Eisaku (1955-1972) oraz przyjaźń Tanaki Kakueia z Ōhirą Masayoshim (1972-1980) ${ }^{145}$.

Frakcje, które w wyborach na przewodniczącego PLD wsparły kontrkandydata zwycięzcy, tworzyły grupę poza „głównym nurtem”"146. W ten sposób powstawała naturalna wewnątrzpartyjna koalicja i opozycja. Opozycja ta nie była w pełni tożsama $\mathrm{z}$ opozycją parlamentarną. Zwycięska frakcja musiała wszakże uważać, aby dążąc do pierwszego celu, jakim była kontrola nad partią, nie doprowadzić do rozpadu całego ugrupowania, gdyż oznaczałoby to niemożność utrzymania władzy w państwie, która stanowiła przecież cel nadrzędny ${ }^{147}$. Aby zapobiec secesji z PLD którejś z frakcji poza „głównym nurtem” konieczne było podzielenie się z nimi stanowiskami państwowymi i partyjnymi.

Czasami jednak wrogość pomiędzy zwycięzcą a pokonanym nie dała się załagodzić przyznaniem stanowisk dla przedstawicieli frakcji, które przegrały rywalizację. Wewnątrz PLD powstawał wówczas wyraźny „przeciwny nurt”, który mógł nawet doprowadzić partię na skraj rozpadu. Parlamentarzyści „przeciwnego nurtu” dążyli do jak najszybszej zmiany władzy wewnątrz PLD. W tym celu nie tylko odmawiali objęcia posad rządowych bądź demonstracyjnie podawali się do dymisji, ale także otwarcie krytykowali premiera i negowali jego politykę. Jednym z głównych bodźców, mogących wywołać przemianę frakcji poza „głównym nurtem” lub nawet „głównego nurtu” we frakcję „przeciwnego nurtu” był brak popularności prezesa Rady Ministrów. W ten

\footnotetext{
${ }^{145}$ Iseri Hirofumi, op.cit., s. 106.

146 Ibidem, s. 85.

${ }^{147}$ Nagamori Seiichi, op.cit., s. 28-29.
} 
sposób stałe zagrożenie ze strony „przeciwnego nurtu” spełniało rolę kontrolną wobec kontrowersyjnych przedsięwzięć rządu ${ }^{148}$.

Normalny tryb wewnątrzpartyjnej rywalizacji mógł zostać jednak zakłócony w przypadku uformowania się „ogólnego głównego nurtu”. Dochodziło do tego wówczas, gdy jedna z frakcji osiągała zdecydowaną przewagę nad pozostałymi, wymuszając „ogólne ukoalicyjnienie” (sōyotōka) praktycznie wszystkich pozostałych grup w PLD. Zgodnie ze słowami Hashimoto Tomisaburō, sekretarza generalnego PLD w czasie kadencji Tanaki Kakueia: „Kontrolując jedną czwartą parlamentarzystów ustanawia się władzę" ${ }^{\text {149 }}$. Z kolei według Iseriego Hirofumiego, nie wystawiając własnego kandydata na szefa partii wystarczy jedynie jedna ósma parlamentarzystów do pełni władzy nad państwem ${ }^{150}$. Kontrolując połowę parlamentarzystów „głównego nurtu” można kontrolować cały „główny nurt”, kontrolując „główny nurt”, czyli ponad połowę PLD, włada się całą partią, zaś wtedy kontroluje się ponad połowę parlamentu i można powołać rząd. W ten sposób do władzy w państwie starczy frakcja zrzeszająca mniej więcej jedną ósmą posłów.

Rezygnując z wystawiania własnego kandydata na stanowisko przewodniczącego partii, przywódca frakcji-hegemona mógł dowolnie mianować na premiera przedstawiciela jakiejś innej grupy wewnątrzpartyjnej, który w naturalny sposób stawał się „kukiełką” (kairai) w jego rękach. Ponieważ pozostałe frakcje nie miały możliwości przeciwstawić się takiemu układowi, były zmuszone do uczestniczenia w tym „ogólnym głównym nurcie”. Był to dla nich jedyny sposób, aby mieć proporcjonalny udział w rozdziale ważniejszych stanowisk. Taki nienaturalny stan panował od początku lat 80 . XX wieku do 1992/1993 roku, kiedy Tanaka Kakuei, a później Takeshita Noboru, „rozdęli” swoją frakcję do niewyobrażalnych wcześniej rozmiarów 140 parlamentarzystów.

Jedną z tajemnic długotrwałych rządów PLD była formuła „sztucznej zmiany władzy" (gijiteki seiken kōtai) ${ }^{151}$. Odpowiedzialność za niepowodzenia gabinetu spadała w Japonii przede wszystkim na frakcję, z której pochodził premier. W odpowiedzi na społeczne żądania zmiany niepopularnego prezesa Rady Ministrów, następny szef rządu często wywodził się $\mathrm{z}$ przeciwnego ideologicznie skrzydła PLD. Jak miał niegdyś powiedzieć Maeo Shigesaburō: „Tak jak wahadło zegara, władza konserwatywna posuwa się do przodu, chwiejąc się w lewo i prawo. Jeśli zachwieje się za bardzo w prawo, powróci na lewą stronę, jeśli wygnie się w lewo, znów wróci na prawo"152. Pojmowana w ten sposób zmiana władzy, tzw. „logika wahadła” (furiko no ronri), była

\footnotetext{
${ }^{148}$ Murakawa Ichirō, Fukuoka Masayuki et al., op.cit., s. 15.

${ }^{149}$ Iseri Hirofumi, op.cit., s. 170.

${ }^{150}$ Ibidem, s. 170-171.

${ }^{151}$ Uchida Kenzō, Habatsu..., s. 175; Kong Uisik, op.cit., s. 139.

${ }^{152}$ Uchida Kenzō, Habatsu..., s. 177.
} 
sztuczna nie tylko dlatego, że dokonywała się w ramach jednej partii, ale również dlatego, że nowy premier często był silnie uzależniony od prawdziwego decydenta, któremu zawdzięczał zwycięstwo w wyborach na stanowisko przewodniczącego PLD.

Kitaoka Shin'ichi zwraca uwagę na rolę opinii publicznej w walce między liderami frakcji $\mathrm{w}$ partii dominującej. Jak pisze: „Jednym ze sposobów uzyskania przewagi w tej rywalizacji było wsłuchiwanie się w głos narodu, więc przywódcy frakcji, łącznie z przewodniczącym [PLD - przyp. aut.], czynili wysiłki, by odkryć i zrealizować oczekiwania ludu. W ten sposób, opierając się na posiadanym z natury przez sam naród poczuciu utrzymania status quo, PLD łagodnie absorbowała oczekiwania obywateli, czasami $\mathrm{z}$ wyprzedzeniem formułowała problemy i, dokonując wewnątrz partii zmiany władzy, która nie pozwalała na eksplozję znudzenia ludu, utrzymała się przez długi czas u rządów. Innymi słowy, za pośrednictwem rywalizacji międzyfrakcyjnej doszło do powstania postępowej partii konserwatywnej, która poprzez miękkie przywództwo sprawowała długoterminową władzę. Ten mechanizm ani nie został stworzony intencjonalnie, ani też nie istniał od samego początku. Co więcej, mechanizm ten ostatnio przestał funkcjonować" ${ }^{153}$. Sprawa chińska była jedną z kwestii, na temat których szefowie frakcji musieli wsłuchiwać się w „głos narodu” i formułować politykę zagraniczną w taki sposób, by utrzymać się u władzy. Łatwość adaptacji do zmian opinii publicznej i sytuacji międzynarodowej zależała jednak od wewnątrzpartyjnych uwarunkowań poszczególnych frakcji w określonym czasie. Na dodatek, na co zwrócił uwagę Kitaoka Shin'ichi, mechanizm ,sztucznej zmiany władzy” przestał działać razem z osłabieniem roli frakcji PLD w latach 90. XX wieku.

\section{Rola frakcji w procesie decyzyjnym}

Wśród politologów zajmujących się japońską sceną polityczną dominuje pogląd, że frakcje odgrywały mało znaczącą rolę w procesie decyzyjnym, w tym także w formułowaniu polityki zagranicznej Japonii. Gerald L. Curtis twierdzi, iż „,nie ma żadnego przekonywującego dowodu, by frakcje kiedykolwiek stanowiły główne jednostki decyzyjne w partii. Od początku rolą frakcji PLD było decydowanie, kim będą liderzy partii, a nie jaka powinna być ich polityka" ${ }^{154}$. Tanaka Akihiko zauważa: „Są prowadzone najróżniejsze dyskusje na temat, jaką rolę odgrywają frakcje PLD. Niemniej jednak pogląd, iż działają niczym grupy polityczne zdaje się nie być licznie reprezentowany. Nie było zbyt wielu przypadków, by frakcja jako całość promowała daną politykę, czy też była jej przeciwna. Na temat polityki wobec Chin można by zapewne powiedzieć to samo” ${ }^{155}$. Z kolei Qingxin Ken Wang podkreśla, że „przydatność podejścia

\footnotetext{
${ }^{153}$ Kitaoka Shin'ichi, op.cit., s. 11.

${ }^{154}$ Gerald L. Curtis, The Japanese Way..., s. 88.

${ }^{155}$ Tanaka Akihiko, op.cit., s. 199-200.
} 
frakcyjnego jest dość ograniczona w przypadku polityki Japonii wobec Chin w okresie powojennym" ${ }^{156}$. Jako argument podaje m.in. fakt, iż ,podejście frakcyjne nie bierze pod uwagę międzynarodowej dystrybucji siły, która wywierała istotny wpływ na politykę Japonii wobec Chin oraz amerykańsko-japońską współpracę w sprawie Chin"157.

Tezy niniejszej książki nie odbiegają daleko od stanowiska Curtisa, Tanaki i Wanga. Należy przy tym zauważyć, że cytowani politologowie nie negują zupełnie roli frakcji w ustalaniu polityki partyjnej, tylko odmawiają im charakteru głównych jednostek decyzyjnych. W niniejszej pracy zaproponowana została jednak metoda analizy wewnątrzpartyjnych uwarunkowań polityki PLD wobec Chin, w której to właśnie frakcje są postawione na pierwszym planie. Autor zgadza się z poglądem Geralda L. Curtisa, iż efektem rywalizacji międzyfrakcyjnej było przede wszystkim ustalanie personalnego składu grupy głównych decydentów w państwie, zwłaszcza zaś wybór przewodniczącego PLD. Niemniej jednak to, jakie osoby czy obozy ideologiczne uzyskały władzę w partii samo w sobie wywierało wpływ na proces decyzyjny. Autor zgadza się również z Tanaką Akihiko, iż frakcje nie były grupami w pełni spójnymi pod względem ideologii. Niemniej jednak lojalność wobec lidera grupy nakazywała jej szeregowym członkom głosowanie w sprawach kluczowych dla relacji japońsko-chińskich zgodnie $\mathrm{z}$ nakazem przywódcy, nawet jeśli było to wbrew ich osobistym przekonaniom. Autor zgadza się wreszcie z Qingxinem Kenem Wangiem, iż wpływ rywalizacji międzyfrakcyjnej na politykę PLD wobec Chin był mniejszy niż chociażby ewolucji otoczenia międzynarodowego. Niemniej jednak i tak warto poświęcić mu więcej uwagi niż w dotychczasowych monografiach na temat japońskiej polityki zagranicznej.

Według Roberta A. Scalapino i Junnosuke Masumiego: „Pod wieloma względami podstawową organizacją polityczną jest frakcja, nie partia. Odzwierciedlając kulturalne uwarunkowania japońskiego społeczeństwa oraz naturę wszystkich japońskich organizacji, frakcja stanowi żywotne centrum procesu politycznego" ${ }^{\text {,158 }}$. Z kolei jak podkreśla Inoguchi Takashi: „Japończycy osiągają konsensus poprzez nieformalne sieci powiązań, więc śledzenie oficjalnych, instytucjonalnych procesów decyzyjnych jest niemal pozbawione sensu" ${ }^{159}$. W takim ujęciu analiza decyzji przełomowych dla stosunków japońsko-chińskich jedynie pod kątem formalnych mechanizmów rządzących funkcjonowaniem głównych organów PLD nie wystarczy do wyczerpującego zbadania wewnątrzpartyjnych uwarunkowań polityki tego ugrupowania wobec Chin. Do 1993/1994 roku frakcyjność była dominującą linią podziału w partii,

\footnotetext{
${ }^{156}$ Qingxin Ken Wang, op.cit., s. 270.

157 Ibidem, s. 270

158 Robert A. Scalapino, Junnosuke Masumi, Parties and Politics in Contemporary Japan, University of California Press, Berkeley 1962, s. 149.

${ }^{159}$ Inoguchi Takashi, Gendai Nihon seiji..., s. 56.
} 
gdyż członkostwo we frakcji decydowało o karierze parlamentarzystów. Niemniej jednak analiza wpływu frakcji na proces decyzyjny w partii jest możliwa dopiero po przyjęciu dwóch ważnych założeń: o ich jednolitym kolorycie ideologicznym oraz o kluczowej roli „głównych nurtów” w ustalaniu partyjnej polityki.

Chociaż frakcje z zasady opierały się na relacjach interpersonalnych, a nie konkretnych programach politycznych, w pewnym uproszczeniu można je uznać za grupy o jednolitej ideologii. Szacunek wobec liderów-założycieli skłaniał ich kobunów do przynajmniej częściowego przejęcia poglądów swoich patronów. Dopóki solidarność członków frakcji była na tyle silna, by grupa funkcjonowała niczym opisana przez Nakane Chie organizacja oparta na strukturze wertykalnej, do koordynacji poglądów jej członków używano hierarchii. W ten sposób nawet jeśli ideologia wyznawana przez lidera nie została zinternalizowana przez wszystkich członków, przeważała nad poglądami mniejszości. Przypadki nieposłuszeństwa wobec przewodniczącego grupy były na tyle rzadkie, że możliwe stało się przypisanie wszystkich członków frakcji do obozu ideologicznego reprezentowanego przez daną grupę jako całość. Jedynie nielicznych frakcji, szczególnie tych, które powstały z połączenia różnorodnych środowisk (np. nurt Kōno Ichirō), nie dało się jasno zakwalifikować do obozu protajwańskiego lub propekińskiego.

Największy wpływ na proces decyzyjny posiadały frakcje należące do „głównego nurtu” i to one najbardziej warunkowały politykę zagraniczną Japonii. Z tego powodu badając wewnątrzpartyjne uwarunkowania polityki PLD wobec Chin należy przede wszystkim dokonać analizy składu poszczególnych „głównych nurtów”. Skoro zaś całe frakcje można przypisać do określonych obozów ideologicznych, można też porównać ilość parlamentarzystów protajwańskich i propekińskich, czy też ,jastrzębi” i „,gołębi” w kolejnych wewnątrzpartyjnych koalicjach. Suma liczby członków poszczególnych frakcji propekińskich w danym ,głównym nurcie” symbolizowała siłę wpływów obozu propekińskiego na rządy w kraju (i analogicznie w przypadku obozu protajwańskiego). Spójność ideologiczna poszczególnych wewnątrzpartyjnych koalicji była jednym z czynników warunkujących nastawienie PLD wobec sprawy chińskiej.

Należy podkreślić, że przyjęta metoda badawcza opiera się na daleko idącym uproszczeniu niezwykle skomplikowanej sytuacji panującej w PLD, ale jest także głęboko osadzona w realiach praktyki politycznej. Dopiero gdy frakcyjność przestała być główną linią podziału w partii w latach 90. XX wieku, rola frakcji w procesie decyzyjnym stała się na tyle niejasna, że badanie zachowania tych grup przestało służyć za podstawowe narzędzie analizy wewnątrzpartyjnych uwarunkowań polityki PLD wobec Chin. Zresztą równolegle zanikły „główne nurty” i dotychczasowa metoda badawcza utraciła swoje walory naukowe. 
* * *

Frakcje personalne w ramach PLD były tworami w dużym stopniu bezprogramowymi i wysoce zinstytucjonalizowanymi. Oprócz determinant systemowych, na ich uformowanie wpłynęły czynniki kulturowe, które tłumaczą, czemu pomimo usilnych prób reformy frakcyjność nadal odgrywa pewną rolę w japońskiej polityce. Mimo osłabienia funkcji, jakie frakcje pełnią w wyborach parlamentarnych czy przy rozdzielaniu funduszy, bycie członkiem danej grupy nadal jest ułatwieniem w karierze, zaś dla jej przywódcy zwiększeniem szansy na zostanie przewodniczącym partii. $Z$ drugiej strony, okres świetności frakcji już minął. W pierwszych trzech okresach (1955-1993) frakcyjność bez wątpienia była dominującą linią podziału w PLD, zaś skład poszczególnych „,głównych nurtów" wywierał wpływ na politykę ugrupowania wobec Chin. Niemniej jednak od lat 90. XX wieku frakcyjność straciła dotychczasowe znaczenie. Po reformie 1994 roku trudno było jednoznacznie określić skład „głównych nurtów" w partii, zaś konflikty interesów między posłami PLD często przebiegały w poprzek afiliacji frakcyjnej.

\section{POZOSTAŁE GRUPY WEWNĄTRZ- I PONADPARTYJNE}

Oprócz frakcji personalnych w ramach PLD wykształciły się także inne rodzaje grup zrzeszających polityków tej partii. Z punktu widzenia wpływu na kształtowanie polityki PLD wobec Chin pewne znaczenie miały klany parlamentarzystów oraz tzw. grupy polityczne. Ponieważ członkowie PLD należeli także do istotnych pod względem ustalania polityki wobec Chin organizacji i stowarzyszeń o charakterze poza- i ponadpartyjnym, również one mogły stanowić narzędzie walki wewnątrzpartyjnej. Szczególną uwagę należy tu poświęcić ligom parlamentarnym oraz organizacjom pozarządowym.

\section{Klany parlamentarzystów}

W przeciwieństwie do frakcji, które były przejawem struktury wertykalnej wewnątrz partii, klany parlamentarzystów (zoku giin) stanowiły w PLD swoistą strukturę horyzontalną ${ }^{160}$. Klany parlamentarzystów oznaczały grupy doświadczonych polityków PLD, którzy specjalizowali się w sprawach związanych z działalnością określonego ministerstwa. Ich powstanie jest kojarzone $\mathrm{z}$ działalnością Tanaki Kakueia ${ }^{161}$. Wpływ zoku na proces decyzyjny stał się widoczny od lat 70 . XX wieku, kiedy zawodowi politycy zdobyli po długoletniej praktyce wystarczające doświadczenie w sprawach określonych resortów. Odtąd klany parlamentarzystów wywierały istotny wpływ na japońskie ustawodawstwo.

\footnotetext{
${ }^{160}$ Yuasa Hiroshi, op.cit., s. 16.

${ }^{161}$ Inoguchi Takashi, Iwai Tomoaki, „Zoku giin” no kenkyū, Nihon Keizai Shinbunsha, Tokio 1987, s. 20.
} 
Yuasa Hiroshi definiuje zoku jako grupę polityków zajmujących się problematyką danego resortu, którzy posiadają doświadczenie piastowania stanowiska przynajmniej przewodniczącego określonej sekcji w ramach Rady Badań Politycznych PLD, a w szczególności ministra bądź przewodniczącego komisji parlamentarnej. Poseł PLD za pierwszej kadencji mógł zazwyczaj liczyć na funkcję szeregowego członka sekcji, za drugiej na wiceprzewodniczącego sekcji, za trzeciej na sekretarza stanu (seimu jikan), zaś przewodniczącym sekcji zostawał od czwartej kadencji ${ }^{162}$. W trakcie tego procesu zdobywania doświadczenia politycy PLD tworzyli także osobiste powiązania z biurokratami danego ministerstwa i w naturalny sposób stawali się reprezentantami interesów tego resortu. Szczególną rolę odgrywał klan strategii parlamentarnej (kokutai zoku), który był odpowiedzialny za kontakty z partiami opozycyjnymi.

Należy jednak podkreślić drugorzędne znaczenie klanów parlamentarzystów w porównaniu z przynależnością frakcyjną. O ile poseł PLD mógł należeć aż do trzech sekcji ${ }^{163}$, czyli do trzech $z o k u$, o tyle poza wyjątkowymi przypadkami na początku istnienia partii, byłoby nie do pomyślenia należeć do więcej niż jednej frakcji. Zresztą to właśnie szefowie frakcji dbali o karierę swoich kobunów, zapewniając im odpowiednie stanowiska partyjne i rządowe, dzięki którym mogli stać się członkami danych klanów. Do najbardziej „opłacalnych” należały klany budownictwa, transportu czy komunikacji, umożliwiające szerokie kontakty ze światem biznesu i, co za tym idzie, zwiększające możliwości pozyskiwania funduszy wyborczych dla frakcji. Niejednokrotnie powiązania takie miały korupcyjny charakter. Wielką popularnością cieszył się także klan rolniczy, dający możliwości reprezentowania interesów ludności wiejskiej, która stanowiła trzon konserwatywnego elektoratu.

Poprzez analizę ilości reprezentantów określonych zoku w danej frakcji można do pewnego stopnia określić jej specjalizację w poszczególnych sferach ustawodawstwa. Na przykład w latach 80 . XX wieku frakcja Takeshity miała szczególne wpływy w klanach budownictwa (kensetsu zoku) i poczty (yūsei zoku), frakcja Abe w klanie transportu (un'yu zoku), zaś frakcja Miyazawy w klanach finansów (ōkura lub zaimu zoku) i opieki społecznej (sharō lub kōsei $z o k u$ ). Poza tym wielu członków prawicowych frakcji Abe i Nakasone należało do klanów edukacji i obrony ${ }^{164}$. Zdarzały się także potężne grupy (np. Tanaki), posiadające wpływowych reprezentantów w każdym klanie. Iseri Hirofumi nazywa je za samym Tanaką Kakueiem ,szpitalami ogólnymi” (sōgō byōin $)^{165}$. W takich skrajnych wypadkach jedność interesu frakcji i zoku, do którego

\footnotetext{
${ }^{162}$ Przy piątej kadencji mógł liczyć na stanowisko przewodniczącego komisji parlamentarnej, zaś od szóstej na stanowisko ministra. Zdarzały się też wyjątki od tej zasady. Szerzej na ten temat: Yuasa Hiroshi, op.cit., s. 11-12; Inoguchi Takashi, Iwai Tomoaki, op.cit., s. 121.

${ }^{163}$ Yuasa Hiroshi, op.cit., s. 22.

${ }^{164}$ Iseri Hirofumi, op.cit., s. 155; Inoguchi Takashi, Iwai Tomoaki, op.cit., s. 150.

${ }^{165}$ Iseri Hirofumi, op.cit., s. 69.
} 
należeli jej członkowie, mogła ulec osłabieniu. Działo się tak dlatego, że przedstawiciele różnych klanów z tej samej frakcji walczyli o sprzeczne interesy własnych ministerstw ${ }^{166}$.

Co istotne, ze względu na różnorodność poglądów ideologicznych nigdy nie istniało jednolite zoku spraw zagranicznych. Przewodniczący Komisji Spraw Zagranicznych Izby Reprezentantów Kōno Tarō przyznał, że zajmowanie się dyplomacją nie jest zbyt korzystne dla polityka, gdyż nie przekłada się ani na głosy, ani na pieniądze ${ }^{167}$. Japońscy wyborcy są zainteresowani przede wszystkim obroną interesów najbliższego otoczenia: rodziny, wioski lub miasta oraz regionu, w którym żyją. O ile więc członek zoku budownictwa czy transportu mógł dzięki swoim wpływom znacząco przyczynić się do modernizacji infrastruktury we własnym okręgu wyborczym, o tyle parlamentarzysta klanu dyplomacji nie miał tu wiele do powiedzenia. Na dodatek w kwestiach handlu międzynarodowego czy polityki bezpieczeństwa sekcja dyplomacji musiała dzielić się wpływami z innymi sekcjami Rady Badań Politycznych PLD ${ }^{168}$.

Poszczególne zoku mogły tylko pośrednio wpływać na politykę partii wobec Chin. Należy tu zwrócić szczególną uwagę na klany edukacji i obrony. Zarówno sekcja edukacji (bunkyō bukai), jak obrony (kokubō bukai) Rady Badań Politycznych PLD były często obsadzane przez frakcje z prawego skrzydła partii. Podobnie jak w przypadku dyplomacji, specjalizowanie się w edukacji czy obronności nie przynosiło wielu doraźnych korzyści politycznych. Jedynie parlamentarzystom o silnych przekonaniach ideologicznych i stabilnej bazie poparcia we własnych okręgach wyborczych zależało na wpływach w tych resortach $^{169}$. „Jastrzębie” dążyli do wychowania młodzieży w duchu patriotyzmu, a nie nadmiernego poczucia winy za zbrodnie dokonane przez Japonię w epoce ekspansjonizmu. Zatwierdzane przez ministrów edukacji kontrowersyjne podręczniki do historii stały się od lat 80 . XX wieku zarzewiem konfliktu z Chinami, więc poglądy ideologiczne członków zoku edukacji miały pewien, choć raczej niezamierzony, wpływ na formułowanie polityki PLD wobec ChRL. Z kolei opanowane przez ,jastrzębi” zoku obrony mogło łagodzić bądź zaostrzać napięcie w stosunkach japońsko-chińskich, używając do tego np. kwestii remilitaryzacji Japonii lub bezpieczeństwa Tajwanu.

Inny charakter miał wpływ na stosunki z Chinami klanów handlu i przemysłu $(s h \bar{o} k \bar{o} z o k u)$ oraz rolnictwa (nōrin zoku). Pierwszemu z nich zależało na pogłębianiu i liberalizacji wymiany handlowej z zagranicą, a więc także na wygaszaniu źródeł sporu z Chinami, wzniecanych przez klany edukacji czy obrony. Z kolei klan rolnictwa starał się bronić rodzimy rynek przed zalewem

\footnotetext{
${ }^{166}$ Ibidem, s. $156-158$.

${ }^{167}$ Wywiad autora z Kōno Tarō...

${ }^{168}$ Jimintō Seichōkai pod red. Nihon Keizai Shinbunsha, Nihon Keizai Shinbunsha, Tokio 1983, s. 36 .

${ }^{169}$ Yuasa Hiroshi, op.cit., s. 147-166; Jimintō Seichōkai, s. 88.
} 
tanimi produktami rolnymi z ChRL, co oczywiście nie sprzyjało tworzeniu przyjacielskiej atmosfery $\mathrm{w}$ relacjach japońsko-chińskich ${ }^{170}$. Wspólną cechą klanów handlowego oraz rolnego był za to ich dystans do sporów ideologicznych. Nawet jeśli działalność polityków jednego z nich współbrzmiała z polityką władz partii wobec Chin, a drugiego stanowiła przeszkodę dla japońskiej dyplomacji, nie były to następstwa zamierzone, a jedynie ,skutki uboczne" przedsięwzięć podyktowanych interesem danego ministerstwa.

Aczkolwiek działalność wyżej wymienionych klanów parlamentarzystów niewątpliwie była jednym z wewnątrzpartyjnych czynników wpływających na politykę wobec Chin, nie jest ona przedmiotem szczegółowej analizy w niniejszej pracy. Wynika to $\mathrm{z}$ faktu, że dążenia poszczególnych zoku tak naprawdę nie dotyczyły polityki PLD wobec Chin jako całości. Omówione zostały jedynie te przypadki ingerencji reprezentantów danych klanów parlamentarzystów w proces decyzyjny, które odbiły się największym echem w stosunkach japońsko-chińskich (np. kwestia podręczników do historii). Należy jednak podkreślić, że incydenty tego typu nie były w stanie zmienić ogólnego kursu japońskiej dyplomacji wobec Chin, wyznaczanego przez poszczególnych premierów i międzyfrakcyjne sojusze wewnątrz PLD.

\section{Grupy polityczne}

Przy omawianiu polityki PLD wobec Chin nie sposób pominąć również tematyki tzw. grup politycznych (seisaku gurūpu lub seisaku shūdan), które sporadycznie formowały się $w$ ramach partii. Oznaczały one zrzeszenia parlamentarzystów z PLD nastawione na prowadzenie dyskusji na temat polityki, ustalanie wspólnego programu oraz promowanie jego wcielenia w życie ${ }^{171}$. W porównaniu z frakcjami personalnymi grupy polityczne zazwyczaj miały mniej wyraźnie wykształconą strukturę wertykalną, zaś spoiwem łączącym ich członków była, przynajmniej z założenia, nie tyle chęć zrobienia kariery, co wspólnota przekonań. Jak podkreśla Inoue Yoshihisa: „Różnicą między frakcją a grupą polityczną jest to, że o ile tak zwane grupy polityczne kładą nacisk na program polityczny, frakcje skupiają się na pieniądzach i stanowiskach" ${ }^{, 172}$.

Ze względu na posiadanie wyraźnych zabarwień ideologicznych, grupy polityczne niejednokrotnie bardzo aktywnie promowały wyznaczone sobie cele, szczególnie w dziedzinie dyplomacji. Ponieważ często były tworami ponadfrakcyjnymi, mogły także spełniać rolę koordynacji działań np. frakcji z lewego bądź prawego skrzydła PLD. W przypadku kształtowania polityki partii wobec

\footnotetext{
${ }^{170}$ Zhao Quansheng dokonał analizy wpływu klanu rolnictwa na protekcjonizm japońskiego przemysłu jedwabniczego, który stał się problemem w relacjach z Chinami w latach 80. XX wieku. Szerzej na ten temat: Zhao Quansheng, Nitchü kankei to Nihon no seiji, Iwanami Shoten, Tokio 1999, s. 39-80.

${ }^{171}$ Inoue Yoshihisa, Habatsu to seisaku shūdan, Kyōikusha, Tokio 1979, s. 7.

${ }^{172}$ Ibidem, s. 16.
} 
Chin szczególne znaczenie miały sytuacje, kiedy powstawały dwie przeciwstawne grupy polityczne, zrzeszające reprezentantów obozu propekińskiego oraz protajwańskiego. Tak było $\mathrm{w}$ połowie lat 60 . XX wieku w przypadku starcia pomiędzy protajwańskim Stowarzyszeniem Badań Problemów Azji oraz propekińskim Stowarzyszeniem Badań Problemów Azji i Afryki ${ }^{173}$.

Podobnie jak klany parlamentarzystów, również grupy polityczne odgrywały jednak drugorzędną rolę $\mathrm{w}$ walce o władzę, a co za tym idzie, także w procesie decyzyjnym w PLD. Wspólny program był po prostu znacznie słabszym „spoiwem” niż pieniądze, umacniające solidarność frakcji personalnych. Zresztą w przeciwieństwie do frakcji, jeden poseł mógł należeć jednocześnie do wielu grup politycznych ${ }^{174}$. Niejednokrotnie stanowiły one tylko tymczasowe stowarzyszenia, wstępny etap do uformowania nowej frakcji personalnej. Czasami transformacja ta kończyła się powodzeniem, jak w przypadku Sōseikai Takeshity Noboru w 1985 roku, czasami zaś nowa frakcja okazywała się zbyt słaba, aby przetrwać, co widać na przykładzie frakcji Nakagawy Ichirō i Ishihary Shintarō, która uformowała się na bazie członków protajwańskiej grupy Seirankai na przełomie lat 70. i 80. XX wieku.

Chociaż niejednokrotnie grupy polityczne powoływano w celu ożywienia dyskursu wewnątrzpartyjnego i znalezienia alternatywy dla uprawianej przez frakcje „polityki pieniądza”, tak naprawdę często stanowiły one tylko narzędzia w rękach szefów frakcji. Nawet jeśli stawały się platformami chwilowej współpracy pomiędzy ideologicznie bliskimi sobie frakcjami, odgrywały znaczącą rolę tylko dopóty, dopóki interes polityczny nakazywał liderom frakcji utrzymywanie tego sojuszu. Krótki czas istnienia i słaba solidarność członków grup politycznych sprawiały, że nie były one kluczowym typem stowarzyszeń wewnątrz partii. $\mathrm{O}$ ile $\mathrm{w}$ kilku przypadkach odegrały znaczącą rolę $\mathrm{w}$ sporze $\mathrm{o}$ stosunki chińsko-japońskie (np. Seirankai w latach $70 . \mathrm{XX}$ wieku), o tyle analiza ich działalności może mieć tylko drugorzędne znaczenie w całościowym przeglądzie uwarunkowań polityki PLD wobec Chin.

\section{Ligi parlamentarne}

Ligi parlamentarne (giin renmei) były organizacjami skupiającymi się na promocji wspólnie podzielanych wartości i celów, zrzeszającymi parlamentarzystów z różnych partii. W dużym stopniu stanowiły ponadpartyjny odpowiednik grup politycznych PLD. Czasami umożliwiały one szefom frakcji przeniesienie debat na ważne tematy na poziom ogólnoparlamentarny w celu wykorzystania wsparcia opozycji do promocji określonych przedsięwzięć politycznych.

Długą, sięgającą nawet okresu sprzed powstania PLD, historię miały także ligi parlamentarne zajmujące się problematyką chińską. Chodzi tu głównie o

\footnotetext{
${ }^{173}$ Szerzej na ten temat $\mathrm{w}$ drugim rozdziale.

${ }^{174}$ Ibidem, s. 30-31.
} 
działalność związków wspierających pozarządowy handel Japonii z ChRL. Zarówno przed, jak i po normalizacji stosunków dyplomatycznych Japonii z Chinami w 1972 roku, istniały ligi promujące kontakty japońsko-chińskie lub japońsko-tajwańskie. Z kolei od lat 90 . XX wieku coraz większą rolę odgrywały także takie grupy, jak Zgromadzenie Parlamentarzystów Odwiedzających Razem Świątynię Yasukuni (Minna de Yasukuni Jinja ni Sanpai Suru Kokkai Giin no Kai), których działalność skupiała się na problematyce świadomości historycznej. Chociaż cele tych lig nie dotyczyły bezpośrednio Chin, obrazowały wzrost nastrojów nacjonalistycznych wewnątrz PLD, który negatywnie wpływał na stosunki japońsko-chińskie.

W maju 1949 roku założona została Parlamentarna Liga Promocji Handlu Chińsko-Japońskiego (Chūnichi Bōeki Sokushin Giin Renmei, w 1953 roku zmieniono nazwę na Ligę Promocji Handlu Japońsko-Chińskiego: Nitchū Bōeki Sokushin Giin Renmei). Zrzeszała ona zarówno licznych polityków konserwatywnych, którzy później współtworzyli PLD, jak też posłów socjalistycznych i komunistycznych ${ }^{175}$. Pierwsze próby nawiązania wymiany handlowej z ChRL skończyły się niepowodzeniem z powodu wybuchu wojny koreańskiej w 1950 roku. Gdy jednak zakończył się najgorętszy etap konfliktu na Półwyspie Koreańskim, politycy propekińscy zaczęli znów snuć plany handlu z Chinami. W 1952 roku Japonia zawarła traktat pokojowy z Republiką Chińską na Tajwanie, nawiązując oficjalne stosunki dyplomatyczne $\mathrm{z}$ reżimem Guomindangu. Oznaczało to, że wszelkie inicjatywy w kontaktach z ChRL musiały przybrać formę współpracy pozarządowej. Innym ograniczeniem były sankcje gospodarcze nałożone przez Stany Zjednoczone na ChRL, którym również Japonia musiała się podporządkować ${ }^{176}$.

Pomimo tych przeszkód opłacalność handlu z Chinami pobudzała jego promotorów do kontynuacji wysiłków. Wynikiem ich starań były kolejne chińsko-japońskie pozarządowe umowy handlowe, zawarte m.in. przez reprezentantów Parlamentarnej Ligi Promocji Handlu Chińsko-Japońskiego. Pierwszą z umów podpisała w czerwcu 1952 roku grupa posłów, wracających przez Chiny z Międzynarodowej Konferencji Gospodarczej w Moskwie. Drugą wynegocjował na przełomie września i października 1953 roku przewodniczący Parlamentarnej Ligi Promocji Handlu Japońsko-Chińskiego, bliski współ-

\footnotetext{
${ }^{175}$ Hatano Masaru, Shimizu Urara, Yūkō no kakehashi o yumemite - Nitchū kokkō seijōka e no kiseki, Gakuyō Shobō, Tokio 2004, s. 5-6.

${ }^{176}$ W 1949 roku państwa Zachodu utworzyły z inicjatywy amerykańskiej Komitet Koordynacyjny ds. Eksportu do Obszarów Komunistycznych (Coordinating Committee for Export to Communist Areas, COCOM). Japonia stała się jego członkiem w 1952 roku, ale Stany Zjednoczone wymusiły na rządzie w Tokio jeszcze większe ograniczenia w handlu z ChRL niż te regulowane przez Komitet. Szerzej na ten temat: Michael Schaller, Altered States. The United States and Japan since the Occupation, Oxford University Press, New York 1997, s. 52-77.
} 
pracownik Hatoyamy Ichirō, Ikeda Masanosuke ${ }^{177}$. Jak widać, luźna formuła ligi parlamentarnej umożliwiła propekińskim politykom kontakt z komunistycznymi Chinami pomimo nieutrzymywania z tym krajem oficjalnych stosunków dyplomatycznych.

Chociaż ligi parlamentarne stworzyły podstawy pod promocję pozarządowego handlu z ChRL przed powstaniem PLD i w pierwszych latach istnienia tego ugrupowania, w następnych okresach nie odegrały już równie doniosłej roli. W latach 50. XX wieku Parlamentarna Liga Promocji Handlu Japońsko-Chińskiego zgłosiła aż 12 uchwał ponaglających rząd w kwestii pogłębiania handlu z ChRL i większość z nich została uchwalona przez parlament, jednak w latach 60. XX wieku nie złożyła już ani jednego nowego projektu rezolucji ${ }^{178}$. Pokazuje to, jak iluzoryczne było znaczenie lig parlamentarnych.

Parlamentarna Liga Przyjaźni Japońsko-Chińskiej (Nitchū Yūkō Giin Renmei) czy Parlamentarne Zgromadzenie Stosunków Japońsko-Tajwańskich (Nikka Kankei Giin Kondankai, od 1997 roku Parlamentarne Zgromadzenie JapońskoTajwańskie: Nikka Giin Kondankai) zostały powołane do życia w 1973 roku i istnieją po dziś dzień. Liczą po kilkuset członków pochodzących z różnych partii, jednak nie należy przeceniać roli, jaką pełnią. Tak naprawdę niemała jest grupa parlamentarzystów, którzy zapisali się do obu tych, zdawałoby się wzajemnie wykluczających się, organizacji. Jak stwierdza Kōno Tarō, politycy po prostu często myślą, że im większej liczby lig parlamentarnych są członkami, tym lepiej ${ }^{179}$. Z kolei Hiranuma Takeo, przewodniczący Parlamentarnego Zgromadzenia Japońsko-Tajwańskiego, przyznaje, że polityków, którzy aktywnie angażują się w działalność stowarzyszenia i nie należą do konkurencyjnej ligi parlamentarnej, jest w rzeczywistości tylko garstka ${ }^{180}$. Widać wyraźnie, że ligi parlamentarne składają się ze zbyt luźno związanych środowisk, by móc odegrać większą rolę w formułowaniu polityki PLD wobec Chin.

\section{Organizacje pozarządowe}

O ile przy pomocy lig parlamentarnych szefowie frakcji mogli $\mathrm{w}$ sprawach ideologicznych czy programowych nawiązywać kontakty z opozycją, o tyle różnorodne organizacje pozarządowe stanowiły dla polityków platformę współpracy ze światem biznesu czy innymi grupami interesu. Organizacje pozarządowe niejednokrotnie służyły także politykom PLD, szczególnie szefom frakcji ,przeciwnego nurtu”, do prowadzenia własnej, nieoficjalnej dyplomacji.

\footnotetext{
${ }^{177}$ Ikeda Masanosuke, Nazo no kuni - Chūkyō tairiku no jittai, Jiji Tsūshinsha, Tokio 1969, s. 331-340.

178 Yoshihide Soeya, Japan's Economic Diplomacy with China, 1945-1978, Clarendon Press, Oxford 1998, s. 32-33.

${ }^{179}$ Wywiad autora z Kōno Tarō...

${ }^{180}$ Wywiad autora z Hiranumą Takeo, Nagatachō Biru, Tokio, 12 III 2009.
} 
Podobnie jak ligi parlamentarne, organizacje pozarządowe miały szczególne znaczenie $\mathrm{w}$ kontaktach $\mathrm{z}$ Chinami $\mathrm{w}$ pierwszym $\mathrm{z}$ omawianych $\mathrm{w}$ pracy okresów. Przed normalizacją stosunków dyplomatycznych Japonii z ChRL w 1972 roku nieoficjalny handel pomiędzy tymi państwami był możliwy właśnie dzięki organizacjom pozarządowym, założonym m.in. przez przyszłych polityków PLD. W 1949 roku powołano do życia Stowarzyszenie Promocji Handlu Chińsko-Japońskiego (Chūnichi Bōeki Sokushinkai), w dużym stopniu opanowane przez ludzi związanych z Japońską Partią Socjalistyczną i Japońską Partią Komunistyczną. To samo środowisko założyło w 1950 roku Stowarzyszenie Przyjaźni Japońsko-Chińskiej (Nitchū Yūkō Kyōkai), mające nie tylko zajmować się wymianą handlową z ChRL, ale także pracować nad ogólną poprawą relacji bilateralnych $\mathrm{w}$ duchu światowego pokoju ${ }^{181}$. Z kolei w 1954 roku powstało Japońskie Stowarzyszenie Promocji Handlu Międzynarodowego (Nihon Kokusai Bōeki Sokushin Kyōkai), zdominowane przez środowisko konserwatywnych przedsiębiorców i polityków, nastawionych na pogłębianie handlu z ChRL. Należeli do niego m.in. tacy posłowie Partii Liberalnej, jak Ishibashi Tanzan czy Ikeda Masanosuke ${ }^{182}$. Właśnie to środowisko w chwili powołania do życia PLD w 1955 roku stało się forpocztą promocji relacji japońsko-chińskich. Dzięki wsparciu m.in. organizacji pozarządowych w październiku 1954 roku doszło do pierwszej wizyty w Japonii grupy polityków z ChRL, delegacji Chińskiego Czerwonego Krzyża z panią Li Dequan i Liao Chengzhim na czele ${ }^{183}$.

Chociaż działalność organizacji pozarządowych zajmujących się kontaktami z ChRL stała się mniej istotna po normalizacji japońsko-chińskich stosunków dyplomatycznych w 1972 roku, dotychczasowe stowarzyszenia nie tylko przetrwały, ale założono też kolejne. W 1975 roku powołano do życia Stowarzyszenie Japońsko-Chińskie (Nitchū Kyōkai), zrzeszające ludzi polityki, biznesu i kultury. Spośród parlamentarzystów PLD w jego działalność zaangażowali się m.in. Kōno Kenzō, Furui Yoshimi i Utsunomiya Tokuma ${ }^{184}$. Istniały również analogiczne organizacje promujące kontakty z Tajwanem, np. powstały w 1956 roku Komitet Współpracy Japońsko-Tajwańskiej (Nikka Kyōryoku Iinkai).

Równie istotna dla kształtowania polityki partii wobec Chin była działalność organizacji reprezentujących wpływowe grupy nacisku, którym czasami przewodniczyli szefowie frakcji PLD. Należy tu wymienić m.in. Nihon Izokukai (Japońskie Stowarzyszenie Osieroconych), skupiające rodziny żołnierzy

\footnotetext{
${ }^{181}$ Yoshihide Soeya, op.cit., s. 25-27.

182 Ibidem, s. 28-29.

${ }^{183}$ Liu Deyou, Toki wa nagarete - Ntchū kankei hishi 50 nen, t. 1, Fujiwara Shoten, Tokio 2002, s. 98 .

${ }^{184}$ Li Enmin, Tenkanki no Chūgoku, Nihon to Taiwan - 1970 nendai Chūnichi minkan keizai gaikō no keii, Ochanomizu Shobō, Tokio 2001, s. 46-48.
} 
poległych w czasie II wojny światowej. Ta nacjonalistyczna organizacja miała ścisłe związki z prawicowymi politykami PLD i poprzez domaganie się wizyt premierów w kontrowersyjnej świątyni Yasukuni mogła pośrednio wpływać na pogorszenie nastrojów w stosunkach japońsko-chińskich ${ }^{185}$. Podobnym stowarzyszeniem była Nippon Kaigi (Konferencja Japońska). Inny typ grup nacisku to organizacje czysto religijne. Należy tu wymienić Jinja Honchō, stowarzyszenie skupiające chramy shintoistyczne, czy prawicową sektę Seichō no Ie (Dom Rozwoju). Wszystkie te grupy dysponowały nawet setkami tysięcy ,głosów organizacyjnych" i konserwatywni politycy nie mogli ignorować ich żądań.

Organizacje pozarządowe spełniały w swoim czasie ważną rolę pośrednika w nieoficjalnych kontaktach japońsko-chińskich. Inne stowarzyszenia, promując swoje cele, pośrednio wpływały na nastroje w stosunkach między rządami w Tokio i Pekinie. $Z$ drugiej strony, ich działalność napotykała na podobne ograniczenia, jak aktywność lig parlamentarnych czy grup politycznych.

$$
* * *
$$

Dążenia klanów parlamentarzystów, grup politycznych, lig parlamentarnych czy organizacji pozarządowych, do których należeli posłowie PLD, bez wątpienia stanowiły jedno z uwarunkowań partyjnej polityki wobec Chin. Niemniej jednak wszystkie te grupy odgrywały jedynie drugorzędną rolę w formułowaniu linii dyplomatycznej przez władze partii. Chociaż klany parlamentarzystów wywierały olbrzymi wpływ na proces decyzyjny w PLD, nigdy nie istniało jednolite zoku dyplomacji. Klany związane z pozostałymi resortami mogły co najwyżej pośrednio wpływać na atmosferę stosunków z Chinami, a nie ustalać ogólne ramy japońskiej polityki zagranicznej. Z kolei grupy polityczne, ligi parlamentarne i organizacje pozarządowe były zazwyczaj oddalone od procesu decyzyjnego, zaś ich możliwości kształtowania polityki wobec Chin zależały od tego, czy aktualny „główny nurt” wewnątrz PLD sprzyjał, czy też przeciwstawiał się ich dążeniom.

\section{PODSUMOWANIE}

Politycy PLD należeli do różnych typów zrzeszeń, mogących wywierać mniejszy lub większy wpływ na politykę partii wobec Chin. Ponieważ jednak główną rolę w walce o władzę w partii już od 1955 roku odgrywały frakcje personalne, zasadne wydaje się skupienie analizy przede wszystkim na zbadaniu składu kolejnych „głównych nurtów” oraz instrumentalnego wykorzystania sprawy chińskiej w rywalizacji międzyfrakcyjnej. Klany polityków, choć były w stanie wpływać na japońskie ustawodawstwo, w dużym stopniu stanowiły jedynie narzędzie w rękach szefów poszczególnych frakcji. Podobnie można scharakteryzować grupy polityczne, które często odgrywały tylko rolę

${ }^{185}$ Szerzej na ten temat w czwartym i piątym rozdziale. 
tymczasowych sojuszy pomiędzy frakcjami. Z kolei związane $\mathrm{z}$ tematyką stosunków japońsko-chińskich ligi parlamentarne czy organizacje pozarządowe niejednokrotnie i tak były zdominowane przez liderów i członków poszczególnych frakcji, służąc im po prostu do pozyskiwania poparcia innych partii bądź ogółu opinii publicznej. Prymat frakcji personalnych w działalności polityków PLD zgadza się $\mathrm{z}$ teorią japońskiego społeczeństwa wertykalnego, zgodnie z którą centralne miejsce w życiu Japończyka może zajmować członkostwo w tylko jednej organizacji.

Chociaż frakcje personalne nie posiadały szczegółowych programów politycznych, da się zauważyć pewne zabarwienia ideologiczne poszczególnych grup. $\mathrm{Na}$,etos” frakcji w dużym stopniu wpłynęły przekonania i doświadczenia ich założycieli, które przetrwały nawet po wycofaniu się przez nich z życia politycznego. Szczególną rolę odgrywał podział frakcji na „główny” i „boczny nurt konserwatywny” oraz na „gołębie” i ,jastrzębie”. Na ich tle można wyróżnić także obóz propekiński i protajwański. Polityka PLD wobec Chin nie była jednak tylko wypadkową przekonań szefów poszczególnych frakcji, ale również zasad rządzących wewnątrzpartyjną rywalizacją o władzę oraz ewolucji systemu międzynarodowego. Pragnienie uczestniczenia w „głównym nurcie” mogło wymuszać na politykach kompromisy w sprawach ideologii, zaś sprawa chińska służyła za jedno z narzędzi walki o stanowisko premiera. Niemałą rolę odgrywały tu zmiany opinii publicznej oraz polityki Stanów Zjednoczonych wobec Chin. Stosunek do USA stanowił wszakże jedno z kryteriów podziału frakcji na „główny” i „boczny nurt konserwatywny”. Ponieważ zaś frakcja Satō zajmowała miejsce centralne na wykresie ideologicznym partii, to właśnie tej grupie najłatwiej było przystosowywać się do zmieniającej się sytuacji międzynarodowej w celu kształtowania ,głównego nurtu”. 


\section{Rozdział II}

\section{SPÓR PIERWSZEGO POKOLENIA PRZYWÓDCÓW FRAKCJI O POLITYKE WOBEC CHIN (1955-1972)}

Wkrótce po powstaniu PLD w 1955 roku wewnątrz partii zaczęły się formować frakcje personalne. Do 1972 roku można mówić o wzajemnej rywalizacji tzw. pierwszego pokolenia ich przywódców. Skomplikowane zaszłości personalne i ideologiczne pomiędzy pierwszoplanowymi politykami wpływały również na kształt partyjnej polityki wobec Chin. W latach 1955-1972 w PLD dominowała protajwańska „oś władzy” Kishi-Satō. Taki system był spójny z ówczesną polityką zagraniczną Japonii, która utrzymywała oficjalne stosunki dyplomatyczne z reżimem Guomindangu. Przeciwwagę dla wyraźnie protajwańskich frakcji Kishiego Nobusuke, Ishiiego Mitsujirō czy Ōno Banboku stanowili mniej wpływowi politycy z lewego skrzydła PLD, jak Matsumura Kenzō, Ishibashi Tanzan czy Miki Takeo, aktywnie starający się nawiązać i utrzymać jak najlepsze relacje z ChRL. Zwolennikami normalizacji stosunków z Chinami kontynentalnymi byli również niektórzy spośród najbardziej prawicowych działaczy partii, szczególnie z frakcji Hatoyamy Ichirō, a później Kōno Ichirō. Chcieli oni w ten sposób zademonstrować niezależność Japonii od dyplomacji Stanów Zjednoczonych.

Pomiędzy skrajnie protajwańskimi i propekińskimi frakcjami, decydującą rolę w tym okresie odgrywali jednak politycy „głównego nurtu konserwatywnego”. Ponieważ aż do 1971 roku Stany Zjednoczone prowadziły wyraźnie antychińską politykę, następcy myśli Yoshidy Shigeru, nie tylko z umiarkowanie protajwańskiej frakcji Satō Eisaku, ale również z umiarkowanie propekińskiej grupy Ikedy Hayato, nie mogli sobie pozwolić na śmielsze kontakty z ChRL. Dopiero po zmianie nastawienia USA wobec Chin pod koniec omawianego okresu ,potencjał propekiński” „głównego nurtu konserwatywnego” mógł się ujawnić w pełni, co było zresztą jednym z głównych czynników stojących za zmianą rozkładu sił wewnątrz PLD.

\section{Sytuacja międzynarodowa w latach 1955-1972}

Lata 1955-1972 były okresem wyraźnej zimnej wojny w Azji Wschodniej. Blok sowiecki i amerykański prowadziły w tym regionie rywalizację przy pomocy swoich sojuszników i państw satelickich. Chociaż Japonia odzyskała niepodległość w kwietniu 1952 roku, po wejściu w życie podpisanego we 
wrześniu 1951 roku traktatu pokojowego z San Francisco ${ }^{1}$, jej polityka wobec Chin była w dużym stopniu zdeterminowana przez sztywne ramy zimnowojennego systemu bipolarnego. Szczególną rolę odgrywała tutaj polityka zagraniczna USA.

W latach 1955-1972 rząd w Waszyngtonie prowadził politykę konfrontacji z Chinami, utożsamianymi z blokiem sowieckim. Zawierając sojusz ze Związkiem Radzieckim w 1950 roku i jednocześnie interweniując w wojnie koreańskiej², ChRL na długie lata straciła możliwości strategicznego lawirowania pomiędzy USA a ZSRR. Polityka Stanów Zjednoczonych w Azji Wschodniej opierała się na „strategii powstrzymywania”, mającej na celu niedopuszczenie do rozprzestrzenienia się komunizmu na tereny byłych kolonii Zachodu ${ }^{3}$. Amerykański udział w wojnie wietnamskiej w latach 60 . XX wieku utrwalał tylko zimnowojenną politykę Stanów Zjednoczonych.

$\mathrm{W}$ omawianym okresie stan napięcia panował pomiędzy obiema stronami chińskiej wojny domowej, znajdującymi się w przeciwległych obozach systemu bipolarnego. Konflikt odżywał periodycznie, chociażby poprzez bombardowania przez Chiny kontynentalne pozostających pod kontrolą reżimu Guomindangu wysp Jinmen i Mazu (1954-1955, 1958) ${ }^{4}$. Zawarty w kwietniu 1952 roku traktat pokojowy Japonii z Republiką Chińską na Tajwanie zapoczątkował dwudziestolecie oficjalnych stosunków dyplomatycznych pomiędzy władzami w Tokio a reżimem Guomindangu. Rząd premiera Yoshidy Shigeru zdecydował się na związek z Tajwanem ze względu na naciski ze strony Stanów Zjednoczonych, starających się umocnić solidarność obozu kapitalistycznego w Azji Wschodniej.

\footnotetext{
${ }^{1} \mathrm{~W}$ wyniku sporu pomiędzy wspierającymi reżim Guomindangu Stanami Zjednoczonymi a Wielką Brytanią, która już od stycznia 1950 roku uznawała rząd ChRL, sygnatariuszem Traktatu w San Francisco nie była żadna ze stron chińskiej wojny domowej. Z kolei niepodległość Japonii została ograniczona nierównoprawnym traktatem sojuszniczym ze Stanami Zjednoczonymi. Szerzej na ten temat: Yoshida Shigeru, Kaisō..., t. 3, s. 82; Fukunaga Fumio, Sengo Nihon..., s. 142-147; Iwanaga Kenkichirō, op.cit., s. 37.

${ }^{2}$ Wojna koreańska rozpoczęła się 25 czerwca 1950 roku atakiem wojsk północnokoreańskich na Koreę Południową. Dwa dni później prezydent USA Harry Truman rozkazał 7. Flocie patrolowanie Cieśniny Tajwańskiej. W październiku 1950 roku do wojny włączyła się po stronie północnokoreańskiej ChRL. Zawieszenie broni zostało podpisane w lipcu 1953 roku. Szerzej na ten temat: Ronald E. Powaski, The Cold War: The United States and the Soviet Union 1917-1991, Oxford University Press, New York 1998, s. 86-90.

${ }^{3}$ W marcu 1947 roku prezydent USA Harry Truman ogłosił tzw. „doktrynę Trumana”, mającą za zadanie „wsparcie wolnych narodów, które opierają się próbom podporządkowania przez zbrojne mniejszości lub presję zewnętrzną”. Po wybuchu wojny koreańskiej ta „strategia powstrzymywania" została wyraźnie rozszerzona na Azję Wschodnią. Szerzej na ten temat: ibidem, s. 72-96.

${ }^{4}$ Dzięki bombardowaniom wysepek Jinmen i Mazu Chińska Armia Ludowo-Wyzwoleńcza zdołała odwrócić uwagę wroga od działań na archipelagu Dachen, który na początku 1955 roku został zdobyty z rąk Guomindangu.
} 
Władze ChRL od samego początku podkreślały nieprawomocność tego traktatu i starały się uprawiać „dyplomację ludową” wobec społeczeństwa japońskiego 5 .

Z czasem jednak system bipolarny w Azji Wschodniej zaczął ulegać przewartościowaniu. Konflikt Chin kontynentalnych ze Związkiem Radzieckim stawał się coraz bardziej wyraźny. Po referacie Chruszczowa w 1956 roku doszło do ochłodzenia w relacjach chińsko-radzieckich ${ }^{6}$. Rozpad jedności bloku komunistycznego był już wyraźnie widoczny pod koniec lat 50. XX wieku. W 1959 roku Związek Radziecki wycofał pomoc dla chińskiego programu nuklearnego, zaś w 1962 roku odmówił wsparcia ChRL w wojnie z Indiami ${ }^{7}$. „Rewolucja kulturalna” w Chinach w drugiej połowie lat 60. XX wieku zwiększyła jeszcze bardziej wzajemne poczucie nieufności. Kulminacją stanu napięcia w relacjach bilateralnych stał się konflikt graniczny nad rzeką Ussuri w 1969 roku, który ukazał wyraźnie wrogość pomiędzy ChRL a ZSRR ${ }^{8}$.

Rozłam w bloku komunistycznym umożliwił Stanom Zjednoczonym podjęcie przełomowej decyzji o zmianie polityki wobec Azji Wschodniej. W 1971 roku doszło do potajemnej wizyty w Pekinie doradcy prezydenta USA ds. bezpieczeństwa narodowego Henry'ego Kissingera. Dzięki zapoczątkowanemu przez prezydenta Richarda Nixona zbliżeniu chińsko-amerykańskiemu system międzynarodowy w Azji Wschodniej zmienił się z dwubiegunowej walki o dominację między USA i ZSRR w „delikatną amerykańsko-chińsko-sowiecką równowagę sił”’. Nowa polityka Stanów Zjednoczonych zbiegła się w czasie z odejściem w cień pierwszego pokolenia przywódców frakcji PLD.

\section{Sytuacja wewnątrzpartyjna w latach 1955-1972}

Rywalizacja w ramach pierwszego pokolenia przywódców frakcji w PLD charakteryzowała się własną dynamiką. Oprócz dominacji w omawianym okresie protajwańskiej „osi władzy” Kishi-Satō, należy tu wymienić niski poziom instytucjonalizacji frakcji personalnych, dużą ilość frakcji małych rozmiarów oraz stosunkowo ważną rolę wszystkich trzech linii podziałów w ramach PLD: pomiędzy „głównym” a „bocznym nurtem konserwatywnym”,

\footnotetext{
5 Tzw. „dyplomacja ludowa” polegała na promocji przez ChRL pozarządowych kontaktów kulturalnych i handlowych. Jej przejawem była m.in. repatriacja z Chin japońskich obywateli. Nieoficjalne kontakty miały na celu przygotowanie gruntu pod przyszłą normalizację stosunków dyplomatycznych. Szerzej na ten temat: Shao Chuan Leng, Japan and Communist China, Doshisha University Press, Kioto 1958, s. 18-36.

${ }^{6}$ Na zamkniętym posiedzeniu XX Zjazdu Komunistycznej Partii Związku Radzieckiego w lutym 1956 roku Nikita Chruszczow dokonał krytyki kultu jednostki w wykonaniu zmarłego w 1953 roku Józefa Stalina. Chruszczow był także zwolennikiem koncepcji „pokojowego współistnienia” z USA. Mao Zedong miał mu za złe złagodzenie polityki wobec Stanów Zjednoczonych. Szerzej na ten temat: Ronald E. Powaski, op.cit., s. 115-146.

${ }^{7}$ Alan Lawrance, China under Communism, Routledge, London 1998, s. 50-54.

${ }^{8}$ Ronald E. Powaski, op.cit., s. 172.

${ }^{9}$ Fujiwara Kiichi, Teikoku to taikoku no aida. Nihon ni totte no Amerika, Chūgoku ni totte no Amerika [w:] Nitchū kankei o dō kōchiku suru ka..., s. 205.
} 
między frakcjami dawnych biurokratów a „ludzi partii” oraz między „jastrzębiami” a „,gołębiami”. W warunkach zimnowojennych również opozycja obozu protajwańskiego i propekińskiego była bardzo widoczna.

Powstała w 1955 roku PLD połączyła w jedne ramy organizacyjne różne środowiska polityków konserwatywnych, którzy zaczęli tworzyć frakcje personalne. Grupy te formowały się spontanicznie na bazie wcześniejszych relacji interpersonalnych między patronami a klientami. W porównaniu z późniejszymi okresami, w latach 1955-1972 przynależność frakcyjna była jednak dość płynna. Początkowo do frakcji należeli tylko członkowie izby niższej parlamentu, zaś i wśród nich było stosunkowo wielu posłów niezależnych. Instytucje frakcji dopiero się tworzyły, w omawianym okresie grupy te nie miały jeszcze własnych sekretariatów czy złożonej struktury hierarchicznej i nie zdążyły wykształcić własnych klanów polityków.

Wykres 2.1 Ewolucja systemu frakcyjnego w PLD w latach 1955-1972.

Frakcje propekińskie _ Frakcje protajwańskie _ Frakcje mieszane

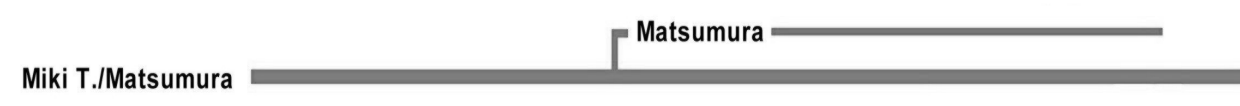

Ishibashi
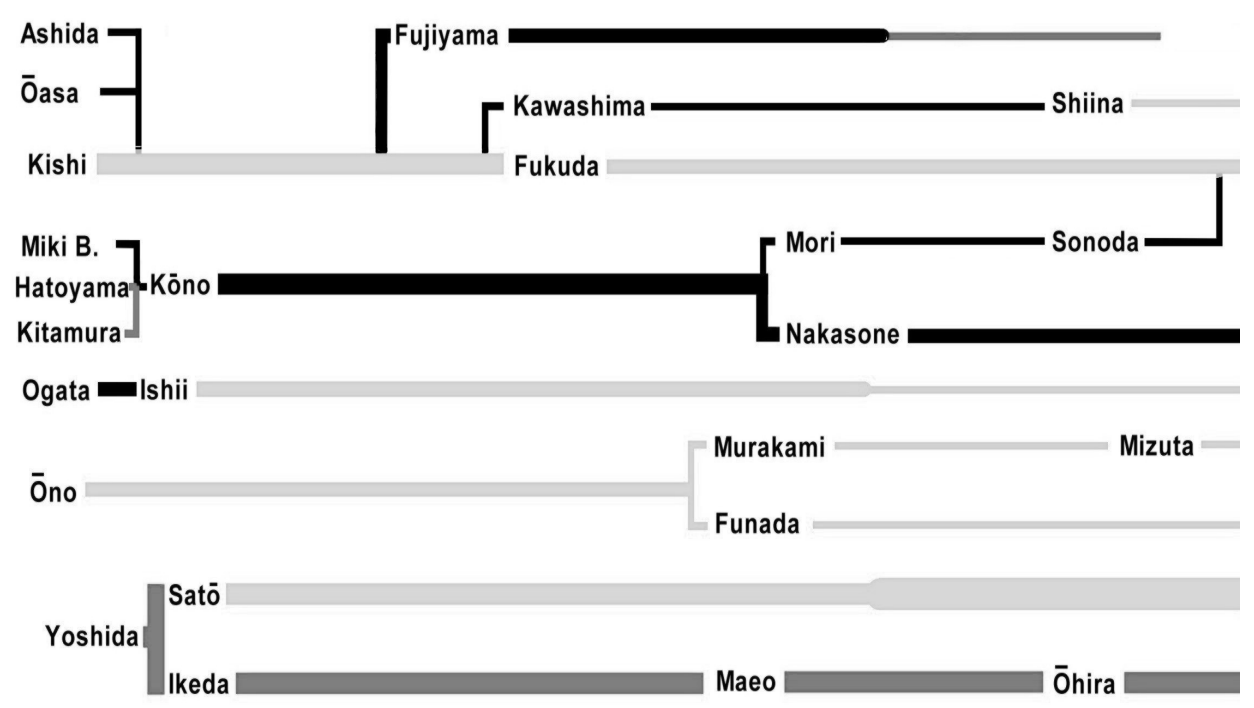

72 '71' , 70

Wielkość frakcji proporcjonalna do grubości kreski.

Opracowanie własne na podstawie m.in.: Iseri Hirofumi, op.cit., s. 11; Tsuchiya Shigeru, op.cit., s. 260; Kitaoka Shin'ichi, op.cit., s. 334-336; Fukunaga Fumio, Habatsu..., s. 80. 
$\mathrm{Z}$ początku istniało wiele małych frakcji, $\mathrm{z}$ których w wyniku fuzji i podziałów wyłoniło się osiem znaczących grup, zwanych potocznie „ośmioma dywizjami” (hakko shidan $)^{10}$. Cztery z nich wywodziły się z Japońskiej Partii Demokratycznej Hatoyamy Ichirō (szefowie frakcji: Kishi Nobusuke, Kōno Ichirō, Miki Takeo, Ishibashi Tanzan), zaś cztery z Partii Liberalnej Ogaty Taketory (szefowie frakcji: Ikeda Hayato, Satō Eisaku, Ōno Banboku, Ishii Mitsujirō). Z czasem „osiem dywizji” ulegało dalszym podziałom i fuzjom, by pod koniec omawianego okresu trzy najsłabsze z nich (Ishibashiego, Ōno i Ishiiego) zanikły lub zostały zmarginalizowane. Przed 1972 rokiem istniało jednak stosunkowo wiele małych frakcji, które mogły stanowić ,języczek u wagi” przy formowaniu „głównych nurtów".

Podstawowe linie podziału w PLD uformowały się w naturalny sposób tuż po jej powstaniu w 1955 roku, jako dziedzictwo ugrupowań, z których wywodzili się poszczególni politycy. Omówiona w pierwszym rozdziale typologia frakcji wykazywała największe nasilenie właśnie do 1972 roku. Ze względu na wiele linii podziału, nie dało się przewidzieć, który z obozów przeważy przy formowaniu „głównych nurtów”. Jedynym znaczącym wyjątkiem okazał się stały sojusz pomiędzy Kishim Nobusuke i Satō Eisaku. Okresy rządów właśnie tych dwóch premierów były czasem, w którym Japonia najbardziej podążała drogą dyplomacji zimnowojennej, utrzymując bardzo dobre stosunki z Tajwanem i bardzo złe z Chinami komunistycznymi. Nawet propekińsko nastawiony Ikeda Hayato musiał się do pewnego stopnia liczyć z wpływami protajwańskiej osi Kishi-Satō, starającej się zahamować proces pogłębiania kontaktów Japonii z ChRL.

\section{HATOYAMA ICHIRŌ I ISHIBASHI TANZAN (1955-1957)}

Ponieważ do zjednoczenia ugrupowań konserwatywnych doszło za rządów Hatoyamy Ichirō, to właśnie środowisko dawnej Japońskiej Partii Demokratycznej uzyskało większe wpływy w nowopowstałej PLD. Przewaga reprezentantów „bocznego nurtu konserwatywnego” trwała do 1960 roku, jednak należy wyraźnie odróżnić politykę wobec Chin Hatoyamy Ichirō oraz Ishibashiego Tanzana od mającej zupełnie inny charakter dyplomacji japońskiej za rządów Kishiego Nobusuke. Zarówno Hatoyama, jak Ishibashi dążyli do ocieplenia relacji z ChRL, nie wykluczając nawet normalizacji stosunków dyplomatycznych z tym państwem.

\section{Rządy Hatoyamy Ichirō i jego wizja stosunków z Chinami}

Rządzący od 1954 roku premier Hatoyama Ichirō poszukiwał stabilnej bazy poparcia dla swojego gabinetu mniejszościowego. Szybko pojawił się ruch promujący ideę zjednoczenia partii konserwatywnych. W Japońskiej Partii

\footnotetext{
${ }^{10}$ Uchida Kenzō, Habatsu..., s. 29.
} 
Demokratycznej dążyli do tego tacy wpływowi politycy, jak Miki Bukichi, Kōno Ichirō czy Kishi Nobusuke, zaś w Partii Liberalnej pomysł fuzji wspierał szczególnie jej przewodniczący Ogata Taketora. Z kolei do zdecydowanych przeciwników zjednoczenia należał w Japońskiej Partii Demokratycznej obóz byłej Partii Reform, przewodzony przez Mikiego Takeo i Matsumurę Kenzō. Zdecydowana większość oponentów utworzenia nowego ugrupowania znajdowała się jednak w Partii Liberalnej. Byli nimi przede wszystkim Satō Eisaku, Ikeda Hayato i Hori Shigeru ${ }^{11}$. Jak widać, podział na zwolenników i przeciwników zjednoczenia przebiegał niezależnie od innych linii podziału, choć zwraca uwagę fakt, że większość ,gołębi” oraz niemal wszyscy zwolennicy „doktryny Yoshidy" nie popierali fuzji. Było to naturalne, biorąc pod uwage wrogość pomiędzy Yoshidą a Hatoyamą oraz obawę przed zdominowaniem nowej partii przez będący wówczas u władzy „boczny nurt konserwatywny”. Warto także zauważyć, że politycy propekińscy znajdowali się tak wśród zwolenników (Hatoyama), jak przeciwników zjednoczenia (Miki Takeo, Matsumura, Ikeda).

Tabela 2.1 Rozkład sił pomiędzy frakcjami PLD w okresie rządów Hatoyamy Ichirō (19551956).

\begin{tabular}{|l|l|l|}
\hline \multicolumn{2}{|c|}{ Frakcje: } \\
\hline ,głównego nurtu” & poza ,głównym nurtem” & ,przeciwnego nurtu” \\
\hline Hatoyama (D, LP, J, P) 13 & Miki/Matsumura (D, LP, G, P) 26 & Yoshida (L, B, G, P) 53 \\
Kishi (D, B, J, T) 34 & Kitamura (D, LP, G, P) 18 & \\
Ōno (L, LP, J, T) 29 & Ōasa (D, LP, J) 9 & \\
Ogata (L, LP) 22 & Ashida (D, B) 7 & \\
Miki Bukichi (D, LP) 18 & & \\
Ishibashi (D, LP, G, P) 13 & & 53 \\
\hline 129 & 60 & \\
L: 2 (51), D: 4 (78), & & \\
B: 1 (34), LP: 5 (95), & & \\
G: 1 (13), J: 3 (76), & & \\
P: 2 (26), T: 2 (63). & & \\
\hline
\end{tabular}

L- dawni członkowie Partii Liberalnej, „główny nurt konserwatywny”, D- dawni członkowie Japońskiej Partii Demokratycznej, ,,boczny nurt konserwatywny”, B- dawni biurokraci, LP- ludzie partii, G- gołębie, J- jastrzębie, P- obóz propekiński, T- obóz protajwański.

Liczebność frakcji (podana przy poszczególnych frakcjach) po wyborach do Izby Reprezentantów z lutego 1955 roku. Uwzględniono tylko parlamentarzystów z Izby Reprezentantów. Liczba członków frakcji Mikiego Bukichiego i Kitamury podana w przybliżeniu. W podsumowaniu „głównego nurtu” podana jest ogólna liczba należących do niego parlamentarzystów oraz liczba frakcji, zaś w nawiasie liczba parlamentarzystów, należących do poszczególnych obozów.

Opracowanie własne na podstawie: Itagaki Eiken, op.cit., s. 27-30; Satō Seizaburō, Matsuzaki Tetsuhisa, Jimintō seiken, Chūō Kōronsha, Tokio 1986, s. 241; Fukui Haruhiro, op.cit., s. 345.

${ }^{11}$ Itagaki Eiken, op.cit., s. 27-29. 
W dniu 15 listopada 1955 roku ostatecznie zwołano kongres założycielski PLD. W tworzeniu nowej partii nie uczestniczył ani Yoshida Shigeru, ani Satō Eisaku. Ponieważ brak było zgody co do osoby, która mogłaby objąć stanowisko przewodniczącego, postanowiono powołać kolegialny zarząd, w którego skład weszli Hatoyama Ichirō, Ogata Taketora, Miki Bukichi oraz Ōno Banboku. Pierwsze wybory szefa partii urządzono dopiero na początku kwietnia 1956 roku. Zgodnie z przewidywaniami wygrał je premier Hatoyama, który nie miał poważnego kontrkandydata po śmierci Ogaty Taketory w styczniu 1956 roku $^{12}$.

W chwili powstania PLD ,główny nurt” premiera Hatoyamy tworzyli zwolennicy zjednoczenia Partii Liberalnej i Japońskiej Partii Demokratycznej, przede wszystkim reprezentanci „bocznego nurtu konserwatywnego”, „ludzie partii" i ,jastrzębie". Z kolei przeciwnicy fuzji, w tym szefowie małych frakcji wywodzących się z Partii Reform, znaleźli się w naturalny sposób poza „„łównym nurtem”, mając mniejszy wpływ na politykę rządu. Ze względu na długą historię rywalizacji Hatoyamy z Yoshidą, można także powiedzieć, że frakcja Yoshidy Shigeru, który po jakimś czasie jednak wstąpił do PLD, należała do „przeciwnego nurtu” w ramach partii. W „głównym nurcie” przeważał obóz protajwański, ale największy wpływ na politykę Japonii w tym okresie wywarły idee samego Hatoyamy. Ponieważ brat Kishiego, Satō Eisaku, odmówił z początku wejścia do PLD, wpływy protajwańskiej frakcji Kishiego były zresztą jeszcze wówczas ograniczone.

Głównym celem rządu Hatoyamy było uczynienie z Japonii równorzędnego partnera Stanów Zjednoczonych i odejście od polityki celowej podległości wobec USA prowadzonej przez Yoshidę Shigeru. Środkiem do manifestacji niezależności Japonii na arenie międzynarodowej mogła stać się normalizacja stosunków dyplomatycznych z ZSRR i ChRL. Hatoyama wielokrotnie pod-

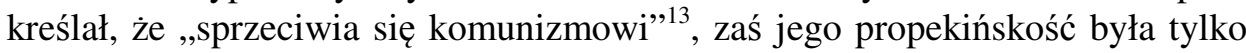
narzędziem, mającym służyć przywróceniu Japonii należnego jej miejsca na arenie międzynarodowej. Również dawny przewodniczący Partii Liberalnej, Ogata Taketora, chociaż miał wielu znajomych na Tajwanie ${ }^{14}$, nie przeciwstawiał się ociepleniu stosunków z ChRL. Według Ōno Banboku, co prawda pod względem ideologicznym Ogata nie zgadzał się z Mao Zedongiem czy Zhou Enlaiem, ale równocześnie był świadomy tego, że nienaturalny stan w relacjach z Chinami kontynentalnymi ostatecznie musi się skończyć ${ }^{15}$. Jak widać, przewodniczący obu partii, które utworzyły PLD, zgadzali się co do konieczności dokonania przełomu w kontaktach japońsko-chińskich. Pośród frakcji poza „głównym nurtem” zbliżeniu z ChRL sprzyjał m.in. Kitamura Tokutarō z

\footnotetext{
${ }^{12}$ Tsuchiya Shigeru, op.cit., s. 185-186; Ogata Taketora-shi kyūshi su, „Mainichi Shinbun” z 29 I 1956, s. 1.

${ }^{13}$ Hatoyama Ichirō, op.cit., s. 195.

${ }^{14}$ Gotō Motoo, Uchida Kenzō, Ishikawa Masumi, op.cit., t. 1, s. 121.

${ }^{15}$ Ōno Banboku, Ōno Banboku kaisōroku, Kōbundō, Tokio 1962, s. 179.
} 
dawnej Partii Reform, który podobnie jak Hatoyama uważał handel z Chinami za środek do usamodzielnienia japońskiej gospodarki ${ }^{16}$.

Z kolei postawa wobec Chin znajdującego się w „przeciwnym nurcie” Yoshidy Shigeru miała złożony charakter. Jako dawny biurokrata Ministerstwa Spraw Zagranicznych, Yoshida był realistą i starał się podejmować decyzje zgodne $\mathrm{z}$ interesem państwa. W latach 20 . XX wieku należał raczej do zwolenników ingerencji w sprawy wewnętrzne Chin ${ }^{17}$. Po klęsce Japonii w II wojnie światowej dostosował się jednak do nowej sytuacji międzynarodowej. Jako premier nawiązał w kwietniu 1952 roku oficjalne stosunki dyplomatyczne z Republiką Chińską na Tajwanie, ale nie uczynił tego z własnej woli. Ze względu na interes gospodarczy Japonii, Yoshida pierwotnie skłaniał się ku uznaniu rządu ChRL, podobnie jak uczyniła to wcześniej Wielka Brytania. Lian Degui podkreśla, że pragmatyczne stanowisko brytyjskie przemawiało do Yoshidy bardziej niż polityka USA ${ }^{18}$. Kiedy jednak Stany Zjednoczone zagroziły, że w razie nawiązania przez Japonię stosunków dyplomatycznych $\mathrm{z}$ władzami w Pekinie Senat USA nie ratyfikuje Traktatu z San Francisco, Yoshida musiał pójść na ustępstwa. W grudniu 1951 roku napisał tzw. „,notkę Yoshidy”, w której zadeklarował wolę oficjalnego uznania reżimu Guomindangu. Z drugiej strony, Yoshida podkreślał, że władze w Tokio wcale nie uznały rządu w Tajpej za reprezentanta całych Chin, zaś traktat pokojowy z Tajwanem odnosi się jedynie do terenów kontrolowanych przez reżim Guomindangu ${ }^{19}$. Był świadomy, iż ChRL potencjalnie stanowi olbrzymi rynek zbytu dla japońskich towarów. Zauważał również, że handel z tym państwem może przyczynić się do wzrostu poziomu życiowego Chińczyków oraz, co za tym idzie, porzucenia przez nich radykalnych poglądów politycznych ${ }^{20}$. Był także zdania, iż zamiast czynić z ChRL wroga, należy ją jak najszybciej odciągnąć od obozu sowieckiego ${ }^{21}$. Według Hosoyi Chihiro, Yoshida skłaniał się ku koncepcji „dwóch Chin”, czyli jednoczesnego uznania rządów w Tajpej i Pekinie ${ }^{22}$.

\footnotetext{
${ }^{16}$ Fukui Haruhiro, op.cit., s. 290.

${ }^{17}$ Yoshida dążył do maksymalizacji wpływów Japonii na arenie międzynarodowej, nawet poprzez ekspansję w Chinach. Z drugiej strony, należał do obozu proamerykańskiego i zgadzał się jedynie na taki ekspansjonizm, który nie doprowadzi do wojny ze Stanami Zjednoczonymi i Wielką Brytanią. Szerzej na ten temat: Tominomori Eiji, op.cit., s. 46; Hara Yoshihisa, Yoshida Shigeru. Sonnō no seijika, Iwanami Shoten, Tokio 2005, s. 41-68.

${ }^{18}$ Lian Degui, Meiguo yu Zhong-Ri guanxi de yanbian, 1949-1972, Shijie Zhishi Chubanshe, Pekin 2006, s. 55-58.

${ }^{19}$ Yoshida Shigeru, Kaisō..., t. 3, s. 81-88; Adachi Toshiaki, Jimintō jinbutsu fūunroku, Yoshida Shigeru kara Ōhira Masayoshi made, Shinsedai Shisutemu Sentā, Tokio 1983, s. 48.

${ }^{20}$ Yoshida Shigeru, Sekai to..., s. 196.

${ }^{21}$ Idem, Kaisō..., t. 1, s. 227.

${ }^{22}$ Hosoya Chihiro, Nihon gaikō no kiseki, Nihon Hōsō Shuppan Kyōkai, Tokio 2001, s. 148.
} 
Jeszcze przed powstaniem PLD, w kwietniu 1955 roku, Chiny i Japonia zawarły pozarządową umowę rybołówczą ${ }^{23}$. Z kolei w maju 1955 roku blisko związany z premierem Hatoyamą przewodniczący Parlamentarnej Ligi Promocji Handlu Japońsko-Chińskiego, Ikeda Masanosuke, wynegocjował w Tokio z delegatami z ChRL trzecią pozarządową umowę handlową. Zakładała ona wyraźne pogłębienie nieoficjalnej współpracy. Zgodnie z jej postanowieniami miano np. dopuścić do wystaw towarów w kraju drugiej strony oraz kontynuować rozmowy na temat utworzenia przedstawicielstw handlowych obdarzonych przywilejami dyplomatycznymi. W kwietniu 1955 roku Hatoyama Ichirō ustnie poparł pogłębianie nieoficjalnych stosunków z Chinami komunistycznymi, obiecując na tym polu ,wsparcie i współpracę" (shiji to kyōryoku $)^{24}$. Premier próbował nawet spotkać się z delegacją chińską, jednak nie udało mu się to, prawdopodobnie ze względu na niezrozumienie jego intencji przez delegację z ChRL ${ }^{25}$. Następstwem trzeciej pozarządowej umowy były m.in. wystawy towarów chińskich w Tokio i Osace jesienią 1955 roku, zaś rok później towarów japońskich w Pekinie i Szanghaju. W październiku 1956 roku przedłużono okres obowiązywania umowy do maja 1957 roku, zaś japoński minister handlu i przemysłu Ishibashi Tanzan zadeklarował gotowość rychłego ustanowienia wzajemnych przedstawicielstw handlowych ${ }^{26}$.

Premier Hatoyama szukał również innych kanałów kontaktu z władzami ChRL. W kwietniu 1955 roku na konferencji w Bandungu ${ }^{27} \mathrm{z}$ Zhou Enlaiem rozmawiał wysłannik rządu japońskiego, Takasaki Tatsunosuke ${ }^{28}$. Było to pierwsze po II wojnie światowej spotkanie między reprezentantami rządów w Tokio i Pekinie ${ }^{29}$. Zarówno Takasaki, jak i będący jednym z członków delegacji

${ }^{23}$ A. Doak Barnett, China and the Major Powers in East Asia, The Brookings Institution, Washington 1977, s. 100.

${ }^{24}$ Ikeda Masanosuke z frakcji Hatoyamy uzyskał ustne zapewnienie premiera o „wsparciu i współpracy" w sprawie postanowień pozarządowej umowy handlowej z ChRL. Na tej podstawie strona japońska sporządziła notkę, potwierdzającą wolę premiera i przekazała ją delegatom z ChRL. Szerzej na ten temat: Liu Deyou, Toki wa.., t. 1., s. 110-118; Yoshihide Soeya, op.cit., s. 37.

${ }^{25}$ Hatoyama proponował na miejsce rozmowy miejscowość wypoczynkową Hakone. Strona chińska sądziła, że premier nie chce spotkać się w Tokio, by podkreślić nieoficjalny charakter rozmowy i odmówiła. Jeden z chińskich tłumaczy, Li Deyou przyznaje jednak, że Hatoyama pragnął spotkać się w Hakone, gdyż poddawał się tam kuracji (był ciężko chory i poruszał się na wózku inwalidzkim). Szerzej na ten temat: Liu Deyou, Toki wa.., t. 1., s. 114.

${ }^{26}$ Uchida Kenzō, Sengo Nihon no hoshu seiji, Iwanami Shoten, Tokio 1969, s. 185.

${ }^{27} \mathrm{~W}$ konferencji w Bandungu brali udział przedstawiciele państw azjatyckich i afrykańskich. Uczestniczyli w niej zwłaszcza politycy z krajów postkolonialnych, które niedawno uzyskały niepodległość. Konferencja położyła podwaliny pod przyszły ruch państw niezaangażowanych w konfrontację zimnowojenną. Uczestnicząc w niej Zhou Enlai starał się ukazać pokojowe oblicze ChRL. Szerzej na ten temat: Alan Lawrance, op.cit., s. 46.

${ }^{28}$ Hatano Masaru, Shimizu Urara, op.cit., s. 104.

${ }^{29}$ Fujiyama Aiichirō, Seiji waga michi. Fujiyama Aiichirō kaisōroku, Asahi Shinbunsha, Tokio Osaka - Kitakiusiu - Nagoja 1976, s. 50-51. 
Fujiyama Aiichirō, mieli w przyszłości aktywnie zaangażować się jako posłowie „przeciwnego nurtu” w promocję pozarządowego handlu z ChRL ${ }^{30}$. Z kolei w grudniu 1955 roku Japonię odwiedził jako przewodniczący delegacji naukowej z ChRL chiński poeta i historyk Guo Moruo. Został nawet zaproszony przez Parlamentarną Ligę Promocji Handlu Japońsko-Chińskiego do japońskiego parlamentu, gdzie powitało go około 60 posłów. Próbował się z nim spotkać także premier Hatoyama, ale Guo Moruo nie przyjął tej propozycji ${ }^{31}$.

Sytuacja międzynarodowa nie sprzyjała jednak normalizacji stosunków z komunistycznymi Chinami. Hatoyama pragnął prowadzić bardziej samodzielną politykę zagraniczną, ale nie chciał zupełnego zerwania sojuszu ze Stanami Zjednoczonymi. Wręcz przeciwnie, w warunkach narastającej zimnej wojny USA zależało na remilitaryzacji Japonii, co zgadzało się z dążeniami ,jastrzębi” wewnątrz PLD. Skoro zaś rząd w Waszyngtonie utrzymywał oficjalne stosunki z ZSRR, prowadząc jednocześnie politykę izolacji ChRL na arenie międzynarodowej, przełom w kontaktach japońsko-sowieckich zdawał się znacznie bardziej realny niż w relacjach z Chinami kontynentalnymi. Wskazywały na to również zmiany $\mathrm{w}$ polityce ZSRR po śmierci Józefa Stalina oraz „duch Genewy", który zapanował po 1955 roku $^{32}$. Poza tym starająca się o przyjęcie do ONZ Japonia nie mogła narażać się reżimowi Guomindangu, który posiadając stałego członka w Radzie Bezpieczeństwa był w stanie zablokować ten proces ${ }^{33}$. Dlatego też premier Hatoyama musiał przyznać w parlamencie w marcu 1956 roku: „Jest rzeczą oczywistą, że pragnę normalizacji stosunków dyplomatycznych między Japonią a Chinami, jednak ponieważ rząd Republiki Chińskiej ma uznanie $\mathrm{w}$ ONZ, to on jest krajem utrzymującym przyjacielskie relacje $\mathrm{z}$ Japonią. Skoro zaś pozostaje on w konflikcie z Chinami komunistycznymi, niemożliwe jest uznanie Chin komunistycznych, uznając jednocześnie rząd Republiki Chińskiej. Wobec tego, nie mając wyboru, chcę stopniowo, krok po

\footnotetext{
${ }^{30}$ Takasaki Tatsunosuke miał wojenne doświadczenia związane z Chinami. W 1942 roku został prezesem spółki akcyjnej Manshū Jūkōgyō Kaihatsu, działającej w Mandżurii. Tuż po wojnie służył swoim doświadczeniem kolejnym władzom kontrolującym Mandżurię. W trakcie pobytu w Chinach Takasakiego uderzyła korupcja w armii Guomindangu, zaś natchnął go porządek i dyscyplina panujące w Chińskiej Armii Ludowo-Wyzwoleńczej. Stało się to jedną z podstaw jego propekińskiego nastawienia. Szerzej na ten temat: Yoshihide Soeya, op.cit., s. 17-18; Chen Yongqin, Gaoqi Dazhizhu yu 20 shiji 40 niandai Liaoning diqu de tiemeiye, „Nandu Xuetan” 2008, vol. 28, no. 5, s. 119-122.

${ }^{31}$ Hatoyama nawiązał kontakt z Guo Moruo poprzez wspólnego znajomego. Ponieważ obawiał się reakcji Stanów Zjednoczonych na oficjalne spotkanie, zaproponował, by do rozmowy doszło „przypadkiem” w trakcie spaceru w jednym z parków. Guo Moruo nie przystał jednak na te warunki. Szerzej na ten temat: Liu Deyou, Toki wa..., t. 1., s. 123-145.

${ }^{32} \mathrm{Na}$ konferencji w Genewie w lipcu 1955 roku doszło do pierwszego po II wojnie światowej amerykańsko-radzieckiego spotkania na szczycie. Doprowadziło ono do chwilowego odprężenia w relacjach pomiędzy oboma supermocarstwami, przerwanego interwencją ZSRR na Węgrzech jesienią 1956 roku. Szerzej na ten temat: Ronald E. Powaski, op.cit., s. 113-118.

${ }^{33}$ Yoshihide Soeya, op.cit., s. 42.
} 
kroku starać się o normalizację stosunków międzynarodowych pogłębiając handel i relacje dyplomatyczne"34.

Zdając sobie sprawę $\mathrm{z}$ niesprzyjających zbliżeniu na linii Tokio-Pekin uwarunkowań międzynarodowych, Hatoyama Ichirō poświęcił całą energię problemowi normalizacji stosunków dyplomatycznych ze Związkiem Radzieckim $^{35}$. Tym samym odłożył problem stosunków z ChRL na później. W warunkach narastającej rywalizacji międzyfrakcyjnej Hatoyama podał się do dymisji w październiku 1956 roku, zaraz po osiągnięciu głównego dyplomatycznego celu swojego gabinetu.

\section{Stracona okazja do zbliżenia z ChRL za rządów Ishibashiego Tanzana}

W krótkim okresie pomiędzy powstaniem PLD a dymisją Hatoyamy frakcje uległy znaczącej przemianie. Umarło lub odeszło w cień kilku wpływowych polityków (Miki Bukichi, Ashida Hitoshi, Kitamura Tokutarō), zaś w wyniku fuzji i zaniku najmniejszych frakcji wykształcił się system „ośmiu dywizji”. Po śmierci Ogaty Taketory, uważanego za pewnego następcę Hatoyamy na stanowisku premiera, przewodnictwo nad jego frakcją objął protajwańsko usposobiony Ishii Mitsujirō. Złożywszy urząd premiera, Hatoyama Ichirō wycofał się z polityki, zaś przywództwo nad większością członków jego frakcji przejął Kōno Ichirō. Do frakcji Kōno dołączyło także wielu innych polityków, szczególnie z grup Mikiego Bukichiego i Kitamury Tokutarō. Z kolei przy okazji wyborów na przewodniczącego PLD frakcja Yoshidy Shigeru uległa praktycznemu rozłamowi na grupy Ikedy Hayato, który poparł Ishibashiego, oraz Satō Eisaku, który wsparł swojego brata, Kishiego ${ }^{36}$. Był to początek „osi władzy" Kishi-Satō. Satō początkowo sterował frakcją spoza partii, której członkiem stał się dopiero w lutym 1957 roku $^{37}$. Yoshida pozostał posłem do 1963 roku, jednak nie odgrywał już pierwszoplanowej roli w partii.

Wybory przewodniczącego PLD z grudnia 1956 roku po raz pierwszy ukazały, jak zaciekła może być rywalizacja o władzę między szefami frakcji. Kandydaci poszukiwali strategicznych sojuszy, w których drugorzędną rolę odgrywały kwestie ideologiczne, najważniejsze zaś były obietnice stanowisk czy wręcz korzyści majątkowych. Za faworyta uważano Kishiego Nobusuke, który zdecydowanie wygrał pierwszą turę, otrzymując 223 głosy. Do drugiej tury wyborów przeszedł razem z Ishibashim Tanzanem (151 głosów). Ishibashi zwyciężył stosunkiem 258 do 251 głosów. Wybór na przewodniczącego

\footnotetext{
${ }^{34}$ Posiedzenie Komisji Spraw Zagranicznych Izby Reprezentantów (Shūgiin Gaimu Iinkai) z 29 III 1956 roku, nr 24, Archiwum Obrad Parlamentu Japonii.

${ }^{35}$ Normalizacji stosunków dyplomatycznych z ZSRR sprzeciwiała się proamerykańska frakcja Yoshidy, grożąc nawet stworzeniem nowej partii. Szerzej na ten temat: Kitaoka Shin'ichi, op.cit., s. 78-79.

${ }^{36}$ Satō Eisaku, Satō Eisaku Nikki, t. 1, Asahi Shinbunsha, Tokio 1998, s. 392-396.

${ }^{37}$ Kishi Nobusuke, Kishi Nobusuke kaikoroku - Hoshu gōdō to anpo kaitei, Kōsaidō, Tokio 1983, s. 284.
} 
zawdzięczał wcześniejszemu porozumieniu z trzecim w pierwszej turze Ishiim Mitsujirō ${ }^{38}$. „Główny nurt” utworzony przez szefów frakcji, którzy poparli Ishibashiego Tanzana, nie był zbyt spójny ideologicznie. Dominował w nim obóz „gołębi” i „ludzi partii”, ale panowała względna równowaga pomiędzy środowiskiem propekińskim i protajwańskim. Ishibashi promował kontakty z władzami w Pekinie, ale liderzy dwóch ważnych frakcji: Ishii Mitsujirō oraz Ōno Banboku, utrzymywali bliskie relacje z reżimem Guomindangu.

Tabela 2.2 Rozkład sił pomiędzy frakcjami PLD w okresie rządów Ishibashiego Tanzana (1956-1957).

\begin{tabular}{|l|l|l|}
\hline \multicolumn{2}{|c|}{ Frakcje: } \\
\hline ,głównego nurtu” & poza ,głównym nurtem” & ,przeciwnego nurtu” \\
\hline Ishibashi (D, LP, G, P) 13 & Kōno (D, LP, J) 37 & - \\
Ōno (L, LP, J, T) 29 & Kishi (D, B, J, T) 34 & \\
Miki/Matsumura (D, LP, G, P) 26 & Satō (L, B, T) 15 & \\
Ishii (L, LP, T) 22 & Ōasa (D, LP, J) 9 & \\
Ikeda (L, B, G, P) 19 & & \\
\hline 109 & 95 & - \\
L: 3 (70), D: 2 (39), & & \\
B: 1 (19), LP: 4 (90), & & \\
G: 3 (58), J: 1 (29), & & \\
P: 3 (58), T: 2 (51). & & \\
\hline
\end{tabular}

L- dawni członkowie Partii Liberalnej, główny nurt konserwatywny, D- dawni członkowie Japońskiej Partii Demokratycznej, boczny nurt konserwatywny, B- dawni biurokraci, LP- ludzie partii, G- gołębie, J- jastrzębie, P- obóz propekiński, T- obóz protajwański.

Liczebność frakcji (podana przy poszczególnych frakcjach) po wyborach do Izby Reprezentantów z lutego 1955 roku. Uwzględniono tylko parlamentarzystów z Izby Reprezentantów. W podsumowaniu „głównego nurtu” podana jest ogólna liczba należących do niego parlamentarzystów oraz liczba frakcji, zaś w nawiasie liczba parlamentarzystów, należących do poszczególnych obozów.

Opracowanie własne na podstawie: Kitaoka Shin'ichi, op.cit., s. 334, Iseri Hirofumi, op.cit., s. 109; Uchida Kenzō, Habatsu..., s. 63; Satō Seizaburō, Matsuzaki Tetsuhisa, op.cit., s. 241.

Ishii Mitsujirō był przed wojną sekretarzem generała-gubernatora Tajwanu ${ }^{39}$. W latach 1916-1921 przebywał na Tajwanie jako wysoki urzędnik władz kolonialnych. Służył pod rozkazami kolejnych japońskich administratorów wyspy: Andō Teibiego, Akashiego Motojirō i Dena Kenjirōo ${ }^{40}$. Miał w tym okresie okazję spotkać się z uciekającymi z kontynentu patriotami chińskimi,

\footnotetext{
${ }^{38}$ Tsuchiya Shigeru, op.cit., s. 186.

${ }^{39}$ Phil Deans, The Taiwan Question. Reconciling the Irreconcilable [w:] Chinese-Japanese Relations in the Twenty-first Century pod red. Marie Sőderberg, Routledge, London - New York 2002, s. 90.

${ }^{40}$ Ishii Mitsujirō, Kaisō 88 nen, Karuchā Shuppansha, Tokio 1976, s. 150-214.
} 
Sun Wenem ${ }^{41}$ i Hu Hanminem. Chociaż otrzymał rozkaz pilnowania, by nie zeszli na ląd w trakcie krótkiego pobytu na Tajwanie, nie ukrywał szacunku dla tych czołowych działaczy Guomindangu ${ }^{42}$. Po powrocie do Japonii Ishii pracował jako dziennikarz w „Asahi Shinbun”, gdzie poznał Ogatę Taketorę i Kōno Ichirō ${ }^{43}$. Po II wojnie światowej został politykiem i zaangażował się w promocję przyjacielskich relacji z reżimem Guomindangu. Przyznawał, że misję tę powierzył mu sam Yoshida Shigeru. W sierpniu 1956 roku Ishii Mitsujirō zorganizował 20-osobową delegację ludzi polityki i biznesu, z którą udał się na Tajwan. W trakcie spotkania z prezydentem Jiang Jieshim podziękował mu za łaskawą postawę wobec pokonanej Japonii i obiecał rozwijać współpracę japońsko-tajwańską ${ }^{44}$. Do frakcji Ishiiego należało też wielu innych posłów protajwańskich, jak Nadao Hirokichi.

Z kolei Ōno Banboku przed II wojną światową zaliczał się do grona bezpośrednich współpracowników Hatoyamy Ichirō, dzieki którego wsparciu zdobył mandat poselski. W latach 50. XX wieku Ōno do samego końca pozostał jednak w obozie Yoshidy Shigeru, starając się doprowadzić do pojednania pomiędzy Yoshidą a Hatoyamą. Jego frakcja stanowiła nietypową dla „głównego nurtu konserwatywnego" grupe „ludzi partii” w zdominowanym przez byłych biurokratów nurcie Yoshidy ${ }^{45}$. Ōno nie posiadał co prawda tak silnych związków z Tajwanem, jak Ishii, ale należał do obozu protajwańskiego, podobnie jak wielu polityków z jego frakcji. Nie krył podziwu dla Jiang Jieshiego za łaskawą postawę wobec pokonanej Japonii. Poznał osobiście prezydenta Tajwanu i starał się go zaprosić do Japonii ${ }^{46}$. Tajpej odwiedzał wielokrotnie, np. stojąc na czele japońskiej delegacji w 1955 roku $^{47}$.

Premier Ishibashi Tanzan był zdeklarowanym liberałem i pacyfistą. Już w okresie przedwojennym ostro krytykował japoński ekspansjonizm i kolonializm. Jako dziennikarz postępowej gazety „Tōyō Keizai Shinpō” wzywał m.in. do ograniczenia zbrojeń i wycofania wojsk z Mandżurii. Pomimo wielu utrudnień ze strony władz, kontynuował tę krytykę przez cały okres II wojny światowej ${ }^{48}$.

\footnotetext{
${ }^{41}$ Sun Wen (Sun Zhongshan, Sun Yat-sen, 1866-1925): jeden z założycieli pierwszej Republiki Chińskiej na przełomie 1911 i 1912 roku, przewodniczący Guomindangu do 1925 roku. Szerzej na ten temat: Edward Kajdański, op.cit., s. 251-252.

${ }^{42}$ Ishii Mitsujirō, op.cit., s. 174-176.

${ }^{43}$ Ibidem, s. 306-311.

${ }^{44}$ Ibidem, s. 400-403.

${ }^{45}$ Ōno Banboku, op.cit., s. 68-116.

${ }^{46}$ Ibidem, s.62-65.

${ }^{47}$ Sengo nikka kankei jūyō jikōshi z 9 XI 1963 [w:] Nichi-Chūka Minkoku kankei, A'1.2.1.7, Archiwum Dyplomatyczne Ministerstwa Spraw Zagranicznych w Tokio.

${ }^{48} \mathrm{Z}$ jednej strony Ishibashi Tanzan był idealistą, $\mathrm{z}$ drugiej zaś zawsze szukał pragmatycznych uzasadnień dla swoich przekonań. Uważał, iż w świecie coraz bardziej intensywnych powiązań gospodarczych wojna jest nieopłacalna zarówno dla państwa pokonanego, jak i zwycięskiego, zaś Japonia powinna stosować wobec Chin zasadę „otwartych drzwi”. Ostrzegał także, iż ingerencja w wewnętrzne sprawy Chin doprowadzi do utrwalenia wśród Chińczyków nastrojów antyjapońskich,
} 
W 1946 roku wszedł do świata polityki jako minister finansów w pierwszym rządzie Yoshidy Shigeru. Ponieważ popadł w konflikt o politykę gospodarczą z okupacyjnymi władzami amerykańskimi, już w 1947 roku zakazano mu pełnienia urzędów publicznych, podobnie jak politykom przedwojennym. Po zniesieniu zakazu objął stanowisko ministra handlu i przemysłu w rządzie Hatoyamy Ichirō w 1954 roku. Wzywał wówczas do normalizacji oficjalnych stosunków dyplomatycznych z ChRL i ZSRR, nawet pomimo sprzeciwu Stanów Zjednoczonych. Był również gorącym zwolennikiem rozwoju wymiany handlowej z ChRL ${ }^{49}$.

W przeciwieństwie do większości polityków nurtu konserwatywnego, Ishibashi Tanzan nie był antykomunistą. Jako gorący zwolennik teorii ekonomicznych Adama Smitha i promotor wolnego rynku uważał, że kapitalizm jest najbardziej rozsądnym systemem gospodarczym, ale jako liberał był elastyczny ideologicznie. Już w 1923 roku, niedługo po powstaniu Komunistycznej Partii Chin, Ishibashi wysoko ocenił to ugrupowanie w swoich $\operatorname{artykułach}^{50}$. Również w chwili powołania do życia ChRL ze spokojem obserwował sytuację na kontynencie azjatyckim. Według niego komunizm w Chinach był tylko metodą budowy niezależnego państwa i jako taki przypominał japońską Restaurację Meiji z 1868 roku $^{51}$. Tak naprawdę zarówno kapitalizm, jak i komunizm miały prowadzić do tego samego celu, jakim była stabilizacja oraz dobrobyt $^{52}$. Ishibashi czynił przy tym jednak zastrzeżenie, że system komunistyczny nie powinien ograniczać wolności jednostki ${ }^{53}$.

Jak widać, Ishibashi Tanzan był idealistą, postacią charyzmatyczną, zdolną do dokonania przełomu w stosunkach $\mathrm{z}$ Chinami. Z drugiej strony, baza poparcia Ishibashiego zaczęła się kruszyć tuż po wyborach. Idealistyczne usposobienie nowego premiera zdecydowało zapewne o tym, iż pragnąc zapobiec nadmiernym podziałom wewnątrzpartyjnym zaoferował ważne stanowiska reprezentantom frakcji, które wsparły w wyborach Kishiego. Dzięki temu, chociaż pozostały one poza „głównym nurtem”, nie uformowały wyraźnego „przeciwnego nurtu”. Takie postępowanie wywołało jednak niezadowolenie w

które w przyszłości będą jedynie przeszkodą w kontaktach z tym potężnym państwem, którego olbrzymiego terytorium i tak nie da się w pełni kontrolować. Szerzej na ten temat: Masuda Hiroshi, Anadorazu, kanshō sezu, hirefu sezu - Ishibashi Tanzan no tai-Chūgoku gaikōron, Sōshisha, Tokio 1993, s. 31-39; Ishibashi Tanzan, Tanzan kaisō, Iwanami Shoten, Tokio 2007, s. 197-208.

${ }^{49}$ Masuda Hiroshi, Ishibashi Tanzan. Riberarisuto no shinzui, Chūō Kōron Shinsha, Tokio 1995, s. 204; Hatano Masaru, Shimizu Urara, op.cit., s. 110.

${ }^{50}$ Masuda Hiroshi, Anadorazu..., s. 74.

${ }^{51}$ W 1868 roku obalono w Japonii władzę siogunów, przywracając rządy cesarzy. Był to początek gwałtownej modernizacji i absorpcji zachodnich wzorców kulturowych. Szerzej na ten temat: Ewa Pałasz-Rutkowska, Katarzyna Starecka, Japonia, Wydawnictwo TRIO, Warszawa 2004, s. 29-35.

${ }_{52}^{52}$ Masuda Hiroshi, Anadorazu..., s. 143-145.

${ }^{53}$ Ishibashi Tanzan, Ishibashi Tanzan hyōronshū pod red. Matsuo Takayoshiego, Iwanami Shoten, Tokio 1984, s. 264. 
gronie sojuszników Ishibashiego. Nowy premier powierzył stanowisko ministra spraw zagranicznych szefowi największej frakcji, Kishiemu Nobusuke, ale posunięciem tym skłócił się z Ishiim Mitsujirō. W zamian za wsparcie w wyborach na przewodniczącego PLD, Ishii miał objąć posadę wicepremiera, jednak sprzeciwiał się temu Kishi ${ }^{54}$. Obrażony Ishii odmówił przyjęcia innego resortu i nie wszedł do rządu ${ }^{55}$. W ten sposób jedność „głównego nurtu” została poważnie naruszona. Na dodatek protajwańsko usposobiony Kishi Nobusuke, jako minister spraw zagranicznych, uzyskał duży wpływ na dyplomację Japonii.

Obejmując urząd, Ishibashi Tanzan ogłosił pięć obietnic politycznych. Jedną z nich było ,ustanowienie pokojowego świata i normalizacja stosunków japońskochińskich" ${ }^{56}$. Najbliższy kobun i sekretarz gabinetu Ishibashiego, Ishida Hirohide, przyznaje, że na polecenie premiera rozmawiał $\mathrm{w}$ tej sprawie $\mathrm{z}$ Yoshidą Shigeru. Yoshida był pozytywnie nastawiony do idei normalizacji stosunków dyplomatycznych z Chinami i podkreślił, że ChRL nie będzie wiecznie członkiem obozu sowieckiego ${ }^{57}$. Biorąc jednak pod uwagę konieczność zachowania równowagi $w$ partii, jak też ówczesne realia zimnowojenne, Ishibashi musiał nieco stonować swoje nastawienie wobec Chin. Zaraz po zwycięstwie $\mathrm{w}$ wyborach na przewodniczącego PLD Ishibashi spotkał się $\mathrm{z}$ amerykańskim zastępcą sekretarza stanu ds. Azji Wschodniej i Pacyfiku, Walterem S. Robertsonem, który upomniał Japonię, by przestrzegała ograniczeń $\mathrm{w}$ handlu z $\mathrm{ChRL}^{58}$. Niedługo po objęciu stanowiska premiera Ishibashi powiedział: „Niezależnie od tego, czy ONZ jest w błędzie, czy nie, napiętnuje komunistyczne Chiny jako napastnika [w Korei - przyp. aut.], więc najpierw należy uzyskać od ONZ zmianę postawy. Obecnie, tak jak do tej pory, pragnę pracować nad pogłębianiem stosunków gospodarczych z ChRL" ${ }^{\text {"59 }}$. Ishibashiemu rzeczywiście zależało na zawarciu czwartej pozarządowej umowy handlowej z ChRL, gdyż w maju 1957 roku mijał okres obowiązywania trzeciej. Miał także nadzieję na rozluźnienie narzuconych przez USA ograniczeń w eksporcie towarów do krajów komunistycznych ${ }^{60}$. Z kolei minister spraw zagranicznych Kishi Nobusuke czynił starania, aby współpraca gospodarcza z ChRL nie wyszła poza minimalne ramy nieoficjalnej wymiany handlowej ${ }^{61}$. Pod koniec stycznia 1957 roku podkreślił: „Nie ma potrzeby tworzenia chińskiego przedstawiciel-

\footnotetext{
${ }^{54}$ Kishi Nobusuke, op.cit., s. 279.

${ }^{55}$ Tsuchiya Shigeru, op.cit., s. 187-188.

${ }^{56}$ Kunihiro Masao, Sōshu aru hoshu seijika Miki Takeo, Tachibana Shuppan, Tokio 2005, s. 85.

${ }^{57}$ Ishida Hirohide, Watashi no seikai Shōwashi, Tōyō Keizai Shinpōsha, Tokio 1986, s. 99.

${ }^{58}$ Chūkyō bōeki nado hanashiau - Ishibashi sōsai Ro Bei kokumujikan ho to, „Asahi Shinbun” z 20 XII 1956, s. 2.

${ }^{59}$ Hatano Masaru, Shimizu Urara, op.cit., s. 110.

${ }^{60}$ Ibidem, s. 113.

${ }^{61}$ A. Doak Barnett, op.cit., s. 101.
} 
stwa handlowego. Jeżeliby jednak je utworzono, będziemy pobierać odciski palców przedstawicieli" ${ }^{62}$.

Nadzieje, jakie można by wiązać z propekińskim nastawieniem rządu Ishibashiego nie spełniły się. Już pod koniec lutego 1957 roku, po zaledwie dwóch miesiącach urzędowania, Ishibashi musiał podać się do dymisji z powodu przepracowania i zapalenia płuc. Chociaż później doszedł do zdrowia i próbował kontynuować forsowanie propekińskiej polityki w partii, władza zdążyła już przejść w ręce jego rywala. $Z$ jednej strony, biorąc pod uwagę upór Ishibashiego w promocji stosunków z ChRL, można oczekiwać, że gdyby rządził dłużej, mógłby doprowadzić do znacznego polepszenia w stosunkach bilateralnych. Świadczą o tym słowa samego Ishibashiego, który po dymisji przepraszał, że nie zrealizował swoich zamiarów wobec Chin z powodów zdrowotnych, dodając, że zamierza temu zadaniu poświęcić resztę życia ${ }^{63}$. Z drugiej strony, należy pamiętać o ograniczeniach zimnowojennej rzeczywistości, których nawet Ishibashi Tanzan prawdopodobnie nie potrafiłby przezwyciężyć. Jak zauważa Kitaoka Shin'ichi: ,Jest także wielu ludzi mówiących, iż gdyby Ishibashi był zdrowy, dokonałby przełomu w stosunkach japońsko-chińskich. Nie da się powiedzieć, jak by się stało. Nie ulega wątpliwości, że Ishibashi był we współczesnej Japonii publicystą o rzadko spotykanych zdolnościach. Jednakże, niezależnie od polityki wewnętrznej, trudno jest stwierdzić, czy w dyplomacji były warunki do zrealizowania tej polityki (w szczególności sytuacja wewnętrzna w Stanach Zjednoczonych i Chinach)" ${ }^{\text {(64 }}$.

$$
* * *
$$

Zarówno za rządów Hatoyamy Ichirō, jak Ishibashiego Tanzana, istniała szansa na dokonanie przełomu $\mathrm{w}$ relacjach $\mathrm{z}$ Chinami. Chociaż obaj premierzy wywodzili się z „bocznego nurtu konserwatywnego”, w którym znajdowało się także wielu polityków protajwańskich, starali się o poprawę stosunków z ChRL. W skład „głównego nurtu” Hatoyamy Ichirō wchodzili tacy stronnicy reżimu Guomindangu, jak Kishi Nobusuke, ale sam premier pragnął wykorzystać problem nawiązania stosunków z Chinami komunistycznymi do umocnienia niezależności Japonii na arenie międzynarodowej. Łatwiej było jednak wykorzystać w tym celu „kartę sowiecką” i sprawa chińska została odłożona na później. Również „główny nurt” utworzony przez Ishibashiego Tanzana miał potencjał do poprawy relacji z ChRL. Nagła choroba Ishibashiego oraz szybkie osłabienie bazy poparcia dla rządu w partii pokrzyżowały jednak plany „gołębi” z PLD.

\footnotetext{
${ }^{62}$ Hatano Masaru, Shimizu Urara, op.cit., s. 112.

${ }^{63}$ Ishibashi Tanzan, Ishibashi..., s. 277.

${ }^{64}$ Kitaoka Shin'ichi, op.cit., s. 84.
} 


\section{KISHI NOBUSUKE (1957-1960)}

Za rządów premiera Kishiego Nobusuke nastroje w stosunkach japońskochińskich uległy diametralnym zmianom. Silnie zarysowana już protajwańska „oś władzy” Kishi-Satō na długo zdominowała dynamikę rywalizacji międzyfrakcyjnej w PLD, zaś Japonia na dobre pogrążyła się w logice zimnej wojny. Po rządach dwóch propekińsko nastawionych premierów nastały najtrudniejsze czasy w relacjach Japonii z ChRL. Ich symbolem stała się wizyta Kishiego w Tajpej czy incydent z flagą w Nagasaki.

\section{„Główny nurt” Kishiego Nobusuke i źródła jego protajwańskości}

Po podaniu się premiera Ishibashiego do dymisji, przewodniczącym PLD został wybrany w wyniku narady Kishi Nobusuke. Początkowo nie dokonano żadnych większych zmian personalnych $\mathrm{w}$ gabinecie, jednak wewnątrz PLD frakcje „głównego nurtu” i mu przeciwne praktycznie zamieniły się miejscami. Ishii Mitsujirō przyjął postawę neutralną pomiędzy „,głównym” a „przeciwnym nurtem", oczekując na rozwój sytuacji. Na samym początku do wyraźnych stronników Kishiego nie należał także Ōno Banboku, jednak już w lipcu 1957 roku został pozyskany do „głównego nurtu” stanowiskiem wiceprzewodniczącego PLD ${ }^{65}$. W międzyczasie zniknęła mała frakcja Ōasy Tadao.

„Główny nurt” uformowany pod przewodnictwem Kishiego był całkiem spójny ideologicznie. Reprezentował przeciwległe do poprzedniego „głównego nurtu”, prawe skrzydło partii. Do władzy doszli politycy protajwańscy, zaś „przeciwny nurt” tworzyły wyłącznie frakcje propekińskie. Z kolei frakcja Satō, chociaż była centrowa pod względem ideologicznym, współtworząc „oś władzy” z frakcją Kishiego przejęła w dużym stopniu jej protajwański charakter. Pomimo odmiennych nazwisk Kishi i Satō byli rodzonymi braćmi. Pochodzili z wielodzietnej rodziny i Satō Nobusuke jako dziecko zmienił nazwisko na Kishi, dawne nazwisko swojego ojca ${ }^{66}$.

Do „głównego nurtu” należała m.in. grupa Kōno. Stanowiła ona ciekawy przykład frakcji o mieszanym nastawieniu wobec Chin. Z jednej strony zrzeszała wielu następców propekińskiej myśli Hatoyamy, z drugiej zaś należeli do niej również liczni członkowie obozu protajwańskiego. Kōno Ichirō jeszcze przed II wojną światową został kobunem Hatoyamy, przejmując od niego znaczną część poglądów politycznych. Podobnie jak Hatoyama był zdeklarowanym antykomunistą, ale aktywnie wspierał swojego oyabuna w staraniach o normalizację

\footnotetext{
${ }^{65}$ Hara Yoshihisa, Kishi Nobusuke. Kensei no seijika, Iwanami Shoten, Tokio 2007, s. 200.

${ }^{66}$ Wang Zhensuo, op.cit., s. 110.
} 
stosunków dyplomatycznych z ZSRR ${ }^{67}$. We frakcji przeważali ,jastrzębie”, jednak należeli do niej także dawni członkowie umiarkowanej grupy Kitamury ${ }^{68}$.

Tabela 2.3 Rozkład sił pomiędzy frakcjami PLD w okresie rządów Kishiego Nobusuke w latach 1957-1959.

\begin{tabular}{|l|l|l|}
\hline \multicolumn{2}{|c|}{ Frakcje: } \\
\hline ,głównego nurtu” & poza ,głównym nurtem” & ,przeciwnego nurtu” \\
\hline Kishi (D, B, J, T) 54 & Ishii (L, LP, T) 22 & Miki/Matsumura (D, LP, G, P) 34 \\
Satō (L, B, T) 36 & & Ikeda (L, B, G, P) 33 \\
Ōno (L, LP, J, T) 37 & & Ishibashi (D, LP, G, P) 14 \\
Kōno (D, LP, J) 33 & & \\
\hline 160 & 22 & 81 \\
L: 2 (73), D: 2 (87), & & \\
B: 2 (90), LP: 2 (70), & & \\
G: 0, J: 3 (124), & \\
P: 0, T: 3 (127). & & \\
\hline
\end{tabular}

L- dawni członkowie Partii Liberalnej, główny nurt konserwatywny, D- dawni członkowie Japońskiej Partii Demokratycznej, boczny nurt konserwatywny, B- dawni biurokraci, LP- ludzie partii, G- gołębie, J- jastrzębie, P- obóz propekiński, T- obóz protajwański.

Liczebność frakcji (podana przy poszczególnych frakcjach) po wyborach do Izby Reprezentantów z maja 1958 roku. Uwzględniono tylko parlamentarzystów z Izby Reprezentantów. W podsumowaniu „głównego nurtu” podana jest ogólna liczba należących do niego parlamentarzystów oraz liczba frakcji, zaś w nawiasie liczba parlamentarzystów, należących do poszczególnych obozów.

Opracowanie własne na podstawie: Kitaoka Shin’ichi, op.cit., s. 334; Uchida Kenzō, Habatsu..., s. 63; Iseri Hirofumi, op.cit., s. 109.

Kishi Nobusuke bez wątpienia był centralną osobą „tajwańskiego lobby" w PLD w pierwszym okresie jej istnienia. Jego osobiste związki z Chinami sięgały jeszcze czasów sprzed zimnej wojny. Jako zwolennik gospodarki centralnie planowanej, nastawionej na potrzeby ekspansjonistycznej polityki Japonii, Kishi posiadał rozległe kontakty ze stacjonującą w Mandżurii Armią Kwantuńską (jap. Kantōgun, chiń. Guandongjun). Umocnił je jeszcze bardziej w latach 1936-1939, kiedy oddelegowano go z Ministerstwa Handlu i Przemysłu do okupowanej przez Japonię Mandżurii, by planował jej rozwój gospodarczy ${ }^{69}$. Zabrał tam ze sobą swojego najwierniejszego współpracownika, Shiinę Etsusaburō, który był bratankiem dawnego wysokiego urzędnika cywilnej administracji Tajwanu, Gotō Shinpeia ${ }^{70}$. W 1941 roku Kishi został ministrem handlu i przemysłu w

\footnotetext{
${ }^{67}$ Kōno Ichirō, Kōno Ichirō jiden, Tokuma Shoten, Tokio 1965, s. 180-268.

${ }^{68}$ Hatakeyama Takeshi, Habatsu no uchimaku, Rippu Shobō, Tokio 1975, s. 60; Uchida Kenzō, Sengo Nihon no..., s. 218.

${ }^{69}$ Chińscy ministrowie w marionetkowym rządzie stworzonego w 1932 roku Państwa Mandżurii (jap. Manshūkoku, chiń. Manzhouguo) byli tylko figurantami, rzeczywista władza spoczywała w rękach ich japońskich doradców.

${ }^{70}$ Kobayashi Hideo, Manshū to Jimintō, Shinchōsha, Tokio 2005, s. 85.
} 
militarystycznym rządzie Tōjō Hidekiego (1941-1944). Stało się to główną przyczyną uwięzienia Kishiego w latach 1945-1948 jako osoby podejrzanej o bycie zbrodniarzem wojennym klasy A.

Kiedy w 1949 roku siły Guomindangu zostały zepchnięte na Tajwan, środowisko dawnych żołnierzy japońskich zawiązało tzw. „Białe Oddziały” (chiń. Baituan), które szkoliły wojsko reżimu Jiang Jieshiego. Byli wśród nich również niegdysiejsi członkowie Armii Kwantuńskiej. Właśnie poprzez ich pośrednictwo Kishi Nobusuke nawiązał osobiste stosunki $\mathrm{z}$ prezydentem Jiangiem i jego otoczeniem ${ }^{71}$. Jak pisze Honzawa Jirō: „Wróg wroga często bywał przyjacielem. Aby wygrać wojnę domową z komunistami Jiang Jieshi użył dawną armię japońską (Armię Kwantuńską). Na początku została wykorzystana jako siła bojowa, jednak później wciągnęła do współpracy także przedwojennych biurokratów, przedsiębiorców i polityków mających powiązania z wojskowymi wysokiej rangi. Jiang Jieshi z Tajwanu zainwestował w tę akcję olbrzymie fundusze. W ten sposób doszło do uformowania się w Nagatachō [potoczna nazwa japońskiej sceny politycznej - przyp. aut.] siedliska tajwańskiego lobby. Jak mówi senior świata polityki, Matsuno Raizō (były dyrektor Agencji Obrony), bracia Kishi Nobusuke i Satō Eisaku byli tu pierwsi na liście" ${ }^{, 72}$.

Kishiemu bliskie były idee japońskiego nacjonalizmu oraz „wielkoazjanizmu” (daitōashugi), które uformowały także jego nastawienie wobec Chin. Jeszcze w czasach studenckich na Tokijskim Uniwersytecie Imperialnym (Tōkyō Teikoku Daigaku) wywarły na niego wpływ konserwatywne poglądy konstytucjonalisty Uesugiego Shinkichiego, który podkreślał suwerenną władzę cesarza i wartości japońskie (tzw. kokusuishugi) ${ }^{73}$. Innym istotnym dla Kishiego myślicielem był Ōkawa Shūmei, sądzony po II wojnie światowej jako zbrodniarz wojenny klasy A z powodu propagowania ,wielkoazjanizmu”. Według tego nurtu Japonia powinna stać na czele wyzwolenia narodów azjatyckich spod panowania mocarstw zachodnich. Idee te stały u podstaw japońskiego ekspansjonizmu i próby utworzenia Strefy Wspólnego Dobrobytu Wielkiej Azji Wschodniej (Daitōa Kyōeiken) ${ }^{74}$. Chęć uczynienia z Japonii przewodniej siły w Azji Wschodniej widoczna była także w okresie kadencji Kishiego jako premiera. Zagrożenie dla tej wizji stanowiły komunistyczne Chiny.

Z reżimem Guomindangu Kishiego Nobusuke łączyły głównie poglądy antykomunistyczne. Kiedy pod koniec 1948 roku wojska Jiang Jieshiego wyraźnie przegrywały wojnę z siłami KPCh, przebywający w więzieniu Kishi pisał $\mathrm{w}$ pamiętniku, iż Stany Zjednoczone powinny wspomóc Guomindang

\footnotetext{
${ }^{71}$ Chen Fenglin, Shixi An Xinjie (Kishi Nobusuke) neige shiqi de Ri-Tai guanxi, „Dongbeiya Luntan" 2004, vol. 13, no. 1, s. 89-90.

${ }^{72}$ Honzawa Jirō, Taiwan robī, Dētahausu, Tokio 1998, s. 114-115.

${ }^{73}$ Hara Yoshihisa, Kishi Nobusuke. Kensei..., s. 23.

${ }^{74}$ Idem, Kishi Nobusuke shōgenroku, Mainichi Shinbunsha, Tokio 2003, s. 353-356.
} 
bezpośrednią interwencją militarną, a nie tylko pieniędzmi ${ }^{75}$. Antykomunizm Kishiego widać wyraźnie także w programie założonej przez niego w 1952 roku partii, Sojuszu Odbudowy Japonii (Nippon Saiken Renmei). Wśród głównych celów tego ugrupowania, razem z hasłami zmiany konstytucji i zacieśnienia sojuszu ze Stanami Zjednoczonymi, znalazła się także: „Budowa pokojowego państwa poprzez prowadzenie samodzielnej dyplomacji i zapobieżenie inwazji komunizmu"76. Chęć przeciwstawienia się blokowi sowieckiemu motywowała do działania właściwie cały obóz konserwatywny w Japonii, jednak politycy frakcji Kishiego w PLD reprezentowali pod tym względem stanowisko bardziej dogmatyczne od przeciętnej.

Jako premier, Kishi sam wypowiadał się na temat swojego antykomunizmu. Na posiedzeniu Komisji Spraw Zagranicznych Izby Reprezentantów pod koniec lipca 1957 roku stwierdził: „Jak już wcześniej mówiłem, zdecydowanie stoję na stanowisku, że idea budowy Państwa Japońskiego, droga, którą powinniśmy kroczyć, w zupełności polega na liberalnej demokracji. W tym znaczeniu jestem antykomunistą. Sprzeciwiam się komunizmowi. Jednakże nie mam zamiaru ingerować $\mathrm{w}$ sprawy wewnętrzne krajów zbudowanych na bazie komunizmu i próbować zmienić je w liberalne demokracje. Z drugiej strony moim zdaniem, jako że Japonia jest krajem liberalnej demokracji w znaczeniu przed chwilą powiedzianym, staramy się zrealizować tę ideę i musimy zawsze uważać na spiski mające na celu zakłócenie naszej polityki wewnętrznej czy myśli

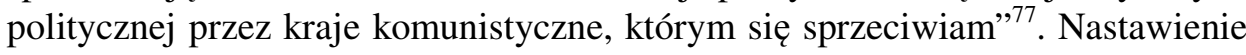
na tropienie „spisków” komunistycznych nie mogło sprzyjać dobrej atmosferze w kontaktach z ChRL.

\section{Ku zamrożeniu kontaktów z ChRL}

Pomimo antykomunistycznych poglądów i dobrych osobistych stosunków z Jiang Jieshim, ze względu na interes Japonii Kishi Nobusuke nie pragnął zupełnie zrywać nieoficjalnych kontaktów z ChRL, póki nie przekraczały one ram pozarządowej wymiany handlowej i kulturalnej. Jako minister spraw zagranicznych Kishi podkreślił w lutym 1957 roku w parlamencie: „Co do problemu Chin, zamierzamy we wszystkich aspektach zwiększać stosunki handlowe oraz wymianę kulturalną, jednakże uważam, że na obecnym etapie nie nadeszła jeszcze pora na normalizację czy przywrócenie stosunków dyplomatycznych z Chinami" ${ }^{78}$. Pamiętniki Kishiego dobrze obrazują jego nastawienie do handlu z ChRL: „Od chwili powołania do życia gabinetu Kishiego tacy przywódcy, jak Zhou Enlai czy Chen Yi często krytykowali rząd

\footnotetext{
${ }^{75}$ Idem, Kishi Nobusuke. Kensei..., s. 129.

${ }^{76}$ Kobayashi Hideo, op.cit., s. 121.

${ }^{77}$ Posiedzenie Komisji Spraw Zagranicznych Izby Reprezentantów (Shūgiin Gaimu Iinkai) z 31 VII 1957 roku, nr 26, Archiwum Obrad...

${ }^{78}$ Posiedzenie plenarne Izby Radców (Sangiin honkaigi) z 6 II 1957 roku, nr 5, Archiwum Obrad...
} 
Kishiego w przemówieniach i deklaracjach. (...) Czułem co prawda, że członkowie Partii Komunistycznej zazwyczaj ani nie są szczerzy, ani nie działają w dobrej woli i nie można się do nich odnosić jak do «istot ludzkich» w naszym rozumieniu, ale wypowiedzi liderów ChRL były zupełnie nie do zrozumienia. Mimo to, Chiny kontynentalne pozostawały w bliskich stosunkach z Japonią nie tylko pod względem gospodarczym, ale też kulturowym i było pożądane dążyć do przyjaźni z tym narodem, więc myślałem, że należy chwytać okazję posuwania się w tym kierunku" ${ }^{79}$. W słowach Kishiego nie widać sympatii do komunistycznych Chin, ale pobrzmiewa w nich także gotowość do pewnej współpracy z tym państwem. Rząd Kishiego rzeczywiście pracował nad złagodzeniem zakazu eksportu niektórych towarów do ChRL, jednak w porównaniu z gabinetem Ishibashiego przestało to już być sprawą priorytetową ${ }^{80}$.

Niedługo po objęciu urzędu premiera, Kishi udał się z wizytą do państw Azji Południowo-Wschodniej. Dążył do wzmocnienia stosunków gospodarczych między Japonią a tym regionem oraz rozwiązania kwestii odszkodowań wojennych. Wspierając rozwój gospodarczy Azji Południowo-Wschodniej chciał przyczynić się do zahamowania ekspansji komunizmu ${ }^{81}$. Jak podkreśla Hara Yoshihisa: „Należy pamiętać, że takie podejście Kishiego do Azji niekoniecznie było niespójne $\mathrm{z}$ jego niegdysiejszą ideą «Strefy Wspólnego Dobrobytu Wielkiej Azji Wschodniej» z Japonią na czele czy «wielkoazjanizmu». W przeprowadzonym z nim w późniejszych latach wywiadzie potwierdził, że «wielkoazjanizm», który sam wyznawał przed wojną, oraz powojenne zainteresowanie Azją «idealnie się łączą», «ma to również związek z faktem, iż pojechałem do Państwa Mandżurii», innymi słowy «raczej nie ma przerwy» pomiędzy jego okresem «przedwojennym» i «powojennym», tylko «są one spójne» ${ }^{\prime 2}$.

W drodze powrotnej z Azji Południowo-Wschodniej Kishi odwiedził w dniach 2-4 czerwca 1957 roku Tajwan, gdzie odbył kilka rozmów z prezydentem Jiang Jieshim. W pamiętnikach Kishi przyznaje: „Złożyłem Jiang Jieshiemu podziękowanie za łaskę rządu chińskiego, który w chwili zakończenia wojny odpowiedział cnotą na nienawiść. Ze szczerego serca wyraziłem także wdzięczność, że sprzeciwił się podziałowi okupowanej Japonii, jak też wsparł ideę zachowania instytucji cesarza. Odtąd moje stosunki z Tajwanem są głębokie i długotrwałe" ${ }^{\text {" }}$. Najwięcej kontrowersji narosło wokół kwestii deklaracji przez Kishiego wsparcia dla koncepcji odbicia przez reżim Guomindangu Chin kontynentalnych. Mimo że premier wyjaśniał, że nie wyraził bezpośrednio wsparcia dla idei

\footnotetext{
${ }^{79}$ Kishi Nobusuke, op.cit., s. 365.

${ }^{80}$ Hatano Masaru, Shimizu Urara, op.cit., s. 132.

${ }^{81}$ Kobayashi Hideo, op.cit., s. 168-170.

${ }^{82}$ Hara Yoshihisa, Kishi Nobusuke. Kensei..., s. 190.

${ }^{83}$ Kishi Nobusuke, op.cit., s. 315.
} 
zbrojnego ataku na kontynent ${ }^{84}$, media z ChRL i tak ostro krytykowały jego wizytę na Tajwanie. Kishi oświadczył wszakże, iż „polityka Japonii jest bezwzględnie antykomunistyczna" oraz obiecał nie nawiązywać oficjalnych stosunków dyplomatycznych z Chinami komunistycznymi ${ }^{85}$.

Oprócz Kishiego również inni protajwańscy politycy z PLD starali się promować związki Japonii z reżimem Guomindangu. Jeszcze w kwietniu 1957 roku Ishii Mitsujirō zorganizował $\mathrm{w}$ Tokio razem $\mathrm{z}$ sekretarzem prezydenta Jianga, Zhang Qunem, pierwszą konferencję założonego rok wcześniej Komitetu Współpracy Japońsko-Tajwańskiej (jap. Nikka Kyōryoku Iinkai, chiń. Zhong-Ri Hezuocejin Weiyuanhui lub Ri-Hua Hezuo Weiyuanhui). Skupiał on antykomunistyczne środowiska świata polityki, biznesu i kultury. Do 1971 roku Komitet miał zorganizować 16 konferencji w Tokio i Tajpej, głównie na temat rozwoju wzajemnego handlu, inwestycji, pomocy technologicznej czy wymiany personelu $^{86}$. W jego działalność zaangażowali się m.in. Kishi Nobusuke, Ōno Banboku, Funada Naka, Kaya Okinori czy Fukuda Takeo ${ }^{87}$. Ishii Mitsujirō przyznaje, że początkowo wciągnął do tej inicjatywy także ministra spraw zagranicznych Fujiyamę Aiichirō ${ }^{88}$. Symbolem dobrych stosunków japońskotajwańskich stała się wizyta w Japonii specjalnego wysłannika Jiang Jieshiego, Zhang Quna, we wrześniu 1957 roku. Ashida Hitoshi podkreśla, że Zhanga niepokoiły tylko plany pogłębienia handlu pozarządowego między Japonią a $\mathrm{ChRL}^{89}$.

W 1957 roku rzeczywiście toczyła się gorąca debata na temat czwartej umowy handlowej z ChRL. W lipcu 1957 roku rząd w Tokio złagodził ograniczenia w handlu z tym państwem ${ }^{90}$. Największe emocje budziła jednak kwestia pobierania

\footnotetext{
${ }^{84}$ Kishi Nobusuke oświadczył w parlamencie w sierpniu 1957 roku: „Nie jest prawdą, iż powiedziałem, że kontratak na kontynent byłby w porządku, jak to jest przekazywane przez gazety. Rozmowa wyglądała tylko tak. Prezydent Jiang Jieshi powiedział, że chociaż patrząc na sytuację w Japonii, wyobraża sobie, że w Japonii panuje opinia, iż ponieważ Tajwan jest mały i znajduje się w ciężkiej sytuacji, jest lekceważony przez Chiny kontynentalne, to jednak odwieczną ideą narodu chińskiego jest zachowanie wolności. Jeśli spojrzy się na czterotysiącletnią historię Chin, nie ma narodu równie kochającego wolność i dążącego do prawdziwej wolności, jak naród chiński. Patrząc z naszego punktu widzenia na obecną sytuację w Chinach, wolność jest tam ograniczana. Chociażby taki stan miał trwać tymczasowo, nie będzie się długo utrzymywał. Chociaż więc nie wiadomo, czy wyzwolenie Chin potrwa pięć, czy dziesięć lat, na pewno się zrealizuje. Prezydent Jiang Jieshi powiedział, że tak świadczy historia, sam też ma wiarę i niewzruszoną determinację wyzwolić Chiny kontynentalne. Prawdą jest, że ja wyraziłem jedynie uznanie dla tego ducha i niezachwianej wiary, nic więcej”. Źródło: Posiedzenie Komisji Spraw Zagranicznych Izby Radców (Sangiin Gaimu Iinkai) z 1 VIII 1957 roku, nr 1, Archiwum Obrad...

${ }^{85}$ Kishi sōri Shō sōtō to kaidan no ken z 4 VI 1957 [w:] Honpō yōjin shogaikoku hōmon, Ajia Taiheiyō shokoku, A'1.5.1, Archiwum Dyplomatyczne...

${ }^{86}$ Chen Fenglin, Shixi An Xinjie..., s. 92.

${ }^{87}$ Huang Dahui, op.cit., s. 39-40.

${ }^{88}$ Ishii Mitsujirō, op.cit., s. 402.

${ }^{89}$ Ashida Hitoshi, Ashida Hitoshi nikki, t. 6, Iwanami Shoten, Tokio 1986, s. 391-393.

${ }^{90}$ Michael Schaller, op.cit., s. 92.
} 
odcisków palców od chińskich przedstawicieli w Japonii. Premier Zhou Enlai nazwał wręcz takie pomysły „zniewagą wobec Chin"91. Kiedy we wrześniu 1957 roku delegacja japońska z przewodniczącym Parlamentarnej Ligi Promocji Handlu Japońsko-Chińskiego Ikedą Masanosuke na czele przybyła do Pekinu na rozmowy $\mathrm{w}$ sprawie czwartej umowy, spotkała się $\mathrm{z}$ bardzo chłodnym przyjęciem. Jako członek frakcji Kishiego, Ikeda był w stanie wynegocjować z rządem pewne ustępstwa $\mathrm{w}$ sprawie statusu przedstawicielstwa handlowego ChRL w Japonii, jednak nadal nie mógł sprostać żądaniom strony chińskiej ${ }^{92}$. Ze względu na poważną różnicę zdań i niemożność osiągnięcia kompromisu rozmowy uległy faktycznemu zawieszeniu pod koniec 1957 roku $^{93}$.

Powróciwszy do Japonii, Ikeda Masanosuke podjął starania w celu rozwiązania problemów na drodze do zawarcia czwartej umowy. Udało mu się skłonić rząd Kishiego do szybkiego przygotowania projektu zmiany ustawy o rejestracji cudzoziemców, aby wydłużyć okres pobytu w Japonii bez wymogu zostawienia odcisków palców $\mathrm{z}$ dwóch miesięcy do jednego roku ${ }^{94}$. W lutym 1958 roku, po zażartych sporach wewnątrzpartyjnych, Komisja Badań Spraw Zagranicznych PLD (Jimintō Gaikō Chōsakai), podlegająca Radzie Badań Politycznych, uchwaliła cztery zasady dotyczące memorandum nt. japońskochińskiej umowy handlowej. Ich postanowienia na tyle ingerowały $\mathrm{w}$ treść memorandum, że Ikeda Masanosuke rozważał rezygnację z ponownej podróży do $\mathrm{Chin}^{95}$. Mimo wszystko delegacja japońska wznowiła negocjacje w Pekinie i na początku marca 1958 roku zawarła czwartą umowę handlową z ChRL. Treść traktatu i dołączonego do niego memorandum wyraźnie odbiegała jednak od wcześniejszych ustaleń wewnątrzpartyjnych ${ }^{96}$. W Japonii miano utworzyć chińskie przedstawicielstwo handlowe, zaś przedstawicielom zapewnić bezpieczeństwo i możliwość wykonywania obowiązków. Co najważniejsze, zgodzono

\footnotetext{
${ }^{91}$ Hatano Masaru, Shimizu Urara, op.cit., s. 134.

92 Strona japońska była gotowa zgodzić się tylko na 5 przedstawicieli bez przywilejów dyplomatycznych, od których nie będzie się pobierać odcisków palców, oraz na 10 asystentów. Z kolei strona chińska żądała zgody na przyjęcie 30 przedstawicieli, nie licząc rodzin, z pełnymi przywilejami dyplomatycznymi, w tym ze zwolnieniem od pobierania odcisków palców. Szerzej na ten temat: ibidem, s. 140-141.

${ }^{93}$ Okazaki Yūji, Ikeda Masanosuke to sengo shoki nitchū bōeki (1): Minkan bōeki kyōtei ni honsō - Shōnai shusshin seijika no ashiato, „Tōhoku Kōeki Bunka Daigaku Sōgō Kenkyūronshū” 2002, vol. 3, s. 102-104.

${ }^{94}$ Idem, Ikeda Masanosuke to sengo shoki nitchū bōeki (2): Minkan bōeki kyōtei ni honsō - Shōnai shusshin seijika no ashiato, „Tōhoku Kōeki Bunka Daigaku Sōgō Kenkyūronshū” 2002, vol. 4, s. 118-119.

95 „Cztery zasady” to: 1) nieprzyznawanie przywilejów dyplomatycznych przedstawicielom handlowym, 2) usunięcie artykułu o prawie do wywieszania flagi państwowej, 3) ustalenie liczby członków na minimum niezbędne do wykonywania obowiązków, 4) pozarządowy wymiar umowy i konieczność uzyskania na nią zgody rządu. Szerzej na ten temat: ibidem, s. 119.

${ }^{96}$ Prawdopodobnie jednak Kishi Nobusuke wyraził zgodę na podpisanie umowy przez Ikedę Masanosuke. Szerzej na ten temat: ibidem, s. 122.
} 
się także na prawo do wywieszania flagi państwowej i niepobieranie odcisków palców od przedstawicieli handlowych ${ }^{97}$.

Podpisanie nowej umowy handlowej szybko wywołało zdecydowaną reakcję rządu w Tajpej. Na początku marca 1958 roku rzecznik prasowy tajwańskiego Ministerstwa Spraw Zagranicznych skrytykował pomysł wywieszania flagi ChRL, zaś w połowie marca Yuan Ustawodawczy (tajwański parlament) nakazał niezawieranie kontraktów handlowych ze stroną japońską ${ }^{98}$. Protesty reżimu Guomindangu natychmiast pobudziły do działania protajwańskie skrzydło w PLD, do którego należał wszakże sam premier. Pod koniec marca 1958 roku Kishi Nobusuke przekazał tajwańskiemu ambasadorowi notę, w której podkreślił, iż czwarta umowa handlowa nie oznacza ani uznania ChRL, ani zgody na przyznanie przedstawicielom handlowym przywilejów dyplomatycznych czy prawa do wywieszania flagi państwowej ${ }^{99}$. Z kolei na początku kwietnia 1958 roku premier oświadczył: „Biorąc pod uwagę konieczność zwiększenia handlu japońsko-chińskiego, szanuję ducha czwartej pozarządowej «japońsko-chińskiej umowy handlowej» oraz zapewniam wsparcie i współpracę w celu osiągnięcia zwiększenia handlu w zakresie dopuszczalnym przez prawo wewnętrzne naszego kraju, opierając się na fakcie nieuznawania wcześniej rządu [ChRL przyp. aut.], a także mając na względzie obecny stan stosunków międzynarodowych"100. Jak widać, zamiast obiecanej w umowie ,zgody rządu", premier zadeklarował jedynie na wzór Hatoyamy „wsparcie i współpracę” dla inicjatywy, a na dodatek wskazał na ograniczenia wewnątrzpaństwowe i zagraniczne, za którymi kryły się realia zimnowojenne i presja reżimu Guomindangu. Co więcej, tego samego dnia sekretarz gabinetu Kishiego, Aichi Kiichi, wyjaśnił otwarcie: „Ponieważ nie uznajemy Chin komunistycznych jako rządu, jest oczywiste, że nie możemy potwierdzić prawa do wywieszania tak zwanej flagi państwowej Chin komunistycznych w przedstawicielstwach prywatnego handlu" ${ }^{\text {"101 }}$. Widać było wyraźnie, że Kishi Nobusuke dążył do wymiany handlowej z ChRL jedynie w takim wymiarze, w jakim nie wpłynęłaby ona na dobre relacje z Tajwanem.

Nastawiona na zacieśnianie więzi ze Stanami Zjednoczonymi oraz niekomunistycznymi państwami Azji Wschodniej, w tym z Tajwanem, dyplomacja rządu Kishiego musiała nieuchronnie prowadzić do wzrostu napięcia na linii TokioPekin. Kwestionowanie postanowień czwartej umowy handlowej tylko zaostrzyło sytuację. Na dodatek rozpoczęta właśnie w ChRL polityka „,wielkiego skoku" wywołała radykalizację chińskiej dyplomacji ${ }^{102}$. W tych okolicznościach

\footnotetext{
${ }^{97}$ Yoshihide Soeya, op.cit., s. 38.

${ }^{98}$ Hatano Masaru, Shimizu Urara, op.cit., s. 146.

${ }^{99} \mathrm{Ni}$ Zhimin, Ikeda naikaku ni okeru nitchū kankei to Ōhira Masayoshi (sono 1), „Ryūkoku Daigaku Keizaigaku Ronshū” 2005, vol. 44, no. 5, s. 82.

${ }^{100}$ Okazaki Yūji, Ikeda Masanosuke to sengo shoki nitchū bōeki (2)..., s. 123.

${ }^{101}$ Ibidem, s. 123.

102 Tzw. "wielki skok naprzód" (dayuejin), rozpoczęty w 1958 roku, był koncepcją Mao Zedonga. Polegał m.in. na planach pełnej kolektywizacji chińskiego społeczeństwa czy próbach
} 
doszło do incydentu, który stał się bezpośrednią przyczyną zupełnego zamrożenia nieoficjalnych kontaktów na linii Pekin-Tokio. Na początku maja 1958 roku w sklepie w Nagasaki, w którym otwarta była wystawa znaczków chińskich, młody Japończyk związany ze środowiskami prawicowymi zerwał zawieszoną tam flagę ChRL ${ }^{103}$. Nie oskarżono go o obrazę flagi narodowej, a tylko o zniszczenie mienia, i wkrótce wypuszczono $\mathrm{z}$ aresztu. Zdarzenie to wywołało ostry protest rządu w Pekinie. Stowarzyszenie Przyjaźni JapońskoChińskiej wzywało ministra spraw zagranicznych Fujiyamę do zapobieżenia ingerencji reżimu Guomindangu w sprawy wewnętrzne Japonii, oficjalnego uznania chińskiej flagi oraz surowego ukarania sprawcy incydentu ${ }^{104}$. Mimo to tacy protajwańscy politycy, jak Ishii Mitsujirō, zdecydowanie sprzeciwiali się przeproszeniu Chin ${ }^{105}$. Władze ChRL całą odpowiedzialność zrzuciły na gabinet Kishiego i 11 maja 1958 roku całkowicie zawiesiły wszelką wymianę handlową czy kulturalną z Japonią ${ }^{106}$. Według premiera Kishiego była to jawna ingerencja w kampanię wyborczą przed nadchodzącymi wyborami do japońskiej Izby Reprezentantów ${ }^{107}$.

W każdym razie czwarta umowa handlowa miała nigdy nie wejść w życie. W ten sposób zmarnowany został wysiłek propekińskich polityków z PLD, którzy doprowadzili do zawarcia pozarządowych umów handlowych z komunistycznymi Chinami ${ }^{108}$. W lipcu 1958 roku rząd w Pekinie ogłosił „trzy zasady polityczne", które miały być podstawą ewentualnego wznowienia relacji w przyszłości ${ }^{109}$. W rządzie japońskim szczególnie minister spraw zagranicznych Fujiyama Aiichirō zdawał się zabiegać o przełamanie impasu w stosunkach z Chinami. We wrześniu 1958 roku wspomniał nawet, że wyspy Jinmen i Mazu, które pozostawały pod kontrolą reżimu Guomindangu, ostatecznie będą musiały

chałupniczej produkcji stali. Przyczynił się do poważnego kryzysu gospodarczego, klęski głodu i śmierci około 20 mln Chińczyków. Szerzej na ten temat: Alan Lawrance, op.cit., s. 57-63; Roman Sławiński, Historia Chin i Tajwanu, Wydawnictwo Naukowe ASKON, Warszawa 2002, s. 89.

${ }^{103}$ Nagasaki ni okeru Chūkyō hata hikikudashi jiken z 7 V 1958 [w:] Kokki bujoku jiken zakken, D2.3.0.8, Archiwum Dyplomatyczne...

${ }^{104}$ Nagasaki no Chūgoku kokki jiken narabi ni Taiwan no naisei kanshō ni kan suru yōseisho z 7 V 1958 [w:] Kokki bujoku jiken zakken, D2.3.0.8, Archiwum Dyplomatyczne...

${ }^{105}$ Ishii Mitsujirō, op.cit., s. 420-421.

${ }^{106}$ Mōri Kazuko, Nitchū kankei: Sengo kara shinjidai e, Iwanami Shoten, Tokio 2006, s. 41-42.

${ }^{107}$ Według Kishiego presja ze strony ChRL miała skompromitować PLD i zapewnić dobry wynik Japońskiej Partii Socjalistycznej. Szerzej na ten temat: Kishi Nobusuke, op.cit., s. 417-418.

${ }^{108}$ Wkrótce Parlamentarna Liga Promocji Handlu Japońsko-Chińskiego uległa rozpadowi ze względu na różnicę zdań pomiędzy posłami z PLD a socjalistami. Szerzej na ten temat: Hatano Masaru, Shimizu Urara, op.cit., s. 160-164.

109 „Trzy zasady polityczne” to: 1) zaprzestać aktów wrogości wobec Chin i nie powtarzać ich w przyszłości, 2) zakończyć politykę „,dwóch Chin”, 3) nie wstrzymywać przywrócenia oficjalnych stosunków chińsko-japońskich. Szerzej na ten temat: Ni Zhimin, Ikeda naikaku... (sono 1), s. 83. 
być zwrócone ChRL, gdyż znajdowały się bardzo blisko wybrzeża tego państwa ${ }^{110}$.

Warto zwrócić uwagę na zachowanie Ikedy Masanosuke. Polityk ten, który od początku lat 50. XX wieku niestrudzenie zabiegał o pogłębianie wymiany handlowej między Japonią a ChRL i osobiście podpisał trzy $\mathrm{z}$ czterech pozarządowych umów w tej sprawie, od czasu incydentu z flagą w Nagasaki zaczął zajmować coraz bardziej krytyczne stanowisko wobec Chin. $Z$ jednej strony zawiedziony był postawą ChRL ${ }^{111}$, z drugiej zaś jego poczynania $\mathrm{w}$ dużym stopniu warunkowane były przez przynależność frakcyjną. Dopóki należał do frakcji Hatoyamy Ichirō, który wspierał ideę normalizacji stosunków dyplomatycznych z ZSRR i ChRL, propekiński zapał Ikedy współgrał z linią polityczną jego oyabuna. Ikeda Masanosuke od lat utrzymywał jednak także bardzo dobre kontakty personalne z Kishim Nobusuke, którego wsparł w wyborach na przewodniczącego PLD po podaniu się do dymisji Hatoyamy. Jako członek frakcji Kishiego nie mógł wyjść poza ramy dyplomacji ówczesnego rządu $^{112}$. Przez resztę swojej kariery politycznej Ikeda Masanosuke należał do obozu protajwańskiego $\mathrm{w}$ partii ${ }^{113}$.

\section{Ku nowemu sojuszowi ze Stanami Zjednoczonymi}

Od samego początku głównym zadaniem rządu Kishiego była „racjonalizacja stosunków japońsko-amerykańskich" ${ }^{\text {"114 }}$, ukształtowanych przez traktat sojuszniczy z 1951 roku $^{115}$. Zbliżenie z Tajwanem i niekomunistycznymi krajami Azji Południowo-Wschodniej służyło także przekonaniu USA, iż Japonia jest w stanie wziąć większą odpowiedzialność za bezpieczeństwo Azji Wschodniej. Ratyfikacja nowego układu sojuszniczego ze Stanami Zjednoczonymi stała się

\footnotetext{
${ }^{110}$ Zhai Xin, Zhanhou Riben de zhengjing fenli dui-Hua zhengce - Yi An Xinjie neige wei li, „Shixue Jikan” 2008, nr 2, s. 71.

111 Ikeda Masanosuke oskarżał stronę chińską o brak woli osiągnięcia kompromisu, zbyt wygórowane żądania oraz uparte odchodzenie od zasady „rozdziału polityki od gospodarki”, którą sama sformułowała w 1953 roku. Szerzej na ten temat: Ikeda Masanosuke, Nazo no kuni..., s. 337371.

${ }^{112}$ Okazaki Yūji, Ikeda Masanosuke to sengo shoki nitchū bōeki (2)..., s. 125.

${ }^{113}$ Ikeda Masanosuke poświęcił się badaniu historii i kultury Chin. Z jednej strony czuł podziw dla cywilizacji chińskiej, z drugiej zaś ostrzegał przed wrodzonym okrucieństwem narodu chińskiego. Szerzej na ten temat: Ikeda Masanosuke, Shina minzokusei no kaimei, Naigai Jijō Kenkyūjo, Tokio 1971, s. 359-372; idem, Chūgoku minzoku no tokusei, Naigai Jijō Kenkyūjo, Tokio 1975, s. 5-252.

${ }^{114}$ Hara Yoshihisa, Kishi Nobusuke. Kensei..., s. 185.

115 Traktat sojuszniczy z 1951 roku nie był równorzędny. Premier Yoshida nie chciał pozwolić na szybką remilitaryzację kraju i wzięcie przez Japonię razem z USA współodpowiedzialności za obronę Azji Wschodniej. W zamian za zgodę na odroczenie pełnej remilitaryzacji Japonii, Stany Zjednoczone uzyskały w traktacie praktyczną swobodę dysponowania swoim wojskiem w Japonii bez konsultacji z władzami w Tokio. Szerzej na ten temat: I. M. Destler, Priscilla Clapp, Hideo Sato, Haruhiro Fukui, Managing an Alliance: The Politics of U.S.-Japanese Relations, The Brookings Institution, Washington 1976, s. 10-13.
} 
priorytetem, dla którego premier był gotowy poświęcić swoją dalszą karierę polityczną. Kishi pragnął uczynić z Japonii równorzędnego partnera USA. Umowa budziła jednak liczne kontrowersje nie tylko w społeczeństwie japońskim czy opozycji parlamentarnej, ale również wewnątrz samej PLD. Ratyfikacji sprzeciwiały się praktycznie wszystkie frakcje poza „głównym nurtem”. Debata na temat traktatu wywarła również duży wpływ na równowagę sił pomiędzy stronnictwem protajwańskim i propekińskim w PLD.

Tabela 2.4 Rozkład sił pomiędzy frakcjami PLD w okresie rządów Kishiego Nobusuke w latach 1959-1960.

\begin{tabular}{|l|l|l|}
\hline \multicolumn{2}{|c|}{ Frakcje: } \\
\hline ,głównego nurtu” & poza ,głównym nurtem” & ,przeciwnego nurtu” \\
\hline Kishi (D, B, J, T) 54 & Ishii (L, LP, T) 22 & Miki/Matsumura (D, LP, G, P) 34 \\
Satō (L, B, T) 36 & & Kōno (D, LP, J) 33 \\
Ōno (L, LP, J, T) 37 & & Ishibashi (D, LP, G, P) 14 \\
Ikeda (L, B, G, P) 33 & & \\
\hline 160 & 22 & 81 \\
L: 3 (106), D: 1 (54), & & \\
B: 3 (123), LP: 1 (37), & & \\
G: 1 (33), J: 2 (91), & & \\
P: 1 (33), T: 3 (127). & & \\
\hline
\end{tabular}

L- dawni członkowie Partii Liberalnej, główny nurt konserwatywny, D- dawni członkowie Japońskiej Partii Demokratycznej, boczny nurt konserwatywny, B- dawni biurokraci, LP- ludzie partii, G- gołębie, J- jastrzębie, P- obóz propekiński, T- obóz protajwański.

Liczebność frakcji (podana przy poszczególnych frakcjach) po wyborach do Izby Reprezentantów z maja 1958 roku. Uwzględniono tylko parlamentarzystów z Izby Reprezentantów. W podsumowaniu „głównego nurtu” podana jest ogólna liczba należących do niego parlamentarzystów oraz liczba frakcji, zaś w nawiasie liczba parlamentarzystów, należących do poszczególnych obozów.

Opracowanie własne na podstawie: Hara Yoshihisa, Kishi..., s. 208-210; Iseri Hirofumi, op.cit., s. 109; Kitaoka Shin'ichi, op.cit., s. 334.

Wewnątrzpartyjny spór o ratyfikację umowy stał się główną przyczyną zmian w „głównym nurcie” Kishiego w 1959 roku. Obok Mikiego, Ishiiego i Ishibashiego również jeden $\mathrm{z}$ dotychczasowych stronników Kishiego, Kōno Ichirō, starał się zapobiec zawarciu traktatu, przechodząc w styczniu 1959 roku do „przeciwnego nurtu”116. Zamiast niego do „głównego nurtu” wstąpił Ikeda Hayato, zachęcany do tego przez dawnego kolegę z czasów szkolnych, Satō Eisaku, jak i samego Yoshidę Shigeru, który zaakceptował nowy traktat z USA. Najważniejszym bodźcem do dołączenia do wewnątrzpartyjnej koalicji była

\footnotetext{
${ }^{116}$ Kōno Ichirō był zwolennikiem jednoczesnego z ratyfikacją traktatu uchwalenia nowej ustawy administracyjnej, która by regulowała status amerykańskich baz wojskowych. Duże znaczenie w odejściu Kōno z „głównego nurtu” miał też jego uraz do Kishiego po tym, jak premier pozbawił go w styczniu 1959 roku stanowiska przewodniczącego Rady Generalnej PLD. Szerzej na ten temat: Hara Yoshihisa, Kishi Nobusuke. Kensei..., s. 207.
} 
jednak dla Ikedy nadzieja na wygranie następnych wyborów na przewodniczącego PLD dzięki wsparciu udzielonemu przez „oś władzy” Kishi-Satōo ${ }^{117}$.

Po zmianie przymierzy „główny nurt” Kishiego stał się nieco mniej spójny ideologicznie, ale generalnie zachował swój protajwański charakter. W jego skład wszedł propekińsko nastawiony Ikeda, ale nadal dominowali zwolennicy umocnienia stosunków z reżimem Guomindangu oraz ,jastrzębie”. Inną ważną cechą nowego „głównego nurtu” była przewaga frakcji „głównego nurtu konserwatywnego". Chociaż władzę zachował jeszcze premier wywodzący się z Japońskiej Partii Demokratycznej, zapowiadało to niedługi powrót do rządów następców myśli Yoshidy Shigeru. Istotna była także przewaga frakcji dawnych biurokratów.

Zamrożenie nieoficjalnych relacji z ChRL oraz plany zacieśnienia sojuszu japońsko-amerykańskiego stały się przyczyną narastającego niezadowolenia propekińskich frakcji ,przeciwnego nurtu”. Zaczęły one demonstrować swój sprzeciw wobec rządu Kishiego poprzez uprawianie „dyplomacji alternatywnej”. W celu promocji idei wznowienia relacji japońsko-chińskich we wrześniu 1959 roku ChRL odwiedził Ishibashi Tanzan, zabierając ze sobą m.in. Utsunomiyę Tokumę. W trakcie rozmowy z premierem Zhou Enlaiem Ishibashi przedstawił ideę japońsko-chińsko-amerykańsko-sowieckiego sojuszu pokojowego ${ }^{118}$. Zgodził się również na „trzy zasady polityczne”, jak też na zasadę nierozdzielności polityki od gospodarki (jap. seikei fukabun, chiń. zhengjing bukefen). Kishi przyznaje, że nie sprzeciwiał się specjalnie samemu wyjazdowi Ishibashiego do Chin, ale deklarację o odejściu od zasady rozdziału polityki od gospodarki (czyli ograniczenia kontaktów z ChRL do relacji pozarządowych) uważał za przedwczesną ${ }^{119}$.

W październiku 1959 roku Chiny odwiedził po raz pierwszy po II wojnie światowej ${ }^{120}$ również współprzewodniczący frakcji Mikiego, Matsumura Kenzō. Zabrał ze sobą kilku polityków ze swojej frakcji, m.in. Takeyamę Yūtarō i Furuia Yoshimiego. Matsumurę zaskoczyła gościnność, z jaką został przyjęty i

\footnotetext{
117 Ówczesny minister spraw zagranicznych, Fujiyama Aiichirō, wspomina, że Yoshida zaakceptował nowy traktat sojuszniczy z USA po półrocznych dyskusjach i negocjacjach, które prowadził m.in. Kishi Nobusuke. W wyniku akceptacji traktatu przez Yoshidę, zgodził się na niego również Ikeda Hayato. Z kolei Kōno Ichirō miał zgłaszać sprzeciw tylko dlatego, że chciał użyć sprawy traktatu do rywalizacji z Kishim. Szerzej na ten temat: Fujiyama Aiichirō, op.cit., s. 93-97.

${ }^{118}$ Masuda Hiroshi, Anadorazu..., s. 210.

${ }^{119}$ Hara Yoshihisa, Kishi Nobusuke shōgenroku, s. 217-219.

${ }^{120}$ Przed wojną Matsumura kilkakrotnie odwiedzał Chiny. Np. w 1928 roku pojechał do Mandżurii jako członek delegacji parlamentarnej, odpowiedzialnej za zbadanie sprawy wypadku kolejowego, w którym zginął tamtejszy warlord, Zhang Zuolin. Delegacja wykryła, że wypadek został przygotowany przez japoński wywiad, co skompromitowało rząd Tanaki Giichiego i zmusiło go do podania się do dymisji. Szerzej na ten temat: Endō Kazuo, Matsumura Kenzō, KNB Kōsan Kabushiki Gaisha Shuppankyoku, Toyama 1975, s. 71; Zhai Xin, Songcun Qiansan jituan he Zhongguo, Shehui Kexue Wenxian Chubanshe, Pekin 2007, s. 75-80.
} 
zapał Chińczyków w budowie nowego państwa. Odtąd miał aktywnie włączyć się w ruch promocji kontaktów z ChRL i krytyki rządu Kishiego ${ }^{121}$. Podobnie jak Ishibashi, Matsumura Kenzō nie był antykomunistą. Jak napisał: „Dzielenie Azji na czerwoną i białą oraz doprowadzanie do ich konfrontacji nie jest korzystne ani dla Azji, ani także dla Japonii. Również przywódcom Chin powtarzam, aby podchodzić do Azji z szerokiego punktu widzenia, nie mówiąc o czerwonych czy białych" ${ }^{122}$. Matsumura podkreślał, iż Japonia powinna spełniać rolę pośrednika pomiędzy Stanami Zjednoczonymi a ChRL, ponieważ z jednej strony należy do obozu „wolnego świata”, z drugiej zaś jest kulturowo bliska Chinom ${ }^{123}$. Tagawa Seiichi zwraca także uwagę na nić porozumienia, czy wręcz przyjaźń, jaka się stopniowo narodziła między Matsumurą Kenzō a Zhou Enlaiem. Obaj politycy mieli sobie obiecać: „Dokonajmy przełomu w stosunkach japońsko-chińskich poprzez kontakty interpersonalne" ${ }^{124}$. Matsumura już wcześniej zaprzyjaźnił się z Liao Chengzhim, chińskim dyplomatą odpowiedzialnym za kontakty z Japonią, który był jego młodszym kolegą z Uniwersytetu Waseda ${ }^{125}$.

Zhai Xin podkreśla, że grupa polityków skupionych wokół Matsumury Kenzō (chiń. Songcun jituan) posiadała odmienny charakter niż pozostałe frakcje w PLD $^{126}$. Niektórzy z jej członków należeli zresztą do innych frakcji, np. Tagawa Seiichi do frakcji Kōno-Nakasone. Ponieważ grupa Matsumury liczyła zaledwie kilka osób, była bardzo spójna pod względem ideologicznym. Jej członkowie przejęli idee swojego oyabuna. Furui Yoshimi pisał: „Chociaż nie ma potrzeby kłócenia się z sąsiednimi Chinami, myśli się, że skoro Stany Zjednoczone się kłócą, to i Japonia musi się kłócić. (...) Nie jest to umysł Japończyków, tylko umysł Amerykanów. Twarz jest japońska, ale umysł amerykański. Takie niespójne postępowanie osiągnęło swoje granice. Ameryka i Japonia są osobnymi krajami"127. Furui Yoshimi nie przykładał także przesadnej wagi do różnic ideologicznych pomiędzy Chinami a Japonią. Jak zauważał: „W ludzkim społeczeństwie istnieją rzeczy głębiej osadzone niż ideologia. Wspólnota narodu, sąsiednich towarzyszy, rasy czy kultury, tradycyjna przyjaźń czy przywiązanie nie wygasną $\mathrm{w}$ przeciągu trzystu lub pięciuset lat. Błędem jest

\footnotetext{
${ }^{121}$ Tagawa Seiichi, Matsumura Kenzō to Chūgoku, Yomiuri Shinbunsha, Tokio 1972, s. 88.

${ }^{122}$ Matsumura Kenzō, Kakō getsuen. Matsumura Kenzō ibunshō pod red. Matsumury Masanao et al., Seirin Shoin Shinsha, Tokio 1978, s. 240.

${ }^{123}$ Ibidem, s. 254.

${ }^{124}$ Tagawa Seiichi, Matsumura Kenzō..., s. 102.

${ }^{125}$ Endō Kazuo, op.cit., s. 199.

${ }^{126}$ Zhai Xin, Songcun Qiansan jituan he Zhong-Ri bangjiao zhengchanghua, „Ribenxuekan” 2008, nr 2, s. 29.

${ }^{127}$ Furui Yoshimi, Nitchū 18 nen. Ichi seijika no kiseki to tenbō, Makino Shuppan, Tokio 1978, s. 194.
} 
zapominanie o tak głęboko zasadzonych rzeczach i dzielenie wszystkiego według ideologii” 128 .

Nasilając krytykę wobec protajwańskiej polityki Kishiego, frakcje Ishibashiego i Mikiego/Matsumury zaczęły umacniać wzajemną solidarność przed ostateczną fazą sporu o nową umowę sojuszniczą z USA. W połowie stycznia 1960 roku liberalni politycy $\mathrm{z}$ Ishibashim na czele skierowali do premiera apel w sprawie charakteru japońskiej dyplomacji. Proponowali w nim współpracę japońsko-amerykańską $\mathrm{w}$ celu przygotowania normalizacji stosunków dyplomatycznych z ChRL oraz zwołanie konferencji pięciu mocarstw: Japonii, USA, Chin, ZSRR oraz Indii, aby ponownie rozważyć kształt nowej japońskoamerykańskiej umowy sojuszniczej ${ }^{129}$.

Traktat o wzajemnej współpracy i bezpieczeństwie pomiędzy Japonią a USA został jednak podpisany w Waszyngtonie 19 stycznia 1960 roku, zaś jego ratyfikacja spotkała się $\mathrm{w}$ Japonii $\mathrm{z}$ gwałtownymi protestami i zamieszkami społecznymi. Oprócz wywołania zmiany składu „głównego nurtu” w PLD, problem zawarcia nowego traktatu sojuszniczego $\mathrm{z}$ USA stał się także następnym czynnikiem powodującym wzrost napięcia $w$ relacjach Japonii $\mathrm{z}$ ChRL. Z punktu widzenia władz w Pekinie wzmocnienie sojuszu amerykańskojapońskiego było środkiem skierowanym przeciwko blokowi komunistycznemu oraz dowodem na odrodzenie ,japońskiego militaryzmu”, wspierającego aktywnie amerykańską obecność na Tajwanie ${ }^{130}$.

W samej umowie najwięcej kontrowersji strony chińskiej budziła tzw. „klauzula dalekowschodnia”. Artykuł 4 porozumienia brzmiał: „Od czasu do czasu strony będą się wzajemnie konsultować w sprawie implementacji niniejszego Traktatu, oraz, na prośbę którejkolwiek ze Stron, kiedykolwiek zagrożone będzie bezpieczeństwo Japonii lub międzynarodowy pokój i bezpieczeństwo na Dalekim Wschodzie"131. Wzmianka o „Dalekim Wschodzie” pojawiła się także $\mathrm{W}$ artykule 6 traktatu: „W celu przyczynienia się do bezpieczeństwa Japonii oraz utrzymania pokoju i bezpieczeństwa na Dalekim Wschodzie, nadaje się Stanom Zjednoczonym prawo do używania przez ich siły

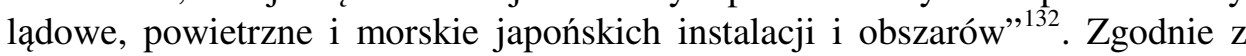
interpretacją rządu Kishiego zakres terminu „Daleki Wschód” obejmował: „Tereny mniej więcej na północ od Filipin, Japonię i regiony peryferyjne, które zawierają również Koreę Południową oraz tereny pod władzą Republiki Chińskiej” ${ }^{133}$. Władze ChRL zdecydowanie protestowały przeciw „klauzuli

\footnotetext{
${ }^{128}$ Ibidem, s. 195.

${ }^{129}$ Hatano Masaru, Shimizu Urara, op.cit., s. 182.

${ }^{130}$ Chen Fenglin, Shixi An Xinjie..., s. 90-91.

${ }^{131}$ Treaty of Mutual Cooperation and Security between Japan and the United States of America, dostępne na stronie internetowej: http://www.mofa.go.jp/region/n-america/us/q\&a/ref/1.html, uzyskane 27 VI 2008.

132 Ibidem.

${ }^{133}$ Hara Yoshihisa, Kishi Nobusuke. Kensei..., s. 217.
} 
dalekowschodniej”, wskazując, że jest to tylko środek mający zapewnić USA dominację w regionie i ochronę reżimu Guomindangu ${ }^{134}$.

Można powiedzieć, że sprzeciw frakcji poza „głównym nurtem” wobec nowego sojuszu z USA nierozerwalnie związał się z demonstracją propekińskości. Furui Yoshimi z frakcji Mikiego/Matsumury krytykował rząd za to, że z powodu „klauzuli dalekowschodniej” Japonia może być niepotrzebnie zamieszana w ewentualny konflikt między ChRL i Tajwanem o wyspy Jinmen i Mazu $^{135}$. W lutym 1960 roku frakcja Mikiego założyła Stowarzyszenie Badań Problemu Chińskiego (Chūgoku Mondai Kenkyūkai), zaś frakcja Ishibashiego Stowarzyszenie Badań Polepszenia Stosunków Japońsko-Chińskich (Nitchū Kokkō Kaizen Kenkyūkai). W tym samym miesiącu utworzono również ponadpartyjne Zgromadzenie Parlamentarne ds. Stosunków Japońsko-Chińskich (Nitchū Mondai Giin Kondankai). W dniu 19 maja 1960 roku nowy traktat sojuszniczy z USA został przegłosowany w Izbie Reprezentantów przy demonstracyjnej absencji takich propekińskich polityków, jak Miki Takeo, Matsumura Kenzō, Ishibashi Tanzan, Kōno Ichirō, Kitamura Tokutarō, Takasaki Tatsunosuke, Utsunomiya Tokuma, Furui Yoshimi czy Sonoda Sunao ${ }^{136}$.

Ratyfikacja traktatu sojuszniczego z USA była ostatnim dokonaniem gabinetu Kishiego. Przeforsowawszy ją w parlamencie, premier musiał się wywiązać ze swoich obietnic przekazania władzy w partii i państwie następnemu przewodniczącemu frakcji. Kiedy nowa umowa weszła w życie w czerwcu 1960 roku, Kishi Nobusuke podał się do dymisji. Zadanie polepszenia atmosfery w relacjach Japonii z ChRL miało już spaść na barki kolejnego premiera.

$$
\text { * * * }
$$

W chwili powstania w 1957 roku „główny nurt” premiera Kishiego był spójny ideologicznie, zrzeszając przede wszystkim ,jastrzębi” z obozu protajwańskiego. Chociaż w 1959 roku nastąpiło osłabienie jego ideologicznej jedności poprzez dołączenie do niego Ikedy Hayato, nadal dominowali w nim zwolennicy jak najbliższych stosunków z reżimem Guomindangu. Następstwem prawicowego nastawienia „głównego nurtu”, w szczególności zaś samego premiera Kishiego, było bardzo wyraźne ochłodzenie w relacjach Japonii z ChRL. Chociaż sam Kishi Nobusuke próbował kontynuować wymianę handlową z Chinami, okazało się to niewykonalne ze względu na jego zażyłe kontakty z Jiang Jieshim. Chinom komunistycznym nie wystarczała rola źródła surowców i rynku zbytu

\footnotetext{
${ }^{134}$ Ówczesny minister spraw zagranicznych i przyszły promotor nieoficjalnego handlu z ChRL, Fujiyama Aiichirō, wspomina jednak, że chociaż zdawał sobie sprawę z chińskich protestów, nie były one dla niego najważniejszym problemem, gdyż chciał przede wszystkim przywrócić Japonii równorzędną pozycję wobec USA. Szerzej na ten temat: Fujiyama Aiichirō, op.cit., s. 89-90.

${ }^{135}$ Iyasu Tadashi, Aru hoshu seijika - Furui Yoshimi no kiseki, Ochanomizu Shobō, Tokio 1987, s. 119.

${ }^{136}$ Hatano Masaru, Shimizu Urara, op.cit., s. 182-184; Fukunaga Fumio, Sengo Nihon..., s. 213.
} 
dla towarów japońskich, jaką pełniły w okresie obowiązywania pozarządowych umów handlowych. Protajwański premier nie był w stanie wyjść naprzeciw oczekiwaniom rządu w Pekinie i sprzeciwiał się takim symbolicznym gestom, jak zgoda na wywieszanie flagi ChRL w chińskich przedstawicielstwach handlowych. Z kolei ratyfikacja nowego traktatu sojuszniczego z USA była dla władz KPCh jedynie dowodem zacieśniania militarnych więzi między Japonią a Tajwanem. PLD pod przewodnictwem Kishiego Nobusuke nie była w stanie wyjść poza ramy rywalizacji zimnowojennej. Nie mógł tego zmienić również sprzeciw takich propekińskich frakcji ,przeciwnego nurtu”, jak Mikiego/Matsumury czy Ishibashiego.

\section{IKEDA HAYATO (1960-1964)}

Po trzech latach wyraźnie protajwańskich i antykomunistycznych rządów Kishiego Nobusuke przewodniczącym PLD został następca myśli Yoshidy Shigeru, Ikeda Hayato. W ten sposób władza wróciła do reprezentanta "głównego nurtu konserwatywnego". Z jednej strony prorynkowo nastawiony Ikeda spoglądał z nadzieją na możliwości handlu z ChRL, z drugiej zaś jego propekińskie nastawienie musiało być hamowane przez realia zimnej wojny. Obok dążenia do odbudowy kraju filarem ,doktryny Yoshidy” było wszakże zdecydowane oparcie się na potędze Stanów Zjednoczonych, zaś władze w Waszyngtonie podejrzliwie traktowały wszelkie kontakty Japonii z komunistycznymi Chinami. Niemniej jednak, w przeciwieństwie do Kishiego Nobusuke, Ikeda był gotowy pogłębiać wymianę handlową z ChRL, nawet narażając na szwank dobre relacje z Tajwanem.

\section{Hamowane odprężenie w stosunkach japońsko-chińskich}

Ikeda Hayato doszedł do władzy dzięki zbliżeniu do osi Kishi-Satō pod koniec rządów Kishiego Nobusuke. Kiedy Kishi podał się do dymisji, zgodnie z oczekiwaniami wsparł w wyborach kandydaturę Ikedy. W ten sposób odwdzięczył mu się za pomoc $\mathrm{w}$ ratyfikacji nowego traktatu sojuszniczego $\mathrm{z}$ USA, jednak złamał obietnicę złożoną wcześniej Ōno Banboku ${ }^{137}$, co spowodowało wyjście frakcji Ōno z ,głównego nurtu”. Inną ważną zmianą było powstanie w 1960 roku frakcji Fujiyamy Aiichirō, który z powodów personal-

\footnotetext{
${ }^{137}$ W styczniu 1959 roku Kishi potajemnie obiecał na piśmie Ōno Banboku, iż w zamian za jego wsparcie dla rządu, poprze go razem z Satō Eisaku i Kōno Ichirō jako swojego następcę. Z kolei po Ōno premierami mieli zostać kolejno Kōno i Satō. Według Kishiego cała umowa przestała obowiązywać jeszcze w 1959 roku, kiedy Kōno opuścił „główny nurt”. Jako wytrawny polityk Kishi obiecał wsparcie w wyborach także Ikedzie, Ishiiemu i Fujiyamie. Szerzej na ten temat: Uchida Kenzō, Habatsu..., s. 55-59; Tsuchiya Shigeru, op.cit., s. 191-192; Kishi Nobusuke, op.cit., s. 455-456; Ōno Banboku, op.cit., s. 145-149.
} 
nych dokonał rozłamu we frakcji Kishiego ${ }^{138}$. Co ciekawe, pomimo bliskich dotąd związków z Kishim, Fujiyama miał się w przyszłości okazać jednym z czołowych przedstawicieli stronnictwa propekińskiego w PLD. Jak opisuje w pamiętnikach, chociaż już jako minister spraw zagranicznych miał odmienne od Kishiego zdanie w sprawie stosunków z Chinami, dopiero przy okazji wyborów na przewodniczącego PLD w 1960 roku na dobre zerwał ze swoim dawnym oyabunem $^{139}$. Fujiyama jeszcze jako przedsiębiorca przed II wojną światową wielokrotnie odwiedzał Chiny i spotykał się nawet z samym Jiang Jeshim. Pomimo dawnych związków z kierownictwem Guomindangu, Fujiyama był realistą i przyznawał, iż należy rozmawiać z KPCh, gdyż to ona kontroluje Chiny kontynentalne ${ }^{140}$. Póki co jednak do frakcji Fujiyamy należeli także liczni politycy protajwańscy i grupa miała mieszany charakter pod względem nastawienia wobec Chin.

W ,głównym nurcie” Ikedy znowu dominowali dawni biurokraci, przeważało także środowisko "głównego nurtu konserwatywnego", panowała za to względna równowaga sił pomiędzy „gołębiami” a ,jastrzębiami”. Co ważne, spośród trzech dużych frakcji, które przejęły władzę w partii, aż dwie były związane z reżimem Guomindangu. Co prawda sam Ikeda Hayato patrzył z nadzieją na możliwości ocieplenia stosunków z ChRL, musiał się jednak liczyć z protajwańską ,osią władzy” Kishi-Satō, dzięki której wsparciu wygrał wybory ${ }^{141}$. $\mathrm{Na}$ dodatek, ponieważ wsparł Kishiego w ratyfikacji nowego sojuszu z USA, naraził się takim propekińskim politykom, jak Miki Takeo, Ishibashi Tanzan czy Kōno Ichirō ${ }^{142}$.

Pomimo wszystkich wewnątrzpartyjnych ograniczeń, gabinet Ikedy stanowił nową jakość po wyraźnie protajwańskich rządach Kishiego. Ikeda Hayato, jako dawny biurokrata z Ministerstwa Finansów, kładł nacisk przede wszystkim na rozwój gospodarczy Japonii ${ }^{143}$. Zaraz po objęciu urzędu ogłosił sławny ,plan podwojenia dochodu" (shotoku baizō keikaku), mający stać się podstawą jego

\footnotetext{
138 Fujiyama Aiichirō jako minister spraw zagranicznych walnie przyczynił się do wynegocjowania nowego traktatu sojuszniczego z USA i oczekiwał wsparcia przez Kishiego swojej kandydatury na przewodniczącego PLD. Kishi jednak, pomimo wcześniejszych zachęt do kandydowania, tuż przed wyborami radził Fujiyamie wycofać się z rywalizacji i poprzeć Ikedę. Fujiyama kandydował jednak, zajmując trzecie miejsce w trakcie pierwszego głosowania. Szerzej na ten temat: Fujiyama Aiichirō, op.cit., s. 116-126; Hara Yoshihisa, Kishi Nobusuke. Kensei..., s. 232; Tsuchiya Shigeru, op.cit., s. 194.

${ }^{139}$ Fujiyama Aiichirō, op.cit., s. 126.

${ }^{140}$ Ibidem, s. 166-170.

${ }^{141}$ Ikeda opierał się jednak inicjatywom pogłębienia relacji z Tajwanem. Kishi Nobusuke przyznawał, że Jiang Jieshi nie krył niezadowolenia $\mathrm{z}$ faktu, że Ikeda wielokrotnie przelatywał nad Tajwanem, ale nigdy nie złożył wizyty w Tajpej. Szerzej na ten temat: Hara Yoshihisa, Kishi Nobusuke shōgenroku, s. 160.

${ }^{142}$ Hatano Masaru, Shimizu Urara, op.cit., s. 192.

${ }^{143}$ Ikeda Hayato, Kinkō zaisei. Fu - senryō-ka 3 nen no omoide, Chūō Kōron Shinsha, Tokio 1999, s. 3-6.
} 
programu politycznego. Zakładał on podwojenie dochodu narodowego w przeciągu dekady ${ }^{144}$. Linia Ikedy była w pełni zgodna z „doktryną Yoshidy” i zwiastowała odprężenie na linii Tokio-Pekin ${ }^{145}$. Nowemu gabinetowi wyszedł naprzeciw także rząd Chin kontynentalnych, potrzebujący współpracy gospodarczej z Japonią po katastrofalnych skutkach „,wielkiego skoku”. Wkrótce po ustanowieniu rządu Ikedy doszło do pierwszej od dwóch lat wizyty pozarządowej delegacji z ChRL ${ }^{146}$, zaś już w sierpniu 1960 roku Zhou Enlai ogłosił „trzy zasady handlowe”, które miały uzupełnić „trzy zasady polityczne” wznowienia relacji z Japonią. Stały się one podstawą rozwoju tzw. „handlu przyjacielskiego" (jap. $y \bar{u} k \bar{o}$ bōeki, chiń. youhao maoyi), który oznaczał częściowe przywrócenie nieoficjalnej wymiany sprzed 1958 roku $^{147}$.

Jeszcze przed objęciem stanowiska premiera Ikeda Hayato wykazywał zainteresowanie wznowieniem handlu z ChRL na poziomie pozarządowym. Podobnie jak Yoshida, uważał, że ChRL raz na zawsze opuści obóz sowiecki ze względu na różnice kulturowe pomiędzy narodem rosyjskim a chińskim ${ }^{148}$. Podkreślał: „Sądzę, że naród chiński jest narodem bogatym w koncepcje ekonomiczne i można pomyśleć, że w przyszłości demokracja zapewne przeważy nad komunizmem. Uważam, iż pod tym względem handel Japonii z Chinami komunistycznymi może mieć znaczenie edukacyjne" ${ }^{149}$. Jak widać, podobnie jak Kishi Ikeda był antykomunistą, ale miał zupełnie inną koncepcję obrony Japonii przed tą ideologią. Zamiast pogłębiać relacje z reżimem Jiang Jieshiego, wolał poprzez handel z Chinami wpływać na porzucenie przez to państwo radykalnych idei. W styczniu 1960 roku Ikeda przyciągnął uwagę dziennikarzy deklaracją: „Ten rok, po rozwiązaniu problemu traktatu sojuszni-

\footnotetext{
${ }^{144}$ Itō Masaya, Ikeda Hayato to sono jidai, Asahi Shinbunsha, Tokio 1985, s. 78-84.

${ }^{145}$ Karol Żakowski, Polityka Japonii wobec Republiki Chińskiej na Tajwanie [w:] Rosja, Chiny, Japonia $w$ polityce globalnej pod. red. Małgorzaty Pietrasiak i Małgorzaty Rączkiewicz, Wydawnictwo Wyższej Szkoły Handlowej im. Króla Stefana Batorego, Piotrków Trybunalski 2008, s. 123.

${ }^{146}$ Hatano Masaru, Shimizu Urara, op.cit., s. 193.

147 „Trzy zasady handlowe” dotyczyły: 1) umów międzyrządowych, 2) umów pozarządowych, 3) wzięcia po uwagę czynników indywidualnych. O ile umowy międzyrządowe mogły być zawierane tylko z państwami, z którymi ChRL utrzymywała oficjalne stosunki dyplomatyczne, stworzono możliwość zawierania kontraktów pozarządowych między firmami chińskimi, a „przyjaznymi” firmami japońskimi. W przypadku sprzyjającej atmosfery politycznej, kontrakty takie mogły być nawet zawierane na dłuższe okresy. Aby uzyskać status firmy „przyjaznej”, przedsiębiorstwo musiało uznać „trzy zasady polityczne” i „trzy zasady handlowe”, jak też uzyskać rekomendację od jednej z japońskich organizacji promujących handel chińsko-japoński, bądź partii lewicowej. ChRL wykorzystywała „przyjacielskie firmy” do celów politycznych. Np. w 1967 roku ich pracownicy musieli uczestniczyć w manifestacjach przeciw wizycie premiera Satō na Tajwanie. Szerzej na ten temat: Ni Zhimin, Ikeda naikaku... (sono 1), s. 92-96; Hatano Masaru, Shimizu Urara, op.cit., s. 193; Yoshihide Soeya, op.cit., s. 60-78.

${ }^{148}$ Itō Masaya, Nihon saishō retsuden 21 - Ikeda Hayato, Jiji Tsūshinsha, Tokio 1985, s. 201.

${ }^{149}$ Ikeda, Satō seikenki no Nihon gaikō pod red. Hatano Sumio, Minerva Shobō, Tokio 2004, s. 136.
} 
czego z USA, będzie rokiem handlu japońsko-chińskiego"150. Nic dziwnego, że $\mathrm{w}$ rozmowach $\mathrm{z}$ japońskimi dyplomatami władze w Tajpej nie kryły obaw związanych z nowym szefem rządu ${ }^{151}$.

Tabela 2.5 Rozkład sił pomiędzy frakcjami PLD w okresie rządów Ikedy Hayato w latach 1960-1962.

\begin{tabular}{|l|l|l|}
\hline \multicolumn{2}{|c|}{ Frakcje: } \\
\hline ,głównego nurtu” & poza ,głównym nurtem” & „przeciwnego nurtu” \\
\hline Ikeda (L, B, G, P) 48 & Fujiyama (D, LP) 26 & Kōno (D, LP, J) 31 \\
Kishi (D, B, J, T) 45 & & Ōno (L, LP, J, T) 26 \\
Satō (L, B, T) 44 & & Miki/Matsumura (D, LP, G, P) 25 \\
& & Ishii (L, LP, T) 17 \\
& & Ishibashi (D, LP, G, P) 5 \\
\hline 137 & 26 & 104 \\
L: 2 (92), D: 1 (45), & & \\
B: 3 (137), LP: 0, & & \\
G: 1 (48), J: 1 (45), & & \\
P: 1 (48), T: 2 (89). & & \\
\hline
\end{tabular}

L- dawni członkowie Partii Liberalnej, główny nurt konserwatywny, D- dawni członkowie Japońskiej Partii Demokratycznej, boczny nurt konserwatywny, B- dawni biurokraci, LP- ludzie partii, G- gołębie, J- jastrzębie, P- obóz propekiński, T- obóz protajwański.

Liczebność frakcji (podana przy poszczególnych frakcjach) po wyborach do Izby Reprezentantów z listopada 1960 roku. Uwzględniono tylko parlamentarzystów z Izby Reprezentantów. W podsumowaniu „głównego nurtu" podana jest ogólna liczba należących do niego parlamentarzystów oraz liczba frakcji, zaś w nawiasie liczba parlamentarzystów, należących do poszczególnych obozów.

Opracowanie własne na podstawie: Kitaoka Shin'ichi, op.cit., s. 334; Iseri Hirofumi, op.cit., s. 109; Tsuchiya Shigeru, op.cit., s. 195; Fukui Haruhiro, op.cit., s. 344.

Po objęciu stanowiska premiera, we wrześniu 1960 roku Ikeda stwierdził: „Nie ma możliwości na wyrażenie zgody na umowę międzyrządową $\mathrm{z}$ pierwszego punktu [trzech zasad handlowych ChRL - przyp. aut.]. Jednakże zgadzamy się na powrót do zawartego $\mathrm{w}$ drugim punkcie handlu na podstawie kontraktów prywatnych, który był już prowadzony przed incydentem z flagą $\mathrm{w}$ Nagasaki" ${ }^{152}$. Z kolei w październiku 1960 roku Ikeda Hayato powiedział w parlamencie: „Jeśli chodzi o stosunki z Chinami kontynentalnymi, uważam, iż pożądane jest polepszać je stopniowo, z poszanowaniem wzajemnych punktów widzenia oraz $\mathrm{w}$ oparciu o zasadę nieingerencji w politykę wewnętrzną. Oczywiście szczególnie chętnie witam okazję do wznowienia pozostającego

\footnotetext{
${ }^{150}$ Itō Masaya, Ikeda Hayato to..., s. 88.

${ }^{151}$ Chō Gun hishochōra to no kaidan no ken z 26 VII 1960 [w:] Nichi-Chūka Minkoku kankei, A'1.2.1.7, Archiwum Dyplomatyczne...

${ }^{152}$ Hatano Masaru, Shimizu Urara, op.cit., s. 194-195.
} 
niegdyś w stanie zamrożenia handlu japońsko-chińskiego"153. Jak twierdzi Ni Zhimin, w pierwszych przemowach nowego premiera wyraźnie widać jego ostrożną postawę, by zbyt radykalnie propekińskimi wypowiedziami nie zrazić do siebie osi Kishi-Satōo ${ }^{154}$. Rzeczywiście, na zjeździe Komitetu Współpracy Japońsko-Tajwańskiej w styczniu 1961 roku pojawiły się głosy krytyki wobec japońskich firm, które rozpoczęły „,handel przyjacielski” z ChRL ${ }^{155}$. Z kolei według Uchidy Kenzō, w przeciwieństwie do Ishibashiego Tanzana czy Matsumury Kenzō, którzy działali z pobudek ideologicznych, propekińskie nastawienie frakcji Ikedy wynikało z materializmu (jitsurishugi) i ,suchego ekonomizmu" (doraina keizaishugi) ${ }^{156}$.

Drugą przeszkodą we współpracy z rządem w Pekinie była polityka Stanów Zjednoczonych. Pomimo wyraźnie prorynkowego charakteru dyplomacji Ikedy, premier musiał się liczyć ze zdaniem rządu w Waszyngtonie, zwłaszcza iż chciał kontynuować proamerykańską ,doktrynę Yoshidy”. Sam Yoshida Shigeru wywierał jeszcze wpływ na politykę swojego kobuna i ostrzegał, by zwrócić więcej uwagi na uzgodnienie japońskiego stanowiska w sprawie chińskiej z USA $^{157}$. Przez 1961 rok Ikeda ,przygotowywał grunt” pod przełom w kontaktach z ChRL, m.in. poprzez wytłumaczenie swoich planów stronie amerykańskiej. Kiedy w czerwcu 1961 roku spotkał się z prezydentem Johnem Fitzgeraldem Kennedym, podkreślił, że „, z powodu tradycji niezwykle ważne jest, by Japonia utrzymywała dobre relacje z Chinami komunistycznymi" ${ }^{\prime 158}$.

\section{Umowa Liao-Takasaki}

Ikeda Hayato wyraźnie dążył do następnego, po rozpoczęciu „handlu przyjacielskiego", przełomu w kontaktach handlowych z ChRL. W polityce wobec Chin komunistycznych opierał się jednak, podobnie jak Kishi Nobusuke, na zasadzie oddzielenia polityki od gospodarki (jap. seiken bunri, chiń. zhengjing fenli). Ikeda starał się utrzymywać jak najlepsze kontakty gospodarcze z ChRL, ze względu na presję amerykańską unikając jednocześnie zerwania stosunków dyplomatycznych z Tajwanem. Z drugiej strony, w przeciwieństwie do Kishiego, Ikeda wolny był od hamujących poczynania japońskiej dyplomacji osobistych związków z reżimem Guomindangu. Jedynie protajwańska oś KishiSatō powstrzymywała zbyt śmiałe przedsięwzięcia na polu współpracy z ChRL. Aby uzyskać większą swobodę w realizacji polityki wobec Chin, Ikeda musiał

${ }^{153}$ Posiedzenie plenarne Izby Reprezentantów (Shūgiin honkaigi) z 21 X 1960 roku, nr 3, Archiwum Obrad...

${ }^{154}$ Ni Zhimin, Ikeda naikaku... (sono 1), s. 89.

${ }^{155}$ Nikka Kyōryoku Iinkai kaigi ni kan suru ronpyō no ken z 13 I 1961 [w:] Nichi-Chūka Minkoku kankei, A'1.2.1.7, Archiwum Dyplomatyczne...

${ }^{156}$ Uchida Kenzō, Sengo Nihon no..., s. 196-197.

${ }^{157}$ Shioguchi Kiichi, Kikigaki: Ikeda Hayato, Asahi Shinbunsha, Tokio - Osaka - Kitakiusiu Nagoja 1975, s. 194.

${ }^{158}$ Itō Masaya, Nihon saishō retsuden 21..., s. 181. 
dokonać „odwrócenia przymierzy” wewnątrz partii. W tym celu zbliżył się do największych frakcji ,ludzi partii”: Mikiego, Kōno i Ōno.

$\mathrm{O}$ zmianie tej zadecydowały nie tylko względy programowe. Ikeda dobrze zdawał sobie sprawę z tego, że górujący nad nim pod względem doświadczenia politycznego Satō tylko czekał na okazję do usunięcia premiera ze stanowiska, by z pomocą Kishiego samemu zostać szefem rządu. Wewnątrz frakcji Satō zaczęła narastać krytyka przynoszącej premierowi popularność wśród społeczeństwa polityki szybkiego wzrostu gospodarczego ${ }^{159}$. Dla osi Kishi-Satō rządy Ikedy były niezbędnym interwałem, gdyż w burzliwym 1960 roku opinia publiczna nie zaakceptowałaby brata Kishiego jako premiera, ale z założenia miały to być rządy krótkie ${ }^{160}$. Ikeda nie miał jednak zamiaru łatwo oddać władzy i w lipcu 1962 roku został ponownie wybrany na przewodniczącego PLD, wykorzystując m.in. własną popularność poświadczoną zwycięstwem PLD w wyborach do Izby Radców. Wkrótce też dopuścił do posad ministerialnych szefów dotychczasowych frakcji ,przeciwnego nurtu”, dokonując zmiany przymierzy wewnątrz partii ${ }^{161}$.

Do 1962 roku frakcje w PLD uległy pewnym przemianom. Zaraz po przejęciu przywództwa we frakcji Kishiego w październiku 1962 roku przez Fukudę Takeo ${ }^{162}$, opuścił ją Kawashima Shōjirō, który nie chciał odejść z „głównego nurtu" Ikedy ${ }^{163}$. Stworzył on własną grupę polityków z byłej frakcji Kishiego, którzy jednak byli „ludźmi partii”, a nie dawnymi biurokratami, jak większość członków frakcji Fukudy ${ }^{164}$. W międzyczasie praktycznie zanikła frakcja Ishibashiego, której wpływy stopniowo zmniejszały się od czasu krótkiego sprawowania funkcji premiera przez jej przewodniczącego. Zresztą sam Ishibashi przegrał w wyborach do parlamentu w 1963 roku i zakończył karierę polityczną. Obóz propekiński w PLD utracił w ten sposób jednego z najwybitniejszych członków, jednak rolę frakcji Ishibashiego w dużym stopniu miała przejąć frakcja Fujiyamy ${ }^{165}$. Najbliżsi współpracownicy Ishibashiego, na czele z Ishidą Hirohide i Utsunomiyą Tokumą, pozostawali jednak bezfrakcyjni aż do 1971 roku $^{166}$.

\footnotetext{
${ }^{159}$ Tsuchiya Shigeru, op.cit., s. 196-197.

${ }^{160}$ Uchida Kenzō, Habatsu..., s. 64-66.

${ }^{161}$ Tsuchiya Shigeru, op.cit., s. 196-197.

162 Jeszcze w maju 1962 roku frakcje Satō i Fukudy utworzyły Klub Odnowy Oblicza Partii (Tōfū Sasshin Kondankai), żądając gruntownej reformy struktur PLD, m.in. rozwiązania frakcji. Obok wykorzystania sprawy chińskiej było to wówczas główne narzędzie rywalizacji z nowym „głównym nurtem" Ikedy Hayato. Szerzej na ten temat: Iyasu Tadashi, Seitō habatsu no shakaigaku. Taishū minshusei no nihonteki tenkai, Sekai Shisōsha, Kioto 1983, s. 167-169.

${ }^{163}$ Uchida Kenzō, Habatsu..., s. 70.

${ }^{164}$ Kawashima Shōjirō pod red. Kawashima Shōjirō Sensei Tsuisōroku Henshū Iinkai, Kōyū Kurabu, Tokio 1971, s. 376-380.

${ }^{165}$ Uchida Kenzō, Habatsu..., s. 42-44.

${ }^{166}$ Ishida Hirohide, op.cit., s. 31.
} 
Tabela 2.6 Rozkład sił pomiędzy frakcjami PLD w okresie rządów Ikedy Hayato w latach 1962-1964.

\begin{tabular}{|l|l|l|}
\hline \multicolumn{2}{|c|}{ Frakcje: } \\
\hline ,głównego nurtu” & poza ,głównym nurtem” & ,przeciwnego nurtu” \\
\hline Ikeda (L, B, G, P) 60 & Fujiyama (D, LP) 34 & Satō (L, B, T) 91 \\
Kōno (D, LP, J) 67 & Ishii (L, LP, T) 28 & Fukuda (D, B, J, T) 25 \\
Miki/Matsumura (D, LP, G, P) 49 & & \\
Ōno (L, LP, J, T) 40 & & \\
Kawashima (D, LP, J) 20 & 62 & 116 \\
\hline 236 & & \\
L: 2 (100), D: 3 (136), & & \\
B: 1 (60), LP: 4 (176), & & \\
G: 2 (109), J: 3 (127), & & \\
P: 2 (109), T: 1 (40). & & \\
\hline
\end{tabular}

L- dawni członkowie Partii Liberalnej, główny nurt konserwatywny, D- dawni członkowie Japońskiej Partii Demokratycznej, boczny nurt konserwatywny, B- dawni biurokraci, LP- ludzie partii, G- gołębie, J- jastrzębie, P- obóz propekiński, T- obóz protajwański.

Liczebność frakcji (podana przy poszczególnych frakcjach) po wyborach do Izby Reprezentantów z listopada 1963 roku. Uwzględniono członków frakcji z obu izb parlamentu. W podsumowaniu „głównego nurtu” podana jest ogólna liczba należących do niego parlamentarzystów oraz liczba frakcji, zaś w nawiasie liczba parlamentarzystów, należących do poszczególnych obozów.

Opracowanie własne na podstawie: Kitaoka Shin’ichi, op.cit., s. 334; Uchida Kenzō, Habatsu..., s. 70; Iseri Hirofumi, op.cit., s. 109; Satō Seizaburō, Matsuzaki Tetsuhisa, op.cit., s. 243.

Dzięki „odwróceniu przymierzy” i związaniu się z „ludźmi partii” Ikeda zmienił oblicze „głównego nurtu”, jednak trudno powiedzieć, by uzyskał zupełną swobodę w prowadzeniu polityki wobec Chin. Odsunął co prawda od władzy najpotężniejszy ośrodek protajwański, oś Kishi-Satō, jednak nowy „główny nurt” nadal nie był w pełni spójny ideologicznie. Współtworzyły go dwie frakcje ,gołębi” i aż trzy ,jastrzębi”. Mimo że dominowały grupy propekińskie, ważnym wyjątkiem było protajwańskie nastawienie Ōno Banboku oraz części członków grupy Kōno i Kawashimy. Niemniej jednak największy wpływ na politykę zagraniczną zachował sam Ikeda. Miał on zresztą w tej sprawie pełne wsparcie propekińsko nastawionego Mikiego Takeo, który stał na czele frakcji średnich rozmiarów. Z kolei mimo że do frakcji Kōno należało wielu polityków protajwańskich, sam Kōno Ichirō raczej sprzyjał zbliżeniu z ChRL.

Podobna sytuacja panowała w nowo powstałej frakcji Kawashimy. Chociaż skupiała ona licznych posłów protajwańskich, jak Shiina Etsusaburō, nastawienie jej lidera wobec Chin było ambiwalentne. Kawashima Shōjirō był co prawda bliskim współpracownikiem Kishiego Nobusuke, jednak, podobnie jak Fujiyama Aiichirō, po utworzeniu własnej frakcji w dużym stopniu odszedł od linii dyplomatycznej swojego dawnego oyabuna. Chociaż miał wielu przyjaciół na Tajwanie, zaprzestał podróży do Tajpej i poświęcił się promocji idei zbliżenia z władzami w Pekinie. Jego propekińskie poglądy umocniło spotkanie z Zhou 
Enlaiem na konferencji państw azjatyckich i afrykańskich w Dżakarcie w kwietniu 1965 roku. Za późniejszych rządów Satō Eisaku Kawashima bezskutecznie promował $\mathrm{np}$. ideę ustanowienia regularnych japońsko-chińskich spotkań ministerialnych ${ }^{167}$.

Razem ze zmianą sojuszy wewnątrz partii Ikeda zaczął coraz bardziej aktywnie zabiegać o wznowienie nieoficjalnego handlu z ChRL. Podążająca ścieżką szybkiego wzrostu gospodarczego Japonia pilnie potrzebowała nowych rynków zbytu dla swoich towarów. Jeszcze w maju 1962 roku premier powiedział na konferencji prasowej: „Co do promocji handlu japońskochińskiego, chciałbym ustanowić system odroczonej płatności na wzór państw Europy Zachodniej. Japonia będzie prowadziła handel $\mathrm{z}$ Chinami wedle własnego osądu"168. Z kolei w lipcu 1962 roku Ikeda powierzył rozmowy ze stroną chińską Matsumurze Kenzō, współprzewodniczącemu będącej już częścią „głównego nurtu” frakcji Mikiego. W tym samym miesiącu na posiedzeniu frakcji Ikedy swój plan pogłębienia współpracy handlowej z ChRL przedstawił prezes firmy lotniczej ANA Okazaki Kaheita ${ }^{169}$. Po naradach m.in. z ministrem spraw zagranicznych Ōhirą Masayoshim z frakcji Ikedy, Matsumura odwiedził ChRL w połowie września 1962 roku, gdzie spotkał się z Zhou Enlaiem. Towarzyszyli mu m.in. Furui Yoshimi i Tagawa Seiichi. Jego misja położyła fundamenty pod zawarcie nowej umowy handlowej z Chinami. Matsumura Kenzō i Zhou Enlai zgodzili się, że należy dążyć do normalizacji japońskochińskich stosunków dyplomatycznych poprzez tzw. „metodę akumulacji” (jap. tsumiage hōshiki, chiń. jilei fangshi), czyli stopniowe zacieśnianie wzajemnych relacji gospodarczych i politycznych ${ }^{170}$.

Pod koniec października 1962 roku do ChRL udała się delegacja japońska pod przewodnictwem Takasakiego Tatsunosuke. W dniu 9 listopada 1962 roku podpisano Memorandum ws. ogólnego handlu chińsko-japońskiego, zwane potocznie od nazwisk dwóch głównych sygnatariuszy umową Liao-Takasaki. W ten sposób ustanowiono tzw. „,handel LT” (jap. LT bōeki, chiń. LT maoyi), który miał się rozwijać obok nadal istniejącego "handlu przyjacielskiego" ${ }^{171}$. W Japonii powołano do życia Radę Kontaktów ds. Ogólnego Handlu JapońskoChińskiego z Takasakim Tatsunosuke jako przewodniczącym ${ }^{172}$, zaś w ChRL

\footnotetext{
${ }^{167}$ Kawashima..., s. 269-403.

${ }^{168} \mathrm{Ni}$ Zhimin, Ikeda naikaku... (sono 1), s. 90.

${ }^{169}$ Yoshihide Soeya, op.cit., s. 82.

${ }^{170}$ Sun Hongyan, Zhong-Ri guanxi zhong de LT maoyi, „Changchun Daxue Xuebao” 2007, vol. 17, no. 3, s. 58; Ni Zhimin, Ikeda naikaku... (sono 1), s. 98-99.

${ }^{171}$ Postawienia umowy Liao-Takasaki miały obowiązywać 5 lat. Ustalono w niej zakres towarów mogących podlegać wymianie na podstawie kontraktów między firmami z obu krajów. Zgodzono się także na dalsze rozmowy ws. odroczonej płatności przez ChRL za część towarów oraz zakupu na raty fabryk z Japonii. Szerzej na ten temat: Yoshihide Soeya, op.cit., s. 79-91.

${ }^{172}$ Po śmierci Takasakiego w 1964 roku przewodniczącym Rady Kontaktów ds. Ogólnego Handlu Japońsko-Chińskiego został Okazaki Kaheita. Szerzej na ten temat: ibidem, s. 91.
} 
utworzono analogiczne biuro z Liao Chengzhim na czele. Ze względu na zaangażowanie gabinetu Ikedy w rozmowy ze stroną chińską oraz położenie podstaw pod udział w handlu oficjalnych instytucji japońskich, umowa LiaoTakasaki jest często nazywana „półrządową" ${ }^{173}$, choć w rzeczywistości miała pozarządowy charakter ${ }^{174}$.

Zdawało się, że jest szansa na długofalową, stopniową poprawę relacji Japonii z ChRL. Może o tym świadczyć zaskakujące potajemne spotkanie poprzez pośrednictwo Tagawy Seiichiego między Kōno Ichirō a dwoma chińskimi dyplomatami, Sun Pinghua i Wang Xiaoxue w maju 1963 roku. Było ono dowodem na to, że Kōno, przewodzący jednej z największych frakcji w PLD, na poważnie myślał o kontynuacji polityki Hatoyamy Ichirō i normalizacji w przyszłości stosunków dyplomatycznych z ChRL. Musiał jednak postępować z niezwykłą ostrożnością, gdyż wielu członków jego frakcji było politykami protajwańskimi ${ }^{175}$. Na zakończenie spotkania z gośćmi z ChRL Kōno Ichirō miał powiedzieć: „Przywrócenie stosunków z Chinami przez takich biurokratycznych polityków, jak Ikeda czy Satō jest niemożliwe. Kiedy nadejdzie czas, ja tego z pewnością dokonam" ${ }^{176}$. Pokazuje to, że o ile grupa osób bezpośrednio zaangażowanych $\mathrm{w}$ pozarządowy handel $\mathrm{z}$ ChRL była nieliczna, o tyle wielu wpływowych polityków w PLD było gotowych na posunięcia sprzyjające kontaktom z komunistycznymi Chinami, gdy tylko będzie temu bardziej sprzyjać sytuacja międzynarodowa.

Jak podkreśla syn Kōno Ichirō, Kōno Yōhei, jego ojciec tak naprawdę pozostawał pod silnym wpływem Tagawy Seiichiego, który należał do nalbliższych współpracowników Matsumury ${ }^{177}$. Tagawa był zresztą krewnym Kōno i posłem z sąsiedniego okręgu wyborczego w prefekturze Kanagawa. Z kolei brat Kōno Ichirō, parlamentarzysta Izby Radców Kōno Kenzō, zwracał także uwagę na wpływ samego Matsumury Kenzō na postawę Kōno Ichirō. Obaj byli „ludźmi partii” i pozostawali w bardzo zażyłych stosunkach. Przewodniczący dawnej frakcji Hatoyamy aż do śmierci w 1965 roku miał na poważnie rozważać możliwość udania się do ChRL. Według Kōno Kenzō, chciał w ten sposób zapisać się w historii, podobnie jak Yoshida Shigeru dzięki podpisaniu Traktatu z San Francisco czy Hatoyama Ichirō dzięki normalizacji stosunków dyplomatycznych z ZSRR ${ }^{178}$.

Ocieplenie na linii Tokio-Pekin zaniepokoiło reżim Guomindangu i obóz protajwański w PLD. Premier Ikeda musiał umiejętnie lawirować pomiędzy

\footnotetext{
${ }^{173} \mathrm{Ni}$ Zhimin, Ikeda naikaku... (sono 1), s. 102-103.

${ }^{174}$ Yoshihide Soeya, op.cit., s. 79.

${ }^{175}$ Tagawa Seiichi, Nitchū kōryū to Jimintō ryōshūtachi, Yomiuri Shinbunsha, Tokio 1983., s. 717.

${ }^{176}$ Ibidem, s. 15.

${ }^{177}$ Wywiad autora z Kōno Yōheiem...

${ }^{178}$ Kōno Kenzō, Gichō ichidai. Kōno Kenzō kaisōki, Asahi Shinbunsha, Tokio - Osaka Kitakiusiu - Nagoja 1978, s. 117-157.
} 
żądaniami pogłębienia współpracy ze strony ChRL a blokującymi takie inicjatywy politykami z tajwańskiego lobby. W sierpniu 1963 roku rząd w Tokio wyraził zgodę na sprzedaż stronie chińskiej przez japońską firmę Kurashiki Rayon fabryki nylonu. Co ważne, zapowiedziano udzielenie ChRL kredytu na ten cel w wysokości 2 mln USD przez Japoński Bank Eksportowo-Importowy ${ }^{179}$. Spotkało się to $\mathrm{z}$ ostrym sprzeciwem ze strony władz w Tajpej. Sekretarz prezydenta Jiang Jieshiego, Zhang Qun, wezwał wówczas ambasadora Japonii, mówiąc mu: „Jeśli Japonia teraz zdecyduje się na wspomożenie władzy Partii Komunistycznej, nie będzie miała usprawiedliwienia nie tylko wobec Republiki Chińskiej, ale także wobec całej Azji" ${ }^{180}$. Wkrótce też władze w Tajpej zaczęły poprzez Komitet Współpracy Japońsko-Chińskiej pobudzać do działania takich członków „tajwańskiego lobby”, jak Kishi Nobusuke czy, co ważne, pozostający w ,głównym nurcie" PLD Ōno Banboku ${ }^{181}$.

Ponieważ władze w Tokio pomimo nacisków nie złagodziły swojego stanowiska, kryzys w stosunkach japońsko-tajwańskich pogłębiał się. We wrześniu 1963 roku doszło do kilku przypadków obrzucenia kamieniami ambasady japońskiej w Tajpej ${ }^{182}$. Reżim Guomindangu odwołał nawet z Japonii swojego ambasadora, który wrócił na Tajwan pod koniec września 1963 roku ${ }^{183}$. Jednocześnie tajwański Yuan Ustawodawczy stwierdził: „Wobec pomocy gospodarczej Japonii dla Chin komunistycznych, rząd nie powinien wahać się przed decyzją o zerwaniu stosunków dyplomatycznych" ${ }^{184}$. Równolegle, na początku października 1963 roku, doszło do otwarcia wystawy towarów japońskich w Pekinie, w którym uczestniczył m.in. Ishibashi Tanzan. Strona chińska uświetniła tę uroczystość powołując do życia Stowarzyszenie Przyjaźni Chińsko-Japońskiej (Zhong-Ri Youhao Xiehui) ${ }^{185}$. W takich okolicznościach rozpoczął się incydent, który miał się przemienić w prawdziwą ,próbę sił” w PLD pomiędzy będącym u władzy skrzydłem propekińskim a obozem protajwańskim.

\section{Incydent z Zhou Hongqingiem}

Na początku października 1963 roku Zhou Hongqing, tłumacz z delegacji ChRL na odbywającą się w Japonii konferencję dotyczącą maszyn hydraulicznych, postanowił tuż przed wyjazdem szukać azylu za granicą. Próbował dojechać do

\footnotetext{
${ }^{179}$ Pierwsze próby eksportu na rynek chiński firma Kurashiki Rayon podjęła jeszcze w latach 50. $\mathrm{XX}$ wieku, jednak musiała $\mathrm{z}$ nich zrezygnować po zamrożeniu relacji chińsko-japońskich w 1958 roku. Szerzej na ten temat: Ni Zhimin, Ikeda naikaku... (sono 1), s. 104-111.

${ }^{180}$ Chen Fenglin, Chitian Yongren neige shiqi de Ri-Tai guanxi, „Guoji Luntan” 2004, vol. 6, no. 6, s. 49 .

${ }^{181} \mathrm{Ni}$ Zhimin, Ikeda naikaku... (sono 1), s. 110.

${ }^{182}$ Ibidem, s. 111.

${ }^{183}$ Yoshihide Soeya, op.cit., s. 96-97.

${ }^{184}$ Chen Fenglin, Chitian Yongren..., s. 49.

${ }^{185}$ Zhuhe Riben gongye zhanlanhui kaimu, ,Renmin Ribao” z 6 X 1963, s. 1.
} 
ambasady Republiki Chińskiej na Tajwanie, ale przez pomyłkę dostał się do placówki radzieckiej ${ }^{186}$. Istnieją wątpliwości, czy jego decyzja o ucieczce została powzięta spontanicznie, czy też Zhou nosił się z tym zamiarem od dawna ${ }^{187}$. Jak później sam twierdził, dostawał tajemnicze telefony z pogróżkami i zdecydował się starać o azyl w stanie obniżonej świadomości po spożyciu alkoholu ${ }^{188}$. Strona radziecka przekazała Zhou japońskiej policji. Ponieważ jego wiza właśnie wygasła, aresztowano go za bezprawne przebywanie na terenie Japonii. Początkowo Zhou wyraźnie domagał się azylu na Tajwanie, później zaś prosił o możliwość pozostania w Japonii. Delegaci z ChRL starali się nakłonić uciekiniera do powrotu, podkreślając, że w ojczyźnie nie będzie ukarany ani on, ani jego rodzina. W końcu, po otrzymaniu listu od małżonki, proszącej go o porzucenie zamiaru szukania azylu, Zhou zmienił zdanie i zadeklarował chęć powrotu do domu ${ }^{189}$. Niedługo potem japoński urząd imigracyjny przystąpił do repatriacji niedoszłego azylanta i zdawało się, że incydent zakończy się równie nagle, jak się zaczął.

Okazało się jednak, że gdy japońskie władze rozpoczęły procedury zmierzające do zwrotu Zhou ChRL, stosunkowo spokojna do tej pory postawa rządu w Tajpej uległa gwałtownej zmianie. Pod koniec października 1963 roku ambasador Japonii na Tajwanie otrzymał notę od samego Jiang Jieshiego. Prezydent Republiki Chińskiej podkreślił w niej wagę incydentu, ostrzegając, że wydanie Zhou Hongqinga Chinom komunistycznym będzie naruszeniem praw człowieka i z pewnością negatywnie wpłynie na stosunki japońsko-tajwańskie. Dwa dni później władze Tajwanu poinformowały stronę japońską, że Zhou powinien na razie pozostać w Japonii, w odosobnieniu od „elementów lewicowych". Dopiero w takich warunkach miał uzyskać szansę podjęcia ostatecznej decyzji, czy będzie się ubiegał o azyl na Tajwanie ${ }^{190}$.

Ponieważ sprawa Zhou Hongqinga szybko urosła do rangi symbolu, mogła pokrzyżować plany Ikedy Hayato, który starał się zachować delikatną równowagę między dążeniami do gospodarczego zbliżenia z ChRL a koniecznością utrzymania oficjalnych stosunków dyplomatycznych z reżimem Jiang Jieshiego. W listopadzie 1963 roku można było zauważyć dalsze przejawy pogarszania się relacji japońsko-tajwańskich. Tajwańskie wydawnictwa demonstracyjnie odmówiły publikacji części japońskich reklam, zaś w niektórych regionach uczniowie ogłosili ,ruch pięciu nie”: przeciw kupowaniu japońskich produktów, używaniu języka japońskiego, oglądaniu japońskich filmów, słucha-

\footnotetext{
${ }^{186} \mathrm{Ni}$ Zhimin, Ikeda naikaku ni okeru nitchū kankei to Ōhira Masayoshi (sono 3), „Ryūkoku Daigaku Keizaigaku Ronshū” 2005, vol. 45, no. 3, s. 35.

${ }^{187}$ Ibidem, s. 37.

${ }^{188}$ Riben pengyou he aiguo huaqiao dali bangzhu Zhou Hongqing fanhui zuguo, „Renmin Ribao” z 13 I 1964, s. 3.

${ }^{189}$ Ni Zhimin, Ikeda naikaku... (sono 3), s. 37.

${ }^{190}$ Ibidem, s. 38.
} 
niu japońskiej muzyki oraz czytaniu japońskich książek i czasopism ${ }^{191}$. Ważyła się także sprawa uczestnictwa reprezentacji Republiki Chińskiej w mających się odbyć w Tokio w 1964 roku Igrzyskach Olimpijskich ${ }^{192}$.

Tymczasem narastał spór wewnątrz PLD, zagrażając jedności partii. Przywódcy protajwańskich frakcji zaczęli zabiegać o podporządkowanie się zaleceniom władz w Tajpej i odroczenie momentu wydania Zhou ChRL. Pod koniec października 1963 roku na Tajwan udał się Ōno Banboku jako japoński wysłannik na 79. urodziny Jiang Jieshiego. Po spotkaniach z najważniejszymi tajwańskimi dostojnikami stwierdził, iż ,istnieje ryzyko, że w razie wydania Zhou Chinom komunistycznym, stosunki japońsko-tajwańskie zostaną zerwane" 193 . Razem z Ōno członkiem delegacji był inny reprezentant obozu protajwańskiego w PLD, marszałek Izby Reprezentantów Funada Naka. W trakcie jego rozmowy z sekretarzem prezydenta Jianga, Zhang Qunem, Zhang miał powiedzieć: „Japonia powinna wykazać rozwagę polityczną. Dobry przyjaciel Chin [Tajwanu], pan Kaya, będąc obecnie ministrem sprawiedliwości, nadzoruje ten incydent. Jestem pewien, że poradzi sobie używając koniecznych środków" ${ }^{194}$. Słowa te oznaczały, iż władze w Tajpej dobrze zdawały sobie sprawę z siły ich lobby w łonie japońskiej partii rządzącej. W trakcie trwania incydentu reżim Guomindangu trzykrotnie wysyłał do Japonii delegacje w celu umacniania oporu protajwańskiego obozu w ramach PLD. Spotykały się one z Ōno Banboku z ,głównego nurtu”, jak też z ważnymi politykami z frakcji poza „głównym nurtem”, w szczególności z Kishim Nobusuke. Sprawa Zhou Hongqinga mogła wręcz stać się spoiwem, umacniającym jedność sił pragnących odsunięcia od władzy premiera Ikedy ${ }^{195}$.

Jak już wcześniej wspomniano, reżim Guomindangu największe nadzieje pokładał w postawie ówczesnego japońskiego ministra sprawiedliwości. Kaya Okinori był skazanym na karę dożywotniego pozbawienia wolności zbrodniarzem wojennym klasy A, uwolnionym w 1955 roku, a także jednym z najzacieklejszych antykomunistów w PLD. Piastował również stanowisko przewodniczącego prawicowej organizacji zrzeszającej rodziny żołnierzy poległych w czasie II wojny światowej (Nihon Izokukai). Kaya utrzymywał bardzo dobre kontakty z reżimem Guomindangu i od kiedy incydent z Zhou Hongqingiem stał się dla władz Tajwanu sprawą priorytetową, natychmiast zaczął używać swych wpływów do opóźniania momentu wydania Zhou Chinom. Ponieważ zaś urząd imigracyjny podlegał Ministerstwu Sprawiedliwości, Kaya

\footnotetext{
${ }^{191}$ Ibidem, s. 40.

${ }^{192} \mathrm{He}$ Yan, „Zhou Hongqing shijian” yu Mei-Ri-Tai sanjiao guanxi, „Dangdai Zhongguoshi Yanjiu" 2006, vol. 13 no. 5, s. 94.

${ }^{193}$ Ni Zhimin, Ikeda naikaku... (sono 3), s. 39.

${ }^{194}$ Ibidem.

195 Ibidem, s. 41.
} 
Okinori miał kompetencje, aby odroczyć ekstradycję niedoszłego azylanta do ChRL.

Tymczasem, stawszy się przedmiotem sporu międzynarodowego, sam Zhou Hongqing miał ograniczone możliwości decydowania o swoim losie. Według „Renmin Ribao" Zhou, początkowo zwiedziony „groźbami i pokusami” odwiedzających go przedstawicieli reżimu Jiang Jieshiego, szybko zauważył swój błąd, poczuł przypływ patriotyzmu i „rozpoczął walkę o powrót do ojczyzny". Kiedy zaś władze japońskie nie chciały udzielić mu pozwolenia na opuszczenie kraju, na początku listopada 1963 roku zdecydował się na pięciodniowy protest głodowy. Wkrótce potem wydał oświadczenie, w którym powtórzył: „Chcę koniecznie powrócić do ChRL. Za nic nie pojadę na Tajwan. Gdyby chciano mnie siłą zabrać na Tajwan, nie pojadę tam, choćbym miał umrzeć" ${ }^{196}$. Kaya Okinori nie zamierzał jednak ustąpić. Pod pretekstem osłabienia Zhou po głodówce, minister sprawiedliwości zlecił przewiezienie uciekiniera do szpitala Czerwonego Krzyża ${ }^{197}$. Ta przymusowa „kuracja” miała potrwać ponad miesiąc. Kaya wciąż miał nadzieję, że Zhou w końcu zmieni zdanie i znowu wystąi o azyl polityczny na Tajwanie ${ }^{198}$.

Wobec dużych emocji, jakie incydent budził tak na arenie międzynarodowej, jak wewnątrz PLD, premier Ikeda musiał przyjąć postawę wyczekującą. Należący do frakcji Ikedy minister spraw zagranicznych Ōhira Masayoshi powiedział po spotkaniu z Kayą Okinorim pod koniec listopada 1963 roku, że ze względu na niejasność woli Zhou Hongqinga, postanowili się dodatkowo upewnić co do jego prawdziwych zamierzen ${ }^{199}$. Nie tylko obóz protajwański wywierał jednak presję na rząd w Tokio. Równie wielka była determinacja członków obozu propekińskiego, zarówno spoza, jak i wewnątrz PLD. W sprawę Zhou zaangażowali się tacy znani promotorzy stosunków Japonii z ChRL, jak Ishibashi Tanzan czy Matsumura Kenzō. Zwolennicy powrotu Zhou

\footnotetext{
${ }^{196}$ Riben pengyou..., s. 3.

${ }^{197}$ Ni Zhimin, Ikeda naikaku... (sono 3), s. 43.

${ }^{198}$ Jeszcze w połowie grudnia 1963 roku, na posiedzeniu parlamentarnej Komisji Sprawiedliwości, Kaya uparcie wyjaśniał odpowiadając na pytania posłów: „Człowiek będący tematem rozważań, Zhou Hongqing, nie ma jasnej koncepcji, do którego regionu chce się udać i gdzie chce przebywać. Wyjaśnienie jego zamysłu jest ważne, nadal jednak jest on niewyraźny, nie ma warunków do potwierdzenia jego decyzji, a ponieważ jest to kluczową sprawą, obecnie upewniamy się co do tej sytuacji. (...) Trudno jest stwierdzić, czy myśli tego człowieka są koniecznie zgodne z jego wolą. (...) Co więcej, rząd Republiki Chińskiej ma spore wątpliwości, czy sprawa jest traktowana z poszanowaniem prawdziwej wolnej woli tej osoby. Istnieje potrzeba jednoczesnego wyjaśnienia tego drogą dyplomatyczną. Dlatego też, z bardzo obiektywnego punktu widzenia, poprzez ustalenie, gdzie zgodnie $\mathrm{z}$ wolną wolą ten człowiek chce się udać, mam nadzieję stworzyć warunki, które zadowolą każdą stronę. Staram się, aby uczynić to jak najszybciej”. Źródło: Posiedzenie Komisji Sprawiedliwości Izby Reprezentantów (Shūgiin Hōmu Iinkai) z 17 XII 1963 roku, nr 4, Archiwum Obrad...

${ }^{199}$ Ni Zhimin, Ikeda naikaku... (sono 3), s. 42.
} 
do ChRL organizowali liczne zbiórki pieniędzy i podpisów, wiece oraz demonstracje ${ }^{200}$.

Ostatecznie 24 grudnia 1963 roku, po kolejnej rozmowie z Kayą, Ōhira oświadczył, że upewniwszy się co do woli Zhou, zostanie on zwolniony do końca roku. Wkrótce japońskie Ministerstwo Spraw Zagranicznych zaczęło przygotowywać plany ewakuacji Japończyków z Tajwanu na wypadek zerwania stosunków dyplomatycznych z tym krajem ${ }^{201}$. Pod koniec grudnia 1963 roku Zhou Hongqing został wydany przedstawicielstwu Czerwonego Krzyża z ChRL, zaś w połowie stycznia 1964 roku powrócił do Chin. W ten sposób po trzech miesiącach zakończył się incydent z niedoszłym azylantem, jednak wywołany przez niego kryzys w stosunkach japońsko-tajwańskich nadal trwał. Kolejnym zadaniem premiera Ikedy stało się załagodzenie niezadowolenia reżimu Guomindangu i, co za tym idzie, sporu wewnątrz PLD.

\section{Wygaszenie sporu z Tajwanem}

Decyzja o wydaniu Zhou Hongqinga ChRL wywołała kolejną eskalację napięcia w stosunkach japońsko-tajwańskich. Jeszcze pod koniec grudnia 1963 roku reżim Guomindangu potwierdził dymisję odwołanego we wrześniu ambasadora w Japonii oraz zdecydował się na odesłanie do kraju kolejnych wysokich urzędników ambasady (chargé d'affaires, dwóch radców i pierwszego sekretarza $)^{202}$. W połowie stycznia 1964 roku, już po odpłynięciu Zhou do ChRL, władze w Tajpej ogłosiły wstrzymanie rządowych zakupów w Japonii oraz zawiesiły eksport do Japonii 100 tys. ton ryżu wartego $15 \mathrm{mln}$ USD. Doszło też do wtargnięcia demonstrantów do ambasady Japonii na Tajwanie ${ }^{203}$.

Wobec groźby zerwania oficjalnych stosunków dyplomatycznych z reżimem Jiang Jieshiego, tajwańskie lobby w PLD zaczęło intensywnie zabiegać o uczynienie przez rząd w Tokio pojednawczych gestów wobec władz w Tajpej. Przegrawszy $\mathrm{z}$ obozem propekińskim $\mathrm{w}$ sprawie Zhou Hongqinga, politycy protajwańscy żądali, aby premier Ikeda w zamian poszedł na ustępstwa w innych ważnych dla Guomindangu kwestiach. Na początku stycznia 1964 roku z Ikedą Hayato spotkał się Ishii Mitsujirō, zachęcając premiera do wysłania na Tajwan Yoshidy Shigeru w celu przygotowania gruntu pod ocieplenie stosunków bilateralnych ${ }^{204}$. Wkrótce również reżimowi Jiang Jieshiego zaczęło zależeć na jak najszybszej poprawie atmosfery $w$ relacjach $\mathrm{z}$ Japonią. Pod koniec stycznia 1964 roku oficjalne stosunki dyplomatyczne z ChRL nawiązała Francja i zbliżenie na linii Tokio-Tajpej chociaż częściowo mogłoby zatrzeć złe wrażenie wywołane przez to zdarzenie. Jednocześnie w japońskim Ministerstwie

\footnotetext{
${ }^{200}$ Riben pengyou..., s. 3.

${ }^{201} \mathrm{Ni}$ Zhimin, Ikeda naikaku... (sono 3), s. 44.

${ }^{202}$ Yoshihide Soeya, op.cit., s. 97.

${ }^{203}$ He Yan, op.cit., s. 95.

${ }^{204}$ Ni Zhimin, Ikeda naikaku... (sono 3), s. 49.
} 
Spraw Zagranicznych badano możliwość prowadzenia przez Japonię polityki „dwóch Chin”, czyli utrzymywania relacji jednocześnie z rządem w Tajpej i Pekinie $^{205}$.

Yoshida Shigeru złożył wizytę na Tajwanie w dniach 23-27 lutego 1964 roku. W tym czasie trzykrotnie spotkał się z Jiang Jieshim, starając się dokonać przełomu $\mathrm{w}$ relacjach $\mathrm{z}$ Tajwanem ${ }^{206}$. Stronie tajwańskiej zależało przede wszystkim na ograniczeniu do minimum handlu Japonii z komunistycznymi Chinami. Po powrocie Yoshidy do kraju również tacy protajwańscy politycy, jak Kishi Nobusuke czy Ishii Mitsujirō nalegali, aby nie zwiększać wymiaru współpracy z ChRL ${ }^{207}$. Ikeda musiał pójść na ustępstwa, by złagodzić protesty frakcji „przeciwnego nurtu”. Na początku marca 1964 roku PLD wydała „wspólne stanowisko” w sprawie chińskiej. Z jednej strony podkreślono w nim, że Japonia utrzyma oficjalne relacje $\mathrm{z}$ Tajwanem, z drugiej zaś zwrócono uwagę na znaczenie historycznych więzi japońsko-chińskich, z powodu których rząd w Tokio nie może zupełnie zerwać kontaktów z ChRL niczym Stany Zjednoczone. Uchwała PLD była owocem kompromisu pomiędzy obozem protajwańskim a propekińskim i wyznaczała granice pogłębiania współpracy $\mathrm{z}$ władzami w Pekinie $^{208}$.

Aby zakończyć kryzys $\mathrm{w}$ relacjach $\mathrm{z}$ reżimem Guomindangu należało uregulować problem eksportu fabryk do ChRL za kredyty z japońskich banków. Po naradzie m.in. $\mathrm{z}$ ministrem spraw zagranicznych Ōhirą, na początku maja 1964 roku Yoshida Shigeru potajemnie przekazał stronie tajwańskiej tzw. „notkę Yoshidy" ${ }^{\text {209 }}$. Zostało w niej stwierdzone, że dołoży się starań, aby eksport fabryk

${ }^{205}$ Kokufu Taiwan mondai kenkyū kadaian z 28 I 1964 [w:] Nichi-Chūka Minkoku kankei, A'1.2.1.7, Archiwum Dyplomatyczne...

${ }^{206}$ Przed wyjazdem Yoshida otrzymał dyrektywy z Ministerstwa Spraw Zagranicznych, by podczas rozmowy z Jiang Jieshim przyznać, że Japonia postrzega komunizm jako zagrożenie, ale z powodu ograniczeń konstytucyjnych nie może prowadzić w równym stopniu antykomunistycznej polityki, jak Tajwan i Korea Południowa. Kierowany przez Ōhirę Masayoshiego resort podkreślał także sprzeciw wobec planów odbicia siłą Chin kontynentalnych przez reżim Guomindangu. Zauważał również, że nie można w nieskończoność opierać relacji z Tajwanem na poczuciu wdzięczności wobec Jiang Jieshiego. Szerzej na ten temat: Chūka Minkoku seifu to hanashiau beki jikō, hatsugen yōshian z 17 I 1964 [w:] Honpō yōjin shogaikoku hōmon, Ajia Taiheiyō shokoku, A'1.5.1, Archiwum Dyplomatyczne...

${ }^{207}$ Ni Zhimin, Ikeda naikaku... (sono 3), s. 49-50.

${ }^{208}$ Joseph Y. S. Cheng, Sino-Japanese Relations in Ikeda's Premiership, „China Report” 1977, vol. 13 , no. 2 , s. 55 .

${ }^{209}$ Była to już druga ,notka Yoshidy” w sprawie polityki wobec Chin, po piśmie z 1951 roku. Według Lin Jinjinga, pierwotnie druga „notka Yoshidy” została sporządzona przez stronę tajwańską i zawierała znacznie dalej idące stwierdzenia niż ta przekazana władzom w Tajpej przez rząd w Tokio w maju 1963 roku. W pierwotnej wersji miała być zawarta m.in. deklaracja o bezterminowym powstrzymaniu się od pomocy gospodarczej dla ChRL. Yoshida potwierdził autentyczność jej treści w liście wysłanym stronie tajwańskiej po powrocie do kraju. W japońskich archiwach dyplomatycznych rzeczywiście zachowała się korespondencja o tej treści między Yoshidą a Zhang Qunem. Szerzej na ten temat: Chō Gun hishochō ni takushitaru „Shō sōtō yori 
do ChRL był dokonywany wyłącznie na poziomie pozarządowym. Podkreślono także, iż w tym roku (tj. 1964) Japoński Bank Eksportowo-Importowy nie udzieli kredytu na eksport fabryki włókien chemicznych do Chin komunistycznych ${ }^{210}$. Był to czasowy kompromis mający na celu danie szansy władzom Tajwanu na „zachowanie twarzy” w tym przeciągającym się sporze ${ }^{211}$. Znakiem, że relacje tajwańsko-japońskie zaczęły powracać do stanu sprzed 1963 roku było mianowanie w czerwcu 1964 roku przez rząd w Tajpej byłego ambasadora w Stanach Zjednoczonych na nowego ambasadora w Japonii ${ }^{212}$. Dokumenty japońskiego Ministerstwa Spraw Zagranicznych z tego okresu potwierdzają, że rząd Ikedy nie miał zamiaru zrywać stosunków dyplomatycznych z reżimem Guomindangu, by nawiązać je z ChRL ${ }^{213}$. Z drugiej strony, był gotowy ignorować „mniejsze protesty” władz w Tajpej, przyjmując postawę „spokojnego realizmu" (reiseina riarizumu) ${ }^{214}$.

Ostatnim krokiem ku naprawie stosunków Japonii z reżimem Guomindangu po incydencie z Zhou Hongqingiem była wizyta na Tajwanie ministra spraw zagranicznych Ōhiry Masayoshiego. Stała się ona dobrym dopełnieniem misji Yoshidy, który przecież poleciał do Tajpej tylko jako osoba prywatna. Podróż Ōhiry miała jednak również głębokie znaczenie, biorąc pod uwagę rywalizację międzyfrakcyjną w PLD. Na lipiec 1964 roku przewidziane były wybory przewodniczącego partii i przeciw ubiegającemu się o trzecią kadencję Ikedzie Hayato uformował się silny front protajwańskich polityków, wspierających kandydaturę Satō Eisaku. Było oczywiste, że aby zwyciężyć Ikeda musiał pozyskać także głosy przynajmniej części parlamentarzystów blisko związanych z reżimem Jiang Jieshiego. Na domiar złego, w maju 1964 roku zmarł Ōno Banboku, jeden z najważniejszych członków „głównego nurtu”. O ile Ikeda był pewien wsparcia samego Ōno (Ōno nie lubił Satō), zachowanie członków dawnej frakcji Ōno po śmierci lidera stało się mniej przewidywalne ${ }^{215}$. Wielu z nich utrzymywało bliskie kontakty z reżimem Guomindangu. Symbolicznym

Yoshida Shigeru sensei ni tai suru dengon” z 19 III 1964 [w:] Honpō yōjin shogaikoku hōmon, Ajia Taiheiyō shokoku, A'1.5.1, Archiwum Dyplomatyczne...; Lin Jinjing, Ume to sakura - Sengo no nikka kankei, Sankei Shuppan, Tokio - Osaka 1984, s. 204-208.

${ }^{210}$ Yoshida Shigeru, Yoshida moto sōri kara Chō Gun hishochō ate henrin z 7 V 1964 [w:] Honpō yōjin shogaikoku hōmon, Ajia Taiheiyō shokoku, A’1.5.1, Archiwum Dyplomatyczne...

${ }^{211} \mathrm{~W}$ marcu 1964 roku Tajwan odwiedził wiceminister spraw zagranicznych Mōri Matsuhei z frakcji Mikiego/Matsumury. W raporcie z wizyty podkreślił, że nie ma potrzeby rezygnacji z eksportu fabryk do Chin, ale należy dać stronie tajwańskiej szansę na „zachowanie twarzy” poprzez wstrzymanie oficjalnych pożyczek dla ChRL. Szerzej na ten temat: Mōri Matsuhei, Hōka hōkoku z 16 III 1964 [w:] Nichi-Chūka Minkoku kankei, A’1.2.1.7, Archiwum Dyplomatyczne...

${ }^{212}$ Chen Fenglin, Chitian Yongren..., s. 51.

${ }^{213}$ Nikka kankei ni kan suru jakkan no kangaekata z 2 III 1964 [w:] Nichi-Chūka Minkoku kankei, A'1.2.1.7, Archiwum Dyplomatyczne...

${ }^{214}$ Kokufushi saikin no tai-Nichi ronpyō ni tsuite z 22 V 1964 [w:] Nichi-Chūka Minkoku kankei, A'1.2.1.7, Archiwum Dyplomatyczne...

${ }^{215}$ Yamada Eizō, Seiden Satō Eisaku, t. 1, Shinchōsha, Tokio 1988, s. 431. 
gestem, mającym zjednać Ikedzie przychylność środowisk protajwańskich było właśnie wysłanie zaufanego polityka z własnej frakcji, Ōhiry, do Tajpej ${ }^{216}$.

Ōhira Masayoshi rozpoczął wizytę na Tajwanie 3 lipca 1964 roku. Następnego dnia, w trakcie spotkania z Jiang Jieshim, Ōhira zgodził się, iż komunizm jest poważnym zagrożeniem dla wolności w Azji Wschodniej. Na dodatek przyznał, że Japonia wyczekuje dnia wyzwolenia Chin kontynentalnych spod komunizmu ${ }^{217}$. Wizyta japońskiego ministra spraw zagranicznych na Tajwanie ostatecznie zakończyła wywołany incydentem z Zhou Hongqingiem stan napięcia w relacjach na linii Tokio-Tajpej. Unormowanie stosunków z Republiką Chińską na Tajwanie i uśmierzenie niezadowolenia protajwańskiego lobby wewnątrz PLD przyniosło również wymierne korzyści premierowi Ikedzie Hayato. W dniu 10 lipca 1964 roku został on wybrany na trzecią kadencję przewagą zaledwie dziesięciu głosów. Kilka dni później reżim Guomindangu zniósł zakaz dokonywania rządowych zakupów w Japoniii ${ }^{218}$.

W międzyczasie toczyły się chińsko-japońskie negocjacje w sprawie utworzenia $\mathrm{w}$ obu krajach przedstawicielstw handlowych, przewidzianych $\mathrm{w}$ umowie Liao-Takasaki. Ponieważ kwestia statusu przedstawicieli leżała u podstaw zamrożenia relacji bilateralnych w 1958 roku, obie strony podchodziły do niej z wielką ostrożnością. Przygotowane przez Matsumurę Kenzō w kwietniu 1964 roku $^{219}$ memorandum w tej sprawie spotkało się ze zdecydowanym protestem Kayi Okinoriego, starającego się maksymalnie ograniczyć przywileje chińskich delegatów. Ostatecznie w lipcu 1964 roku rząd w Tokio przyjął kompromisowy projekt, po czym minister sprawiedliwości Kaya wydał zgodę na przybycie do Japonii przedstawicieli handlowych z ChRL. We wrześniu 1964 roku oficjalnie otworzono Tokijskie Biuro Łącznikowe Biura Liao Chengzhiego. W tym samym miesiącu dokonano również wymiany korespondentów prasowych ${ }^{220}$. Co ciekawe, pozytywnie ustosunkowana do polityki Ikedy strona chińska tym razem nie naciskała nawet na uzyskanie prawa do wywieszania flagi państwowej w placówce handlowej ${ }^{221}$.

\footnotetext{
${ }^{216} \mathrm{Ni}$ Zhimin, Ikeda naikaku... (sono 3), s. 54.

${ }^{217}$ Lin Jinjing, op.cit., s. 209.

${ }^{218} \mathrm{Ni}$ Zhimin, Ikeda naikaku... (sono 3), s. 55-58.

${ }^{219}$ W kwietniu 1964 roku Matsumura Kenzō odwiedził ChRL po raz trzeci po II wojnie światowej. Jak wspomina Tagawa Seiichi, rozmawiano wówczas nawet na temat zawarcia w przyszłości umowy lotniczej i pocztowej między Japonią a Chinami. Szerzej na ten temat: Tagawa Seiichi, Matsumura Kenzō..., s. 116-118.

${ }^{220} \mathrm{~W}$ drugiej połowie lat $60 . \mathrm{XX}$ wieku, w czasie „rewolucji kulturalnej” w ChRL, władze w Pekinie wydaliły z Chin licznych japońskich dziennikarzy za „nieprzyjazną działalność”. Szerzej na ten temat: ibidem, s. 99.

${ }^{221}$ Chińscy przedstawiciele handlowi mieli nie prowadzić żadnej działalności politycznej, zaś ich liczbę ograniczono do 5 osób. Aby uniknąc konieczności pobierania odcisków palców strona chińska każdorazowo wysyłała delegatów na okresy krótsze niż rok. Szerzej na ten temat: Ni Zhimin, Ikeda naikaku ni okeru nitchū kankei to Ōhira Masayoshi (sono 2), „Ryūkoku Daigaku Keizaigaku Ronshū” 2005, vol. 45, no. 2, s. 151-161.
} 
Niestety, już dwa miesiące po wyborze na trzecią kadencję Ikeda Hayato musiał podać się do dymisji z powodu ciężkiej choroby. W ten sposób ze świata polityki odchodził człowiek, który pomimo niesprzyjającej sytuacji międzynarodowej doprowadził nieoficjalne relacje Japonii z ChRL na najwyższy poziom w całym okresie lat 1955-1972.

$$
\text { * * * }
$$

Rządy Ikedy Hayato stanowiły zdecydowanie nową jakość w stosunkach japońsko-chińskich. Chociaż za swojej pierwszej kadencji jako przewodniczący PLD Ikeda musiał się liczyć ze zdaniem wspierających go protajwańskich frakcji Kishiego i Satō, już z chwilą objęcia funkcji premiera sygnalizował chęć odmrożenia nieoficjalnych relacji z ChRL. Możliwość pokazania w pełni swojego propekińskiego nastawienia Ikeda uzyskał jednak dopiero po „odwróceniu przymierzy” wewnątrz PLD i odseparowaniu się od osi Kishi-Satō w 1962 roku. Premier stworzył wówczas warunki do zawarcia umowy LiaoTakasaki, która wywołała zdecydowane protesty Tajwanu. W tych okolicznościach sprawa chińska stała się jednym z głównych narzędzi rywalizacji o władzę w partii. Oś Kishi-Satō starała się wykorzystać pogłębiony przez incydent z Zhou Hongqingiem kryzys w stosunkach z reżimem Guomindangu do umocnienia solidarności skrzydła protajwańskiego i krytyki rządu. Ikeda Hayato zdołał jednak uśmierzyć niezadowolenie władz w Tajpej dzięki „notce Yoshidy" i nieprzyznaniu przedstawicielstwom handlowym ChRL zbyt rozległych uprawnień. W ten sposób udało mu się stworzyć podstawy pod rozwój handlu z Chinami komunistycznymi, jednocześnie zachowując władzę pomimo przewagi w partii polityków protajwańskich. Nagła dymisja Ikedy Hayato oznaczała jednak przedwczesny koniec zbliżenia z ChRL.

\section{SATŌ EISAKU (1964-1972)}

Długi, prawie ośmioletni, okres rządów Satō Eisaku był czasem odejścia od linii dyplomatycznej Ikedy Hayato i powrotu do władzy protajwańskiej osi KishiSatō. Mimo iż sam Satō nie był inicjatorem pogorszenia stosunków z ChRL, jego kadencja przypadła na trudny dla relacji japońsko-chińskich okres „rewolucji kulturalnej” w Chinach. Na dodatek premier pozostawał pod wpływem starszego brata. Kishi Nobusuke, chociaż już nie pełnił funkcji przewodniczącego frakcji, nadal promował relacje $\mathrm{z}$ reżimem Jiang Jieshiego, podobnie zresztą, jak wielu innych parlamentarzystów w ,głównym nurcie”. Z drugiej strony, ze względu na swój centrowy charakter, frakcja Satō mogła dość elastycznie zmieniać swój ideologiczny koloryt zależnie od koniunktury politycznej. Zbliżenie amerykańsko-chińskie w 1971 roku leżało u podstaw przyszłego odejścia tej grupy od nastawienia protajwańskiego. 


\section{Umiarkowana protajwańskość ,głównego nurtu” Satō Eisaku}

W listopadzie 1964 roku Zgromadzenie Parlamentarzystów PLD z Obu Izb postanowiło, że nowy premier zostanie wybrany w drodze nominacji przez odchodzącego szefa rządu. Bliski śmierci Ikeda Hayato, idąc za radą Kawashimy Shōjirō i Mikiego Takeo, wskazał na swojego następcę Satō Eisaku. Ze względu na mało konfliktowy sposób wyboru przewodniczącego PLD, nowy „główny nurt" zrzeszał większość liczących się frakcji. Nie brali w nim udziału tylko tacy politycy, jak Kōno Ichirō, który był zawiedzony nominacją, ponieważ miał nadzieję na zwycięstwo własnej kandydatury ${ }^{222}$. W skład „głównego nurtu” początkowo nie weszła również dawna frakcja Ōno, w której rozpoczęła się walka o władzę pomiędzy Funadą Naką a Murakamim Isamu ${ }^{223}$.

Tabela 2.7 Rozkład sił pomiędzy frakcjami PLD w okresie rządów Satō Eisaku w latach 1964-ok. 1967.

\begin{tabular}{|l|l|l|}
\hline \multicolumn{2}{|c|}{ Frakcje: } \\
\hline ,głównego nurtu” & poza ,głównym nurtem” & ,przeciwnego nurtu” \\
\hline Satō (L, B, T) 91 & Ōno (L, LP, J, T) 40 & Kōno (D, LP, J) 67 \\
Fukuda (D, B, J, T) 25 & Fujiyama (D, LP) 34 & Matsumura (D, LP, G, P) 4 \\
Ikeda (L, B, G, P) 60 & & \\
Miki (D, LP, G, P) 45 & & \\
Kawashima (D, LP, J) 20 & & \\
Ishii (L, LP, T) 28 & & 71 \\
\hline 269 & 74 & \\
L: 3 (179), D: 3 (90), & & \\
B: 3 (176), LP: 3 (93), & & \\
G: 2 (105), J: 2 (45), & & \\
P: 2 (105), T: 3 (144). & & \\
\hline
\end{tabular}

L- dawni członkowie Partii Liberalnej, główny nurt konserwatywny, D- dawni członkowie Japońskiej Partii Demokratycznej, boczny nurt konserwatywny, B- dawni biurokraci, LP- ludzie partii, G- gołębie, J- jastrzębie, P- obóz propekiński, T- obóz protajwański.

Liczebność frakcji (podana przy poszczególnych frakcjach) po wyborach do Izby Reprezentantów z listopada 1963 roku. Uwzględniono członków frakcji z obu izb parlamentu. Liczebność frakcji Mikiego i Matsumury podana w przybliżeniu. W podsumowaniu „głównego nurtu” podana jest ogólna liczba należących do niego parlamentarzystów oraz liczba frakcji, zaś w nawiasie liczba parlamentarzystów, należących do poszczególnych obozów.

Opracowanie własne na podstawie: Iseri Hirofumi, op.cit., s. 109; Kitaoka Shin'ichi, op.cit., s. 335; Fukui Haruhiro, op.cit., s. 344; Satō Seizaburō, Matsuzaki Tetsuhisa, op.cit., s. 243.

Z kolei tuż po rekomendacji przez Mikiego Ikedzie kandydatury Satō w 1964 roku grupę Mikiego opuścił razem ze swoimi kobunami sprzeciwiający się temu posunięciu dotychczasowy współprzewodniczący frakcji, Matsumura Kenzō. Chociaż przed objęciem władzy Satō zdawał się sprzyjać kontaktom z ChRL,

${ }^{222}$ Itagaki Eiken, op.cit., s. 48.

${ }^{223}$ Kyū Ōno-ha ga jijitsujō bunretsu, „Asahi Shinbun” z 11 VIII 1960, s. 2. 
Matsumura nie dowierzał jego propekińskim gestom: „Politycy pochodzący z biurokracji nie prowadzą śmiałej polityki. On po prostu dużo mówi, ponieważ opinia publiczna pragnie normalizacji stosunków japońsko-chińskich. Poza tym Satō jest bratem Kishiego. Z pewnością będzie sprzyjał Stanom Zjednoczonym. Bez względu na to, ile lat by nie upłynęło, nie rozwiąże problemu chińskiego" 224 . Matsumura był zdecydowany przeciwstawiać się obozowi protajwańskiemu, choćby to miało oznaczać wieczną przynależność do „przeciwnego nurtu".

Jak widać w tabeli 2.7, „główny nurt” Satō opierał się na dość szerokiej koalicji różnorodnych frakcji. Panowała w nim równowaga pomiędzy wszystkimi obozami, ale tylko, jeśli się weźmie pod uwagę ilość frakcji. Ponieważ grupa Satō była największa, jej charakter narzucał koloryt ideologiczny całego „głównego nurtu”. Widać w nim wyraźną przewagę parlamentarzystów pochodzących z dawnej Partii Liberalnej, środowiska byłych biurokratów oraz stronnictwa protajwańskiego. Umiarkowany charakter nadawały mu jednak dwie duże frakcje Ikedy i Mikiego. Dzięki nim dominowało stronnictwo „gołębi”, a i przewaga obozu protajwańskiego nie była przytłaczająca.

W miarę zrównoważony charakter ,głównego nurtu” Satō można także wytłumaczyć cechami charakteru i stylem sprawowania władzy przez nowego premiera. W przeciwieństwie do pochodzącego z Ministerstwa Finansów Ikedy Hayato, Satō Eisaku wywodził się z Ministerstwa Transportu i doświadczenia zdobyte w trakcie pracy w tym resorcie wywarły duży wpływ na jego umiejętności polityczne. Jako biurokrata Satō zajmował się m.in. negocjacjami ze związkami zawodowymi kolejarzy, dzięki czemu nauczył się sztuki wysłuchiwania racji drugiej strony konfliktu i dostosowywania się do zmian otoczenia $^{225}$. Gdy przeszedł do świata polityki, potrafił umiejętnie dbać o harmonię wewnątrzpartyjną i zjednywać sobie przyjaciół poprzez zakulisowe kontakty oraz staranne dobieranie współpracowników. Jego ulubioną lekturą były wykazy parlamentarzystów, zawierające ich życiorysy ${ }^{226}$. Dzięki temu nazywano go „Satō od spraw personalnych" (jinji no Satōo ${ }^{227}$. Nie znał się na dyplomacji, tylko na polityce wewnętrznej ${ }^{228}$, zaś w kontaktach zagranicznych raczej nie kierował się ideologią, tylko interesem politycznym ${ }^{229}$.

$\mathrm{W}$ porównaniu z innymi frakcjami, skupiona wokół Satō grupa polityków rzeczywiście posiadała najmniej jasno określoną linię ideologiczną, która by wpływała na jej zachowanie $\mathrm{w}$ rywalizacji wewnątrzpartyjnej. Jak zostało podkreślone w pierwszym rozdziale, była to frakcja środka, mogąca elastycznie

\footnotetext{
${ }^{224}$ Endō Kazuo, op.cit., s. 252.

${ }^{225}$ Gotō Motoo, Uchida Kenzō, Ishikawa Masumi, op.cit., t. 2, s. 56-57.

${ }^{226}$ Senda Hisashi, Satō naikaku kaisō, Chūō Kōronsha, Tokio 1987, s. 182-183.

${ }^{227}$ Uchida Kenzō, Sengo..., s. 60.

${ }^{228}$ Gotō Motoo, Uchida Kenzō, Ishikawa Masumi, op.cit., t. 2, s. 56-57.

${ }^{229}$ Ibidem, s. 135.
} 
dostosowywać się do zmian otoczenia politycznego. Z jednej strony Satō Eisaku należał do „głównego nurtu konserwatywnego" Yoshidy Shigeru, z drugiej zaś, jako brat Kishiego, współtworzył „oś władzy” razem z najważniejszą frakcją „bocznego nurtu konserwatywnego”. Z jednej strony frakcję Satō tworzyli przede wszystkim dawni biurokraci, z drugiej zaś, jako jedna z największych grup, siłą rzeczy musiała skupiać także licznych „ludzi partii”. W przypadku najbardziej związanego z ideologią kryterium podziału, frakcję tę w ogóle trudno jasno zidentyfikować jako zrzeszającą „gołębie” czy ,jastrzębie”. Należały do niej różnorodne środowiska polityków skupionych przede wszystkim na zwiększaniu własnych wpływów, zwłaszcza poprzez dobre kontakty ze światem biznesu. Chociaż Satō można nazwać politykiem umiarkowanie protajwańskim, jego nastawienie wobec reżimu Guomindangu wynikało nie tyle $\mathrm{z}$ osobistych relacji z Jiang Jieshim czy skrajnie antykomunistycznych przekonań, co raczej z wpływu starszego brata oraz uwarunkowań międzynarodowych. Okres długich rządów Satō Eisaku przypadł wszakże na czas „rewolucji kulturalnej” w ChRL ${ }^{230}$, kiedy trudno było w ogóle poważnie myśleć o zbliżeniu na linii Tokio-Pekin. Poza tym ministrem spraw zagranicznych został Shiina Etsusaburō z frakcji Kawashimy, który posiadał silne związki z reżimem Guomindangu.

Co ciekawe, kiedy w 1964 roku Satō Eisaku kandydował na przewodniczącego partii, w jego wypowiedziach na temat Chin było widać aktywną postawę, mogącą świadczyć nie tylko o chęci kontynuacji liberalnej linii dyplomatycznej Ikedy, a nawet o gotowości posunięcia się o krok dalej niż zwykłe rozdzielenie polityki od gospodarki. Satō oświadczył m.in.: „Jeśli uzyskam władzę, poświęcę się polepszaniu stosunków chińsko-japońskich”231. Wyrażał także nadzieję, iż ChRL „wstąpi do społeczności międzynarodowej”232. Na dodatek w kwietniu 1964 roku Satō pojawił się na Chińskiej Wystawie Gospodarczej i Handlowej w Tokio ${ }^{233}$, zaś w następnym miesiącu w trakcie spotkania z przewodniczącym Chińskiego Komitetu Promocji Handlu Międzynarodowego Nan Hanchenem sprawiał wrażenie jeszcze bardziej zainteresowanego pogłębianiem handlu z ChRL, niż sam premier Ikeda. Zdawał się nawet zgadzać na zasadę nierozdzielności polityki od gospodarki. Strona chińska bardzo wysoko oceniła postawę brata Kishiego i przez następne miesiące

\footnotetext{
230 „Wielka proletariacka rewolucja kulturalna” (wuchan jieji wenhua dageming) została rozpoczęta w 1966 roku i trwała do 1969 roku lub, według innej interpretacji, aż do 1976 roku. Miała polegać na usunięciu ze społeczeństwa elementów „kontrrewolucyjnych” oraz „starych myśli, starej kultury, starych zwyczajów, starych nawyków”. Była elementem walki Mao Zedonga o władzę w KPCh, przyczyniła się do kryzysu gospodarczego, zamieszek społecznych oraz uwięzienia i śmierci wielu osób w ChRL. Szerzej na ten temat: Alan Lawrance, op.cit., s. 66-81; Edward Kajdański, op.cit., s. 224-225.

${ }^{231}$ Zang Peihong, Zuoteng neige shiqi „Ri-Tai” guanxi, „Riben Wenti Yanjiu” 2000, nr 4, s. 51.

${ }^{232}$ Ibidem, s. 51.

${ }^{233}$ Satō Eisaku, op.cit., t. 2, Tokio 1998, s. 118.
} 
utrzymywała z nim kontakt poprzez Kuno Chūjiego, posła z frakcji Satō. Kuno już prawie udało się ustalić z władzami w Pekinie, że Satō Eisaku spotka się z Zhou Enlaiem w Rangunie, gdy nagle we wrześniu 1964 roku Ikeda Hayato podał się do dymisji. Nic dziwnego, że strona chińska pokładała wielkie nadzieje w nowym premierze ${ }^{234}$.

Wiele wskazuje na to, że powodem propekińskich deklaracji Satō Eisaku była nie tyle rzeczywista chęć dokonania przełomu w relacjach z ChRL, co raczej pragnienie instrumentalnego wykorzystania sprawy chińskiej w zbliżających się wyborach na przewodniczącego PLD. Paradoksalnie, o ile Ikeda Hayato przygotowywał się do nich usilnie pracując nad wygaszeniem kryzysu w stosunkach japońsko-tajwańskich, Satō Eisaku starał się pokazać, że nie jest równie protajwański, jak jego brat. Dzięki temu mógł uzyskać wsparcie świata biznesu, opinii publicznej i choćby części propekińskich polityków z PLD. Szczególnie zabiegał o potajemny sojusz z propekińsko nastawionym Fujiyamą Aiichirō $^{235}$. Już w styczniu 1964 roku członkowie frakcji Satō i związani z nią doradcy rozpoczęli pracę nad projektem tzw. „Operacji Satō” (Satō Operēshon), w którym sformułowano strategię wyborczą. Sprawa chińska zajmowała w niej kluczowe miejsce. Doradcy Satō przypuszczali, że razem z prognozowanym wzrostem poziomu życia mieszkańców ChRL, polityka tego kraju stanie się bardziej pokojowa. Sugerowali, iż w średnio- lub długoterminowej perspektywie również Japonia będzie musiała dokonać przełomu w relacjach $\mathrm{z}$ władzami w Pekinie $^{236}$. Zang Peihong podkreśla, że ze względu na wzrost pozycji międzynarodowej ChRL dzięki nawiązywaniu oficjalnych stosunków dyplomatycznych z coraz większą ilością krajów, sprawa chińska cieszyła się wówczas dużym zainteresowaniem wśród japońskiego społeczeństwa. „Wobec tego, aby zdobyć głosy wyborców, ktokolwiek by nie kandydował na premiera, musiał wykazywać aktywną postawę wobec stosunków chińsko-japońskich"237.

Z chwilą jednak, gdy Satō został szefem rządu w listopadzie 1964 roku, ten pojednawczy wobec Chin komunistycznych ton bardzo szybko uległ złagodzeniu, przemieniając się w bierną chęć kontynuacji dotychczasowych kontaktów. Tuż po inauguracji Satō starał się jeszcze ukazać swój dystans wobec reżimu Guomindangu, mówiąc: „Nie uważamy, aby życzliwość, jaką prezydent Jiang okazał w chwili zakończenia wojny, mogła ograniczać sposób życia narodu japońskiego. Jesteśmy bardzo wdzięczni prezydentowi Jiangowi, ale nie możemy rozwiązywać problemów opierając się na takich emocjach"238. Jednakże już w listopadzie 1964 roku Satō nie zgodził się na wjazd do Japonii burmistrza Pekinu, członka Biura Politycznego Komitetu Centralnego KPCh

\footnotetext{
${ }^{234}$ Tagawa Seiichi, Nitchū kōryū..., s. 25-32.

${ }^{235}$ Yamada Eizō, op.cit., t. 1, s. 433.

${ }^{236}$ Senda Hisashi, op.cit., s. 97-114.

${ }^{237}$ Zang Peihong, op.cit., s. 52.

${ }^{238}$ Ibidem, s. 51.
} 
Peng Zhena, który chciał uczestniczyć w kongresie Japońskiej Partii Komunistycznej ${ }^{239}$. Pod koniec listopada 1964 roku nowy prezes Rady Ministrów oświadczył w parlamencie: „Jak dotąd rząd, utrzymując oficjalne stosunki dyplomatyczne z rządem Republiki Chińskiej, kontynuował realne handlowe i inne kontakty $\mathrm{z}$ Chinami kontynentalnymi na poziomie prywatnym, na podstawie zasady oddzielenia polityki od gospodarki. Nie mam zamiaru zmieniać tej podstawowej polityki, nawet teraz, gdy Chiny przeprowadziły próby nuklearne, ale trzeba powiedzieć, że waga sprawy chińskiej staje się coraz większa. Uważam, iż problem ten należy traktować z ostrożnością i powagą, zwracając uwagę na zmianę sytuacji międzynarodowej”"240.

Jak widać, nie było już śladu po deklaracjach o gotowości przyjęcia zasady nierozdzielności polityki od gospodarki. Wcześniejsze wyraźnie propekińskie wypowiedzi były prawdopodobnie jedynie środkiem, mającym ułatwić rywalizację w wyborach z lipca 1964 roku, a później przekonać Ikedę Hayato, że Satō będzie godnym kontynuatorem jego polityki ${ }^{241}$. Złudzeń co do propekińskości „głównego nurtu" Satō nie pozostawiała już wypowiedź ministra spraw zagranicznych Shiiny Etsusaburō z grudnia 1964 roku: „Nasz kraj, który utrzymuje stosunki dyplomatyczne z Republiką Chińską, jak też ma z nią historycznie bliskie kontakty, dochowując wierności tej przyjaźni, nie może się dobrze odnosić do działań, mających za cel po prostu usunięcie rządu owego kraju z ONZ"242.

Zang Peihong zwraca też uwagę na międzynarodowe uwarunkowania postawy Satō. Podkreśla, że ,inaczej niż w przypadku gabinetu Ikedy, dla rządu Satō oprócz starań o rozwój gospodarczy kraju, ważnym celem dyplomatycznym było również odzyskanie Okinawy ${ }^{243}$. Aby przejąć inicjatywę w negocjacjach dyplomatycznych, rząd japoński musiał prowadzić spójną ze Stanami Zjednoczonymi politykę wobec Tajwanu" ${ }^{\text {"24 }}$. O ile zaś kadencja Ikedy przypadła na okres relatywnego odprężenia amerykańsko-chińskiego za rządów prezydenta Kennedy'ego i odsunięcia w ChRL od władzy radykałów po „wielkim skoku”, kadencja Satō miała wypaść w niesprzyjającym dla współpracy z Chinami komunistycznymi czasie „rewolucji kulturalnej” i eskalacji wojny wietnam-

\footnotetext{
${ }^{239}$ Tagawa Seiichi, Nitchū kōryū..., s. 32.

${ }^{240}$ Posiedzenie plenarne Izby Reprezentantów (Shūgiin honkaigi) z 21 XI 1964 roku, nr 3, Archiwum Obrad...

${ }^{241}$ Hatano Masaru, Shimizu Urara, op.cit., s. 197-198.

${ }^{242}$ Posiedzenie Komisji Spraw Budżetowych Izby Radców (Sangiin Yosan Iinkai) z 9 XII 1964 roku, nr 3, Archiwum Obrad...

${ }^{243}$ Okinawa, jak i całe wyspy Riukiu, znajdowała się od 1945 roku pod bezpośrednią okupacją USA.

${ }^{244}$ Zang Peihong, op.cit., s. 52.
} 
skiej $^{245}$. Kolejnym wydarzeniem, które utrudniało zbliżenie $\mathrm{z}$ władzami w Pekinie były pierwsze testy nuklearne Chin, przeprowadzone pod koniec 1964 $\mathrm{roku}^{246}$. Obiektywne uwarunkowania utwardzały tylko bierną postawę Satō w sprawie chińskiej, co działało na korzyść stronnictwa protajwańskiego. Z czasem stało się to jedną z przyczyn wyjścia z „głównego nurtu” frakcji propekińskich.

\section{Powrót do ,logiki zimnej wojny”}

Pod koniec stycznia 1965 roku władze Japonii ogłosiły, iż Japoński Bank Eksportowo-Importowy nie wspomoże finansowo zakupu przez ChRL fabryki winylu od firmy Nichibō Puranto. W lutym 1965 roku Satō Eisaku wyjaśnił na posiedzeniu Komisji Spraw Budżetowych Izby Reprezentantów, iż „notka Yoshidy" uniemożliwia korzystne dla Chin komunistycznych rozstrzygnięcie w tej sprawie. Mimo że „notka Yoshidy” miała obowiązywać jedynie w 1964 roku, premier nadał jej bezterminową ważność. W swoim dzienniku przyznał, że „lepiej unikać rozgniewania Tajwanu" ${ }^{\text {247 }}$. W ten sposób posunięcie, które w zamierzeniu Ikedy Hayato miało być tylko tymczasowym środkiem złagodzenia gniewu Jiang Jieshiego, w wyniku dojścia do władzy w PLD skrzydła protajwańskiego stało się realną przeszkodą $\mathrm{w}$ pozarządowej wymianie handlowej z ChRL. Decyzja premiera Satō od razu spotkała się ze zdecydowanym protestem ChRL i propekińskich polityków w partii. Ishibashi Tanzan apelował wręcz, by problem ten nie stał się „drugim incydentem z flagą w Nagasaki”. Jednakże pomimo podkreślania przez ministra handlu i przemysłu Mikiego Takeo, że „notka Yoshidy” nie ogranicza wymiany z ChRL, interpretacja premiera w naturalny sposób przeważyła, zaś skala „handlu LT” zaczęła spadać $^{248}$. Strona chińska odwołała plany zakupu od Japonii około 40 fabryk i innych instalacji ${ }^{249}$. Na dodatek pojawiły się kolejne problemy $\mathrm{z}$ wydawaniem wiz delegatom z ChRL ${ }^{250}$.

Tymczasem w grudniu 1964 roku protajwańskie skrzydło PLD założyło własną grupę polityczną, Stowarzyszenie Badań Problemów Azji (Ajia Mondai Kenkyūkai). Jego członkowie, jak Kaya Okinori, w większości rekrutowali się spośród zwolenników premiera Satō Eisaku i stanowili solidną podstawę jego rządów. Ich celem było przede wszystkim blokowanie rozwoju nieoficjalnych kontaktów handlowych z ChRL oraz promocja pomocy gospodarczej dla

\footnotetext{
${ }^{245}$ Xu Jianhua, Meiguo Dongya ezhi zhanlüe dui 20 shiji 60 niandai Zhong-Ri minjian maoyi de yingxiang, „Wuhan Daxue Xuebao (Renwen Kexue Ban)” 2007, vol. 60, no. 1, s. 110-112; Yoshihide Soeya, op.cit., s. 50.

${ }^{246}$ Ikeda, Satō..., s. 138-157; Utsunomiya Tokuma, Hoashi Kei, Iwamura Michio, Chūgoku kaku jikken-go no sekai no dōkō to nitchū kankei, „Ajia Keizai Junpō” 1964, nr 594, s. 1-11.

${ }^{247}$ Satō Eisaku, op.cit., t. 2, s. 235.

${ }^{248}$ Hatano Masaru, Shimizu Urara, op.cit., s. 201-204.

${ }^{249}$ Yoshihide Soeya, op.cit., s. 99-100.

${ }^{250}$ Satō Eisaku, op.cit., t. 2, s. 403-404.
} 
Tajwanu $^{251}$. W odpowiedzi na powstanie tej organizacji, skrzydło propekińskie w PLD powołało do życia w styczniu 1965 roku Stowarzyszenie Badań Problemów Azji i Afryki (Ajia-Afurika Mondai Kenkyūkai). Miało ono za cel promocję wstąpienia ChRL do ONZ, pogłębienie handlu z Chinami oraz nawiązanie kontaktów $\mathrm{z}$ tym państwem poprzez spotkania na szczeblu ambasadorów $^{252}$. Stowarzyszenie Badań Problemów Azji i Afryki tworzyli w szczególności politycy poza „głównym nurtem” i „,przeciwnego nurtu”, jak Fujiyama Aiichirō i Matsumura Kenzōo ${ }^{253}$. Należący do niego parlamentarzyści, np. bliski środowisku Mikiego Utsunomiya Tokuma, wystosowali do premiera Satō apel, by prowadził samodzielną dyplomację, a także by przekonał prezydenta USA Lyndona Johnsona do porzucenia antychińskiej polityki ${ }^{254}$. W styczniu 1965 roku 63 proc. członków Stowarzyszenia Badań Problemów Azji należało do „głównego nurtu” w PLD, zaś w lipcu 1966 roku odsetek ten zwiększył się do około 67 proc. Z kolei w Stowarzyszeniu Badań Problemów Azji i Afryki udział parlamentarzystów poza „głównym nurtem” i „przeciwnego nurtu" wynosił odpowiednio około 77 proc. w styczniu 1965 roku i 86 proc. w lipcu $1966 \mathrm{roku}^{255}$. Jasno widać, że oba obozy rozpoczęły proces umacniania swojej solidarności, który w końcu miał doprowadzić do wyraźnej polaryzacji ideologicznej pomiędzy protajwańskim ,głównym” i propekińskim ,,przeciwnym nurtem" wewnątrz partii.

Na podstawie tabeli 2.8 można zauważyć pewną zależność. W „głównym nurcie" dwie wyraźnie protajwańskie frakcje Fukudy i Ishiiego w ogóle nie posiadały reprezentantów w Stowarzyszeniu Badań Problemów Azji i Afryki. Należało jednak do niego kilku członków umiarkowanie protajwańskiej frakcji Satō i jeden członek mieszanej pod względem nastawienia do Chin frakcji Kawashimy. Najciekawsze jednak, że nawet w umiarkowanie propekińskiej frakcji Ikedy liczba członków grupy kojarzonej z reżimem Guomindangu przeważała nad członkami Stowarzyszenia Badań Problemów Azji i Afryki. W „głównym nurcie” jedynie propekińska frakcja Mikiego posiadała nieco więcej reprezentantów w grupie promującej relacje z ChRL. Świadczy to o tym, że przynależność do „głównego nurtu” wymuszała na propekińskich politykach zachowanie rezerwy do grup, które były im bliskie ideologicznie, ale też krytykowały politykę premiera. Odwrotną tendencję można zauważyć we frakcjach poza „głównym nurtem” lub „przeciwnego nurtu”. W mieszanej pod względem nastawienia wobec Chin frakcji Fujiyamy widać przewagę członków Stowarzyszenia Badań Problemów Azji i Afryki. Tendencja ta występuje w jeszcze większym stopniu w podobnej ideologicznie frakcji Kōno, która jednak

\footnotetext{
${ }^{251}$ Hatano Masaru, Shimizu Urara, op.cit., s. 201.

${ }^{252}$ Huang Dahui, op.cit., s. 36-37.

${ }^{253}$ Mōri Kazuko, op.cit., s. 19-20.

${ }^{254}$ Hatano Masaru, Shimizu Urara, op.cit., s. 200-201.

${ }^{255}$ Yoshihide Soeya, op.cit., s. 56.
} 
była bardziej krytycznie nastawiona do rządu Satō. Nie dziwi też zupełny brak członków najbardziej propekińskiej frakcji Matsumury w Stowarzyszeniu Badań Problemów Azji. Najciekawsze jednak, że także w protajwańskiej dawnej frakcji Ōno widać przewagę członków grupy promującej kontakty z ChRL. Taka postawa była bardziej objawem chęci przeciwstawienia się rządowi niż działaniem uwarunkowanym ideologicznie.

Tabela 2.8 Liczba członków Stowarzyszenia Badań Problemów Azji (SBPA) oraz Stowarzyszenia Badań Problemów Azji i Afryki (SBPAA) według przynależności frakcyjnej w PLD.

\begin{tabular}{|l|l|l|l|l|l|l|l|l|l|l|}
\hline & \multicolumn{4}{|c|}{ Frakcje ,głównego nurtu” } & \multicolumn{4}{c|}{ Pozostałe frakcje } \\
\cline { 2 - 12 } & Satō & Fukuda & Ishii & $\begin{array}{l}\text { Kawa- } \\
\text { shima }\end{array}$ & Ikeda & Miki & $\begin{array}{l}\text { Fuji- } \\
\text { yama }\end{array}$ & Ōno & Kōno & $\begin{array}{l}\text { Matsu- } \\
\text { mura }\end{array}$ \\
\hline SBPA & 17 & 13 & 10 & 4 & 11 & 7 & 7 & 7 & 2 & 0 \\
\hline SBPAA & 6 & 0 & 0 & 1 & 8 & 9 & 9 & 12 & 17 & 6 \\
\hline
\end{tabular}

Dane ze stycznia 1965 roku. Stan sprzed rozpadu dawnej frakcji Ōno. Źródło: Yoshihide Soeya, op.cit., s. 56.

Pomimo protestów skrzydła propekińskiego, rząd Satō coraz wyraźniej podążał tą samą drogą, co gabinet Kishiego. Stowarzyszenie Badań Problemów Azji bacznie śledziło poczynania premiera, zaś japońska dyplomacja całkowicie oparła się na polityce partnerstwa ze Stanami Zjednoczonymi. W warunkach zaostrzającej się wojny wietnamskiej oznaczało to powrót do zimnowojennej logiki świata bipolarnego. Coraz lepiej układała się też współpraca Japonii z reżimem Guomindangu. W połowie 1964 roku Stany Zjednoczone ogłosiły zamiar zakończenia $\mathrm{w}$ następnym roku planu pomocy gospodarczej dla Republiki Chińskiej na Tajwanie ${ }^{256}$. Władze w Tajpej postanowiły wówczas zwrócić się z prośbą o wsparcie finansowe do Japonii. Temat ten został poruszony w grudniu 1964 roku na zorganizowanej na Tajwanie 9. konferencji Komitetu Współpracy Japońsko-Chińskiej. Problem pomocy gospodarczej omawiał także jeden z głównych członków „głównego nurtu” w PLD, Ishii Mitsujirō, jako specjalny wysłannik premiera do Tajpej w marcu 1965 roku. Ostatecznie w kwietniu 1965 roku Japonia przyznała reżimowi Guomindangu pożyczkę na 5 lat na łączną kwotę $150 \mathrm{mln}$ USD. Polityka pomocy finansowej dla Tajwanu była kontynuowana przez cały okres rządów premiera Satō. W ten sposób japońsko-tajwańskie powiązania gospodarcze uległy znacznemu wzmocnieniu. Atmosferę przyjaźni w relacjach wzajemnych podkreślono we wspólnej deklaracji, ogłoszonej przy okazji wizyty w Japonii ministra spraw zagranicznych Tajwanu, Shen Changhuana w sierpniu $1965 \mathrm{roku}^{257}$. Zresztą

\footnotetext{
${ }^{256}$ Było to spowodowane wysokimi kosztami wojny w Wietnamie oraz osiągnięciem przez Tajwan zadowalającego poziomu rozwoju gospodarczego.

${ }^{257}$ Nikka kyōdō komyunike z 16 VIII 1965 [w:] Nichi-Chūka Minkoku kankei, A’1.2.1.7, Archiwum Dyplomatyczne...
} 
wobec rozpoczętej w 1966 roku ,rewolucji kulturalnej” w ChRL, rząd w Tokio nie miał w tym okresie możliwości rozwoju handlu z Chinami komunistyczny$\mathrm{mi}^{258}$.

Fukui Haruhiro podkreśla, że obóz propekiński był bezsilny wobec protajwańskiej polityki rządu. Kwestię chińską omawiano w kilku organach podległych Radzie Badań Politycznych PLD, jak Komisja Badań Spraw Zagranicznych (Gaikō Chōsakai) czy Podkomisja Spraw Chińskich (Chūgoku Shōiinkai), ale żaden z nich nie był w stanie podjąć jakiejkolwiek konkretnej wiążącej decyzji. Obóz propekiński był na tyle silny, by wykorzystać niepisaną zasadę konsensusu w partii i zablokować inicjatywy ustawodawcze posłów protajwańskich, ale także nie mógł przeforsować własnych ustaw. Z kolei wobec paraliżu organów partyjnych ostateczne słowo należało do rządu i biurokracji, które stały na straży status quo, czyli utrzymania oficjalnych relacji z Republiką Chińską na Tajwanie ${ }^{259}$.

W 1967 roku przewodniczącym Komisji Badań Spraw Zagranicznych został wiceprzewodniczący partii Kawashima Shōjirō, który wykazywał elastyczną postawę w sprawie chińskiej i aż do śmierci w 1970 roku rozmyślał o podróży do Pekinu. Co prawda Kawashima doprowadził do przegłosowania w maju 1968 roku uchwały wzywającej rząd m.in. do dopuszczenia ChRL do udziału w konferencjach międzynarodowych, ale nie stanowiła ona poważnego wyzwania dla protajwańskiego charakteru polityki rządu Satō. Wręcz przeciwnie, dyskusja w oficjalnych organach partii i symboliczne ustępstwa wobec ,przeciwnego nurtu" miały służyć zaspokojeniu potrzeby wyrażenia własnego zdania przez posłów propekińskich i uniknięciu rozłamu w partii ${ }^{260}$. Tominomori Eiji uważa z kolei, że zgłoszony w 1969 roku przez gabinet Satō pomysł rozpoczęcia rozmów z ChRL na szczeblu ambasadorów miał na celu jedynie poprawę wizerunku rządu przed wyborami parlamentarnymi. Świadczy o tym fakt, że żaden $\mathrm{z}$ rządowych projektów nawiązania kontaktów z Chinami nie wyszedł poza ramy luźnych propozycji ${ }^{261}$.

\section{Kulminacja napięcia w relacjach z ChRL}

Około 1967 roku „główny nurt” Satō uległ ostatecznej transformacji w kierunku wyraźnie protajwańskiego składu frakcyjnego. W 1965 roku zmarł po ciężkiej chorobie Ikeda Hayato. Jeszcze pod koniec 1964 roku przywództwo w jego grupie przejął Maeo Shigesaburō. W 1966 roku nasilił on krytykę wobec rządu, opuszczając tym samym ,główny nurt”"262. Podobnie jak Ikeda, Maeo wywodził

\footnotetext{
${ }^{258}$ Zang Peihong, op.cit., s. 52-53.

${ }^{259}$ Fukui Haruhiro, op.cit., s. 321-324; Huang Dahui, op.cit., s. 44-47.

${ }^{260}$ Kawashima..., s. 409-411.

${ }^{261}$ Tominomori Eiji, op.cit., s. 229-230.

${ }^{262}$ Bezpośrednią przyczyną wyjścia frakcji Maeo z ,głównego nurtu” była seria afer korupcyjnych związanych z posłami PLD (tzw. kuroi kiri jiken) z 1966 roku. Szerzej na ten temat: Tsuchiya Shigeru, op.cit., s. 199-200.
} 
się z biurokracji Ministerstwa Finansów i przejął po swoim oyabunie umiarkowane poglądy polityczne, np. na temat prymatu gospodarki nad ideologią ${ }^{263}$. Maeo był zwolennikiem liberalizmu ekonomicznego i znoszenia barier w handlu międzynarodowym ${ }^{264}$. Głosił także konieczność pogłębienia współpracy $\mathrm{z}$ państwami o ustroju komunistycznym, przy wzajemnym poszanowaniu zasady nieingerencji w sprawy wewnętrzne ${ }^{265}$.

W 1965 roku umarł również inny z czołowych parlamentarzystów PLD, Kōno Ichirō. Śmierć Kōno i Ikedy, dwóch wpływowych polityków propekińskich, utrudniła promotorom handlu z ChRL zawiązanie spójnej koalicji przeciw władzy Satō ${ }^{266}$. W 1966 roku grupa Kōno uległa ostatecznemu podziałowi na przeciwną rządom Satō frakcję Nakasone Yasuhiro oraz wspierającą premiera frakcję Moriego Kiyoshiego. Do 1968 roku jednak również grupa Nakasone weszła w skład „głównego nurtu” ${ }^{\text {"67 }}$. Z kolei Miki Takeo w 1968 roku przeszedł do wewnątrzpartyjnej opozycji po tym, jak odszedł ze stanowiska ministra spraw zagranicznych $\mathrm{z}$ powodu innego od premiera zdania na temat statusu baz amerykańskich na Okinawie ${ }^{268}$. Odtąd Miki stał się jednym $\mathrm{z}$ najbardziej zdeterminowanych krytyków protajwańskiej polityki Satō i głównym kontrkandydatem premiera w wyborach na przewodniczącego PLD w 1968 i 1970 roku. Z kolei frakcja zmarłego jeszcze w 1964 roku Ōno uległa w sierpniu 1965 roku ostatecznemu rozpadowi na grupy Funady Naki i Murakamiego Isamu ${ }^{269}$. Obie frakcje zachowały protajwański charakter. Funada Naka od dawna należał do najbardziej aktywnych członków Komitetu Współpracy JapońskoTajwańskiej ${ }^{270}$, zaś jako marszałek Izby Reprezentantów posiadał duże wpływy w parlamencie ${ }^{271}$. Zarówno frakcja Funady, jak i Murakamiego, z czasem weszły w skład ,głównego nurtu”.

\footnotetext{
${ }^{263}$ Maeo Shigesaburō, Seijika no hōjōki, Risōsha, Tokio 1981, s. 365-381.

${ }^{264}$ Idem, Gendai seiji no kadai, Mainichi Shinbunsha, Tokio 1976, s. 81-82.

${ }^{265}$ Ibidem, s. 196-197.

${ }^{266}$ Hatano Masaru, Shimizu Urara, op.cit., s. 203.

${ }^{267}$ Tagawa Seiichi, Matsumura Kenzō..., s. 130-131.

${ }^{268}$ Miki Takeo był zdania, że zakaz sprowadzania i składowania broni nuklearnej powinien odnosić się także do terenu wysp Riukiu, kiedy zostaną one zwrócone Japonii spod amerykańskiej okupacji. Satō Eisaku i biurokraci z Ministerstwa Spraw Zagranicznych byli przekonani, że Amerykanie nie przystaną na takie warunki. Ostatecznie jednak Mikiemu udało się przeforsować formułę „bez atomu, tak jak główny ląd” (kaku nuki hondo nami), choć zostało zawarte potajemne porozumienie, że w nadzwyczajnych okolicznościach USA może sprowadzić broń nuklearną na Okinawę. Satō później utrzymywał, że wcielenie w życie zasady „bez atomu, tak jak główny ląd” było jego zasługą. Szerzej na ten temat: Tsuchiya Shigeru, op.cit., s. 201; Kunihiro Masao, op.cit., s. $78-89$

${ }^{269}$ Fukui Haruhiro, op.cit., s. 141.

${ }^{270}$ Ibidem, s. 315.

${ }^{271}$ Funada Naka, Satō Kiichirō, Serizawa Kōjirō, Matsuda Tsuneji, Watashi no rirekisho. Dai 26 $s h \bar{u}$, Nihon Keizai Shinbunsha, Tokio 1968, s. 223-224.
} 
Tabela 2.9 Rozkład sił pomiędzy frakcjami PLD w okresie rządów Satō Eisaku w latach ok. 1967-1972.

\begin{tabular}{|l|l|l|}
\hline \multicolumn{2}{|c|}{ Frakcje: } \\
\hline ,głównego nurtu” & poza ,głównym nurtem” & ,przeciwnego nurtu” \\
\hline Satō (L, B, T) 106 & - & Maeo (L, B, G, P) 62 \\
Fukuda (D, B, J, T) 56 & & Miki (D, LP, G, P) 48 \\
Nakasone (D, LP, J) 52 & & Fujiyama (D, LP, P) 8 \\
Ishii (L, LP, T) 21 & Matsumura (D, LP, G, P) 3 \\
Kawashima (D, LP, J) 18 & & \\
Funada (L, LP, J, T) 18 & & \\
Mori (D, LP, J) 13 & & \\
Murakami (L, LP, J, T) 13 & & \\
\hline 297 & - & \\
L: 4 (158), D: 4 (139), & & \\
B: 2 (162), LP: 6 (135), & \\
G: 0, J: 5 (170), & \\
P: 0, T: 6 (214). & & \\
\hline
\end{tabular}

L- dawni członkowie Partii Liberalnej, główny nurt konserwatywny, D- dawni członkowie Japońskiej Partii Demokratycznej, boczny nurt konserwatywny, B- dawni biurokraci, LP- ludzie partii, G- gołębie, J- jastrzębie, P- obóz propekiński, T- obóz protajwański.

Liczebność frakcji (podana przy poszczególnych frakcjach) po wyborach do Izby Reprezentantów z grudnia 1969 roku. Uwzględniono członków frakcji z obu izb parlamentu. W podsumowaniu „głównego nurtu” podana jest ogólna liczba należących do niego parlamentarzystów oraz liczba frakcji, zaś w nawiasie liczba parlamentarzystów, należących do poszczególnych obozów.

Opracowanie własne na podstawie: Fukunaga Fumio, Habatsu..., s. 80; Tsuchiya Shigeru, op.cit., s. 199-203; Kitaoka Shin'ichi, op.cit., s. 335.

Zmiany zaszły także we frakcji Fujiyamy. W pierwszym okresie rządów Satō Fujiyama Aiichirō zgodził się wstąpić do gabinetu jedynie pod presją tych członków swojej frakcji, którzy byli nadal związani ze swoim dawnym oyabunem, Kishim Nobusuke (frakcja Fujiyamy wywodziła się wszakże z frakcji Kishiego). Chociaż więc Fujiyama nie zgadzał się z polityką premiera i pozostawał poza „głównym nurtem”, nie przechodził do „przeciwnego nurtu”, by zachować jedność swojej frakcji. Z tego powodu w 1968 roku odmówił kandydowania w wyborach na przewodniczącego PLD przeciwko Satō Eisaku, mimo że gorąco zachęcał go do tego obóz propekiński. Szczególnie grupa Matsumury planowała wypromować Fujiyamę na męża stanu zdolnego do dokonania przełomu w relacjach z ChRL ${ }^{272}$. Wysiłki Fujiyamy, by zapobiec rozłamowi swojej frakcji ostatecznie okazały się daremne. W 1968 roku posłowie niezadowoleni $\mathrm{z}$ propekińskich poglądów Fujiyamy opuścili jego frakcję. Założyli luźną grupę pod przywództwem Nanjō Tokuo, która wkrótce przeszła do frakcji Fukudy ${ }^{273}$. W ten sposób grupa Fujiyamy stała się znacznie

${ }^{272}$ Iyasu Tadashi, Aru hoshu..., s. 170.

${ }^{273}$ Fujiyama Aiichirō, op.cit., s. 182-195. 
mniejsza, ale też bardziej spójna ideologicznie. Sam Fujiyama zaś, nie piastując już stanowiska ministra, mógł przejść do ,przeciwnego nurtu” i razem z Matsumurą Kenzō poświęcić się promocji pozarządowego handlu z ChRL.

W latach 1966-1968, ,główny nurt” Satō przemienił się z szerokiej koalicji w bardzo spójny ideologicznie sojusz frakcji prawicowych. Wyraźnie dominowali w nim ,jastrzębie” i politycy protajwańscy. Z kolei względna równowaga panowała pomiędzy członkami dawnej Japońskiej Partii Demokratycznej i Partii Liberalnej oraz między środowiskiem byłych biurokratów i „ludzi partii”. W oczy rzuca się także rozrost grupy Satō, która przekroczyła stu członków w obu izbach parlamentu. Mimo bezwzględnej dominacji frakcji premiera, w partii nie wytworzył się „ogólny główny nurt” z powodu istnienia wyraźnego ,przeciwnego nurtu", skupiającego wszystkie grupy propekińskie. Protajwańskie nastawienie nowego "głównego nurtu" miało stać się coraz bardziej widoczne w polityce zagranicznej Japonii w drugiej połowie lat 60 . XX wieku.

We wrześniu 1967 roku Satō Eisaku odwiedził Tajwan jako drugi premier Japonii po Kishim Nobusuke. W rozmowie z nim Jiang Jieshi podkreślił, że zamieszanie polityczne w Chinach stwarza okazję do kontrataku w wojnie domowej $^{274}$. Co prawda Satō nie wyraził jasnego wsparcia dla polityki zbrojnego odbicia Chin kontynentalnych przez reżim Guomindangu, ale obiecał, że wszelka wymiana handlowa czy kulturowa Japonii z ChRL będzie przebiegać tylko w ramach rozdziału polityki od gospodarki. Obie strony stwierdziły także, że wzmocnienie współpracy między ich krajami jest konieczne dla promocji pokoju i dobrobytu w regionie ${ }^{275}$. W listopadzie 1967 roku Japonię odwiedził na zaproszenie premiera Satō syn Jiang Jieshiego, Jiang Jingguo ${ }^{276}$. Obóz propekiński w PLD z Matsumurą Kenzō na czele ostro krytykował wizytę Satō na Tajwanie jako przedsięwzięcie, które tylko utrudni zbliżenie z ChRL ${ }^{277}$. „Przeciwny nurt” był jednak w mniejszości i miał ograniczone możliwości wpływania na posunięcia premiera.

Oprócz zmian w ,głównym nurcie” wewnątrz PLD, jednym z powodów demonstracyjnie protajwańskiej dyplomacji Satō był także fakt, że japońskoamerykańskie negocjacje w sprawie zwrotu wysp Riukiu wchodziły właśnie w decydującą fazę. Ukazując wyraźne wsparcie dla amerykańskich sojuszników w regionie oraz dla globalnej polityki Stanów Zjednoczonych, rząd w Tokio miał nadzieję na bezproblemową ratyfikację przyszłej umowy przez Kongres USA. W listopadzie 1967 roku premier Satō wydał razem z prezydentem Johnsonem wspólny komunikat, w którym stwierdzono: „Zwróciwszy uwagę na fakt, iż Chiny komunistyczne rozwijają broń nuklearną, zgodzono się, że ważne jest

\footnotetext{
${ }^{274}$ Satō-Shō kaidan gijiroku z 12 IX 1967 [w:] Honpō yōjin shogaikoku hōmon, Ajia Taiheiyō shokoku, A'1.5.1, Archiwum Dyplomatyczne...; Satō Eisaku, op.cit., t. 3, Tokio 1998, s. 130-132.

${ }^{275}$ Zang Peihong, op.cit., s. 53.

${ }^{276}$ Lin Jinjing, op.cit., s. 218.

${ }^{277}$ Yamada Eizō, op.cit., t. 2, s. 98.
} 
stworzenie takich warunków, by kraje Azji nie znajdowały się pod wpływem groźby ze strony ChRL"278. Komunikat spotkał się z krytyką ze strony władz w Pekinie, dla których stanowił on dowód na wskrzeszenie ,japońskiego militaryzmu" (Riben junguozhuyi) $)^{279}$. Z kolei w listopadzie 1969 roku Satō przyznał we wspólnej deklaracji po spotkaniu z prezydentem Richardem Nixonem, że „także utrzymanie pokoju i bezpieczeństwa w regionie Tajwanu jest niezwykle ważnym czynnikiem dla bezpieczeństwa Japonii ${ }^{280}$. Była to cena za zwrot wysp Riukiu, jednak takie wypowiedzi doprowadziły do eskalacji kryzysu w, i tak już napiętych, relacjach na linii Tokio-Pekin.

W międzyczasie, po pięciu latach obowiązywania, wygasła w 1967 roku umowa Liao-Takasaki. W lutym 1968 roku tacy propekińscy politycy, jak Tagawa Seiichi i Furui Yoshimi z grupy Matsumury, oraz przedsiębiorca Okazaki Kaheita, pojechali do ChRL, by wynegocjować nową umowę. Uznawszy „trzy zasady polityczne” oraz zasadę nierozdzielności polityki od gospodarki, zawarli na początku marca 1968 roku porozumienie regulujące handel na poziomie pozarządowym, przy czym miało ono obowiązywać jedynie przez rok. W ten sposób rozpoczęto „handel memorandowy” (oboegaki bōeki), zwany inaczej „handlem MT” (MT bōeki $)^{281}$. Był to krok wstecz w porównaniu z umową Liao-Takasaki. Dzięki krótkiemu okresowi obowiązywania umów, władze ChRL mogły przy okazji corocznych renegocjacji wymuszać od propekińskich polityków w PLD coraz dalej idące polityczne oświadczenia, zawierające krytykę rządu Satōo ${ }^{282}$. Nic dziwnego, że za każdym razem po powrocie do kraju polityków propekińskich nie czekało gorące przyjęcie ${ }^{283}$. Jak wspomina Furui Yoshimi: „Byliśmy obwiniani nie tylko przez skrajnych antykomunistów. Mówiono, że jesteśmy elementami antypartyjnymi, zaś część ludzi nazywała nas zdrajcami kraju"284. Furui miał za złe rządzącym Japonią, że nie doceniali znaczenia handlu z ChRL i stali się ,,więźniami spóźnionej «alergii

\footnotetext{
${ }^{278}$ Satō sōri to Jonson Bei daitōryō to no aida no kyōdō komyunike z 15 XI 1967 [w:] Nitchū kankei kihon shiryōshū 1949 nen - 1997 nen, Zaidan Hōjin Kazankai, Tokio 1998, s. 299.

${ }^{279}$ Mei-Ri huitan de zuie yinmou, ,Renmin Ribao” z 21 XI 1967, s. 6.

${ }^{280}$ Satō sōri to Nikuson Bei daitōryō to no aida no kyōdō komyunike z 21 XI 1969 [w:] Nitchū kankei kihon..., s. 322.

${ }^{281}$ Hatano Masaru, Shimizu Urara, op.cit., s. 210-211.

${ }^{282}$ W lutym 1971 roku Okazaki Kaheita, Furui Yoshimi i Matsumoto Shun'ichi podpisali na przykład wspólną deklarację, w której zawarte były słowa: „Obie strony zgodziły się i skrytykowały fakt, że japońscy reakcjoniści wzmacniając współpracę z imperializmem amerykańskim i wskrzeszając japoński militaryzm, biorą udział w agresji i ekspansji amerykańskiego imperializmu w Azji”. Oświadczenie to zostało skrytykowane m.in. przez protajwańskie Stowarzyszenie Badań Problemów Azji. Szerzej na ten temat: ibidem, s. 220-221.

${ }^{283}$ Zresztą w okresie „rewolucji kulturalnej” propekińscy posłowie z PLD także w Chinach nie byli przyjmowani równie przyjaźnie, jak wcześniej. Wykazujący największe zrozumienie dla uwarunkowań japońskiej sceny politycznej Liao Chengzhi, Sun Pinghua czy Wang Xiaoxue byli wówczas odsunięci od dyplomacji. Szerzej na ten temat: Tagawa Seiichi, Nitchū kōryū..., s. 88-89. ${ }^{284}$ Furui Yoshimi, Nitchü 18 nen..., s. 92.
} 
ideologicznej»" 285 . W trakcie negocjacji drugiej umowy w 1969 roku Furui Yoshimi wziął na siebie pełną odpowiedzialność za memorandum. Jak podkreśla: „Myślałem, że za wszelką cenę nie można dopuścić do zerwania tego kanału kontaktów, nie tylko ze względu na obecny handel, ale także dla przyszłych stosunków japońsko-chińskich, i doprowadziłem negocjacje do końca" ${ }^{286}$.

Według Yamady Eizō, wrogość pomiędzy Satō Eisaku a krytykującymi go członkami grupy Matsumury stała się jednym z czynników stojących na przeszkodzie w zbliżeniu japońsko-chińskim. Satō próbował później szukać innych niż ,przeciwny nurt” we własnej partii kanałów kontaktu z władzami KPCh, zaś ChRL nie chciała okazać się nielojalna wobec osób, które tak długo narażały się na krytykę za propekińskie sympatie ${ }^{287}$. Wzajemne usztywnienie stanowiska obu stron wpłynęło zapewne na to, że rząd japoński podjął intensywniejsze starania nawiązania dialogu $\mathrm{z}$ władzami w Pekinie dopiero po „szoku Nixona”, mimo że już od eskalacji konfliktu chińsko-radzieckiego w 1969 roku było widać narastającą wspólnotę interesów pomiędzy Chinami a Stanami Zjednoczonymi ${ }^{288}$.

Na przełomie marca i kwietnia 1970 roku doszło do ostatniej przed śmiercią wizyty w Chinach ciężko chorego już Matsumury Kenzō, któremu towarzyszyli m.in. Kawasaki Hideji i Tagawa Seiichi. Tym razem jednak prócz kobunów Matsumura wziął ze sobą także przywódcę innej frakcji „przeciwnego nurtu”, Fujiyamę Aiichirō. Od dawna zamierzał przedstawić go Zhou Enlaiowi i „,namaścić" na swojego następcę jako głównego promotora handlu z ChRL ${ }^{289}$. Zirytowany protajwańską polityką rządu Satō premier Zhou w trakcie spotkania z Matsumurą Kenzō ogłosił tzw. „cztery zasady handlu”. Zgodnie z nimi

\footnotetext{
${ }^{285}$ Idem, Furui Yoshimi ibunshū pod red. Matsuo Takayoshiego, Nitchū Yūkō Kaikan, Tokio 1997, s. 181.

${ }^{286}$ Idem, Nitchū 18 nen..., s. 96.

${ }^{287}$ Yamada Eizō, op.cit., t. 2, s. 248-249.

${ }^{288} \mathrm{~W}$ trakcie chińsko-radzieckich starć nad rzeką Ussuri w 1969 roku władze w Waszyngtonie dały do zrozumienia, że opowiedzą się po stronie ChRL w przypadku radzieckiego ataku nuklearnego na ten kraj. Jednocześnie rozpoczęła się redukcja liczby amerykańskich żołnierzy w Wietnamie, amerykańskim naukowcom, studentom i dziennikarzom pozwolono na podróże do Chin oraz zniesiono obowiązujący Amerykanów limit 100 USD na zakupy w Chinach. Szerzej na ten temat: Ronald E. Powaski, op.cit., s. 172-173.

${ }^{289}$ Fujiyama wspomina, iż obawiał się, że premier Zhou nadal ma mu za złe rolę, jaką odegrał jako minister spraw zagranicznych w okresie rządów Kishiego Nobusuke. Jednakże Matsumura Kenzō jeszcze w 1962 roku rozmawiał z Zhou Enlaiem o Fujiyamie i wyczuł, że premier ChRL wspomina raczej z sympatią spotkanie z Fujiyamą w trakcie konferencji w Bandungu w 1955 roku. Odtąd Matsumura usilnie próbował zaangażować Fujiyamę w promocję stosunków z rządem w Pekinie, ale dopiero po opuszczeniu frakcji Fujiyamy przez protajwańską grupę Nanjō Tokuo w 1968 roku nastały ku temu sprzyjające okoliczności. Szerzej na ten temat: Fujiyama Aiichirō, op.cit., s. 179-199.
} 
przedsiębiorstwa japońskie musiały jasno zadeklarować, czy chcą prowadzić interesy z ChRL, czy też z Tajwanem ${ }^{290}$.

Japońskie firmy szybko dostosowały się do nowej sytuacji, masowo deklarując przestrzeganie „czterech zasad” w celu prowadzenia zyskownego handlu z Chinami komunistycznymi, w których właśnie kończyła się „,rewolucja kulturalna" ${ }^{291}$. Był to zwiastun wielkiej zmiany, jaka miała nastąpić w międzynarodowej pozycji ChRL. Wyczuwając zbliżający się przełom, propekińscy politycy powołali do życia w grudniu 1970 roku Parlamentarną Ligę Promocji Przywrócenia Japońsko-Chińskich Stosunków Dyplomatycznych (Nitchū Kokkō Kaifuku Giin Renmei). Obok posłów opozycyjnych należało do niej 91 parlamentarzystów z PLD, zaś przewodniczącym został Fujiyama Aiichirō $^{292}$. Z kolei w maju 1971 roku jeden z członków „przeciwnego nurtu” w PLD, minister handlu i przemysłu Miyazawa Kiichi z frakcji Maeo-Ōhiry, ogłosił, że „notka Yoshidy” ustanowiła ograniczenie w udzielaniu kredytów ChRL jedynie na jeden rok i już nie krępuje działań japońskiego rządu ${ }^{293}$.

\section{„Szok Nixona” i spóźnione próby zbliżenia z ChRL}

W czerwcu 1971 roku Japonia podpisała ze Stanami Zjednoczonymi Traktat o zwrocie Okinawy, zaś 15 lipca 1971 roku prezydent Richard Nixon ujawnił tajną misję Henry'ego Kissingera w Pekinie ${ }^{294}$ i plany złożenia wizyty w ChRL. Ten tzw. „szok Nixona” znacząco wpłynął na sposób traktowania sprawy chińskiej wewnątrz PLD. Oświadczenie prezydenta Stanów Zjednoczonych zaskoczyło Satō, gdyż zgodnie z umową z 1970 roku strona amerykańska miała się konsultować w sprawie chińskiej z władzami Japonii ${ }^{295}$. Natychmiastowej aktywizacji uległo propekińskie skrzydło w PLD, nasilając krytykę protajwańskiej polityki rządu. Już dwa dni po „szoku Nixona” dominacja „osi władzy” Kishi-Satō została naruszona w Izbie Radców. Dzięki wsparciu partii opozycyjnych „przeciwnemu nurtowi” udało się wybrać na marszałka izby wyższej brata Kōno Ichirō (i stryja Kōno Yōheia), Kōno Kenzō. W ten sposób z tego ważnego stanowiska odsunięto Shigemune Yūzō, który był blisko związany

\footnotetext{
290 „Cztery zasady handlu” to deklaracja, że ChRL nie będzie prowadzić handlu z firmami, które: 1) wspierają Guomindangowską politykę kontrataku na kontynent bądź południowokoreańską politykę ataku na Koreę Północną, 2) inwestują na Tajwanie lub w Korei Południowej, 3) dostarczają Stanom Zjednoczonym broń do walki w Indochinach, 4) są wspólnymi przedsiębiorstwami japońsko-amerykańskimi. Szerzej na ten temat: Mōri Kazuko, op.cit., s. 45-46; Hatano Masaru, Shimizu Urara, op.cit., s. 216.

${ }^{291}$ Zang Peihong, op.cit., s. 53; Huang Dahui, op.cit., s. 128-139.

${ }^{292}$ Hatano Masaru, Shimizu Urara, op.cit., s. 219-220.

${ }^{293}$ Sengo Nihon no taigai seisaku pod red. Watanabe Akio, Yūhikaku, Tokio 1985, s. 228.

${ }^{294}$ Doradca prezydenta USA ds. bezpieczeństwa narodowego Henry Kissinger odwiedził ChRL w dniach 9-11 lipca 1971 roku. W rozmowie z Zhou Enlaiem zgodził się m.in., że Tajwan należy uważać za część Chin. Szerzej na ten temat: Ronald E. Powaski, op.cit., s. 173.

${ }^{295}$ Sengo Nihon no taigai..., s. 223.
} 
z premierem ${ }^{296}$. Kōno Kenzō jeszcze jako wicemarszałek Izby Radców odwiedził ChRL w 1966 roku, mimo że Satō Eisaku odradzał mu tę wizytę. Podobnie jak brat, pozostawał pod silnym wpływem idei Matsumury Kenzo ${ }^{297}$.

Jednocześnie reżim Guomindangu starał się umocnić solidarność obozu protajwańskiego w PLD. Na przełomie lipca i sierpnia 1971 roku Japonię odwiedził Zhang Qun, który spotkał się m.in. z premierem Satō oraz takimi politykami „głównego nurtu”, jak Kishi Nobusuke, Kaya Okinori, Funada Naka czy Ishii Mitsujirōo ${ }^{298}$. Bezskutecznie próbował także nawiązać kontakt z Ōhirą Masayoshim $^{299}$. Nowa polityka Stanów Zjednoczonych wobec Chin diametralnie zmieniła pozycję międzynarodową ChRL, wymuszając na japońskim premierze zrewidowanie dotychczasowej linii dyplomatycznej. Tuż po „szoku Nixona” Satō zapisał w swoim dzienniku: „Czyżby to był dowód na to, że postawa Chin komunistycznych stała się bardziej elastyczna? To powód do szczerych gratulacji, ale odtąd problem Tajwanu stanie się jeszcze trudniejszy do rozwiązania" ${ }^{300}$. Słowa te ukazują ambiwalentne uczucia premiera. Pod koniec swojej kadencji Satō Eisaku z jednej strony starał się ratować pozycję Tajwanu w ONZ, z drugiej zaś podejmował próby nawiązania kontaktu z przywódcami KPCh. Japońska opinia publiczna oraz przede wszystkim świat biznesu zaczęły intensywnie podkreślać konieczność zbliżenia z ChRL. Jako wytrawny polityk frakcji środka Satō rozumiał, że interes polityczny nakazuje elastyczne dostosowanie się do nowej sytuacji. Z kolei jako następca myśli Yoshidy Shigeru wiedział, iż dzięki zbliżeniu amerykańsko-chińskiemu znika jedno z głównych ograniczeń japońskiej dyplomacji wobec Chin. Z drugiej strony, jako brat Kishiego Nobusuke, nie potrafił tak po prostu zerwać oficjalnych stosunków dyplomatycznych z bliskim mu reżimem Guomindangu ${ }^{301}$. Ta dwutorowa polityka Satō jest często nazywana „dyplomacją kaczego pluskania wodą" (ahiru no mizu kaki gaikō) ${ }^{302}$. Autorem tej metafory był ówczesny minister spraw zagranicznych, Fukuda Takeo. Tak jak kaczka zdaje się bez wysiłku płynąć po powierzchni wody, a jednak pod wodą energicznie przebiera nogami, tak gabinet Satō Eisaku zdawał się prowadzić jednoznacznie protajwańską

\footnotetext{
${ }^{296}$ Kōno Kenzō, op.cit., s. 34-36.

297 Ibidem, s. 89-117.

${ }^{298}$ Tamura Shigenobu, Tomashima Norio, Koeda Yoshito, Nikka dankō to nitchū kokkō seijōka, Nansōsha, Tokio 2000, s. 116-119.

${ }^{299}$ Co prawda Zhang Qun spotkał się z Ōhirą, ale nie doszło nawet do prawdziwej rozmowy. Zhang nie był też zadowolony z rozmowy z premierem Satō i poczuł, że atmosfera w PLD przestaje sprzyjać kontaktom z reżimem Guomindangu. Szerzej na ten temat: Honda Yoshihiko, Nitchūtai miezaru kizuna. Chūgoku shunō tsūyaku no mita gaikō hiroku, Nihon Keizai Shinbunsha, Tokio 2006, s. 86-89.

${ }^{300}$ Satō Eisaku, op.cit., t. 4, Tokio 1997, s. 377.

${ }^{301}$ Horikoshi Sakuji podkreśla, że Kishi pozostawał w stałym kontakcie z ambasadorem Tajwanu i cały czas hamował propekińskie inicjatywy premiera. Szerzej na ten temat: Horikoshi Sakuji, Sengo seiji rimenshi, Iwanami Shoten, Tokio 1998, s. 280.

302 Tamura Shigenobu, Tomashima Norio, Koeda Yoshito, op.cit., s. 128.
} 
politykę, ale jednocześnie złagodził ton wypowiedzi na temat ChRL i zaczął potajemnie szukać kontaktu z władzami $\mathrm{KPCh}^{303}$.

Wkrótce po „szoku Nixona”, 17 lipca 1971 roku, premier Satō oświadczył w parlamencie: „Nie muszę mówić, że dla naszego kraju ważne jest utrzymanie i wzmocnienie stosunków opartych na przyjaźni i dobrej woli z takimi państwami ościennymi, jak Korea Południowa czy Republika Chińska. Szczególnie problem chiński jest najważniejszym zadaniem naszej dyplomacji w latach 70 . Wychodząc z punktu widzenia, że działania rządu Chińskiej Republiki Ludowej wywierają wielki wpływ na złagodzenie napięcia na Dalekim Wschodzie, rząd z rozwagą podejmie środki ku polepszeniu stosunków japońsko-chińskich. Uważam, że w tym celu niezbędne jest pogłębienie wzajemnego zrozumienia poprzez rozmowy na różne tematy, respektując własne punkty widzenia" ${ }^{304}$. W dniu 22 lipca 1971 roku PLD przedstawiła po gorącej debacie Rezolucję ws. przywrócenia stosunków japońsko-chińskich. Co prawda upoważniała ona rząd do „szybkiej normalizacji stosunków” oraz „wspierania uczestnictwa ChRL w społeczności międzynarodowej”, ale „ze zwróceniem uwagi na dotychczasowe stosunki naszego kraju $\mathrm{z}$ Republiką Chińską na podstawie japońskotajwańskiego traktatu pokojowego" 305 . Jednoczesne podkreślanie tych dwóch sprzecznych celów dobrze charakteryzuje ówczesną dyplomację Japonii.

Pierwszą okazją do nawiązania przez Satō Eisaku kontaktu z władzami w Pekinie stał się pogrzeb zmarłego nagle pod koniec sierpnia 1971 roku Matsumury Kenzō. Na uroczystość przyjechał do Japonii wiceprzewodniczący Stowarzyszenia Przyjaźni Chińsko-Japońskiej Wang Guoquan. Nie dość, że premier nie robił żadnych trudności w wydaniu pozwolenia na wjazd Wanga do kraju, to jeszcze zaskoczył polityków propekińskich, wysyłając sekretarza swojego gabinetu, Takeshitę Noboru, by powitał chińskiego gościa na lotnisku $^{306}$. Satō Eisaku zabiegał o pośrednictwo dawnego sakretarza Matsumury, Tagawy Seiichiego, w przygotowaniu spotkania z Wangiem. Tagawa jednak nie do końca wierzył w szczerość intencji premiera. Podejrzewał, że Satō próbuje tylko wykonać spektakularny gest, który by przedłużył jego rządy. Jak sam przyznał, w trakcie pogrzebu starał się, by Wang Guoquan nie przechodził obok japońskiego premiera. Satō Eisaku udało się tylko podać rękę gościowi z Chin ${ }^{307}$.

Tymczasem w ONZ ważyły się losy uznania za prawowitego przedstawiciela Chin ChRL zamiast reżimu Guomindangu. Japonia miała odegrać w tym sporze ważną rolę promotora polityki Stanów Zjednoczonych, które co prawda rozpoczęły proces zbliżenia z Chinami kontynentalnymi, ale nie zamierzały

\footnotetext{
${ }^{303}$ Sengo Nihon no taigai..., s. 230.

${ }^{304}$ Posiedzenie plenarne Izby Reprezentantów (Shūgiin honkaigi) z 17 VII 1971 roku, nr 3, Archiwum Obrad...

${ }^{305}$ Hatano Masaru, Shimizu Urara, op.cit., s. 224.

${ }^{306}$ Tamura Shigenobu, Tomashima Norio, Koeda Yoshito, op.cit., s. 119-120.

${ }^{307}$ Tagawa Seiichi, Nitchū kōryū..., s. 63-69.
} 
porzucić swojego tajwańskiego sojusznika. Dwa projekty rezolucji zgłoszonych przez USA miały opóźnić dopuszczenie ChRL do Rady Bezpieczeństwa oraz umożliwić Tajwanowi chociaż częściowe zachowanie dotychczasowej pozycji międzynarodowej. Pierwszy z nich to projekt tzw. Rezolucji odwróconej ważnej kwestii (Gyaku jūyō jikō shitei ketsugian). Miał on za zadanie uczynienie z problemu usunięcia Republiki Chin z ONZ ważnej kwestii, wymagającej dwóch trzecich głosów w Zgromadzeniu Ogólnym. Druga z rezolucji dotyczyła tzw. formuły podwójnej reprezentacji (fukugō nijū daihyōsei). Miała ona umożliwić Tajwanowi utrzymanie miejsca w Zgromadzeniu Ogólnym nawet w przypadku wejścia ChRL do Rady Bezpieczeństwa ${ }^{308}$.

Kwestia wsparcia przez Japonię obu rezolucji jako wnioskodawca podzieliła nawet frakcję Satō. Np. Kuno Chūji, który w 1964 roku był pośrednikiem w kontaktach między Satō Eisaku a Zhou Enlaiem, skłaniał się do odrzucenia prośby amerykańskiej ${ }^{309}$. Ostatecznie z powodu różnicy zdań w Radzie Badań Politycznych i Radzie Generalnej PLD, we wrześniu 1971 roku zarząd partii powierzył decyzję w tej sprawie samemu szefowi rządu ${ }^{310}$. Sekretarz gabinetu Satō, Takeshita Noboru, wyjawia w pamiętnikach, co wówczas usłyszał od premiera w prywatnej rozmowie: „Na następnej sesji Zgromadzenia Ogólnego ONZ Rezolucja odwróconej ważnej kwestii zostanie zapewne odrzucona, zaś rząd Republiki Chińskiej wydalony z ONZ. Jednakże moja epoka za wszelką cenę dochowa wierności reżimowi Guomindangu. Lepiej, by później następny człowiek (premier) poprowadził politykę zagraniczną zgodnie $\mathrm{z}$ decyzją ONZ”,311. Takeshita dodaje przy tym: „Było to oparte na przekonaniach premiera Satō, u podstaw których leżała wschodnia filozofia lojalności. Niezależnie, czy było to słuszne, czy też nie, myślę że nauczyłem się bardzo wiele"312. Słowa te pokazują, że nawet tak elastyczny ideologicznie człowiek, jak Satō Eisaku, poprzez wieloletnie prowadzenie polityki protajwańskiej $\mathrm{w}$ pewnym stopniu usztywnił swoje stanowisko. Zgodnie z obawami premiera, bieg historii był przeciwny do linii dyplomatycznej Tokio. W dniu 25 października 1971 roku Zgromadzenie Ogólne ONZ przegłosowało rezolucję, zgodnie z którą komu-

\footnotetext{
${ }^{308}$ Od 1951 roku sprawa członkostwa ChRL w ONZ była rozpatrywana przez Zgromadzenie Ogólne ONZ. Do 1960 roku corocznie uchwalano odłożenie dyskusji nad tą kwestią na przyszłość. Z kolei w latach 1961-1970, kiedy do ONZ wstąpiło wiele propekińskich państw postkolonialnych, z inicjatywy Stanów Zjednoczonych uchwalano rezolucję, która czyniła z kwestii wstąpienia Chin do ONZ tzw. „ważną kwestię”, czyli problem wymagający większości dwóch trzecich głosów. Jednakże na początku lat 70. XX wieku obóz państw propekińskich powiększył się na tyle, że i to nie wystarczało, by powstrzymać akces Chin. Stąd pomysł Rezolucji odwróconej ważnej kwestii i formuły podwójnej reprezentacji. Szerzej na ten temat: Lin Jinjing, op.cit., s. 246-249.

${ }^{309}$ Tagawa Seiichi, Matsumura Kenzō..., s. 191.

${ }^{310}$ Lin Jinjing, op.cit., s. 245-246.

311 Takeshita Noboru, Shōgen. Hoshu Seiken, Yomiuri Shinbunsha, Tokio 1991, s. 64-65.

${ }^{312}$ Ibidem, s. 66.
} 
nistyczne Chiny przejęły od reżimu Guomindangu pozycję stałego członka Rady Bezpieczeństwa ${ }^{313}$. Nie zgodzono się również na formułę podwójnej reprezentacji. Jak podkreśla Tomoda Seki, wydarzenie to wywarło olbrzymi wpływ na nastawienie Japonii wobec ChRL, gdyż poszanowanie zasad ustalanych przez ONZ stanowiło jeden z filarów dyplomacji rządu w Tokio ${ }^{314}$.

Skrzydło propekińskie w PLD zdecydowanie sprzeciwiało się wsparciu przez Japonię obu rezolucji. Tacy politycy, jak Miki Takeo, Maeo Shigesaburō i jego następca na stanowisku szefa frakcji, Ōhira Masayoshi, a nawet należący do „głównego nurtu” Nakasone Yasuhiro, nasilili krytykę dyplomatycznej linii rządu ${ }^{315}$. Na początku października 1971 roku przewodniczący Parlamentarnej Ligi Promocji Przywrócenia Japońsko-Chińskich Stosunków Dyplomatycznych Fujiyama Aiichirō podpisał w Pekinie wspólną deklarację, zawierającą „,cztery zasady przywrócenia stosunków dyplomatycznych"316. Ponieważ swoim samowolnym postępowaniem naraził się władzom partyjnym, przez następne miesiące toczyła się dyskusja o sankcjach wobec niego ${ }^{317}$. Z kolei kiedy pod koniec października 1971 roku w parlamencie ważyło się wotum nieufności wobec ministra spraw zagranicznych Fukudy Takeo, obok Fujiyamy Aiichirō w głosowaniu demonstracyjnie nie uczestniczyli tacy propekińscy politycy, jak Utsunomiya Tokuma, Furui Yoshimi, Kawasaki Hideji, Tagawa Seiichi, Yamaguchi Toshio czy syn Kōno Ichirō, Kōno Yōhei ${ }^{318}$. Wewnątrzpartyjny dyskurs na temat normalizacji stosunków dyplomatycznych z ChRL stopniowo przybierał na sile i stawał się coraz bardziej związany z rywalizacją o sukcesję po mającym niedługo ustąpić ze stanowiska Satō Eisaku ${ }^{319}$.

\footnotetext{
${ }^{313}$ Ni Zhimin, Tanaka naikaku ni okeru nitchū kokkō seijōka to Ōhira Masayoshi (sono 1), „Ryūkoku Daigaku Keizaigaku Ronshū” 2006, vol. 45, no. 5, s. 35-38.

${ }^{314}$ Tomoda Seki, op.cit., s. 44.

315 Tamura Shigenobu, Tomashima Norio, Koeda Yoshito, op.cit., s. 120-121.

316 „Cztery zasady przywrócenia stosunków dyplomatycznych” to uznanie, że: 1) rząd ChRL jest jedynym prawowitym reprezentantem narodu chińskiego; 2) prowincja Tajwan jest nieodłączną częścią terytorium ChRL; 3) traktat japońsko-tajwański z 1952 roku jest bezprawny, nie ma mocy obowiązującej i należy go odrzucić; 4) należy przywrócić członkostwo ChRL w ONZ, w tym w Radzie Bezpieczeństwa, usuwając jednocześnie z ONZ przedstawicielstwo reżimu Guomindangu. Ponieważ wkrótce czwarta zasada została wcielona w życie, mówiono później o „trzech zasadach przywrócenia stosunków dyplomatycznych". Szerzej na ten temat: ibidem, s. 125.

317 Fujiyama został skazany na zawieszenie piastowania stanowisk partyjnych, przy czym wykonanie wyroku zostało odłożone bezterminowo. Według Fujiyamy skazano go, gdyż Komisja Dyscypliny Partyjnej (Tōki Iinkai) była opanowana przez protajwańskich ,jastrzębi”. Spośród 14 członków Komisji tylko jedna osoba, członek frakcji Mikiego, była przeciwko sankcjom. Szerzej na ten temat: Fujiyama Aiichirō, op.cit., s. 209-211.

${ }^{318}$ Fujiyama Aiichirō wspomina, iż grupa ta rozważała później, czy nie zbojkotować także głosowania nad wotum nieufności wobec całego rządu. Ponieważ byłoby to bardzo poważnym naruszeniem dyscypliny partyjnej, jedynie Fujiyama Aiichirō i Kōno Yōhei byli zdecydowani na ten radykalny krok, ale ostatecznie nawet oni postanowili wziąć udział w głosowaniu. Szerzej na ten temat: ibidem, s. 205-207.

${ }^{319}$ Szerzej na ten temat $\mathrm{w}$ następnym rozdziale.
} 
Tuż po wstąpieniu ChRL do ONZ otoczenie Satō Eisaku podjęło potajemnie drugą próbę nawiązania dialogu z władzami w Pekinie. Pod koniec października 1971 roku bliski współpracownik premiera, sekretarz generalny PLD Hori Shigeru, powierzył uzgodniony z samym Satō i ministrem spraw zagranicznych Fukudą Takeo list do Zhou Enlaia udającemu się właśnie do ChRL gubernatorowi Tokio Minobe Ryōkichiemu. Hori przyznawał w nim, że „są jedne Chiny, ChRL jest rządem reprezentującym Chiny, a Tajwan jest terytorium narodu chińskiego" ${ }^{320}$. Wykazywał także gotowość do wizyty w Pekinie i rozpoczęcia rozmów na temat ustanowienia stosunków bilateralnych. Zhou Enlai odmówił jednak przyjęcia listu, krytykując „politykę dwóch Chin” prowadzoną przez Satō ${ }^{321}$. Tagawa Seiichi wspomina, iż osobiście był szczególnie zbulwersowany listem Horiego, gdy wiadomość o nim przedostała się do wiadomości publicznej. Chociaż Hori Shigeru wcześniej prosił Tagawę o pośrednictwo $\mathrm{w}$ rozmowach ze stroną chińską, nie skonsultował z nim treści listu, przez co zawierał on szereg sformułowań nie do przyjęcia dla strony chińskiej $^{322}$.

W 1972 roku, szczególnie po amerykańsko-chińskim Komunikacie Szanghajskim $^{323}$, Satō Eisaku także w oficjalnych wypowiedziach zaczął coraz bardziej zdecydowanie deklarować poparcie dla idei rozmów w sprawie normalizacji stosunków dyplomatycznych z ChRL. Pod koniec lutego 1972 roku, przyznał, że Tajwan należy do ChRL, jednak na początku marca 1972 roku poprawił się, iż „można zrozumieć stanowisko ChRL, że Tajwan jest częścią jej terytorium"324. Taka niezdecydowana postawa spotkała się z krytyką władz w Pekinie. Według Hirokishiego Sakujiego, powodem nagłej zmiany zdania przez Satō była presja ze strony Kishiego ${ }^{325}$. Zrażone wieloletnią protajwańską postawą premiera władze w Pekinie już wcześniej dawały wyraźne znaki, że nie wiążą żadnych nadziei z obecnym gabinetem. Kiedy we wrześniu 1971 roku ChRL odwiedził polityk frakcji zmarłego Matsumury, Kawasaki Hideji, usłyszał bezpośrednio od Zhou Enlaia, iż strona chińska z chęcią ugości u siebie nowego

\footnotetext{
${ }^{320}$ Hori Shigeru, Sengo seiji no oboegaki, Mainichi Shinbunsha, Tokio 1975, s. 128-130.

${ }^{321}$ Sadako Ogata, Normalization with China: A Comparative Study of U.S. and Japanese Processes, Institute of East Asian Studies University of California, Berkeley 1988, s. 40.

${ }^{322} \mathrm{~W}$ liście nie było np. napisane, że rząd ChRL jest ,,jedynym” prawowitym rządem Chin, zaś sformułowanie, iż „Tajwan jest terytorium narodu chińskiego” nie oznaczało tego samego, co „Tajwan jest nierozłączną częścią Chin” i dopuszczało istnienie dwóch państw chińskich. Szerzej na ten temat: Tagawa Seiichi, Nitchū kōryū...., s. 138-139.

${ }^{323}$ Komunikat Szanghajski został podpisany 27 lutego 1972 roku przez prezydenta USA Richarda Nixona i premiera ChRL Zhou Enlaia. Strona amerykańska przyjęła w nim do wiadomości stanowisko ChRL, że są jedne Chiny, a Tajwan jest ich częścią. Zadeklarowała także stopniowe wycofywanie wojsk z Tajwanu. Szerzej na ten temat: Tamura Shigenobu, Tomashima Norio, Koeda Yoshito, op.cit., s. 137-138.

${ }^{324}$ Satō setsuretsuna engi, „Pekin Shūhō” z 7 III 1972, vol. 10, no. 10, s. 21.

${ }^{325}$ Horikoshi Sakuji, op.cit., s. 280.
} 
japońskiego premiera i ministra spraw zagranicznych, jednak nie życzy sobie wizyty ani Kishiego Nobusuke, ani Satō Eisaku ${ }^{326}$.

Podobnie jak brat, Satō podał się do dymisji zaraz po osiągnięciu najważniejszego zadania swojej kadencji. W połowie maja 1972 roku wyspy Riukiu zostały przekazane Japonii spod okupacji amerykańskiej, zaś w następnym miesiącu premier oficjalnie ogłosił koniec swoich długich rządów. Po latach Satō przyznał, że jego pokolenie spłaciło dług wdzięczności wobec Jiang Jieshiego, co dało wolną rękę w formułowaniu polityki wobec Chin przez kolejnych przewodniczących PLD ${ }^{327}$.

$$
* * *
$$

Rządy Satō Eisaku były pod wieloma względami okresem powrotu do linii dyplomatycznej Kishiego Nobusuke. Po kilkuletniej próbie zbliżenia z ChRL, podjętej przez Ikedę Hayato, Satō wrócił do ostrożnej postawy swojego brata, starając się pogłębiać handel z komunistycznymi Chinami tylko na tyle, na ile nie zaszkodziłoby to dobrym stosunkom $\mathrm{z}$ reżimem Guomindangu. W obu „głównych nurtach" Satō, a szczególnie w drugim z nich, dominowali przedstawiciele protajwańskiego skrzydła PLD. Z kolei skrzydło propekińskie, którego działalność z oczywistych względów osłabła w okresie „rewolucji kulturalnej”, zaktywizowało się na początku lat 70 . XX wieku, kiedy było już widać lawinowo rosnące uznanie dla ChRL na arenie międzynarodowej. „Szok Nixona" wymusił zresztą na samym Satō szukanie nowych dróg porozumienia z rządem w Pekinie. Premier, jako przywódca frakcji środka, był najbardziej elastyczny ideologicznie ze wszystkich czołowych polityków PLD. Świadczą o tym próby nawiązania kontaktu ze stroną chińską tuż przed objęciem władzy w 1964 roku, jak i „dyplomacja kaczego pluskania wodą” w 1971 roku. Z drugiej strony, pozostając pod wpływem brata i protajwańskich polityków, na których opierała się jego władza, Satō do samego końca nie mógł wyjść poza ramy „polityki dwóch Chin”. Rozbieżność pomiędzy deklaracjami a czynami premiera sprawiła, że władze w Pekinie straciły do niego zaufanie. Zadanie normalizacji stosunków dyplomatycznych z ChRL miało już być wykonane przez następne pokolenie szefów frakcji w PLD.

\section{PODSUMOWANIE}

W latach 1955-1972 widać wyraźną korelację pomiędzy składem „głównych nurtów" wewnątrz PLD a nastrojem panującym w stosunkach japońsko-chińskich. Im bardziej jednolite ideologicznie były „główne nurty”, tym łatwiej rządowi japońskiemu przychodziło określanie swojego stanowiska wobec Chin.

\footnotetext{
${ }^{326}$ Kawasaki Hideji, Nitchū fukkō-go no sekai. Gekidō no dorama 1 nen kara, Nyū Saiensusha, Tokio 1972, s. 20-21.

${ }^{327}$ Adachi Toshiaki, op.cit., s. 354.
} 
Bardzo ważne dla formułowania polityki w sprawie chińskiej były protajwańskie bądź propekińskie przekonania przewodniczącego partii, jednak równie istotne mogły się okazać poglądy szefów frakcji wspierających premiera, szczególnie jeżeli mieli oni szerokie wpływy w PLD. Wyraźnie widać to na przykładzie pierwszego okresu rządów Ikedy Hayato (1960-1962), kiedy nie mógł on w pełni rozwinąć swoich planów dotyczących współpracy handlowej z ChRL, dopóki nie uniezależnił się od dwóch głównych frakcji protajwańskich. Jednakże również politycy poza ,głównym nurtem” byli w stanie wywierać presję na premiera, szczególnie jeżeli piastowali ważne posady państwowe. Wystarczy przypomnieć przypadek Kishiego Nobusuke jako ministra spraw zagranicznych w rządzie Ishibashiego Tanzana czy Kayi Okinoriego jako ministra sprawiedliwości w rządzie Ikedy Hayato.

Przez zdecydowaną większość omówionego w rozdziale okresu w Japonii rządziła oś Kishi-Satō, bądź to bezpośrednio (kadencja Kishiego w latach 19571960, kadencja Satō w latach 1964-1972), bądź też wywierając wpływ na premiera zza kulis (kadencja Ikedy w latach 1960-1962). Właściwie tylko w krótkim okresie rządów Ishibashiego Tanzana (1956-1957) oraz w drugiej fazie rządów Ikedy Hayato (1962-1964) „oś władzy” była zepchnięta do roli wewnątrzpartyjnej opozycji. Dzięki długotrwałej dominacji dużych protajwańskich frakcji Kishiego i Satō, Japonia w przeciwieństwie do wielu krajów Europy Zachodniej nie nawiązała oficjalnych stosunków dyplomatycznych z ChRL przed 1972 rokiem. Oczywiście równie istotne były tu bliskie stosunki ze Stanami Zjednoczonymi. Zimnowojenna polityka rządu w Waszyngtonie hamowała w szczególności poczynania przywiązanych do „doktryny Yoshidy” frakcji „głównego nurtu konserwatywnego". Z tego powodu zmiana polityki wobec ChRL przez Stany Zjednoczone w 1971 roku nie tylko umocniła propekińskie nastawienie byłej frakcji Ikedy, ale również zapoczątkowała proces ideologicznej przemiany w do tej pory protajwańskiej frakcji Satō. Przemiana ta zwiastowała rozpoczęcie nowego okresu w stosunkach japońsko-chińskich. 


\section{Rozdział III}

\section{SPRAWA CHIŃSKA NA TLE ,WOJNY KAKU-FUKU” (1972-1980)}

Zbliżenie amerykańsko-chińskie ułatwiło dokonanie przełomu w sprawie chińskiej wewnątrz PLD. Rok 1972 przyniósł zmianę pokoleniową w partii i koniec długoletniej dominacji protajwańskiej „osi władzy” Kishi-Satō. Trwający do 1980 roku okres rywalizacji pomiędzy Tanaką Kakueiem a Fukudą Takeo, czyli tzw. „wojna Kaku-Fuku”, miał się charakteryzować wyraźnym zaostrzeniem rywalizacji międzyfrakcyjnej. Ponieważ zaś zmiana pokoleniowa w PLD zbiegła się z ważną ewolucją pozycji ChRL na arenie międzynarodowej, sprawa chińska stała się w latach 70. XX wieku jednym z częściej wykorzystywanych narzędzi walki politycznej w partii.

Ukształtowana w 1972 roku nowa „oś władzy” Tanaka-Ōhira miała wyraźnie propekińskie nastawienie. Polityka wobec ChRL była wręcz jednym z głównych czynników cementujących sojusz pomiędzy Tanaką Kakueiem a Ōhirą Masayoshim. Ponieważ zaś oprócz tych dwóch dużych frakcji „głównego nurtu konserwatywnego" również frakcja Mikiego miała zdecydowanie propekińskie nastawienie, w omawianym okresie politycy dążący do pogłębiania współpracy z Chinami komunistycznymi stanowili już większość w PLD. Głównym ośrodkiem starającym się zakłócać współpracę na linii Tokio-Pekin była frakcja rywalizującego z Tanaką o władzę w partii Fukudy Takeo, jak też mniejsze, ale za to bardziej spójne ideologicznie, frakcje Shiiny Etsusaburō czy Nakagawy Ichirō. Szczególną rolę spełniała grupa polityczna Seirankai, zrzeszająca młodszych parlamentarzystów o skrajnie protajwańskich poglądach. Działalność polityków związanych z reżimem Guomindangu osłabła dopiero po zawarciu Traktatu o pokoju i przyjaźni między Japonią a ChRL w 1978 roku oraz rozpoczęciu przez władze KPCh polityki reform i otwarcia na świat.

\section{Sytuacja międzynarodowa w latach 1972-1980}

W latach 70. XX wieku nastąpiło odprężenie w stosunkach amerykańskochińskich, umożliwione m.in. dzięki zapowiedziom zakończenia wojny wietnamskiej. Prezydent Richard Nixon zdecydował się na wycofanie wojsk z Wietnamu po zawarciu Układów paryskich w styczniu 1973 roku ${ }^{1}$. W połowie

\footnotetext{
${ }^{1}$ Układy paryskie zostały zawarte 27 stycznia 1973 roku pomiędzy rządami USA, Republiki Wietnamu i Demokratycznej Republiki Wietnamu, jak też władzami rewolucyjnymi reprezentującymi komunistów z Wietnamu Południowego. Przewidywały zawieszenie broni w wojnie wietnamskiej, wycofanie wojsk amerykańskich $\mathrm{z}$ Wietnamu oraz utworzenie
} 
lat 70. XX wieku Stany Zjednoczone zmieniły jednak nieco priorytety swojej dyplomacji, kładąc nacisk na odprężenie w relacjach ze Związkiem Radzieckim². W naturalny sposób skutkowało to spowolnieniem tempa rozmów na temat normalizacji stosunków dyplomatycznych z wrogo nastawionymi wobec ZSRR Chinami komunistycznymi. Przełom nastąpił dopiero za rządów prezydenta Jamesa Cartera. W dniu 1 stycznia 1979 roku Stany Zjednoczone ustanowiły oficjalne stosunki dyplomatyczne z ChRL, zrywając je jednocześnie $\mathrm{z}$ Tajwanem. USA i Chiny miały wręcz wzmocnić współpracę przeciw Związkowi Radzieckiemu, który w 1979 roku rozpoczął interwencję zbrojną w Afganistanie ${ }^{3}$.

W omawianym okresie wewnątrz KPCh zaszła przełomowa zmiana władzy, która wywarła wielki wpływ na nastroje panujące w stosunkach chińskojapońskich. Po śmierci Zhou Enlaia i Mao Zedonga w 1976 roku od rządów odsunięto obóz radykalnie lewicowy (tzw. „bandę czworga”), zaś do głosu doszło bardziej umiarkowane środowisko, mniej dogmatycznie podchodzące do idei komunizmu. Od 1978 roku rzeczywistą władzę w partii dzierżył Deng Xiaoping, który zasadniczo zmienił ideologiczny kurs KPCh, nastawiając się na politykę modernizacji kraju, szybkiego wzrostu gospodarczego i stopniowej liberalizacji rynku${ }^{4}$. Stworzyło to również podstawy do pogłębiania chińskojapońskiej wymiany handlowej.

Tymczasem dokonała się także ważna zmiana pokoleniowa na tajwańskiej scenie politycznej. W 1975 roku zmarł prezydent Jiang Jieshi. Realną władzę odziedziczył jego syn, premier Jiang Jingguo, który został nowym przewodniczącym Guomindangu, zaś w 1978 roku także prezydentem kraju ${ }^{5}$. Po utracie mandatu w ONZ w 1971 roku Republika Chińska na Tajwanie była coraz bardziej izolowana na arenie międzynarodowej. W 1972 roku zerwała z nią stosunki dyplomatyczne Japonia, w 1975 roku Filipiny i Tajlandia, zaś w 1979 roku Stany Zjednoczone ${ }^{6}$.

Międzynarodowej Komisji Kontroli, nadzorującej wcielenie ugody w życie. Szerzej na ten temat: Ronald E. Powaski, op.cit., s. 187-194.

2 Symbolami odprężenia na linii Waszyngton-Moskwa był Układ o ograniczeniu zbrojeń strategicznych (SALT I) z 1972 roku, porozumienie z Władywostoku o ograniczeniu liczby strategicznych wyrzutni i bombowców z 1974 roku czy Akt końcowy Konferencji Bezpieczeństwa i Współpracy w Europie z 1975 roku. Szerzej na ten temat: Sadako Ogata, op.cit., s. 56-58.

${ }^{3}$ ZSRR wsparł zbrojnie obóz komunistyczny w Afganistanie, zaś Stany Zjednoczone dostarczały broń bojownikom islamskim. ZSRR wycofał wojska z Afganistanu w 1989 roku. Szerzej na ten temat: Ronald E. Powaski, op.cit., s. 223-267.

${ }^{4}$ Karin Tomala, Procesy reform zmieniaja Chiny [w:] Chiny. Przemiany państwa i społeczeństwa w okresie reform 1978-2000 pod red. Karin Tomali, Wydawnictwo TRIO, Warszawa 2003, s. 11.

${ }^{5}$ Itō Kiyoshi, Taiwan - 400 nen no rekishi to tenbō, Chūō Kōron Shinsha, Tokio 2003, s. 250.

${ }^{6}$ Pod koniec lat 70. XX wieku spośród liczących się państw rząd Guomindangu uznawała już tylko Korea Południowa, Arabia Saudyjska czy RPA. Szerzej na tent temat: Nakamura Katsunori, Huang Zhaotang, Asano Kazuo, Tokuoka Hitoshi, Zoku. Unmei kyōdōtai to shite no Nihon to Taiwan, Waseda Shuppan, Tokio 2005, s. 50-61. 


\section{Sytuacja wewnątrzpartyjna w latach 1972-1980}

W latach 70. XX wieku dynamika rywalizacji międzyfrakcyjnej wewnątrz PLD uległa istotnej ewolucji. Oprócz ukształtowania się nowej „osi władzy” TanakaŌhira zmiany te polegały na nasileniu się walki o władzę, stopniowym zanikaniu małych frakcji oraz zamazaniu linii podziału pomiędzy frakcjami dawnych biurokratów a „ludzi partii”. Ze względu na ostatnią z tych zmian, przy przedstawianiu poszczególnych „głównych nurtów” zaznaczana będzie odtąd tylko opozycja „głównego” i „bocznego nurtu konserwatywnego”, ,jastrzębi” i „gołębi” oraz obozu protajwańskiego i propekińskiego.

Wykres 3.1 Ewolucja systemu frakcyjnego w PLD w latach 1972-1980.

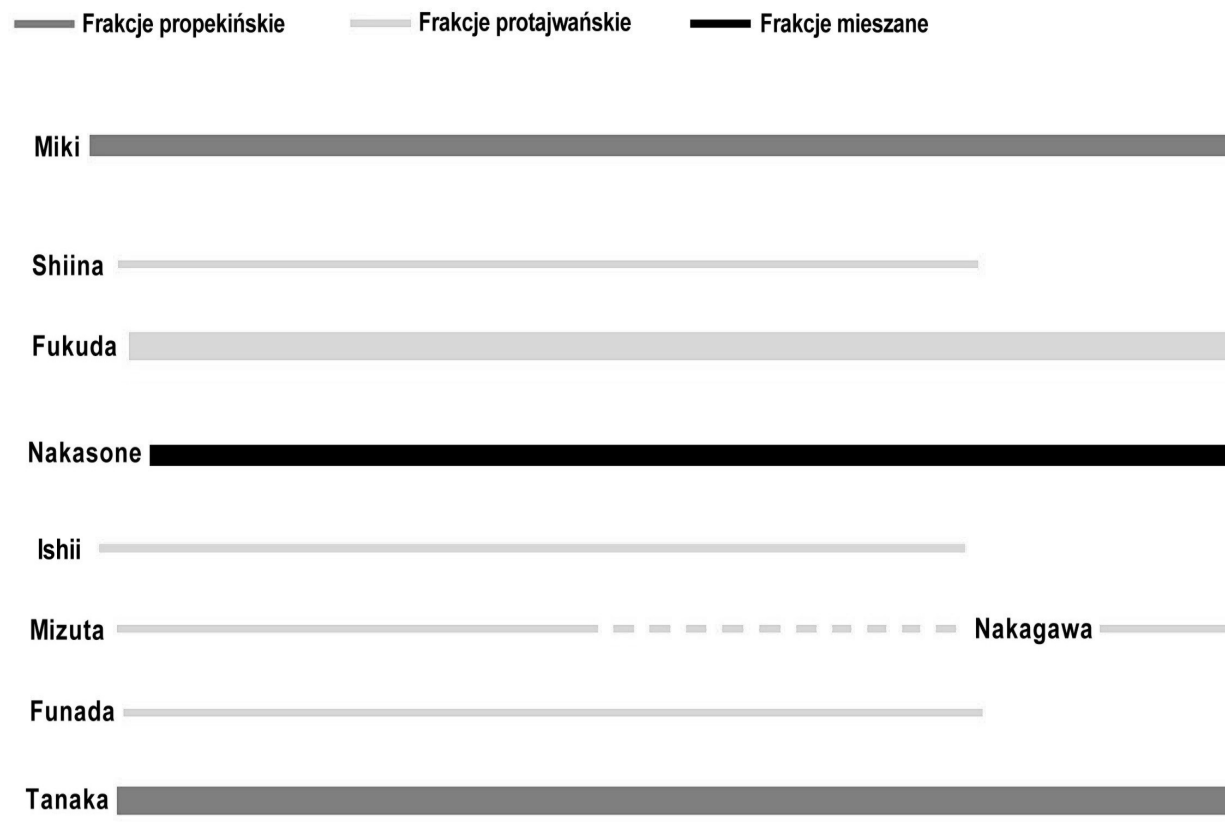

\section{Ōhira}

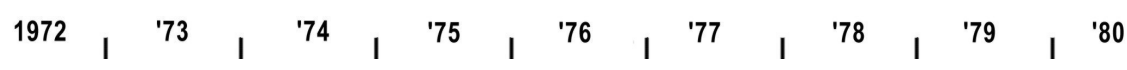

Wielkość frakcji proporcjonalna do grubości kreski. Linia przerywana oznacza frakcję po śmierci lidera.

Opracowanie własne na podstawie m.in.: Iseri Hirofumi, op.cit., s. 11; Tsuchiya Shigeru, op.cit., s. 260; Kitaoka Shin'ichi, op.cit., s. 334-336; Satō Seizaburō, Matsuzaki Tetsuhisa, op.cit., s. 241243; Fukunaga Fumio, Habatsu..., s. 80.

Trwająca w latach 1972-1980 „wojna Kaku-Fuku” (Kaku-Fuku sensō) spowodowała znaczące podniesienie się „temperatury” rywalizacji między- 
frakcyjnej ${ }^{7}$. Co prawda także wcześniej zdarzały się momenty, w których PLD znajdowała się na skraju rozpadu, nigdy jednak walka polityczna pomiędzy dwoma konkurentami nie stała się aż tak wyraźną i długotrwałą determinantą zachowań szefów frakcji. Ze względu na niespotykany dotąd wzrost napięcia pomiędzy dwoma czołowymi liderami frakcji, wszelkie ,zawieszenia broni” w ich rywalizacji miały przejściowy charakter. Można wręcz powiedzieć, że wewnątrz PLD ukształtował się swoisty system bipolarny. W porównaniu z poprzednim okresem, w latach 1972-1980 można zauważyć znacznie więcej sytuacji, w których razem z ,głównym nurtem” formował się wyraźny „przeciwny nurt”, jawnie dążący do obalenia rządu. Praktycznemu zanikowi uległy natomiast frakcje zachowujące neutralność pomiędzy tymi dwoma biegunami rywalizacji o władzę.

W celu polepszenia swojej pozycji w walce wewnątrzpartyjnej, oba obozy „wojny Kaku-Fuku” usilnie zabiegały o rekrutację nowych członków do własnych frakcji. Tanaka Kakuei przejął od Satō Eisaku zwyczaj masowego wcielania do przewodzonej przez siebie grupy także parlamentarzystów z Izby Radców, którzy wcześniej znajdowali się na uboczu rywalizacji międzyfrakcyjnej $^{8}$. Taktyka ta została szybko przyjęta także przez Fukudę Takeo i innych szefów frakcji. Nie wszystkie grupy potrafiły sobie poradzić z wyzwaniami nowej epoki. Najmniejsze frakcje padły ofiarą aktywnie poszerzających swoje wpływy większych grup, w szczególności Tanaki i Fukudy. W ten sposób na miejsce dotychczasowych „ośmiu dywizji” narodził się tzw. „system pięciu dużych frakcji” (go daihabatsu taisei). Tak naprawdę tylko trzy z nich były naprawdę duże. Frakcje Tanaki i Fukudy zrzeszały około osiemdziesięciu parlamentarzystów, zaś Ōhiry ponad sześćdziesięciu. Dwie pozostałe (Nakasone i Mikiego) można nazwać frakcjami średniego rozmiaru, skupiającymi od czterdziestu do pięćdziesięciu członków ${ }^{9}$. Oprócz pięciu dużych frakcji istniało także kilka małych grup, liczących od kilku do kilkunastu parlamentarzystów, jednak ich wpływy stopniowo malały. Mniejsze frakcje były wchłaniane przez większe ośrodki, zaś pod koniec lat 70. XX wieku oprócz „wielkiej piątki” pozostała już tylko frakcja Nakagawy.

\section{TANAKA KAKUEI (1972-1974)}

Rządy Tanaki Kakueia przyniosły nagły przełom w polityce PLD wobec ChRL. Ponieważ Tanaka wygrał rywalizację o fotel premiera z Fukudą Takeo głównie dzięki zręcznemu wykorzystaniu sprawy chińskiej do uzyskania poparcia frakcji propekińskich, normalizacja stosunków dyplomatycznych z ChRL była jednym z priorytetów jego gabinetu. Po szybkim osiągnięciu tego celu i zerwaniu

\footnotetext{
${ }^{7}$ Itagaki Eiken, op.cit., s. 66-67.

${ }^{8}$ Fukunaga Fumio, Habatsu..., s. 79.

${ }^{9}$ Iseri Hirofumi, op.cit., s. 89.
} 
oficjalnych kontaktów z reżimem Jiang Jieshiego, musiał jednak stawić czoła gwałtownej reakcji protajwańskiego skrzydła partii, skupionego wokół Fukudy Takeo. Szczególnie młodzi politycy protajwańscy, zrzeszeni w grupie Seirankai, bezwzględnie protestowali przeciw dalszej degradacji statusu Tajwanu na arenie międzynarodowej. Zarówno normalizacja japońsko-chińskich stosunków dyplomatycznych, jak zawarcie później umowy lotniczej z ChRL, mogły dojść do skutku przede wszystkim dzięki wpływom Tanaki Kakueia i determinacji jego głównego sojusznika w partii, Ōhiry Masayoshiego.

\section{Rywalizacja o sukcesję po premierze Satō}

Do 1972 roku we frakcjach PLD zaszła wyraźna zmiana pokoleniowa. O ile Fukuda Takeo i Nakasone Yasuhiro zostali liderami swoich grup już w latach 60. $\mathrm{XX}$ wieku, na początku lat $70 . \mathrm{XX}$ wieku dołączyli do nich jeszcze dwaj przedstawiciele drugiego pokolenia. W 1971 roku przywództwo w dawnej frakcji Ikedy przejął od Maeo Shigesaburō Ōhira Masayoshi, zaś w 1972 roku podobna zmiana władzy nastąpiła we frakcji Satō, której większość członków pociągnął za sobą Tanaka Kakuei. Okres rywalizacji tej czwórki polityków, razem z należącym jeszcze do pierwszego pokolenia Mikim Takeo, jest nazywany San-Kaku-Dai-Fuku-Chī od wymowy znaków tworzących nazwiska lub imiona szefów pięciu dużych grup ${ }^{10}$.

$\mathrm{Na}$ początku lat 70. XX wieku obie frakcje „osi władzy” Kishi-Satō pozostawały w bardzo bliskich stosunkach po kilkunastu latach nieustannej współpracy. Kiedy długie rządy Satō Eisaku dobiegały końca, premier postanowił razem $\mathrm{z}$ bratem przeforsować $\mathrm{w}$ partii wybór następcy. Zgodnie $\mathrm{z}$ zamysłem Satō i Kishiego kolejnym przewodniczącym PLD i premierem miał zostać minister spraw zagranicznych Fukuda Takeo, lider dawnej frakcji Kishiego. Wobec tego planu narastał jednak wewnątrz frakcji Satō sprzeciw innego wpływowego polityka, Tanaki Kakueia, który widział siebie samego w roli bezpośredniego następcy swojego oyabuna. Jak opisuje w pamiętnikach Fukuda Takeo, tuż po ogłoszeniu rezygnacji ze stanowiska premiera w czerwcu 1972 roku, Satō miał wezwać do siebie obu polityków. Poprosił ich by, skoro mają ze sobą konkurować, obiecali przynajmniej, iż którykolwiek z nich wygrałby pierwszą turę wyborów, drugi całkowicie wesprze go w następnej turze. Według Fukudy obaj zgodzili się na te warunki. ,Jednakże później Tanaka zaczął pracować nad związkiem politycznym z Mikim Takeo i Ōhirą Masayoshim [którzy również kandydowali w wyborach - przyp. aut.]. Znaczyło to jasno, że nawet gdyby zajął drugie miejsce w pierwszej turze, Tanaka dążył do zwycięstwa w ostatecznym głosowaniu dzięki sojuszowi trzech frakcji, co było naruszeniem poprzedniej przysięgi" ${ }^{\prime 1}$.

\footnotetext{
${ }^{10}$ Lata 1972-1980 są z kolei nazywane okresem San-Kaku-Dai-Fuku.

${ }^{11}$ Fukuda Takeo, Watashi no rirekisho [w:] Kishi Nobusuke et al., Watashi no rirekisho. Hoshu seiken no ninaite, Nihon Keizai Shimbun Shuppansha, Tokio 2007, s. 187.
} 
Minister spraw zagranicznych Fukuda nie wiedział jednak, że Tanaka zaczął szukać skutecznej metody zbliżenia do Mikiego i Ōhiry znacznie wcześniej niż w połowie 1972 roku. „Szok Nixona” i przyjęcie ChRL do ONZ w 1971 roku sprawiły, że świat biznesu, jak też japońska opinia publiczna, zaczęły deklarować wsparcie dla procesu normalizacji stosunków dyplomatycznych z rządem w Pekinie ${ }^{12}$. Huang Dahui podkreśla, że chociaż dotychczas kwestie polityki zagranicznej nie odgrywały decydującego znaczenia w wyborach na przewodniczącego PLD, tym razem sytuacja różniła się. Normalizacja stosunków dyplomatycznych z ChRL miała służyć odnowie oblicza partii po prawie ośmioletnich rządach Satō ${ }^{13}$. Wobec tego stało się oczywiste, że zwycięży ten kandydat, który dobrze „rozegra” sprawę chińską. Nawet sam Fukuda Takeo przyznaje: „Pośród krajów ONZ frakcja chińska stopniowo zaczynała stanowić większość, również w Japonii panowały nastroje propekińskie, zaś wewnątrz PLD plusy i minusy normalizacji stosunków dyplomatycznych były rozważane na równi. Myślałem, że także premier Satō dobrze zdawał sobie $\mathrm{z}$ tego sprawę, obserwując nurt historii. W tym okresie opinia publiczna miała wrażenie, że japońska dyplomacja wobec Chin jest opóźniona. Było tak dlatego, że nie kończyła się wewnątrzpartyjna dyskusja, jak też ze względu na troskę o prezydenta Jiang Jieshiego. (...) Prezydent [Jiang Jieshi - przyp. aut.] nieustannie nie szczędził pomocy, aby obecna Japonia nie została podzielona jak Niemcy, zachowała Dwór Cesarski, odbudowała się i rozwinęła. Uważałem za oczywiste, że w okresie, gdy przewodzony przez tego prezydenta Tajwan znalazł się $\mathrm{w}$ bardzo trudnym położeniu w społeczności międzynarodowej, należy podejść do tej sytuacji nie zapominając o długu wdzięczności” ${ }^{14}$. Tanaka Kakuei pozbawiony był podobnych „skrupułów” i szybko zauważył, że sprawa chińska będzie idealnym narzędziem rywalizacji z Fukudą. Należało tylko przedstawiać siebie jako zdecydowanego zwolennika przełomu w relacjach z ChRL, zaś głównego oponenta jako polityka hamującego nieuchronny proces normalizacji stosunków dyplomatycznych z rządem w Pekinie.

Jak podkreśla Hatakeyama Takeshi, Tanaka Kakuei właściwie nie reprezentował żadnej ideologii ${ }^{15}$. W przeciwieństwie do takich polityków, jak Miki Takeo, Fujiyama Aiichirō czy Ōhira Masayoshi, do początku lat 70. XX wieku trudno było go zdecydowanie zaliczyć do skrzydła propekińskiego. Takeshita Noboru mówi wprost o postawie swojego oyabuna wobec Chin:

12 O ile w 1964 roku tylko 10-15 proc. społeczeństwa japońskiego wspierało pomysł natychmiastowego uznania rządu ChRL, w kwietniu 1972 roku było to już blisko 67 proc. Z drugiej strony, zaledwie około 20 proc. społeczeństwa zgadzało się na zerwanie stosunków dyplomatycznych z reżimem Guomindangu. Szerzej na ten temat: Huang Dahui, op.cit., s. 234239.

${ }^{13}$ Ibidem, s. 65.

${ }^{14}$ Fukuda Takeo, Watashi no..., op.cit., s. 184-185.

${ }^{15}$ Hatakeyama Takeshi, op.cit., s. 71. 
„Odczuwam, że po prostu zręcznie wpasował się w nurt historii,"16. Z kolei Iseri Hirofumi podkreśla: „Istnieją wątpliwości, czy Tanaka rzeczywiście wykazywał zapał do problemów tak związanych z ideologią, jak przywrócenie stosunków japońsko-chińskich. W okresie Satō nawet nie wypowiada się na ten temat"17. Jednakże w lipcu 1971 roku, tuż po „szoku Nixona”, będący wówczas sekretarzem generalnym PLD Tanaka powierzył dyrektorowi Wydziału Chin Ministerstwa Spraw Zagranicznych Hashimoto Hiroshiemu zadanie przygotowania raportu, w którym miały być zbadane możliwości nawiązania stosunków dyplomatycznych z ChRL. Widać było, że w przeciwieństwie do swojego frakcyjnego oyabuna Satō Eisaku, Tanaka zaczął się skłaniać ku jednoznacznemu opowiedzeniu się po stronie rządu w Pekinie, nawet kosztem zerwania oficjalnych relacji z Tajwanem. Podkreślał, że o ile dług wdzięczności wobec Jiang Jieshiego jest istotny $\mathrm{w}$ przypadku relacji interpersonalnych, o tyle nie powinien wpływać na działania rządu, determinowane przez interes narodowy ${ }^{18}$. W styczniu 1972 roku Tanaka razem z ministrem sprawiedliwości Maeo Shigesaburō sprzeciwił się nałożeniu sankcji karnych na Fujiyamę Aiichirō, który kilka miesięcy wcześniej podpisał w Pekinie „,cztery zasady przywrócenia stosunków dyplomatycznych" ${ }^{19}$.

Jednocześnie Tanaka Kakuei zaczął dyskretnie dawać do zrozumienia stronie chińskiej, iż to właśnie on, jako przyszły premier, byłby osobą zdolną do dokonania historycznego przełomu w stosunkach japońsko-chińskich. Wykorzystał do tego celu m.in. Fujiyamę Aiichirō, którego zapewnił, że zamierza pojechać do Chin wkrótce po objęciu stanowiska prezesa Rady Ministrów. Kiedy Fujiyama w marcu 1972 roku ponownie odwiedził ChRL, przekazał władzom w Pekinie przesłanie od Tanaki ${ }^{20}$. Strategia ta okazała się skuteczna i od marca 1972 roku władze KPCh nieoficjalnymi kanałami, m.in. podczas spotkań z delegacjami japońskich partii opozycyjnych, zaczęły sugerować, że pokładają wielkie oczekiwania wobec osoby Tanaki ${ }^{21}$.

Chińskie deklaracje ułatwiły Tanace dalsze zacieśnianie więzów z propekińskimi frakcjami ,przeciwnego nurtu”. W nocy 21 kwietnia 1972 roku Tanaka

\footnotetext{
${ }^{16}$ Takeshita Noboru, Seiji to wa nani ka - Takeshita Noboru kaikoroku, Kōdansha, Tokio 2001, s. 260.

${ }^{17}$ Iseri Hirofumi, op.cit., s. 151.

${ }^{18}$ Gerald L. Curtis, The Logic of Japanese Politics. Leaders, Institutions, and the Limits of Change, Columbia University Press, New York 1999, s. 13.

${ }^{19}$ Hayasaka Shigezō, Seijika Tanaka Kakuei, Shūeisha, Tokio 1993, s. 400-402.

${ }^{20}$ Fujiyama wspomina, że przed wyjazdem spotkał się z Tanaką Kakueiem, gdyż dobrze znał propekińską postawę Ōhiry Masayoshiego i Mikiego Takeo, ale chciał wybadać nastawienie Tanaki. Podkreśla także, iż Zhou Enlai był bardzo zainteresowany ówczesną sytuacją wewnątrz PLD. Fujiyama wytłumaczył chińskiemu premierowi, że choć Tanaka pochodzi z frakcji Satō, nie będzie naśladowcą protajwańskiej polityki swojego oyabuna. Szerzej na ten temat: Fujiyama Aiichirō, op.cit., s. 211-215.

${ }^{21}$ Hayasaka Shigezō, Seijika..., s. 402-403.
} 
spotkał się z Ōhirą Masayoshim i innym propekińskim politykiem, Furuiem Yoshimim z byłej frakcji Matsumury, który miał w maju udać się do Chin. Jak zauważa Hayasaka Shigezō, Tanaka zadeklarował wówczas: „Jeżeli zostanę premierem, mianuję Ōhirę ministrem spraw zagranicznych i z całych sił będę się starał o przełom w stosunkach japońsko-chińskich"22. Z kolei w maju 1972 roku, poprzez polityka z opozycyjnej partii Kōmeitō, Ninomiyę Bunzō, Tanaka przekazał odręczny list o podobnej treści samemu Zhou Enlaiowi ${ }^{23}$. Poczuwszy, że ma już w PLD solidną bazę poparcia dla własnej kandydatury, Tanaka zdecydował się na założenie oddzielnej grupy wewnątrzpartyjnej. Na początku maja 1972 roku oficjalnie powołał do życia własną frakcję, do której przeszło 81 parlamentarzystów z frakcji Satō ${ }^{24}$. Z kolei 24 członków grupy Satō pod przywództwem Horiego Shigeru wstąpiło do frakcji Fukudy ${ }^{25}$. W ten sposób „oś władzy" Kishi-Satō uległa zniszczeniu, zaś powstałe na jej miejsce frakcje Fukudy i Tanaki miały ze sobą zaciekle rywalizować przez niemal cały okres swojego istnienia.

Wkrótce też doszło do uformowania nowej ,osi władzy”, która miała dominować wewnątrz PLD przez następnych osiem lat i położyć podwaliny pod propekiński charakter japońskiej dyplomacji. Tym razem głównym spoiwem przymierza frakcji nie były braterskie więzy, jak w przypadku Kishiego Nobusuke i Satō Eisaku, ale dozgonna przyjaźń, jaka łączyła Tanakę Kakueia z Ōhirą Masayoshim. Fukunaga Fumio zwraca uwagę na podobne doświadczenia życiowe obu polityków, które ich zbliżyły do siebie. W przeciwieństwie do pozostałych przywódców frakcji drugiego pokolenia, Tanaka i Ōhira pochodzili ze skrajnie ubogich rodzin i do wszystkiego doszli dzięki własnemu wysiłkowi ${ }^{26}$. Chociaż w latach 60. XX wieku należeli do rywalizujących ze sobą frakcji Satō i Ikedy-Maeo, starali się wzajemnie wspierać. Ōhira zwykł mawiać o Tanace Kakueiu: „Nasze relacje nie są tylko przygodną przyjaźnią. Będą trwały nawet po odejściu ze świata polityki” ${ }^{, 27}$. Również Tanaka wierzył, że Ōhira go nigdy nie zdradzi ${ }^{28}$.

Ōhira Masayoshi już w 1963 roku, jako minister spraw zagranicznych w rządzie Ikedy, jasno zadeklarował: „Gdyby Pekin miał być powitany w ONZ odbierając gratulacje świata, również Japonia powinna podjąć się normalizacji stosunków dyplomatycznych z Pekinem”,29. W 1966 roku powtórzył: „Myślę, że

\footnotetext{
22 Ibidem, s. 403.

${ }^{23}$ Ni Zhimin, Tanaka naikaku... (sono 1), s. 49.

${ }^{24}$ Ibidem, s. 47.

${ }^{25}$ Hori Shigeru, op.cit., s. 139.

${ }^{26}$ Fukunaga Fumio, Ōhira Masayoshi. „Sengo hoshu” to wa nanika, Chūō Kōron Shinsha, Tokio 2008, s. 16.

${ }^{27}$ Ibidem, s. 162.

${ }^{28}$ Satō Akiko, Watashi no Tanaka Kakuei nikki, Shinchōsha, Tokio 1994, s. 35-36.

${ }^{29}$ Ōhira Masayoshi, Ōhira Masayoshi kaisōroku - Shiryōhen, Ōhira Masayoshi Kaisōroku Kankōkai, Tokio 1982, s. 210.
} 
jest pewne, iż jeśli międzynarodowa opinia publiczna zdecydowanie przyzna, że Pekin ma prawo reprezentować Chiny [w ONZ - przyp. aut.], polityka naszego kraju wobec ONZ i Chin stanie przed wielkim punktem zwrotnym, zaś krajowa opinia publiczna stanie się coraz bardziej aktywna" ${ }^{\text {"30 }}$. Z kolei we wrześniu 1971 roku ostatecznie stwierdził: „Sądzę, że sytuacja dojrzała już do rozwiązania tak zwanego problemu chińskiego”,31, zaś w maju 1972 roku dodał: „Mając obowiązek ustanowienia pokoju $\mathrm{w}$ Azji, musimy spieszyć się $\mathrm{z}$ normalizacją stosunków japońsko-chińskich, aby osiągnąć wieczne pojednanie obu narodów"32.

W dniu 2 czerwca 1972 roku doszło do wspólnego zgromadzenia frakcji Tanaki i Ōhiry, na którym postanowiono zawrzeć sojusz przed zbliżającymi się wyborami na przewodniczącego PLD ${ }^{33}$. Rozpoczęta w ten sposób współpraca dwóch grup wywodzących się z nurtu Yoshidy miała przetrwać aż do śmierci Ōhiry w 1980 roku. Sprawa chińska odgrywała kluczową rolę w uformowaniu tej nowej „osi władzy”. Już kilka dni wcześniej, pod koniec maja 1972 roku, w trakcie spotkania z premierem Zhou Enlaiem Furui Yoshimi podkreślił: „Tanaka i Ōhira z pewnością się sprzymierzą. Jeśli tak się stanie, ta armia sojusznicza będzie w przewadze. Wśród tej dwójki Tanaka jest silniejszy. W razie powołania gabinetu Tanaki, Ōhira zostanie ministrem spraw zagranicznych. W przypadku Tanaki i Ōhiry prawdopodobieństwo, że ich sposób myślenia na temat sprawy chińskiej będzie się zgadzał z moim wynosi 90 proc. Gdyby powstał rząd Fukudy, prawdopodobieństwo, że jego sposób myślenia będzie się zgadzał z moim jest bardzo małe, choć nie zerowe. Wynosi przynajmniej 5 proc." 34 Wypowiedź Furuia Yoshimiego wskazuje, jak skutecznie Tanace udało się przekonać do siebie propekińskich polityków ze środowiska zmarłego Matsumury Kenzō.

Po przypieczętowaniu przez Tanakę sojuszu z Ōhirą nadeszła kolej na zdobycie poparcia następnego propekińskiego polityka, Mikiego Takeo. Miki od dawna planował normalizację stosunków dyplomatycznych z ChRL i w latach 60. XX wieku niejednokrotnie rozmawiał na ten temat $\mathrm{z}$ chińskimi dyplomatami przyjeżdżającymi do Japonii. W okresie, gdy był ministrem spraw zagranicznych (1966-1968), Chiny ogarnęła „rewolucja kulturalna” i Miki miał ograniczone możliwości działania, jednak potajemnie spotykał się z naukowcami zajmującymi się problematyką chińską, by wysłuchać ich opinię. Jak wspomina Kunihiro Masao, sekretarz i tłumacz Mikiego, w trakcie rozmowy ze znanym brytyjskim historiozofem Arnoldem Toynbeem Miki miał powiedzieć: „Niezależnie czy takie jest historyczne przeznaczenie, czy nie,

\footnotetext{
${ }^{30}$ Ibidem, s. 184.

${ }^{31}$ Ibidem, s. 210.

${ }^{32}$ Ibidem, s. 219.

${ }^{33}$ Ni Zhimin, Tanaka naikaku... (sono 1), s. 49.

${ }^{34}$ Ibidem.
} 
dziwne, by stosunki japońsko-chińskie pozostawały nieunormowane. Jeśli obejmę władzę, normalizację stosunków japońsko-chińskich postawię na pierwszym miejscu"35. W kwietniu 1972 roku Miki, jako pierwszy z przywódców liczących się frakcji, poleciał do Pekinu, gdzie spotkał się z premierem Zhou Enlaiem. Uzyskał wówczas od niego bardzo ważne zapewnienie, że Chiny zrzekną się reparacji wojennych od Japonii ${ }^{36}$. Jak widać, nawiązanie stosunków dyplomatycznych z ChRL stało się dla Mikiego problemem o kluczowym znaczeniu. Jego wieloletnie starania docenili członkowie dawnej frakcji Ishibashiego Tanzana. We wrześniu 1971 roku tacy propekińscy politycy, jak Ishida Hirohide, Utsunomiya Tokuma czy Yamaguchi Toshio, zdecydowali się wstąpić do frakcji Mikiego. Ishida przyznaje, że uczynili to mając nadzieję, że Miki spełni marzenie Ishibashiego i nawiąże stosunki dyplomatyczne z ChRL ${ }^{37}$.

Wspólne pochodzenie z ,bocznego nurtu konserwatywnego” łączyło jednak Mikiego ze środowiskiem Fukudy Takeo. Ogata Sadako podkreśla: „Pierwotnie Miki myślał o sojuszu z Fukudą, ale kiedy w trakcie swojej podróży do Pekinu wyczuł, że Chiny nie są przygotowane na dokonanie normalizacji z Fukudą, porzucił ten pomysł i zwrócił się ku dwóm pozostałym [kandydatom na przewodniczącego PLD - przyp. aut.]"38. Starczyło, by Tanaka potwierdził wobec Mikiego wolę dokonania przełomu w relacjach z ChRL, aby pozyskać jego wsparcie w decydującym głosowaniu. W dniu 2 lipca 1972 roku Tanaka Kakuei, Ōhira Masayoshi i Miki Takeo zawarli wspólną umowę programową. Stwierdzili w niej m.in.: „Mając na względzie światowy nurt przełamania epoki zimnowojennej, będziemy w duchu pokojowego współistnienia aktywnie starać się o złagodzenie napięcia międzynarodowego. Normalizacja japońskochińskich stosunków dyplomatycznych jest obecnie zgodna z opinią narodu. Poprzez negocjacje międzyrządowe poprowadzimy rozmowy, mając za cel zawarcie traktatu pokojowego z ChRL" ${ }^{, 39}$. Nie wszyscy we frakcji Mikiego byli zadowoleni z sojuszu z Tanaką. Kilkuosobowa grupa Hayakawy Takashiego zdecydowała się zerwać ze swoim oyabunem i wesprzeć Fukudę ${ }^{40}$.

Do umowy Tanaki, Ōhiry i Mikiego wkrótce dołączył także Nakasone Yasuhiro. Nakasone wspomina, że poparł Tanakę, ponieważ uważał go za osobę zdolną do dokonania szybkiego przełomu w relacjach $\mathrm{z}$ Chinami, w przeciwieństwie do Fukudy, utożsamianego z dyplomacją rządu Satō ${ }^{41}$. Satō Eisaku zapisał w swoim dzienniku na początku kwietnia 1972 roku, że Nakasone potajemnie wysłał list do Zhou Enlaia, jednak prawdopodobnie nie

\footnotetext{
${ }^{35}$ Kunihiro Masao, op.cit., s. 130-131.

${ }^{36}$ Ibidem, s. 134.

${ }^{37}$ Ishida Hirohide, op.cit., s. 133-134.

${ }^{38}$ Sadako Ogata, op.cit., s. 46.

${ }^{39}$ Tamura Shigenobu, Tomashima Norio, Koeda Yoshito, op.cit., s. 145.

${ }^{40}$ Tominomori Eiji, op.cit., s. 263-264.

${ }^{41}$ Nakasone Yasuhiro, Watashi no rirekisho [w:] Kishi Nobusuke et al., op.cit., s. 550-551.
} 
doczekał się odpowiedzi ${ }^{42}$. Jak podkreśla Tagawa Seiichi, Nakasone Yasuhiro był jednym z „uczniów” głównego promotora pozarządowego handlu z ChRL, Matsumury Kenzō. Często radził się Matsumury, zaś Matsumura pokładał w nim duże nadzieje jako w przyszłym przywódcy PLD. W czasie ostatniej przed śmiercią wizyty w ChRL w 1970 roku Matsumura bronił będącego wówczas dyrektorem Agencji Obrony Nakasone przed krytyką ze strony Zhou Enlaia ${ }^{43}$. Z kolei Nakasone Yasuhiro przyznaje, że po „szoku Nixona” pobudziła go do działania niezłomna wola doprowadzenia do normalizacji stosunków dyplomatycznych z Chinami, okazana przez znajdującego się na łożu śmierci Matsumurę Kenzō ${ }^{44}$. Jak widać, chociaż Nakasone zaliczał się do obozu ,jastrzębi”, podobnie jak Kōno Ichirō znajdował się pod silnym wpływem idei Matsumury. W ten sposób Tanaka mógł liczyć na wsparcie aż czterech frakcji spośród „wielkiej piątki” i niemal zupełne osamotnienie Fukudy.

Do 1972 roku dokonały się również przemiany wewnątrz mniejszych frakcji PLD. W 1970 roku zmarł Kawashima Shōjirō, zaś przywództwo nad jego grupą przejął protajwańsko nastawiony Shiina Etsusaburō. W 1971 roku Murakami Isamu, próbując doprowadzić do zjednoczenia byłej frakcji Ōno, przekazał stanowisko przewodniczącego swojej grupy Mizucie Mikio, który opuścił frakcję Funady ${ }^{45}$. Do frakcji Mizuty przeszła również część członków frakcji Fujiyamy. Co prawda także sam Fujiyama Aiichirō miał przyłączyć się do frakcji Mizuty, jednak odstręczyła go postawa młodych protajwańskich posłów z tej grupy z Nakagawą Ichirō na czele. Ostatecznie przy Fujiyamie pozostał tylko jeden poseł i jego frakcja praktycznie przestała istnieć ${ }^{46}$. Z kolei po śmierci Matsumury Kenzō w 1971 roku podobny los czekał także jego frakcję. Lider innej małej grupy, Mori Kiyoshi, zmarł w 1968 roku. W 1970 roku przywództwo nad jego frakcją przejął Sonoda Sunao, który w 1972 roku zdecydował się poprzeć Fukudę. Mori Yoshirō przypuszcza, że Sonoda Sunao, chociaż był politykiem propekińskim, nie mógł głosować w wyborach na szefa partii na Tanakę Kakueia, gdyż nie chciał być w jednym obozie z frakcją Nakasone. Grupy Sonody i Nakasone wszakże zaciekle rywalizowały ze sobą, gdyż wywodziły się z tej samej frakcji Kōno. Zaraz po wyborach grupa Sonody połączyła się z frakcją Fukudy ${ }^{47}$. Z kolei członkowie grupy Ishiiego postanowili

\footnotetext{
${ }^{42}$ Satō Eisaku, op.cit., t. 5, Tokio 1997, s. 79.

${ }^{43}$ Tagawa Seiichi, Matsumura Kenzō..., s. 129-131.

${ }^{44}$ Nakasone Yasuhiro, Jiseiroku - Rekishi hōtei no hikoku to shite, Shinchōsha, Tokio 2004, s. 54.

${ }^{45}$ Hatakeyama Takeshi, op.cit., s. 95.

${ }^{46}$ Sam Fujiyama wycofał się z polityki w 1976 roku, utrzymując tylko stanowisko prezesa Japońskiego Stowarzyszenia Promocji Handlu Międzynarodowego, które przejął po Ishibashim Tanzanie. Szerzej na ten temat: Fujiyama Aiichirō, op.cit., s. 240-262.

${ }^{47}$ Mori Yoshirō. Jimintō to seiken kōtai pod red. Iokibe Makoto, Itō Motoshige, Yakushijiego Katsuyukiego, Asahi Shinbunsha, Tokio 2007, s. 56-57.
} 
nie zmieniać lidera, mimo że sam Ishii Mitsujirō przeszedł na emeryturę w 1972 roku $^{48}$.

Tabela 3.1 Rozkład sił pomiędzy frakcjami PLD w okresie rządów Tanaki Kakueia w latach 1972-1974.

\begin{tabular}{|l|l|l|}
\hline \multicolumn{2}{|c|}{ Frakcje: } \\
\hline ,głównego nurtu” & poza ,głównym nurtem” & ,przeciwnego nurtu” \\
\hline Tanaka (L, P) 88 & - & Fukuda (D, J, T) 91 \\
Ōhira (L, G, P) 65 & & Ishii (L, T) 14 \\
Miki (D, G, P) 47 & \\
Nakasone (D, J) 44 & & \\
Shiina (D, J, T) 22 & & \\
Mizuta (J, T) 15 & & \\
Funada (L, J, T) 13 & - & 105 \\
\hline 294 & & \\
L: 3 (166), D: 3 (113), & \\
G: 2 (112), J: 4 (94), & \\
P: 3 (200), T: 3 (50). & & \\
\hline
\end{tabular}

L- dawni członkowie Partii Liberalnej, główny nurt konserwatywny, D- dawni członkowie Japońskiej Partii Demokratycznej, boczny nurt konserwatywny, G- gołębie, J- jastrzębie, P- obóz propekiński, T- obóz protajwański.

Liczebność frakcji (podana przy poszczególnych frakcjach) po wyborach do Izby Reprezentantów z grudnia 1972 roku. Uwzględniono członków frakcji z obu izb parlamentu. W podsumowaniu „głównego nurtu” podana jest ogólna liczba należących do niego parlamentarzystów oraz liczba frakcji, zaś w nawiasie liczba parlamentarzystów, należących do poszczególnych obozów.

Opracowanie własne na podstawie: Fukunaga Fumio, Habatsu..., s. 80, Eguchi Nobuyuki, Habatsu saihensei to nyūrīdā, Kyōikusha, Tokio 1985, s. 67; Kitaoka Shin'ichi, op.cit., s. 335.

Do wyborów na przewodniczącego PLD doszło na początku lipca 1972 roku. Dzięki wsparciu niekandydującego Nakasone, Tanaka Kakuei zajął pierwsze miejsce z przewagą zaledwie sześciu głosów nad Fukudą Takeo. W drugiej turze Ōhira Masayoshi i Miki Takeo dotrzymali umowy, głosując na Tanakę. Większość małych frakcji dołączyło do obozu najbardziej prawdopodobnego zwycięzcy. Dzięki temu Tanaka wyraźnie wygrał z Fukudą stosunkiem głosów 282 do 190 , zostając pierwszym przewodniczącym PLD i premierem z drugiego pokolenia szefów frakcji ${ }^{49}$. Zgodnie z obietnicą, ministrem spraw zagranicznych został Ōhira. Również Miki i Nakasone otrzymali ważne stanowiska w gabinecie, zaś członkowie frakcji Fukudy odmówili wstąpienia do rządu ${ }^{50}$, sygnalizując powstanie wyraźnego ,przeciwnego nurtu” wewnątrz partii ${ }^{51}$.

„Główny nurt” Tanaki skupiał podobną ilość członków dawnej Partii Liberalnej i Japońskiej Partii Demokratycznej. Chociaż należały do niego aż

\footnotetext{
${ }^{48}$ Ishii Mitsujirō, op.cit., s. 457.

${ }^{49}$ Tsuchiya Shigeru, op.cit., s. 203-205.

${ }^{50}$ Tamura Shigenobu, Tomashima Norio, Koeda Yoshito, op.cit., s. 149.

${ }^{51}$ Fukuda Takeo został ministrem finansów dopiero w listopadzie 1973 roku.
} 
cztery frakcje ,jastrzębi”, były one znacznie mniejszymi grupami od frakcji „gołębi”, więc panowała pod tym względem równowaga. Jako że najważniejszym czynnikiem, który doprowadził do sojuszu Tanaki z Ōhirą, Mikim i Nakasone były wspólne poglądy na temat konieczności normalizacji oficjalnych stosunków dyplomatycznych z ChRL, nowa wewnątrzpartyjna koalicja miała wyraźnie propekiński charakter. Protajwańskie frakcje Shiiny, Mizuty i Funady skupiały małą liczbę członków i tak naprawdę w „głównym nurcie” dominowały trzy duże grupy propekińskie (200 parlamentarystów z frakcji propekińskich wobec zaledwie $50 \mathrm{z}$ grup protajwańskich). Zresztą pozyskanie przez Tanakę Shiiny Etsusaburō miało służyć jedynie uspokojeniu rządu w Tajpej i nie mogło zmienić polityki nowego gabinetu.

Chociaż najważniejszą przyczyną wsparcia przez Tanakę idei nawiązania stosunków dyplomatycznych z ChRL była chęć uzyskania władzy, można także wskazać inne pobudki, którymi się kierował. Jako członkowi „głównego nurtu konserwatywnego" bliskie mu były poglądy Yoshidy Shigeru i Ikedy Hayato. Pamiętał także o tym, że jednym z niespełnionych marzeń Yoshidy było oficjalne uznanie rządu w Pekinie ${ }^{52}$. Tanaka przyznaje, że kiedy w 1956 roku doszło do rozłamu frakcji Yoshidy, rozmyślał o wstąpieniu do grupy Ikedy, ale ostatecznie wybrał frakcję Satō. Niemniej jednak do samego końca utrzymywał dobre relacje z Ikedą, z którym był zresztą spowinowacony poprzez zięcia ${ }^{53}$. Jak widać, relacje interpersonalne od dawna wiązały Tanakę z obozem propekińskim. Były one dodatkowo wzmacniane przyjacielskimi relacjami pomiędzy Tanaką a Ōhirą. Ponieważ zaś Tanaka miał reputację „człowieka czynu”, gdy objął urząd premiera można się było spodziewać szybkiego przełomu w stosunkach japońsko-chińskich. Nowy szef rządu wspomina: „Gdy przejąłem od Satō stanowisko premiera, byłem przekonany, że należy natychmiast dokonać normalizacji japońsko-chińskich stosunków dyplomatycznych. Mam taki styl postępowania, że gdy tylko podejmę decyzję, od razu przechodzę do jej wykonania. Determinacja i realizacja. Jednakże wówczas sprawa ta budziła pewne kontrowersje i nie było jeszcze decyzji partyjnej. Poza tym wielu ludzi sądziło, że nie ma specjalnej konieczności szybkiego wiązania się z Chinami. Ja jednak twierdziłem, iż dla pokoju na Dalekim Wschodzie Japonia i Chiny muszą nawiązać stosunki wzajemne. Nie ustąpiłem ani kroku w moim postanowieniu"s4.

\section{Normalizacja stosunków dyplomatycznych z ChRL}

Ponieważ umiejętne wykorzystanie sprawy chińskiej było jedną z głównych przyczyn zwycięstwa Tanaki, aby utrzymać solidarność „głównego nurtu” premier musiał spełnić obietnice złożone frakcjom propekińskim. Od samego

\footnotetext{
${ }^{52}$ Gotō Motoo, Uchida Kenzō, Ishikawa Masumi, op.cit., t. 2, s. 161.

${ }^{53}$ Hayasaka Shigezō, Hayasaka Shigezō no „Tanaka Kakuei” kaisōroku, Shōgakukan, Tokio 1987, s. 70-74.

${ }^{54}$ Ibidem, s. 221.
} 
początku normalizacja stosunków dyplomatycznych z ChRL stała się priorytetem polityki zagranicznej nowego rządu ${ }^{55}$. Tuż po wyborze na przewodniczącego PLD Tanaka Kakuei powiedział na konferencji prasowej: „Patrząc z punktu widzenia dwutysiącletniej historii, trwające ćwierć wieku powojenne stosunki japońsko-chińskie są jedynie krótką chwilą. Będę szczerze pracował nad normalizacją, aby nie doszło znowu do sporów. Do tej pory jednostronnie sprawiamy Chinom problemy. Jednakże sytuacja dojrzała już do normalizacji”, ${ }^{, 56}$. Dalej idące deklaracje złożył 7 lipca 1972 roku minister spraw zagranicznych Ōhira: „Co do podejścia do traktatu japońsko-tajwańskiego, jest nie do pomyślenia, aby mógł on obowiązywać w sytuacji, gdy dopełniona zostanie normalizacja stosunków japońsko-chińskich" ${ }^{57}$. Wypowiedź ta pokazuje, że nowy gabinet zamierzał zerwać ze skazaną na niepowodzenie promocją polityki „dwóch Chin”, prowadzoną przez rząd Satō. Władze w Tokio szybko rozpoczęły też nieoficjalne negocjacje ze stroną chińską na temat warunków normalizacji stosunków dyplomatycznych ${ }^{58}$.

Nowa „oś władzy” wywodziła się z „głównego nurtu konserwatywnego”, więc kładła nacisk również na uzgodnienie swojego stanowiska ze Stanami Zjednoczonymi. Oparcie się na USA w sprawach bezpieczeństwa było wszakże jedną z podstaw „doktryny Yoshidy”. Na przełomie sierpnia i września 1972 roku Tanaka Kakuei spotkał się na Hawajach z prezydentem Richardem Nixonem i przyrzekł mu kontynuację traktatu sojuszniczego po normalizacji japońsko-chińskich stosunków dyplomatycznych. Ōhira Masayoshi wspomina: „Martwiłem się, czy strona chińska zgodzi się na rozpoczęcie rozmów o normalizacji stosunków dyplomatycznych, gdy Traktat o wzajemnej współpracy i bezpieczeństwie pomiędzy Japonią a USA będzie kontynuowany. Chodzi o to, że do tej pory strona chińska poddawała bezwzględnej krytyce japońskoamerykański system sojuszniczy. Po szczycie japońsko-amerykańskim z uwagą śledziłem zachowanie strony chińskiej. Jednakże strona chińska nie zareagowała

\footnotetext{
${ }^{55}$ Nie oznacza to jednak, by Tanaka nie krył obaw związanych z normalizacją stosunków dyplomatycznych z ChRL. Japońska opinia publiczna sprzyjała normalizacji, ale skłaniała się ku polityce „dwóch Chin”. Premier wiedział, że niepowodzenie w negocjacjach z władzami w Pekinie będzie oznaczać koniec jego gabinetu. Dopiero pod wpływem perswazji Ōhiry Masayoshiego podjął decyzję o ,postawieniu wszystkiego na jedną kartę” i jak najszybszym przekonaniu PLD do swojej wizyty w Pekinie. Szerzej na ten temat: Ni Zhimin, Tanaka naikaku ni okeru nitchū kokkō seijōka to Ōhira Masayoshi, sono 2, „Ryūkoku Daigaku Keizaigaku Ronshū” 2007, vol. 46, no. 5, s. 49; Akio Watanabe, Japanese Public Opinion and Foreign Affairs: 1964 1973 [w:] The Foreign Policy of Modern Japan pod red. Roberta A. Scalapino, University of California Press, Berkeley 1977, s. 124-131.

${ }^{56}$ Hayasaka Shigezō, Seijika..., s. 406.

${ }^{57}$ Tamura Shigenobu, Tomashima Norio, Koeda Yoshito, op.cit., s. 149.

${ }^{58}$ Podstawą rozmów stała się tzw. „nota Takeiriego”. Przewodniczący ugrupowania Kōmeitō Takeiri Yoshikatsu odwiedził ChRL na przełomie lipca i sierpnia 1972 roku i spotkał się z Zhou Enlaiem. Stanowisko strony chińskiej przekazał ministrowi Ōhirze. Szerzej na ten temat: ibidem, s. 154-155; Hayasaka Shigezō, Seijika..., s. 411-412.
} 
w szczególny sposób na wspólne oświadczenie, wydane po szczycie japońskoamerykańskim. Pomyślałem wówczas, że skoro strona chińska nie protestuje przeciwko Traktatowi o wzajemnej współpracy i bezpieczeństwie pomiędzy Japonią a USA, który jest podstawą systemu San Francisco, należy rozwiązać tak długo odkładany na później problem normalizacji japońsko-chińskich stosunków dyplomatycznych" "59.

Ze względu jednak na silne stronnictwo protajwańskie w PLD, zerwanie oficjalnych kontaktów z reżimem Jiang Jieshiego nadal było niezwykle trudnym zadaniem. Jak podkreśla Hayasaka Shigezō, prowadzona przez długie lata rządów osi Kishi-Satō dyplomacja zimnowojenna wpłynęła nawet na mentalność urzędników w Ministerstwie Spraw Zagranicznych. Ministrowi Ōhirze trudno było przekonać do aktywnej współpracy protajwańsko usposobione osoby w resorcie zarządzanym dotąd przez Fukudę Takeo ${ }^{60}$. Aby nie dopuścić do rozpadu partii, Tanaka musiał podjąć szereg działań, które uśmierzyłyby niezadowolenie polityków blisko związanych z reżimem Guomindangu. Jednym z nich była zamiana w połowie lipca 1972 roku dotychczasowej wewnątrzpartyjnej Komisji Badań Spraw Chińskich (Chūgoku Mondai Chōsakai) w szerszą platformę wymiany opinii, Konferencję ds. Normalizacji Stosunków Japońsko-Chińskich (Nitchū Kokkō Seijōka Kyōgikai). Brało w niej udział aż 249 spośród 431 ówczesnych parlamentarzystów z PLD ${ }^{61}$. Dzięki temu premier stworzył organ bezpośrednio mu podległy, omijając jurysdykcję Rady Badań Politycznych i Rady Generalnej PLD ${ }^{62}$.

W dniu 24 lipca 1972 roku Tanaka Kakuei podkreślił na Konferencji: „Aby normalizacja japońsko-chińskich stosunków dyplomatycznych zakończyła się sukcesem, potrzebny jest konsensus i silne wsparcie ze strony sprawującej władzę PLD. Ja i minister spraw zagranicznych Ōhira Masayoshi, pozostając w bliskim kontakcie z przewodniczącym Kosaką, pragniemy rozwinąć szczegółowe środki japońsko-chińskich negocjacji międzyrządowych. Co do mojej wizyty w Chinach, pragnę by decyzję podjęła owa Konferencja. Proszę o uważną analizę jako rząd i koalicja" ${ }^{63}$. Również przewodniczący Konferencji, były minister spraw zagranicznych Kosaka Zentarō z frakcji Ōhiry, wyraził nadzieję, że „normalizacja stosunków dyplomatycznych nie będzie etapem sporu, tylko osiągnięcia konsensusu" ${ }^{\circ 4}$.

Wbrew oczekiwaniom Tanaki i Kosaki, dwumiesięczne obrady Konferencji stały się areną werbalnych ataków na politykę rządu przez skrzydło protajwańskie. Szczególnie aktywnie linię dyplomatyczną nowego gabinetu

\footnotetext{
${ }^{59}$ Ōhira Masayoshi, Watashi no rirekisho, Nihon Keizai Shinbunsha, Tokio 1978, s. 123-124.

${ }^{60}$ Hayasaka Shigezō, Seijika..., s. 408-409.

${ }^{61}$ Ibidem, s. 415.

${ }^{62}$ Zhao Quansheng, op.cit., s. 99.

${ }^{63}$ Hayasaka Shigezō, Seijika..., s. 416.

${ }^{64}$ Tamura Shigenobu, Tomashima Norio, Koeda Yoshito, op.cit., s. 158.
} 
krytykowali tacy ,jastrzębie” jak Kaya Okinori, Nakagawa Ichirō czy Watanabe Michio. Głównym punktem spornym stało się podejście do zawartego w 1952 roku traktatu pokojowego z reżimem Guomindangu. Skrzydło protajwańskie chciało utrzymania go w mocy obowiązującej nawet po ewentualnej normalizacji stosunków dyplomatycznych z ChRL, bezwzględnie sprzeciwiając się zerwaniu oficjalnych kontaktów z rządem w Tajpej. Gwałtowny sprzeciw wzbudziło nawet nazwanie przez ministra Ōhirę traktatu z 1952 roku ,japońskotajwańskim" (nittai) zamiast ,japońsko-chińskim” (nikka) ${ }^{65}$. Z kolei 3 sierpnia 1972 roku Kaya Okinori powiedział, odnosząc się do deklaracji ministra spraw zagranicznych Japonii: „Sprawa Tajwanu jest bardzo poważnym problemem, nie powinno się lekkomyślnie wyciągać wniosków o «zerwaniu stosunków dyplomatycznych»" ${ }^{66}$. Politycy protajwańscy podkreślali, iż w przypadku zakończenia oficjalnych kontaktów Tajwan z pewnością podejmie środki odwetowe, oraz że należy dochować wierności sojusznikowi, a nie zupełnie ulegać żądaniom władz w Pekinie ${ }^{67}$. Atmosfera dyskusji stopniowo stawała się coraz bardziej napięta. Posłowie protajwańscy nazywali przewodniczącego Kosakę oszustem, a nawet rzucali z gniewu popielniczkami i butelkami z sokiem $^{68}$.

Chociaż obrady Konferencji przebiegały gwałtownie i nic nie wskazywało na możliwość osiągnięcia konsensusu, 5 września 1972 roku ostatecznie udało się uchwalić Podstawowe zasady normalizacji stosunków japońsko-chińskich (Nitchū kokkō seijōka kihon hōshin). Jak napisał Hayasaka Shigezō: „złagodzenie stanowiska młodych jastrzębi w całości wynikało z nieoficjalnej osobistej perswazji Tanaki" ${ }^{69}$. Premier rzeczywiście cały czas starał się osłabić opór prawego skrzydła PLD poprzez zakulisowe rozmowy ${ }^{70}$. Co ciekawe, duża część młodych członków obozu protajwańskiego, np. Nakagawa Ichirō z frakcji Mizuty, wsparła Tanakę w wyborach na przewodniczącego PLD. Premierowi udało się złagodzić ich opór i przekonać do ugodowości. Dzięki temu również starsi reprezentanci obozu protajwańskiego, jak Kaya Okinori, musieli przyjąć

\footnotetext{
${ }^{65}$ Hayasaka Shigezō, Seijika..., s. 418.

${ }^{66}$ Tamura Shigenobu, Tomashima Norio, Koeda Yoshito, op.cit., s. 159.

${ }^{67}$ Ibidem, s. 160.

${ }^{68}$ Ibidem, s. 160-161; Karol Żakowski, 1972 nen nitchū kokkō seijōka o meguru Jimintō-nai tairitsu [w:] Civilisation of Evolution, Civilisation of Revolution: Metamorphoses in Japan 19002000 pod red. A. Jabłońskiego, S. Meyera, K. Mority, Manggha Museum of Japanese Art \& Technology, Kraków 2009, s. 499.

${ }^{69}$ Hayasaka Shigezō, Seijika..., s. 419.

70 Jeszcze w lipcu 1972 roku Tanaka nawiązał kontakt ze Stowarzyszeniem Problemów Dyplomatycznych (Gaikō Mondai Kondankai), grupą polityczną założoną przez Kishiego Nobusuke, Kayę Okinoriego, Ishiiego Mitsujirō i Nadao Hirokichiego. Próbował także nakłonić do swojego zdania inne prawicowe stowarzyszenia w PLD. Szerzej na ten temat: Huang Dahui, op.cit., s. 74-75.
} 
bardziej kompromisową postawę ${ }^{71}$. W tekście Podstawowych zasad znalazło się sformułowanie: „Przy okazji rozmów w sprawie normalizacji stosunków japońsko-chińskich rząd naszego kraju powinien mieć na względzie następujące punkty. Wobec bliskich stosunków naszego kraju z Republiką Chińską, prowadząc negocjacje należy w szczególności zwrócić dostateczną uwagę na kontynuację dotychczasowych stosunków" ${ }^{72}$. Podstawowe zasady zostały przyjęte w tym kształcie jako decyzja partyjna przez Radę Generalną pod przewodnictwem Suzukiego Zenkō z frakcji Ōhiry ${ }^{73}$. Termin „dotychczasowe stosunki” (jürai no kankei) był później inaczej interpretowany przez różne obozy w PLD. O ile stronnictwo protajwańskie twierdziło, że obejmują one również stosunki dyplomatyczne, dla zwolenników normalizacji sformułowanie to oznaczało tylko konieczność utrzymania nieoficjalnych kontaktów. Niejasność tego terminu umożliwiła rządowi częściowe wyciszenie sporu wewnątrzpartyjnego. Dzięki temu 14 września 1972 roku delegacja pod przewodnictwem Kosaki Zentarō mogła udać się do ChRL, aby w rozmowie z Zhou Enlaiem uzgodnić szczegóły rychłej wizyty premiera Tanaki.

Tymczasem Tanaka Kakuei musiał podjąć jeszcze jedno działanie, mające uspokoić nastroje wewnątrzpartyjne. $\mathrm{Na}$ wieść o możliwości zerwania oficjalnych stosunków dyplomatycznych, reżim Guomindangu nasilił antyjapońską kampanię, grożąc przerwaniem kontaktów gospodarczych, a nawet przywróceniem stanu wojny, wysłaniem wojska na sporne z Japonią bezludne wyspy Senkaku/Diaoyutai ${ }^{74}$ i możliwością blokady Cieśniny Tajwańskiej dla

${ }^{71}$ Liu Deyou, Toki wa..., t. 2., s. 504; Ni Zhimin, Tanaka naikaku ni okeru nitchū kokkō seijōka to Ōhira Masayoshi, sono 3, „Ryūkoku Daigaku Keizaigaku Ronshū” 2007, vol. 47, no. 3, s. 66-67.

${ }^{72}$ Podstawowe zasady normalizacji stosunków japońsko-chińskich to: 1) dokonanie normalizacji w oparciu o Kartę Narodów Zjednoczonych i 10 zasad z Bandungu; 2) szacunek dla różnic systemowych i nieinterwencja w politykę wewnętrzną; 3) powstrzymanie się od stosowania siły zbrojnej lub groźby jej użycia; 4) zwiększenie równorzędnej wymiany gospodarczej i kulturowej; 5) współpraca na rzecz pokoju i dobrobytu w Azji. Szerzej na ten temat: Tamura Shigenobu, Tomashima Norio, Koeda Yoshito, op.cit., s. 161-162; Hayasaka Shigezō, Seijika..., s. 419-420.

${ }^{73}$ Lin Jinjing, op.cit., s. 280-281.

${ }^{74}$ Japonia inkorporowała wyspy Senkaku/Diaoyutai do prefektury Okinawa w 1895 roku jako terra nullius (ziemię niczyją). Przez następne 50 lat archipelag był bezsprzecznym terytorium japońskim, zaś w latach 1945-1972 podlegał administracji amerykańskiej. Zarówno Republika Chińska na Tajwanie, jak ChRL zgłosiły pretensje do archipelagu dopiero na początku lat 70 . XX wieku, podając dowody historyczne na to, że Chińczycy od wieków wykorzystywali wyspy Senkaku/Diaoyutai jako punkty nawigacyjne, element linii obrony wybrzeża czy obszar rybacki. Bezpośrednią przyczyną zgłoszenia roszczeń było wykrycie dużych złóż ropy naftowej i gazu ziemnego pod dnem Morza Wschodniochińskiego pod koniec lat 60. XX wieku. Szerzej na ten temat: Jan Rowiński, Problem wysp Senkaku (Tiaoyi Liedao) w stosunkach chińsko-japońskich, PISM (wydane na prawach rękopisu), Warszawa 1982, s. 6-28; Unryu Suganuma, Sovereign Rights and Territorial Space in Sino-Japanese Relations. Irredentism and the Diaoyu/Senkaku Islands, Association for Asian Studies, University of Hawai'i Press, Honolulu 2000, s. 42-151; Harada Nobuo, Senkaku shotō - Sappō Ryūkyū Shiroku o yomu, Yōju Shorin, Ginowan 2006, s. 5121; Kinjō Hiroyuki, Senkaku kaitei shigen wa Okinawa no zaisan, Bōdāinku, Naha 2005, s. 4-18. 
japońskich statków ${ }^{75}$. Aby załagodzić tę napiętą atmosferę oraz uśmierzyć głos niezadowolenia w partii, Tanaka Kakuei mianował wiceprzewodniczącym PLD bliskiego współpracownika Kishiego Nobusuke, Shiinę Etsusaburō, by wysłać go z delikatną misją na Tajwan. Shiina był zdania, że nie należy się spieszyć z normalizacją stosunków dyplomatycznych z ChRL i trzeba najpierw zapewnić utrzymanie oficjalnych relacji $z$ reżimem Guomindangu ${ }^{76}$. Na polecenie premiera miał jednak przekazać władzom w Tajpej informację o planach uznania rządu ChRL oraz wyrazić chęć kontynuacji bliżej niesprecyzowanych „dotychczasowych stosunków” z Republiką Chińską.

Wiceprzewodniczący PLD odwiedził Tajwan w dniach 17-19 września 1972 roku, czyli równolegle z nadal trwającymi rozmowami Kosaki Zentarō z Zhou Enlaiem. W Tajpej spotkał się z bardzo chłodnym przyjęciem ze strony władz Guomindangu i antyjapońskimi demonstracjami ludności. Tanaka nie powiedział wprost Shiinie, jakie słowa ma przekazać stronie tajwańskiej, jednak powierzył mu notkę, w której było jasno napisane: „Po wyrażeniu prezydentowi Jiang Jieshiemu podziękowania za głęboką wyrozumiałość i troskę wobec Japonii po przegranej wojnie, chcę być zrozumiany, że skoro zarówno rząd Republiki Chińskiej, jak rząd pekiński trwają przy stanowisku, iż istnieją jedne Chiny, w przypadku normalizacji stosunków japońsko-chińskich, japońskotajwańskie relacje dyplomatyczne niestety nie będą mogły być utrzymane"77. Shiina Etsusaburō miał tylko wyrazić chęć kontynuowania nieoficjalnych kontaktów gospodarczych i kulturowych, ale w trakcie spotkania z sekretarzem Jiang Jieshiego, Zhang Qunem, posunął się znacznie dalej $w$ swoich oświadczeniach. Powtórzywszy wolę zachowania „dotychczasowych stosunków” z Podstawowych zasad, wytłumaczył również, iż chodzi o „utrzymanie wszystkich dotychczasowych stosunków, razem z kontaktami dyplomatycznymi" ${ }^{78}$. Chociaż Shiina nie był w stanie uzyskać aprobaty reżimu Guomindangu dla polityki gabinetu Tanaki, jego misja przyczyniła się do w miarę spokojnej reakcji władz w Tajpej na porozumienie między rządem w Tokio i Pekinie. Sam Shiina jednak czuł się później oszukany, twierdząc, że przed wyjazdem na Tajwan ani Tanaka, ani Ōhira nie powiedzieli mu jasno, jaką wiadomość ma przekazać reżimowi Guomindangu ${ }^{79}$.

Mimo energicznych zabiegów Tanaka nie potrafił uspokoić wszystkich członków stronnictwa protajwańskiego. Tuż przed wyjazdem premiera do Pekinu zwolennicy reżimu Guomindangu nasilili wręcz kampanię przeciw propekińskiemu gabinetowi. Kishi Nobusuke, Shiina Etsusaburō czy Fukuda Takeo podkreślali, że posunięcie to jest przedwczesne. Jednocześnie główni

\footnotetext{
${ }^{75}$ Tamura Shigenobu, Tomashima Norio, Koeda Yoshito, op.cit., s. 36.

${ }^{76}$ Okazaki Hisahiko, Taiwan mondai wa Nihon mondai, Kairyūsha, Tokio 2008, s. 61-62.

${ }^{77}$ Tamura Shigenobu, Tomashima Norio, Koeda Yoshito, op.cit., s. 55.

${ }^{78}$ Ibidem, s. 167.

${ }^{79}$ Honda Yoshihiko, op.cit., s. 112-119; Ni Zhimin, Tanaka naikaku... (sono 3), s. 58-59.
} 
promotorzy zbliżenia z ChRL stali się celem ataków skrajnych nacjonalistów z tzw. „grup prawicowych” (uyoku dantai). W centrum Tokio pojawiły się furgonetki $\mathrm{z}$ megafonami, dzień $\mathrm{w}$ dzień kontynuujące krytykę rządu. Rozwieszono również plakaty z napisem: „Zdrajca kraju, Tanaka Kakuei”, zaś do domu ministra Ōhiry wrzucano listy z pogróżkami ${ }^{80}$. Ważnym problemem pozostawała także kwestia ewentualnego złożenia Chinom przeprosin za japońskie zbrodnie z czasów II wojny światowej. Ponieważ władze w Tokio nie uczyniły takiego gestu nawet w traktacie pokojowym z Republiką Chińską na Tajwanie w 1952 roku, ,jastrzębie” z PLD tym bardziej sprzeciwiali się przepraszaniu Chin komunistycznych. Jeszcze w lipcu 1972 roku tacy prawicowi politycy, jak Kishi Nobusuke, Kaya Okinori, Ishii Mitsujirō, Nadao Hirokichi, Nakagawa Ichirō czy Tamaki Kazuo ostrzegli we wspólnym oświadczeniu, iż należy podejść do tej sprawy z wielką ostrożnością ${ }^{81}$.

Tanaka i Ōhira byli jednak zdecydowani jak najszybciej doprowadzić do końca proces normalizacji stosunków z ChRL i 25 września 1972 roku udali się w tym celu do Pekinu. Tuż przed wyjazdem Tanaka Kakuei odwiedził groby trzech propekińskich premierów: Yoshidy Shigeru, Hatoyamy Ichirō i Ikedy Hayato. Złożył też wizytę u ciężko chorego Ishibashiego Tanzana ${ }^{82}$. W ten sposób oddał hołd swoim poprzednikom, którzy pomimo chęci dokonania przełomu w relacjach z ChRL nie mogli tego uczynić z powodu niesprzyjającej sytuacji międzynarodowej. Tanaka odwiedził również swojego dawnego oyabuna, Satō Eisaku ${ }^{83}$. Także Ōhira Masayoshi przed wyjazdem poczynił niezbędne przygotowania. Jak wspomina zięć i sekretarz ministra spraw zagranicznych, Morita Hajime, Ōhira do samego końca liczył się z możliwością zamachu na swoje życie przez skrajnie prawicowe bojówki ${ }^{84}$. Przed wyjazdem spisał testament i powiedział swoim najbliższym współpracownikom, iż w razie porażki rozmów prawdopodobnie nie będzie mógł wrócić do kraju ${ }^{85}$.

Obawy Ōhiry nie sprawdziły się. Po kilkudniowych negocjacjach ze stroną chińską ${ }^{86}$ premierzy Tanaka Kakuei i Zhou Enlai podpisali 29 września 1972

\footnotetext{
${ }^{80}$ Tamura Shigenobu, Tomashima Norio, Koeda Yoshito, op.cit., s. 168-169.

${ }^{81}$ Okada Minoru, Nitchū kankei to ODA - tai-Chū ODA o meguru seiji gaikōshi nyūmon, Nihon Kyōhōsha, Tokio 2008, s. 60-61.

${ }^{82}$ Syn Ishibashiego Tanzana wspomina, że ojciec nie mógł powstrzymać łez wzruszenia, gdy otrzymał telegram z życzeniami od Zhou Enlaia. Na łożu śmierci z radością oglądał telewizyjną transmisję wizyty Tanaki w ChRL. Szerzej na ten temat: Liu Deyou, Toki wa..., t. 2., s. 544.

${ }^{83}$ Satō Akiko, op.cit., s. 105.

${ }^{84}$ Morita Hajime, Arai Shunzō, Bunjin saishō Ōhira Masayoshi, Shunjūsha, Tokio 1982, s. 186.

${ }^{85}$ Wang Zude, Daping Zhengfang yu Zhong-Ri youhao guanxi, „Jiangxi Shifan Daxue Xuebao” 1996, vol. 29 no. 4, s, 73

${ }^{86} \mathrm{~W}$ trakcie negocjacji pojawiło się kilka punktów spornych. Strona japońska nie chciała się zgodzić na uznanie, że traktat z Tajwanem z 1952 roku nie posiada mocy prawnej, a tylko, że wygaśnie. Wobec tego utrzymywała, iż nie można „zakończyć stanu wojny” z ChRL, ani Chiny nie mogą zrzec się prawa do odszkodowań, gdyż stało się to już w 1952 roku. Z kolei strona chińska zabiegała o bardziej bezpośrednie przeprosiny za inwazję na Chiny z czasów II wojny
} 
roku Wspólną deklarację pomiędzy rządem Japonii a rządem ChRL. Zgodnie ze słowami Ōhiry: „Obie strony odrzuciły drobne różnice i skupiły się na wspólnym celu. Różnice zdań albo zostały zapisane paralelnie jako różnice, albo też, stosując wyrażenia Janusowe (bóg bramy z rzymskich mitów - miał jedno ciało, ale dwie twarze), udało się jakoś przezwyciężyć trudne problemy i wypracowaliśmy historyczną wspólną deklarację japońsko-chińską" ${ }^{87}$. We Wspólnej deklaracji zadecydowano o ustanowieniu oficjalnych stosunków dyplomatycznych i wymianie ambasadorów. Stwierdzono także: „Strona japońska w pełni zdaje sobie sprawę ze swojej odpowiedzialności i głęboko żałuje, iż Japonia przysporzyła w przeszłości poprzez wojnę poważnych szkód narodowi chińskiemu" 88 . W trakcie negocjacji premier Tanaka, obawiając się reakcji prawego skrzydła PLD, próbował przeforsować łagodniejszą wersję przeprosin, mówiąc o ,przysporzeniu kłopotów” Chinom w czasie wojny, jednak spotkało się to $\mathrm{z}$ wyraźnym sprzeciwem władz w Pekinie. Słowa „głęboko żałuje” w ostatniej chwili dopisał ołówkiem do tekstu deklaracji Ōhira Masayoshi, biorąc na siebie olbrzymie ryzyko stania się obiektem krytyki ze strony ,jastrzębi" ${ }^{89}$. Z kolei strona chińska zadeklarowała rezygnację z prawa do odszkodowań wojennych. W kwestii Tajwanu władze w Tokio przyznały, że „rząd ChRL jest jedynym prawowitym rządem Chin”, oraz że „dostatecznie rozumieją i szanują stanowisko Chińskiej Republiki Ludowej”, iż „Tajwan jest nieodłączną częścią terytorium ChRL"90.

Władze w Tajpej natychmiast zareagowały na normalizację stosunków japońsko-chińskich zrywając kontakty dyplomatyczne $\mathrm{z}$ rządem w Tokio. Zresztą już 29 września 1972 roku Ōhira Masayoshi oświadczył na konferencji prasowej: „Poza tym, chociaż nie zostało to poruszone we Wspólnej deklaracji, mogę potwierdzić, że w wyniku normalizacji stosunków japońsko-chińskich traktat pokojowy z Republiką Chińską wygasł straciwszy rację bytu. Takie jest stanowisko rządu japońskiego" ${ }^{91}$. Nieoficjalne stosunki japońsko-tajwańskie zostały jednak utrzymane. Na miejsce ambasady Japonii w Tajpej powołano Stowarzyszenie Wymiany (jap. Kōryū Kyōkai, chiń. Jiaoliu Xiehui), zaś reżim Guomindangu miało reprezentować w Japonii Stowarzyszenie Stosunków Wschodnioazjatyckich (chiń. Yadong Guanxi Xiehui, jap. Tōa Kankei Kyōkai) ${ }^{92}$. W ten sposób zakończył się dwudziestoletni okres oficjalnych stosunków dyplomatycznych pomiędzy władzami w Tokio i Tajpej, a rozpoczęła się era

światowej. Szerzej na ten temat: Hayasaka Shigezō, Seijika..., s. 422-439; Tamura Shigenobu, Tomashima Norio, Koeda Yoshito, op.cit., s. 168-176, Sadako Ogata, op.cit., s. 52-55.

${ }^{87}$ Ōhira Masayoshi, Watashi no..., s. 125.

${ }^{88}$ Nihonkoku seifu to Chūka Jinmin Kyōwakoku seifu no kyōdō seimei z 29 IX 1972 [w:] Nitchū kankei kihon..., s. 428-429.

${ }^{89}$ Okada Minoru, op.cit., s. 19-63.

${ }^{90}$ Ibidem.

${ }^{91}$ Tamura Shigenobu, Tomashima Norio, Koeda Yoshito, op.cit., s 179.

${ }^{92}$ Ibidem, s. 77. 
relacji pozarządowych. W kontaktach z Tajwanem Japonia miała zastosować tę samą zasadę, jaką wcześniej posługiwała się wobec ChRL, czyli rozdzielenie gospodarki od polityki ${ }^{93}$.

\section{Utworzenie Seirankai}

Normalizacja stosunków z ChRL spotkała się ze zdecydowaną krytyką ze strony japońskich środowisk nacjonalistycznych ${ }^{94}$ oraz pobudziła do aktywniejszej działalności stronnictwo protajwańskie w PLD. Oskarżało ono Tanakę Kakueia o niedotrzymanie postanowień z 5 września 1972 roku, pogwałcenie decyzji partii i zerwanie „dotychczasowych stosunków” z reżimem Guomindangu ${ }^{95}$. Tacy wpływowi politycy, jak Kishi Nobusuke, Funada Naka czy Ishii Mitsujirō nie kryli oburzenia niesłownością Tanaki i Ōhiry ${ }^{96}$. Z kolei młodsi posłowie obozu protajwańskiego, Watanabe Michio i Hamada Kōichi, nazywali oświadczenie Ōhiry o zerwaniu stosunków dyplomatycznych z reżimem Guomindangu ,pogwałceniem konstytucji”. Według nich decyzja o abrogacji traktatu z Tajwanem mogła być podjęta tylko za zgodą parlamentu. Ōhira Masayoshi wyjaśniał, że takie działania, jak ustanowienie ambasad czy wymiana ambasadorów, należą do prerogatyw rządu i nie wymagają zatwierdzenia przez władzę ustawodawczą ${ }^{97}$.

Po wydaniu Wspólnej deklaracji pozostał jednak problem podpisania szeregu ważnych umów japońsko-chińskich dotyczących handlu, rybołówstwa czy komunikacji lotniczej. Dzięki temu skrzydło protajwańskie miało możliwości blokowania lub choćby opóźniania dalszego zacieśniania relacji z rządem w Pekinie. W połowie marca 1973 roku powstał Parlamentarny Związek Stosunków Japońsko-Tajwańskich (Nikka Kankei Giin Kondankai, w skrócie Nikkakon) na czele z Nadao Hirokichim z frakcji Ishiiego, zrzeszający 152 członków obu izb parlamentu. Stał się on alternatywą dla Parlamentarnej Ligi Przyjaźni Japońsko-Chińskiej (Nitchū Yūkō Giin Renmei) pod przewodnictwem Fujiyamy Aiichirō, liczącej 144 parlamentarzystów z PLD ${ }^{98}$.

\footnotetext{
${ }^{93}$ Podobnie jak wcześniej reprezentanci ChRL, teraz nieoficjalni przedstawiciele Tajwanu musieli corocznie opuszczać Japonię i występować o nową wizę, by uniknąć obowiązku zostawiania odcisków palców. Szerzej na ten temat: Lin Jinjing, op.cit., s. 360.

${ }^{94}$ Suzaki Shin'ichi, Sengo Nihon no hoshu shisō to uyokuteki nashonarizumu [w:] Sengo Nihonjin no ishiki kōzō pod red. Suzakiego Shin'ichiego, Azusa Shuppansha, Matsudo 2007, s. 47.

${ }^{95}$ Tamaki Kazuo Kirokushū Hensan Iinkai, Seitō seijika Tamaki Kazuo, Gakushū Kenkyūsha, Tokio 1988, s. 101-102.

${ }^{96}$ Ishii Mitsujirō, op.cit., s. 453-455.

${ }^{97}$ Lin Jinjing, op.cit., s. 322-323.

${ }^{98}$ Hong N. Kim, The Tanaka Government and the Politics of the Sino-Japanese Civil Aviation Pact, 1972-1974, „World Affairs” 1975, Vol. 137, no. 4, s. 289.
} 
W lipcu 1973 roku w ramach partii powstała także radykalna antykomunistyczna grupa polityczna Seirankai (Stowarzyszenie Błękitnej Burzy) ${ }^{99}$. Zapisało się do niej 31 parlamentarzystów: 10 z frakcji Fukudy, 9 z frakcji Nakasone, 4 z frakcji Shiiny, 3 z frakcji Mizuty, 1 z frakcji Mikiego i 4 bezfrakcyjnych. Seirankai zrzeszało głównie młodych członków partii, którzy jednak posiadali stabilną bazę poparcia wśród elektoratu w konserwatywnych wiejskich okręgach, dzięki czemu nie musieli obawiać się głoszenia radykalnych poglądów ${ }^{100}$. Kilku z członków grupy miało później odegrać ważne role w japońskiej polityce. Byli to zwłaszcza przyszli przewodniczący frakcji: Watanabe Michio, Mitsuzuka Hiroshi, Yamasaki Taku, Etō Takami, Nakagawa Ichirō i Ishihara Shintarō, a także przyszły premier Mori Yoshirō czy przyszły przewodniczący Rady Badań Politycznych PLD i minister edukacji, Fujio Masayuki.

Działacze Seirankai zyskali na rozgłosie własną krwią z opuszków palców przypieczętowując ,"pakt krwi” (keppan) ${ }^{101}$. Przywódca grupy, Nakagawa Ichirō, argumentował to następująco: „Czuliśmy wyraźnie odpowiedzialność obrony wolnej Japonii i była potrzeba gotowości na pakt krwi. Wierząc, że rozumie to wielu mających serce Japończyków, my z Seirankai jesteśmy gotowi walczyć stawiając czoło licznym trudom"102. Nakagawa należał do frakcji Mizuty i był dawnym sekretarzem protajwańskiego polityka Ōno Banboku ${ }^{103}$. Przyczynę powstania grupy tłumaczył następująco: „Impulsem do założenia Seirankai było poczucie zawodu wobec Tanaki Kakueia. Wśród członków Seirankai niemal wszyscy prócz frakcji Fukudy w wyborach na przewodniczącego w 1972 roku zagłosowali na Tanakę. (...) Także ja oddałem głos na Tanakę, na kolanach przepraszając Fukudę, który dla mnie tyle zrobił. Naród był już zmęczony długą biurokratyczną polityką Satō Eisaku, a my również dusiliśmy się i pragnęliśmy odmiany sytuacji. (...) Kiedy jednak Tanaka został premierem, zmienił się. Przywrócił stosunki dyplomatyczne z komunistycznymi Chinami, odrzucając Jiang Jieshiego, dobroczyńcę pokonanej Japonii, który w przeciwieństwie do

\footnotetext{
${ }^{99}$ Nazwa grupy została wymyślona przez Ishiharę Shintarō, który przed wejściem do świata polityki był też sławnym powieściopisarzem. Miała oznaczać czyste niebo po gwałtownej letniej burzy, symbolizujące żywiołowość nowego ruchu. Szerzej na ten temat: Shioda Michio, Inochi moyuru seijika Tamaki Kazuo, Gurafusha, Tokio 1988, s. 163.

${ }^{100}$ Kawachi Takashi, Chi no seiji - Seirankai to iu monogatari, Shinchōsha, Tokio 2009, s. 37-40.

${ }^{101}$ Na pomysł paktu krwi wpadł Ishihara Shintarō. Tylko jeden poseł z Saitamy uciekł ze strachu przed ceremonią. Jak opisuje Shioda Michio, później okazało się, że politycy, którzy wylali mniej krwi, szybciej stracili zapał do działalności w Seirankai. Szerzej na ten temat: Shioda Michio, op.cit., s. 164-165.

${ }^{102}$ Nakagawa Ichirō, Makoto no „taisei-nai kakushin” to wa nanika [w:] Nakagawa Ichirō, Ishihara Shintarō et al., Seirankai - Keppan to yūkoku no ronri, Rōman, Tokio 1973, s. 191.

${ }^{103}$ Watanabe Tsuneo kaikoroku pod red. Itō Takashiego, Mikuriyi Takashiego, Iio Juna, Chūō Kōron Shinsha, Tokio 2000, s. 313.
} 
Związku Radzieckiego nie internował nikogo [z japońskich żołnierzy - przyp. aut.]"104.

Jako ponadfrakcyjna grupa polityczna, Seirankai posiadało jasno określony program. Wśród celów stowarzyszenia zawierała się „ochrona wolnego społeczeństwa”, prowadzenie dyplomacji „w bliskich kontaktach z państwami liberalnymi”, reforma edukacji czy ,ustanowienie wolnej, niezależnej konstytucji" ${ }^{105}$. Podstawy polityki zagranicznej według Seirankai sformułował Fujio Masayuki: „Dyplomacja naszego kraju musi być prowadzona zgodnie z linią zachowania bezpieczeństwa, chroniąc naród japoński przed zagrożeniami ze strony wszystkich znajdujących się w Azji krajów komunistycznych, jak KRL-D, ZSRR, ChRL, które posiadają zdolności bezpośredniego lub pośredniego ataku fizycznego. (...) Chociaż postępuje rozluźnienie napięcia w stosunkach amerykańsko-sowieckich i amerykańsko-chińskich, nadal kryje się za nim podstawowa rywalizacja między Wschodem a Zachodem. ZSRR i ChRL, dwa potężne państwa nuklearne, które zupełnie różnią się od naszego kraju ideologią i systemem społecznym, ciągle są źródłem zagrożenia dla naszego państwa. (...) Sam rząd wysoko ocenia ustanowienie stosunków dyplomatycznych z ChRL we wrześniu zeszłego roku, jednak zerwawszy kontakty z Republiką Chińską, która tak długo nie szczędziła pomocy w odbudowie i rozwoju naszego kraju, poważnie naruszył solidarność państw wolnego świata. Należy podkreślić, że z punktu widzenia naszego bezpieczeństwa straciliśmy bardzo dużo, a zyskaliśmy niewiele $\mathrm{i}$ był to krok niezgodny z podstawowymi założeniami dyplomacji naszego państwa. Wobec tego przy następnych japońsko-chińskich umowach biznesowych należy uważać, by jeszcze bardziej nie naruszyć obecnie istniejących politycznych, gospodarczych i kulturalnych stosunków między naszym krajem a rządem Republiki Chińskiej"106.

Wspólna krytyka propekińskiej polityki premiera Tanaki była głównym impulsem do utworzenia Seirankai. Tamaki Kazuo ${ }^{107}$ porównywał radość z normalizacji stosunków dyplomatycznych z ChRL do wiwatów na cześć zawarcia przez Japonię sojuszu z Hitlerem i Mussolinim w latach 30. XX wieku, po „nielojalnym” zerwaniu przyjacielskich relacji z Wielką Brytanią ${ }^{108}$. Inny z członków Seirankai, Abe Kigen z frakcji Nakasone, porównywał propekińskich

\footnotetext{
${ }^{104}$ Kawachi Takashi, op.cit., s. 46.

${ }^{105}$ Nakagawa Ichirō, Ishihara Shintarō et al., op.cit, s. 195-196.

${ }^{106}$ Ibidem, s. 197-202.

${ }^{107}$ Tamaki Kazuo został wybrany do Izby Radców dzięki wsparciu sekty Seichō no Ie, dlatego musiał podporządkować się jej wskazaniom. Przywódca sekty, Taniguchi Masaharu, był orędownikiem przywrócenia konstytucji Meiji i gorącym zwolennikiem reżimu Guomindangu. W sierpniu 1972 roku Tamaki zawiózł na Tajwan list od Taniguchiego do Jiang Jieshiego. Spotkał się wówczas m.in. z Jiang Jingguo, któremu obiecał „zachowanie etyki” i obronę interesów Tajwanu w Japonii. Szerzej na ten temat: Tamaki Kazuo Kirokushū Hensan Iinkai, op.cit., s. 91-92.

${ }^{108}$ Tamaki Kazuo, Seirankai no shōrai to Nihon [w:] Nakagawa Ichirō, Ishihara Shintarō et al., op.cit., s. 176-177.
} 
posłów z PLD do „gejsz bez cnoty” i „,kobiet z kabaretu”109. Z kolei Nakao Eiichi z frakcji Nakasone przyznawał, że nie uważał za coś złego ustanowienia stosunków z ChRL, ale nie mógł się zgodzić na porzucenie Tajwanu, ,jedynego przyjaciela w sąsiedztwie”. Japońską politykę zagraniczną nazywał dyplomacją „ekonomicznego zwierzęcia” (ekonomikku animaru), które w wyniku szybkiego wzrostu gospodarczego zapomniało o swoim „sercu”, skupiając się jedynie na korzyściach materialnych. Postulował przywrócenie w partii moralności i oblicza ideologicznego, którym w chwili powstania PLD był antykomunizm ${ }^{110}$.

Jak widać, Seirankai zrzeszało polityków o wyraźnie nacjonalistycznych przekonaniach, którzy deklarowali gotowość wcielania swoich idei w życie niezależnie od zmieniającej się sytuacji międzynarodowej. Grupę tę nazywano także „oddziałem do zadań specjalnych frakcji Fukudy” (Fukuda-ha betsudotai) ${ }^{111}$. Wielu członków Seirankai było blisko związanych z Fukudą, ale działając w osobnej organizacji nie narażało swojego oyabuna na bezpośrednią krytykę z powodu agresywnych metod rywalizacji politycznej.

\section{Opór obozu protajwańskiego wobec umowy lotniczej z ChRL}

Prawe skrzydło PLD zaciekle broniło interesów reżimu Guomindangu przy rozpoczętych w listopadzie 1972 roku negocjacjach w sprawie japońskochińskiej umowy lotniczej. Rządowi Tanaki zależało na jej szybkim podpisaniu, gdyż strona chińska dawała do zrozumienia, że bez postępów w negocjacjach umowy lotniczej nie będzie także zawarta niezwykle ważna dla japońskiej gospodarki umowa handlowa. Podkreślając politykę ,jednych Chin”, ChRL nie chciała się zgodzić zwłaszcza na korzystanie z tych samych lotnisk przez przewoźników z Chin kontynentalnych i Tajwanu, ani na używanie przez tajwańskie samoloty emblematów Republiki Chińskiej. Tymczasem konflikt w PLD narastał, uniemożliwiając premierowi Tanace przystanie na żądania ChRL. Kishi Nobusuke, Nadao Hirokichi czy Fukuda Takeo zdecydowanie protestowali przeciwko jakimkolwiek ustępstwom na rzecz rządu w Pekinie, które mogłyby pogłębić degradację międzynarodowego statusu Tajwanu. Jesienią 1973 roku 69 parlamentarzystów z PLD pojechało na Tajwan, by przeprosić za zerwanie stosunków dyplomatycznych i przysiąc wsparcie protestów reżimu Jiang Jieshiego wobec umowy lotniczej z ChRL ${ }^{112}$. Równolegle członkowie Seirankai prowadzili bardzo intensywną działalność antyrządową. Na posiedzeniach parlamentu otwarcie krytykowali premiera Tanakę.

\footnotetext{
${ }^{109}$ Abe Kigen, Jinzai yōsei wa kokka no kyūmu, shuppatsuten [w:] Minato Tetsurō et al., Seirankai kara no chokugen, Rōman, Tokio 1974, s. 161.

${ }^{110}$ Nakao Eiichi, Seirankai wa kaku tatakau [w:] Nakagawa Ichirō, Ishihara Shintarō et al., op.cit., s. 24-39.

${ }^{111}$ Tamaki Kazuo Kirokushū Hensan Iinkai, op.cit., s. 150.

${ }^{112}$ Hong N. Kim, op.cit., s. 287-290.
} 
Na początku stycznia 1974 roku do ChRL udał się minister spraw zagranicznych Ōhira Masayoshi, gdzie podpisał bilateralną umowę handlową. Po intensywnych negocjacjach udało mu się także nakłonić rząd w Pekinie do złagodzenia stanowiska w sprawie umowy lotniczej. Strona chińska zgodziła się, by utrzymać loty między Japonią a Tajwanem, jeśli tylko firmę JAL zastąpi oddzielne przedsiębiorstwo, zaś emblematy na samolotach z Republiki Chińskiej, do których doda się napis „Tajwan” w nawiasie, będą traktowane jako „oznaczenia prywatne”, a nie znaki państwowe. Ponieważ jednak nadal miano usunąć samoloty tajwańskie z lotnisk używanych przez przewoźników z ChRL, nawet ten kompromis spotkał się $\mathrm{z}$ ostrą opozycją ze strony działaczy protajwańskich. Po powrocie do Japonii Ōhira Masayoshi sporządził z pomocą Ministerstwa Transportu sześciopunktowe wytyczne na temat umowy, oparte na rozmowach ze stroną chińską ${ }^{113}$. Miały one stać się przedmiotem dyskusji w odpowiednich komisjach i sekcjach Rady Badań Politycznych PLD.

Na posiedzeniu Komisji Badań Spraw Zagranicznych PLD w połowie stycznia 1974 roku starły się obozy polityków promujących umowę oraz próbujących powstrzymać jej podpisanie. Fujio Masayuki z frakcji Fukudy przekazał protest Jiang Jingguo podkreślając, że zmiany w emblematach na samolotach Republiki Chińskiej sugerowałyby, że Tajwan jest tylko prowincją ChRL. Stronnictwo protajwańskie zwracało także uwagę na fakt, że Tajwan zajmuje drugie miejsce po Stanach Zjednoczonych jako partner handlowy Japonii i nie wolno lekceważyć jego stanowiska. Innego zdania był m.in. Kōno Yōhei z frakcji Nakasone, który twierdził, że zawarcie umowy lotniczej jest obowiązkiem Japonii, zapisanym we Wspólnej deklaracji z 1972 roku, wobec czego należy jak najszybciej doprowadzić rozmowy do końca ${ }^{114}$.

Z kolei na posiedzeniu Seirankai 18 stycznia 1974 roku członkowie tej grupy zadecydowali, że rozpoczną działania w celu złożenia wotum nieufności wobec ministra spraw zagranicznych Ōhiry Masayoshiego. Równocześnie podobną intencję wyrazili politycy z Parlamentarnego Związku Stosunków JapońskoTajwańskich ${ }^{115}$. Na dodatek na corocznym Konwencie PLD, który odbył się następnego dnia, Nakao Eiichi nie zawahał się przed ostrą publiczną krytyką rządu Tanaki m.in. z powodu planów zawarcia umowy lotniczej z ChRL. Było to niezmiernie rzadkie wydarzenie, gdyż dotychczas na Konwentach skupiano

113 Wytyczne Ōhiry przewidywały: 1) utrzymanie dotychczasowych połączeń lotniczych z Tajwanem na poziomie pozarządowym w chwili podpisania umowy z ChRL; 2) odsunięcie od połączeń z Tajwanem japońskiej firmy JAL; 3) utrzymanie emblematów China Air Lines (CAL), ale przy dodaniu wyrazu „Tajwan” w nawiasie; 4) udostępnienie lotniska Narita liniom z ChRL, zaś starego lotniska tokijskiego Haneda liniom z Tajwanu; 5) przeniesienie lotów między Tajwanem a lotniskiem w Osace do innego portu lotniczego; 6) przeniesienie służby naziemnej CAL w Japonii do firmy zastępczej. Szerzej na ten temat: Tamaki Kazuo Kirokushū Hensan Iinkai, op.cit., s. 118-119.

114 Ōare no Jimin gōdō kaigi - Seirankai nado Taiwan o yōgo, „Asahi Shinbun” z 17 I 1974, s. 2.

${ }^{115}$ Gaishō fushinnin no kamae - Jimintō shintaiha to Seirankai, „Asahi Shinbun” z 19 I 1974, s. 2. 
się na ceremoniach, odkładając na bok wewnątrzpartyjne spory ${ }^{116}$. Pod koniec stycznia 1974 roku członkowie Seirankai zorganizowali w Tokio „wiec narodowy" (kokumin shūkai) z udziałem 25 tys. uczestników. Wzywali na nim do rewizji konstytucji, reformy edukacji w duchu narodowym i zakończenia „uległej” dyplomacji gabinetu Tanaki. Ishihara Shintarō jawnie zadeklarował, że celem ugrupowania jest doprowadzenie do upadku rządu ${ }^{117}$.

Napięcie sięgnęło szczytu na początku lutego 1974 roku. Na sesjach Rady Generalnej PLD, na których rozpatrywano sprawę umowy lotniczej z ChRL, doszło do zaciekłych kłótni. Chociaż spośród działaczy Seirankai członkami Rady byli tylko Fujio Masayuki i Tamaki Kazuo, dziesięciu następnych przyszło na obrady jako obserwatorzy ${ }^{118}$. Szczególnie słynący z wybuchowości Hamada Kōichi bronił stanowiska Seirankai, przewracając stoły oraz rozrzucając popielniczki i szklanki ${ }^{119}$. Z powodu tak napiętej atmosfery osiągnięcie jakiegokolwiek kompromisu przez wszystkich członków Rady Generalnej okazało się niemożliwe. Przygotowanie uchwały powierzono czterem najwyższym urzędnikom (tō yon-yaku) PLD, którymi byli: wiceprzewodniczący Shiina Etsusaburō, sekretarz generalny Hashimoto Tomisaburō z frakcji Tanaki, przewodniczący Rady Generalnej Suzuki Zenkō z frakcji Ōhiry oraz przewodniczący Rady Badań Politycznych Mizuta Mikio. W dniu 9 lutego 1974 roku wydali oni oświadczenie, że równocześnie z zawarciem umowy z ChRL rząd powinien osiągnąć porozumienie z reżimem Guomindangu, zachowując istniejące połączenia lotnicze z Tajwanem. Nakazali również, aby ostateczny kompromis był wypracowany przez rząd $\mathrm{w}$ porozumieniu $\mathrm{z}$ czterema najwyższymi urzędnikami PLD. Pomimo sprzeciwu posłów protajwańskich oświadczenie razem $\mathrm{z}$ sześcioma dyrektywami Ōhiry w sprawie umowy zostało przyjęte przez Radę Generalną jako decyzja partyjna ${ }^{120}$. Sam fakt, że doszło do głosowania w Radzie Generalnej, gdzie zwyczajowo dążono do konsensusu, świadczył o determinacji obu stron sporu. Przeciwko decyzji głosowało 4 spośród 24 obecnych członków Rady $^{121}$.

Dzięki powierzeniu negocjacji w sprawie umowy zarządowi PLD i samej Radzie Ministrów, członkowie Seirankai utracili bezpośredni wpływ na proces decyzyjny w tej kwestii. Nie oznaczało to jednak, by stronnictwo protajwańskie zostało zupełnie pozbawione głosu. Wszakże wiceprzewodniczący PLD Shiina był blisko związany z reżimem Guomindangu, a z frakcji przewodniczącego Rady Badań Politycznych Mizuty pochodził m.in. przywódca Seirankai,

\footnotetext{
${ }^{116}$ Saninsen e funki unagasu. Jimintō Taikai - Undō hōshin o saitaku, „Asahi Shinbun” z 19 I 1974, wydanie wieczorne, s. 1.

${ }^{117}$ Tamaki Kazuo Kirokushū Hensan Iinkai, op.cit., s. 107-111.

${ }^{118}$ Kawachi Takashi, op.cit., s. 112.

${ }^{119}$ Tamaki Kazuo Kirokushū Hensan Iinkai, op.cit., s. 112.

${ }^{120}$ Jimin seifu an no kihon ryōshō, „Asahi Shinbun” z 10 II 1974, s. 2.

${ }^{121}$ Kawachi Takashi, op.cit., s. 124-125.
} 
Nakagawa Ichirō. Na dodatek przewodniczący Rady Generalnej Suzuki Zenkō był człowiekiem słynącym $\mathrm{z}$ dążenia do kompromisu za wszelką cenę i stronienia od rozwiązań siłowych. Na wątpliwości polityków protajwańskich, czy ich zdanie zostanie wzięte pod uwagę w czasie negocjacji, Suzuki Zenkō odpowiedział: „Będziemy cierpliwie kontynuować rozmowy, by osiągnąć jak najlepszy wynik. Chciałbym, abyście zaufali zarządowi partii”'122. Członkowie Seirankai mogli już tylko nalegać, by nie doszło do podpisania umowy z ChRL bez jednoczesnego zawarcia analogicznego traktatu z reżimem Guomindangu.

Tymczasem agresywne zachowanie Hamady Kōichiego i innych posłów protajwańskich pobudziło do działania umiarkowanych polityków z PLD, którzy 5 lutego 1974 roku ogłosili powstanie nowej grupy politycznej, Konferencji Normalizacji Partii (Tō Seijōka Renraku Kaigi), mającej być przeciwieństwem Seirankai. Członkostwo w niej zadeklarowali tacy stosunkowo młodzi parlamentarzyści, jak Itō Masayoshi i Katō Kōichi z frakcji Ōhiry, Yamashita Ganri z frakcji Tanaki, Sakamoto Misoji z frakcji Mikiego czy Tagawa Seiichi i Kōno Yōhei z frakcji Nakasone. Byli to niemal wyłącznie przedstawiciele „głównego nurtu”, rzucał się za to w oczy brak członków frakcji Fukudy ${ }^{123}$. Powstanie nowej grupy z jednej strony wzmacniało solidarność „głównego nurtu”, z drugiej zaś było wyrazem niezadowolenia polityków propekińskich z powodu braku zdecydowanych działań zarządu partii przeciwko agresywnym zachowaniom posłów Seirankai. Nieformalnym liderem umiarkowanych polityków został Kōno Yōhei, zaś media przypuszczały, iż Kōno zamierza utworzyć własną frakcję ${ }^{124}$.

Premier Tanaka był zdecydowany zawrzeć umowę lotniczą z ChRL przed wyborami do Izby Radców w lipcu 1974 roku. Dzięki sukcesowi dyplomatycznemu mógłby liczyć na lepszy wynik wyborczy i zwiększyć swoje szanse na zachowanie stanowiska premiera. Z kolei Morita Hajime wspomina, że Ōhira Masayoshi za żadną cenę nie chciał ustąpić ze swoich wytycznych w sprawie umowy lotniczej. Pomimo ostrej krytyki ze strony członków Seirankai, minister spraw zagranicznych zamierzał zawrzeć traktat w kształcie wynegocjowanym w styczniu 1974 roku $^{125}$. Biurokraci z Ministerstwa Spraw Zagranicznych rozpoczęli żmudne rozmowy z członkami Seirankai, próbując ich przekonać do złagodzenia stanowiska. Jak zauważa Zhao Quansheng, o ile Watanabe Michio wykazał częściowe zrozumienie dla trudnej sytuacji rządu, Fujio Masayuki czy Nakagawa Ichirō byli nieustępliwi ${ }^{126}$. Pod koniec marca 1974 roku w Pekinie

\footnotetext{
${ }^{122}$ Tamaki Kazuo Kirokushū Hensan Iinkai, op.cit., s. 120.

${ }^{123}$ Jimin hato-ha giin shin gurūpu hossoku. Seirankai to no tairitsu tsuyomeru, „Asahi Shinbun” z 6 II 1974, s. 2.

${ }^{124}$ Shizuka ni senkō suru Jimin wakate hato-ha, „Nikkei Business” z 4 III 1974, s. 43.

${ }^{125}$ Morita Hajime, Saigo no tabi. Nokosareta yuiitsu no Ōhira saishō nikki, Gyōsei Mondai Kenkyūjo, Tokio 1981, s. 112-122.

${ }^{126}$ Zhao Quansheng, op.cit., s. 197.
} 
rozpoczęła się ostatnia runda rozmów w sprawie umowy. Równolegle Japonia starała się osiągnąć porozumienie z reżimem Guomindangu. O ile jednak rząd w Tajpej był gotów zgodzić się na zastąpienie JAL przez innego japońskiego przewoźnika czy na niekorzystanie z tych lotnisk, na których miały lądować samoloty z ChRL, zdecydowanie sprzeciwiał się zamknięciu biur China Air Lines (CAL) w Japonii czy dodaniu na samolotach napisu „Tajwan” w nawiasie $^{127}$. Na początku kwietnia 1974 roku Suzuki Zenkō oświadczył, że nawet gdyby nie doszło do podpisania umowy na poziomie pozarządowym $\mathrm{z}$ Tajwanem w chwili zawarcia traktatu $\mathrm{z}$ ChRL, nie będzie to pogwałceniem decyzji partii z 9 lutego 1974 roku, jeśli tylko zostaną zachowane warunki utrzymania istniejących połączeń lotniczych. Taka interpretacja uchwały partyjnej spotkała się z ostrym sprzeciwem członków Seirankai ${ }^{128}$.

Stawało się coraz bardziej widoczne, że celem skrzydła protajwańskiego jest obalenie gabinetu Tanaki i wybór Fukudy Takeo na nowego przewodniczącego partii. Na wiosnę 1974 roku skrajnie prawicowe środowiska z PLD nasiliły krytykę polityki rządu, organizując masowe demonstracje. Po dzielnicy rządowej jeździły samochody nacjonalistów, którzy poprzez megafony głosili antychińskie hasła ${ }^{129}$. Na dodatek 10 kwietnia 1974 roku jeden z członków frakcji Fukudy i czołowy polityk Seirankai, Fujio Masayuki, ujawnił na posiedzeniu Rady Generalnej PLD oświadczenie ministra Ōhiry, przygotowane do upublicznienia w chwili podpisania umowy lotniczej z ChRL. Wynikało z niego, że Japonia miała zadeklarować, iż nie uznaje emblematów na samolotach CAL za znaki państwowe. Fujio ostro skrytykował Ōhirę Masayoshiego za naruszenie postanowień wewnątrzpartyjnych, które nakazywały konsultowanie się w sprawie umowy z zarządem partii ${ }^{130}$. Ujawnienie oświadczenia wywołało ostrą reakcję reżimu Guomindangu, co ostatecznie uniemożliwiło gabinetowi Tanaki osiągnięcie kompromisu w tej sprawie z rządem w Tajpej ${ }^{131}$.

Kontrowersyjne działania Fujio Masayukiego świadczyły o bezsilności członków Seirankai, którzy nie byli w stanie zmienić polityki partii kreowanej przez „główny nurt” Tanaki. W połowie kwietnia 1974 roku Ōhira Masayoshi uzyskał ostateczną zgodę zarządu PLD na zawarcie umowy. Protesty przedstawicieli obozu protajwańskiego na posiedzeniu Rady Generalnej PLD 19 kwietnia 1974 roku miały już tylko symboliczne znaczenie. Umowa lotnicza z Chinami komunistycznymi została podpisana 20 kwietnia 1974 roku. Tego samego dnia minister spraw zagranicznych Ōhira oświadczył, że Japonia od chwili normalizacji stosunków dyplomatycznych z ChRL w 1972 roku nie uważa emblematów na tajwańskich samolotach za flagę państwową, ani CAL za

\footnotetext{
${ }^{127}$ Hong N. Kim, op.cit., s. 292-294.

128 Jitsumu seiji o heikō tōgi. Pekin no nitchū kōkū kōshō, „Asahi Shinbun” z 3 IV 1974, s. 2.

${ }^{129}$ Li Enmin, op.cit., s. 79.

${ }^{130}$ Nitchū kōshō naiyō o bakuro Nikka Giinkon, „Asahi Shinbun” z 11 IV 1974, s. 2.

${ }^{131}$ Hong N. Kim, op.cit., s. 293-294.
} 
„przewoźnika reprezentującego państwo"132. Władze w Tajpej w geście protestu zerwały wszelkie cywilne połączenia lotnicze z Japonią, deklarując jednocześnie zamknięcie tajwańskiej przestrzeni powietrznej dla japońskich samolotów ${ }^{133}$. Jednocześnie trzech działaczy Seirankai: Nakagawa Ichirō, Watanabe Michio i Morishita Motoharu podało się do dymisji ze stanowisk wiceministerialnych ${ }^{134}$.

Obóz protajwański nie zamierzał jednak dać za wygraną. W dniu 22 kwietnia 1974 roku na wspólnym zebraniu działaczy Parlamentarnego Związku Stosunków Japońsko-Tajwańskich oraz Seirankai przyjęto rezolucję, wzywającą premiera do wzięcia odpowiedzialności za kryzys $\mathrm{w}$ stosunkach $\mathrm{z}$ reżimem Guomindangu. Politycy protajwańscy rozpoczęli także kampanię przeciwko ratyfikacji umowy lotniczej $\mathrm{z}$ ChRL, argumentując, że najpierw należy przywrócić połączenia $\mathrm{z}$ Tajwanem ${ }^{135}$. Umowa została jednak ratyfikowana przez Izbę Reprezentantów 7 maja 1974 roku przy absencji 80 posłów. Wśród nieobecnych na głosowaniu byli m.in. Kishi Nobusuke, Funada Naka, członkowie Seirankai i 40 parlamentarzystów z frakcji Fukudy ${ }^{136}$. Na dodatek trzech działaczy Seirankai w Izbie Reprezentantów, w tym Hamada Kōichi, zagłosowało przeciw umowie ${ }^{137}$. Ostatecznie we wrześniu 1974 roku samoloty pasażerskie rozpoczęły regularne loty między Japonią a ChRL ${ }^{138}$.

Pomimo zawarcia umowy lotniczej z ChRL popularność Tanaki wśród obywateli gwałtownie spadała. W wyniku ,szoku naftowego” z 1973 roku oraz „dyskursu o przebudowie Archipelagu Japońskiego" "139 wzrosła inflacja, zaś Japonia stanęła na skraju recesji gospodarczej. Na dodatek w 1974 roku reporterzy ujawnili aferę z ,polityką pieniądza” (kinken seiji), stosowaną przez Tanakę Kakueia przy kupowaniu poparcia politycznego ${ }^{140}$. W atmosferze

\footnotetext{
${ }^{132}$ Nitchū kōkū kyōtei chōin ni sai shite no Ōhira gaimu daijin danwa z 20 IV 1974 [w:] Nitchū kankei kihon..., s. 470-471.

${ }^{133}$ Hong N. Kim, op.cit., s. 295.

${ }^{134}$ Lin Jinjing, op.cit., s. 411.

${ }^{135}$ Hong N. Kim, op.cit., s. 295-296.

${ }^{136}$ Sadako Ogata, op.cit., s. 82.

${ }^{137}$ Kawachi Takashi, op.cit., s. 129.

${ }^{138}$ Hong N. Kim, op.cit., s. 296.

139 „Dyskurs o przebudowie Archipelagu Japońskiego” (Nihon Rettō kaizōron) był filarem polityki wewnętrznej rządu Tanaki. Zakładał zmniejszenie nierówności w poziomie rozwoju pomiędzy najbogatszymi a najbiedniejszymi regionami kraju poprzez prowadzone na wielką skalę inwestycje w infrastrukturę komunikacyjną. Spowodował wzrost cen surowców budowlanych i nieruchomości. Szerzej na ten temat: Hayasaka Shigezō, Seijika..., s. 452-474; Tanaka Kakuei, Nihon Rettō kaizōron, Nikkan Kōgyō Shinbunsha, Tokio 1972, s. 2-201.

${ }^{140}$ Aferę ujawniło czasopismo „Bungei Shunjū” w artykule w numerze listopadowym. Zgodnie z jego treścią, przy okazji wyborów do Izby Radców z lipca 1974 roku doszło do licznych korupcyjnych powiązań między światem polityki a biznesu, za które był odpowiedzialny Tanaka Kakuei. W proteście przeciw premierowi dymisję złożyli m.in. tacy członkowie rządu, jak Miki Takeo i Fukuda Takeo. Szerzej na ten temat: Tsuchiya Shigeru, op.cit., s. 206; Ishikawa Masumi, op.cit., s. 127-128.
} 
skandalu i przy lawinowo spadającym poparciu społecznym dla rządu premier Tanaka musiał podać się do dymisji w listopadzie 1974 roku.

$* \quad * \quad *$

Nigdy wcześniej ani później żaden lider frakcji nie wygrał rywalizacji o stanowisko przewodniczącego PLD dzięki tak sprawnemu posłużeniu się sprawą chińską, jak Tanaka Kakuei. Po „szoku Nixona” i przyjęciu ChRL do ONZ w 1971 roku normalizacja stosunków dyplomatycznych z Chinami kontynentalnymi była tylko kwestią czasu, nie wiedziano jedynie kto, kiedy i na jakich warunkach jej dokona. Opierając się na poparciu obozu protajwańskiego Fukuda Takeo nie mógł wyjść naprzeciw oczekiwaniom społecznym. Dzięki potajemnym kontaktom z Zhou Enlaiem i przekonaniu do siebie skrzydła propekińskiego w PLD, Tanaka Kakuei wygrał rywalizację o stanowisko przewodniczącego partii i energicznie przystąpił do realizacji obietnicy złożonej Ōhirze, Mikiemu i Nakasone. Aby uspokoić nastroje wśród polityków protajwańskich, nowy rząd uciekł się do zawarcia w Podstawowych zasadach niejasnego sformułowania o utrzymaniu ,dotychczasowych stosunków" z reżimem Guomindangu, jak też do wysłania na Tajwan Shiiny Etsusaburō. Tylko dzięki determinacji Tanaki i Ōhiry do normalizacji stosunków japońskochińskich doszło już niecałe trzy miesiące od powołania rządu. To przełomowe wydarzenie stało się jednak przyczyną dalszej eskalacji napięcia pomiędzy propekińskim „głównym nurtem” a umacniającym swoją solidarność tajwańskim lobby w PLD. W szczególności powstanie Seirankai w 1973 roku sygnalizowało, że zwolennicy reżimu Guomindangu nie zamierzają dać za wygraną i będą zaciekle bronić interesów Tajwanu. Żmudne negocjacje w sprawie umowy lotniczej z ChRL były tego najlepszym dowodem.

\section{MIKI TAKEO (1974-1976)}

Rządy Mikiego Takeo, w przeciwieństwie do kadencji Tanaki Kakueia, były okresem zastoju w stosunkach japońsko-chińskich. Pomimo propekińskiego nastawienia premiera negocjacje Traktatu o pokoju i przyjaźni z ChRL stanęły w martwym punkcie. Oprócz niestabilnej sytuacji rządu w Pekinie, wpływ na ten stan miały uwarunkowania wewnątrz PLD. Współtworzące ,główny nurt" Mikiego frakcje protajwańskie okazały się znaczącą przeszkodą w prowadzeniu aktywnej dyplomacji wobec Chin komunistycznych. Z kolei problem „klauzuli antyhegemonistycznej” został przez nie wykorzystany jako wygodne narzędzie do zablokowania rozmów w sprawie Traktatu o pokoju i przyjaźni z Chinami.

\section{„Gołąb” wśród ,jastrzębi”}

Po podaniu się do dymisji premiera Tanaki rozpoczął się następny etap „,wojny Kaku-Fuku". Skompromitowany w skandalu korupcyjnym Tanaka Kakuei miał odtąd brać w niej udział pośrednio, wspierając kandydaturę swojego 
najbliższego sojusznika, Ōhiry Masayoshiego. Aby uniknąć grożącej rozpadem partii rywalizacji między obiema stronami „wojny”, zdecydowano się powierzyć prawo nominacji następnego przewodniczącego partii wiceprzewodniczącemu PLD, Shiinie Etsusaburō. Shiina pamiętał o upokorzeniu, jakie spotkało go dwa lata wcześniej w trakcie wizyty na Tajwanie, obwiniając za nie ówczesnego ministra spraw zagranicznych Ōhirę Masayoshiego. Wszakże to Ōhira oświadczył w 1972 roku, że Japonia zerwie oficjalne stosunki dyplomatyczne z reżimem Guomindangu. Shiina, który w trakcie wizyty na Tajwanie obiecał utrzymanie „dotychczasowych stosunków” z władzami w Tajpej, stracił wówczas twarz wobec Jiang Jieshiego ${ }^{141}$. Jak sam przyznał, w 1974 roku nie mianował Ōhiry, gdyż podejrzewał go o „przyjmowanie pieniędzy z ChRL" Po namyśle, w grudniu 1974 roku Shiina wskazał na nowego przewodniczącego PLD Mikiego Takeo. Ponieważ Miki był powszechnie uważany za polityka walczącego z korupcją i od dawna promował idee reformy wewnątrzpartyjnej, jego nominacja służyła poprawie wizerunku partii wśród społeczeństwa po skandalu z „polityką pieniądza" ${ }^{143}$. Chociaż w 1972 roku Miki wsparł Tanakę w wyborach na przewodniczącego PLD, w 1974 roku opuścił „główny nurt” w wyniku tzw. „wojny tokushimskiej” ${ }^{144}$. Od tego czasu związał się z obozem Fukudy Takeo. Podobnie uczynił pragnący pozostać w kręgu ścisłej władzy Nakasone Yasuhiro i wszystkie małe frakcje. W ten sposób oś Tanaka-Ōhira została zdegradowana do roli wewnątrzpartyjnej opozycji.

„Główny nurt" utworzony przez Mikiego Takeo opierał się na współpracy polityków „bocznego nurtu konserwatywnego”. Co ciekawe, o ile frakcja premiera skupiała „gołębi”, w niemal wszystkich pozostałych grupach przeważali ,jastrzębie”. Podobny dysonans panował także pod względem nastawienia do sprawy chińskiej. Chociaż Miki Takeo od dawna należał do czołowych promotorów relacji z ChRL, zostawszy premierem musiał polegać wewnątrz partii na poparciu takich protajwańskich polityków, jak Fukuda Takeo czy Shiina Etsusaburō, który go wszakże wyznaczył na szefa rządu. Guan Ying podkreśla, iż jako przedstawiciel jednej z najsłabszych frakcji w PLD, Miki Takeo musiał szukać bazy poparcia w głównym przeciwniku Tanaki i Ōhiry, a

\footnotetext{
${ }^{141}$ Fujita Yoshirō, Shiina saitei, Sankei Shuppan, Tokio 1979, s. 92-93.

${ }^{142}$ Itō Masaya, Jimintō sengokushi - Kenryoku no kenkyū, Asahi Sonorama, Tokio 1983, s. 199.

${ }^{143}$ Tsuchiya Shigeru, op.cit., s. 207-208.

${ }^{144}$ Termin „,wojna tokushimska” (Tokushima sensō) odnosi się do wydarzeń z lipca 1974 roku. W wyborach do Izby Radców, które się wówczas odbyły, Tanaka Kakuei przeforsował na oficjalnego kandydata PLD w Tokushimie wicesekretarza swojego gabinetu, Gotōdę Masaharu. Wywołało to gwałtowny protest Mikiego Takeo, który sam pochodził z Tokushimy i promował w tym okręgu członka własnej frakcji, Kujime Kentarō. Kujime był już zresztą członkiem Izby Radców i zgodnie z obyczajem partyjnym należała mu się nominacja na kandydata PLD. Po zaciekłej rywalizacji Kujime Kentarō zwyciężył w wyborach jako kandydat niezależny, zaś stosunki między Tanaką a Mikim uległy bezpowrotnemu pogorszeniu. Frakcja Mikiego już nigdy nie weszła w sojusz z frakcją Tanaki. Szerzej na ten temat: Kunihiro Masao, op.cit., s. 157-162.
} 
tym samym pójść na ustępstwa w polityce wobec ChRL ${ }^{145}$. Z kolei Tagawa Seiichi zauważa, że rząd Mikiego był mieszanką obozu ,jastrzębi” i „gołębi”, zaś najważniejsze stanowiska $\mathrm{w}$ partii zdominowali reprezentanci obozu protajwańskiego. Przewodniczącym Rady Generalnej PLD został Nadao Hirokichi z frakcji Ishiiego, przewodniczącym Rady Badań Politycznych dawny kobun Satō, Matsuno Raizō, zaś stanowisko wiceprzewodniczącego partii nadal piastował Shiina Etsusaburō ${ }^{146}$.

Tabela 3.2 Rozkład sił pomiędzy frakcjami PLD w okresie rządów Mikiego Takeo w latach 1974-1976.

\begin{tabular}{|l|l|l|}
\hline \multicolumn{2}{|c|}{ Frakcje: } \\
\hline ,głównego nurtu” & poza ,głównym nurtem” & „przeciwnego nurtu” \\
\hline Miki (D, G, P) 45 & - & Tanaka (L, P) 90 \\
Fukuda (D, J, T) 79 & & Ōhira (L, G, P) 64 \\
Nakasone (D, J) 41 & \\
Shiina (D, J, T) 20 & & \\
Mizuta (J, T) 15 & \\
Funada (L, J, T) 12 & & \\
Ishii (L, T) 9 & & \\
\hline 221 & \\
L: $2(21)$, D: 4 (200), & & \\
G: 1 (45), J: 5 (167), & & \\
P: 1 (45), T: 5 (135). & & \\
\hline
\end{tabular}

L- dawni członkowie Partii Liberalnej, główny nurt konserwatywny, D- dawni członkowie Japońskiej Partii Demokratycznej, boczny nurt konserwatywny, G- gołębie, J- jastrzębie, P- obóz propekiński, T- obóz protajwański.

Liczebność frakcji (podana przy poszczególnych frakcjach) po wyborach do Izby Radców z lipca 1974 roku. Uwzględniono członków frakcji z obu izb parlamentu. W podsumowaniu ,głównego nurtu" podana jest ogólna liczba należących do niego parlamentarzystów oraz liczba frakcji, zaś w nawiasie liczba parlamentarzystów, należących do poszczególnych obozów.

Opracowanie własne na podstawie: Satō Seizaburō, Matsuzaki Tetsuhisa, op.cit., s. 243; Kitaoka Shin'ichi, op.cit., s. 335.

Propekińskie nastawienie Mikiego było znane od lat. Miki Takeo nie był skrajnym antykomunistą, zaś po drugiej wojnie światowej promował ducha spółdzielczości, który miał stanowić „trzecią drogę" między kapitalizmem a socjalizmem $^{147}$. Za rządów Ishibashiego Tanzana wspierał propekińskie dążenia premiera pełniąc funkcję sekretarza generalnego partii. Z kolei jako przyjaciel Matsumury Kenzō, w latach 60. XX wieku działał na rzecz pozarządowego handlu z ChRL. Z drugiej strony, Miki był przywódcą liczącej się frakcji (choć

\footnotetext{
${ }^{145}$ Guan Ying, Zhong,-Ri heping youhao tiaoyue dijie tanpan zhi yanjiu, „Zhejiang Daxue Xuebao (Renwen Shehui Kexueban)" 2003, vol. 33, no. 6, s. 137.

${ }^{146}$ Chae-Jin Lee, The Making of the Sino-Japanese Peace and Friendship Treaty, „Pacific Affairs” 1979, vol. 52, no. 3, s. 424; Tagawa Seiichi, Nitchū kōryū..., s. 152.

${ }^{147}$ Kunihiro Masao, op.cit., s. 46-47.
} 
raczej średnich rozmiarów) i mając ambicje zostania premierem nie mógł opowiadać się równie jednoznacznie jak Matsumura za normalizacją stosunków dyplomatycznych z Chinami w chwili, gdy nie sprzyjały temu uwarunkowania międzynarodowe (np. „rewolucja kulturalna”). Dążąc do osiągnięcia jak największego zysku politycznego, często sprzymierzał się z protajwańskim skrzydłem PLD. Stało się to zresztą przyczyną jego rozstania z Matsumurą w 1964 roku. Mikiego nazywano „politykiem bałkańskim” (Barukan seijika), gdyż, podobnie jak przed I wojną światową państwa bałkańskie między mocarstwami, musiał lawirować pomiędzy największymi frakcjami, odkładając na później zadania, których nie mógł $\mathrm{w}$ danej chwili zrealizować ${ }^{148}$. Odkąd jednak Miki wyszedł z „głównego nurtu” Satō pod koniec lat 60. XX wieku, bezwzględnie poświęcił się promocji przyjaznych kontaktów z ChRL. W 1972 roku wsparł Tanakę, co spotkało się z niezadowoleniem części członków jego własnej frakcji. Grupę Mikiego opuścili wówczas tacy protajwańscy politycy, jak Tamaki Kazuo, który został później jednym z głównych działaczy Seirankai ${ }^{149}$.

Widać więc, że Miki Takeo nie po raz pierwszy sprzymierzył się z prawym skrzydłem PLD, pod wieloma względami tak odległym od jego osobistych przekonań. Dzięki pojednawczej postawie wobec obozu protajwańskiego mógł mieć natomiast nadzieję na przeforsowanie niezwykle ważnych reform, mających położyć kres korupcji, uosabianej przez postać Tanaki Kakueia ${ }^{150}$. Ponieważ także Fukuda Takeo od dawna należał do zwolenników gruntownej odnowy życia politycznego, plany te miały szansę powodzenia dopóki zachowana zostanie solidarność ,głównego nurtu”. Chociaż więc Miki na początku swoich rządów wykazywał aktywnie propekińską postawę, z czasem na dyplomację jego gabinetu musiały wywrzeć wpływ uwarunkowania wewnątrzpartyjne, jak też zmiana sytuacji międzynarodowej w regionie. Jest to widoczne szczególnie na przykładzie rozmów w sprawie Traktatu o pokoju i przyjaźni z ChRL.

\section{Negocjacje w sprawie traktatu pokojowego z ChRL}

We Wspólnej deklaracji z 1972 roku rządy Japonii i ChRL zadeklarowały jako cel przyszłych rozmów zawarcie traktatu pokojowego. Negocjacje w tej sprawie rozpoczął jeszcze w 1974 roku rząd Tanaki, jednak poważnym problemem okazała się kwestia tzw. „klauzuli antyhegemonistycznej”. Na wzór chińsko-

\footnotetext{
${ }^{148}$ Ibidem, s. 109-110.

149 Tamaki Kazuo podążył za swoim bezpośrednim oyabunem, Hayakawą Takashim, który dołączył do obozu Fukudy. Głosować na Fukudę nakazywała także Tamakiemu prawicowa sekta Seichō no Ie, będąca jego główną bazą poparcia w wyborach do Izby Radców. Szerzej na ten temat: Shioda Michio, op.cit., s. 156-158.

${ }^{150}$ Mikiemu Takeo udało się doprowadzić do uchwalenia dwóch ważnych ustaw: w sprawie wyborów na urzędy publiczne oraz ograniczeń w finansowaniu partii przez przedsiębiorców. Zgodnie $\mathrm{z}$ ostatnią z nich ustanowiono górną granicę datków na $100 \mathrm{mln}$ jenów rocznie od pojedynczego przedsiębiorcy. Szerzej na ten temat: Iseri Hirofumi, op.cit., s. 74.
} 
amerykańskiego Komunikatu Szanghajskiego, została ona zawarta w artykule 7 chińsko-japońskiej Wspólnej deklaracji z 1972 roku. Stwierdzała: „Normalizacja stosunków japońsko-chińskich nie jest wymierzona w państwa trzecie. Oba kraje, nie dążąc samemu do hegemonii w regionie Azji-Pacyfiku, będą się też sprzeciwiać jakiemukolwiek innemu państwu lub grupie państw, starających się ustanowić taką hegemonię”"151. O ile strona japońska nie postrzegała „klauzuli antyhegemonistycznej" w wymiarze strategicznym, dla dyplomacji chińskiej stanowiła ona istotne narzędzie służące utworzeniu zjednoczonego frontu przeciwko ZSRR ${ }^{152}$. W następnych latach pojawił się szereg czynników, które utrudniały powtórzenie klauzuli również w traktacie pokojowym. Od 1974 roku ChRL nasiliła krytykę ekspansji wpływów ZSRR w Indochinach i Afryce, nazywając Związek Radziecki mocarstwem „hegemonicznym”. W ten sposób kontrowersyjna klauzula stała się jednoznacznie tożsama $\mathrm{z}$ polityką antyradziecką ${ }^{153}$.

Dla japońskiej dyplomacji zadaniem równie ważnym, jak zawarcie traktatu pokojowego z ChRL, było podpisanie analogicznej umowy ze Związkiem Radzieckim. Ponieważ rząd w Tokio dążył do odzyskania tzw. Terytoriów Północnych ${ }^{154}$, musiał zwracać szczególną uwagę na wszelkie szanse porozumienia ze stroną sowiecką. Kiedy zaś po podpisaniu z ChRL Komunikatu Szanghajskiego w 1972 roku Stany Zjednoczone zaczęły wykorzystywać zbliżenie z władzami w Pekinie jako „kartę przetargową” w rozmowach z ZSRR, nastąpiło odprężenie na linii Waszyngton-Moskwa, którego również Japonia nie mogła ignorować. Zmiana polityki amerykańskiej zachęciła rząd w Tokio do bardziej energicznego szukania porozumienia ze Związkiem Radzieckim, tym bardziej że same władze ZSRR starały się odciągnąc Japonię od pogłębiania kontaktów z ChRL. Rząd w Moskwie proponował np. otwarcie się na japońskie inwestycje w infrastrukturę na Syberii, mające umożliwić dostawy surowców energetycznych do Japonii ${ }^{155}$.

\footnotetext{
${ }^{151}$ Nihonkoku seifu to Chūka Jinmin Kyōwakoku seifu no kyōdō...

${ }^{152}$ Hidenori Ijiri, Sino-Japanese Controversy since the 1972 Diplomatic Normalization, „The China Quarterly" 1990, nr 124, s. 641-642.

${ }^{153}$ Kazuhiko Togo, Japan's Foreign Policy, 1945-2009: The Quest for a Proactive Policy, Brill Academic Publisher, Leiden/Boston 2010, s. 132.

${ }^{154}$ Terytoria Północne (Hoppō Ryōdo) oznaczają teren wysp Etorofu, Kunashiri i Shikotan oraz archipelagu Habomai, położonych na północ od Hokkaidō. Zostały one zajęte przez ZSRR w 1945 roku. Strona sowiecka utrzymywała, że stanowią część Wysp Kurylskich i że Japonia zrzekła się praw do nich z momentem kapitulacji po II wojnie światowej, na mocy postanowień konferencji w Jałcie i Poczdamie. Z kolei według strony japońskiej, „Terytoria Północne” przed 1945 rokiem nigdy nie należały do Rosji, zaś w 1945 roku ZSRR zajął je bezprawnie. Szerzej na ten temat: Arkadiusz Gębski, Problem „Terytoriów Pótnocnych” [w:] Wspótczesna Japonia - mocarstwo na rozdrożu pod red. Elżbiety Potockiej i Małgorzaty Pietrasiak, Wydawnictwo Uniwersytetu Łódzkiego, Łódź 2004, s. 125-130.

${ }^{155} \mathrm{~W}$ październiku 1973 roku doszło do wizyty premiera Tanaki w Moskwie. We Wspólnym komunikacie z Breżniewem obie strony zadeklarowały chęć rozszerzenia współpracy w dziedzinie
} 
Od 1972 roku głównym celem radzieckiej dyplomacji wobec rządu w Tokio stało się niedopuszczenie do zawarcia w chińsko-japońskim traktacie pokojowym „klauzuli antyhegemonistycznej”. Według strony sowieckiej była ona wyraźnie skierowana przeciwko ZSRR. Chociaż więc premier Miki wyznaczył na ministra spraw zagranicznych propekińsko nastawionego Miyazawę Kiichiego $\mathrm{z}$ frakcji Ōhiry ${ }^{156} \mathrm{i}$ starał się doprowadzić do jak najszybszego zawarcia Traktatu o pokoju i przyjaźni z ChRL, uwarunkowania zewnętrzne stanowiły poważną przeszkodę dla dyplomacji jego rządu wobec Chin. Jednocześnie były one na rękę protajwańskiemu skrzydłu w PLD, stanowiącemu podstawę „głównego nurtu” premiera. Powołując się na opór Związku Radzieckiego, politycy blisko związani z reżimem Guomindangu mogli przywołać obiektywny argument przeciwko zawarciu traktatu pokojowego z ChRL i tym samym blokować dalsze zacieśnianie więzi z rządem w Pekinie ${ }^{157}$. Na dodatek strona chińska zaczęła wątpić w propekińskie nastawienie Mikiego Takeo, gdy wyraził on kondolencje po śmierci prezydenta Tajwanu Jiang Jieshiego w kwietniu 1975 roku $^{158}$.

Premier starał się jednak za wszelką cenę doprowadzić do porozumienia z władzami KPCh, proponując kompromisową interpretację ,,antyhegemonizmu" i uruchamiając osobiste kontakty ze stroną chińską ${ }^{159}$. Również minister Miyazawa przygotował tzw. „cztery zasady Miyazawy”, które stały się japońskimi warunkami zawarcia „klauzuli antyhegemonistycznej” w traktacie pokojowym ${ }^{160}$. We wrześniu 1975 roku japoński minister spraw zagranicznych spotkał się na sesji Zgromadzenia Ogólnego ONZ w Nowym Jorku z szefem dyplomacji ChRL, Qiao Guanhua, jednak władze KPCh nie chciały się zgodzić na ustępstwa. Miyazawa Kiichi przyznaje: „Wyglądało na to, że także w Chinach walka o władzę po rewolucji kulturalnej stawała się coraz bardziej

handlu, rybołówstwa, nauki, rolnictwa i technologii, jak też rozwoju Syberii. Odniesiono się również do „uregulowania nierozwiązanych po II wojnie światowej problemów”, co według strony japońskiej oznaczało zgodę na uwzględnienie w negocjacjach kwestii terytorialnej. Szerzej na ten temat: Sadako Ogata, op.cit., s. 79-80.

${ }^{156}$ Chociaż Miyazawa należał do znajdującej się w „przeciwnym nurcie” frakcji Ōhiry, utrzymywał bliskie kontakty z Mikim, ponieważ był spokrewniony z jego żoną, Mutsuko. Szerzej na ten temat: Marugame Hiroaki, Bōryaku no habatsu ningengaku, Keizaikai, Tokio 1983, s. 147148.

${ }^{157}$ Zhong-Ri guanxi 30 nian 1972-2002 pod red. Xu Zhixiana, Shishi Chubanshe, Pekin 2002, s. 75-76; Guan Ying, op.cit., s. 135.

${ }^{158}$ Chalmers Johnson, Japan: Who Governs? The Rise of the Developmental State, W. W. Norton \& Company, New York - London 1995, s. 249.

${ }^{159}$ Sadako Ogata, op.cit., s. 84.

160 „Cztery zasady Miyazawy” to: 1) sprzeciw wobec hegemonii nie tylko w regionie AzjiPacyfiku, ale w skali globalnej; 2) klauzula nie jest skierowana przeciwko żadnemu określonemu krajowi; 3) klauzula nie oznacza żadnej wspólnej akcji Japonii i Chin; 4) klauzula nie pozostaje w niezgodzie z zasadami Karty Narodów Zjednoczonych. Szerzej na ten temat: Kikigaki. Miyazawa..., s. 264; Sadako Ogata, op.cit., s. 84. 
skomplikowana i negocjacje w sprawie umowy za nic nie posuwały się do przodu" ${ }^{161}$. Z powodu bezkompromisowej postawy strony chińskiej w listopadzie 1975 roku ostatecznie przerwano rozmowy w sprawie traktatu pokojowego $^{162}$. Ostatni rok rządów Mikiego Takeo zbiegł się z burzliwym okresem rywalizacji o władzę w KPCh, co nie stwarzało sprzyjających warunków do wznowienia negocjacji ${ }^{163}$.

Skrzydło protajwańskie żądało, by zamiast Traktatowi o pokoju i przyjaźni z ChRL premier poświęcił więcej uwagi przywróceniu przyjaznych kontaktów z reżimem Guomindangu. Szczególnie palącym problemem była konieczność wznowienia połączeń lotniczych pomiędzy oboma krajami. Tuż po nominacji na przewodniczącego partii, Miki obiecał Shiinie Etsusaburō, że cel ten umieści wśród priorytetów japońskiej polityki zagranicznej ${ }^{164}$. W kwietniu 1975 roku na Tajwan wybrali się m.in. Satō Eisaku z synem Shinjim, by wziąć udział w pogrzebie prezydenta Jiang Jieshiego ${ }^{165}$. Rząd w Tajpej dawał do zrozumienia, że Japonia musi cofnąć „znieważające” oświadczenie Ōhiry Masayoshiego na temat symboli narodowych Republiki Chińskiej. W lipcu 1975 roku minister spraw zagranicznych Miyazawa Kiichi przyznał w parlamencie, że rząd w Tokio nie zaprzecza, iż symbole Republiki Chińskiej są uznawane za flagę narodową przez kraje utrzymujące oficjalne stosunki dyplomatyczne $z$ reżimem Guomindangu. Oświadczenie to starczyło, by Nadao Hirokichi przekonał stronę tajwańską do przywrócenia połączeń lotniczych. Jednocześnie deklaracja Miyazawy spotkała się z krytyką ze strony władz w Pekinie. Nawet zmiana we wrześniu 1976 roku ministra spraw zagranicznych na innego członka obozu propekińskiego, Kosakę Zentarō, nie pomogła stronie japońskiej w negocjacjach Traktatu o pokoju i przyjaźni z ChRL ${ }^{166}$.

Tymczasem zaostrzała się również rywalizacja międzyfrakcyjna w PLD, zaś premierowi coraz trudniej było utrzymać równowagę wewnątrzpartyjną. „Przeciwny nurt” Tanaki i Ōhiry wykorzystywał brak efektów w negocjacjach z

\footnotetext{
${ }^{161}$ Kikigaki. Miyazawa..., s. 264.

${ }^{162}$ Sadako Ogata, op.cit., s. 84-85.

${ }^{163}$ W 1975 roku duży wpływ na politykę ChRL wywierało radykalnie lewicowe skrzydło KPCh, nazwane później „,bandą czworga” (si ren bang). W 1976 roku umarli Zhou Enlai i Mao Zedong, co wywołało nasilenie walki o władzę między obozem radykalnym a umiarkowanym. W październiku 1976 roku od rządów odsunięto „bandę czworga” (Jiang Qing, Zhang Chunqiao, Yao Wenyuan, Wang Hongwen), oskarżaną o planowanie zamachu stanu, zaś do głosu doszło bardziej umiarkowane środowisko związane z Hua Guofengiem. Szerzej na ten temat: Alan Lawrance, op.cit., s. 97-99; Edward Kajdański, op.cit., s. 18.

${ }^{164} \mathrm{Z}$ drugiej strony, gdy wkrótce po nominacji Shiina umówił Mikiego na spotkanie z reprezentantem Tajwanu w Japonii, Miki wykazał ostrożną postawę. Zamiast spotkać się osobiście $\mathrm{z}$ przedstawicielem reżimu Guomindangu, jedynie porozmawiał z nim przez telefon, mimo że znajdowali się w tym samym hotelu. Szerzej na ten temat: Fujita Yoshirō, op.cit., s. 117-164.

${ }^{165}$ Satō Eisaku, op.cit., t. 6, Tokio 1999, s. 333-336.

${ }^{166}$ Lin Jinjing, op.cit., s. 414-436.
} 
ChRL do krytyki rządu ${ }^{167}$. Chociaż „czysty Miki” nadal był popularny w społeczeństwie, poparcie dla PLD spadało w wyniku ujawnionego w 1976 roku skandalu z firmą Lockheed ${ }^{168}$. Pragnąc dokładnie wyjaśnić aferę, Miki spotkał się z oporem osi Tanaka-Ōhira. Co więcej, także frakcje dotychczas należące do „głównego nurtu” rozpoczęły krytykę szefa rządu. Snując plany ustawy antymonopolowej Miki naraził się m.in. Shiinie Etsusaburō, który go wszakże wyznaczył na przewodniczącego PLD. Widząc szansę na zdobycie władzy, również Fukuda Takeo nasilił krytykę premiera. W ten sposób „główny nurt” niemal przestał istnieć, skupiając tylko frakcje Mikiego i Nakasone. W drugiej połowie 1976 roku już prawie wszystkie grupy wewnątrz partii nawoływały do dymisji rządu (tzw. Miki oroshi) ${ }^{169}$. W takich warunkach Miki Takeo nie był w stanie prowadzić efektywnej dyplomacji wobec Chin. Po słabym wyniku PLD w wyborach parlamentarnych musiał podać się do dymisji w grudniu 1976 roku. Tagawa Seiichi z dawnej grupy Matsumury nie krył zawodu rządami Mikiego: „Chociaż Miki miał ostry instynkt patrzenia w przyszłość i dzięki tej dalekowzroczności bardzo wcześnie zaczął okazywać chęć porozumienia z Chinami, to gdy natrafił na różne przeszkody i problemy przy realizacji swych zamiarów, brakowało mu odwagi i energii, by je przezwyciężyć" ${ }^{170}$.

$$
* * *
$$

Kadencja Mikiego Takeo była okresem straconej szansy na kontynuację zapoczątkowanego przez Tanakę procesu odprężenia w stosunkach z ChRL. Chociaż sam premier należał do najbardziej zdecydowanych promotorów współpracy z Chinami kontynentalnymi, nie był w stanie swobodnie realizować swojej polityki. Jako przewodniczący najmniejszej z pięciu dużych frakcji musiał polegać na współpracy $\mathrm{z}$ większymi grupami w PLD. Skoro zaś oś Tanaka-Ōhira była zamieszana w ,politykę pieniądza”, jedynym wyborem była kooperacja ze skrzydłem protajwańskim. Te wewnątrzpartyjne ograniczenia były potęgowane przez niesprzyjające porozumieniu z ChRL uwarunkowania zewnętrzne, w szczególności kwestię „klauzuli antyhegemonistycznej” i za-

\footnotetext{
167 Yung H. Park, The “Anti-Hegemony” Controversy in Sino-Japanese Relations, „Pacific Affairs" 1976, vol. 49, no. 3, s. 481-482.

${ }^{168}$ W 1976 roku komisja Senatu USA podała do publicznej wiadomości, że firma Lockheed wręczyła łapówki politykom z wielu krajów w zamian za korzystne dla niej wyniki przetargów na zakup samolotów. Na liście podejrzanych znalazł się także Tanaka Kakuei, który miał otrzymać 500 mln jenów. Tanaka został aresztowany w lipcu 1976 roku, zaś w następnym miesiącu wyszedł na wolność za kaucją. W 1983 roku został skazany na 4 lata pozbawienia wolności, jednak nie trafił do więzienia, do końca życia apelując do wyższych instancji sądu. Szerzej na ten temat: Kitaoka Shin'ichi, op.cit., s. 191-192; Hoshi Hiroshi, op.cit., s. 118-119.

${ }^{169}$ W sierpniu 1976 roku frakcje „przeciwnego nurtu” utworzyły Radę Ustanowienia Systemu Solidarnej Partii (Kyotō Taisei Kakuritsu Kyōgikai), umacniając współpracę w celu odsunięcia od władzy Mikiego Takeo. Szerzej na ten temat: Tsuchiya Shigeru, op.cit., s. 208-209; Iyasu Tadashi, Seitō..., s. 266-269.

${ }^{170}$ Tagawa Seiichi, Nitchū kōryū..., s. 59.
} 
burzeń na chińskiej scenie politycznej. Sprawa zawarcia Traktatu o pokoju i przyjaźni z rządem w Pekinie siłą rzeczy musiała zostać odłożona na przyszłość.

\section{FUKUDA TAKEO (1976-1978)}

O ile Miki Takeo był działaczem propekińskim, a nie osiągnął żadnych sukcesów w polityce wobec ChRL, o tyle Fukuda Takeo, chociaż uważany za postać blisko związaną z reżimem Guomindangu, miał doprowadzić do podpisania Traktatu o pokoju i przyjaźni z Chinami komunistycznymi. Ten paradoksalny przypadek da się wytłumaczyć zarówno zmianą sytuacji w ChRL, jak i specyficznymi uwarunkowaniami wewnątrz PLD w latach 1976-1978. W 1978 roku władzę w Chinach objął Deng Xiaoping, co zwiastowało rozpoczęcie reform wewnętrznych i stabilizację sceny politycznej w tym kraju. Tym razem Fukuda Takeo, podobnie jak Tanaka Kakuei w 1972 roku, próbował wykorzystać te sprzyjające okoliczności do zwiększenia swoich wpływów w partii.

\section{„Zawieszenie broni” w ,wojnie Kaku-Fuku”}

Fukuda Takeo doszedł do władzy nie dzięki zwycięstwu nad osią Tanaka-Ōhira, ale dzięki ugodzie z tymi dwoma wpływowymi politykami. W listopadzie 1976 roku miał podpisać z Ōhirą Masayoshim tajemne porozumienie. Przyrzekł w nim, iż sprawy wewnątrzpartyjne powierzy w dużym stopniu Ōhirze, oraz że odstąpi mu władzę po dwóch latach rządów ${ }^{171}$. Mając wsparcie osi TanakaŌhira, której zależało na jak najszybszym odsunięciu od władzy „,czystego Mikiego", Fukuda został wyznaczony na nowego przewodniczącego partii na Zgromadzeniu Parlamentarzystów PLD z Obu Izb w grudniu 1976 roku. Nowy „główny nurt” stworzyły wszystkie frakcje, które doprowadziły do upadku gabinetu Mikiego Takeo. Zgodnie z obietnicą, Fukuda mianował Ōhirę sekretarzem generalnym PLD. W międzyczasie partię opuściła mała grupa młodych polityków na czele z Kōno Yōheiem i Tagawą Seiichim, którzy dążyli do gruntownej reformy politycznej, by wyeliminować przyczyny korupcji. Założyli oni oddzielną partię, Nowy Klub Liberalny (Shin Jiyū Kurabu) ${ }^{172}$.

Jako że „główny nurt” Fukudy Takeo był wynikiem chwilowego kompromisu między obozem Fukudy a Tanaki, należały do niego bardzo różnorodne środowiska. Dominowali reprezentanci „głównego nurtu konserwatywnego”, chociaż sam premier wywodził się z dawnej Japońskiej Partii Demokratycznej.

\footnotetext{
${ }^{171}$ Porozumienie zostało zawarte potajemnie w Hotelu Pacific w mieście Shukugawa pod Tokio. Świadkami byli Hori Shigeru, Sonoda Sunao i Suzuki Zenkō. O tym, że zostało rzeczywiście zawarte może świadczyć fakt zmienienia wkrótce długości kadencji przewodniczącego PLD z trzech do dwóch lat. Szerzej na ten temat: Azumane Chimao, Hitoshikarazaru o ureeru. Moto shushō Suzuki Zenkō kaikoroku, Iwate Nippōsha, Morioka 2004, s. 76-77.

${ }^{172}$ Ishikawa Masumi, op.cit., s. 133.
} 
Widać także wyraźną przewagę ,jastrzębi” nad „gołębiami”, szczególnie pod względem ilości frakcji. Mimo że w skład „głównego nurtu” wchodziło aż pięć grup protajwańskich, tylko jedna $\mathrm{z}$ nich była duża i tak naprawdę panowała względna równowaga pomiędzy zwolennikami władz w Pekinie i Tajpej. Premier Fukuda doszedł do władzy dzięki porozumieniu z propekińską osią Tanaka-Ōhira i musiał liczyć się z jej zdaniem w sprawach chińskich.

Tabela 3.3 Rozkład sił pomiędzy frakcjami PLD w okresie rządów Fukudy Takeo w latach 1976-1978.

\begin{tabular}{|l|l|l|}
\hline \multicolumn{2}{|c|}{ Frakcje: } \\
\hline ,głównego nurtu” & poza ,głównym nurtem” & „przeciwnego nurtu” \\
\hline Fukuda (D, J, T) 75 & - & Nakasone (D, J) 45 \\
Tanaka (L, P) 86 & & Miki (D, G, P) 41 \\
Ôhira (L, G, P) 59 & \\
Shiina (D, J, T) 13 & \\
Mizuta (J, T) 13 & \\
Funada (L, J, T) 11 & & \\
Ishii (L, T) 4 & & \\
\hline 261 & 86 \\
L: 4 (160), D: 2 (88), & & \\
G: 1 (59), J: 4 (112), & & \\
P: 2 (145), T: 5 (116). & & \\
\hline
\end{tabular}

L- dawni członkowie Partii Liberalnej, główny nurt konserwatywny, D- dawni członkowie Japońskiej Partii Demokratycznej, boczny nurt konserwatywny, G- gołębie, J- jastrzębie, P- obóz propekiński, T- obóz protajwański.

Liczebność frakcji (podana przy poszczególnych frakcjach) po wyborach do Izby Reprezentantów z grudnia 1976 roku. Uwzględniono członków frakcji z obu izb parlamentu. W podsumowaniu „głównego nurtu” podana jest ogólna liczba należących do niego parlamentarzystów oraz liczba frakcji, zaś w nawiasie liczba parlamentarzystów, należących do poszczególnych obozów.

Opracowanie własne na podstawie: Satō Seizaburō, Matsuzaki Tetsuhisa, op.cit., s. 243; Kitaoka Shin'ichi, op.cit., s. 335.

Co ciekawe, Fukuda Takeo miał podobne doświadczenia związane z Chinami, jak jego oyabun Kishi Nobusuke. Jako biurokrata z Ministerstwa Finansów został wysłany w 1941 roku do Nankinu, aby przez dwa lata pracować w roli doradcy ds. finansów przy kolaboracyjnym rządzie Chin z Wang Jingweiem na czele $^{173}$. Protajwańskie nastawienie Fukudy Takeo, przejęte od Kishiego, było wyraźnie widoczne w czasie piastowania przez niego stanowiska ministra spraw zagranicznych w latach 1971-1972. Fukuda sam podkreśla, że w otoczeniu premiera Satō, w przeciwieństwie do Horiego Shigeru, reprezentował wówczas „ostrożne stanowisko” jeśli chodzi o normalizację stosunków dyplomatycznych

\footnotetext{
${ }^{173}$ Wang Jingwei został szefem marionetkowego projapońskiego rządu w Nankinie w 1940 roku, zaś zmarł w Nagoi w 1944 roku. Fukuda podkreśla, że Wang Jingwei miłował Chiny podobnie, jak stronnictwo Jiang Jieshiego, tylko wybrał inny sposób ratowania ojczyzny. Szerzej na ten temat: Fukuda Takeo, Kaiko 90 nen, Iwanami Shoten, Tokio 1995, s. 48-56.
} 
z ChRL. Wyjaśnia, iż było mu bardzo trudno rozwiązać ten problem ze względu na dwie kwestie: utrzymywanie relacji z reżimem Guomindangu i niepokój o reakcję Związku Radzieckiego. Dlatego też Fukuda przyznaje nie bez nutki zazdrości: „Nawet mi się nie śniło, że Tanaka po zaledwie około dwóch miesiącach od powołania rządu poleci do Pekinu. Myślałem, że najpierw jeszcze trochę popracuje nad przygotowaniem otoczenia, ale Tanaka po prostu tego dokonał. Z jednej strony był zbyt pośpieszny, ale patrząc z szerszej perspektywy można też powiedzieć, iż nurt historii na świecie podążał w tym kierunku, zaś Tanaka go zręcznie uchwycił"174.

Chociaż Fukuda Takeo reprezentował skrzydło protajwańskie, jako przewodniczący jednej z największych frakcji nie mógł sobie pozwolić na jawne akcje wspierania reżimu Guomindangu po zerwaniu z nim oficjalnych stosunków dyplomatycznych w 1972 roku. Do tego służyło mu Seirankai, które działało na korzyść Fukudy, destabilizując wewnątrzpartyjną bazę poparcia rządu Tanaki. Sam Fukuda nie miał równie silnych przekonań antykomunistycznych, jak Kishi Nobusuke $^{175}$. Sam mówił o sobie: „Powiada się, że Fukuda jest jastrzębiem, ale czymże jest jastrząb? Nie znam definicji. W polityce potrzebna jest rezolutna, silna postawa. Jeśli zachowanie silnej postawy wobec trudności oznacza bycie jastrzębiem, to mogę być jastrzębiem. Jeśli zaś oznacza to brak elastyczności i sztywną postawę, to nie jestem jastrzębiem"176. Zostawszy premierem dzięki porozumieniu z propekińskim obozem Tanaki i Ōhiry, Fukuda stanął przed zadaniem zawarcia Traktatu o pokoju i przyjaźni z ChRL. Najpierw jednak musiał zapanować nad protajwańskim środowiskiem w swojej własnej frakcji.

\section{Droga do zawarcia Traktatu o pokoju i przyjaźni z ChRL}

Fukuda Takeo przyznaje: „Od samego początku, od chwili powołania rządu Fukudy uważałem, że trzeba doprowadzić do podpisania Traktu o pokoju i przyjaźni pomiędzy Japonią a Chinami. Nie mogliśmy przy tym zapominać, że nie wolno było spowodować pogorszenia ówczesnych stosunków naszego kraju z ZSRR (...) Na ministra spraw zagranicznych powołałem Hatoyamę Iichirō, najstarszego syna Hatoyamy Ichirō, którego Związek Radziecki uważał za «postać prosowiecką» [w 1956 roku premier Hatoyama Ichirō nawiązał stosunki dyplomatyczne z ZSRR - przyp. aut.]. W ten sposób dałem Związkowi Radzieckiemu sygnał, że podpisanie Traktatu o pokoju i przyjaźni pomiędzy Japonią a Chinami nie ma na celu pogorszenia stosunków z ZSRR"177. Słowa Fukudy pokazują, że kwestia „klauzuli antyhegemonistycznej” nadal stanowiła ważną przeszkodę w rozmowach ze stronach chińską. Hatoyama lichirō

\footnotetext{
${ }^{174}$ Ibidem, s. 203-206.

${ }^{175}$ Honzawa Jirō, Taiwan..., s. 153.

${ }^{176}$ Kiyomiya Ryū, Fukuda seiken 714-nichi, Gyōsei Mondai Kenkyūjo, Tokio 1984, s. 7.

${ }^{177}$ Fukuda Takeo, Kaiko..., s. 227-228.
} 
deklarował gotowość wznowienia rozmów ze stroną chińską ${ }^{178}$, ale postęp w negocjacjach zależał także od postawy władz w Pekinie.

Dopiero gdy w połowie 1977 roku sytuacja na chińskiej scenie politycznej zaczęła się coraz bardziej krystalizować i widać było, że do władzy stopniowo dochodzi umiarkowane skrzydło $\mathrm{KPCh}^{179}$, propekińscy parlamentarzyści z PLD zaczęli wywierać presję na rząd w celu ostatecznego uregulowania kwestii podpisania traktatu z ChRL. W październiku 1977 roku powstała Rada Promocji Japońsko-Chińskiego Traktatu o Pokoju i Przyjaźni (Nitchū Heiwa Yūkō Jōyaku Sokushin Kyōgikai) z Kosaką Zentarō jako przewodniczącym ${ }^{180}$. W tym samym miesiącu do Pekinu udali się Nikaidō Susumu i Gotōda Masaharu. Dwaj wpływowi członkowie frakcji Tanaki podjęli próbę wynegocjowania kompromisowej interpretacji „klauzuli antyhegemonistycznej”181. Jednocześnie działalność nasilił Furui Yoshimi z dawnej grupy Matsumury, odwiedzając dwukrotnie Chiny w latach 1977-1978. Furui podkreślał, że należy przystać na „klauzulę antyhegemonistyczną". Uważał, iż jest ona tak naprawdę korzystna dla Japonii i to Chinom należy dziękować za to, że wyrzekają się dążenia do hegemonii w regionie ${ }^{182}$.

Premier Fukuda zdawał sobie sprawę, iż nie jest w stanie powstrzymać „nurtu historii”. Na konferencji prasowej w listopadzie 1977 roku przyznał, że sytuacja zaczyna powoli sprzyjać wznowieniu negocjacji z ChRL. Jednocześnie wezwał do siebie ambasadora Japonii w Pekinie Satō Shōjiego, który poradził mu, by rozpocząć rozmowy chociażby po to, aby uniknąć wykorzystania kwestii traktatu przez skrzydło propekińskie $\mathrm{w}$ walce politycznej ${ }^{183}$. Rzeczywiście, wkrótce potem przy okazji rekonstrukcji rządu Fukuda zastąpił na stanowisku ministra spraw zagranicznych Hatoyamę Iichirō znanym z poglądów propekińskich Sonodą Sunao z własnej frakcji ${ }^{184}$. Sonoda wywodził się z dawnej grupy Kōno. Na przełomie lat 60. i 70. XX wieku przewodził jednej z mniejszych frakcji w PLD, by w 1972 roku dołączyć do grupy Fukudy. Z tego powodu był nietypowym, propekińskim członkiem tej tradycyjnie protajwańskiej frakcji. Sonoda od dawna utrzymywał dobre relacje z ChRL. Już

\footnotetext{
${ }^{178}$ Tsuisō. Hatoyama Iichirō pod red. Hatoyama Kaikan, Kadokawa Shoten, Tokio 1996, s. 210211.

${ }^{179}$ W lipcu 1977 roku Deng Xiaoping został przywrócony do władzy jako wicepremier i wiceprzewodniczący KPCh. Próbował forsować ogłoszony jeszcze w 1975 roku przez Zhou Enlaia program „,czterech modernizacji”: rolnictwa, przemysłu, obrony narodowej oraz nauki i techniki. Jednakże dopiero w 1978 roku poglądy Deng Xiaopinga przeważyły w KPCh. Szerzej na ten temat: Sadako Ogata, op.cit., s. 86; Alan Lawrance, op.cit., s. 95-102.

${ }^{180}$ Zhong-Ri guanxi 30 nian..., s. 88.

${ }^{181}$ Gotōda Masaharu, Mikuriya Takashi, Jō to ri-Kamisori Gotōda kaikoroku, t. 1, Kōdansha, Tokio 2006, s. 406-413.

${ }^{182}$ Furui Yoshimi, Furui Yoshimi..., s. 271.

${ }^{183}$ Sadako Ogata, op.cit., s. 86-87.

${ }^{184}$ Guan Ying, op.cit., s. 136.
} 
w 1954 roku jako młody poseł Partii Reform udał się do Chin komunistycznych razem z takimi parlamentarzystami, jak Nakasone Yasuhiro czy Sakurauchi Yoshio ${ }^{185}$. Doszedł wówczas do wniosku, że większość Chińczyków nie rozumie komunizmu, zaś Chin nie należy postrzegać poprzez pryzmat podziałów ideologicznych. Odtąd poświęcił się promocji japońsko-chińskiego handlu pozarządowego i idei normalizacji stosunków bilateralnych ${ }^{186}$. Nic dziwnego, że po nominacji na stanowisko ministra spraw zagranicznych z pełną energią zabrał się do negocjacji Traktatu o pokoju i przyjaźni z ChRL.

W przemówieniu w parlamencie pod koniec stycznia 1978 roku premier znów wyraził gotowość do podjęcia rozmów ze stroną chińską. Negocjacje rzeczywiście wznowiono w lutym 1978 roku $^{187}$. Pod koniec marca 1978 roku Fukuda naradził się z kluczowymi członkami swojego gabinetu w sprawie interpretacji „klauzuli antyhegemonistycznej”, m.in. z ministrem Sonodą Sunao i sekretarzem gabinetu Abe Shintarō. Wkrótce też poprosił sekretarza generalnego PLD Ōhirę Masayoshiego o wypracowanie konsensusu w partii na temat Traktatu o pokoju i przyjaźni z ChRL ${ }^{188}$. Jednym z powodów zdecydowania się Fukudy Takeo na ten krok były przygotowania do następnych wyborów na przewodniczącego PLD. Wbrew umowie z 1976 roku premier snuł plany pozostania na stanowisku na następną kadencję. Ponieważ zaś właśnie wprowadzono system prawyborów na przewodniczącego PLD wśród wszystkich członków i sympatyków partii, popularność kandydatów wśród szerokich mas społecznych miała odegrać większą rolę niż przy dotychczasowych elekcjach. Na początku rządów Fukuda cieszył się niskim poparciem opinii publicznej, która miała mu za złe obalenie gabinetu „czystego” Mikiego ${ }^{189}$. Sukces dyplomatyczny, jakim niewątpliwie byłoby zawarcie układu z ChRL, miał wzmocnić wizerunek Fukudy Takeo jako skutecznego polityka i tym samym zwiększyć jego szanse na utrzymanie się u władzy ${ }^{190}$. Według Kōno Kenzō, Fukuda chciał zetrzeć z siebie przed wyborami wizerunek ,jastrzębia" ${ }^{191}$. Również zmiana postawy Stanów Zjednoczonych wobec Chin miała znaczenie. Nowa administracja prezydenta Jamesa Cartera, zawiedziona brakiem większego postępu w odprężeniu stosunków z ZSRR, zaczęła coraz bardziej zdecydowanie dążyć do normalizacji relacji dyplomatycznych z ChRL. Poza tym Japonia nie uzyskała od Związku Radzieckiego żadnych ustępstw w sprawie Terytoriów Północnych ${ }^{192}$.

\footnotetext{
${ }^{185}$ Zhong-Ri guanxi 30 nian..., s. 5; Liu Deyou, Toki wa..., t. 1., s. 90.

${ }^{186}$ Sonoda Sunao, Sekai Nihon ai, Dai San Seikei Kenkyūkai, Tokio 1981, s. 18-55.

${ }^{187}$ Ibidem, s. 179-180.

${ }^{188}$ Sadako Ogata, op.cit., s. 87-88.

${ }^{189}$ Marugame Hiroaki, op.cit., s. 125-132.

${ }^{190}$ Robert Jakimowicz, Stosunki japońsko-chińskie $w$ latach 1949-2002. Aspekty polityczne $i$ gospodarcze, Wydawnictwo Akademii Ekonomicznej w Krakowie, Kraków 2004, s. 108.

${ }^{191}$ Kōno Kenzō, op.cit., s. 114.

${ }^{192}$ Guan Ying, op.cit., s. 136.
} 
Premier musiał jednak postępować $\mathrm{z}$ niezwykłą ostrożnością, aby nie spowodować nadmiernych protestów najbardziej radykalnych zwolenników reżimu Guomindangu w PLD, w tym w swojej frakcji. W przeciwieństwie do starającego się prowadzić realistyczną dyplomację Fukudy Takeo, członkowie Seirankai nie zważali na rację stanu i nie zgadzali się na jakikolwiek kompromis w sprawie statusu Tajwanu. O ile byli przydatni w latach 1972-1974, kiedy Fukuda otwarcie walczył z premierem Tanaką, o tyle ostrze ich krytyki mogło w każdej chwili skierować się przeciwko ich dotychczasowemu patronowi. Aby uniemożliwić zawarcie Traktatu o pokoju i przyjaźni z ChRL, skrzydło protajwańskie posłużyło się nieuregulowaną do tej pory kwestią spornego z Chinami archipelagu Senkaku/Diaoyutai. W dniu 23 marca 1978 roku w odpowiedzi na interpelację Tamakiego Kazuo, jednego z czołowych polityków Seirankai, rzecznik japońskiego rządu powiedział: „Japonia kontroluje wyspy [Senkaku/Diaoyutai] na Morzu Wschodniochińskim i nie widzi żadnej potrzeby dyskusji na temat ich przynależności z jakimkolwiek innym krajem. Rząd odrzucił chińskie roszczenia do tych wysp jako bezzasadne" ${ }^{193}$. Słowa te świadczyły, iż gabinet Fukudy Takeo nie zamierzał forsować ostatecznego rozstrzygnięcia sporu terytorialnego w Traktacie o pokoju i przyjaźni. Przeciwnicy układu natychmiast wykorzystali sprawę wysp Senkaku/Diaoyutai do mobilizacji poparcia wśród parlamentarzystów i krytyki rządu. Pod koniec marca 1978 roku Stowarzyszenie Badań Problemów Azji ogłosiło swoje stanowisko $\mathrm{w}$ sprawie negocjacji z Chinami, podkreślając negatywny wpływ ewentualnego zawarcia Traktatu o pokoju i przyjaźni na relacje ze Związkiem Radzieckim i na zwierzchnictwo Japonii nad wyspami Senkaku/Diaoyutai ${ }^{194}$. Również przewodniczący Seirankai, minister rolnictwa i leśnictwa Nakagawa Ichirō, zwrócił uwagę na potrzebę poruszenia kwestii spornego archipelagu przy okazji rozmów z ChRL. Tego samego domagała się na początku kwietnia 1978 roku grupa stu deputowanych z PLD podczas spotkania z ministrem spraw zagranicznych Sonodą Sunao ${ }^{195}$.

Swoim zachowaniem członkowie Seirankai sprowokowali stronę chińską do drastycznego kroku, który wzmógł napięcie w stosunkach chińsko-japońskich. W dniu 12 kwietnia 1978 roku na wody wokół archipelagu Senkaku/Diaoyutai wpłynęła prawdziwa flotylla ponad 80 chińskich kutrów rybackich. Statki krążyły w okolicy wysp przez przynajmniej kilka dni, chociaż już raczej poza japońskimi wodami terytorialnymi, zaś ich liczba zmieniała się w czasie. W dniu 17 kwietnia 1978 roku było ich aż około $140^{196}$. Załogi kutrów, które pochodziły

\footnotetext{
${ }^{193}$ Daniel Tretiak, The Sino-Japanese Treaty of 1978: The Senkaku Incident Prelude, „Asian Survey" 1978, vol. 18, no. 12, s. 1241.

${ }^{194}$ Lin Jinjing, op.cit., s. 447-448.

195 Jan Rowiński, Morze Wschodniochińskie: region potencjalnego konfliktu w Azji, PISM (wydane na prawach rękopisu), Warszawa 1990, s. 35.

${ }^{196}$ Daniel Tretiak, op.cit., s. 1244.
} 
z Szanghaju, Tianjinu, Qingdao, Fuzhou i Kantonu, były uzbrojone, w tym w karabiny maszynowe, zaś całą akcją kierowali wojskowi. W odpowiedzi na żądania japońskiej straży przybrzeżnej, aby odpłynąć, Chińczycy wystawili transparenty, głoszące, że wyspy Senkaku/Diaoyutai należą do ChRL ${ }^{197}$. Japoński rząd musiał stanowczo odpowiedzieć na to bezprecedensowe zdarzenie. Minister spraw zagranicznych Sonoda Sunao zawiesił rozmowy w sprawie Traktatu o pokoju i przyjaźni do czasu wyjaśnienia okoliczności incydentu. Było to zbieżne $\mathrm{z}$ dążeniami japońskich polityków protajwańskich, którzy wykorzystując kryzys pragnęli zablokować zawarcie układu. Prawe skrzydło PLD zażądało wstrzymania negocjacji dopóki ChRL nie zaakceptuje przynależności archipelagu do Japonii ${ }^{198}$. Głównym celem krytyki Seirankai po raz kolejny stał się Ōhira Masayoshi. Prawe skrzydło PLD oskarżało go o zawarcie w 1972 roku potajemnego porozumienia z władzami w Pekinie na temat odłożenia na przyszłość sporu o bezludny archipelag ${ }^{199}$.

Widząc, że kryzys dyplomatyczny może uniemożliwić szybkie podpisanie traktatu pokojowego z Japonią, rząd w Pekinie przyjął jednak pojednawczą postawę. Przyrzekł m.in., iż przeprowadzi śledztwo w sprawie incydentu ${ }^{200}$. Rzeczywiście, wkrótce ujawniono, że operacja na wodach wokół wysp Senkaku/Diaoyutai została zorganizowana przez grupę z Szanghajskiego Komitetu Rewolucyjnego. Poinformowano także, iż w Pekinie aresztowano czterech inspiratorów akcji ${ }^{201}$. Z kolei pod koniec kwietnia 1978 roku prezes Towarzystwa Przyjaźni Chińsko-Japońskiej i wiceprzewodniczący Stałego Komitetu Ogólnochińskiego Zgromadzenia Przedstawicieli Ludowych Liao Chengzhi powiedział, że decydenci ChRL dopilnują, aby tego rodzaju wypadki się nie powtórzyły $\mathrm{w}$ przyszłości ${ }^{202}$. Chińskie zapewnienia o dobrej woli pozwoliły premierowi Fukudzie Takeo „wyjść z twarzą” z kryzysu i myśleć o powrocie do negocjacji w sprawie Traktatu o pokoju i przyjaźni. Na dodatek na początku maja 1978 roku prezydent USA James Carter wyraził w rozmowie z Fukudą wsparcie dla idei podpisania japońsko-chińskiego porozumienia ${ }^{203}$. Już 10 maja 1978 roku japoński ambasador w Pekinie Satō Shōji osiągnął porozumienie $\mathrm{z}$ wiceministrem spraw zagranicznych Han Nianlongiem, polegające na odłożeniu na później kwestii spornego archipelagu ${ }^{204}$.

\footnotetext{
${ }^{197}$ Jan Rowiński, Morze Wschodniochińskie..., s. 35-38.

${ }^{198}$ Robert Jakimowicz, Stosunki japońsko-chińskie..., s. 114-115.

${ }^{199}$ Itō Masaya, Jimintō sengokushi..., s. 365-374.

${ }^{200}$ Jan Rowiński, Morze Wschodniochińskie..., s. 37.

${ }^{201}$ Maria Fedorova, The Roots of Sino-Japanese Differences over the Senkaku (Diaoyudao) Islands, ,Far Eastern Affairs” 2005, vol. 33, no. 1, s. 122.

${ }^{202}$ K. T. Chao, East China Sea: Boundary Problems Relating to the Tiao-yu-t'ai Islands, „Chinese Yearbook of International Law and Affairs" 1982, vol. 2, s. 74.

${ }^{203}$ Kiyomiya Ryū, op.cit., s. 179.

${ }^{204}$ Robert Jakimowicz, Stosunki japońsko-chińskie..., s. 115-116.
} 
Członkowie Seirankai nie chcieli jednak ustąpić i do samego końca sprzeciwiali się wznowieniu negocjacji w sprawie traktatu ${ }^{205}$. Aby uspokoić nastroje skrzydła protajwańskiego, Fukuda uciekł się do podobnej metody, jaką zastosował w 1972 roku Tanaka Kakuei - pozwolił jego członkom „wyładować złe emocje" na posiedzeniach wewnątrzpartyjnych. Na spotkaniu Rady Generalnej PLD pod koniec maja 1978 roku politycy blisko związani z reżimem Guomindangu mieli okazję zasygnalizować swoje zaniepokojenie w sprawie Traktatu o pokoju i przyjaźni z ChRL. W końcu zgodzono się na kompromis zaproponowany przez Nakasone Yasuhiro. Uchwalono, iż zawarcie układu z władzami w Pekinie musi się opierać na dwóch zasadach. Według pierwszej z nich Japonia nie mogła być zamieszana w konflikt chińsko-sowiecki. Z kolei zgodnie $\mathrm{z}$ drugą Japonia powinna prowadzić politykę obrony bezpieczeństwa narodowego oraz pokoju i stabilności w Azji, jak też utrzymać swoje prawa terytorialne. Dzięki temu 31 maja 1978 roku rząd w Tokio mógł przekazać stronie chińskiej informację o gotowości do wznowienia negocjacji ${ }^{206}$.

W lipcu 1978 roku rzeczywiście ponownie podjęto rozmowy z ChRL na temat układu, które zakończyły się osiągnięciem kompromisu w sprawie kształtu „klauzuli antyhegemonistycznej" ${ }^{207}$. Tuż przed finalizacją negocjacji protajwańscy politycy z PLD starali się jeszcze raz przeforsować swoje stanowisko na temat archipelagu Senkaku/Diaoyutai, jednak bezskutecznie. Fukuda Takeo wspomina: „Pomiędzy wznowieniem rozmów na poziomie urzędniczym 2 lutego 1978 roku a sierpniową wizytą w Chinach ministra spraw zagranicznych Sonody Sunao, wewnątrz PLD odbyły się narady na każdym poziomie i została wyczerpana dyskusja, przede wszystkim na temat klauzuli antyhegemonistycznej. Jednakże wśród tak zwanej ostrożnej frakcji było wielu ludzi związanych ze mną więzami głębokiej przyjaźni, jak Nadao Hirokichi, Machimura Kingo czy Fujio Masayuki. Byli to ludzie, którzy dzielili ze mną szczęścia i troski przez długi okres działalności politycznej. Dzięki temu wierzyłem, że ostatecznie podporządkują się mojej decyzji i rzeczywiście tak się stało, choć nikt nie wie, jak musiałem się namęczyć, zanim moje starania zakończyły się sukcesem. Dlatego też mam poczucie dumy, że beze mnie te negocjacje byłyby niewykonalne $" 208$.

Sonoda Sunao podkreśla, iż rozważał podanie się do dymisji, jeśli premier nie zgodzi się na jego wyjazd do ChRL w celu zawarcia traktatu pokojowego ${ }^{209}$.

\footnotetext{
${ }^{205}$ Kiyomiya Ryū, op.cit., s. 214-215.

${ }^{206}$ Sadako Ogata, op.cit., s. 99.

${ }^{207}$ Do ostatecznej wersji tekstu traktatu dodano na prośbę japońską m.in. artykuł 4, mający osłabić wymowę „klauzuli antyhegemonistycznej”. Brzmiał on: „Niniejszy traktat nie wpływa na stanowisko żadnego z państw sygnatariuszy w sprawie stosunków z państwami trzecimi”. Źródło: Nihonkoku to Chūka Jinmin Kyōwakoku to no aida no heiwa yūkō jōyaku z 12 VIII 1978 [w:] Nitchū kankei kihon..., s. 514-516.

${ }^{208}$ Fukuda Takeo, Kaiko..., s. 301.

${ }^{209}$ Sonoda Sunao, op.cit., s. 182.
} 
Obawy ministra spraw zagranicznych nie sprawdziły się. Jeden z ówczesnych członków frakcji Fukudy, przyszły szef rządu Mori Yoshirō, wspomina, iż premier wezwał go nagle do siebie na początku sierpnia 1978 roku. Zakomunikował mu wówczas, że postanowił wysłać ministra Sonodę do ChRL w celu podpisania Traktatu o pokoju i przyjaźni z Chinami. Powierzył także Moriemu zadanie wykonania telefonów do wszystkich członków stronnictwa protajwańskiego, aby ich powiadomić o swojej decyzji. Mori przyznaje: „Osoby z obozu jastrzębi, choć były niezadowolone, odpowiedziały, że skoro tak postanowił Pan Fukuda, to nie ma wyjścia" ${ }^{210}$. Według Moriego, premier zdecydował się na zawarcie traktatu głównie ze względu na narastające poczucie zagrożenia ze strony ZSRR, podkreślane przez administrację prezydenta USA Jamesa Cartera. Żegnając delegację japońską, Fukuda miał jednak upomnieć ministra Sonodę, by wyraźnie zaznaczył w rozmowach ze stroną chińską, iż ChRL w Japonii nie może prowadzić działalności politycznej, wykorzystując ruchy antyrządowe ${ }^{211}$.

Ostatecznie chińsko-japoński Traktat o pokoju i przyjaźni został podpisany w Pekinie 12 sierpnia 1978 roku przez ministrów spraw zagranicznych Sonodę Sonao i Huang Hua. Wbrew dążeniom skrzydła protajwańskiego w PLD, umowa nie zawierała żadnych uregulowań dotyczących wysp Senkaku/ Diaoyutai. Mimo to w połowie października 1978 roku traktat został zatwierdzony przez obie izby japońskiego parlamentu. Przeciwko głosowali m.in. Hamada Kōichi i Tamaki Kazuo z Seirankai ${ }^{212}$. Jak zauważył Hosoya Chihiro, Traktat o pokoju i przyjaźni stanowił ważny zwrot $\mathrm{w}$ japońskiej polityce zagranicznej. Władze w Tokio porzuciły „dyplomację równych odległości” (tōkyori gaikō) w kontaktach z ChRL i ZSRR, by wyraźnie opowiedzieć się za pogłębieniem relacji z Chinami ${ }^{213}$. W celu wymiany dokumentów ratyfikacyjnych Japonię odwiedził pod koniec października 1978 roku chiński wicepremier Deng Xiaoping. Była to pierwsza w historii wizyta w Japonii tak ważnego polityka z ChRL. Deng spotkał się nie tylko z premierem Fukudą, ale także z cesarzem Hirohito. Prasa zwróciła uwagę na ówczesną deklarację Deng Xiaopinga, by „odłożyć przyszłym pokoleniom” rozwiązanie sporu o wyspy Senkaku/Diaoyutai ${ }^{214}$.

Osiągnąwszy znaczący sukces dyplomatyczny, Fukuda Takeo spokojnie czekał na grudniowe wybory na przewodniczącego PLD. Oś Tanaka-Ōhira była w stanie pozyskać większość parlamentarzystów w partii, jednak premier spodziewał się, iż dzięki sprawnemu załatwieniu sprawy traktatu pokojowego z

\footnotetext{
${ }^{210}$ Mori Yoshirō. Jimintō..., s. 52.

${ }^{211}$ Ibidem, s. 54-56.

${ }^{212}$ Lin Jinjing, op.cit., s. 454.

${ }^{213}$ Hosoya Chihiro, Nihon gaikō no zahyō, Chūō Kōronsha, Tokio 1979, s. 232-233.

${ }^{214}$ Shimada Masao, Tian Jianong, Sengo nitchū kankei 50 nen - Nitchū sōhō no kadai wa hatasaretaka, Tōhō Shoten, Tokio 1997, s. 332-334.
} 
ChRL, to on odniesie zdecydowane zwycięstwo w prawyborach ${ }^{215}$. Dlatego też środowisko związane z Fukudą Takeo zaczęło nawoływać, aby kandydat, który przegra prawybory wycofał się z rywalizacji. Ōhira starał się marginalizować dokonania premiera na polu dyplomacji. Podkreślał, że Traktat o pokoju i przyjaźni z ChRL był jedynie naturalną kontynuacją Wspólnej deklaracji z 1972 roku $^{216}$. Ostatecznie Ōhira Masayoshi uzyskał bezwzględne wsparcie Tanaki Kakueia i wygrał prawybory. Aby zachować twarz, premier Fukuda musiał przekazać władzę swojemu oponentowi ${ }^{217}$.

$$
* * *
$$

„Główny nurt” Fukudy Takeo był wynikiem czasowej ugody w „wojnie KakuFuku" i od początku charakteryzował się względną równowagą wpływów frakcji protajwańskich i propekińskich. Sam premier, chociaż związany z obozem wspierającym reżim Guomindangu, starał się prowadzić realistyczną politykę zagraniczną. Zawarcie Traktatu o pokoju i przyjaźni z ChRL leżało w interesie Japonii, więc uporawszy się ze sprzeciwem wewnątrz własnej frakcji Fukuda przeforsował podpisanie porozumienia $\mathrm{z}$ rządem w Pekinie. Zresztą dzięki sukcesowi dyplomatycznemu premier mógł liczyć na zwiększenie swojej popularności wśród społeczeństwa i zwycięstwo nad Ōhirą Masayoshim w zbliżających się wyborach. Tak naprawdę więc również i tym razem sprawa chińska stała się narzędziem w „wojnie Kaku-Fuku”.

\section{ÖHIRA MASAYOSHI (1978-1980)}

Rządy Ōhiry Masayoshiego były zwieńczeniem zapoczątkowanego w 1972 roku procesu ocieplenia w stosunkach japońsko-chińskich. W przeciwieństwie do Fukudy, Ōhira należał do obozu propekińskiego w PLD, inaczej niż Tanaka był

\footnotetext{
${ }^{215}$ Itō Masaya, Jimintō sengokushi..., s. 396.

216 „Nitchū” teiketsu wa shushō no honruida? Kaisan fü ga shidai ni yowamaru kehai mo, „Nikkei Business” z 28 VIII 1978, s. 51.

217 Wybory przewodniczącego PLD wśród wszystkich członków i sympatyków partii były elementem reformy wewnątrzpartyjnej, postulowanej jeszcze przez Mikiego Takeo. Prawo głosu mieli wszyscy członkowie PLD, którzy od 2 lat płacili składkę 1,5 tys. jenów oraz ci spośród sympatyków partii (członków Liberalnego Zgromadzenia Ludowego, Jiyū Kokumin Kaigi), którzy do trzech miesięcy przed wyborami wpłacili 10 tys. jenów. Dwóch kandydatów, którzy uzyskali najwięcej głosów, miało przejść do drugiej tury wyborów. Spodziewano się, że dzięki temu pomiędzy kandydatami rozgorzeje rzeczywista debata programowa i wybór nie będzie tylko kwestią strategicznego układu między frakcjami. Okazało się jednak, że efekt prawyborów był odwrotny od zamierzonego. Poszczególne frakcje zwiększyły wysiłki w celu rekrutacji nowych sympatyków partii, do czego potrzebne były ogromne fundusze. Ponieważ zaś najlepsze kontakty ze światem biznesu posiadał Tanaka Kakuei, zwyciężył wspierany przez niego Ōhira Masayoshi. W ten sposób zmiana sposobu wybierania przewodniczącego PLD tylko rozszerzyła wpływy frakcji wśród szeregowych członków partii i pogłębiła ,politykę pieniądza”. Szerzej na ten temat: Iyasu Tadashi, Seitō..., s. 287-288.
} 
jego członkiem na długo przed 1972 rokiem, z kolei sytuacja międzynarodowa w okresie jego rządów bardziej sprzyjała bliskiej współpracy z ChRL niż za kadencji Mikiego. Na lata 1978-1980 przypadł jednak punkt kulminacyjny „wojny Kaku-Fuku” i propekińska „oś władzy” Tanaka-Ōhira stała się celem zaciekłych ataków ze strony frakcji ,przeciwnego nurtu”, w dużym stopniu złożonych z polityków protajwańskich.

\section{Wznowienie wojny ,Kaku-Fuku”}

Wraz ze zbliżaniem się końca kadencji Fukudy Takeo stało się jasne, że dwuletnie „Zawieszenie broni” w „wojnie Kaku-Fuku” dobiegło końca. Obie strony miały powody do wzajemnego obwiniania się. Według obozu Tanaki i Ōhiry, nie chcąc oddać władzy Fukuda złamał przysięgę daną w 1976 roku, zaś według obozu Fukudy, Ōhira zwyciężył w prawyborach tylko dzięki ,polityce pieniądza”. Tymczasem poparcie dla PLD wśród społeczeństwa spadało. Niemal dwuletnie rządy Ōhiry miały być ciągiem starć pomiędzy obozem Tanaki i Fukudy. Fukudę Takeo wspierała m.in. protajwańska frakcja Nakagawy Ichirō. Powstała ona w maju 1979 roku na bazie członków Seirankai ${ }^{218}$. Zrzeszała m.in. polityków z dawnej frakcji Mizuty, która niedługo wcześniej przestała istnieć. Podobny los spotkał frakcje innych polityków przedwojennych: Ishiiego, Shiiny i Funady, którzy z powodu starości musieli usunąc się z polityki ${ }^{219}$.

„Główny nurt” Ōhiry składał się jedynie z dwóch dużych frakcji „głównego nurtu konserwatywnego". Dzięki temu był bardzo spójny ideologicznie. Reprezentował umiarkowane, centro-lewicowe skrzydło PLD, nastawione na pogłębianie współpracy z Chinami. Ōhira utrzymał nawet na stanowisku ministra spraw zagranicznych członka frakcji Fukudy, Sonodę Sunao, doceniając jego rolę w negocjacjach Traktatu o pokoju i przyjaźni z ChRL ${ }^{220}$. Z drugiej strony, podstawa rządów Ōhiry była bardzo niestabilna. Frakcje „przeciwnego nurtu” łącznie posiadały większą liczbę parlamentarzystów niż dwufrakcyjna „oś władzy” i premier musiał się opierać na wsparciu posłów bezfrakcyjnych, by zachować wątłą równowagę wewnątrzpartyjną. Politycy

\footnotetext{
218 „Nakagawa-ha” kyō hata age, „Asahi Shinbun” z 15 V 1979, s. 2.

${ }^{219}$ Według Tominomoriego Eijiego, przyczyną zaniku małych frakcji w 1978 roku było także wprowadzenie systemu prawyborów. Dotychczas ważnym źródłem utrzymania tych grup były środki finansowe otrzymywane od szefów większych frakcji przy okazji wyborów na stanowisko przewodniczącego PLD. Kiedy elekcja Ōhiry została rozstrzygnięta na poziomie szeregowych członków partii, łapówki te straciły sens, podważając też cel istnienia małych frakcji. Szerzej na ten temat: Tominomori Eiji, op.cit., s. 265-266.

${ }^{220}$ Jeden z ówczesnych członków frakcji Fukudy, Mori Yoshirō, twierdzi, że Sonoda nawiązał nić porozumienia z Ōhirą jeszcze za kadencji Fukudy. Według Moriego, Sonoda miał za złe Fukudzie, że ten uczynił go w 1977 roku ministrem spraw zagranicznych zamiast utrzymać na stanowisku sekretarza gabinetu, które przeznaczył dla Abe Shintarō. Sonoda miał specjalnie promować zawarcie Traktatu o pokoju i przyjaźni z ChRL, by móc zostać członkiem rządu także po spodziewanym odstąpieniu stanowiska premiera przez Fukudę propekińskiemu Ōhirze. Szerzej na ten temat: Mori Yoshirō. Jimintō..., s. 47-51.
} 
„przeciwnego nurtu” od samego początku czekali tylko na okazję, aby przywrócić rządy Fukudy Takeo.

Tabela 3.4 Rozkład sił pomiędzy frakcjami PLD w okresie rządów Ōhiry Masyoshiego w latach 1978-1980.

\begin{tabular}{|l|l|l|}
\hline \multicolumn{2}{|c|}{ Frakcje: } \\
\hline ,głównego nurtu” & poza ,głównym nurtem” & ,przeciwnego nurtu” \\
\hline Tanaka (L, P) 85 & - & Fukuda (D, J, T) 75 \\
Ōhira (L, G, P) 70 & & Nakasone (D, J) 48 \\
& & Miki (D, G, P) 42 \\
& & Nakagawa (J, T) 10 \\
\hline 155 & - & 175 \\
L: 2 (155), D: 0, & & \\
G: $\mathbf{1}(\mathbf{7 0})$, J: 0, & & \\
P: 2 (155), T: 0. & & \\
\hline
\end{tabular}

L- dawni członkowie Partii Liberalnej, główny nurt konserwatywny, D- dawni członkowie Japońskiej Partii Demokratycznej, boczny nurt konserwatywny, G- gołębie, J- jastrzębie, P- obóz propekiński, T- obóz protajwański.

Liczebność frakcji (podana przy poszczególnych frakcjach) po wyborach do Izby Reprezentantów z października 1979 roku. Uwzględniono członków frakcji z obu izb parlamentu. W podsumowaniu „głównego nurtu” podana jest ogólna liczba należących do niego parlamentarzystów oraz liczba frakcji, zaś w nawiasie liczba parlamentarzystów, należących do poszczególnych obozów.

Opracowanie własne na podstawie: Satō Seizaburō, Matsuzaki Tetsuhisa, op.cit., s. 243; Kitaoka Shin'ichi, op.cit., s. 335.

Ōhira Masayoshi był godnym kontynuatorem polityki Ikedy Hayato. Jako dawny biurokrata Ministerstwa Finansów Ōhira podporządkował dyplomację interesom gospodarczym kraju ${ }^{221}$. Od wielu lat należał do grona najbardziej aktywnych promotorów stosunków z Chinami komunistycznymi. Wystarczy wspomnieć tylko, że jako sekretarz gabinetu Ikedy, minister spraw zagranicznych w rządach Ikedy i Tanaki, a także sekretarz generalny PLD za kadencji Fukudy, przyczynił się do licznych przełomów w relacjach z ChRL. Był również ulubionym celem krytyki stronnictwa protajwańskiego. Według $\mathrm{Liu} \mathrm{Li,} \mathrm{u}$ podstaw propekińskości Ōhiry leżało pięć przyczyn. Po pierwsze, był on wychowany $\mathrm{w}$ atmosferze poszanowania dla chińskiej kultury. Po drugie, potrafił spojrzeć na ChRL bez uprzedzeń ideologicznych i w miarę obiektywnie ocenić sytuację panującą w tym kraju. Po trzecie, zdawał sobie sprawę, iż przyjazne stosunki z Chinami są konieczne dla rozwoju Japonii i stabilności w regionie. Po czwarte, szczerze żałował za zbrodnie popełnione przez Japonię w erze militaryzmu i pragnął im zadośćuczynić. Po piąte wreszcie, umiał uchwycić nastroje społeczne i przyznać, że normalizacja stosunków dyplomatycznych z

${ }^{221}$ Morita Hajime, Arai Shunzō, op.cit., s. 201-202. 
ChRL jest koniecznością historyczną 222. Z kolei zięć Ōhiry, Morita Hajime, podkreśla, że Ōhira Masayoshi nie opierał swoich decyzji na żadnej ideologii, ani nie był typem polityka narzucającego swoją wolę narodowi. Jeśli jednak wierzył, że ma rację, potrafił zaskakująco twardo trzymać się własnego zdania. Jedną z takich wyjątkowych kwestii miała być sprawa chińska ${ }^{223}$.

Polityka Ōhiry Masayoshiego wobec Chin była częścią jego szerszej wizji japońskiej linii dyplomatycznej. Jako doświadczony dyplomata Ōhira zdawał sobie sprawę z faktu, że stawszy się drugim na świecie mocarstwem gospodarczym ${ }^{224}$, Japonia powinna przewartościować swoją politykę zagraniczną. Już po „szoku Nixona” w 1971 roku zadeklarował, iż razem z osiągnięciem przez Japonię wysokiego poziomu rozwoju gospodarczego oraz, co za tym idzie, relatywnym osłabieniem potęgi Stanów Zjednoczonych, władze w Tokio muszą odgrywać bardziej aktywną rolę na arenie międzynarodowej. Według Ōhiry Japonia miała się wręcz stać główną siłą przewodnią systemu współpracy w Azji Wschodniej. Przyjazne stosunki z Chinami odgrywały w tej wizji kluczową rolę ${ }^{225}$.

W 1978 roku Ōhira ogłosił „strategię ogólnego bezpieczeństwa” (sōgō anzen hoshō senryaku), którą wypracował razem z biurokratami i ludźmi nauki. Zakładała ona konieczność redefinicji wąskiego rozumienia bezpieczeństwa Japonii, postrzeganego dotychczas niemal wyłącznie przez pryzmat sojuszu militarnego z USA, i położenie większego nacisku na współpracę, w tym z krajami rozwijającymi się, w dziedzinie gospodarki, edukacji czy kultury ${ }^{226}$. Będąc doświadczonym dyplomatą Ōhira Masayoshi zdawał sobie sprawę z tego, że tradycyjne rozumienie bezpieczeństwa nie wystarcza $w$ dobie narastania międzynarodowych współzależności gospodarczych. Jak podkreśla Igarashi Akio, „strategia ogólnego bezpieczeństwa” stanowiła po 1945 roku niemal jedyny przykład aktywnego poszukiwania własnej wizji polityki bezpieczeństwa przez zazwyczaj bierną w tej sferze Japonię ${ }^{227}$. Fakt, że jej głównym inicjatorem

\footnotetext{
${ }^{222}$ Liu Li, Daping Zhengfang yu dangdai Zhong-Ri guanxi, „Dongbeiya Luntan” 1999, nr 3, s. 21 23.

${ }^{223}$ Morita Hajime, op.cit., s. 107-112.

224 Pod koniec lat 60. XX wieku PKB Japonii przewyższył PKB każdego z państw zachodnioeuropejskich, co zagwarantowało Japonii drugą po Stanach Zjednoczonych pozycję w świecie. Dopiero w 2010 roku Japonia została pod tym względem prześcignięta przez ChRL.

${ }^{225}$ Yan Shengyi, Dangdai Zhongguo waijiao, Fudan Daxue Chubanshe, Szanghaj 2009, s. 264265.

${ }^{226}$ Ōhira Masayoshi, Ōhira Masayoshi kaisōroku..., s. 282; Karol Zakowski, Kōchikai of the Japanese Liberal Democratic Party and Its Evolution After the Cold War, „The Korean Journal of International Studies" 2011, vol. 9, no. 2, s. 185-186.

${ }^{227} \mathrm{Z}$ powodu wzrostu napięcia $\mathrm{w}$ relacjach amerykańsko-radzieckich po inwazji ZSRR na Afganistan w 1979 roku, w latach 80. XX wieku w japońskiej polityce bezpieczeństwa ponownie podkreślono znaczenie militarnego sojuszu z USA, łagodząc wymowę „strategii ogólnego bezpieczeństwa”. Szerzej na ten temat: Igarashi Akio, Nihon seijiron, Iwanami Shoten, Tokio 2011, s. 212-215.
} 
był Ōhira Masayoshi świadczył o tym, że różnił się on od zdecydowanej większości japońskich polityków, którzy zaabsorbowani problemami wewnątrzkrajowymi poświęcali zazwyczaj mało czasu tworzeniu dalekosiężnych strategii mających determinować politykę Japonii na arenie międzynarodowej.

\section{Sprawa chińska na tle „,starcia czterdziestodniowego” i ,wyborów happeningowych"}

Zawarcie Traktatu o pokoju i przyjaźni z ChRL w 1978 roku usunęło główne źródło sporu pomiędzy obozem propekińskim a protajwańskim w PLD ${ }^{228}$. Posłowie związani z reżimem Guomindangu nadal utrzymywali bliskie kontakty $\mathrm{z}$ władzami w Tajpej ${ }^{229}$, ale kwestia statusu Tajwanu przestała być przedmiotem obrad organów decyzyjnych PLD. Tuż po objęciu stanowiska premiera, Ōhira rozpoczął starania o pogłębienie współpracy gospodarczej z Chinami kontynentalnymi, które właśnie weszły na drogę reform i szybkiego wzrostu gospodarczego pod przewodnictwem Deng Xiaopinga. Jeden z najbliższych współpracowników Ōhiry, Suzuki Zenkō, podkreśla jednak, że w tym okresie znacznie więcej uwagi poświęcano sprawom wewnętrznym niż dyplomacji, co wynikało z bardzo złej kondycji japońskiej gospodarki ${ }^{230}$.

Tymczasem Fukuda Takeo nie mógł pogodzić się z porażką i pragnął powrócić na stanowisko premiera. Pierwszą okazją stały się wybory do Izby Reprezentantów na początku października 1979 roku. PLD uzyskała w nich zły wynik i z trudem utrzymała się u władzy. Skupione wokół Fukudy frakcje „przeciwnego nurtu” nasiliły krytykę wobec rządu Ōhiry, żądając wzięcia przez niego odpowiedzialności za klęskę wyborczą i podania się do dymisji. Był to początek tzw. „starcia czterdziestodniowego" (40 nichi kōsō), które doprowadziło partię na skraj rozpadu. Frakcje ,przeciwnego nurtu” żądały wyboru kandydata na premiera tylko przez posłów PLD z Izby Reprezentantów, w której miałyby większość, zaś obóz Tanaki i Ōhiry nalegał na podjęcie decyzji w gronie parlamentarzystów obu izb, w którym przy wsparciu posłów bezfrakcyjnych była szansa na dominację ,głównego nurtu" ${ }^{\text {"231 }}$. Ostatecznie doszło do bezprecedensowego zgłoszenia w parlamencie dwóch kandydatur na premiera z PLD: Ōhiry i Fukudy. W głosowaniu na początku listopada 1979 roku szefem rządu wybrano urzędującego Ōhirę Masayoshiego, który otrzymał o zaledwie 17 głosów więcej od swojego oponenta z partii. Ostatecznie „starcie czterdziestodniowe" zakończyło się razem z powołaniem nowego gabinetu pod koniec listopada 1979 roku.

\footnotetext{
${ }^{228}$ Sadako Ogata, op.cit., s. 97.

${ }^{229}$ Corocznie Tajwan odwiedzały duże grupy parlamentarzystów z PLD, np. 56 w kwietniu 1978 roku, 80 w styczniu 1979 roku, 57 w kwietniu 1980 roku czy 71 w październiku 1981 roku. Szerzej na ten temat: Lin Jinjing, op.cit., s. 602-604.

${ }^{230}$ Azumane Chimao, op.cit., s. 79.

${ }^{231}$ Tanaka Rokusuke, Ōhira Masayoshi no hito to seiji, Asahi Sonorama, Tokio 1981, s. 133-154.
} 
Sprawa chińska nie posłużyła obozowi Fukudy za narzędzie rywalizacji z osią Tanaka-Ōhira w trakcie „starcia czterdziestodniowego" ${ }^{232}$. Ostatnią większą inicjatywą obozu protajwańskiego w latach 70 . XX wieku było domaganie się uchwalenia przez Japonię specjalnej ustawy regulującej stosunki z Tajwanem na wzór amerykańskiej Ustawy o relacjach z Tajwanem (Taiwan Relations Act), zatwierdzonej przez Kongres USA w 1979 roku $^{233}$. Starania te zakończyły się jednak niepowodzeniem ${ }^{234}$. W międzyczasie toczyły się przygotowania do wizyty premiera w ChRL. Na przełomie maja i czerwca 1979 roku Chiny odwiedził jeden z najbardziej zaufanych członków frakcji Ōhiry, Suzuki Zenkō. $\mathrm{Na}$ jego barkach spoczywało ważne zadanie przekonania Chin, które długo nie zgadzały się na napływ do kraju zagranicznego kapitału, do przyjęcia od Japonii pierwszej pożyczki w jenach. Deng Xiaopinga nie trzeba było jednak przekonywać. Wręcz przeciwnie, sam zaproponował, by japoński kapitał aktywnie uczestniczył w modernizacji Chin. Suzuki Zenkō wspomina: „Czułem, że oferta strony chińskiej jest dowodem zaufania wobec Japonii i otwierają się drzwi wzajemnej koegzystencji”"235. Deng Xiaoping prosił także o japońskie inwestycje w chiński przemysł zbrojeniowy, jednak Suzuki musiał odmówić ze względu na ograniczenia ustrojowe Japonii ${ }^{236}$. Przez następne miesiące Ōhira i będący wówczas przewodniczącym Rady Generalnej PLD Suzuki usilnie pracowali nad osiągnięciem zgody partii na przyznanie Chinom pożyczki w jenach ${ }^{237}$.

W grudniu 1979 roku Ōhira Masayoshi, jako drugi urzędujący japoński premier w historii, złożył wizytę w ChRL. W jej trakcie wyraził nadzieję, że chińsko-japońska wymiana będzie się rozwijać na wszystkich poziomach współpracy. Mając zaufanie do Ōhiry, strona chińska oficjalnie powtórzyła, że nie ma obiekcji przeciwko pozarządowym kontaktom japońsko-tajwańskim ${ }^{238}$. Z kolei aby wspomóc reformy Deng Xiaopinga, premier Japonii zadeklarował

\footnotetext{
${ }^{232}$ Suzaki Shin'ichi, profesor Uniwersytetu Kōbe, zauważa, że ostrożna postawa polityków protajwańskich pod koniec 1979 roku i w latach 80. XX wieku była spowodowana m.in. strachem przed ekspansją radziecką w Afganistanie. „Jastrzębie”, którzy do tej pory starali się hamować pogłębianie stosunków z ChRL twierdząc, że zaszkodzi to relacjom z ZSRR, teraz uznawali Związek Radziecki za większe zagrożenie dla stabilności w regionie niż ChRL. Wywiad autora z Suzakim Shin’ichim, Wydział Kultury Międzynarodowej Uniwersytetu Kōbe, 27 XI 2008.

${ }^{233}$ Ustawa o relacjach z Tajwanem stanowiła podstawę dalszej współpracy amerykańskotajwańskiej w dziedzinie kultury, gospodarki i bezpieczeństwa po normalizacji chińskoamerykańskich stosunków dyplomatycznych w styczniu 1979 roku. Szerzej na ten temat: Nakamura Katsunori, Huang Zhaotang, Asano Kazuo, Tokuoka Hitoshi, op.cit., s. 52; Yu San Wang, Foundation of the Republic of China's Foreign Policy [w:] Foreign Policy of the Republic of China on Taiwan: An Unorthodox Approach pod red. Yu San Wanga, Praeger Publishers, New York 1990, s. 9.

${ }^{234}$ Wywiad autora z Hiranumą Takeo...

${ }^{235}$ Azumane Chimao, op.cit., s. 154.

${ }^{236}$ Ibidem, s. 155.

${ }^{237}$ Ibidem, s. 211-213.

${ }^{238}$ Kawauchi Issei, Ōhira seiken 554-nichi, Gyōsei Mondai Kenkyūjo, Tokio 1982, s. 223-224.
} 
pierwszą nisko oprocentowaną pożyczkę dla ChRL, mającą wynieść 50 mld jenów w ciągu roku ${ }^{239}$. W swoim przemówieniu podkreślił: „Fakt, że państwa świata przyjmują politykę modernizacji Waszego kraju jako błogosławieństwo wynika z oczekiwania, iż polityka ta opiera się na partnerstwie międzynarodowym, zaś pojawienie się bogatszych Chin oznacza lepszy świat. To, że nasz kraj prowadzi politykę zdecydowanego wspomagania modernizacji Chin, wynika nie tylko $\mathrm{z}$ naszego sposobu myślenia, ale także $\mathrm{z}$ tego oczekiwania świata. Trzymając się owego stanowiska obiecuję Państwu, że wobec trudu Waszego kraju nasz kraj nie będzie szczędził aktywnej współpracy”"240.

Japonia stała się pierwszym państwem „wolnego świata”, które przyznało Chinom Rządową Pomoc Rozwojową (Seifu Kaihatsu Enjo, w skrócie ODA od Official Development Assistance $)^{241}$. Decyzja w tej sprawie nie była łatwa i olbrzymią rolę odegrał w niej sam premier. Duże zastrzeżenia zgłaszali biurokraci z Ministerstwa Finansów, obawiający się nowego wydatku z budżetu państwa. Również wewnątrz PLD zdania były podzielone. W „przeciwnym nurcie” pomysł pożyczki w jenach wspierał m.in. przewodniczący Rady Badań Politycznych Kōmoto Toshio z propekińskiej frakcji Mikiego, jednak wielu posłów obawiało się reakcji Zachodu i Związku Radzieckiego. Ostatecznie decyzję o przyznaniu Chinom pomocy rozwojowej podjął sam premier pod koniec listopada 1979 roku, tuż po zakończeniu „starcia czterdziestodniowego”. Dzięki osobistemu wstawiennictwu Ōhiry postanowiono nie nakładać na Chiny dodatkowych warunków udzielenia kredytu, mimo że było to dotychczas powszechną praktyką w przypadku japońskiej pomocy rozwojowej ${ }^{242}$. Aby uśmierzyć głosy niezadowolenia wewnątrz partii i na arenie międzynarodowej, Ōhira Masayoshi sformułował trzy zasady przyznawania ODA Chinom ${ }^{243}$.

\footnotetext{
${ }^{239} \mathrm{Liu} \mathrm{Li}$, op.cit., s. 25.

${ }^{240}$ Ōhira Masayoshi, Ōhira Masayoshi kaisōroku..., s. 316.

${ }^{241}$ Rządowa Pomoc Rozwojowa obejmowała pożyczki w jenach (en shakkan), darmową pomoc finansową (mushō shikin kyōryoku) oraz pomoc techniczną (gijutsu kyōryoku). Pożyczki w jenach o preferencyjnym oprocentowaniu były zdecydowanie najważniejszą częścią ODA. Służyły w szczególności rozbudowie infrastruktury w ChRL (budowa dróg, portów, lotnisk, elektrowni). Darmowa pomoc finansowa, czyli pomoc niewymagająca zwrotu, była dokonywana na mniejszą skalę i przeznaczana na takie cele, jak lecznictwo, edukacja, ruch drogowy czy pomoc ofiarom klęsk żywiołowych. Pomoc techniczna służyła wykształceniu chińskich specjalistów z różnych dziedzin wiedzy. Szerzej na ten temat: Sekiyama Takashi, Nitchū no keizai kankei wa kō kawatta. Tai-Chū en shakkan no 30 nen no kiseki, Kōbunken, Tokio 2008, s. 14-17.

${ }^{242}$ Dodatkowe warunki zwykle dotyczyły obowiązku zakupu produktów japońskich firm w celu realizacji inwestycji w krajach zaciągających kredyt. Premier Ōhira użył jednak swoich wpływów, by nie nakładać na pożyczki w jenach dla Chin tego typu ograniczeń. Szerzej na ten temat: Morita Hajime, Arai Shunzō, op.cit., s. 194.

${ }^{243}$ Zasady te to: 1) mieć na uwadze partnerstwo z USA i państwami Europy; 2) utrzymać równowagę w Azji, szczególnie wobec ASEAN; 3) nie rozwijać współpracy wojskowej. Sformułowanie tych zasad wynikało z obaw państw Zachodu, że Japonia dąży do monopolizacji rynku chińskiego, jak też z niepokojów państw ASEAN o konkurencję ze strony ChRL. Ponieważ
} 
Przyznanie ChRL pierwszej pożyczki w jenach wpłynęło na dalsze ocieplenie w relacjach bilateralnych. W maju 1980 roku Hua Guofeng, jako pierwszy w historii premier ChRL, złożył wizytę w Japonii. Obie strony postanowiły wówczas rozpocząc spotkania dwustronne w ramach Konferencji Gabinetów Japonii i Chin (Nitchū Kakuryō Kaigi) $)^{244}$.

Tymczasem rozpoczął się ostatni epizod „wojny Kaku-Fuku”. W połowie maja 1980 roku parlament rozpatrzył złożony przez Japońską Partię Socjalistyczną wniosek o wotum nieufności wobec rządu Ōhiry. Z powodu nieobecności 69 posłów „,przeciwnego nurtu”, szczególnie z frakcji Fukudy, Mikiego i Nakagawy ${ }^{245}$, opozycji udało się wygrać głosowanie. W odpowiedzi na to premier Ōhira rozwiązał Izbę Reprezentantów. W czerwcu 1980 roku miało dojść do pierwszych w historii jednoczesnych wyborów do obu izb parlamentu, nazwanych potocznie „happeningowymi”. W tej napiętej atmosferze, w samym środku kampanii wyborczej, 12 czerwca 1980 roku premier Ōhira Masayoshi zmarł na zawał serca. Jego śmierć była szokiem dla całej PLD. Politycy „głównego” i „przeciwnego nurtu” ogłosili pojednanie, zaś „wybory happeningowe" z 22 czerwca 1980 roku okazały się historycznym sukcesem $\mathrm{PLD}^{246}$. W ten sposób ośmioletnia „wojna Kaku-Fuku” dobiegła końca.

$$
* * *
$$

Spójny ideologicznie „główny nurt” Ōhiry kontynuował rozpoczęty w 1972 roku proces zbliżenia z Chinami komunistycznymi, udzielając im pierwszej pożyczki w jenach. Wizyta Ōhiry w Pekinie w 1979 roku była symbolicznym zakończeniem okresu przejściowego w stosunkach japońsko-chińskich, w którym Chiny kontynentalne i Tajwan „zamieniły się miejscami” w dyplomacji japońskiej. Ōhira Masayoshi razem z Tanaką Kakueiem położył fundamenty pod wewnątrzpartyjny konsensus w sprawie polityki PLD wobec Chin. Ponieważ za kadencji Ōhiry wszystkie najważniejsze problemy w relacjach z ChRL były już rozwiązane lub odłożone na przyszłość, ucichł także głos polityków protajwańskich. Ani w czasie „starcia czterdziestodniowego”, ani przy okazji kampanii przed „wyborami happeningowymi” sprawa chińska nie służyła za główne narzędzie rywalizacji międzyfrakcyjnej. Podjęta przez Ōhirę decyzja o przyznaniu ChRL pierwszej pożyczki w jenach rozpoczęła za to nową płaszczyznę współpracy w stosunkach japońsko-chińskich, która okazała się

\footnotetext{
wzięto pod uwagę utrzymanie równowagi w Azji, kwota pomocy dla znacznie ludniejszych Chin była ustalana mniej więcej na poziomie kwoty dla Indonezji. Szerzej na ten temat: Sekiyama Takashi, op.cit., s. 46-56.

${ }^{244}$ Shimada Masao, Tian Jianong, op.cit., s. 345.

245 Nakasone Yasuhiro w ostatniej chwili zdecydował się na głosowanie przeciwko wotum nieufności.

${ }^{246}$ Uchida Kenzō, Daburu senkyo no inpakuto [w:] Hoshu kaiki pod red. Uchidy Kenzō, Shiratoriego Reia i Tomity Nobuo, Shinhyōron, Tokio 1981, s. 12-14.
} 
ważnym narzędziem japońskiej dyplomacji wobec Chin w następnych dwóch okresach.

\section{PODSUMOWANIE}

Podobnie jak w poprzednim okresie, w latach 1972-1980 widać wpływ składu „głównych nurtów” na politykę PLD wobec Chin. Na początku lat 70. XX wieku w partii odwróciła się jednak proporcja dominującego wcześniej skrzydła protajwańskiego wobec obozu propekińskiego. Decydujący wpływ na tę przemianę miało przejęcie przywództwa $\mathrm{w}$ blisko związanej $\mathrm{z}$ reżimem Guomindangu frakcji Satō Eisaku przez dążącego do normalizacji stosunków dyplomatycznych z ChRL Tanakę Kakueia. Skrzydło protajwańskie nadal miało jednak wystarczające wpływy, by móc do pewnego stopnia opóźniać przedsięwzięcia propekińskie. Dochodziło do tego zwłaszcza, gdy uwarunkowania międzynarodowe nie sprzyjały kontaktom z ChRL, bądź gdy obóz protajwański stanowił większość składu „głównego nurtu” w PLD. Wystarczy tu przypomnieć kadencję Mikiego Takeo. Z drugiej strony, obóz protajwański był już za słaby, by móc samodzielnie sprawować władzę. Agresja członków Seirankai świadczyła o tym, że politycy blisko związani z reżimem Jiang Jieshiego byli coraz bardziej bezradni wobec ocieplenia na linii Tokio-Pekin.

„Wojna Kaku-Fuku” w dużym stopniu wpłynęła na sposób wykorzystania sprawy chińskiej przez polityków PLD. Nie jest przypadkiem, że w latach 19721980 w PLD dominowała oś Tanaka-Ōhira (rządząc bezpośrednio w latach 1972-1974 i 1978-1980, jak też należąc do „głównego nurtu” Fukudy w latach 1976-1978), która w przeciwieństwie do wcześniejszego sojuszu frakcji Kishiego i Satō miała wyraźnie propekińskie nastawienie. W wyniku ewolucji sytuacji międzynarodowej kwestia nawiązania, a później pogłębienia, kontaktów z Chinami komunistycznymi stała się w latach 70. XX wieku kluczowym zadaniem japońskiej dyplomacji, zgodnym z japońskim interesem narodowym.

O ile Tanaka Kakuei i Ōhira Masayoshi potrafili w pełni wykorzystać ten „,nurt historii” dla umocnienia swojej pozycji w partii, o tyle Fukuda Takeo został zepchnięty do, z góry skazanej na niepowodzenie, roli „obrońcy starego porządku". Kiedy zaś jako premier próbował choćby częściowo skorzystać z popularnych wśród społeczeństwa haseł zbliżenia z ChRL promując zawarcie ze stroną chińską Traktatu o pokoju i przyjaźni, sam musiał stawić czoło tajwańskiemu lobby we własnej frakcji. Podpisanie traktatu pokojowego z ChRL w 1978 roku usunęło główną przyczynę sporów między obozem propekińskim a protajwańskim. W burzliwym okresie rządów premiera Ōhiry obie strony „wojny Kaku-Fuku” nie odwoływały się już równie często jak do tej pory do sprawy chińskiej jako narzędzia rywalizacji. Było to zapowiedzią nowego okresu w formułowaniu polityki PLD wobec ChRL. 


\section{Rozdział IV}

\section{POLITYKA PLD WOBEC CHIN W OKRESIE ,OGÓLNEGO GŁÓWNEGO NURTU” (1980-1993)}

Śmierć Ōhiry Masayoshiego oznaczała koniec „osi władzy” Tanaka-Ōhira, ale nie była zapowiedzią osłabienia obozu propekińskiego w PLD. Wręcz przeciwnie, po zawarciu Traktatu o pokoju i przyjaźni z rządem w Pekinie w 1978 roku oraz wejściu ChRL na drogę modernizacji, w PLD zapanował względny konsensus w sprawie polityki wobec Chin. Niemały wpływ na ten stan rzeczy miało uformowanie się wewnątrz partii na początku lat 80 . XX wieku „ogólnego głównego nurtu", którego trzonem była propekińska frakcja Tanaki, a później Takeshity. Obóz protajwański został wyraźnie zmarginalizowany. Po zaniku frakcji Nakagawy-Ishihary jedynie grupy Fukudy-Abe-Mitsuzuki oraz Nakasone-Watanabe zrzeszały licznych parlamentarzystów blisko związanych z reżimem Guomindangu. Na dodatek nawet wśród polityków protajwańskich można było zauważyć stopniowy zanik zapału w promocji stosunków z władzami w Tajpej.

W latach 80 . XX wieku politycy związani z reżimem Guomindangu nie mieli wielu okazji do użycia sprawy chińskiej w rywalizacji o władzę w PLD. Zacieśnianie współpracy gospodarczej z żywiołowo rozwijającymi się Chinami kontynentalnymi wyraźnie leżało w interesie Japonii, zaś hegemoniczna pozycja frakcji Tanaki-Takeshity sprawiała, że jakiekolwiek przesilenia wewnątrzpartyjne były pozbawione szansy powodzenia. Chociaż od czasu do czasu politycy protajwańscy lub skrajni nacjonaliści wywoływali pomniejsze kryzysy dyplomatyczne na linii Tokio-Pekin, były one dość szybko i sprawnie wyciszane przez frakcje propekińskie. Nawet odpowiedź Japonii na masakrę na placu Tiananmen w 1989 roku była znacznie łagodniejsza od reakcji państw zachodnich. Dopiero rozłam we frakcji Takeshity w 1992 roku i zmiana sytuacji międzynarodowej po zakończeniu zimnej wojny stworzyły warunki do zakwestionowania ,propekińskiego konsensusu” w PLD.

\section{Sytuacja międzynarodowa w latach 1980-1993}

Lata 80. XX wieku to czas eskalacji napięcia w zimnej wojnie pomiędzy Stanami Zjednoczonymi a Związkiem Radzieckim. Ronald Reagan, prezydent USA w latach 1981-1989, rozpoczął decydującą fazę wyścigu zbrojeń ze Związkiem Radzieckim. Borykający się z kryzysem gospodarczym ZSRR nie 
był w stanie dotrzymać kroku amerykańskiej technologii „gwiezdnych wojen”1. W 1985 roku sekretarz generalny Komitetu Centralnego Komunistycznej Partii Związku Radzieckiego Michaił Gorbaczow zainicjował politykę reform, które w dalszej perspektywie doprowadziły do odejścia od gospodarki centralnie planowanej i rozpoczęcia procesu demokratyzacji. Przystąpił także do rozmów z USA na temat rozbrojenia arsenałów nuklearnych ${ }^{2}$. Zmiany te doprowadziły do odprężenia w stosunkach amerykańsko-sowieckich w drugiej połowie lat 80. XX wieku, upadku reżimów komunistycznych w państwach Europy ŚrodkowoWschodniej w 1989 roku i rozpadu ZSRR w grudniu 1991 roku.

Na początku rządów Ronalda Reagana stosunki amerykańsko-chińskie uległy pogorszeniu. Stany Zjednoczone nie tylko zapowiedziały, iż zamierzają sprzedawać broń Tajwanowi niezależnie od sprzeciwu ChRL, ale także naciskały na remilitaryzację Japonii, co spotkało się $\mathrm{z}$ protestami władz $\mathrm{w}$ Pekinie. Jednakże stosunkowo szybko amerykańska polityka wobec Chin uległa zmianie. W 1982 roku Stany Zjednoczone zgodziły się, by stopniowo redukować ilość broni sprzedawanej reżimowi Guomindangu, zaś w 1983 roku zniosły embargo na eksport do ChRL części produktów, które mogły przyczynić się do modernizacji tego kraju. Chociaż w relacjach amerykańsko-chińskich nadal panowała atmosfera braku pełnego zaufania, oba państwa łączył wspólny cel rywalizacji ze Związkiem Radzieckim ${ }^{3}$.

W latach 80. XX wieku ChRL stopniowo wprowadzała reformy wewnętrzne, aby utrzymać wysokie tempo wzrostu gospodarczego. Na przełomie lat 70. i 80. $\mathrm{XX}$ wieku utworzono specjalne strefy ekonomiczne, mające przyciągać zagraniczny kapitał. Jednocześnie rozpoczęto żmudny proces budowy państwa prawa i edukacji kadr niezbędnych do modernizacji przestarzałych metod produkcyjnych. Z drugiej strony, szybki wzrost gospodarczy zwiększył dysproporcje $\mathrm{w}$ rozwoju poszczególnych regionów w Chinach, jak też przyczynił się do pogłębienia rozwarstwienia społecznego. Razem z wprowadzaniem zasad wolnego rynku, komunistyczny ustrój ChRL stał się tylko pustym hasłem. Coraz częściej dochodziło do wybuchów społecznego niezadowolenia z wszechobecnej korupcji, a nawet żądań uzyskania większych swobód obywatelskich. W 1987 roku ze stanowiska sekretarza generalnego KPCh odszedł Hu Yaobang, którego obarczono odpowiedzialnością za antyjapońskie

\footnotetext{
1 W 1983 roku prezydent Reagan ogłosił pięcioletni plan budowy systemu obrony przeciwrakietowej, w którego skład miały wejść m.in. umieszczone na orbicie emitery laserowe. Program miał kosztować 26 mld USD. Szerzej na ten temat: Ronald E. Powaski, op.cit., s. 247249.

${ }^{2}$ Michaił Gorbaczow starał się zmienić oblicze komunizmu. Zamiast walki klas podkreślał znaczenie takich uniwersalnych wartości, jak wolność. Mottem jego reform stała się m.in. „przebudowa” (pieriestrojka) i ,jawność” (głasnost). Szerzej na ten temat: Paul Gregory, How the Soviet System Cracked, „Policy Review” 2008, nr 151, s. 45-60; Ronald E. Powaski, op.cit., s. 251-258.

${ }^{3}$ Ibidem, s. 240-242.
} 
protesty studentów ${ }^{4}$. W dniu 4 czerwca 1989 roku doszło do masakry na placu Tiananmen w Pekinie, w której wojsko zabiło kilkuset protestujących cywili. Incydent ten ukazał granice demokratyzacji w ChRL.

Jednocześnie ważne zmiany zachodziły na Tajwanie. W latach 80 . XX wieku Republika Chińska notowała bardzo wysokie tempo wzrostu gospodarczego i rozwoju zaawansowanych technologii ${ }^{5}$. Już pod koniec lat 70 . XX wieku reżim Guomindangu rozpoczął wprowadzanie powolnych reform, które miały doprowadzić do zmiany ustroju $\mathrm{z}$ autorytarnych rządów jednej partii na wielopartyjną demokrację. W 1986 roku powstało pierwsze ugrupowanie opozycyjne, Demokratyczna Partia Postępu. W 1987 roku zniesiono stan wojenny i anulowano zakaz odwiedzania Chin kontynentalnych. Po śmierci prezydenta Jiang Jingguo w 1988 roku władzę objął projapońsko usposobiony prezydent Li Denghui, gorący zwolennik „tajwanizacji” Guomindangu6. W 1991 roku zniesiono Tymczasowe regulacje obowiązujące w czasie komunistycznej rebelii. Z kolei w 1992 roku anulowano ograniczenia swobody wypowiedzi i odbyły się pierwsze od ponad 40 lat wybory do Yuanu Ustawodawczego. Zwyciężyła w nich Guomindang, ale Demokratyczna Partia Postępu także uzyskała dobry wynik, zdobywając jedną trzecią mandatów ${ }^{7}$. Zmiany te polepszyły wizerunek Tajwanu wśród państw demokratycznych, w tym także w oczach społeczeństwa japońskiego ${ }^{8}$.

\section{Sytuacja wewnątrzpartyjna w latach 1980-1993}

Po śmierci premiera Ōhiry zupełnie zmienił się charakter rywalizacji międzyfrakcyjnej w PLD. Najważniejsze cechy „ogólnego głównego nurtu”, który ukształtował się w latach 80 . XX wieku, to nagły rozrost frakcji TanakiTakeshity, zanik większych sporów wewnątrzpartyjnych w ramach „polityki harmonii" oraz kontynuacja procesu instytucjonalizacji frakcji, razem z którym postępował także stopniowy zanik ich kolorytu ideologicznego. W latach 1980-

\footnotetext{
${ }^{4}$ Alan Lawrance, op.cit., s. 108-117; Karin Tomala, op.cit., s. 11-27.

${ }^{5}$ Nakamura Katsunori, Huang Zhaotang, Asano Kazuo, Tokuoka Hitoshi, op.cit., s. 52-53.

${ }^{6}$ „Tajwanizacja” Guomindangu polegała na przełamaniu przywilejów Chińczyków przybyłych na tę wyspę z innych regionów Chin razem z Jiang Jieshim w latach 40. XX wieku i dopuszczeniu do władzy w partii Chińczyków z Tajwanu, takich jak Li Denghui. Szerzej na ten temat: Roman Sławiński, Historia Tajwanu, Dom Wydawniczy Elipsa, Warszawa 2001, s. 118-124.

7 Wybory do Yuanu Ustawodawczego nie odbywały się od lat 40. XX wieku, kiedy zorganizowano je w kontrolowanej przez Guomindang części Chin kontynentalnych. Z powodu niemożności przeprowadzenia wyborów na terenach ChRL, reprezentanci regionów Chin kontynentalnych przez dziesięciolecia zachowali mandaty poselskie. Szerzej na ten temat: Itō Kiyoshi, op.cit., s. 207-232; Roman Sławiński, Historia Tajwanu, s. 121-122.

${ }^{8} \mathrm{Z}$ drugiej strony, oficjalne stosunki dyplomatyczne z Tajwanem zerwały Arabia Saudyjska w 1990 roku i Korea Południowa w 1992 roku. Prócz Nigru i RPA kontakty dyplomatyczne z tym krajem utrzymywały już tylko małe kraje, szczególnie z Ameryki Środkowej, Oceanii i Afryki. Szerzej na ten temat: Nakamura Katsunori, Huang Zhaotang, Asano Kazuo, Tokuoka Hitoshi, op.cit., s. 56-63.
} 
1993 system pięciu dużych frakcji osiągnął stabilność, która została naruszona dopiero pod koniec omawianego okresu.

Wykres 4.1 Ewolucja systemu frakcyjnego w PLD w latach 1980-1993.

Frakcje propekińskie $\quad$ Frakcje protajwańskie $\quad$ Frakcje mieszane

Kōmoto

\begin{tabular}{l|l|l} 
Fukuda & Abe & Mitsuzuka \\
Nakagawa & Ishihara &
\end{tabular}

Nakasone W Watanabe

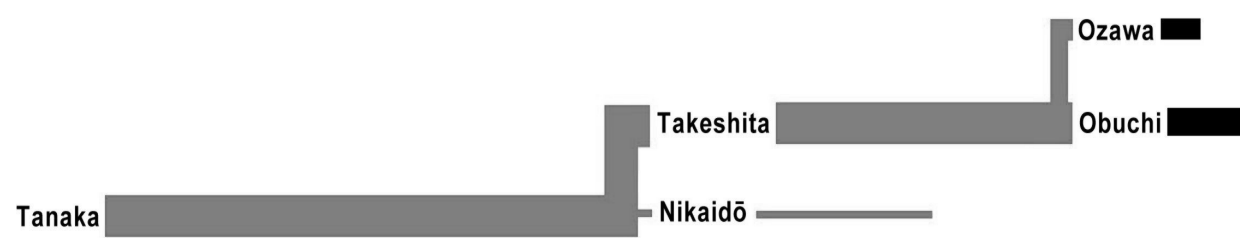

Suzuki Miyazawa

93

Wielkość frakcji proporcjonalna do grubości kreski.

Opracowanie własne na podstawie m.in.: Iseri Hirofumi, op.cit., s. 11; Tsuchiya Shigeru, op.cit., s. 260; Kitaoka Shin'ichi, op.cit., s. 334-336; Satō Seizaburō, Matsuzaki Tetsuhisa, op.cit., s. 241243; Fukunaga Fumio, Habatsu..., s. 80.

Po utracie Ōhiry Masayoshiego, swojego najbliższego przyjaciela i najwierniejszego sojusznika w ,wojnie Kaku-Fuku”, Tanaka Kakuei nie mógł w równym stopniu zaufać żadnemu innemu szefowi dużej frakcji, by stworzyć z nim nową „oś władzy”. Celem Tanaki było oczyszczenie się z zarzutów afery firmy Lockheed, by jeszcze raz stanąć na czele rządu. Aby zrealizować swoje marzenia musiał jednak sprawować realną kontrolę nad PLD, samemu będąc z niej wykluczonym ${ }^{9}$. Po ,starciu czterdziestodniowym” rozumiał także, iż do

\footnotetext{
${ }^{9}$ Po ujawnieniu afery z firmą Lockheed Tanaka Kakuei musiał opuścić PLD. Aż do 1990 roku był jednak posłem w Izbie Reprezentantów, uzyskując bardzo dobre wyniki wyborcze w rodzinnej prefekturze Niigata.
} 
pełni władzy $w$ partii nie starczy niewielka przewaga ilościowa nad „przeciwnym nurtem" 10 . W tej sytuacji jedynym wyjściem było „rozdęcie” własnej frakcji do rozmiarów wyraźnie ponad stu parlamentarzystów. Jedynie posiadający rozległe kontakty ze światem biznesu i, co za tym idzie, niemal nieograniczone środki finansowe Tanaka był w stanie skutecznie zwerbować i utrzymywać przy sobie tak liczne rzesze polityków. Jako szef frakcji-hegemona i „szara eminencja” (kuromaku) Tanaka mógł swobodnie wybierać premiera spośród liderów innych dużych frakcji, czyniąc z niego „marionetkę” (kairai) w swoich rękach ${ }^{11}$. Mechanizm ten pozostał niezmieniony również po przejęciu przywództwa we frakcji Tanaki przez Takeshitę Noboru.

Ponieważ nikt nie był w stanie skutecznie zakwestionować dominacji frakcjihegemona, opór pozostałych grup stał się bezcelowy. Zresztą w latach 80. XX wieku nadal świeża była pamięć o „,wojnie Kaku-Fuku”, która niemal spowodowała odsunięcie PLD od władzy. Z kolei hasła ,jedności partyjnej” podobały się społeczeństwu, co jasno pokazały wybory z 1980 roku. Dlatego też w latach 1980-1993 w PLD praktycznemu zanikowi uległ ,przeciwny nurt”, który by jawnie dążył do obalenia rządu. Oczywiście nadal panował stan napięcia pomiędzy obozami Tanaki i Fukudy, ale co najwyżej dochodziło do wyjścia części frakcji poza „główny nurt" ${ }^{\text {. }}$. W trzecim pokoleniu przywódców frakcji, które doszło do władzy w drugiej połowie lat 80. XX wieku, już praktycznie wszystkie grupy zgodnie współpracowały w ramach „ogólnego głównego nurtu" ${ }^{13}$. Dzięki temu mogły uczestniczyć w rozdziale najważniejszych stanowisk partyjnych i państwowych proporcjonalnie do swojej wielkości ${ }^{14}$. Zresztą różnice ideologiczne pomiędzy politykami trzeciego pokolenia szefów frakcji były znacznie mniejsze niż pomiędzy przywódcami pokolenia pierwszego (1955-1972) czy drugiego (1972-1987). Uwarunkowania te sprawiały, że „sprawa chińska” przestała być jednym z głównych narzędzi rywalizacji międzyfrakcyjnej.

\section{SUZUKI ZENKŌ (1980-1982)}

Suzuki Zenkō kontynuował umiarkowaną politykę Ōhiry Masayoshiego, mając jednocześnie znacznie lepsze warunki do jej implementacji. O ile Ōhira musiał stawiać czoło silnemu ,przeciwnemu nurtowi” wewnątrz PLD, Suzuki działał w ramach „ogólnego głównego nurtu”, w którym wygaszeniu uległa rywalizacja międzyfrakcyjna. Z drugiej strony, dążąc do utrzymania ,polityki harmonii”,

\footnotetext{
${ }^{10}$ Satō Akiko, op.cit., s. 171.

${ }^{11}$ Itō Masaya, Tetsugaku no nai seijika ga kuni o horobosu, Takei Shuppan, Tokio 1989, s. 17-20.

${ }^{12}$ Iseri Hirofumi, op.cit., s. 108.

${ }^{13}$ Ishikawa Masumi, Hirose Michisada, op.cit., s. 218-221.

${ }^{14}$ Yoda Hiroshi, Habatsu rengō soshiki, rīdāshippu, bunretsu kaihi no senjutsu. Jimintō no baai, „Shakai, Keizai Shisutemu” 1986, nr 4, s. 27.
} 
Suzuki musiał wsłuchiwać się również w głos prawego skrzydła PLD, by nie doprowadzić do ponownych konfliktów wewnątrz partii. Koncyliacyjna postawa premiera stała się szczególnie widoczna w czasie pierwszego kryzysu podręcznikowego w 1982 roku.

\section{Początek ,polityki harmonii”}

W 1980 roku, po wygranych wyborach do parlamentu, przywódcy frakcji postanowili uniknąć ostrej rywalizacji przy elekcji następcy tragicznie zmarłego Ōhiry Masayoshiego. Poparcie Tanaki Kakueia uzyskał Suzuki Zenkō, który później przejął także przywództwo w byłej frakcji Ōhiry, i to on został bez głosu sprzeciwu wybrany na nowego przewodniczącego PLD oraz premiera w lipcu 1980 roku $^{15}$. W skład „głównego nurtu” weszła również frakcja Nakasone Yasuhiro. Sam Nakasone w maju 1980 roku, tuż przed głosowaniem wotum nieufności przeciw rządowi Ōhiry, opuścił obóz Fukudy i ponownie sprzymierzył się z Tanaką ${ }^{16}$. W międzyczasie Miki Takeo przekazał przywództwo swojej frakcji Kōmoto Toshio.

Tabela 4.1 Rozkład sił pomiędzy frakcjami PLD w okresie rządów Suzukiego Zenkō w latach 1980-1982.

\begin{tabular}{|c|c|c|}
\hline \multicolumn{3}{|c|}{ Frakcje: } \\
\hline ,głównego nurtu” & poza ,głównym nurtem” & „przeciwnego nurtu” \\
\hline Suzuki $(\mathbf{L}, G, \mathbf{P}) 85$ & Fukuda $^{17}(\mathrm{D}, \mathrm{J}, \mathrm{T}) 77$ & - \\
\hline Tanaka $(\mathbf{L}, \mathbf{P}) 102$ & Kōmoto (D, G, P) 42 & \\
\hline Nakasone $(\mathrm{D}, \mathrm{J}) 53$ & Nakagawa $(\mathrm{J}, \mathrm{T}) 12$ & \\
\hline 240 & 131 & - \\
\hline L: 2 (187), D: 1 (53), & & \\
\hline G: 1 (85), J: 1 (53), & & \\
\hline P: 2 (187), T: 0. & & \\
\hline
\end{tabular}

L- dawni członkowie Partii Liberalnej, główny nurt konserwatywny, D- dawni członkowie Partii Demokratycznej, boczny nurt konserwatywny, G- gołębie, J- jastrzębie, P- obóz propekiński, Tobóz protajwański.

Liczebność frakcji (podana przy poszczególnych frakcjach) po wyborach do Izby Reprezentantów i Radców z czerwca 1980 roku. Uwzględniono członków frakcji z obu izb parlamentu. W podsumowaniu „głównego nurtu” podana jest ogólna liczba należących do niego parlamentarzystów oraz liczba frakcji, zaś w nawiasie liczba parlamentarzystów, należących do poszczególnych obozów.

Opracowanie własne na podstawie: Satō Seizaburō, Matsuzaki Tetsuhisa, op.cit., s. 243; Eguchi Nobuyuki, op.cit., s. 67; Iseri Hirofumi, op.cit., s. 109.

\footnotetext{
${ }^{15}$ Tsuchiya Shigeru, op.cit., s. 213.

${ }^{16}$ Uji Toshihiko, Suzuki seiken 863-nichi, Gyōsei Mondai Kenkyūjo, Tokio 1983, s. 10-11.

${ }^{17}$ Frakcja Fukudy początkowo zbliżyła się do „głównego nurtu”, dlatego część badaczy zalicza ją do „głównego nurtu” w pierwszych miesiącach rządów Suzukiego. Szerzej na ten temat: Eguchi Nobuyuki, op.cit., s. 67.
} 
Suzuki Zenkō proklamował wewnątrz partii tzw. ,politykę harmonii” (wa no seiji). Miała ona być remedium na dotychczasowe ostre spory międzyfrakcyjne. Tuż po wyborze na stanowisko przewodniczącego PLD zadeklarował: „Szczerość zawsze była moim politycznym credo. Starałem się załatwiać sprawy unikając kłótni i dążąc do harmonii. Można to nazwać «polityką harmonii», czy też polityką negocjacji lub polityką dążenia do sprawiedliwości”" ${ }^{18}$. W pamiętnikach podkreślał: „Przyrzekłem sobie w głębi serca, że należy położyć kres takiej wewnątrzpartyjnej rywalizacji i ogłosiłem «politykę harmonii». Ta postawa polityczna nie dotyczyła jedynie sytuacji wewnątrzpaństwowej, ale była kontynuowana również na arenie międzynarodowej jako moje podstawowe stanowisko polityczne"19. Zgodnie z filozofią premiera, każda frakcja otrzymała zadowalającą reprezentację w rządzie, dzięki czemu uniknięto uformowania się ,przeciwnego nurtu”. Nowy ,główny nurt” bardzo przypominał poprzedni. Dominowały w nim frakcje propekińskie i środowisko dawnej Partii Liberalnej. Biorąc pod uwagę fakt, że także Nakasone Yasuhiro był pozytywnie nastawiony do idei pogłębiania współpracy $\mathrm{z}$ ChRL, wewnątrzpartyjna baza poparcia gabinetu Suzukiego sprzyjała utrzymaniu propekińskiego kursu dyplomacji Ōhiry.

Nowy premier już wcześniej nieraz miał do czynienia ze sprawą chińską wewnątrz PLD, wystarczy przypomnieć jego rolę w udzieleniu ChRL pierwszej pożyczki w jenach w ramach ODA w 1979 roku. Wizję stosunków z Chinami odziedziczył po Ōhirze Masayoshim. Kiedy w lipcu 1980 roku na pogrzeb Ōhiry przybył chiński premier Hua Guofeng, Suzuki oświadczył mu: „Chociaż premier Ōhira zmarł, chcę dalej umacniać podstawę przyjaźni chińsko-japońskiej, którą po sobie pozostawił”20. Suzuki był zdeklarowanym „gołębiem”, przywiązanym do „doktryny Yoshidy” i przeciwnikiem remilitaryzacji Japonii. Jako dawny członek Japońskiej Partii Socjalistycznej nie był też skrajnym antykomunistą. Umiarkowana linia polityczna premiera zdawała się gwarantować, że za jego rządów nie dojdzie do większych zatargów z władzami w Pekinie.

W styczniu 1981 roku strona chińska, borykająca się z problemem inflacji i deficytu finansowego, ogłosiła anulowanie części kontraktów na budowę infrastruktury $\mathrm{w}$ ramach pożyczki $\mathrm{w}$ jenach. Władze $\mathrm{w}$ Tokio zareagowały zwiększeniem pomocy gospodarczej dla ChRL, by podtrzymać reformy rozpoczęte w tym kraju. We wrześniu 1981 roku do Pekinu udał się zaufany Tanaki Kakueia, przewodniczący Rady Generalnej PLD Nikaidō Susumu. Efektem jego wizyty było m.in. przyznanie Chinom dodatkowych $300 \mathrm{mld}$ jenów pożyczki ${ }^{21}$. Nic dziwnego, że kiedy na przełomie maja i czerwca 1982 roku Japonię odwiedził Zhao Ziyang stosunki na linii Tokio-Pekin układały się

\footnotetext{
${ }^{18}$ Uji Toshihiko, op.cit., s. 40-41.

${ }^{19}$ Azumane Chimao, op.cit., s. 79.

${ }^{20}$ Uji Toshihiko, op.cit., s. 33.

${ }^{21}$ Tanaka Akihiko, op.cit., s. 113-115.
} 
bardzo dobrze. Chiński premier ogłosił wówczas trzy zasady dotyczące wzajemnych relacji. Były to „pokojowa przyjaźń” (chiń. heping youhao, jap. heiwa yūkō), „równość i wzajemność korzyści” (chiń. pingdeng huli, jap. byōdō gokei) oraz „długotrwała stabilizacja” (chiń. changqi wending, jap. chōki antei) ${ }^{22}$. Zdawało się, że „polityka harmonii” Suzukiego rzeczywiście przynosiła rezultaty i działała łagodząco na stosunki Japonii z ChRL.

Należy jednak zauważyć, iż Suzuki nie był „człowiekiem czynu” pokroju Tanaki Kakueia czy Ōhiry Masayoshiego. W latach 60. i 70. XX wieku wielokrotnie, w sumie przez prawie 10 lat, piastował stanowisko przewodniczącego Rady Generalnej PLD, m.in. w okresie rządów Tanaki. Sam przyznawał, że nauczyło go to poszanowania dla wewnątrzpartyjnych procedur decyzyjnych i dążenia do kompromisu ${ }^{23}$. Jak opisywał w pamiętnikach: „We wrześniu 1972 roku premier Tanaka Kakuei razem z ministrem spraw zagranicznych Ōhirą Masayoshim odwiedzili Pekin i po rozmowie z Mao Zedongiem (...) i Zhou Enlaiem (...) postanowili ustanowić japońsko-chińskie stosunki dyplomatyczne, które były tak długo zerwane. Część PLD zgłaszała silny sprzeciw wobec decyzji w sprawie tej normalizacji stosunków między Japonią a Chinami i dużo czasu zajęła wyczerpująca debata przed przyjęciem rezolucji partyjnej. Wśród kierownictwa dominował głos: «Jak długo przewodniczący Rady Generalnej Suzuki (Zenkō) zamierza pozwalać na dyskusję? Jest jasne, że większość sprzyja rezolucji. Należy szybko podjąć decyzję», jednakże ja przeprowadziłem ciągła trzydniową debatę i doprowadziłem do konsensusu"24. To przywiązanie premiera do poszukiwania kompromisu miało niemały wpływ na przebieg kryzysu podręcznikowego w stosunkach z ChRL w 1982 roku.

\section{Pierwszy kryzys podręcznikowy}

W czerwcu 1982 roku japońskie media skupiły uwagę na wynikach kontroli podręczników do historii, przeprowadzonej przez Ministerstwo Edukacji. Okazało się, iż urzędnicy rekomendowali zmianę niektórych sformułowań odnoszących się do wojny japońsko-chińskiej na łagodniejsze wersje. Na przykład słowo ,inwazja” (shinryaku) miało być zastąpione przez „posuwanie się" (shinshutsu) ${ }^{25}$. Niedługo potem media z Korei Południowej i ChRL

\footnotetext{
${ }^{22}$ Według Tanaki Akihiko, o ile dwie pierwsze zasady odnosiły się do dotychczasowych 10 lat wzajemnych stosunków, trzecia zasada była także deklaracją przyszłej polityki Chin. „Długotrwała stabilizacja” miała służyć osłabieniu wpływu Stanów Zjednoczonych na japońską dyplomację. Szerzej na ten temat: Zhong-Ri guanxi 30 nian..., s. 140; Tanaka Akihiko, op.cit., s. $115-120$.

${ }^{23}$ Azumane Chimao, op.cit., s. 172-173.

${ }^{24}$ Ibidem, s. 152-153.

${ }^{25}$ Wcielenie w życie rekomendacji nie było jednak obowiązkowe i tak naprawdę tekst w żadnym z podręczników nie został zmieniony. Japońskie media błędnie podały, że wskazówki Ministerstwa Edukacji były przymusowe. Szerzej na ten temat: Caroline Rose, The Textbook Issue: Domestic Sources of Japan's Foreign Policy, ,Japan Forum” 1999, vol. 11, no. 2, s. 205-207.
} 
rozpoczęły krytykę rządu w Tokio za wybielanie roli Japonii w II wojnie światowej i sprawa przemieniła się w problem międzynarodowy. Pod koniec lipca 1982 roku Xiao Xiangqian z chińskiego Ministerstwa Spraw Zagranicznych zaprotestował wobec japońskiego ambasadora w Pekinie, mówiąc: „Japońskie Ministerstwo Edukacji w podręcznikach do liceów, gimnazjów i szkół podstawowych fałszuje historię inwazji japońskiego militaryzmu na Chiny, jak też naciska na korektę, by skrywać prawdę na temat wielkiej masakry ${ }^{26}$ nankińskiej”"27.

Jedną z przyczyn pojawienia się problemu podręczników do historii były przemiany, jakie zaszły wewnątrz klanu (zoku) edukacji w PLD. W 1976 roku partię opuściło kilku wpływowych członków tego klanu, którzy utworzyli Nowy Klub Liberalny, małą partię, mającą stanowić alternatywę dla pogrążonej w skandalach korupcyjnych PLD. Do grupy tej należeli Kōno Yōhei (przyszły przewodniczący PLD), Tagawa Seiichi (promotor nieoficjalnego handlu z ChRL w latach 60. XX wieku), Yamaguchi Toshio czy Kobayashi Masami. Jako że byli to politycy o stosunkowo umiarkowanych poglądach, pod ich nieobecność klan edukacji został jeszcze bardziej niż poprzednio zdominowany przez skrajnie prawicowych parlamentarzystów na czele z Morim Yoshirō i Mitsuzuką Hiroshim z frakcji Fukudy czy Machimurą Kingo z dawnej frakcji Ishiiego. Nie będąc już skrępowanymi sprzeciwem środowiska „gołębi”, nacjonalistyczni posłowie przeforsowali na początku lat 80 . XX wieku nowe dyrektywy w sprawie zatwierdzania podręczników do historii ${ }^{28}$.

Uji Toshihiko zwraca uwagę, że w 1982 roku wewnątrz PLD uformowały się trzy grupy, mające rozbieżne opinie na temat sposobu rozwiązania kryzysu. Pierwsza z nich skupiała "gołębi” i żądała natychmiastowego przystania na żądania Korei Południowej i Chin. Stanowisku temu bliscy byli też biurokraci z Ministerstwa Spraw Zagranicznych, dążący do szybkiego wygaszenia sporu ${ }^{29}$. Również minister spraw zagranicznych Sakurauchi Yoshio z frakcji Nakasone skłaniał się ku korekcie kontrowersyjnych treści w podręcznikach ${ }^{30}$. Druga grupa zrzeszała ,jastrzębi”, w szczególności z zoku edukacyjnego. Środowisko to zdecydowanie broniło systemu państwowej kontroli podręczników, nazywając protesty innych państw, ,interwencją w sprawy wewnętrzne” Japonii. Trzeci obóz nie chciał blokować zmiany systemu kontroli podręczników, ani nie negował, że Japonia dokonała inwazji w Chinach, ale starał się także uniknąć wrażenia, że rząd w Tokio ugiął się pod presją międzynarodową. Suzuki Zenkō,

\footnotetext{
${ }^{26} \mathrm{~W}$ grudniu 1937 roku wojsko japońskie zdobyło Nankin, dokonując rzezi mieszkańców tego miasta. Liczba ofiar nie jest dokładnie znana, ale podaje się ją w dziesiątkach, a nawet setkach tysięcy osób. Szerzej na ten temat: Ewa Pałasz-Rutkowska, Katarzyna Starecka, op.cit., s. 142.

${ }^{27}$ Shimada Masao, Tian Jianong, op.cit., s. 346.

${ }^{28}$ Yuasa Hiroshi, op.cit., s. 155-157, Hoshu kaiki, s. 191-193.

${ }^{29}$ Uji Toshihiko, op.cit., s. 308-309

${ }^{30}$ Itō Masaya, Shin Jimintō sengokushi, Asahi Sonorama, Tokio 1983, s. 81.
} 
chociaż sam był „gołębiem”, dążąc do „polityki harmonii” w naturalny sposób skłaniał się ku poglądom trzeciej grupy ${ }^{31}$.

Co ciekawe, ówczesny minister edukacji Ogawa Heiji, jako brat pierwszego ambasadora Japonii w ChRL, należał do stronnictwa propekińskiego i frakcji Suzukiego. Z drugiej strony, Ogawa musiał brać pod uwagę głos broniących swoich interesów biurokratów z Ministerstwa Edukacji oraz związanych z nimi polityków z zoku edukacyjnego. Razem z premierem wyjaśniał stronie chińskiej, że zmiany proponowane przez Ministerstwo Edukacji nie są obowiązkowe i nie mają nic wspólnego ze skrajnym subiektywizmem japońskich podręczników sprzed 1945 roku. Nie zadowoliło to jednak władz w Pekinie, które na początku sierpnia 1982 roku odwołały zaplanowaną na jesień wizytę Ogawy w ChRL. Ponieważ zaś we wrześniu 1982 roku do Chin miał się udać Suzuki Zenkō, spór wymagał szybkiego rozwiązania ${ }^{32}$.

$\mathrm{W}$ celu poradzenia sobie z kryzysem rozpoczęły się negocjacje pomiędzy Ministerstwem Edukacji a Ministerstwem Spraw Zagranicznych. Nie przyniosły one jednak rezultatów, zaś sprawa została powierzona bezpośredniej decyzji premiera i sekretarza jego gabinetu ${ }^{33}$. Ponieważ zaś obaj należeli do umiarkowanej, propekińskiej byłej frakcji Ikedy, kryzys został w końcu zażegnany. Pod koniec sierpnia 1982 roku sekretarz gabinetu Suzukiego, Miyazawa Kiichi, ogłosił jako reprezentant rządu: „Ze strony Chin i Korei Południowej jesteśmy poddawani krytyce, która dotyczy opisów w podręcznikach naszego kraju. Aby rozwijać przyjaźń z sąsiednimi krajami azjatyckimi, rząd będzie dokonywał korekty wsłuchując się w głos tej krytyki" ${ }^{34}$. Po dodatkowych zapowiedziach przez stronę japońską konkretnych zmian w systemie kontroli podręczników, kryzys w stosunkach z ChRL dobiegł końca ${ }^{35}$.

Pod koniec września 1982 roku premier Suzuki Zenkō udał się do ChRL, by uczestniczyć w uroczystościach 10 . rocznicy nawiązania oficjalnych stosunków dyplomatycznych $\mathrm{z}$ tym krajem. Aby zatrzeć złe wrażenie po kryzysie podręcznikowym, potwierdził, że nie ma zmiany w zadeklarowanej przez Tanakę w 1972 roku polityce pojednania obu narodów, zaś Japonia odczuwa odpowiedzialność za krzywdy wyrządzone Chinom w czasie wojny ${ }^{36}$. Podkreślił, iż wszelkie kontrowersyjne zapisy w podręcznikach do historii zostaną szybko poprawione. Oświadczył również, że Japonia pozostanie jedynie mocarstwem gospodarczym i nie ma groźby wskrzeszenia japońskiego militaryzmu ${ }^{37}$. Tuż po powrocie z ChRL Suzuki Zenkō zadeklarował, iż nie będzie ubiegał się o

\footnotetext{
${ }^{31}$ Uji Toshihiko, op.cit., s. 309-310.

${ }^{32}$ Ibidem, s. 307-311.

${ }^{33}$ Caroline Rose, The textbook issue..., s. 211.

${ }^{34}$ Shimada Masao, Tian Jianong, op.cit., s. 347.

${ }^{35}$ Uji Toshihiko, op.cit., s. 317-318.

${ }^{36}$ Shimada Masao, Tian Jianong, op.cit., s. 347.

${ }^{37}$ Uji Toshihiko, op.cit., s. 321-322.
} 
następną kadencję jako przewodniczący PLD. Przyczyną tej zaskakującej decyzji były obawy przed ponownym rozpaleniem rywalizacji wewnątrzpartyjnej, jak też chęć odstąpienia władzy młodszym politykom ${ }^{38}$.

$$
\text { * * * }
$$

Polityka Suzukiego Zenkō była kontynuacją propekińskiej postawy jego poprzedników na stanowisku szefa frakcji, szczególnie Ikedy Hayato i Ōhiry Masayoshiego. Ponieważ zaś władza premiera opierała się na sojuszu z blisko związaną z ChRL potężną frakcją Tanaki Kakueia, Suzuki dysponował stabilną bazą poparcia wewnątrz partii. Z drugiej strony, należy zwrócić uwagę na nowy rodzaj uwarunkowań polityki PLD wobec ChRL, który ujawnił się w 1982 roku. Kryzys podręcznikowy był pierwszym przesileniem w stosunkach japońskochińskich wywołanym przez problem pamięci historycznej. Kwestia różnego podejścia do trudnej przeszłości obu narodów miała odtąd zastąpić rozwiązaną w latach 70. XX wieku sprawę statusu Tajwanu jako główna przeszkoda w relacjach bilateralnych. O ile zaś kwestia tajwańska była problemem czysto dyplomatycznym i decyzje w tej sprawie podejmował bezpośrednio przewodniczący PLD (nigdy nie istniało silne zoku polityki zagranicznej), o tyle w sferze edukacji premier musiał się liczyć ze zdaniem wpływowego zoku edukacyjnego, od 1976 roku opanowanego przez ,jastrzębi”. Mimo to Suzuki mógłby wcześniej wygasić kryzys, gdyby nie przywiązanie do „polityki harmonii” i chęć osiągnięcia konsensusu między lewym a prawym skrzydłem PLD. Na razie jednak ,propekiński konsensus” w partii nie został naruszony, zaś potężny „ogólny główny nurt” był w stanie wyciszyć głos ,,jastrzębi”.

\section{NAKASONE YASUHIRO (1982-1987)}

Długie, pięcioletnie rządy Nakasone Yasuhiro były okresem dalszego pogłębiania współpracy japońsko-chińskiej. Z drugiej strony, problem pamięci historycznej, który ujawnił się za kadencji Suzukiego, powrócił z większą siłą w połowie lat 80 . XX wieku. Tym razem ,oliwy do ognia” dolewał sam premier, odwiedzając w 1985 roku kontrowersyjną świątynię Yasukuni. W przeciwieństwie do Suzukiego, Nakasone był ,jastrzębiem” i dążył do remilitaryzacji Japonii, co nie mogło się spotkać z aprobatą strony chińskiej. O ile więc ogólne ramy „propekińskiego konsensusu” zostały zachowane, nacjonalistyczne przekonania premiera miały pobudzić do działania prawe skrzydło PLD, co pośrednio wywierało negatywny wpływ na relacje japońsko-chińskie.

\section{Gabinet ,Tanakasone”}

Po dymisji Suzukiego Zenkō, Tanaka Kakuei postanowił wesprzeć Nakasone Yasuhiro w wyborach na przewodniczącego PLD. W pewnym momencie realny

${ }^{38}$ Azumane Chimao, op.cit., s. 126-129. 
zdawał się scenariusz rozdziału stanowisk przewodniczącego partii, które otrzymałby Fukuda Takeo oraz premiera, które objąłby Nakasone, jednak ostatecznie doszło do drugich po 1978 roku prawyborów wśród wszystkich członków i sympatyków partii. Dzięki wsparciu potężnej frakcji Tanaki zdecydowanie wygrał je Nakasone Yasuhiro, pokonując Kōmoto Toshio, Abe Shintarō z frakcji Fukudy oraz Nakagawę Ichirō.

Tabela 4.2 Rozkład sił pomiędzy frakcjami PLD w okresie rządów Nakasone Yasuhiro w latach 1982-ok. 1984.

\begin{tabular}{|l|l|l|}
\hline \multicolumn{2}{|c|}{ Frakcje: } \\
\hline ,głównego nurtu” & poza ,głównym nurtem” & „przeciwnego nurtu” \\
\hline Nakasone (D, J) 56 & Fukuda (D, J, T) 68 & - \\
Tanaka (L, P) 120 & Kōmoto (D, G, P) 36 & \\
Suzuki (L, G, P) 79 & Nakagawa (J, T) 7 & \\
\hline 255 & 111 & - \\
L: 2 (199), D: 1 (56), & & \\
G: 1 (79), J: 1 (56), & & \\
P: 2 (199), T: 0. & & \\
\hline
\end{tabular}

L- dawni członkowie Partii Liberalnej, główny nurt konserwatywny, D- dawni członkowie Partii Demokratycznej, boczny nurt konserwatywny, G- gołębie, J- jastrzębie, P- obóz propekiński, Tobóz protajwański.

Liczebność frakcji (podana przy poszczególnych frakcjach) po wyborach do Izby Reprezentantów z grudnia 1983 roku. Uwzględniono członków frakcji z obu izb parlamentu. W podsumowaniu „głównego nurtu” podana jest ogólna liczba należących do niego parlamentarzystów oraz liczba frakcji, zaś w nawiasie liczba parlamentarzystów, należących do poszczególnych obozów.

Opracowanie własne na podstawie: Satō Seizaburō, Matsuzaki Tetsuhisa, op.cit., s. 243; Eguchi Nobuyuki, op.cit., s. 67.

Nakasone był drugim premierem po Suzukim uzależnionym od poparcia Tanaki Kakueia i jego potężnej frakcji. W skład rządu weszło aż sześciu polityków należących do frakcji Tanaki i dwóch kolejnych blisko związanych z Tanaką. Ówczesna prasa japońska prześcigała się w ironicznych komentarzach, np. określając nowy gabinet nazwą „Tanakasone”39. Przynajmniej do 1985 roku Tanaka Kakuei rzeczywiście wywierał wielki wpływ na politykę rządu. „Główny nurt” premiera Nakasone pozostał taki sam, jak Suzukiego, z dominacją frakcji propekińskich. Podobnie jak poprzednio, uniknięto powstania wyraźnego ,przeciwnego nurtu” dzięki przyznaniu ważnych posad rządowych i partyjnych frakcjom pokonanym w wyborach na przewodniczącego PLD ${ }^{40}$.

Jak zostało wspomniane $\mathrm{w}$ rozdziale trzecim, Nakasone Yasuhiro, jako kontynuator myśli Hatoyamy Ichirō i Kōno Ichirō, a także postać blisko związana z Matsumurą Kenzō, był politykiem propekińskim. Już w 1954 roku udał się w dwumiesięczną podróż do ZSRR i ChRL, pomimo zdecydowanego

\footnotetext{
${ }^{39}$ Narai Shigeo, Saishō - Nakasone Yasuhiro, Taishū Nihonsha, Tokio 1988, s. 195.

${ }^{40}$ Iseri Hirofumi, op.cit., s. 117.
} 
sprzeciwu władz Partii Reform, do której wówczas należał ${ }^{41}$. Z kolei w 1956 roku, wbrew szefowi swojej frakcji, Kōno Ichirō, w wyborach na przewodniczącego PLD oddał głos nie na protajwańskiego Kishiego Nobusuke, ale na propekińskiego Ishibashiego Tanzana. Wynikało to m.in. z jego przekonania, że należy kontynuować dzieło Hatoyamy i po nawiązaniu stosunków dyplomatycznych z ZSRR dokonać podobnego przełomu w relacjach z ChRL ${ }^{42}$. Podobnie jak Matsumura, był przekonany, że w Chinach kontynentalnych nacjonalizm przeważa nad komunizmem ${ }^{43}$. Nic dziwnego, że w 1972 roku Nakasone dołączył do „głównego nurtu” Tanaki, który doprowadził do normalizacji stosunków dyplomatycznych z Chinami. Jako minister handlu i przemysłu w gabinecie Tanaki odwiedził ChRL w 1973 roku i obiecał Zhou Enlaiowi pogłębiać japońsko-chińską współpracę gospodarcząa ${ }^{44}$ Wbrew stanowisku polityków protajwańskich Nakasone w pełni zgadzał się z „klauzulą antyhegemonistyczną", wręcz promując ideę sojuszu z ChRL przeciw dominacji $\mathrm{ZSRR}^{45}$. Jak widać, w przeciwieństwie do ugodowego Suzukiego, Nakasone był „człowiekiem czynu”, zdolnym do forsowania swoich przekonań pomimo wewnątrzpartyjnego sprzeciwu.

$\mathrm{Z}$ drugiej strony, do frakcji premiera Nakasone należało wielu działaczy obozu protajwańskiego i byłych członków Seirankai, dlatego trudno ją nazwać propekińską. Poza tym Nakasone Yasuhiro reprezentował prawe, nacjonalistyczne skrzydło PLD. Jego wizja roli Japonii w sojuszu z USA zupełnie różniła się od poglądów pacyfistycznie nastawionego Susukiego Zenkō. Nakasone był zdecydowanym zwolennikiem rewizji konstytucji i remilitaryzacji Japonii $^{46}$. Tuż po objęciu władzy ogłosił „ogólny rozrachunek z polityką powojenną" (sengo seiji no sōkessan). Hasło to stało się mottem jego rządów. Oznaczało „rewizję dotychczasowych podstawowych systemów i mechanizmów bez zważania na tabu" ${ }^{\text {"47 }}$. Obok reformy administracyjnej i finansowej chodziło tu także o zakwestionowanie dotychczasowych ram polityki zagranicznej i bezpieczeństwa, w szczególności pacyfistycznej „doktryny Yoshidy”. „Ogólny rozrachunek z polityką powojenną" był przejawem chęci odgrywania przez Japonię, która osiągnęła już status mocarstwa gospodarczego, bardziej aktywnej roli także w innych sferach działalności międzynarodowej ${ }^{48}$.

\footnotetext{
${ }^{41}$ Narai Shigeo, op.cit., s. 75.

${ }^{42}$ Ibidem, s. 82.

${ }^{43}$ Nakasone Yasuhiro, Nishibe Susumu, Matsui Takafumi, Matsumoto Ken'ichi, „Shōwa 80 nen” sengo no yomikata, Bungei Shunjū, Tokio 2005, s. 79.

${ }^{44}$ Narai Shigeo, op.cit., s. 126.

${ }^{45}$ Nakasone Yasuhiro, Jiseiroku..., s. 132.

${ }^{46}$ Narai Shigeo, op.cit., s. 77-78.

${ }^{47}$ Nakasone Yasuhiro, Takemura Ken'ichi, Inochi no kagiri semi shigure. Nihon seiji ni senryakuteki tenkai o, Tokuma Shoten, Tokio 2003, s. 89.

${ }^{48}$ You Bo, Jueqi zhong de Zhong-Ri guanxi, Shijie Zhishi Chubanshe, Pekin 2009, s. 46-54.
} 
Kiedy premier Nakasone odwiedził Stany Zjednoczone, w rozmowie $\mathrm{z}$ prezydentem Ronaldem Reaganem 17 stycznia 1983 roku powiedział, że „Japonia i USA są wspólnotą losu obejmującą Ocean Spokojny”. Tego samego dnia nazwał Archipelag Japoński „niezatapialnym lotniskowcem przeciwko inwazji Związku Radzieckiego". Wyrażenia te spotkały się z krytyką ze strony chińskich mediów jako oznaki wskrzeszenia japońskiego militaryzmu. Aby uspokoić nastroje w stosunkach bilateralnych, w lutym 1983 roku Nakasone potwierdził w parlamencie, że wojna Japonii z Chinami była inwazją. Równocześnie do Pekinu udał się sekretarz generalny PLD, Nikaidō Susumu z frakcji Tanaki. W ChRL oświadczył, iż „,nie ma zmiany w polityce japońskiego rządu wobec Chin" "49. Jak widać, główni działacze frakcji-hegemona uspokajali władze KPCh, że pomimo prawicowych poglądów nowego premiera „konsensus propekiński" wewnątrz PLD nie został zakwestionowany.

Mimo iż zacieśnianie sojuszu japońsko-amerykańskiego wywoływało głosy niezadowolenia ze strony chińskiej, w pierwszych latach rządów premiera Nakasone stosunki z ChRL układały się bardzo dobrze. W listopadzie 1983 roku Japonię odwiedził sekretarz generalny KPCh Hu Yaobang. Do sformułowanych w 1982 roku przez Zhao Ziyanga trzech zasad stosunków chińsko-japońskich dodał czwartą, „wzajemne zaufanie” (chiń. xianghu xinlai, jap. sōgo shinrai). W celu jego budowy również w następnych pokoleniach, Hu Yaobang zaprosił do ChRL w następnym roku liczącą 3 tys. osób grupę młodzieży japońskiej. Zgodzono się także na utworzenie Komitetu Japońsko-Chińskiej Przyjaźni w XXI wieku (jap. Nitchū Yūkō 21 Seiki Iinkai, chiń. Zhong-Ri Youhao 21 Shiji Weiyuanhui) jako forum wymiany zdania na tematy dotyczące relacji bilateralnych między ludźmi świata nauki, biznesu i polityki z obu krajów ${ }^{50}$. Nakasone zaprosił Hu Yaobanga do swoich prywatnych apartamentów, gdzie zapoznał go ze swoją rodziną. ${ }^{51}$.

Kiedy w marcu 1984 roku Nakasone Yasuhiro złożył wizytę w ChRL, Hu Yaobang przyjął go równie serdecznie. Po raz pierwszy w historii japoński premier został zaproszony do domu sekretarza generalnego KPCh. ${ }^{52}$. W ten sposób pomiędzy oboma politykami zawiązała się nić przyjaźni ${ }^{53}$. W trakcie wizyty w Chinach Nakasone ogłosił decyzję o przyznaniu ChRL na lata 19841989 drugiej pożyczki w ramach ODA, wartej 470 mld jenów ${ }^{54}$. Z kolei w

\footnotetext{
${ }^{49}$ Shimada Masao, Tian Jianong, op.cit., s. 348-349.

${ }^{50}$ Tanaka Akihiko, op.cit., s. 132; Zhong-Ri guanxi 30 nian..., s. 142.

${ }^{51}$ Seki Hei, „Nitchū yūkō” wa Nihon o horobosu! Rekishi ga oshieru „datsu Chūgoku” no hōsoku, Kōdansha, Tokio 2005, s. 105.

${ }^{52}$ Ibidem, s. 106.

${ }^{53}$ Uchida Kenzō, Gendai Nihon no hoshu seiji, Iwanami Shoten, Tokio 1989, s. 138.

${ }^{54}$ Było to znacznie więcej niż 300 mld jenów przyznanych w sumie w ramach pierwszej pożyczki rozpoczętej w 1979 roku przez premiera Ōhirę Masayoshiego. Nakasone „,podarował” Chinom także 10 mld jenów bezzwrotnej pomocy finansowej, dzięki której wybudowano JapońskoChińskie Centrum Młodzieży. Szerzej na ten temat: Sekiyama Takashi, op.cit., s. 72-74.
} 
trakcie przemówienia na Uniwersytecie Pekińskim oświadczył: „Jako najwyższy reprezentant japońskich władz deklaruję tutaj bez jakichkolwiek wątpliwości, że nasz kraj nigdy nie dopuści do ponownego wskrzeszenia militaryzmu" ${ }^{55}$. Również minister spraw zagranicznych Abe Shintarō $\mathrm{z}$ frakcji Fukudy podkreślił: „Japonia nie stanie się mocarstwem militarnym, tylko będzie kontynuować politykę nastawioną jedynie na obronę, trzymając się trzech zasad antynuklearnych [nie posiadać, nie produkować, nie sprowadzać - przyp. aut.]" ${ }^{\prime 56}$. Zresztą niedługo potem, w kwietniu 1984 roku, obie strony rozpoczęły wymianę urzędników wysokiego szczebla z resortów obrony. Kiedy we wrześniu 1984 roku otwarto pierwsze posiedzenie Komitetu Japońsko-Chińskiej Przyjaźni w XXI wieku, zaś na przełomie września i października 1984 roku doszło do obiecanej przez Hu Yaobanga wizyty w Chinach 3 tys. przedstawicieli japońskiej młodzieży, zdawało się, że trudno jest zakłócić atmosferę współpracy dwustronnej $^{57}$. W następnym roku pojawił się jednak kolejny po 1982 roku problem związany z pamięcią historyczną.

\section{Problem wizyty w świątyni Yasukuni i drugi kryzys podręcznikowy}

W 1984 roku rozpoczęły się zmiany w „głównym nurcie” Nakasone. Opuściła go frakcja Suzukiego, który był niezadowolony z nowej polityki bezpieczeństwa prowadzonej przez premiera. Suzuki w 1984 roku próbował wręcz uniemożliwić elekcję przewodniczącego PLD na drugą kadencję, wysuwając na kontrkandydata Nikaidō Susumu z frakcji Tanaki. Jednakże sam Tanaka Kakuei szybko pokrzyżował te plany, wspierając Nakasone ${ }^{58}$. Aby zrekompensować sobie utratę poparcia Suzukiego, Nakasone zbliżył się do frakcji Fukudy, która weszła w skład ,głównego nurtu"59.

\footnotetext{
${ }^{55}$ Tanaka Akihiko, op.cit., s. 133.

${ }^{56}$ Ibidem.

${ }^{57}$ Shimada Masao, Tian Jianong, op.cit., s. 353-355.

${ }^{58}$ Wydarzenie to nazywane jest „dramatem rekomendacji Nikaidō” (Nikaidō yōritsu geki). Suzuki Zenkō liczył na wsparcie Fukudy Takeo, części frakcji Tanaki i niektórych partii opozycyjnych. Od samego początku jednak cele polityków uczestniczących w tym przedsięwzięciu były sprzeczne. O ile Suzukiemu i Fukudzie chodziło o wyeliminowanie wpływów Tanaki, Nikaidō był wierny swojemu oyabunowi i wierzył, że obejmując władzę lepiej przysłuży się mu niż Nakasone, do którego nie miał zaufania. Decyzja Tanaki o wsparciu Nakasone sprawiła, że Nikaidō wycofał się ze „spisku”. Szerzej na ten temat: Hayasaka Shigezō, Kenryoku no shisaitachi, Asuka Shinsha, Tokio 1991, s. 30-37; Okushima Sadao, Jimintō Kanjichōshitsu no 30 nen, Chūō Kōron Shinsha, Tokio 2005, s. 156-160.

${ }^{59}$ Honzawa Jirō, Jimintō..., s. 264-265.
} 
Tymczasem w styczniu 1983 roku samobójstwo popełnił Nakagawa Ichirō ${ }^{60}$. Przywództwo nad jego frakcją przejął Ishihara Shintarō. Podobnie jak inni dawni członkowie Seirankai, Ishihara był gorącym zwolennikiem remilitaryzacji Japonii i rewizji pacyfistycznej konstytucji ${ }^{61}$. Pojednanie pomiędzy Stanami Zjednoczonymi a ChRL, które nastąpiło w latach 70 . XX wieku, uważał za zagrożenie, postrzegając te dwa mocarstwa jako potencjalnych wrogów Japonii. Postulował wobec tego większą asertywność japońskiej dyplomacji, szczególnie wobec USA ${ }^{62}$. Ishihara miał skrajnie prawicowe poglądy na tematy historyczne. Relatywizował znaczenie masakry nankińskiej, podkreślając współwinę za tę zbrodnię żołnierzy chińskich ${ }^{63}$. Był pełen uprzedzeń wobec Chińczyków kontynentalnych, pisząc o nich: „Ponieważ wierzą tylko w pieniądze, są bardzo przebiegli. Bez mrugnięcia oka zabijają ludzi, zdradzają i kradną"64. Od lat mobilizował działaczy nacjonalistycznych do wypraw na sporne z Chinami wyspy Senkaku/Diaoyutai, by zademonstrować ich przynależność do Japonii ${ }^{65}$. We wrześniu 1984 roku frakcja Ishihary zorganizowała „warsztaty” (kenshūkai) na Tajwanie. Było to pierwsze tego typu spotkanie frakcji z PLD poza granicami $\mathrm{kraju}^{66}$. Ta demonstracja bliskich kontaktów z reżimem Guomindangu okazała się jedną z ostatnich inicjatyw grupy. Dwa miesiące później frakcja Ishihary przestała istnieć, zaś jej członkowie z Nakagawą Shōichim (syn Nakagawy Ichirō), Hiranumą Takeo czy samym Ishiharą na czele wstąpili do najbliższej im ideologicznie frakcji Fukudy.

Najważniejsza zmiana dotyczyła jednak układu sił wewnątrz frakcji Tanaki, która rozrosła się na tyle, że w jej łonie pojawiły się podziały na mniejsze grupy. Młodzi parlamentarzyści byli coraz bardziej niezadowoleni z tego, że w wyborach na przewodniczącego partii Tanaka ciągle wspiera liderów innych frakcji, zamiast wystawić kandydata z własnych szeregów. W lutym 1985 roku Takeshita Noboru, chcąc przyspieszyć zmianę pokoleniową, powołał do życia Sōseikai, organizację zrzeszającą młodszych polityków z frakcji-hegemona. Tanaka Kakuei początkowo wyraził na to zgodę, jednak wpadł w złość, gdy

\footnotetext{
${ }^{60}$ Istnieją różne teorie odnośnie do okoliczności śmierci Nakagawy. Jedna z nich mówi o stresie, przepracowaniu i goryczy związanej z przegranymi wyborami na przewodniczącego PLD. Według dawnego członka Seirankai, Hamady Kōichiego, Nakagawa czuł się oszukany przez Fukudę Takeo. Fukuda miał obiecać Nakagawie, że zgodzi się na przejście ze swojej frakcji do frakcji Nakagawy kilku prawicowych polityków. Okazało się jednak, iż Fukudzie chodziło o wchłonięcie grupy Nakagawy, nadając jej pewną autonomię w ramach frakcji Fukudy. Ponieważ Nakagawa bezwzględnie wierzył Fukudzie, ta „zdrada” była dla niego prawdziwym ciosem. Szerzej na ten temat: Hamada Kōichi, Nihon o dame ni shita 9-nin no seijika, Kōdansha, Tokio 1993, s. 139-149.

${ }^{61}$ Ishihara Shintarō, Watanabe Shōichi, Ogawa Kazuhisa, Sore demo „nō” to ieru Nihon, Kōbunsha, Tokio 1990, s. 208-226.

${ }^{62}$ Ishihara Shintarō, Morita Akio, „Nō” to ieru Nihon, Kōbunsha, Tokio 1990, s. 141-160.

${ }^{63}$ Ishihara Shintarō, Tahara Sōichirō, Nippon no chikara, Bungei Shunjū, Tokio 2007, s. 138-140.

${ }^{64}$ Ibidem, s. 188.

${ }^{65}$ Ibidem, s. 217-219.

${ }^{66}$ Ishihara-ha, Taiwan de kenshūkai, „Nihon Keizai Shinbun” z 4 IX 1984, s. 2.
} 
Sōseikai zaczęło prowadzić działalność charakterystyczną dla oddzielnej frakcji. Nie był jednak w stanie stłumić w zarodku tego „zamachu stanu”, gdyż wkrótce dostał wylewu krwi do mózgu i został hospitalizowany. Pogorszenie się stanu zdrowia Tanaki oznaczało nagłe osłabienie jego wpływów wewnątrz partii oraz stopniowe przejmowanie władzy we frakcji przez Takeshitę Noboru ${ }^{67}$.

Tabela 4.3 Rozkład sił pomiędzy frakcjami PLD w okresie rządów Nakasone Yasuhiro w latach ok. 1984-1987.

\begin{tabular}{|l|l|l|}
\hline \multicolumn{2}{|c|}{ Frakcje: } \\
\hline ,głównego nurtu” & poza ,głównym nurtem” & „przeciwnego nurtu” \\
\hline Nakasone (D, J) 75 & Suzuki (L, G, P) 87 & - \\
Tanaka (L, P) 139 & Kōmoto (D, G, P) 34 & \\
Fukuda (D, J, T) 82 & & \\
\hline 296 & 121 & - \\
L: 1 (139), D: 2 (157), & & \\
G: 0, J: 2 (157), & & \\
P: 1 (139), T: 1 (82). & & \\
\hline
\end{tabular}

L- dawni członkowie Partii Liberalnej, główny nurt konserwatywny, D- dawni członkowie Partii Demokratycznej, boczny nurt konserwatywny, G- gołębie, J- jastrzębie, P- obóz propekiński, Tobóz protajwański.

Liczebność frakcji (podana przy poszczególnych frakcjach) po wyborach do Izby Reprezentantów i Radców z lipca 1986 roku. Uwzględniono członków frakcji z obu izb parlamentu. W podsumowaniu „głównego nurtu” podana jest ogólna liczba należących do niego parlamentarzystów oraz liczba frakcji, zaś w nawiasie liczba parlamentarzystów, należących do poszczególnych obozów.

Opracowanie własne na podstawie: Fukunaga Fumio, Habatsu..., s. 80; Iseri Hirofumi, op.cit., s. 109.

Drugi ,główny nurt” premiera Nakasone różnił się od poprzedniego. Widać w nim względną równowagę obozów propekińskiego i protajwańskiego, jak też reprezentantów „głównego” i „,bocznego nurtu konserwatywnego”. Zwraca za to uwagę przewaga ,jastrzębi” nad „gołębiami”. Należy także podkreślić, że w dwóch ostatnich latach rządów Nakasone Yasuhiro był w stanie względnie usamodzielnić się od frakcji-hegemona ${ }^{68}$. Zawdzięczał to swoistej ,wojnie domowej" wewnątrz frakcji Tanaki. O ile w 1985 roku Tanaka Kakuei stracił dawne wpływy w partii, o tyle Takeshita Noboru nie zdążył jeszcze przejąć od niego pełni władzy, by stać się nowym kuromaku. Zresztą Takeshita był

${ }^{67}$ Takeshita szybko przystał na kompromis z Tanaką, który polegał m.in. na ustanowieniu siedziby Sōseikai w biurze frakcji Tanaki (Mokuyō Kurabu). Kiedy Tanaka rozpoczął działania mające na celu stłumienie „buntu”, stronnictwo Takeshity stopniało z 80 do 40 osób. Jednakże choroba Tanaki sprawiła, że większość członków frakcji stopniowo zaczęła przechodzić do obozu Takeshity. Po wylewie krwi do mózgu Tanaka stracił zdolność mowy i pełną kontrolę nad nim przejęła rodzina na czele $\mathrm{z}$ jego córką Makiko. Szerzej na ten temat: Hayasaka Shigezō, Kenryoku..., s. 38-52.

${ }^{68}$ Narai Shigeo, op.cit., s. 250-252. 
młodszy od Nakasone i trudno byłoby pomyśleć, by mógł mu narzucać swoją wolę równie skutecznie, jak czynił to Tanaka. Z drugiej strony, do czasu historycznego zwycięstwa w wyborach do Izby Reprezentantów w 1986 roku, wewnątrzpartyjna podstawa rządów Nakasone nie była stabilna i premier musiał szukać poparcia u prawicowych polityków skupionych we frakcji Fukudy ${ }^{69}$. Nie trzeba było długo czekać na efekty tych przemian.

W dniu 9 sierpnia 1985 roku ogłoszono raport Komitetu w Sprawie Problemu Wizyt Członków Rządu w Świątyni Yasukuni (Kakuryō no Yasukuni Sanpai ni kan suru Kondankai). Wynikało z niego, iż 15 sierpnia 1985 roku, w 40. rocznicę kapitulacji Japonii, premier Nakasone zamierza razem z wszystkimi ministrami złożyć oficjalną wizytę w świątyni Yasukuni w Tokio, poświęconej Japończykom, którzy polegli za ojczyznę ${ }^{70}$. Sama wizyta urzędującego premiera w Yasukuni nie była niczym nowym, właściwie czynili to niemal wszyscy powojenni szefowie rządu $\mathrm{i}$ to wielokrotnie $w$ czasie swoich kadencji ${ }^{71}$. Największe kontrowersje budził fakt, iż od 1978 roku świątynia była poświęcona także 14 zbrodniarzom wojennym klasy A (A-kyū senpan), skazanym przez Trybunał Tokijski ${ }^{72}$. Drugi problem dotyczył daty wizyty. Jako pierwszy 15 sierpnia wizytę w Yasukuni złożył premier Miki Takeo w 1975 roku, jednak zrobił to nieoficjalnie i zanim zaczęto $\mathrm{w}$ niej oddawać hołd zbrodniarzom wojennym klasy $\mathrm{A}^{73}$. Nakasone był pierwszym premierem, który chciał odwie-

\footnotetext{
${ }^{69}$ Itō Masaya, Jimintō „Sonshi” - Sonshi riron ni yoru seijiryokugaku no kaimei, Purejidentosha, Tokio 1989, s. 97-99.

${ }^{70}$ Shintoistyczna świątynia Yasukuni, położona w pobliżu cesarskiego pałacu w Tokio, została zbudowana w 1869 roku jako miejsce oddawania czci Japończykom poległym za ojczyznę i cesarza. Obecną nazwę uzyskała w 1879 roku. Oddaje się w niej hołd 2,5 mln zmarłym, w większości w czasie II wojny światowej. Duże kontrowersje budzi muzeum Yūshūkan, położone w granicach świątyni. Znajdują się w nim wystawy japońskich militariów, nie ma za to żadnej wzmianki o zbrodniach dokonanych przez Japończyków w trakcie II wojny światowej. Szerzej na ten temat: Takahashi Tetsuya, Yasukuni mondai, Chikuma Shobō, Tokio 2005, s. 64-96.

${ }^{71}$ Spośród przewodniczących PLD przed 1985 rokiem jedynie Hatoyama Ichirō i Ishibashi Tanzan nie odwiedzili Yasukuni w trakcie pełnienia obowiązków premiera. Szerzej na ten temat: Takahashi Shigeo, Rekishi ninshiki mondai to nitchū kankei, „Bunka Joshi Daigaku Kiyō. JinbunShakai Kagaku Kenkyū” 2006, nr 14, s. 116-117.

${ }^{72}$ Trybunał Tokijski był sądem, przed którym stanęli japońscy zbrodniarze wojenni z czasów II wojny światowej. Siedmiu spośród zbrodniarzy klasy A, w tym byli premierzy Tōjō Hideki i Hirota Kōki, zostało straconych w 1948 roku. Szerzej na ten temat: Ishikawa Masumi, op.cit., s. 12-13.

${ }^{73}$ Miki uległ w 1975 roku naleganiom ,jastrzębi”, dominujących w jego „głównym nurcie”. Z drugiej strony, ogłosił wówczas 4 zasady odwiedzania świątyni Yasukuni jako osoba prywatna: 1) nie używać samochodu służbowego; 2) ofiary opłacać z prywatnych środków; 3) nie używać tytułu premiera; 4) nie brać ze sobą urzędników publicznych. Trzy z tych zasad (1, 3, 4) zanegował premier Fukuda Takeo w 1978 roku. W 1985 roku Nakasone ogłosił, że pod warunkiem rezygnacji premiera z uczestnictwa w rytuałach shintoistycznych, możliwa jest jego oficjalna wizyta w Yasukuni. Szerzej na ten temat: Yomiuri Shinbun Seijibu, Gaikō o kenka ni shita otoko. Koizumi gaikō 2000 nichi no shinjitsu, Shinchōsha, Tokio 2006, s. 233-234.
} 
dzić Yasukuni oficjalnie i to na dodatek w 40. rocznicę zakończenia II wojny światowej, którą uroczyście obchodzono w Chinach. Ponieważ jednak ChRL do tej pory nigdy nie protestowała przeciw wizytom japońskich szefów rządu w kontrowersyjnej świątyni, nie było powodów do uważania tego problemu za kwestię o znaczeniu międzynarodowym.

Sam Nakasone następująco tłumaczył swoje postępowanie: „Jest błędem myślenie, że moja wizyta w świątyni Yasukuni była wyrazem jakiejś czci dla militaryzmu czy skrajnego nacjonalizmu. (...) Obecnie w Yasukuni oddaje się hołd duszom japońskich żołnierzy poległych na wojnie, łącznie $\mathrm{z}$ wojną japońsko-rosyjską czy II wojną światową. Nie ma innego miejsca, dokąd można by pójść. Dlatego też tam idę i modlę się. Z powodu rozdziału państwa od religii premier nie może występować w rytuałach shintoistycznych. Dlatego, aby nie pojawił się problem pogwałcenia konstytucji, w chwili gdy odwiedziłem świątynię Yasukuni nie było publicznych rytuałów. Jedynie poszedłem i pomodliłem się za ich honor i spokój. (..) Niegdyś świątynia Yasukuni oczywiście była związana z ideologią militarną. Jednakże obecnie jest inaczej. Dzisiaj nie ma związków pomiędzy Yasukuni a wojskiem. Świątynia ta jest utrzymywana tylko ze spontanicznych datków narodu, rząd nie wydaje na nią pieniędzy"74.

Jak już wcześniej wspomniano, u źródeł decyzji premiera o wizycie w Yasukuni leżały nie tylko jego osobiste przekonania, ale również presja środowisk nacjonalistycznych. Jedną z organizacji, która stale wywierała nacisk na PLD, by doprowadzić do oficjalnych wizyt premiera w świątyni, było Nihon Izokukai (Japońskie Stowarzyszenie Osieroconych), skupiające rodziny japońskich żołnierzy poległych w czasie II wojny światowej ${ }^{75}$. Jego prezesem był $\mathrm{w}$ przeszłości m.in. Kaya Okinori, czołowy reprezentant stronnictwa protajwańskiego $\mathrm{w} \mathrm{PLD}^{76}$. Ważną rolę odegrała także zmiana na stanowisku sekretarza gabinetu. Dopóki funkcję tę piastował Gotōda Masaharu, umiarkowany polityk z frakcji Tanaki, powstrzymywał oficjalną wizytę Nakasone w Yasukuni jako pozostawiającą wątpliwości co do zgodności z konstytucją. Gotōda przestrzegał, że Japonia może powrócić na ścieżkę prowadzącą do militaryzmu, jeśli tylko zapomni o żalu za ekspansjonizm z czasów II wojny światowej ${ }^{77}$. Uznawał też za naturalne, iż wizyta premiera w świątyni, w której czci się pamięć po zbrodniarzach wojennych klasy A, musi budzić sprzeciw ofiar zbrodni z przeszłości ${ }^{78}$. W grudniu 1983 roku sekretarzem gabinetu został

\footnotetext{
${ }^{74}$ Nakasone Yasuhiro, Nakasone Yasuhiro - Toppu daun gata seijika. Haisen ku no kokufuku kara sekai no Nihon e, Nakasone Yasuhiro Jimusho, Tokio 1991, s. 16-17.

${ }^{75}$ Xu Wansheng, Riben zhengzhi yu duiwai guanxi, Renmin Chubanshe, Pekin 2006, s. 209-210; Takahashi Tetsuya, op.cit., s. 120-131.

${ }^{76}$ Wang Xiliang, Zhanhou Riben zhengjie zhanzhengguan yanjiu, Shehui Kexue Wenxian Chubanshe, Pekin 2005, s. 106-107.

${ }^{77}$ Gotōda Masaharu, Sei to kan, Kōdansha, Tokio 1994, s. 220-221.

${ }^{78}$ Gotōda Masaharu, Mikuriya Takashi, op.cit., t. 1, s. 112-113.
} 
jednak Fujinami Takao z frakcji Nakasone. Otworzyło to drogę do powołania do życia Komitetu w Sprawie Problemu Wizyt Członków Rządu w Świątyni Yasukuni. Kiedy zaś Komitet wydał raport w sierpniu 1985 roku, premier był już względnie niezależny od obłożnie chorego Tanaki i mógł użyć problemu Yasukuni do umocnienia nadwątlonego poparcia dla gabinetu na prawym skrzydle PLD ${ }^{79}$.

Jak widać, Nakasone nie miał zamiaru wywoływać kryzysu w relacjach $\mathrm{z}$ Chinami, zaś jego wizyta w Yasukuni była pomyślana jako część polityki wewnętrznej w ramach „ogólnego rozrachunku z polityką powojenną”. Reakcja Korei Południowej i Chin była jednak stanowcza. W dniu 14 sierpnia 1985 roku rzecznik chińskiego Ministerstwa Spraw Zagranicznych ostrzegł, że wizyta premiera w świątyni „zrani uczucia narodów wielu krajów azjatyckich” ${ }^{\text {" }}$. Pod koniec sierpnia 1985 roku zaczęła się kampania krytyki japońskiego militaryzmu przez chińskie media. Na początku września 1985 roku przewodniczący Ogólnochińskiego Zgromadzenia Przedstawicieli Ludowych, Peng Zhen, w rozmowie z delegacją frakcji Tanaki podkreślił, że dla przyszłości przyjaźni chińsko-japońskiej lepiej by było, gdyby zaprzestano oficjalnych wizyt w Yasukuni. Z kolei 18 września 1985 roku, w rocznicę japońskiej inwazji w Mandżurii, doszło do antyjapońskiej manifestacji studenckiej na placu Tiananmen w Pekinie. Studenci Uniwersytetu Pekińskiego wznosili hasła surowo krytykujące rząd Nakasone. Ruch ten rozprzestrzenił się także na inne uczelnie w kraju, przybierając rozmiary niepokojące dla kierownictwa $\mathrm{KPCh}^{81}$.

W połowie października 1985 roku Chiny odwiedził minister spraw zagranicznych Abe Shintarō. Obie strony potwierdziły, że należy rozwijać współpracę japońsko-chińską w duchu Wspólnej deklaracji z 1972 roku, Traktatu o pokoju i przyjaźni z 1978 roku oraz czterech zasad wzajemnych relacji sformułowanych przez Zhao Ziyanga i Hu Yaobanga. Tymczasem zbliżały się jesienne ceremonie $\mathrm{w}$ Yasukuni i z uwagą obserwowano, czy premier będzie na nich obecny. Prawe skrzydło PLD, skupione w takich ligach parlamentarnych, jak Rada Parlamentarna Odpowiedzi Duszom Poległych Żołnierzy (Eirei ni Kotaeru Giin Kyōgikai), wywierało silną presję, by cały rząd wziął udział $\mathrm{w}$ uroczystościach. Nakasone Yasuhiro zrezygnował jednak $\mathrm{z}$ kolejnej wizyty w świątyni z powodu „harmonogramu zajęć w parlamencie”. Pod koniec października 1985 roku japoński premier spotkał się w ONZ z Zhao Ziyangiem, któremu oświadczył, że nie ma zmiany w propekińskiej polityce władz w Tokio. Z kolei na początku listopada 1985 roku rząd japoński wydał oświadczenie, w którym podkreślono, że poprzedniej wizyty w Yasukuni nie dokonano w celu rehabilitacji zbrodniarzy wojennych klasy A, a jedynie dla

\footnotetext{
${ }^{79}$ Dōjitsusen asshō de fungiri. Shushō no Yasukuni sanpai chūshi no haikei, „Asahi Shinbun” z 16 VIII 1986, s. 3.

${ }^{80}$ Tanaka Akihiko, op.cit., s. 138.

${ }^{81}$ Ibidem, s. 138-144.
} 
upamiętnienia poległych w czasie wojny. Stwierdzono także, iż oficjalne wizyty w kontrowersyjnej świątyni nie uległy instytucjonalizacji i decyzja w tej sprawie będzie zależeć od osądu samego szefa rządu ${ }^{82}$. Nakasone już nigdy jako premier nie odwiedził Yasukuni. Dzięki temu w grudniu 1985 roku kryzys zdawał się zażegnany ${ }^{83}$. Po latach Nakasone Yasuhiro przyznał, że zrezygnował z wizyt w Yasukuni, gdyż obawiał się, iż problem ten może być wykorzystany w walce o władzę w KPCh. W szczególności chciał, by krytyki uniknął znany z projapońskich poglądów Hu Yaobang, z którym Nakasone łączyła nić przyjaźni ${ }^{84}$.

Ledwie wygasły emocje związane $\mathrm{z}$ wizytą premiera w świątyni Yasukuni, pojawił się następny problem związany z pamięcią historyczną, który mógł przeobrazić się w równie poważny kryzys, jak te w 1982 i 1985 roku. W maju 1986 roku japońskie media podały, że Ministerstwo Edukacji wstępnie zatwierdziło podręcznik pt. Nowa historia Japonii (Shin Nihonshi) przygotowany przez prawicową organizację Narodowa Rada Obrony Japonii (Nihon o Mamoru Kokunmin Kaigi). Jego treść budziła liczne kontrowersje, gdyż wybielała japońskie zbrodnie $\mathrm{z}$ czasów II wojny światowej i gloryfikowała system cesarski. Z książki wynikało m.in., że Japonia nie prowadziła wojny najeźdźczej, tylko wyzwoliła narody Azji spod europejskiego panowania ${ }^{85}$. Na początku czerwca 1986 roku strona chińska przekazała władzom w Tokio swoje zaniepokojenie, twierdząc, że zatwierdzenie nacjonalistycznego podręcznika jest pogwałceniem deklaracji Miyazawy Kiichiego z 1982 roku, w której obiecano brać w tej sprawie pod uwagę zdanie ChRL i Korei Południowej ${ }^{86}$.

Tym razem reakcja rządu japońskiego była zdecydowana. Nie chcąc kolejnej eskalacji napięcia $\mathrm{w}$ relacjach $\mathrm{z}$ Chinami, premier natychmiast nakazał ministrowi edukacji Kaifu Toshikiemu dokonanie gruntownych zmian $\mathrm{w}$ treści podręcznika. Jako że Kaifu pochodził z umiarkowanej frakcji Kōmoto, nie doszło na tym tle do sporów. W przeciwieństwie do ceniącego konsensus Suzukiego, Nakasone osobiście interweniował, chociaż zwyczajem było, że po wstępnym zatwierdzeniu książek nie dokonywano już w nich żadnych zmian. Na początku lipca 1986 roku podręcznik ponownie uzyskał akceptację ministerialną po usunięciu z niego kontrowersyjnych treści ${ }^{87}$. Dzięki szybkiej reakcji premiera Nakasone uniknięto kolejnego kryzysu w stosunkach japońsko-chińskich. Takie postępowanie nie mogło się jednak spotkać z uznaniem wszystkich członków jego partii.

\footnotetext{
${ }^{82}$ Shimada Masao, Tian Jianong, op.cit., s. 360-361.

${ }^{83}$ Tanaka Akihiko, op.cit., s. 148.

${ }^{84}$ Nakasone wspomina, że tacy prominentni politycy KPCh, jak Gu Mu i Wan Li sygnalizowali mu, że w razie kontynuowania wizyt w Yasukuni będzie zagrożona pozycja w partii ich i Hu Yaobanga. Szerzej na ten temat: Nakasone Yasuhiro, Jiseiroku..., s. 137.

${ }^{85}$ Wang Xiliang, op.cit., s. 194-201.

${ }^{86}$ Shimada Masao, Tian Jianong, op.cit., s. 364-365.

${ }^{87}$ Tanaka Akihiko, op.cit., s. 151.
} 


\section{Opór wobec ,propekińskiego konsensusu”}

Pojednawcza polityka premiera Nakasone wobec władz w Pekinie wywołała głosy niezadowolenia ze strony reprezentantów prawego skrzydła PLD. Były one tym większe, że swoją oficjalną wizytą w Yasukuni premier rozbudził wśród ,jastrzębi” nadzieję, że japońska polityka rzeczywiście dokona wyraźnego „skrętu w prawo”. W lipcu 1986 roku „obóz patriotyczny” założył ponadfrakcyjną grupę polityczną, Towarzystwo Podstawowych Problemów Państwa (Kokka Kihon Mondai Dōshikai) z Kameiem Shizuką na czele. Skupiało ono głównie młodych parlamentarzystów najwyżej trzeciej czy czwartej kadencji. Do Towarzystwa należeli tacy politycy, jak Murakami Masakuni z frakcji Nakasone, Hiranuma Takeo i Mori Kiyoshi z frakcji Abe (Fukudy), Koga Makoto i Asō Tarō z frakcji Miyazawy (Suzukiego) czy bezfrakcyjny Suzuki Muneo ${ }^{88}$. We wrześniu 1986 roku na 25 członków aż 10, w tym przewodniczący, pochodziło $\mathrm{z}$ protajwańskiej frakcji Abe, mimo że wchodziła ona w skład ,głównego nurtu”. Jedynie jeden działacz wywodził się za to z prawicowej frakcji Nakasone. Można to wytłumaczyć tym, że ostrze krytyki Towarzystwa było skierowane głównie przeciw osobie premiera i jego kobuni nie chcieli działać wbrew swojemu przełożonemu. Dziwi za to stosunkowo liczna reprezentacja umiarkowanej frakcji Miyazawy (6 osób) ${ }^{89}$. Najwyraźniej wynikało to $\mathrm{z}$ faktu, że znajdowała się ona wówczas poza „głównym nurtem” i ,jastrzębie” z tej frakcji, choć mniej liczni niż we frakcjach Abe i Nakasone, byli w mniejszym stopniu związani lojalnością wobec rządu.

Grupa przypominała Seirankai, można wręcz powiedzieć, że kontynuowała tradycje tego protajwańskiego stowarzyszenia w następnym pokoleniu. Hiranuma Takeo i Suzuki Muneo pełnili kiedyś funkcję sekretarzy Nakagawy Ichirō, Kamei Shizuka przyjaźnił się z Fujio Masayukim, zaś Murakami Masakuni dostał się do świata polityki dzięki wsparciu Tamakiego Kazuo. O ile jednak Seirankai było grupą wyraźnie antykomunistyczną i protajwańską, Towarzystwo nie podkreślało $\mathrm{w}$ swoim manifeście żadnej ideologii, ani nie głosiło sympatii bądź antypatii wobec określonego państwa. Ostrze krytyki jego działaczy było skierowane przeciwko wszelkim „,naciskom z zewnątrz” (gaiatsu), tak ze strony ChRL i Korei Południowej, jak i Stanów Zjednoczonych. Poza tym działalność Towarzystwa Podstawowych Problemów Państwa była tylko cieniem żywiołowych inicjatyw Seirankai, które w latach 70. XX wieku niejednokrotnie siało zamieszanie $\mathrm{w}$ różnych organach $\mathrm{PLD}^{90}$. Przedsięwzięcia Towarzystwa sprowadziły się jedynie do kilku nic nieznaczących protestów,

\footnotetext{
${ }^{88}$ Kyōkasho nado no tai-Nichi hihan, „,naisei kanshō” to hanpatsu - Jimintō wakate ga kai kessei, „Asahi Shinbun” z 1 VIII 1986, s. 2.

${ }^{89}$ Tsubasa hirogeru Jimintō taka-ha no Kokka Kihon Mondai Dōshikai - Gaiatsu e no hanpatsu bane ni, „Asahi Shinbun” z 20 IX 1986, s. 2.

${ }^{90}$ Tsubasa hirogeru..., s. 2.
} 
m.in. wobec „propekińskiego konsensusu” utrzymywanego przez potężną frakcję Tanaki.

W deklaracji utworzenia Towarzystwa jego członkowie stwierdzili: „Wstępem do prawdziwej współpracy międzynarodowej są zasady wzajemnej nieagresji i niepodległości, ale ostatnio wobec naszego kraju z zagranicy uparcie dokonywana jest nieustanna interwencja, ingerując bezpośrednio w takie kwestie wagi państwowej, jak oficjalne wizyty w świątyni Yasukuni czy problem podręczników”91. Kamei Shizuka podkreślił: „Chociaż dochodzi do skrajnej ingerencji $\mathrm{w}$ suwerenne prawa państwa, rząd nie odpowiada na nie $\mathrm{w}$ odpowiedni sposób. (...) Podejście do historii różni się w każdym kraju. Może Chiny czy Korea Południowa odczuwają niechęć do japońskich podręczników. Jeżeli jednak z tego powodu zmienia się ich treść, to jest to ingerencją w sprawy wewnętrzne. Poza tym problem polega na tym, że o ile za granicą domaga się rezygnacji $\mathrm{z}$ oficjalnych wizyt $\mathrm{w}$ Yasukuni, w kraju zdanie na ten temat jest podzielone" ${ }^{, 92}$.

Pomimo nacisków ze strony ,jastrzębi”, Nakasone nie miał tym razem zamiaru odwiedzać Yasukuni 15 sierpnia. Jako polityk propekiński liczył się ze zdaniem rządu w Pekinie, który negatywnie zareagował na pierwszą oficjalną wizytę rok wcześniej. Poza tym w lipcu 1986 roku PLD uzyskała rewelacyjny wynik w wyborach do obu izb parlamentu (zdobyła niemal dwie trzecie mandatów). W dużym stopniu było to zasługą wyjątkowej popularności samego premiera. Zresztą Nakasone umiejętnie wykorzystał wybory do zwiększenia liczebności swojej frakcji w partii. Dzięki temu jego baza poparcia w PLD znacząco się umocniła i nie musiał już ulegać wpływom skrajnych nacjonalistów ${ }^{93}$. Równocześnie do PLD powrócili umiarkowani politycy Nowego Klubu Liberalnego na czele z Kōno Yōheiem (od 1983 roku byli w koalicji z PLD). Na dodatek od grudnia 1985 roku stanowisko sekretarza gabinetu ponownie piastował Gotōda Masaharu z frakcji Tanaki. Teraz nawet należący do „głównego nurtu" przewodniczący Rady Generalnej PLD, Abe Shintarō z prawicowej frakcji Fukudy, musiał bronić „konsensusu propekińskiego”. Podobnie jak jego oyabun Fukuda Takeo w trakcie negocjacji Traktatu o pokoju i przyjaźni z ChRL w 1978 roku, Abe studził zapał radykałów ze swojej własnej frakcji. Na początku sierpnia 1986 roku tłumaczył: „Ten problem [wizyt w świątyni Yasukuni - przyp. aut.] jest przedmiotem dyskusji pomiędzy Japonią a Chinami i można zauważyć, że także rząd się nim martwi. Stosunki japońskochińskie są cenne, więc chcę się skonsultować z partią, czy jest potrzeba

\footnotetext{
${ }^{91}$ Kyōkasho nado..., s. 2.

${ }^{92}$ Ibidem.

${ }^{93}$ Dōjitsusen asshō..., s. 3.
} 
wydania propozycji [wizyty członków rządu w świątyni Yasukuni - przyp. aut.]" ${ }^{, 4}$.

Rezygnacja przez Nakasone $\mathrm{z}$ wizyty w Yasukuni była drugim z rzędu, po nakazaniu zmiany treści kontrowersyjnego podręcznika do historii, ciosem dla obozu ,jastrzębi”. Tymczasem w lipcu 1986 roku ministrem edukacji został Fujio Masayuki, jeden z najbardziej aktywnych działaczy Seirankai w latach 70 . XX wieku. Fujio od samego początku popełniał liczne gafy, krytykując uległą politykę premiera wobec Chin i Korei Południowej. Miarkę przebrała jego wypowiedź dla czasopisma „Bungei Shunjū” na początku września 1986 roku. Fujio powiedział wówczas o masakrze nankińskiej z 1937 roku: „W chwili wtargnięcia do Nankinu wróg przeciwstawiał się i z całych sił starano się usunąć ten opór"95. Wyraził także swoją opinię na temat dyplomacji rządu Nakasone: „Kiedyś politykę zagraniczną Shidehary ${ }^{96}$ nazywano «miękką dyplomacją». Jakaż jednak jest obecna postawa w polityce zagranicznej? Na przykład moje wypowiedzi stały się obiektem krytyki, ale jakże to jest, że starczy tylko, by Korea Południowa czy Chiny powiedziały jedno słowo, a zaraz obiecuje się poprawę. (...) Obecna Japonia najpierw ucina swoje kończyny, by się dostosować do partnera. Trudno powiedzieć, by to była dyplomacja. To samo w przypadku problemu Yasukuni. Czemu trzeba rezygnować z oficjalnej wizyty członków rządu, jakiej dokonano raz w zeszłym roku, gdy tylko pojawią się krytyczne głosy z zewnątrz? Jeśli już, lepiej od początku tego nie robić. (...) Krótko mówiąc, niezwykłą iluzją jest uważać, że dyplomacja polega na dostosowywaniu się do partnera. Taka postawa narusza autorytet i dumę Japonii, i $\mathrm{w}$ przyszłości z pewnością doprowadzi do sytuacji, że zagranica będzie poddawać sobie Japonię, robić ją w głupka, lekceważyć czy dopominać się nie wiadomo czego. Sądzę, że należy się zdecydowanie przeciwstawiać takiej polityce zagranicznej",97.

Misję przekonania Fujio do rezygnacji ze stanowiska ministra edukacji premier powierzył jednemu z członków swojego rządu, Tamakiemu Kazuo. Jak wspomina sekretarz Tamakiego, Higuchi Tsuneo, Tamaki wielokrotnie rozmawiał z Fujio, jednak za nic nie mógł go nakłonić do zmiany poglądów czy dymisji. Nie pomogły nawet wspomnienia wspólnych antykomunistycznych działań na rzecz Tajwanu i Korei Południowej w latach 70. XX wieku. Poprzez

\footnotetext{
${ }^{94}$ Shushō no Yasukuni sanpai o yōsei. Jimintō Sōmukai de Okuno-shi-ra, „Asahi Shinbun” z 6 VIII 1986, s. 2.

${ }^{95}$ Fujio Masayuki, Nomura Takuji et al., Gōchoku dotō no gendai seijika Fujio Masayuki sorekara no 100-nichi, Kindai Seikei Kenkyūkai, Tokio 1987, s. 15.

${ }^{96}$ Shidehara Kijūrō (1872-1951) był ministrem spraw zagranicznych w latach 1924-1927 i 19291931 oraz premierem w latach 1945-1946. W latach 20. i 30. XX wieku wbrew militarystom starał się nie dopuścić do zbrojnej interwencji Japonii w Chinach. Szerzej na ten temat: Shushō retsuden. Itō Hirobumi kara Koizumi Jun'ichirō made pod red. Ujiego Toshihiko, Tōkyō Shoseki, Tokio 2001, s. 222-225.

${ }^{97}$ Fujio Masayuki, Nomura Takuji et al., op.cit., s. 22.
} 
następnego byłego członka Seirankai, ministra transportu Mitsuzukę Hiroshiego, Tamaki Kazuo próbował też apelować do frakcji Abe (Fukudy), do której należał Fujio ${ }^{98}$. Nawet jednak perswazja Fukudy Takeo i Abe Shintarō nie przyniosła skutku. Minister edukacji wolał opuścić frakcję, by „nie przysparzać jej żadnych problemów", niż zmienić swoje przekonania9 ${ }^{99}$. W dniu 8 września 1986 roku Nakasone Yasuhiro zdymisjonował Fujio Masayukiego ze stanowiska ministra edukacji. Był to pierwszy tego typu przypadek w historii PLD ${ }^{100}$. Spotkało się to ze sprzeciwem ze strony Towarzystwa Podstawowych Problemów Państwa. W połowie września 1986 roku jego działacze rozważali, czy nie poddać premiera oficjalnej krytyce na zgromadzeniu parlamentarzystów z PLD. Do realizacji tego planu nie dopuścili Fukuda Takeo i Abe Shintarō, nakazując Kameiowi Shizuce powstrzymać się od radykalnych kroków ${ }^{101}$. Jak widać, przywództwo najbardziej prawicowej frakcji obawiało się pogorszenia relacji z innymi grupami ,głównego nurtu”.

Po wyciszeniu protestów ,jastrzębi”, w listopadzie 1986 roku Nakasone kolejny raz odwiedził ChRL, gdzie potwierdził cztery zasady stosunków chińsko-japońskich sformułowane przez Zhao Ziyanga i Hu Yaobanga, jak też zapowiedział pogłębienie wymiany młodzieży między oboma krajami. Przyznał również: „Kilka problemów, które pojawiły się w relacjach bilateralnych od zeszłego roku, było dla mnie bolesną próbą, jednak odważne stawianie czoła trudnościom bez lęku przed ochlapaniem jest powołaniem polityka. (...) Choćby padał deszcz i wiał wiatr, niewzruszona przyjaźń i współpraca japońsko-chińska stanowi fundament pokoju i stabilności w Azji i na świecie. Od stu słów ważniejsze są czyny oparte na przyjaźni i zaufaniu"102. Jednak tuż po powrocie do kraju pojawiły się następne problemy w relacjach japońsko-chińskich. W grudniu 1986 roku rząd Nakasone postanowił, że wydatki na obronę przekroczą 1 proc. japońskiego PNB ${ }^{103}$. Gdy w styczniu 1987 roku wizytę w Pekinie złożył sekretarz generalny PLD Takeshita Noboru, strona chińska ostrzegła, że chociaż zdaje się to małą sumą, ważny jest symboliczny wydźwięk tej decyzji. Władze KPCh obawiały się też negatywnego wpływu wiadomości o zwiększeniu japońskich wydatków na obronę na nastroje wśród chińskich studentów. Wszakże w styczniu 1987 roku Hu Yaobang zrezygnował ze stanowiska

\footnotetext{
${ }^{98}$ Higuchi Tsuneo, Tamaki Kazuo no yuigon, Asuka Shinsha, Tokio 1987, s. 62-69.

${ }^{99}$ Fujio Masayuki, Nomura Takuji et al., op.cit., s. 39.

${ }^{100}$ Aby pozwolić ministrom na „zachowanie twarzy”, w razie skandali premierzy z PLD zawsze pozwalali członkom rządu na podanie się do dymisji. Zwyczaju takiego nie było przed powstaniem PLD. Z prawa do usunięcia ministrów ze stanowiska korzystał np. Yoshida Shigeru. Szerzej na ten temat: Tomohito Shinoda, op.cit., s. 61-63.

${ }^{101}$ Tsubasa hirogeru..., s. 2.

${ }^{102}$ Narai Shigeo, op.cit., s. 302.

${ }^{103}$ Ograniczenie 1 proc. PNB na wydatki na obronę ustalił w latach 70. XX wieku premier Miki Takeo. Ostatecznie w 1987 roku minimalnie przekroczyły one ten limit. Szerzej na ten temat: I Sanghun, Ilbon-ui jeongchi kwajeong, Doseo Chulpan Bogosa, Seul 2003, s. 99-101.
} 
sekretarza generalnego KPCh, biorąc odpowiedzialność za demonstracje antyjapońskie z poprzedniego miesiąca ${ }^{104}$.

$\mathrm{Na}$ tym nie skończyły się problemy w stosunkach japońsko-chińskich w ostatnim roku rządów premiera Nakasone. W lutym 1987 roku sąd w Osace orzekł, że prawo własności do budynku Kōkaryō w Kioto posiada Republika Chińska na Tajwanie ${ }^{105}$. ChRL zdecydowanie zażądała zmiany tej decyzji, jako negującej zasadę ,jednych Chin". Chociaż sprawa Kōkaryō stanowiła ważny problem międzynarodowy, w PLD nie stała się obiektem sporów w równym stopniu, jak problemy związane z pamięcią historyczną. Zresztą politycy byli właściwie bezsilni $\mathrm{z}$ powodu niezawisłości władzy sądowniczej. Nawet propekiński sekretarz gabinetu, Gotōda Masaharu z frakcji Tanaki podkreślał, że strona chińska musi zrozumieć, iż w Japonii obowiązuje trójpodział władzy i rząd nie może wypowiadać się na temat procesu ${ }^{106}$. Władze w Pekinie nie dawały jednak za wygraną, zaś napięcie w relacjach japońsko-chińskich zaczęło niebezpiecznie wzrastać. W czerwcu 1987 roku poważnym problemem okazała się wypowiedź urzędnika wysokiego szczebla z japońskiego Ministerstwa Spraw Zagranicznych, który wobec płynących z ChRL oskarżeń o wskrzeszenie japońskiego militaryzmu nazwał Deng Xiaopinga „człowiekiem ponad chmurami” (kumo no ue no hito). Z powodu nacisku polityków propekińskich urzędnik musiał odwołać swoje słowa, ale w stosunkach bilateralnych nadal można było wyczuć stan napięcia ${ }^{107}$.

Aby poprawić atmosferę w relacjach z Chinami, we wrześniu 1987 roku w Izbie Reprezentantów przegłosowano uchwałę upamiętniającą 15. rocznicę normalizacji stosunków dyplomatycznych z ChRL. Przygotowano ją $\mathrm{z}$ inicjatywy Parlamentarnej Ligi Przyjaźni Japońsko-Chińskiej na czele z Itō

\footnotetext{
${ }^{104} \mathrm{Hu}$ Yaobang poniósł karę m.in. za swoje projapońskie nastawienie. W KPCh miano mu za złe np. zorganizowanie wizyty w Chinach liczącej 3 tys. osób grupy młodzieży japońskiej. Szerzej na ten temat: Hidenori Ijiri, op.cit., s. 655; Tanaka Akihiko, op.cit., s. 153-155.

${ }^{105}$ Kōkaryō (chiń. Guanghualiao) to akademik w Kioto, w którym mieszkali studenci chińscy. Po II wojnie światowej Uniwersytet Kioto przekazał prawa administrowania nim samym studentom, zaś w 1952 roku prawo własności przyznano Republice Chińskiej na Tajwanie. Jako jednak, że część mieszkańców akademika wspierała ChRL, budynek pozostał pod administracją studentów. W 1967 roku reżim Guomindangu złożył w tej sprawie pozew do sądu. Sąd regionalny w Kioto orzekł w 1977 roku, że w związku z nawiązaniem przez Japonię oficjalnych stosunków dyplomatycznych z ChRL w 1972 roku, prawo własności przeszło na rząd ChRL. W 1982 roku sąd apelacyjny w Osace uchylił jednak to orzeczenie i odesłał sprawę z powrotem do sądu w Kioto. W 1986 roku sąd w Kioto uznał zasadność uchylenia orzeczenia, zaś w lutym 1987 roku sąd apelacyjny w Osace uznał prawo Tajwanu do akademika. Postępowanie sądowe nadal trwa. Obecnie Kōkaryō znajduje się w stanie postępującej ruiny, ponieważ nie wiadomo, kto ma się nim opiekować. Szerzej na ten temat: Yamaoka Susumu, Kōkaryō soshō ni tsuite, „Daitō Bunka Daigaku Hōgaku Kenkyūjo Hō” 1988, nr 5, s. 1-7; Tanaka Akihiko, op.cit., s. 155-156.

${ }^{106}$ Posiedzenie Komisji Rozrachunkowej Izby Radców (Sangiin Kessan Iinkai) z 18 VI 1987 roku, nr 4, Archiwum Obrad...

${ }^{107}$ Tanaka Akihiko, op.cit., s. 155-164.
} 
Masayoshim z frakcji Miyazawy. Jej przyjęcie okazało się jednak okazją do demonstracji swojego niezadowolenia propekińską polityką rządu przez członków Towarzystwa Podstawowych Problemów Państwa. W trakcie głosowania poprzez wstanie z miejsc demonstracyjnie siedzieli tacy ,jastrzębie”, jak Suzuki Muneo, Hiranuma Takeo czy Asō Tarō. Również Shiina Motoo (syn Shiiny Etsusaburō) wyraził swoje niezadowolenie, siadając natychmiast po wstaniu. Kamei Shizuka, który opuścił salę przed głosowaniem powiedział: „Nie podjęliśmy decyzji w sprawie naszego zachowania jako grupa. Myślę jednak, że poszczególni członkowie postąpili tak z własnej wolnej woli, gdyż treść uchwały ukazywała uległość wobec Chin" ${ }^{\text {"108 }}$.

Tymczasem długi, pięcioletni okres rządów Nakasone Yasuhiro dobiegał końca. Dzięki historycznemu zwycięstwu w wyborach parlamentarnych w 1986 roku, premier uzyskał wyjątkowe przedłużenie sprawowania funkcji przewodniczącego PLD o dodatkowy rok ponad regulaminowe dwie dwuletnie kadencje. Gdy okres ten minął w listopadzie 1987 roku, Nakasone podał się do dymisji, kładąc kres rządom drugiego pokolenia przywódców frakcji. Władzę w partii mieli przejąć młodsi politycy.

* * *

Trudno jednoznacznie ocenić rządy Nakasone Yasuhiro. $\mathrm{Z}$ jednej strony był to niewątpliwie polityk propekiński, z drugiej zaś zdeklarowany ,jastrząb”. Właśnie to nacjonalistyczne oblicze premiera stało się przyczyną kilku kryzysów w stosunkach ze stroną chińską. Szczególnie ostatnie lata rządów Nakasone, gdy w jego „głównym nurcie” dominowały frakcje z prawego skrzydła PLD, sprzyjały „patriotycznym" przedsięwzięciom zarówno samego premiera (wizyta w świątyni Yasukuni), jak i członków jego rządu (wypowiedź Fujio Masayukiego). Należy jednak podkreślić, że Nakasone starał się szybko reagować, nie dopuszczając do eskalacji napięcia $w$ relacjach $z$ władzami w Pekinie. Jego nacjonalistyczne posunięcia były pomyślane wyłącznie jako element polityki wewnętrznej, bez zamiaru antagonizowania Chin. Po krytycznej reakcji ChRL na wizytę $\mathrm{w}$ świątyni Yasukuni, Nakasone przerwał długą tradycję jej odwiedzania, zaś $\mathrm{w}$ chwili pojawienia się zastrzeżeń do treści jednego $\mathrm{z}$ podręczników do historii, natychmiast nakazał jego ponowną kontrolę. Z kolei po kontrowersyjnej wypowiedzi Fujio Masayukiego usunął go ze stanowiska, choć dotychczasowi premierzy z PLD nie praktykowali obyczaju dymisjonowania swoich ministrów. Posunięcia te spotkały się z krytyką garstki najbardziej radykalnych ,jastrzębi”, jednak wspierany przez frakcję-hegemona premier Nakasone z łatwością utrzymał ,propekiński konsensus” w ramach partii.

\footnotetext{
${ }^{108}$ Po tym zdarzeniu dyskutowano o ukaraniu posłów, którzy pogwałcili dyscyplinę partyjną, jednak ponieważ decyzja o uchwale została podjęta przez zarząd PLD bez dyskusji w Radzie Generalnej, zrezygnowano z jakichkolwiek sankcji. Szerzej na ten temat: Nitchū yūkō ketsugi de Jimin taka-ha ga tōgi mushi. Kiritsu sezu hantai no ishi, , „Asahi Shinbun” z 11 IX 1987, s. 2.
} 


\section{TAKESHITA NOBORU (1987-1989)}

Objęcie władzy przez Takeshitę Noboru nie zapowiadało żadnych zmian w polityce PLD wobec Chin. Wręcz przeciwnie, dawny kobun Tanaki miał przynajmniej równie propekińskie poglądy, jak Nakasone, za to nie należał do obozu ,jastrzębi”. Stosunkowo umiarkowana postawa przywódcy frakcji środka dawała nadzieję, że za jego rządów nie dojdzie do kryzysów związanych z pamięcią historyczną. $\mathrm{Z}$ drugiej strony, kadencja Takeshity przypadła na okres choroby i śmierci cesarza Hirohito, który odegrał niezwykle kontrowersyjną rolę w czasie II wojny światowej. Zakończenie starej ery miało wywołać w Japonii dyskurs na temat trudnej historii obu krajów. Nie pozostał on bez wpływu na atmosferę w relacjach japońsko-chińskich.

\section{Trzecie pokolenie przywódców frakcji}

Razem z ustąpieniem Nakasone Yasuhiro ze stanowiska premiera do władzy doszło trzecie pokolenie przewodniczących frakcji w PLD. Jeszcze w 1986 roku Abe Shintarō, zięć Kishiego Nobusuke, przejął przywództwo nad frakcją Fukudy, zaś Miyazawa Kiichi nad frakcją Suzukiego. Tranzycję pokoleniową dopełnił Takeshita Noboru, oficjalnie powołując do życia w lipcu 1987 roku grupę Keiseikai, do której przeszła przytłaczająca większość członków obozu Tanaki ${ }^{109}$. W ten sposób zakończył się dwuletni okres „wojny domowej” wewnątrz frakcji-hegemona. Jedynie kilku polityków w podeszłym wieku do samego końca pozostało wiernych Tanace, skupiając się wokół Nikaidō Susumu ${ }^{110}$.

Abe, Takeshita i Miyazawa nazywani są w japońskiej politologii „nowymi

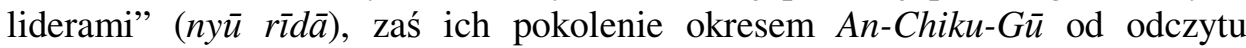
pierwszych znaków ich trzech nazwisk. Zgodnie ze słowami Takeshity Noboru: „Poczynając od Yoshidy Shigeru, przez Kishiego Nobusuke i Ikedę Hayato po Satō Eisaku, starsi powojenni koledzy urodzeni w erze Meiji [1868-1912 przyp. aut.] są wielcy we wszystkim, gdyż doświadczyli okresu, gdy Japonia była niegdyś jednym z pięciu mocarstw świata. To pokolenie obejmuje też Nakasone Yasuhiro, chociaż narodził się on w erze Taishō [1912-1926 - przyp. aut.]. (...) W porównaniu z nimi, urodzony w 8 roku ery Taishō [1919 rok przyp. aut.] Miyazawa, w 13 roku [1924 rok - przyp. aut.] Abe i nasze pokolenie spędziło młodzieńcze życie w okresie gwałtownych przemian przed, w czasie $\mathrm{i}$ po wojnie, więc nauczyło się nie trzymać własnego zdania za wszelką cenę i adaptować do zmian rzeczywistości. Co więcej, my, zwani wówczas nowymi

\footnotetext{
${ }^{109}$ Takeshita Noboru, Shōgen..., s. 171-172.

${ }^{110}$ Hayasaka Shigezō podkreśla, że Takeshita do samego końca obawiał się, iż Tanaka odzyska siły i zdławi jego „rebelię”. Rodzina Tanaki nie przepadała za Takeshitą i starała się promować Nikaidō, przez co nie wszyscy politycy frakcji Tanaki przeszli do frakcji Takeshity. Szerzej na ten temat: Hayasaka Shigezō, Kenryoku..., s. 54-61.
} 
liderami, osobiście doświadczyliśmy zażartej walki o władzę w tzw. erze «SanKaku-Dai-Fuku». Z tego powodu mieliśmy silną wolę odcięcia się w naszym okresie od polityki nienawiści. Poza tym, gdy się zbadało poszczególne programy polityczne, okazało się, że opierają się one na wspólnych ideach. Krótko mówiąc, nie byliśmy liderami typu: «Idź za mną», tylko politykami obserwującymi rzeczywistość i poszukującymi harmonii" ${ }^{111}$.

Tabela 4.4 Rozkład sił pomiędzy frakcjami PLD w okresie rządów Takeshity Noboru w latach 1987-1989.

\begin{tabular}{|l|l|l|}
\hline \multicolumn{2}{|c|}{ Frakcje: } \\
\hline ,głównego nurtu” & poza ,głównym nurtem” & „przeciwnego nurtu” \\
\hline Takeshita (L, P) 135 & Nikaidō (L, G, P) 4 & - \\
Abe (D, J, T) 82 & & \\
Miyazawa (L, G, P) 87 & & \\
Nakasone (D, J) 75 & & \\
Kōmoto (D, G, P) 34 & 4 & - \\
\hline 413 & & \\
L: 2 (222), D: 3 (191), & & \\
G: 2 (121), J: 2 (157), & & \\
P: 3 (256), T: 1 (82). & & \\
\hline
\end{tabular}

L- dawni członkowie Partii Liberalnej, główny nurt konserwatywny, D- dawni członkowie Partii Demokratycznej, boczny nurt konserwatywny, G- gołębie, J- jastrzębie, P- obóz propekiński, Tobóz protajwański.

Liczebność frakcji (podana przy poszczególnych frakcjach) po wyborach do Izby Reprezentantów z lipca 1986 roku. Uwzględniono członków frakcji z obu izb parlamentu. Liczba członków frakcji Takeshity i Nikaidō podana w przybliżeniu. W podsumowaniu „głównego nurtu” podana jest ogólna liczba należących do niego parlamentarzystów oraz liczba frakcji, zaś w nawiasie liczba parlamentarzystów, należących do poszczególnych obozów.

Opracowanie własne na podstawie: Fukunaga Fumio, Habatsu..., s. 80; Kitaoka Shin'ichi, op.cit., s. 336.

Słowa Takeshity dobrze obrazują charakter trzeciego pokolenia przywódców frakcji. Nastawienie na ,wykuwanie" kompromisu podczas zakulisowych spotkań i unikanie otwartych sporów oznaczało nie tylko kontynuację ,polityki harmonii" proklamowanej przez Suzukiego, ale jeszcze jej pogłębienie. Decyzja o wyborze nowego przewodniczącego PLD została powierzona premierowi Nakasone. W ten sposób uniknięto ,polityki nienawiści”, która towarzyszy oficjalnym wyborom przewodniczącego PLD. Po wywiadzie z trzema „nowymi liderami”, Nakasone Yasuhiro wskazał na swojego następcę przywódcę największej frakcji, Takeshitę Noboru.

Zgodnie z zasadą poszanowania harmonii wewnątrzpartyjnej, do „głównego nurtu” Takeshity Noboru weszły niemal wszystkie frakcje, dostając proporcjonalną do swojej wielkości liczbę stanowisk ministerialnych. Jedynym wyjątkiem

${ }^{111}$ Takeshita Noboru, Shōgen..., s. 173-174. 
była mała grupa Nikaidō Susumu ${ }^{112}$. Nikaidō czuł niechęć do Takeshity jako do człowieka, który zdradził Tanakę Kakueia. Tak szeroka platforma wewnątrzpartyjna siłą rzeczy musiała być niespójna ideologicznie. Zrzeszała zarówno licznych reprezentantów ,głównego” i „bocznego nurtu konserwatywnego”, jak też ,jastrzębi” i „gołębi”. Widać jedynie wyraźną przewagę obozu propekińskiego nad protajwańskim. Różnice ideologiczne pomiędzy frakcjami stały się jednak znacznie mniej wyraźne niż w okresie rządów drugiego pokolenia przywódców PLD. Takeshita Noboru zapoczątkował tradycję regularnych spotkań sekretarzy generalnych wszystkich frakcji w partii (habatsu no jimusōchō kaigi). Ten nieformalny organ służył instytucjonalizacji ,polityki harmonii". Aby uniknąc otwartych konfliktów wewnątrzpartyjnych, wysocy przedstawiciele każdej frakcji wymieniali informacje na temat bieżących spraw i razem ustalali ogólny kierunek polityki ugrupowania ${ }^{113}$. W praktyce oznaczało to dalsze wzmocnienie dominacji frakcji Takeshity ${ }^{114}$. „Propekiński konsensus” został zinstytucjonalizowany, zaś na jego straży stali odtąd wszyscy liderzy frakcji, dyscyplinując tych członków własnych grup, którzy by podjęli działania wbrew ogólnym ramom polityki PLD.

Tabela 4.5 Liczba członków Parlamentarnej Ligi Przyjaźni Japońsko-Chińskiej (PLPJ-C) oraz Parlamentarnego Zgromadzenia Stosunków Japońsko-Tajwańskich (PZSJ-T) według przynależności frakcyjnej w PLD.

\begin{tabular}{|c|c|c|c|c|c|c|c|}
\hline & $\begin{array}{l}\text { Tanaka/ } \\
\text { Takeshita }\end{array}$ & \begin{tabular}{|l|} 
Suzuki/ \\
Miyazawa
\end{tabular} & Kōmoto & Nakasone & $\begin{array}{l}\text { Fukuda/ } \\
\text { Abe }\end{array}$ & Inni & $\begin{array}{l}\text { W } \\
\text { sumie }\end{array}$ \\
\hline PLPJ-C & 48 & 41 & 16 & 32 & 16 & 6 & 159 \\
\hline PZSJ-T & 22 & 13 & 8 & 25 & 36 & 12 & 116 \\
\hline Oba & 15 & 11 & 3 & 14 & 14 & 3 & 60 \\
\hline Żadne & 11 & 8 & 5 & 6 & 7 & 2 & 39 \\
\hline
\end{tabular}

Dane z lutego 1986 roku. Uwzględniono jedynie parlamentarzystów z Izby Reprezentantów. Źródło: Tanaka Akihiko, op.cit., s. 201-202.

Warto się przyjrzeć danym dotyczącym członkostwa polityków poszczególnych frakcji w ligach parlamentarnych zajmujących się relacjami z ChRL bądź z Tajwanem. Jak widać w tabeli 4.5, tuż przed objęciem władzy przez trzecie pokolenie liderów PLD w połowie lat 80 . XX wieku nadal można było mówić o pewnych kolorytach ideologicznych określonych frakcji. W grupie Suzukiego członkowie Parlamentarnej Ligi Przyjaźni Japońsko-Chińskiej aż trzykrotnie przeważali nad politykami z Parlamentarnego Zgromadzenia Stosunków Japońsko-Tajwańskich. Podobną tendencję, chociaż w nieco mniejszej skali, widać także w innych frakcjach propekińskich: Tanaki i Kōmoto. W grupie Nakasone panowała względna równowaga pomiędzy członkami obu lig

\footnotetext{
${ }^{112}$ Kikuchi Hisashi, Sōri daijin Takeshita Noboru, Piipurusha, Tokio 1987, s. 14-15.

${ }^{113}$ Nonaka Naoto, Jimintō seiji no owari, Chikuma Shobō, Tokio 2008, s. 143.

${ }^{114}$ Kikuchi Hisashi, Sōri daijin..., s. 148.
} 
parlamentarnych. Jedynie frakcję Fukudy można było nazwać protajwańską, z ponad dwukrotną przewagą posłów należących do Parlamentarnego Zgromadzenia Stosunków Japońsko-Tajwańskich. Podobna tendencja występowała wśród polityków bezfrakcyjnych. Stosunkowo niewielka była grupa posłów nienależących do którejkolwiek z dwóch lig parlamentarnych (39 osób). Zwracało za to uwagę spore grono polityków zapisanych do obu, zdawałoby się konkurencyjnych, lig (60 osób). Świadczyło to o postępującym osłabieniu rywalizacji między obozem propekińskim a protajwańskim w PLD.

Podobnie jak Tanaka Kakuei, Takeshita Noboru posiadał rozległe wpływy w zoku budownictwa i poczty, nie był za to specjalistą $\mathrm{w}$ kwestiach polityki zagranicznej. Motto jego kadencji, ,rodzinny dom i kreacja” (furusato to sōsei), kładło nacisk na politykę wewnętrzną i nawiązywało do „dyskursu o przebudowie Archipelagu Japońskiego" Tanaki ${ }^{115}$. Takeshita należał także do klanu strategii parlamentarnej, odpowiedzialnego za negocjacje z opozycją. Nauczyło go to ugodowości i dążenia do kompromisu w sprawach ideologicznych. Chociaż na przełomie lat 60. i 70. XX wieku Takeshita był sekretarzem gabinetu znienawidzonego przez władze KPCh premiera Satō Eisaku, później, jako jeden z czołowych członków propekińskiej frakcji Tanaki, nawiązał liczne znajomości z politykami z Chin komunistycznych. Po raz pierwszy odwiedził ChRL już we wrześniu 1972 roku jako członek delegacji pod przewodnictwem Kosaki Zentarō, która przygotowała grunt pod historyczną wizytę premiera Tanaki w Pekinie. Choć sam przyznaje, że nie odegrał wówczas żadnej ważnej roli ${ }^{116}$, później często odwiedzał Chiny i zawsze spotykał się z wielką sympatią decydentów chińskich dla polityków z frakcji Tanaki ${ }^{117}$.

Do najlepszych przyjaciół Takeshity Noboru należał Abe Shintarō. Abe był zięciem Kishiego Nobusuke i w pewnym stopniu przejął od niego poglądy polityczne. Sam zwykł mawiać o sobie: „Jeśli chodzi o dyplomację, jestem jastrzębiem, zaś pod względem polityki wewnętrznej jestem gołębiem" 118 . Rzeczywiście, w przeciwieństwie do swojego teścia, Abe nie działał zbyt aktywnie na rzecz rewizji pacyfistycznej konstytucji, nie protestował także przeciwko odwołaniu przez premiera Nakasone wizyty w świątyni Yasukuni w 1986 roku. Jednakże w kwestiach dyplomacji jego postawa przypominała podejście Kishiego. Abe Shintarō prowadził ściśle proamerykańską politykę, przykładając znacznie mniejszą wagę niż „gołębie” do „uległych działań schlebiających Chinom czy Korei Północnej”" ${ }^{119}$. Z drugiej strony, Abe reprezentował młodsze pokolenie prawicowych polityków, które nie było już tak

\footnotetext{
115 Takeshita Noboru, Subarashii kuni Nihon, Kōdansha, Tokio 1987, s. 3-26.

${ }^{116}$ Idem, Seiji to wa..., s. 276-278.

${ }^{117}$ Idem, Shōgen..., s. 84.

${ }^{118}$ Yamagiwa Sumio, Abe Shinzō monogatari, Kōbunsha 21, Tokio 2003, s. 129.

${ }^{119}$ Ibidem, s. 129-130.
} 
ściśle związane z reżimem Guomindangu, jak protajwańscy parlamentarzyści pokroju Kishiego.

Abe Shintarō piastował stanowisko ministra spraw zagranicznych przez niemal całą kadencję Nakasone Yasuhiro. Proklamował wówczas tzw. „twórczą dyplomację" (sōzōteki gaikō), która miała polegać na większej niż dotychczas aktywności Japonii na arenie międzynarodowej. Wśród zasad polityki zagranicznej wymieniał zarówno wzmocnienie współpracy $\mathrm{z}$ demokratycznymi państwami Zachodu, jak i budowę wzajemnego zaufania z krajami o innych ustrojach i ideologiach niż Japonia. Wspierał zwiększenie wydatków budżetowych na Siły Samoobrony, zapewniając jednocześnie, że Japonia nie zamierza zostać mocarstwem militarnym ${ }^{120}$. Abe przyjął pragmatyczną postawę wobec modernizujących się Chin. Zięć Kishiego deklarował, iż władze w Tokio wspierają reformy w ChRL i są gotowe do pogłębienia dialogu z tym państwem. Był także świadomy tego, że bliskie relacje z Chinami są dla Stanów Zjednoczonych ważną kartą przetargową $w$ zimnowojennej rywalizacji ze Związkiem Radzieckim ${ }^{121}$.

Co ciekawe, w latach 80. XX wieku nawet sam Kishi Nobusuke złagodził swoje stanowisko wobec ChRL. W 1983 roku uczestniczył w uroczystościach żałobnych w ambasadzie chińskiej w Tokio po śmierci Liao Chengzhiego. Próbował także, m.in. poprzez Abe Shintarō, wybadać nastawienie reżimu Guomindangu wobec swojej ewentualnej wizyty w ChRL. Władze w Tajpej chłodno zareagowały na tę inicjatywę i ostatecznie Kishi nie zobaczył północnowschodnich regionów Chin, które chciał jeszcze raz odwiedzić przed śmiercią ${ }^{122}$. Zachowanie Kishiego dobrze obrazuje generalną zmianę nastawienia ,jastrzębi” w PLD do modernizujących się Chin. Ponieważ ChRL coraz mniej przypominała państwo komunistyczne, zdeklarowani antykomuniści musieli zrewidować swoje podejście do tego kraju. Kishi Nobusuke zmarł w 1987 roku. Mimo że pod koniec życia próbował zbliżyć się do władz w Pekinie, ostatecznie zachował wierność reżimowi Guomindangu, zaś jego śmierć była ciosem dla obozu protajwańskiego.

W okresie rządów „nowych liderów” coraz więcej dawnych członków Seirankai uzyskiwało stanowiska ministerialne. Zdecydowana większość z nich różniła się od Fujio Masayukiego, który przedłożył własne poglądy nad karierę polityczną ${ }^{123}$. Jeden $\mathrm{z}$ ówczesnych działaczy Towarzystwa Podstawowych

\footnotetext{
${ }^{120}$ Abe Shintarō, Nagano Nobutoshi, Sōzōteki gaikō o mezashite, Gyōsei Mondai Kenkyūjo, Tokio 1984, s. 82-281.

${ }^{121}$ Abe Shintarō, Nihon gaikō no shishin, Shintarō Kai, Tokio 1984, s. 95-140.

${ }^{122}$ Zhong-Ri guanxi 30 nian..., s. 303-304.

${ }^{123} \mathrm{~W}$ latach $80 . \mathrm{XX}$ wieku Fujio wielokrotnie odwiedzał Tajwan na czele delegacji PLD, również gdy piastował stanowisko przewodniczącego Rady Badań Politycznych. Szerzej na ten temat: Ding Zhaozhong, Zhong-Ri fujiao-hou Riben zhengjie jijin qin-Tai shili de shanbian, „Guoji Luntan” 2008, vol. 10, no. 4, s. 47; Fujio Seichōkaichō wa Taiwan hōmon e, „Nihon Keizai Shinbun" z 22 VI 1985, s. 2.
} 
Problemów Państwa, Hiranuma Takeo, przyznaje, że w miarę awansu w partii środowisko związane z Seirankai musiało porzucić, bądź przynajmniej złagodzić, swoje radykalne poglądy i przyjąc bardziej realistyczną postawę polityczną ${ }^{124}$. Dymisja Fujio w 1986 roku pokazała, do czego może prowadzić uparte trzymanie się skrajnie nacjonalistycznych przekonań. Fujio Masayuki z żalem przyznawał, że gdyby jego dawny kolega Tamaki Kazuo był tego samego zdania co on, to „czyż nie podalibyśmy się razem do dymisji?" ${ }^{25}$ Z kolei kiedy inny dawny członek Seirankai, Nakayama Masaaki, odwiedził ChRL w 1988 roku jako minister poczty, Hamada Kōichi nazwał takie postępowanie „zdradą"126. Kolejnymi przykładami polityków z Seirankai, którzy zrobili karierę w PLD byli Mitsuzuka Hiroshi i Watanabe Michio. Gdy na przełomie lat 80. i 90. XX wieku objęli funkcję liderów frakcji, niewiele zostało $\mathrm{z}$ ich protajwańskiego zapału $\mathrm{z}$ lat 70. XX wieku. Po części sytuację tę można wytłumaczyć także faktem, że prezydent Tajwanu w latach 1978-1988, Jiang Jingguo, miał znacznie słabsze personalne powiązania z Japonią niż jego ojciec Jiang Jieshi ${ }^{127}$.

\section{Koniec ery Shōwa}

Pomimo umiarkowanych poglądów samego premiera, okres rządów Takeshity Noboru obfitował w podobne problemy w relacjach japońsko-chińskich, jak te, które wystąpiły w ostatnich latach kadencji Nakasone Yasuhiro. Nieprzemyślane wypowiedzi współtworzących „główny nurt” ,jastrzębi” od czasu do czasu spotykały się z ostrą krytyką ze strony ChRL. W kwietniu 1988 roku dyrektor Agencji Lądu Okuno Seisuke stwierdził w odpowiedzi na pytanie o swoje wizyty w świątyni Yasukuni: „W relacjach z Chinami dochodzi do różnych nieporozumień, ponieważ jest to państwo komunistyczne i słabo rozumie religię. (...) To godne pożałowania, że cały naród jest poruszany przez wypowiedzi Deng Xiaopinga. (...) Biała rasa utrzymywała w Azji kolonie. Wyszło jednak tak, jakby tylko Japonia była zła. Któż był państwem napastniczym? To była biała rasa" ${ }^{, 28}$. Na dodatek, gdy strona chińska złożyła oficjalny protest, Okuno dodał: „Ja jestem osobą, która nienawidzi używać słowa inwazja. Sądzę, że wówczas Japonia nie miała takiego zamiaru" ${ }^{129}$. W maju 1988 roku sekretarz gabinetu, Obuchi Keizō, sprostował jednak, że japoński rząd uznaje wojnę z Chinami za napastniczą, zaś Okuno Seisuke musiał podać się do dymisji ${ }^{130}$.

W sierpniu 1988 roku premier Takeshita Noboru odwiedził ChRL, aby uczcić 10. rocznicę podpisania Traktatu o pokoju i przyjaźni. Na spotkaniu z Deng Xiaopingiem zapowiedział udzielenie Chinom trzeciej pożyczki w jenach na lata

\footnotetext{
${ }^{124}$ Wywiad autora z Hiranumą Takeo...

${ }^{125}$ Fujio Masayuki, Nomura Takuji et al., op.cit., s. 41.

${ }^{126}$ Seikai memo, Moto Seirankai, shinchü-ha ni kuragae?, ,Yomiuri Shinbun” z 7 VII 1988, s. 3.

${ }^{127}$ Honda Yoshihiko, op.cit., s. 145.

${ }^{128}$ Tanaka Akihiko, op.cit., s. 168.

${ }^{129}$ Ibidem, s. 169.

${ }^{130}$ Ibidem.
} 
1990-1995. Jej wysokość znacząco przekroczyła poprzednią i wyniosła 810 mld jenów ${ }^{131}$. W Japonii toczył się spór pomiędzy Ministerstwem Spraw Zagranicznych, które chciało zwiększenia kwoty przeznaczonej dla Chin, oraz Ministerstwem Finansów, starającym się ograniczyć wydatki budżetowe. Dopiero za osobistym wstawiennictwem premiera udało się przeforsować plan Ministerstwa Spraw Zagranicznych ${ }^{132}$. W sprawie Kōkaryō Takeshita stwierdził, że Japonia będzie pracować nad rozwiązaniem problemu w poszanowaniu zasady jednych Chin ${ }^{133}$. Podkreślił również, że rząd w Tokio nie zmieni ustalonej w 1972 roku polityki wobec Tajwanu ${ }^{134}$. Zdawało się wówczas, iż wszelkie nieporozumienia $w$ relacjach bilateralnych zostały wyciszone. Wkrótce doszło jednak do zdarzenia, które mogło zakłócić tę atmosferę przyjaźni.

Na jesieni 1988 roku ciężko zachorował cesarz Hirohito (Shōwa). Rząd japoński nakazał pohamowanie się obywateli od rozrywki i okazywanie przez media szacunku wobec monarchy. Cesarz Hirohito zmarł na początku stycznia 1989 roku po ponad 60 latach panowania. Ponieważ wstąpił na tron w 1926 roku, był głową państwa w okresie II wojny światowej. Takeshita Noboru z przejęciem zajął się przygotowaniem pogrzebu cesarza, tym bardziej że posłowie z Towarzystwa Podstawowych Problemów Państwa dbali, by wszystkie ceremonie przebiegały zgodnie $\mathrm{z}$ wielowiekową tradycją ${ }^{135}$. Aby nie mówić źle o zmarłym, premier popełnił jednak poważną gafę, która mogła przemienić się w kolejny kryzys w stosunkach japońsko-chińskich. W połowie lutego 1989 roku stwierdził w Izbie Reprezentantów: „To, czy wojna prowadzona przez Japonię była wojną napastniczą, czy nie, jest problemem, przy którym należy poczekać na osąd historyków następnego pokolenia"136. Aby uciszyć głos krytyki, który pojawił się wobec tego oświadczenia, Takeshita 24 lutego 1989 roku wyraził żal z powodu swoich słów. Tego samego dnia w trakcie ceremonii pogrzebowych cesarza został upomniany przez uczestniczącego w nich chińskiego ministra spraw zagranicznych Qian Qichena, który powiedział: „Dopiero przy właściwym podejściu do historii będzie można umacniać chińsko-japońską przyjaźń" ${ }^{137}$. Wkrótce też Takeshita potwierdził w parlamencie, że Japonia prowadziła wojnę napastniczą i szanuje przyjaźń z Chinami.

Dzięki temu wizyta premiera Li Penga w Japonii w kwietniu 1989 roku mogła się odbyć w atmosferze przyjaźni. Takeshita Noboru odniósł się wówczas do problemu Tajwanu: „Opierając się na Wspólnej deklaracji japońsko-chińskiej,

\footnotetext{
${ }^{131}$ Sekiyama Takashi, op.cit., s. 75-77.

${ }^{132}$ Jimintō Seichōkai, s. 135.

${ }^{133}$ Shimada Masao, Tian Jianong, op.cit., s. 382.

${ }^{134}$ Gotō Kenji, Takeshita seiken 576-nichi, Gyōken Shuppankyoku, Tokio 2000, s. 325.

135 Ibidem, s. 256.

${ }^{136}$ Shimada Masao, Tian Jianong, op.cit., s. 381.

${ }^{137}$ Ibidem.
} 
Japonia nie popiera zasady «jednych Chin, jednego Tajwanu», rząd japoński nie rozwija stosunków politycznych z Tajwanem, ani tym bardziej nie wspiera «niepodległości Tajwanu»" ${ }^{138}$. Obiecał także budowę w Chinach Centrum Ochrony Środowiska im. Przyjaźni Japońsko-Chińskiej ze środków bezzwrotnej pomocy finansowej w ramach ODA. Na dodatek w trakcie spotkania Li Penga z cesarzem Akihito (Heisei), nowy cesarz stwierdził: „Wyrażam żal z powodu nieszczęśliwych zdarzeń, do których doszło we współczesnej historii" ${ }^{139}$. Nie były to co prawda przeprosiny, ale i tak pierwsze wyrażenie przez japońskiego monarchę „żalu” za zbrodnie wojenne miało pewne znaczenie symboliczne. Mogło też dawać nadzieję, że wraz z pochowaniem kontrowersyjnego cesarza Hirohito stosunki japońsko-chińskie będą mogły rzeczywiście wejść w nową erę wzajemnego zrozumienia.

Kiedy Takeshita Noboru obejmował urząd premiera jako lider frakcjihegemona w PLD, zapowiadano jego długie rządy. W czerwcu 1988 roku ujawniono jednak aferę firmy Recruit, w którą zamieszanych było kilkudziesięciu czołowych japońskich polityków, w tym sam prezes Rady Ministrów $^{140}$. Takeshita Noboru ustąpił ze stanowiska w atmosferze skandalu na początku czerwca 1989 roku.

$$
* * *
$$

W czasie rządów Takeshity Noboru w stosunkach japońsko-chińskich pojawiły się problemy podobne do tych, które nasiliły się pod koniec kadencji Nakasone Yasuhiro. Chociaż Takeshita należał do frakcji umiarkowanej ideologicznie, nie był w stanie zupełnie uciszyć głosu ,jastrzębi”, piastujących wysokie stanowiska w państwie. Mógł jedynie reagować na nie po fakcie, jak w przypadku wypowiedzi Okuno Seisuke. Z kolei śmierć cesarza i konieczność otoczenia jej odpowiednim dekorum sprawiły, że sam premier popełnił gafę, którą później musiał odwołać. Niemniej jednak nadal nie było widać przesłanek końca „propekińskiego konsensusu”, utrzymywanego w ramach „ogólnego głównego nurtu”. Wręcz przeciwnie, kontynuowana przez trzecie pokolenie szefów frakcji „polityka harmonii” wyraźnie działała na korzyść zwolenników pogłębiania przyjacielskich relacji z ChRL. Frakcja Abe, chociaż nadal najbardziej protajwańska, powoli upodabniała się pod względem ideologii do innych grup wewnątrz PLD. Przejawem tego procesu było złagodzenie skrajnych poglądów przez dawnych członków Seirankai.

\footnotetext{
138 Ibidem, s. 384.

${ }^{139}$ Ibidem, s. 385 .

${ }^{140} \mathrm{~W} 1988$ roku wyszło na jaw, że w połowie lat 80. XX wieku kilkudziesięciu polityków z różnych partii uzyskało możliwość zakupu po preferencyjnych cenach akcji firmy Recruit (Rikurūto Kosumosu) przed jej debiutem na giełdzie. Z tego powodu samobójstwo popełnił w kwietniu 1989 roku sekretarz Takeshity, Aoki Ihei. Szerzej na ten temat: Hoshi Hiroshi, op.cit., s. 119-120; Iwase Tatsuya, Ware banshi ni ataisu. Dokyumento Takeshita Noboru, Shinchōsha, Tokio 1999, s. 115-191.
} 


\section{UNO SŌSUKE I KAIFU TOSHIKI (1989-1991)}

Uno Sōsuke i Kaifu Toshikiemu przyszło rządzić w okresie bardzo istotnym dla przyszłości stosunków japońsko-chińskich. Masakra na placu Tiananmen drastycznie zmieniła nastawienie państw Zachodu wobec ChRL i wymusiła na Japonii nałożenie na Chiny sankcji gospodarczych. Incydent ten stanowił największe z dotychczasowych wyzwań dla „konsensusu propekińskiego” w PLD. Obaj premierzy byli jednak całkowicie uzależnieni od poparcia frakcji Takeshity, co oznaczało kontynuację propekińskiej polityki poprzedniego rządu.

\section{„Główny nurt” Uno Sōsuke i reakcja Japonii na masakrę na placu Tiananmen}

Ponieważ w skandal korupcyjny firmy Recruit zamieszani byli wszyscy ówcześni przywódcy głównych frakcji, w PLD rozpoczęło się poszukiwanie kandydata na przewodniczącego partii, który byłby na tyle „czysty”, by uzyskać poparcie społeczne. Takeshita od dawna chciał mianować na następcę swojego przyjaciela Abe Shintarō, ale afera korupcyjna i nagła choroba Abe mu to uniemożliwiła. Ostatecznie wybór padł na Uno Sōsuke, wcześniej szerzej nieznanego członka frakcji Nakasone. Uno był wygodnym kandydatem dla Takeshity, gdyż zapewniał uczestnictwo w „głównym nurcie” frakcji Nakasone. Jak twierdzi Hayasaka Shigezō, ustępujący premier traktował wybór Uno jako środek tymczasowy, by zastąpić go przez Abe Shintarō, gdy tylko odzyska on zdrowie $^{141}$.

Uno Sōsuke był politykiem o długim stażu jako parlamentarzysta, ale wcześniej nie należał do grona głównych decydentów w partii. Był też pierwszym w historii przewodniczącym PLD, który nie piastował jednocześnie funkcji lidera frakcji ${ }^{142}$. Dzięki temu Takeshita Noboru miał jeszcze łatwiejsze zadanie w kontrolowaniu go niż Tanaka Kakuei w wywieraniu wpływu na Suzukiego Zenkō i Nakasone Yasuhiro. Poza tym Uno Sōsuke nie był politykiem o radykalnych poglądach i trudno się było spodziewać, by w polityce zagranicznej wykazał inicjatywy sprzeczne z dotychczasową linią dyplomatyczną Japonii. Zresztą Uno piastował wcześniej urząd ministra spraw zagranicznych w gabinecie Takeshity.

Uno Sōsuke przyszło pełnić funkcję premiera tylko przez dwa miesiące, jednak był to okres o dużym znaczeniu dla przyszłości relacji japońskochińskich. Uno objął rządy 3 czerwca 1989 roku, zaś następnego dnia doszło do masakry na placu Tiananmen w Pekinie ${ }^{143}$. Wydarzenie to poruszyło japońską i

\footnotetext{
${ }^{141}$ Hayasaka Shigezō, Kenryoku..., s. 98-100.

${ }^{142}$ Również Suzuki Zenkō w chwili powołania na stanowisko przewodniczącego PLD nie był szefem frakcji, ale został nim wkrótce potem.

${ }^{143} \mathrm{~W}$ dniu 4 czerwca 1989 roku wojsko chińskie rozpędziło tłum studentów okupujących plac Tiananmen w centrum Pekinu. Ofiarami przemocy padło przynajmniej kilkuset zabitych i kilka
} 
światową opinię publiczną, ale komentarze członków gabinetu Uno były wyważone. Minister spraw zagranicznych Mitsuzuka Hiroshi oświadczył 4 czerwca 1989 roku: „Niezwykła szkoda, że doszło do tragedii rozlewu krwi, akurat gdy Chiny są w trakcie stabilnego rozwoju, idąc drogą liberalizacji. Mam nadzieję, że Chiny jak najszybciej powrócą do stanu spokoju" ${ }^{144}$. Chociaż Mitsuzuka krytycznie ocenił postępowanie władz KPCh, trudno w tej wypowiedzi dostrzec radykalne poglądy dawnego członka Seirankai. W podobnym tonie wypowiadał się Uno Sōsuke. W dniu 6 czerwca premier podkreślił: „W żadnym razie nie rozważamy niczego w rodzaju sankcji”, choć wkrótce potem dodał, że nie oznacza to, że sankcje na pewno nie zostaną nałożone ${ }^{145}$. Uno był zdania, iż Japonia nie może nakładać sankcji na naród chiński, który tyle wycierpiał ze strony armii japońskiej w okresie II wojny światowej ${ }^{146}$. W dniu 7 czerwca 1989 roku wyjaśnił w parlamencie: „Trzeba być świadomym, że stosunki między Japonią a Chinami zupełnie różnią się od stosunków chińsko-amerykańskich. Jest tak dlatego, że mamy doświadczenie niegdysiejszej wojny z Chinami. W Traktacie o pokoju i przyjaźni między Japonią a Chinami zostało wyraźnie stwierdzone, że żałujemy za to, iż w przeszłości poprzez wojnę przysporzyliśmy cierpienia narodowi chińskiemu. (...) Myślę, że należy za wszelką cenę unikać wypowiedzi, w których robiłoby się czarno-białe podziały" ${ }^{\prime 47}$.

Co ciekawe, wśród ,jastrzębi” z PLD, którzy dominowali w „głównym nurcie", nie pojawiły się większe głosy krytyki wobec ChRL. Można to wytłumaczyć wpływami propekińskiej frakcji Takeshity, ale także charakterem dotychczasowych postulatów nacjonalistów z partii. Wszakże za kadencji premiera Nakasone Towarzystwo Podstawowych Problemów Państwa domagało się nieingerencji zagranicy w sprawy wewnętrzne Japonii, więc teraz to samo środowisko nie mogło interweniować w wewnętrzne problemy Chin. „Jastrzębi” ze swojej frakcji uspokajał także ciężko chory Abe Shintarō. Według niego incydent na placu Tiananmen nie wywołał żadnej poważnej zmiany w relacjach japońsko-chińskich i Japonia powinna kontynuować trzecią pożyczkę w jenach dla ChRL. Abe uważał, iż jego kraj musi prowadzić niezależną politykę zagraniczną, a nie tylko ślepo naśladować amerykańską dyplomację wobec

tysięcy rannych. Protesty rozpoczęły się po śmierci Hu Yaobanga w kwietniu 1989 roku jako spontaniczne manifestacje żałobne. Demonstracje stopniowo przemieniły się w szeroki ruch domagający się m.in. poszanowania praw człowieka i zmian w KPCh. Szerzej na ten temat: Alan Lawrance, op.cit., s. 117-120.

${ }^{144}$ Tanaka Akihiko, op.cit., s. 173.

${ }^{145}$ Ibidem, s. 174.

${ }^{146}$ David Shambaugh, China and Japan towards the Twenty-First Century: Rivals for Preeminence or Complex Interdependence? [w:] China and Japan. History, Trends, and Prospects pod red. Christophera Howe'a, Oxford University Press, New York 1996, s. 85.

${ }^{147}$ Posiedzenie plenarne Izby Reprezentantów (Shūgiin honkaigi) z 7 VI 1989 roku, nr 18, Archiwum Obrad... 
Chin $^{148}$. Umiarkowana postawa zięcia Kishiego Nobusuke i przewodniczącego jedynej frakcji w PLD, którą można jeszcze było nazwać protajwańską, pokazywała jak wielki wpływ na świadomość parlamentarzystów wywarł „propekiński konsensus", utrzymywany przez całe lata 80 . XX wieku.

Tabela 4.6 Rozkład sił pomiędzy frakcjami PLD w okresie rządów Uno Sōsuke w 1989 roku.

\begin{tabular}{|l|l|l|}
\hline \multicolumn{3}{|c|}{ Frakcje: } \\
\hline ,głównego nurtu” & poza ,głównym nurtem” & „przeciwnego nurtu” \\
\hline Nakasone (D, J) 75 & Miyazawa (L, G, P) 87 & - \\
Takeshita (L, P) 135 & Kōmoto (D, G, P) 34 & \\
Abe (D, J, T) 82 & Nikaidō (L, G, P) 4 & \\
\hline 292 & 125 & - \\
L: 1 (135), D: 2 (157), & & \\
G: 0, J: 2 (157), & & \\
P: 1 (135), T: 1 (82). & & \\
\hline
\end{tabular}

L- dawni członkowie Partii Liberalnej, główny nurt konserwatywny, D- dawni członkowie Partii Demokratycznej, boczny nurt konserwatywny, G- gołębie, J- jastrzębie, P- obóz propekiński, Tobóz protajwański.

Liczebność frakcji (podana przy poszczególnych frakcjach) po wyborach do Izby Reprezentantów i Radców z lipca 1986 roku. Uwzględniono członków frakcji z obu izb parlamentu. W podsumowaniu „głównego nurtu” podana jest ogólna liczba należących do niego parlamentarzystów oraz liczba frakcji, zaś w nawiasie liczba parlamentarzystów, należących do poszczególnych obozów.

Opracowanie własne na podstawie: Fukunaga Fumio, Habatsu..., s. 80; Hayasaka Shigezō, Kenryoku..., s. 98-100.

Mimo łagodnych wypowiedzi japońskich polityków, rząd w Tokio musiał razem z resztą „wolnego świata” przedsięwziąć sankcje wobec Chin. Jeszcze 4 czerwca 1989 roku japońskie Ministerstwo Spraw Zagranicznych nakazało wstrzymanie podróży do Pekinu, zaś 7 czerwca również ewakuację z tego miasta Japończyków. Chociaż początkowo deklarowano chęć kontynuacji współpracy w ramach ODA, 20 czerwca 1989 roku Japonia ogłosiła zawieszenie trzeciej pożyczki dla ChRL, jak też bezzwrotnej pomocy w postaci finansowania budowy Centrum Ochrony Środowiska im. Przyjaźni Japońsko-Chińskiej. Z drugiej strony, w gronie wysoko rozwiniętych państw Zachodu Japonia od samego początku pełniła rolę ,adwokata Chin”. Na szczycie G-7 w Paryżu w połowie lipca 1989 roku z japońskiej inicjatywy w deklaracji krytykującej Chiny zapisano także pojednawcze zdanie: „Oczekujemy, że poprzez wznowienie działań mających na celu reformy polityczne i gospodarcze, jak też otwartość, władze chińskie stworzą warunki do uniknięcia izolacji Chin i jak najszybszego przywrócenia współpracy"149. Już na początku sierpnia 1989 roku rząd w Tokio

\footnotetext{
${ }^{148}$ Abe Shintarō, Tanaka Yōnosuke, Shin seiki e no kakehashi, Raifusha, Tokio 1990, s. 40-42.

${ }^{149}$ Sekiyama Takashi, op.cit., s. 80-81.
} 
„wyszedł przed szereg”, udzielając Chinom pomocy humanitarnej w wysokości około 200 mln jenów na walkę z następstwami wielkiej powodzi w Syczuanie ${ }^{150}$.

Tymczasem popularność gabinetu Uno Sōsuke wyraźnie spadała. Jeszcze w czerwcu 1989 roku media nagłośniły romans premiera z kochanką, zaś w lipcu 1989 roku PLD poniosła dotkliwą porażkę w wyborach do Izby Radców, po raz pierwszy przegrywając z Japońską Partią Socjalistyczną. PLD utraciła większość mandatów w izbie wyższej, co znacznie utrudniło jej proces ustawodawczy ${ }^{151}$. Premier wziął na siebie odpowiedzialność za przegraną i na początku sierpnia 1989 roku podał się do dymisji ${ }^{152}$.

\section{„Główny nurt” Kaifu Toshikiego i problem zniesienia sankcji wobec ChRL}

Po zaledwie dwóch miesiącach rządów Uno sytuacja w PLD nie uległa większym zmianom. Jedynie we frakcji Nakasone rozpoczął się proces przekazywania władzy Watanabe Michio, ostatecznie zakończony w 1990 roku. Podobnie jak poprzednio, Takeshita Noboru poszukiwał odpowiedniego kandydata na premiera. Stan zdrowia Abe Shintarō nie uległ poprawie, więc Takeshita razem Kanemaru Shinem, który był drugim wpływowym politykiem frakcjihegemona, postanowili wykreować kolejnego „figuranta”. Wybór padł na Kaifu Toshikiego z frakcji Kōmoto, niegdyś przewodzonej przez „czystego” Mikiego Takeo. Miało to być nowe ,,antidotum” na skandal korupcyjny firmy Recruit. Ostatecznie Abe Shintarō i Watanabe Michio zgodzili się na osobę Kaifu ${ }^{153}$. W wyborach kandydowali także Ishihara Shintarō, wspierany przez część członków frakcji Watanabe i Abe, oraz Hayashi Yoshirō z frakcji Nikaidō, wspierany przez Miyazawę Kiichiego, jednak Kaifu Toshiki zwyciężył zdecydowanie. Ponieważ Miyazawa podjął intensywniejsze działania na rzecz swojego kandydata, jego grupa znalazła się poza nowym „głównym nurtem”, choć nadal w ramach ,ogólnego głównego nurtu”.

„Główny nurt” Kaifu Toshikiego składał się z różnych środowisk. Chociaż sam premier był „,gołębiem” i przeciwnikiem rewizji konstytucji ${ }^{154}$, przeważali w nim ,jastrzębie". Z drugiej strony, ,polityka harmonii” na tyle umocniła się w partii, że koloryt ideologiczny frakcji wchodzących w skład „głównych nurtów” miał coraz mniejsze znaczenie dla dyplomacji Japonii. Podobnie jak Uno, Kaifu był mało wpływowym politykiem i musiał całkowicie polegać na wsparciu Takeshity Noboru ${ }^{155}$. Nowy premier posiadał niewielkie doświadczenie w sprawach dyplomacji, wcześniej piastował $\mathrm{w}$ rządzie jedynie funkcję ministra

\footnotetext{
${ }^{150}$ Tanaka Akihiko, op.cit., s. 179.

${ }^{151}$ PLD już nigdy nie odzyskała większości mandatów w Izbie Radców. Aby przeforsować ustawy musiała odtąd nakłaniać do nich opozycję lub zawierać porozumienia koalicyjne z mniejszymi partiami.

${ }^{152}$ Hayasaka Shigezō, Saishō no utsuwa, Kuresutosha, Tokio 1992, s. 58-68.

${ }^{153}$ Idem, Kenryoku..., s. 116.

${ }^{154}$ Kaifu Toshiki, Seiji to kane - Kaifu Toshiki kaikoroku, Shinchōsha, Tokio 2010, s. 79.

${ }^{155}$ Iwase Tatsuya, op.cit., s. 41-42.
} 
edukacji. Wywodził się z najmniejszej z pięciu dużych frakcji, w której na dodatek nie pełnił funkcji lidera, więc łatwo było nim sterować zza kulis. Co więcej, Kaifu Toshiki od dawna utrzymywał bardzo dobre stosunki z Takeshitą Noboru, mówiono wręcz, że jest ,potajemnym członkiem frakcji Takeshity” we frakcji Kōmoto ${ }^{156}$. Frakcyjny oyabun Kaifu, Kōmoto Toshio, był jednym z najbogatszych Japończyków i właścicielem firmy Sankō Kisen zajmującej się transportem morskim ${ }^{157}$. Podobnie jak Miki Takeo, Kōmoto należał do obozu „gołębi”. Podkreślał, że Japonia powinna działać na rzecz społeczności międzynarodowej nie na polu militarnym, tylko gospodarczym i sprzeciwiał się wzrostowi wydatków na Siły Samoobrony ponad 1 proc. PNB ${ }^{158}$.

Tabela 4.7 Rozkład sił pomiędzy frakcjami PLD w okresie rządów Kaifu Toshikiego w latach 1989-1991.

\begin{tabular}{|l|l|l|}
\hline \multicolumn{2}{|c|}{ Frakcje: } \\
\hline ,głównego nurtu” & poza ,głównym nurtem” & ,przeciwnego nurtu” \\
\hline Kōmoto (D, G, P) 33 & Miyazawa (L, G, P) 80 & - \\
Takeshita (L, P) 104 & Nikaidō (L, G, P) 4 & \\
Abe (D, J, T) 91 & & \\
Watanabe (D, J) 63 & 84 & - \\
\hline 291 & & \\
L: 1 (104), D: 3 (187), & & \\
G: 1 (33), J: 2 (154), & & \\
P: 2 (137), T: 1 (91). & & \\
\hline
\end{tabular}

L- dawni członkowie Partii Liberalnej, główny nurt konserwatywny, D- dawni członkowie Partii Demokratycznej, boczny nurt konserwatywny, G- gołębie, J- jastrzębie, P- obóz propekiński, Tobóz protajwański.

Liczebność frakcji (podana przy poszczególnych frakcjach) po wyborach do Izby Reprezentantów z lutego 1990 roku. Uwzględniono członków frakcji z obu izb parlamentu. W podsumowaniu „głównego nurtu” podana jest ogólna liczba należących do niego parlamentarzystów oraz liczba frakcji, zaś w nawiasie liczba parlamentarzystów, należących do poszczególnych obozów.

Opracowanie własne na podstawie: Asahi Shinbun Seijibu, Takeshita-ha shihai, Asahi Shinbunsha, Tokio 1992, s. 171; Fukunaga Fumio, Habatsu..., s. 80; Kitaoka Shin'ichi, op.cit., s. 336.

Następca Nakasone Yasuhiro na stanowisku szefa dawnej frakcji Kōno Ichirō, Watanabe Michio, należał do obozu ,jastrzębi”. Krytykował materializm i pogoń za pieniądzem, która zagościła w sercach Japończyków w wyniku położenia nadmiernego nacisku na szybki rozwój gospodarczy. Podobnie jak Nakasone, postulował przywrócenie Japonii tradycyjnych wartości i zwiększenie

\footnotetext{
${ }^{156}$ Hayasaka Shigezō, Kenryoku..., s. 112-113.

${ }^{157}$ Gdy jednak w latach 80. XX wieku firma Sankō Kisen zbankrutowała, wpływy polityczne Kōmoto uległy znacznemu osłabieniu. Szerzej na ten temat: Kikuchi Hisashi, Jimintō habatsu..., s. 28-30.

${ }^{158}$ Kōmoto Toshio, Sekai no naka no Nihon. Dai 3 shū. 80 nendai seiji e no teigen, Shin Seisaku Kenkyūkai, Tokio 1984, s. 15-203.
} 
jej zaangażowania w sprawy globalne ${ }^{159}$. W latach $70 . \mathrm{XX}$ wieku Watanabe należał do najbardziej aktywnych członków Seirankai i w przeciwieństwie do Nakasone można go nazwać politykiem protajwańskim. Z drugiej strony, w wyniku awansu w partii w latach 80. XX wieku podejście Watanabe do stosunków japońsko-chińskich stało się bardziej pragmatyczne. Również jego nacjonalizm uległ złagodzeniu. W latach 90 . XX wieku Watanabe podkreślał: „Aby Japonia nie powtórzyła błędów popełnionych w przeszłości, ważna jest skuteczność edukacji na temat historii nowożytnej i współczesnej"

Wobec ChRL rząd Kaifu kontynuował pojednawczą politykę gabinetu Uno. W połowie sierpnia 1989 roku Chiny odwiedził dawny poseł PLD z frakcji Ishibashiego, Utsunomiya Tokuma, zaś w połowie września 1989 roku w ChRL przebywała delegacja Parlamentarnej Ligi Przyjaźni Japońsko-Chińskiej z Itō Masayoshim na czele. W rozmowie z Itō premier Li Peng powiedział, że docenia łagodną reakcję Japonii na incydent na placu Tiananmen i oczekuje dalszego polepszenia wzajemnych relacji. Ponieważ delegacja uznała sytuację w Pekinie za stabilną, 25 września 1989 roku Japonia zniosła zakaz lotów do stolicy Chin. Z kolei 28 września 1989 roku ChRL odwiedziła 150-osobowa delegacja japońskiej młodzieży na czele z jednym z najbardziej wpływowych polityków frakcji Takeshity, Okudą Keiwą ${ }^{161}$. Widać było, że propekińska frakcja-hegemon poszukiwała rozwiązania kryzysu, jednak musiała także brać pod uwagę nastroje międzynarodowe, a w szczególności postawę Stanów Zjednoczonych ${ }^{162}$. Kiedy w listopadzie 1989 roku strona chińska zaczęła badać możliwość wizyty w ChRL członka japońskiego rządu, władze w Tokio odpowiedziały, że jeszcze za wcześnie na taki krok. Na początku grudnia 1989 roku przyznano natomiast Chinom po raz pierwszy od masakry na placu Tiananmen bezzwrotną pomoc finansową na projekt zaplanowany przed zawieszeniem ODA. Wkrótce wznowiono też wymianę kulturalną między oboma krajami ${ }^{163}$.

W kwietniu 1990 roku sekretarz generalny PLD, Ozawa Ichirō z frakcji Takeshity, zaczął razem z ministrem spraw zagranicznych Nakayamą Tarō

\footnotetext{
${ }^{159}$ Watanabe Michio, Kakizawa Kōji, Ibuki Bunmei, Shin hoshu kakumei, Nesuko, Tokio 1994, s. 38.

${ }^{160}$ Ibidem, s. 126.

${ }^{161}$ Okuda Keiwa należał do grupy tzw. „siedmiu zarządców” (nana bugyō) frakcji Takeshity. Oprócz niego byli to: Ozawa Ichirō, Watanabe Kōzō, Hata Tsutomu, Hashimoto Ryūtarō, Obuchi Keizō i Kajiyama Seiroku. Wyżej w hierarchii frakcyjnej znajdowali się tylko Takeshita Noboru i Kanemaru Shin.

${ }^{162}$ Po koniec lat 80 . XX wieku Japonia osiągnęła tak wysoki poziom rozwoju gospodarczego, że była postrzegana przez Stany Zjednoczone jako niebezpieczny konkurent, a nawet nowe zagrożenie na miejsce słabnącego ZSRR. Rząd w Tokio obawiał się, że szybkie zniesienie sankcji wobec Chin przyczyniłoby się tylko do nasilenia antyjapońskich nastrojów w USA. Szerzej na ten temat: Tanaka Akihiko, op.cit., s. 183-184.

${ }^{163}$ Ibidem, s. 179-183.
} 
badać możliwość zniesienia sankcji wobec Chin niezależnie od zachowania państw Zachodu. W maju 1990 roku Chiny odwiedził przewodniczący Rady Badań Politycznych PLD, Watanabe Michio. W czasie spotkań z Li Pengiem i Jiang Zeminem docenił chińskie wysiłki w celu przywrócenia spokoju po incydencie na placu Tiananmen, przyrzekając jednocześnie, że Japonia ,,przygotuje środowisko" pod pełne wznowienie pomocy rozwojowej dla Chin ${ }^{164}$. Był to kolejny po Mitsuzuce Hiroshim dawny członek Seirankai, któremu przyszło czynić wysiłki na rzecz poprawy relacji japońsko-chińskich. Niedługo potem doszło do wizyty w Pekinie byłego premiera Uno Sōsuke ${ }^{165}$. Jak widać, cała plejada japońskich polityków, od lewego po prawe skrzydło PLD, pracowała nad wyciszeniem kryzysu w stosunkach z Chinami. Było to dowodem na to, że „konsensus propekiński”, utrzymywany m.in. przez potężną frakcję Takeshity, nie uległ załamaniu.

Dopiero jednak gdy w czerwcu 1990 roku pojawiły się pierwsze oznaki odprężenia na linii Waszyngton-Pekin, Japonia mogła zacząć poważnie myśleć o zniesieniu sankcji wobec Chin ${ }^{166}$. Na szczycie G-7 w Houston w lipcu 1990 roku japoński premier przekazał prezydentowi USA George'owi Bushowi zamiar wznowienia pożyczki w jenach dla ChRL. Kaifu Toshiki wspomina: „Z Azji jedynie Japonia uczestniczy w G-7. (...) Dlatego też gdy wziąłem udział w szczycie, głośno broniłem interesów Azji. Na przykład w sprawie Chin, które z powodu incydentu na placu Tiananmen doznawały sankcji od G-7, twierdziłem: «Nie wolno izolować. Dla stabilności Azji Japonia będzie czynić starania, by

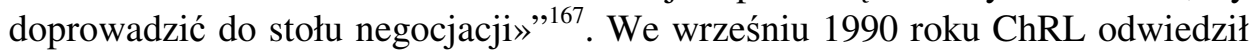
Takeshita Noboru, zaś w listopadzie 1990 roku rząd japoński oficjalnie zadecydował o wznowieniu pożyczki dla Chin w ramach ODA ${ }^{168}$.

\section{Koniec zimnej wojny}

Incydent na placu Tiananmen nie był jedynym problemem w relacjach japońskochińskich za rządów Kaifu Toshikiego. Zakończenie zimnej wojny sprawiło, że Japonia znalazła się w nowym otoczeniu międzynarodowym i musiała rozpocząć proces przewartościowania dotychczasowej polityki zagranicznej. Odprężenie w relacjach między USA a ZSRR umożliwiło przegłosowanie w Radzie Bezpieczeństwa ONZ rezolucji potępiającej Irak za inwazję na Kuwejt i podjęcie interwencji pod egidą ONZ. Stany Zjednoczone również od Japonii

\footnotetext{
${ }^{164}$ Watanabe moto Seichōkaichō, kyō Ri Hō shushō to kaidan. En shakkan de iken kōkan, „Mainichi Shinbun” z 3 V 1990, s. 2.

${ }^{165}$ Shimada Masao, Tian Jianong, op.cit., s. 405.

${ }^{166}$ W czerwcu 1990 roku Chiny pozwoliły na wyjazd z kraju działacza opozycyjnego, który zbiegł do amerykańskiej ambasady w ChRL. Z kolei rząd USA przystał na przedłużenie statusu najwyższego uprzywilejowania wobec Chin. Szerzej na ten temat: Tanaka Akihiko, op.cit., s. 185.

${ }^{167}$ Kaifu Toshiki, Kokorozashi aru kokka Nihon no kōsō, Tōyō Keizai Shinpōsha, Tokio 1995, s. 134.

${ }^{168}$ Tanaka Akihiko, op.cit., s. 185-186.
} 
domagały się aktywnego udziału w operacji Pustynna Burza ${ }^{169}$. „Doktryna Yoshidy” przestała pasować do nowej rzeczywistości. Większe militarne zaangażowanie Japonii za granicą nie oznaczało już niebezpiecznego opowiedzenia się po stronie Stanów Zjednoczonych w zimnej wojnie, ale wręcz przeciwnie, mogło przyczynić się do zaprowadzenia i utrzymania pokoju w zapalnych regionach świata.

We wrześniu 1990 roku Japonia rozpoczęła starania o przegłosowanie Ustawy o pokojowej współpracy z ONZ (Kokuren heiwa kyōryoku hōan), zakładającej możliwość wysłania za granicę Sił Samoobrony. Promotorem ustawy był m.in. Ozawa Ichirō z frakcji Takeshity, jak też zoku obrony w PLD. Projekt spotkał się jednak z krytyką Chin, wrażliwych na wszelkie objawy remilitaryzacji Japonii. Zresztą również w PLD nadal duże wpływy posiadały środowiska pacyfistyczne, więc ustawa została odrzucona w listopadzie 1990 roku. Kiedy jednak armia sojusznicza rozpoczęła militarną interwencję w Iraku w styczniu 1991 roku, Japonia musiała odpowiedzieć na amerykańskie prośby o pomoc. Rząd w Tokio nie tylko przeznaczył duże fundusze na operację, ale również wysłał statki Sił Samoobrony do transportu uchodźców. Z kolei w lutym 1991 roku Ozawa Ichirō stwierdził, iż uczestnictwo w misjach utrzymania pokoju pod egidą ONZ mieści się w ramach konstytucji. Rozpoczęto też pracę nad odpowiednią ustawą (Kokuren heiwa iji katsudō kyōryoku hōan, w skrócie PKO od Peace Keeping Operations), mającą zalegalizować udział Sił Samoobrony w takich operacjach $^{170}$. Pociągnięcia te wywołały dalszą eskalację napięcia w relacjach $\mathrm{z}$ ChRL, która oskarżała Japonię o wskrzeszenie militaryzmu ${ }^{171}$.

Koniec zimnej wojny zbiegł się z rozpoczęciem procesu demokratyzacji ustroju Republiki Chińskiej na Tajwanie. W 1988 roku szefem Guomindangu po raz pierwszy został Chińczyk z Tajwanu, Li Denghui. Li studiował w Japonii, biegle znał język japoński, w czasie II wojny światowej służył w japońskiej armii i nie ukrywał sympatii do Kraju Kwitnącej Wiśni ${ }^{172}$. Projapońskie nastawienie prezydenta Tajwanu zjednało mu licznych wielbicieli w Japonii. W lipcu 1991 roku wyszło na jaw, że Kanemaru Shin, jeden z najbardziej wpływowych polityków frakcji Takeshity, zamierzał zaprosić Li Denghuia do Japonii w połowie sierpnia 1991 roku. Kanemaru odwiedził Tajwan w czerwcu 1991 roku i wówczas obiecał zorganizować wizytę prezydenta Tajwanu ${ }^{173}$.

\footnotetext{
${ }^{169}$ W sierpniu 1990 roku Irak dokonał zbrojnej aneksji Kuwejtu. Interwencja w styczniu 1991 roku wojsk państw ONZ pod nazwą operacji Pustynna Burza doprowadziła do odbicia Kuwejtu z rąk Irakijczyków. Szerzej na ten temat: Ishikawa Masumi, op.cit., s. 170-171.

${ }^{170}$ Ustawa o udziale Japonii $\mathrm{w}$ misjach pokojowych ONZ została ostatecznie uchwalona za rządów Miyazawy Kiichiego w czerwcu 1992 roku. Szerzej na ten temat: Kikigaki. Miyazawa..., s. 295-305.

${ }^{171}$ Shimada Masao, Tian Jianong, op.cit., s. 410-412.

${ }^{172}$ Li Denghui, Taiwan no shuchō, PHP Kenkyūjo, Tokio 1999, s. 22-32.

${ }^{173}$ Taiwan no Ri Tōki sōtō hōnichi fujō. Kanemaru-shi-ra shōsei ni Chūgoku hanpatsu. Seifu kuryo, ,Yomiuri Shinbun” z 10 VII 1991, s. 1.
} 
ChRL szybko zareagowała, ostrzegając, iż byłoby to zakwestionowanie zasady ,jednych Chin”. Również Parlamentarna Liga Przyjaźni Japońsko-Chińskiej z Itō Masayoshim z frakcji Miyazawy na czele stanowczo zaprotestowała przeciw kontrowersyjnym planom Kanemaru ${ }^{174}$.

Co zaskakujące, nawet tradycyjne środowiska protajwańskie w PLD nie poparły inicjatywy zaproszenia Li Denghuia. Wręcz przeciwnie, nasiliły krytykę Kanemaru, mówiąc: „Póki nie ma zmiany w stanowisku Chin i Tajwanu, zostaniemy tylko użyci przez tajwańską propagandę (wobec Chin)"175. Okazało się, że władze w Tajpej już wcześniej próbowały pobudzić Parlamentarne Zgromadzenie Stosunków Japońsko-Tajwańskich do działania w sprawie zaproszenia, jednak jego członkowie nalegali, by odłożyć tę inicjatywę, gdyż była sprzeczna ze stanowiskiem Japonii, uznającej władze w Pekinie za jedyny prawowity rząd. Ponieważ zaś reżim Guomindangu próbował uzyskać zaproszenie od Kanemaru bez konsultacji ze Zgromadzeniem, dotychczasowi przywódcy obozu protajwańskiego w PLD stwierdzili, iż nie cieszą się już zaufaniem władz w Tajpej. Z tego powodu przewodniczący Zgromadzenia Fujio Masayuki zrezygnował ze stanowiska razem z innym ważnym działaczem tej ligi parlamentarnej, synem Satō Eisaku, Satō Shinjim ${ }^{176}$ z frakcji Takeshity ${ }^{177}$. Szczegóły tych wydarzeń nie są jasne, ale zdaje się, że dawne środowisko Seirankai straciło protajwański zapał z lat 70. XX wieku. W latach 80. XX wieku ,jastrzębie” wielokrotnie walczyli w obronie swojej interpretacji historii, jednak nie byli już skłonni aktywnie wspierać interesów Republiki Chińskiej na Tajwanie. Dawny obóz protajwański uległ praktycznemu rozkładowi, zaś Parlamentarne Zgromadzenie Stosunków Japońsko-Tajwańskich trwało tylko siłą inercji, nie spełniając nadziei, które w nim pokładały władze w Tajpej.

Warto także zwrócić uwagę na zachowanie samego Kanemaru Shina. Polityk ten od dziesięcioleci był przyjacielem i najbliższym współpracownikiem Takeshity Noboru, a nawet oficjalnym przewodniczącym frakcji-hegemona. Kanemaru od dawna odwiedzał Tajwan i utrzymywał bliskie kontakty $\mathrm{z}$ reżimem Guomindangu. Fakt, że jego „uśpione” do tej pory protajwańskie powiązania „obudziły się" nagle w 1991 roku odzwierciedlał w jakimś stopniu zmianę nastrojów międzynarodowych po zakończeniu zimnej wojny. Wszakże propekińskość najbardziej elastycznej ideologicznie frakcji środka nie była dana raz na zawsze i mogła podlegać ewolucji, podobnie jak protajwańska frakcja Satō uległa przeobrażeniu w propekińską frakcję Tanaki w 1972 roku. Jednakże

\footnotetext{
${ }^{174}$ Ri Taiwan sōtō hōnichi no ugoki. Seifu ga chinseika ni kenmei. Naigai ni fukuzatsu-na hamon, „Yomiuri Shinbun” z 11 VII 1991, s. 2.

${ }^{175}$ Ibidem.

${ }^{176}$ Satō Shinji przyznawał, że stał się członkiem obozu protajwańskiego dzięki ojcu. Szerzej na ten temat: „Shintai-ha” ni mo aratana jidai, Satō Shinji Nikkakon shin kaichō (fōkasu), „Nihon Keizai Shinbun" z 23 V 1996, s. 5.

${ }^{177}$ Nikka Kankei Giin Kondankai 2 kanbu ga yakushoku jinin e. Taiwan gawa to Kanemaru moto fukusōri o hihan, ,Yomiuri Shinbun” z 12 VII 1991, s. 2.
} 
do takiego kroku niezbędna była kolejna zmiana pokoleniowa. Takeshita Noboru do samego końca pozostał strażnikiem ,propekińskiego konsensusu”. Gdy tylko strona chińska zaprotestowała przeciw wizycie Li Denghuia, nakazał Kanemaru odwołanie tego przedsięwzięcia. Hayasaka Shigezō pisze wręcz, że Takeshita „uratował” w ten sposób Kanemaru, który nie zdawał sobie sprawy, że plany wizyty Li Denghuia spotkają się z takim oporem. Takeshita użył wszystkich swoich wpływów, aby wyciszyć sprawę ${ }^{178}$.

Szybkie zakończenie problemu zaproszenia Li Denghuia po myśli rządu w Pekinie było tym ważniejsze, że zbliżała się wizyta Kaifu Toshikiego w Chinach. W sierpniu 1991 roku japoński premier spotkał się z Li Pengiem i ogłosił całkowite przywrócenie normalnych kontaktów japońsko-chińskich po incydencie na placu Tiananmen. Potwierdził również przyznanie Chinom pożyczki w jenach na 1991 rok oraz zaprosił do Japonii sekretarza generalnego KPCh, Jiang Zemina ${ }^{179}$. Li Peng upomniał Kaifu, by strona japońska respektowała zasadę ,jednych Chin" i nie pozwalała na wizytę w Japonii Li Denghuia ${ }^{180}$. Mimo to szczyt minął w przyjaznej atmosferze przygotowań do nadchodzącej w 1992 roku 20. rocznicy nawiązania stosunków bilateralnych. Jak podkreśla Zhao Quansheng, była to pierwsza po wydarzeniach na placu Tiananmen wizyta w ChRL przywódcy ważnego wysoko rozwiniętego kraju ${ }^{181}$.

Tymczasem w decydującą fazę weszły przygotowania do wprowadzenia $\mathrm{w}$ życie przygotowywanej od końca lat 80 . XX wieku reformy systemu politycznego. Z powodu oporu wewnątrz PLD, we wrześniu 1991 roku partia zadecydowała jednak o odrzuceniu trzech ustaw kluczowych w tej sprawie ${ }^{182}$. Kaifu Toshiki chciał rozwiązać parlament, by wymusić reformę. Początkowo do tego zdania przychylał się także Takeshita Noboru, jednak ostatecznie zadecydował o wycofaniu swojego poparcia dla premiera. Mimo że Kaifu był popularny wśród społeczeństwa, pozbawiony szans na reelekcję na następną kadencję musiał zrzec się stanowiska ${ }^{183}$.

$$
* * *
$$

Zarówno Uno Sōsuke, jak i Kaifu Toshiki, byli zależni od poparcia Takeshity Noboru. Powołując na urząd premiera mniej wpływowych polityków, frakcja-

\footnotetext{
${ }^{178}$ Hayasaka Shigezō, Kenryoku..., s. 142-144.

${ }^{179}$ Shimada Masao, Tian Jianong, op.cit., s. 406.

${ }^{180}$ Ri Taiwan sōtō hōnichi no ugoki - Chūgoku shushō ga kensei. Nitchū shunō kaidan, „Yomiuri Shinbun" z 11 VIII 1991, s. 2.

${ }^{181}$ Zhao Quansheng, op.cit., s. 237.

182 Ustawy te dotyczyły zmiany ordynacji wyborczej, zaostrzenia przepisów na temat finansowania partii i wprowadzenia subwencji państwowych dla ugrupowań politycznych. PLD pracowała nad projektem reformy od czasu skandalu korupcyjnego z firmą Recruit w 1988 roku, jednak niezwykle trudno było osiągnąć kompromis, gdyż zmiany dotyczyły żywotnych interesów polityków. Szerzej na ten temat: Asahi Shinbun Seijibu, op.cit., s. 16-19.

${ }^{183}$ Ibidem, s. 28-51.
} 
hegemon zdominowała proces decyzyjny w partii. W takich warunkach nie mogło dojść do większych zmian w japońskiej polityce zagranicznej. Wyważona reakcja Japonii na masakrę na placu Tiananmen wyraźnie pokazała, jak bardzo „propekiński konsensus” wpływał na zachowanie polityków PLD. Nawet dawni członkowie Seirankai, Mitsuzuka Hiroshi i Watanabe Michio, musieli pracować w ramach „ogólnego głównego nurtu” na rzecz zażegnania kryzysu w relacjach japońsko-chińskich i zniesienia sankcji gospodarczych nałożonych na ChRL. Również sprawa uczestnictwa Japonii w misjach pokojowych ONZ nie wywołała większego wzrostu napięcia w kontaktach wzajemnych. Bardziej znaczący był incydent z próbą zaproszenia Li Denghuia. Ponieważ promotorem wizyty prezydenta Tajwanu w Japonii był Kanemaru Shin, jeden z czołowych polityków grupy Takeshity, można to uznać za pierwszą ,rysę” na propekińskim charakterze frakcji-hegemona. Takeshita Noboru podjął jednak sprawne działania na rzecz odwołania wizyty, gdy tylko pojawiły się głosy niezadowolenia ze strony ChRL. Zresztą fakt, iż inicjatywy nie wsparły nawet tradycyjne protajwańskie środowiska w PLD świadczy o tym, że nie była to poważna próba zakwestionowania ,propekińskiego konsensusu”.

\section{MIYAZAWA KIICHI (1991-1993)}

Miyazawa Kiichi rządził w okresie, w którym rodził się nowy pozimnowojenny porządek światowy. Nagłej zmianie uległy także międzynarodowe uwarunkowania polityki Japonii wobec Chin. Jednocześnie w PLD narastał ferment, który miał doprowadzić do rozpadu frakcji-hegemona i fundamentalnych zmian w strukturze rywalizacji wewnątrzpartyjnej. Ponieważ jednak Miyazawa należał do środowiska umiarkowanych polityków, za jego kadencji ogólne ramy „propekińskiego konsensusu" pozostały nienaruszone. Postawa premiera wobec Chin przypominała politykę jego dawnych frakcyjnych oyabunów: Ikedy Hayato i Ōhiry Masayoshiego.

\section{Kontynuacja idei Ikedy i Ōhiry}

W chwili rezygnacji Kaifu Toshikiego ze stanowiska premiera było oczywiste, że jego następcą zostanie osoba, która uzyska poparcie frakcji Takeshity ${ }^{184}$. Kandydaturę zgłosili Miyazawa Kiichi, Watanabe Michio i Mitsuzuka Hiroshi, który właśnie przejął przewodnictwo we frakcji zmarłego Abe Shintarō. Decyzję o wsparciu jednego z nich miało podjąć grono trzech najbardziej wpływowych polityków frakcji-hegemona: Takeshita Noboru, Kanemaru Shin i Ozawa Ichirō. Ozawa upokorzył kandydatów, wzywając ich kolejno do swojego biura na „wywiad”, w którym badał ich przekonania polityczne. Jednocześnie toczyły się

\footnotetext{
${ }^{184}$ Frakcja Takeshity zdecydowała się nie wystawiać kandydata na przewodniczącego PLD ze swego grona, chociaż Kanemaru Shin próbował promować na kandydata Ozawę Ichirō. Szerzej na ten temat: ibidem, s. 53-97.
} 
zakulisowe rozmowy, które nie były pozbawione „targów” stanowiskami dla frakcji-hegemona w nowym rządzie. Mimo że Kanemaru i Ozawa sympatyzowali z bliższym im ideologicznie Watanabe, ostatecznie postanowili poprzeć przodującego w sondażach opinii publicznej Miyazawę ${ }^{185}$. Zresztą jako polityk doświadczony w kwestiach ekonomicznych był on najlepszym wyborem w okresie kryzysu gospodarczego ${ }^{186}$. Chociaż więc dotychczasowe stosunki między Miyazawą a Takeshitą były raczej chłodne, Miyazawa Kiichi uzyskał wsparcie frakcji-hegemona i z łatwością pokonał kontrkandydatów ${ }^{187}$.

Tabela 4.8 Rozkład sił pomiędzy frakcjami PLD w okresie rządów Miyazawy Kiichi w latach 1991-1993.

\begin{tabular}{|l|l|l|}
\hline \multicolumn{2}{|c|}{ Frakcje: } \\
\hline ,głównego nurtu” & poza ,głównym nurtem” & ,przeciwnego nurtu” \\
\hline Miyazawa (L, G, P) 82 & Mitsuzuka (D, J, T) 76 & - \\
Takeshita (L, P) 105 & Watanabe (D, J) 68 & \\
Kōmoto (D, G, P) 31 & & - \\
\hline 218 & 144 & \\
L: 2 (187), D: 1 (31), & & \\
G: 2 (113), J: 0, & & \\
P: 3 (218), T: 0. & & \\
\hline
\end{tabular}

L- dawni członkowie Partii Liberalnej, główny nurt konserwatywny, D- dawni członkowie Partii Demokratycznej, boczny nurt konserwatywny, G- gołębie, J- jastrzębie, P- obóz propekiński, Tobóz protajwański.

Liczebność frakcji (podana przy poszczególnych frakcjach) w grudniu 1991 roku. Uwzględniono członków frakcji z obu izb parlamentu. W podsumowaniu ,głównego nurtu” podana jest ogólna liczba należących do niego parlamentarzystów oraz liczba frakcji, zaś w nawiasie liczba parlamentarzystów, należących do poszczególnych obozów.

Opracowanie własne na podstawie: Asahi Shinbun Seijibu, op.cit., s. 131-171.

Do 1991 roku we frakcjach w PLD zaszły pewne zmiany. Grupa Nikaidō stopniała do dwóch osób i praktycznie przestała istnieć. Od samego początku zrzeszała polityków w podeszłym wieku, więc wraz z ich stopniowym przechodzeniem na emeryturę w naturalny sposób zakończyła swą działalność. Z kolei po śmierci Abe Shintarō w maju 1990 roku w dawnej frakcji Kishiego doszło do walki o władzę pomiędzy Mitsuzuką Hiroshim a Katō Mutsukim. Zwyciężył

\footnotetext{
${ }^{185}$ Hayasaka Shigezō, Saishō no..., s. 171-172.

${ }^{186} \mathrm{~W}$ drugiej połowie lat 80 . XX wieku ceny akcji na giełdzie tokijskiej nadmiernie urosły w wyniku umocnienia się kursu jena i spekulacji na rynku nieruchomości. „Bańka” pękła w 1990 roku. Rozpoczął się okres bessy na giełdzie i spowolnienia wzrostu gospodarczego. Szerzej na ten temat: François Gipouloux, La fin du mythe de la toute-puissance économique? [w:] Jean-Marie Bouissou, François Gipouloux, Eric Seizelet, Japon: le déclin?, Editions Complexe, Bruxelles 1995, s. 102-130; Ishikawa Masumi, op.cit., s. 175; Ewa Pałasz-Rutkowska, Katarzyna Starecka, op.cit., s. 325.

${ }^{187}$ Asahi Shinbun Seijibu, op.cit., s. 53-135.
} 
Mitsuzuka, ale Katō wystąpił z frakcji wraz z kilkunastoma politykami. Grupa Katō szybko opuściła partię i nie przekształciła się w nową frakcję.

„Główny nurt” Miyazawy był bardzo spójny ideologicznie. Wyraźnie przeważało w nim środowisko „,gołębi” oraz polityków propekińskich. Dominowali również przedstawiciele „głównego nurtu konserwatywnego”. Miyazawa doszedł do władzy dzięki poparciu frakcji Takeshity, jednak trudno powiedzieć, by był od niej zależny w równym stopniu, jak Uno Sōsuke i Kaifu Toshiki. Tym razem premierem został wszakże lider frakcji, i to jednej $\mathrm{z}$ największych. Między Takeshitą a Miyazawą miała zostać zawarta niepisana umowa, że pierwszy z nich przejmie kontrolę nad sprawami partyjnymi, podczas gdy drugi będzie mógł się zająć kwestiami rządowymi, w tym polityką zagraniczną państwa ${ }^{188}$.

Miyazawa Kiichi od dawna należał do obozu propekińskiego. Podobnie jak Ikeda Hayato i Ōhira Masayoshi, do świata polityki przeszedł z biurokracji Ministerstwa Finansów. W młodości był sekretarzem Ikedy ${ }^{189}$, pamiętał okres rządów Yoshidy Shigeru i w naturalny sposób uznał „doktrynę Yoshidy” za swoje polityczne credo. Jako minister spraw zagranicznych w rządzie Mikiego Takeo prowadził, z przyczyn obiektywnych zakończone ostatecznie niepowodzeniem, rozmowy w sprawie Traktatu o pokoju i przyjaźni z ChRL, zaś jako sekretarz gabinetu Suzukiego Zenkō wydał deklarację, kończącą pierwszy kryzys podręcznikowy w 1982 roku. W latach 80. XX wieku Miyazawa wspierał modernizację Chin, podkreślając jednocześnie, iż nawet jeśli ChRL porzuci politykę reform, nie powinna stać się zagrożeniem dla społeczności międzynarodowej ${ }^{190}$. W latach 90. XX wieku zauważał, że Chiny osiągnęły już status mocarstwa i ważne jest, by aktywnie angażować się w pokojową współpracę z tym państwem. Według niego Japonia powinna powstrzymać się od rewizji konstytucji czy remilitaryzacji i skupić się na pogłębianiu związków z krajami ościennymi ${ }^{191}$.

Z drugiej strony, były sekretarz Miyazawy Kiichiego, Nakatsu Nobuyoshi, zauważa, że Chiny nie zajmowały uprzywilejowanego miejsca w dyplomacji premiera $^{192}$. Sam Miyazawa przyznawał, iż znacznie łatwiej rozmawiało mu się z Amerykanami niż z Jiang Zeminem, który miał ,zupełnie inne poczucie wartości”" ${ }^{193}$. Nakatsu podkreśla jednak przywiązanie Miyazawy do ogólnych ram „doktryny Yoshidy” i mechanizmów wolnorynkowych, jak też jego dążenie

\footnotetext{
${ }^{188}$ Ibidem, s. 105.

${ }^{189}$ Miyazawa Kiichi, Tōkyō - Washinton mitsudan, Chūō Kōron Shinsha, Tokio 1999, s. 17-18.

${ }^{190}$ Miyazawa Kiichi, Kōsaka Masataka, Utsukushii Nihon e no chōsen, Bungei Shunjū, Tokio 1984, s. 88-89.

${ }^{191}$ Miyazawa Kiichi, 21 seiki e no ininjō, Shōgakukan, Tokio 1995, s. 77-79.

${ }^{192}$ Wywiad autora z Nakatsu Nobuyoshim, radnym prefektury Hiroshima, byłym sekretarzem premiera Miyazawy Kiichiego, Fukuyama, 6 I 2009.

${ }_{193}$ Miyazawa Kiichi. Hoshu honrȳ u no kiseki pod red. Iokibe Makoto, Itō Motoshige, Yakushijiego Katsuyukiego, Asahi Shinbunsha, Tokio 2006, s. 47-48.
} 
do harmonii międzynarodowej i poszukiwania kompromisu w relacjach z innymi państwami ${ }^{194}$. Miyazawa Kiichi był przeciwnikiem nakładania na ChRL sankcji gospodarczych. Apelował o większe zrozumienie sytuacji panującej w tym państwie przy jednoczesnym powstrzymaniu się od ingerencji w jego sprawy wewnętrzne $^{195}$. Jak sam wspomina, na szczycie G-7 w Tokio w lipcu 1993 roku przekonywał prezydenta Williama Clintona, by Stany Zjednoczone nie rezygnowały z klauzuli najwyższego uprzywilejowania wobec Chin ${ }^{196}$. W tym prorynkowym podejściu widać bezpośrednią kontynuację idei Ikedy i Ōhiry.

\section{Problem „kobiet pocieszycielek” i wizyta pary cesarskiej w ChRL}

Miyazawa Kiichi musiał sobie poradzić z kolejnym problemem historycznym, który wyszedł na jaw jeszcze za rządów Kaifu Toshikiego. W maju 1990 roku w Korei Południowej nagłośniono sprawę kobiet, które w czasie II wojny światowej były zmuszane do pracy w domach publicznych zarządzanych przez japońską armię. W grudniu 1991 roku te tzw. „kobiety pocieszycielki” (jap. ianfu, chiń. weianfu, kor. wianbu) złożyły pozew sądowy, żądając odszkodowania od władz w Tokio. Problem szybko rozprzestrzenił się na inne kraje Azji Wschodniej, w tym ChRL. W styczniu 1992 roku sekretarz gabinetu, Katō Kōichi z frakcji Miyazawy, przyznał, iż wojsko japońskie uciekało się do takich godnych potępienia praktyk i przeprosił ofiary ${ }^{197}$.

Rząd ChRL nie naciskał jednak równie zdecydowanie jak władze w Seulu na uregulowanie kwestii ,kobiet pocieszycielek”, licząc raczej na inicjatywę strony japońskiej. Wszakże dopiero co wznowiono normalne kontakty bilateralne po masakrze na placu Tiananmen i kierownictwo KPCh nie chciało doprowadzić do kolejnego kryzysu międzynarodowego. Poza tym zbliżała się data wizyty w Pekinie cesarza Akihito. Rząd Chin przykładał do tego wydarzenia wielką wagę, gdyż była to okazja do pokazania światu, iż sytuacja w ChRL powróciła już do normy. Ponieważ zaś sprawa wyjazdu cesarza do Pekinu budziła wielkie kontrowersje wśród ,jastrzębi” w PLD, zbytnia eskalacja napięcia z powodu problemu „kobiet pocieszycielek” mogła tylko dać prawicowym politykom pretekst do odwołania wizyty ${ }^{198}$.

Rok 1992 minął w atmosferze obchodów 20. rocznicy nawiązania japońskochińskich stosunków dyplomatycznych. W kwietniu Japonię odwiedził Jiang

\footnotetext{
${ }^{194}$ Wywiad autora z Nakatsu Nobuyoshim...

${ }^{195}$ Li Jianmin, Lengzhan hou Riben de „putong guojiahua” yu Zhong-Ri guanxi de fazhan, Zhongguo Shehui Kexue Chubanshe, Pekin 2005, s. 175.

${ }^{196}$ Kikigaki. Miyazawa..., s. 320.

${ }^{197}$ Shimada Masao, Tian Jianong, op.cit., s. 413-415.

${ }^{198}$ Co prawda ChRL zrzekła się odszkodowań wojennych w 1972 roku, jednak część ofiar była zdania, że nie uniemożliwia to prywatnych pozwów wobec rządu Japonii. W czasie obrad Ogólnochińskiego Zgromadzenia Przedstawicieli Ludowych w marcu 1992 roku złożono projekt rezolucji wspierającej starania ofiar. Nie została ona jednak przyjęta. Szerzej na ten temat: ibidem, s. 417-418.
} 
Zemin. Przywódca KPCh $\mathrm{z}$ jednej strony odniósł się do problemów historycznych i obaw strony chińskiej związanych z planami uczestnictwa Sił Samoobrony w misjach zagranicznych, z drugiej zaś podkreślił wagę stabilnych kontaktów dobrosąsiedzkich. Miyazawa Kiichi zapewnił: „Japonia trzyma się polityki nieposiadania broni nuklearnej i nie stanie się mocarstwem militarnym. Jest oczywiste, że przy utrzymywaniu długotrwałych relacji bilateralnych pojawiają się spory, ale zgadzam się ze słowami sekretarza generalnego [KPCh - przyp. aut.], że trzeba je «rozwiązać poprzez nasilenie kontaktów pomiędzy przywódcami i konsultacje»" "199. Jiang Zemin odwiedził również ciężko chorego Tanakę Kakueia, dziękując za jego wkład w normalizację japońsko-chińskich stosunków dyplomatycznych. Zaprosił go także do Chin. Większe znaczenie miała nadchodząca wizyta w ChRL cesarza Akihito. Premier Miyazawa nie mógł jednak jeszcze obiecać Jiangowi, że na pewno do niej dojdzie ze względu na sprzeciw ,jastrzębi” wewnątrz PLD ${ }^{200}$.

Kwestia wizyty cesarza w ChRL była niezwykle delikatną sprawą. Miyazawa Kiichi podkreślał, że sam wiedział, iż cesarzowi w Chinach nic nie grozi, zaś minister spraw zagranicznych Watanabe Michio sprzyjał temu przedsięwzię$\operatorname{ciu}^{201}$. Przyznawał także, że poprzez zakulisowe rozmowy musiał przekonać do wizyty skrajną prawicę ${ }^{202}$. Prawe skrzydło PLD obawiało się, iż ChRL wykorzysta odwiedziny Akihito do celów politycznych ${ }^{203}$. Działacze nacjonalistyczni nie chcieli też, by cesarz przeprosił Chiny za zbrodnie z czasów II wojny światowej. Jeszcze w lipcu 1991 roku kwestia wyjazdu Akihito do ChRL, jako problem wagi państwowej, stała się przedmiotem obrad Rady Generalnej PLD. Od tego czasu toczyła się gorąca debata pomiędzy ,jastrzębiami” a politykami propekińskimi $^{204}$. Prawicowi członkowie PLD próbowali użyć m.in. sprawy sporu o wyspy Senkaku/Diaoyutai, by nie dopuścić do wizyty ${ }^{205}$. Na początku sierpnia 1992 roku Fujio Masayuki przedstawił listę z 57 podpisami parlamentarzystów domagających się odłożenia wyjazdu. Jednakże większość polityków w Radzie Generalnej PLD nie podzielała tego zdania ${ }^{206}$. Ostatecznie o przełamaniu impasu zadecydował Nakasone Yasuhiro, który polecił przewodniczącemu Rady Generalnej, Satō Takayukiemu z frakcji Watanabe, aktywną promocję

\footnotetext{
199 Ibidem, s. 419-420.

${ }^{200}$ Ibidem, s. 421-424.

${ }^{201}$ Kikigaki. Miyazawa..., s. 310-311.

${ }^{202}$ Miyazawa Kiichi. Hoshu honryū..., s. 49.

${ }^{203}$ Nakajima Mineo, Dépasser la diplomatie de l'amitié, „Cahiers du Japon” 1993, nr 55, s. 23.

${ }^{204}$ Murakawa Ichirō, op.cit., s. 56.

${ }^{205}$ W lutym 1992 roku władze w Pekinie ustaliły zasięg morza terytorialnego ChRL, umieszczając w granicach państwa m.in. sporne z Japonią wyspy Senkaku/Diaoyutai. „Jastrzębie” w PLD twierdzili, że ChRL może użyć wizytę cesarską do potwierdzenia swojej zwierzchności nad archipelagiem. Szerzej na ten temat: Linus Hagström, Quiet power: Japan's policy in regard to the Pinnacle Islands, „The Pacific Review” 2005, vol. 18, no. 2, s. 161-171.

${ }^{206}$ Shimada Masao, Tian Jianong, op.cit., s. 428.
} 
wizyty. Satō, dotychczas sceptycznie nastawiony wobec tego przedsięwzięcia, posłuchał swojego dawnego oyabuna i doprowadził do złagodzenia oporu „jastrzębi”,207. Miyazawa poprosił również Fukudę Takeo o przekonanie prawicowych posłów do wizyty cesarza w Chinach ${ }^{208}$.

Zresztą podobne działania prowadzili także przedstawiciele „głównego nurtu”. Jeszcze w czerwcu 1992 roku do kraju został wezwany japoński ambasador w ChRL, by wytłumaczyć posłom, iż przeprosiny za wydarzenia z przeszłości nie są stawiane przez władze w Pekinie jako warunek wizyty cesarza. Z kolei w sierpniu 1992 roku sekretarz gabinetu Katō Kōichi zaprosił do dyskusji prawicowych naukowców i przedsiębiorców, by złagodzić ich stanowisko. Postarał się także o pośrednictwo w rozmowach nacjonalistycznej organizacji Jinja Honcho $^{209}$. Ostatecznie pod koniec sierpnia 1992 roku premier Miyazawa podjął decyzję o wizycie cesarza w ChRL. Dzięki temu we wrześniu 1992 roku były premier Nakasone mógł przywieźć władzom Chin oficjalne potwierdzenie przyjęcia zaproszenia. Para cesarska odwiedziła Chiny w październiku 1992 roku. W trakcie wizyty cesarz Akihito wyraził ,głęboki żal” z powodu wydarzeń z czasów II wojny światowej, ale zgodnie z wolą ,jastrzębi” nie pojawiło się słowo ,przepraszam"210. Jak podkreśla Jan Rowiński, wizytę cesarza w Chinach można uznać za apogeum „dyplomacji przyjaźni” w relacjach japońskochińskich $^{211}$.

Tymczasem w PLD doszło do ważnych przemian, które miały doprowadzić do końca istnienia „ogólnego głównego nurtu”. W sierpniu 1992 roku Kanemaru Shin został oskarżony o korupcję w związku z aferą firmy Sagawa Kyūbin i wkrótce zmuszony do rezygnacji ze stanowiska wiceprzewodniczącego partii ${ }^{212}$. $\mathrm{W}$ ten sposób Ozawa Ichirō utracił potężnego protektora, dzięki któremu w stosunkowo młodym wieku doszedł do najwyższych stanowisk partyjnych. We frakcji-hegemonie rozpoczęła się rywalizacja o sukcesję po Takeshicie i Kanemaru $^{213}$. Starły się w niej dwa obozy: Obuchiego Keizō oraz Ozawy Ichirō

\footnotetext{
${ }^{207}$ Murakawa Ichirō, op.cit., s. 57.

${ }^{208}$ Zhong-Ri guanxi 30 nian..., s. 229.

${ }^{209}$ Wywiad autora z Katō Kōichim, Parlament Japonii, Tokio, 13 III 2009.

${ }^{210}$ Shimada Masao, Tian Jianong, op.cit., s. 427-434.

${ }^{211}$ Jan Rowiński, Stosunki chińsko-japońskie na nowym etapie [w:] Japonia na poczatku XXI wieku. Polityka, gospodarka, społeczeństwo $i$ stosunki $z$ Polska pod red. Krzysztofa Gawlikowskiego i Małgorzaty Ławacz, Wydawnictwo Adam Marszałek, Toruń 2008, s. 198.

${ }^{212}$ W 1992 roku odkryto, że firma transportowa Sagawa Kyūbin przekazała Kanemaru łapówkę w wysokości 500 mln jenów. Ujawniono także kontakty PLD z yakuzq poprzez prezesa tokijskiej Sagawa Kyūbin, Watanabe Hiroyasu. W październiku 1992 roku Kanemaru Shin zrzekł się mandatu posła. Szerzej na ten temat: Morita Minoru, Seikai tairan. Jimintō kaitai shintō sōsei, Tōyō Keizai Shinpōsha, Tokio 1993, s. 63-66.

${ }^{213}$ Pomiędzy dawnymi przyjaciółmi, Takeshitą Noboru i Kanemaru Shinem, od lat narastał konflikt. Kanemaru miał za złe Takeshicie, że od kiedy został premierem w 1987 roku, przestał się z nim konsultować w wielu sprawach. Na dodatek o ile Kanemaru promował w partii Ozawę
} 
wspieranego przez Hatę Tsutomu. Ustępujący szef frakcji, Takeshita Noboru, poparł grupę Obuchiego. Ponieważ stronnicy Ozawy (około 40 parlamentarzystów) byli w mniejszości, w październiku 1992 roku dokonali rozłamu, zakładając oddzielną frakcję Haty o nazwie Forum Reform XXI (Kaikaku Fōramu 21). Frakcja-hegemon przestała istnieć, zaś grupa Obuchiego stała się zaledwie czwartą co do wielkości frakcją w PLD. W czerwcu 1993 roku Hata z Ozawą wsparli złożone przez opozycję wotum nieufności wobec gabinetu Miyazawy, zaś premier rozwiązał parlament i rozpisał nowe wybory. Frakcja Haty opuściła wówczas PLD, zakładając Partię Odnowy (Shinseitō) ${ }^{214}$. W wyborach z lipca 1993 roku PLD po raz pierwszy w historii swojego istnienia uzyskała wyraźnie mniej niż połowę mandatów w Izbie Reprezentantów. Dzięki temu Ozawa mógł wejść w koalicję z siedmioma innymi partiami, powołując w sierpniu 1993 roku rząd Hosokawy Tsutomu. W ten sposób PLD znalazła się w opozycji.

Równocześnie coraz bardziej widoczne były przejawy załamywania się „konsensusu propekińskiego” w PLD. Od początku lat 90. XX wieku władze w Tajpej energicznie zabiegały o wzmocnienie więzów z Japonią. Kiedy w 1992 roku rozpadła się propekińska frakcja-hegemon w PLD, zniknęła jedna $z$ przeszkód na drodze do tego celu. W lutym 1993 roku do Tokio przyjechał jako osoba prywatna minister spraw zagranicznych Tajwanu, Qian Fu. Była to pierwsza od zerwania stosunków dyplomatycznych w 1972 roku wizyta w Japonii tajwańskiego urzędnika tak wysokiego szczebla. Qian Fu spotkał się z byłym premierem Fukudą Takeo oraz z dwoma szefami frakcji: Obuchim Keizō oraz przewodniczącym Rady Badań Politycznych PLD, Mitsuzuką Hiroshim. W tym samym okresie Japonię odwiedził tajwański wiceminister gospodarki Jiang Bingkun, spotykając się z ministrem transportu Morim Yoshirō z frakcji Mitsuzuki ${ }^{215}$. Władze w Pekinie zaprotestowały przeciw obu wizytom.

W grudniu 1993 roku po ciężkiej chorobie zmarł Tanaka Kakuei. Przed śmiercią zdążył jeszcze w sierpniu 1992 roku po raz ostatni odwiedzić ChRL, gdzie spotkał się m.in. z premierem Li Pengiem ${ }^{216}$. W ostatnich miesiącach życia Tanaka był świadkiem rozpadu swojej dawnej frakcji i utraty władzy przez PLD. Jego śmierć symbolicznie zbiegła się z końcem „ogólnego głównego nurtu” i załamaniem się w partii ,propekińskiego konsensusu”, którego był autorem.

Ichirō, o tyle Takeshita miał do niego ambiwalentny stosunek. Szerzej na ten temat: Hayasaka Shigezō, Kenryoku..., s. 145-146.

${ }^{214}$ Równolegle PLD opuściła mniejsza grupa parlamentarzystów pod przewodnictwem Takemury Masayoshiego, tworząc Nową Partię Zwiastun (Shintō Sakigake). Szerzej na ten temat: Morita Minoru, op.cit., s. 15-16.

${ }^{215}$ Nittai jitsumu kōryū no kakudai e. Taiwan gaikō buchō ga hōnichi no seika kyōchō, „Yomiuri Shinbun" z 20 II 1993, s. 4.

${ }^{216}$ Shimada Masao, Tian Jianong, op.cit., s. 428. 
* * *

Miyazawa Kiichi to ostatni z premierów rządzących w warunkach „ogólnego głównego nurtu". W jego polityce wobec Chin można zauważyć dziedzictwo dyplomacji Ikedy Hayato, Ōhiry Masayoshiego czy Suzukiego Zenkō. Będąc liderem umiarkowanej frakcji, dążył do wzmocnienia przyjacielskich kontaktów z ChRL w duchu poszanowania mechanizmów rynkowych i stabilizacji sytuacji międzynarodowej. Postawa Miyazawy wobec problemu „kobiet pocieszycielek” i promocja wizyty cesarza w Chinach naraziły premiera na krytykę ze strony partyjnych ,jastrzębi”. Z kolei rozpad frakcji-hegemona i utrata władzy przez PLD w 1993 roku zwiastowały już nową epokę, w której zakwestionowany został ,propekiński konsensusu” w partii.

\section{PODSUMOWANIE}

W przeciwieństwie do dwóch poprzednich okresów, w latach 1980-1993 skład poszczególnych „głównych nurtów” nie miał większego wpływu na kształt polityki PLD wobec Chin. Ponieważ w kolejnych wewnątrzpartyjnych koalicjach nieustannie dominowała frakcja Tanaki-Takeshity, nie różniły się one zbytnio od siebie pod względem ideologicznym. Wszystkie „główne nurty” były mniej lub bardziej propekińskie, zaś premierem ani razu nie został przedstawiciel najbardziej protajwańskiej frakcji Fukudy-Abe. Ta „monotonia” działała na rzecz utrzymania przyjaznej atmosfery w kontaktach na linii Tokio-Pekin. Istnienie propekińskiego „ogólnego głównego nurtu” było jednym z czynników sprawiających, że wszelkie kryzysy w stosunkach japońsko-chińskich zostały wyciszone, zanim urosły do niebezpiecznych rozmiarów.

Jednocześnie niemal zupełnemu zanikowi uległ obóz protajwański w partii. Dawne środowisko Seirankai, skupione we frakcji Nakagawy-Ishihary, ostatecznie przyłączyło się do frakcji Fukudy-Abe. Nawet jednak posłowie, którzy w latach 70. XX wieku aktywnie bronili interesów reżimu Guomindangu, w latach 80. i na początku lat 90. XX wieku praktycznie zawiesili swą protajwańską działalność. Nadal istniało Parlamentarne Zgromadzenie Stosunków Japońsko-Tajwańskich, ale incydent z próbą zaproszenia Li Denghuia przez Kanemaru Shina w 1991 roku pokazał, że władze w Tajpej nie miały z tej grupy większego pożytku. Niegdysiejsi członkowie Seirankai, jak Tamaki Kazuo, Watanabe Michio czy Mitsuzuka Hiroshi, awansowali w partii i stracili zapał do promocji interesów reżimu Guomindangu. Zresztą w trzecim pokoleniu przywódców PLD, które doszło do władzy w 1987 roku, podziały ideologiczne pomiędzy frakcjami straciły swą dawną wyrazistość.

Chociaż ,propekiński konsensus" nie został zakwestionowany nawet po masakrze na placu Tiananmen, w PLD od czasu do czasu podnosił się głos niezadowolenia wobec ,uległej” polityki rządu wobec Chin. Miejsce stronnictwa protajwańskiego zajął w pewnym sensie obóz ,jastrzębi”, zresztą tworzyli go 
częściowo dawni członkowie Seirankai. Wybuchające niemal cyklicznie kryzysy $\mathrm{w}$ relacjach $\mathrm{z}$ rządem $\mathrm{w}$ Pekinie $\mathrm{z}$ powodu problemów historycznych (sprawa podręczników, wizyt w świątyni Yasukuni, „,kobiet pocieszycielek”) lub kwestii związanych z remilitaryzacją Japonii (sprawa zacieśnienia sojuszu z USA, zwiększenia wydatków wojskowych, uczestnictwa w misjach pokojowych ONZ) były dla nacjonalistów okazją do promocji swoich poglądów. Przedsięwzięcia ,jastrzębi” nie miały jednak bezpośredniego związku z polityką PLD wobec Chin. Działacze Towarzystwa Podstawowych Problemów Państwa rzucali wyzwanie ,propekińskiemu konsensusowi” nie dlatego, że chcieli zakwestionować politykę przyjaźni japońsko-chińskiej, ale ponieważ nie zgadzali się na ingerencję jakiegokolwiek państwa $\mathrm{w}$ wewnętrzne sprawy Japonii. Dopiero rozpad frakcji-hegemona w 1992 roku i głębokie przewartościowanie systemu frakcyjnego po utracie władzy przez PLD w 1993 roku stworzyły warunki, by ich głos stał się wyraźniej słyszany. 


\section{Rozdział V}

\section{STOSUNKI JAPOŃSKO-CHIŃSKIE W DOBIE DEREGULACJI SYSTEMU FRAKCYJNEGO W PLD (1993-2006)}

Rozpad frakcji Takeshity oznaczał koniec „,ogólnego głównego nurtu”, który tak długo stabilizował system wewnątrzpartyjny i wzmacniał propekiński charakter japońskiej dyplomacji. W następnym okresie PLD musiała stawić czoła radykalnym zmianom, zarówno w sytuacji międzynarodowej na świecie, jak i na japońskiej scenie politycznej. Od połowy lat 90. XX wieku narastał stan napięcia na linii Tokio-Pekin. ChRL gwałtownie zwiększała swój budżet wojskowy oraz zaczęła okazywać bardziej asertywną postawę w sporze terytorialnym na Morzu Wschodniochińskim. Z kolei demokratyzacja Republiki Chińskiej i „,szantaż rakietowy" ze strony Chin komunistycznych wobec władz w Tajpej sprawiły, że kwestia statusu Tajwanu ponownie stała się przedmiotem zaciętej debaty w PLD. Równolegle nasileniu uległy problemy historyczne.

Tym razem nie istniała już propekińska frakcja-hegemon, mogąca złagodzić narastające napięcie w stosunkach z ChRL. Reforma ordynacji wyborczej dała początek okresowi deregulacji systemu frakcyjnego. Osłabienie wpływów frakcji w PLD najskuteczniej wykorzystała dawna grupa Kishiego, dotychczas trzymana z dala od władzy przez ugrupowania ,głównego nurtu konserwatywnego". Hasła remilitaryzacji, większej aktywności w regionalnym systemie bezpieczeńsywa i rewizji konstytucji, głoszone przez prawe, w dużym stopniu protajwańskie, skrzydło partii pasowały do wyzwań epoki pozimnowojennej. Zresztą nawet frakcję Obuchiego trudno już było nazwać równie propekińską, jak w dobie rządów Tanaki i Takeshity. W miarę wyraźny do tej pory koloryt ideologiczny poszczególnych grup wewnątrzpartyjnych uległ częściowemu zamazaniu razem z osłabieniem więzi lojalności łączących liderów frakcji z ich szeregowymi członkami.

\section{Sytuacja międzynarodowa w latach 1993-2006}

W odpowiedzi na rozpad ZSRR i koniec zimnej wojny Stany Zjednoczone musiały przewartościować swoją politykę zagraniczną. Główny cel zbliżenia amerykańsko-chińskiego, pokonanie Związku Radzieckiego, został osiągnięty. Dla administracji prezydenta USA Williama Clintona (1993-2001), a w jeszcze większym stopniu George'a Walkera Busha (2001-2009), Chiny komunistyczne stawały się bardziej konkurentem niż strategicznym partnerem. Zaniepokojenie budziło m.in. łamanie praw człowieka przez władze w Pekinie. Również 
zbombardowanie ambasady chińskiej w Belgradzie w 1999 roku, incydent z samolotem szpiegowskim w 2001 roku $^{1}$ oraz operacje wojsk USA w Afganistanie i w Iraku po zamachach terrorystycznych 11 września 2001 roku przyczyniły się do wzrostu wzajemnej nieufności w stosunkach chińskoamerykańskich.

W 1993 roku przewodniczącym ChRL został Jiang Zemin, należący do trzeciego pokolenia przywódców KPCh. Za jego kadencji Chiny kontynuowały wprowadzanie mechanizmów wolnorynkowych, co znalazło odzwierciedlenie w zasadzie „trzech reprezentacji”, przyjętej na XVI Zjeździe KPCh w 2002 roku $^{2}$. Masakra na placu Tiananmen w 1989 roku pokazała, że potrzebna jest nowa ideologia, mogąca, obok tracącego na aktualności komunizmu, skutecznie legitymizować władzę partii. W tym celu Jiang Zemin rozpoczął na początku lat 90. XX wieku kampanię „,edukacji patriotycznej” “. Jej „,skutkiem ubocznym” okazał się wzrost uczuć antyjapońskich w społeczeństwie chińskim ${ }^{4}$. W 2003 roku przewodniczącym ChRL został Hu Jintao, który jednak musiał rywalizować w KPCh z ,grupą szanghajską” skupioną wokół Jiang Zemina.

W latach 90. XX wieku było już wyraźnie widać, iż w wyniku wysokiego tempa wzrostu gospodarczego Chiny komunistyczne mają realne możliwości stania się mocarstwem globalnym. Pogrążona w stagnacji gospodarczej Japonia postrzegała ChRL nie tylko jako partnera, jak dotychczas, ale także jako konkurenta na rynku międzynarodowym ${ }^{5}$. W 1997 roku Chiny odzyskały Hongkong z

\footnotetext{
${ }^{1} \mathrm{~W}$ marcu 1999 roku amerykańskie samoloty pomyłkowo zbombardowały ambasadę ChRL w Belgradzie, zabijając trzech Chińczyków i raniąc 23 innych. Incydent wywołał falę antyamerykańskich demonstracji w Chinach. Z kolei w kwietniu 2001 roku doszło do kolizji amerykańskiego samolotu obserwacyjnego EP-3 z chińskim myśliwcem, który rozbił się w Morzu Południowochińskim. Amerykański samolot został zmuszony do lądowania na chińskiej wyspie Hainan. Szerzej na ten temat: Peter Hays Gries, China's New Nationalism. Pride, Politics, and Diplomacy, University of California Press, Berkeley - Los Angeles - London 2004, s. 1-17.

2 Zgodnie z zasadą ,trzech reprezentacji” (san ge daibiao) zaakceptowano w KPCh m.in. prywatnych przedsiębiorców, co pokazuje jak bardzo ideologia państwowa oddaliła się od komunizmu. Szerzej na ten temat: Amako Satoshi, Ribenren yanli de Zhongguo, Shehui Kexue Wenxian Chubanshe, Pekin 2006, s. 125-126.

${ }^{3}$ Caroline Rose, Sino-Japanese Relations. Facing The Past. Looking to The Future?, Routledge Curzon, London - New York 2005, s. 52; Karol Żakowski, Antyjapońskie oblicze nacjonalizmu chińskiego [w:] Fenomen Chin. Wybrane problemy polityki wewnętrznej i zagranicznej Chińskiej Republiki Ludowej pod red. Małgorzaty Pietrasiak, Wydawnictwo Uniwersytetu Łódzkiego, Łódź 2007, s. 155-156.

${ }^{4}$ Równocześnie pogarszało się nastawienie japońskiej opinii publicznej wobec Chin. O ile w latach 80. XX wieku sympatię do Chin odczuwało prawie 70 proc. Japończyków, po masakrze na placu Tiananmen w 1989 roku wskaźnik ten spadł do około 50 proc., po próbach rakietowych w Cieśninie Tajwańskiej do około 45 proc., zaś po protestach antyjapońskich w 2005 roku do zaledwie około 30 proc. Szerzej na ten temat: Mōri Kazuko, op.cit., s. 194-196; Amako Satoshi, op.cit., s. 11-12.

${ }^{5}$ Shen Haitao, Nitchū kankei shinka e no atarashii kokoromi, Nihonkyō Hōsha, Kawaguchi 2004, s. 18.
} 
rąk brytyjskich, zaś w 1999 roku Makau od Portugalczyków. Jeszcze w latach 80. XX wieku nasiliły się naciski na władze Republiki Chińskiej, by również Tajwan zjednoczył się z ChRL na zasadzie ,jednego państwa, dwóch systemów" szczeblu między ChRL a Republiką Chińską ${ }^{7}$. W 1996 roku ChRL zorganizowała zakrojone na szeroką skalę ćwiczenia wojskowe i próby rakietowe w Cieśninie Tajwańskiej, które spotkały się z potępieniem ze strony Stanów Zjednoczonych i Japonii. Kolejnym środkiem wywarcia presji na Tajwan była „ustawa antysecesyjna” z marca 2005 roku $^{8}$.

W latach 1993-2006 Tajwan kontynuował demokratyzację swojego ustroju. System partyjny na wyspie ewoluował w kierunku dwóch dużych bloków zjednoczonych wokół Guomindangu oraz Demokratycznej Partii Postępu. W pierwszych w pełni wolnych wyborach na prezydenta Republiki Chińskiej w 1996 roku zwyciężył Li Denghui z Guomindangu, zaś w 2000 roku jego następcą został Chen Shuibian z Demokratycznej Partii Postępu. Dojście do władzy zwolennika ogłoszenia przez Tajwan niepodległości wywołało dalszą eskalację napięcia $\mathrm{w}$ relacjach ponad Cieśniną Tajwańską ${ }^{9}$. W wyborach parlamentarnych w 2001 i 2004 roku zwyciężyła Demokratyczna Partia Postępu, ale blok ugrupowań skupionych wokół Guomindangu zachował większość mandatów w Yuanie Ustawodawczym. Chociaż zakończenie demokratyzacji Tajwanu nie przełożyło się na oficjalne uznanie jego rządu przez państwa demokratyczne $^{10}$, przyczyniło się do polepszenia wizerunku władz w Tajpej w krajach Zachodu i Japonii.

\footnotetext{
${ }^{6}$ Zarówno Hongkongowi, jak i Makau zapewniono utrzymanie odrębnego ustroju oraz szeroką autonomię przez 50 lat. Szerzej na ten temat: Andrzej Chojnowski, Jan Rowiński, Hongkong $u$ progu XXI wieku [w:] Azja Wschodnia na przełomie XX $i$ XXI wieku. Przemiany polityczne $i$ spoteczne pod red. Krzysztofa Gawlikowskiego, Wydawnictwo TRIO, Warszawa 2004, s. 148164; Karol Żakowski, Hongkong w nowej rzeczywistości [w:] Wspótczesne Chiny. Kultura Polityka - Gospodarka pod red. Małgorzaty Pietrasiak, Wydawnictwo Uniwersytetu Łódzkiego, Łódź 2005, s. 86-98.

${ }^{7}$ Rozmowy między Tajwanem a ChRL doprowadziły m.in. do podpisania umowy o wzajemnej wymianie porywaczy. Szerzej na ten temat: Roman Sławiński, Historia Tajwanu, s. 146.

${ }^{8}$ Poprzez „ustawę antysecesyjną" ChRL ponownie dała do zrozumienia, że w razie ogłoszenia przez Tajwan niepodległości Chiny nie zawahają się przed zbrojnym atakiem na tę wyspę. Szerzej na ten temat: Nakamura Katsunori, Huang Zhaotang, Asano Kazuo, Tokuoka Hitoshi, op.cit., s. 29; Edward Haliżak, Polityka $i$ strategia Chin $w$ ksztattowaniu międzynarodowego bezpieczeństwa, Wydawnictwo Naukowe Scholar, Warszawa 2007, s. 81.

${ }^{9}$ Nakamura Katsunori, Huang Zhaotang, Asano Kazuo, Tokuoka Hitoshi, op.cit., s. 162-181

${ }^{10}$ W 1996 roku stosunki dyplomatyczne z Tajwanem zerwał Niger. W tym samym roku ostatni z dużych krajów uznających Tajwan, RPA, ogłosił, że zamierza zerwać oficjalne kontakty dyplomatyczne w 1997 roku. Szerzej na ten temat: Unmei kyōdōtai to shite no Nihon to Taiwan. Posuto reisen jidai no kokka senryaku pod red. Nakamury Katsunoriego, Tendensha, Tokio 1997, s. $100-101$.
} 
W latach 90. XX wieku nasileniu uległy procesy globalizacyjne. Dzięki postępowi technologicznemu oraz przyjęciu gospodarki wolnorynkowej przez państwa dawnego bloku sowieckiego znacznie wzrósł międzynarodowy przepływ kapitału oraz wartość bezpośrednich inwestycji zagranicznych, zaś razem z nimi wzmocniła się współzależność gospodarcza pomiędzy państwami uczestniczącymi w wymianie handlowej. Procesy te były widoczne także w relacjach chińsko-japońskich. Po „,pęknięciu bańki” na giełdzie tokijskiej japońskie firmy zamiast Stanów Zjednoczonych coraz częściej zaczęły wybierać Chiny jako miejsce budowy nowych fabryk. Dzięki temu już w 1993 roku ChRL z Hongkongiem awansowała na drugie miejsce po USA pod względem wartości japońskich inwestycji zagranicznych ${ }^{11}$. Z kolei w 2002 roku, 30 lat po nawiązaniu oficjalnych stosunków dyplomatycznych między Japonią a Chinami, wartość handlu między oboma krajami wyniosła 101,5 mld jenów, czyli 90 razy więcej niż w 1972 roku. W latach 1980-2002 zależność chińskiego handlu od Japonii (wartość handlu pomiędzy dwoma krajami jako procent PKB danego państwa) wzrosła z 3 do 8,3 proc., zaś uzależnienie japońskiego handlu od Chin z 0,9 do 2 proc. ${ }^{12}$ Procesy globalizacyjne wymuszały na rządach obu państw utrzymanie dobrych relacji gospodarczych nawet przy eskalacji napięcia w stosunkach bilateralnych.

\section{Sytuacja wewnątrzpartyjna w latach 1993-2006}

Po 1993 roku dynamika rywalizacji wewnątrz PLD uległa głębokim zmianom. W wyniku reformy ordynacji wyborczej rozpoczął się proces deregulacji frakcyjności w partii, zaś „system pięciu dużych frakcji” uległ praktycznemu rozkładowi. Oznaczało to także zanik dotychczasowego podziału na frakcje „głównego nurtu”, poza „głównym nurtem” czy „przeciwnego nurtu”. Zamiast tego przybierała na sile linia podziału pomiędzy ,jastrzębiami” a „gołębiami”. Umiarkowani politycy byli coraz bardziej bezsilni wobec nasilenia się poglądów nacjonalistycznych w partii. Działalność wznowił także obóz protajwański.

Reforma ordynacji wyborczej i zniesienie okręgów wyborczych średnich rozmiarów, jak też zaostrzenie przepisów dotyczących finansowania partii politycznych, oznaczały osłabienie wpływów frakcji w PLD ${ }^{13}$. Kariera poszczególnych polityków przestała być zależna od ich lojalności wobec liderów grup wewnątrzpartyjnych. Proces ten został jeszcze bardziej pogłębiony za kadencji premiera Koizumiego Jun'ichirō (2001-2006), który jawnie starał się dopro-

\footnotetext{
${ }^{11}$ Kazuo (John) Fukuda, Japan's Economic Advance into China: Meeting of Asia's Two Giants, „Journal of Marketing Management” 1997, no. 13, s. 219.

${ }^{12}$ Kenji Hattori, Sino-Japanese Economic Relations, „The Japanese Economy” 2003-4, vol. 31, no. 3-4, s. 51-52.

${ }^{13}$ Jin Changsu, 90 nyeondae ihu-ui Ilbon jeongchi [w:] Hyeondae Ilbon Hakhoe, Ilbon jeongchi ron, Nonhyeong, Seul 2009, s. 134-136.
} 
wadzić do zniszczenia systemu frakcyjnego. Z drugiej strony, wzrosła rola centralnych organów partii, w szczególności zaś jej przewodniczącego.

Wykres 5.1 Ewolucja systemu frakcyjnego w PLD w latach 1993-2006.

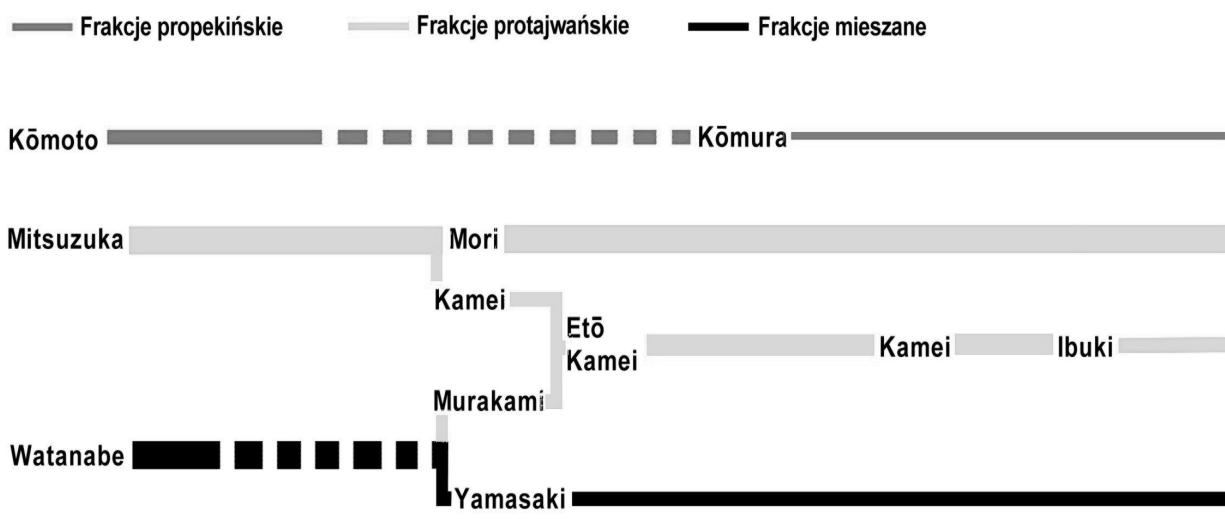

Obuchi Hashimoto $\square \square \square \square$ Tsushima

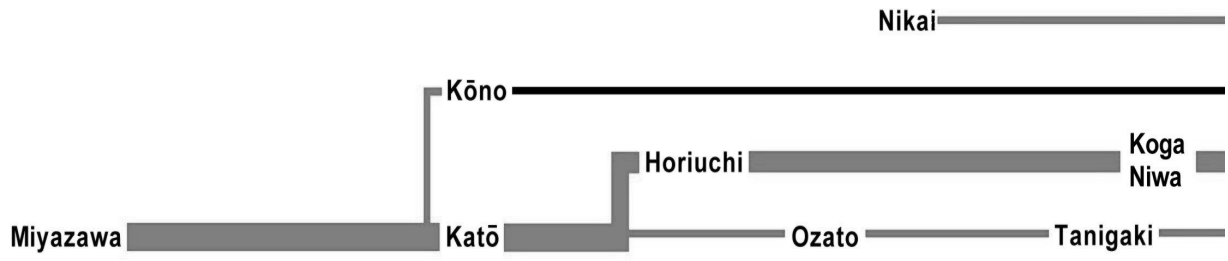

, 06

Wielkość frakcji proporcjonalna do grubości kreski. Linia przerywana oznacza frakcję bez formalnego przewodniczącego.

Opracowanie własne na podstawie m.in.: Tsuchiya Shigeru, op.cit., s. 260; Kitaoka Shin'ichi, op.cit., s. 334-336; Fukunaga Fumio, Habatsu..., s. 80.

Jednocześnie postępował proces utraty przez frakcje wyraźniejszych kolorytów ideologicznych. Jak podkreślał na początku XXI wieku były przewodniczący dawnej frakcji Ikedy, Katō Kōichi, o ile w okresie zimnowojennym politycy dowiadywali się z gazet, jaką ideologię posiada dana frakcja i na tej podstawie wybierali grupę, do której chcieli należeć, obecnie te cechy charakterystyczne frakcji niemal zupełnie zanikły ${ }^{14}$. Frakcje były „rozrywane” zarówno przez presję z zewnątrz, jak i od wewnątrz. Z jednej strony politycy

${ }^{14}$ Katō Kōichi, Atarashiki Nihon no katachi, Daiyamondosha, Tokio 2005, s. 42. 
PLD zaczęli się utożsamiać bardziej z partią niż z frakcjami, z drugiej zaś mieli więcej swobody w wypowiadaniu własnego zdania w sprawie chińskiej, gdyż osłabła kontrola nad nimi frakcyjnych liderów. Dlatego też, chociaż wykres 5.1 został zbudowany w sposób analogiczny do trzech poprzednich, należy pamiętać, że granice pomiędzy zaznaczonymi na nim obozami propekińskim i protajwańskim stały się znacznie mniej wyraźne niż w erze zimnowojennej.

W latach 90. XX wieku frakcje przestały pełnić swoją dotychczasową rolę najważniejszych grup w partii, determinujących skład kolejnych ,głównych nurtów”. Ze względu na osłabienie lojalności członków frakcji wobec lidera grupy, wybór na przewodniczącego partii nie był już zależny tylko od zakulisowych sojuszy pomiędzy przewodniczącymi frakcji. Niejednokrotnie ujawniały się podziały wewnątrzfrakcyjne i głosy członków jednej grupy rozdzielały się na kilku kandydatów ${ }^{15}$. W takich warunkach coraz trudniej było wyraźnie określić, które frakcje znajdowały się w ścisłym kręgu władzy w PLD. Często część grupy można było zaliczyć do „głównego nurtu”, część zaś do „przeciwnego nurtu”, wobec czego dotychczasowa metoda badania cech kolejnych „głównych nurtów" utraciła swoje walory naukowe. Michael Jonathan Green zwraca uwagę, iż w wyniku osłabienia PLD, frakcji i biurokracji, japońska polityka zagraniczna stała się znacznie mniej przewidywalna i bardziej zależna od nastrojów społecznych $^{16}$. Z kolei Hiranuma Takeo podkreśla, że w procesie decyzyjnym w partii większą rolę zaczęły odgrywać osobiste przekonania poszczególnych szefów PLD, którzy w mniejszym stopniu niż dotychczas musieli dbać o równowagę sił pomiędzy frakcjami ${ }^{17}$. Podobnego zdania jest Honzawa Jirō. Według niego osłabienie frakcyjności oznaczało naruszenie wewnątrzpartyjnej demokracji i umożliwiło ,dyktatorskie” metody sprawowania władzy przez przewodniczących PLD ${ }^{18}$.

Równolegle ze stopniowym osłabianiem się wpływów frakcji wewnątrz PLD coraz bardziej widoczne stawało się wzmocnienie poglądów nacjonalistycznych i protajwańskich w partii. Jak podkreśla Mike M. Mochizuki, w wyniku demokratyzacji systemu politycznego w Republice Chińskiej politycy protajwańscy nie musieli się już obawiać, że wspierając władze w Tajpej będą oskarżani przez liberalny elektorat o działanie na rzecz autorytarnego reżimu Guomindangu $^{19}$. Z kolei szefowie frakcji nie byli już na tyle wpływowi, by móc

\footnotetext{
${ }^{15}$ Tazaki Shirō, Kajiyama Seiroku. Shi ni gao ni emi o tataete, Kōdansha, Tokio 2005, s. 375-376.

${ }^{16}$ Michael Jonathan Green, Japan's Reluctant Realism. Foreign Policy Challenges in an Era of Uncertain Power, Palgrave Macmillian, New York 2003, s. 8.

${ }^{17}$ Wywiad autora z Hiranumą Takeo...

${ }^{18}$ Honzawa Jirō, Habatsu no shūen to Nihon no shinro. Koizumi seiji no isan, Nagasaki Shuppan, Tokio 2008, s. 58-60.

19 Przewodniczący Parlamentarnego Zgromadzenia Japońsko-Tajwańskiego Hiranuma Takeo przyznaje, że w wyniku demokratyzacji Tajwanu politycy, którzy już wcześniej sympatyzowali z Tajwanem, zaczęli jeszcze bardziej gorliwie działać na rzecz tego kraju. Wywiad autora z Hiranumą Takeo...
} 
hamować protajwańskie czy skrajnie nacjonalistyczne przedsięwzięcia członków swoich grup ${ }^{20}$. O ile jednak frakcje Mitsuzuki i Watanabe od dawna skupiały wielu członków obozu ,jastrzębi”, w latach 90 . XX wieku można było zauważyć coraz więcej polityków o wyraźnie prawicowych poglądach także w innych frakcjach. W szczególności niegdyś najpotężniejsza grupa Tanaki-Takeshity pod przewodnictwem Obuchiego Keizō straciła dużo ze swojego dawnego umiarkowanego charakteru. Wraz z dojściem do czołowych stanowisk takich protajwańskich polityków, jak Kajiyama Seiroku czy sam Obuchi Keizō, trudno było też ją nadal nazywać frakcją wyraźnie propekińską.

Jako że problemy historyczne były w latach 90 . XX wieku jednym $\mathrm{z}$ najistotniejszych czynników wpływających na atmosferę w stosunkach z ChRL, kwestia postrzegania roli Japonii w II wojnie światowej przez poszczególnych liderów PLD stała się jeszcze ważniejsza niż w poprzedniej dekadzie. Z drugiej strony, chociaż po zimnej wojnie pojawiły się nowe problemy, i tak każdy kolejny japoński premier musiał podkreślać kluczowe dla Japonii znaczenie relacji z Chinami ${ }^{21}$. Powiązania gospodarcze pomiędzy ChRL a Japonią były zbyt głębokie, by móc zakwestionować system zapoczątkowany normalizacją stosunków bilateralnych w 1972 roku.

\section{KŌNO YŌHEI (1993-1995)}

Po krótkich rządach „nowych liderów” władza powędrowała w ręce czwartego pokolenia przywódców PLD. Kōno Yōhei to pierwszy w historii przewodniczący tej partii, który nigdy nie został premierem Japonii. Chociaż Kōno był politykiem zdecydowanie propekińskim, jako szef PLD w latach 1993-1995 i minister spraw zagranicznych w latach 1994-1996 musiał stawić czoło licznym problemom w stosunkach z ChRL, które ujawniły się po zakończeniu zimnej wojny. Nie będąc zaś premierem, ani nawet szefem frakcji, miał ograniczone możliwości wpływania na politykę Japonii wobec Chin.

\section{Postawa polityczna Kōno Yōheia i reforma wewnątrzpartyjna}

Czwarte pokolenie przywódców PLD zrzeszało polityków, którzy rozpoczynali kariery parlamentarne na przełomie lat 60. i 70. XX wieku. Tylko jeden spośród pięciu przewodniczących tej partii w latach 1993-2006, Mori Yoshirō, nie był potomkiem parlamentarzysty. Pozostali odziedziczyli okręgi wyborcze po ojcach, zazwyczaj przejmując od nich także przynajmniej część poglądów politycznych i kontaktów personalnych w PLD. Również wśród członków obozu

\footnotetext{
${ }^{20}$ Mike M. Mochizuki, Dealing with a Rising China [w:] Japan in International Politics. The Foreign Policies of an Adaptive State pod red. T. U. Bergera, M. M. Mochizukiego i J. Tsuchiyamy, Lynne Rienner Publishers, Boulder - London 2007, s. 239-241.

${ }^{21}$ Zhong-Ri guanxi 30 nian..., s. 205.
} 
protajwańskiego i propekińskiego dużą grupę stanowili działacze, którzy nastawienie wobec Chin odziedziczyli poprzez powiązania rodzinne.

Po utracie władzy w 1993 roku w PLD nasilił się ruch młodszych polityków dążących do odnowy oblicza partii. Pierwszym krokiem w tym celu był wybór w lipcu 1993 roku na nowego przewodniczącego znanego z reformistycznych poglądów Kōno Yōheia, który pokonał Watanabe Michio. Od dawna jednym z postulatów Kōno było rozwiązanie frakcji w PLD, uważanych za źródło korupcji i bardzo źle postrzeganych przez opinię publiczną ${ }^{22}$. Zostało to jasno stwierdzone we wrześniu 1993 roku w raporcie powołanej wcześniej przez Kōno Kwatery Reformy Partii (Tō Kaikaku Honbu) ${ }^{23}$. Zresztą tak naprawdę działalność frakcji zamarła w chwili utraty władzy. Jednym z powodów ich istnienia była wszakże rywalizacja o rozdział stanowisk rządowych, do których PLD jako partia opozycyjna nie miała już dostępu. Na dodatek reforma systemu wyborczego, dokonana przez rząd Hosokawy Morihiro w 1994 roku, zniosła kolejną przyczynę istnienia grup wewnątrzpartyjnych - konkurencję między ich członkami w okręgach wyborczych średnich rozmiarów. W grudniu 1994 roku wszystkie frakcje oficjalnie zamknęły swoje biura, ale tak naprawdę kontynuowały działalność ${ }^{24}$. Z drugiej strony, ich rola w partii uległa nieodwracalnemu osłabieniu.

PLD powróciła do władzy w czerwcu 1994 roku, wchodząc w koalicję z Japońską Partią Socjalistyczną i Nową Partią Zwiastun (Shintō Sakigake) ${ }^{25}$. Aby przekonać socjalistów do zawarcia porozumienia, Kōno Yōhei odstąpił wówczas stanowisko premiera przewodniczącemu Japońskiej Partii Socjalistycznej, Murayamie Tomiichiemu. Od tej chwili PLD musiała przy ustalaniu polityki wobec Chin brać pod uwagę także stanowisko swoich koalicyjnych partnerów. Będący jednym z twórców koalicji Nonaka Hiromu z frakcji Obuchiego nie ukrywał zadowolenia, że Japońska Partia Socjalistyczna, która od dziesięcioleci głosiła skrajny pacyfizm, w chwili dojścia do władzy złagodziła swoją politykę i uznała zgodność z konstytucją sojuszu japońsko-amerykańskiego czy istnienia Sił Samoobrony ${ }^{26}$. Socjaliści byli politykami propekińskimi, jak też zwolennikami złożenia wyraźnych przeprosin narodom Azji za zbrodnie japońskie z

\footnotetext{
${ }^{22}$ Kōno Yōhei, Hakushu wa iranai - Atarashii seiji o motomete, Tōyō Insatsu, Kioto 1976, s. 37.

${ }^{23}$ Hashimoto Ryūtarō, Seiken dakkai ron, Kōdansha, Tokio 1994, s. 70.

${ }^{24}$ Kondo wa honki? Jimin 5 habatsu kanban oroshita ga... gizō no koe mo, „Mainichi Shinbun” z 22 XII 1994, s. 2.

${ }^{25}$ Doszło wówczas do sporu wewnątrz PLD, z kim należy zawiązać koalicję. Większość była za sojuszem z socjalistami, ale Watanabe Michio sprzyjał porozumieniu ze środowiskiem Ozawy Ichirō, grożąc nawet, że w przeciwnym razie opuści partię razem ze swoją grupą. Ostatecznie nie doszło do większego rozłamu w PLD, jednak partię opuścił Kaifu Toshiki, który został liderem Nowej Partii Postępu (Shinshintō), powołanej do życia z inicjatywy Ozawy. Szerzej na ten temat: Murakami Masakuni, Hirano Sadao, Fudesaka Hideyo, Jimintō wa naze tsuburenai no ka, Gentōsha, Tokio 2007, s. 252-274.

${ }^{26}$ Nonaka Hiromu, Watashi wa tatakau, Bungei Shunjū, Tokio 2001, s. 137-139.
} 
czasów II wojny światowej ${ }^{27}$. Z kolei w skład Nowej Partii Zwiastun wchodzili głównie dawni parlamentarzyści PLD, jak syn Sonody Sunao, Sonoda Hiroyuki, czy wnuk premiera Hatoyamy Ichirō, Hatoyama Yukio. Podobnie do socjalistów, w większości byli to „gołębie” i politycy propekińscy. Sonoda Hiroyuki przyznawał, że kontakty z ChRL odziedziczył po ojcu ${ }^{28}$, zaś Hatoyama Yukio był bardzo umiarkowanym politykiem stroniącym od ruchów nacjonalistycznych ${ }^{29}$.

Tabela 5.1 Rozkład sił pomiędzy frakcjami PLD oraz partie koalicyjne w czasie przewodnictwa Kōno Yōheia w latach 1993-1995.

\begin{tabular}{|l|l|}
\hline \multicolumn{1}{|c|}{ Cechy i liczebność frakcji PLD } & \multicolumn{1}{c|}{ Partie koalicyjne (od 1994) } \\
\hline Miyazawa (L, G, P) 68 & Japońska Partia Socjalistyczna (G, P) 140 \\
Mitsuzuka (D, J, T) 74 & Nowa Partia Zwiastun (G, P) 13 \\
Watanabe (D, J) 70 & \\
Obuchi (L) 64 & \\
Kōmoto (D, G, P) 27 & \\
Bezfrakcyjni 6 & \\
\hline 309 & 153 \\
\hline
\end{tabular}

L- dawni członkowie Partii Liberalnej, główny nurt konserwatywny, D- dawni członkowie Partii Demokratycznej, boczny nurt konserwatywny, G- gołębie, J- jastrzębie, P- obóz propekiński, Tobóz protajwański.

Liczebność frakcji (podana przy poszczególnych frakcjach) po wyborach do Izby Reprezentantów w lipcu 1993 roku. Uwzględniono członków frakcji z obu izb parlamentu. Liczebność Japońskiej Partii Socjalistycznej podana w przybliżeniu.

Opracowanie własne na podstawie: Fukunaga Fumio, Habatsu..., s. 80; Hoshi Hiroshi, op.cit., s. $177-181$.

Kōno Yōhei reprezentował lewe skrzydło w PLD, o czym świadczą losy jego długiej kariery politycznej. Po śmierci w 1965 roku ojca, Kōno Ichirō, przywódcy jednej z największych frakcji w partii, w młodym wieku odziedziczył jego okręg wyborczy. Od samego początku można było zauważyć, że pod pewnymi względami różnił się od swojego ojca. O ile Kōno Ichirō był reprezentantem obozu ,jastrzębi”, jego syna można nazwać zdeklarowanym „gołębiem”, całe życie przeciwstawiającym się rewizji pacyfistycznej konstytucji czy ingerencji nacjonalistów w treść podręczników do historii.

Jednakże pod jednym względem Kōno Yōhei miał takie same poglądy, jak jego ojciec. Pozostając pod silnym wpływem zapału spokrewnionego z nim

\footnotetext{
${ }^{27}$ W okresie zimnowojennym Japońska Partia Socjalistyczna była postrzegana jako partia antysystemowa. Chociaż należeli do niej także umiarkowani politycy, przeważały w niej elementy marksistowsko-leninowskie. Do czasów Murayamy Tomiichiego jedynym premierem z tego ugrupowania był Katayama Tetsu w latach 1947-1948. Szerzej na ten temat: Gerald L. Curtis, The Japanese Way..., s. 117-156; Ishikawa Masumi, op.cit., s. 36-103.

${ }^{28}$ Liu Deyou, Toki wa..., t. 2., s. 763-764.

${ }^{29}$ Mori Seiho, Hatoyama Yukio to Hatoyama-ke 4-dai, Chūō Kōron Shinsha, Tokio 2009, s. 160180.
} 
Tagawy Seiichiego, jak też wywodzącego się $\mathrm{z}$ tego samego środowiska „bocznego nurtu konserwatywnego" Matsumury Kenzō, Kōno należał do stronnictwa propekińskiego. W 1971 roku razem z grupą Matsumury demonstracyjnie opuścił głosowanie w sprawie wotum nieufności wobec ministra spraw zagranicznych Fukudy Takeo, odpowiedzialnego za działania w celu niedopuszczenia komunistycznych Chin do ONZ. W 1976 roku Kōno Yōhei dokonał rozłamu w PLD, zakładając razem z Tagawą Seiichim Nowy Klub Liberalny. Jak zostało wspomniane w rozdziale czwartym, wyjście z partii Kōno i kilku innych umiarkowanych polityków, członków zoku edukacyjnego, było jedną z przyczyn pojawienia się $\mathrm{w}$ latach 80 . XX wieku problemów związanych $\mathrm{z}$ podręcznikami do historii.

Kiedy w 1986 roku Kōno Yōhei powrócił do PLD, nie wstąpił do frakcji Nakasone, która kontynuowała tradycje grupy jego ojca, tylko do frakcji Miyazawy. Sam tłumaczy, iż postąpił tak, gdyż nie odpowiadała mu prawicowa ideologia Nakasone Yasuhiro, zaś czuł duży osobisty szacunek do Miyazawy Kiichiego $^{30}$. Kōno miał umiarkowane poglądy na temat historii. Uważał, że Japończycy nadal nie odczuwają w wystarczającym stopniu żalu za krzywdy wyrządzone w przeszłości narodom azjatyckim ${ }^{31}$. W sierpniu 1993 roku Kōno Yōhei, jako sekretarz gabinetu Miyazawy, przedstawił kolejny raport na temat wyników badań w sprawie problemu „kobiet pocieszycielek”. Zawierał on słowa „uczuć żalu i przeprosin” za ten proceder ${ }^{32}$. Kōno przyznaje, że z powodu raportu był ostro krytykowany w partii przez takich ,jastrzębi”, jak Abe Shinzō, Nakagawa Shōichi czy Hiranuma Takeo. Uważał, iż nacjonalizm jest niebezpieczny, jeśli używa się go w celu wzmocnienia jedności narodu bez zwracania dostatecznej uwagi na sytuację międzynarodową ${ }^{33}$.

Zarówno nowy przewodniczący partii, jak i partnerzy koalicyjni PLD po jej powrocie do władzy w 1994 roku, byli politykami umiarkowanymi ideologicznie i sprzyjali przyjaznym kontaktom z ChRL. Jednocześnie wzmocniły się jednak wpływy obozu ,jastrzębi” i stronnictwa protajwańskiego w PLD, zaś pozbawiony stabilnej bazy poparcia w partii Kōno nie był w stanie skutecznie kontrolować tych środowisk. Osłabienie dyscypliny wewnątrz frakcji dawało nacjonalistycznym politykom niemal wolną rękę w głoszeniu swoich poglądów.

\section{Problem wizyty Li Denghuia i przeprosin za zbrodnie wojenne}

Wkrótce po odsunięciu PLD od władzy Ozawa Ichirō, będący „szarą eminencją” stojącą za rządem Hosokawy Morihiro, zdradził zamiar zaproszenia do Japonii prezydenta Tajwanu Li Denghuia. Podobnie jak dwa lata wcześniej analogiczne oświadczenie Kanemaru Shina, inicjatywa ta spotkała się z ostrym sprzeciwem

\footnotetext{
${ }^{30}$ Wywiad autora z Kōno Yōheiem...

${ }^{31}$ Hoshu seijika wa ureeru pod red. „Sekai” Henshūbu, Iwanami Shoten, Tokio 1986, s. 330.

${ }^{32}$ Ōnuma Yasuaki, ,Ianfu” mondai to wa nan datta no ka, Chūō Kōron Shinsha, Tokio 2007, s. 3.

${ }^{33}$ Wywiad autora z Kōno Yōheiem...
} 
władz w Pekinie ${ }^{34}$. Tym razem jednak sprawa nie została wyciszona równie szybko, jak w 1991 roku. Wszakże PLD nie sprawowała już władzy, zaś nawet w tej partii ,propekiński konsensus” został zakwestionowany razem z rozpadem utrzymującej go przez lata frakcji Tanaki-Takeshity. O ile do lat 90. XX wieku ze względu na czynniki historyczne, geograficzne i kulturowe strona japońska uważała relacje z ChRL za „stosunki szczególne”, po zakończeniu zimnej wojny zmieniła je na „stosunki normalne”. Władze w Tokio przestały traktować Chiny w sposób uprzywilejowany, nauczyły się mówić „nie” i coraz częściej apelowały np. o przestrzeganie praw człowieka. Było to częścią transformacji Japonii w kierunku „normalnego państwa” (jap. futsū no kuni, chiń. putong guojia), proklamowanego przez Ozawę Ichirō ${ }^{35}$. Ozawa pragnął utworzenia z Japonii w pełni niezależnego kraju o wszystkich atrybutach siły, gotowego do stawienia czoła wyzwaniom ery pozimnowojennej. W wydanej w 1993 roku książce Plan przebudowy Japonii domagał się rewizji pacyfistycznej konstytucji, by umożliwić większą aktywność Japonii na arenie międzynarodowej ${ }^{36}$. Jak twierdzi Hugo Dobson, Ozawa promował nową normę w rozumieniu konstruktywistycznym, która miała zastąpić „doktrynę Yoshidy”37.

Chociaż do wizyty Li Denghuia ostatecznie nie doszło za rządów Hosokawy, dyskusja publiczna na ten temat powróciła w sierpniu 1994 roku, tuż po utworzeniu koalicji PLD z Japońską Partią Socjalistyczną. Okazało się wówczas, iż prezydent Tajwanu został zaproszony przez organizatorów Azjatyckich Zawodów Olimpijskich w Hiroszimie. Wewnątrz PLD szybko rozpoczął się spór między obozem propekińskim i protajwańskim. Tym razem, inaczej niż w 1991 roku, Parlamentarne Zgromadzenie Stosunków Japońsko-Tajwańskich z Fujio Masayukim na czele aktywnie zaangażowało się w zbieranie podpisów pod petycją promującą wizytę Li Denghuia ${ }^{38}$. Ruch ten poparł m.in. syn Abe Shintarō i wnuk Kishiego Nobusuke, Abe Shinzō z frakcji Mitsuzuki, przebywający akurat w Tajpej razem z grupą protajwańskich parlamentarzystów z PLD ${ }^{39}$. Ostatecznie w październiku 1994 roku zamiast Li Denghuia Japonię odwiedził wiceprzewodniczący Yuanu Wykonawczego Xu Lide. Ponieważ i on był wysokim przedstawicielem władz w Tajpej, kierownictwo KPCh zdecydowanie skrytykowało tę wizytę jako pogwałcenie zasady utrzymywania przez Japonię jedynie pozarządowych kontaktów z Tajwanem. Na znak protestu na zawody nie

\footnotetext{
${ }^{34}$ Taiwan no Ri Tōki no hōnichi ni hantai hyōmei Chūgoku gaimu jikan, „Yomiuri Shinbun” z 12 IX 1993, s. 2.

${ }^{35}$ Zhong-Ri guanxi 30 nian..., s. 214.

${ }^{36}$ Ozawa Ichirō, Nihon kaizō keikaku, Kōdansha, Tokio 2006, s. 102-126.

${ }^{37}$ Hugo Dobson, Japan and United Nations Peacekeeping. New Pressures, New Responses, Routledge Curzon, London - New York 2003, s. 31.

${ }^{38}$ Ri sōtō no hōnichi mondai. Jimintō Nikka Giin Kondankai ga „kangei” shomei e, „Yomiuri Shinbun" z 10 IX 1994, s. 3.

${ }^{39}$ Ri Taiwan sōtō hōnichi. Hōtai no Jimintō kokkai giindan ni shiji to shinchōron, „Yomiuri Shinbun" z 9 IX 1994, s. 2.
} 
przyjechał przedstawiciel ChRL ${ }^{40}$. Z drugiej strony, jeszcze pod koniec września 1994 roku Kōno Yōhei spotkał się w Nowym Jorku z ministrem spraw zagranicznych Qian Qichenem, obiecując mu, że również w przyszłości nie dopuści do wizyty Li Denghuia w Japonii ${ }^{41}$. Dzięki temu przewodniczącemu PLD udało się uniknąć całkowitego bojkotu zawodów przez Chiny. Niemniej jednak cały incydent pokazał, że obóz protajwański znacząco wzmocnił swoje wpływy w partii. Coraz częściej dochodziło zarówno do wizyt prawicowych polityków w Tajpej, jak i wysokich rangą urzędników Republiki Chińskiej w Japonii $^{42}$.

Tymczasem ponownie dały o sobie znać problemy historyczne. Gdy w 1993 roku premier Hosokawa Morihiro nazwał wojnę na Pacyfiku wojną napastniczą, spotkał się z ostrą krytyką ze strony ,jastrzębi” z pozostającej wówczas w opozycji PLD. Zawiązali oni nawet Komitet Badania Historii (Rekishi Kentō Iinkai), mający za pomocą wykładów i publikacji zadbać o upowszechnianie pochlebnej dla Japonii wersji wydarzeń z czasów II wojny światowej. W jego działalność zaangażowali się tacy znani politycy, jak Hashimoto Ryūtarō z frakcji Obuchiego czy Mori Yoshirō z frakcji Mitsuzuki ${ }^{43}$. Przewodniczącym Komitetu został Yamanaka Sadanori z frakcji Watanabe, zaś sekretarzem parlamentarzysta PLD z Izby Radców, Itagaki Tadashi, syn zbrodniarza wojennego klasy A, generała Itagakiego Seishirō. Działalność Komitetu Badania Historii okazała się wstępem do skrajnie prawicowego ruchu uczczenia zbliżającej się okrągłej rocznicy kapitulacji Japonii ${ }^{44}$.

Na 15 sierpnia 1995 roku miała przypaść 50. rocznica zakończenia II wojny światowej. $Z$ tej okazji w japońskim parlamencie zamierzano przyjąć symboliczną uchwałę, zawierającą przeprosiny za zbrodnie popełnione $\mathrm{w}$ okresie ekspansjonizmu. Ponieważ zgoda na tę rezolucję była jednym z punktów umowy koalicyjnej z Japońską Partią Socjalistyczną i Nową Partią Zwiastun, władze PLD musiały za wszelką cenę przekonać do uchwały własnych członków. Nie było to jednak łatwe, gdyż skrajnie prawicowe organizacje pozarządowe, mające powiązania $\mathrm{z}$ nacjonalistycznymi politykami, zrzeszyły się w Narodowym Komitecie 50. Rocznicy Zakończenia Wojny (Shūsen 50 Shūnen Kokumin Iinkai) i zorganizowały prawdziwą kampanię przeciwko rezolucji. Przewodziły jej Komitet Obrony Japonii (Nihon o Mamoru Kai), Narodowa Rada Obrony Japonii (Nihon o Mamoru Kokumin Kaigi), Nihon Izokukai czy Stowarzyszenie Odpowiedzi Duszom Poległych Żołnierzy (Eirei ni Kotaeru Kai). Jeszcze w

\footnotetext{
${ }^{40}$ Shimada Masao, Tian Jianong, op.cit., s. 474.

41 „Seikai tenbyō” Murayama gaikō. Genba ni onbu, mienu rinen, „Yomiuri Shinbun” z 4 X 1994, s. 2.

${ }^{42}$ Zhong-Ri guanxi 30 nian..., s. 253.

${ }^{43}$ Caroline Rose, Sino-Japanese..., s. 53.

${ }^{44}$ Zhong-Ri guanxi 30 nian..., s. 254-255; Wang Xiliang, op.cit., s. 237-238.
} 
1994 roku organizacje te rozpoczęły zbieranie podpisów przeciw przeprosinom ${ }^{45}$. W grudniu 1994 roku powstała Parlamentarna Liga Upamiętnienia 50. Rocznicy Zakończenia Wojny (Shūsen 50 Shūnen Kokkai Giin Renmei) z Okuno Seisuke na czele, która szerzyła ruch sprzeciwu wśród prawicowych parlamentarzystów z PLD ${ }^{46}$. W lutym 1995 roku Murakami Masakuni z trzema innymi politykami PLD odwiedził Tajwan, by zaprosić Li Denghuia na uroczystości uczczenia pamięci japońskich żołnierzy poległych w czasie II wojny światowej ${ }^{47}$. Z kolei w kwietniu 1995 roku demonstracyjnie zrzekł się mandatu poselskiego dawny działacz Seirankai, Ishihara Shintarō, protestując przeciw uległej polityce Japonii wobec $\mathrm{Chin}^{48}$. Równolegle nasilał się ruch pacyfistycznych organizacji pozarządowych, domagających się wyraźnych przeprosin. Zaangażowała się w niego m.in. wdowa po byłym premierze Mikim Takeo ${ }^{49}$.

Pośród członków zarządu partii jedynie sekretarz generalny PLD z Izby Radców, Murakami Masakuni z frakcji Watanabe, sprzeciwiał się rezolucji. W szczególności nie chciał, by wojna została w niej nazwana napastniczą, ani by umieszczono wzmiankę o władzy kolonialnej Japonii w Azji. Przeciwnego zdania był szczególnie przewodniczący Rady Badań Politycznych, Katō Kōichi z frakcji Miyazawy, który dążył do wyraźnego nazwania zbrodni japońskich po imieniu. Po długich negocjacjach z takimi prawicowymi organizacjami, jak Jinja Honchō czy Nihon Izokukai, Katō wypracował kompromisowe, dwuznaczne sformułowanie, aby uzyskać zgodę Murakamiego. Murakami Masakuni wspomina jednak, że został oszukany, gdyż w ostatecznym tekście uchwały dokonano drobnej modyfikacji, przez co wyraźnie wskazano na winę Japonii w czasie wojny $^{50}$. Rezolucja została uchwalona w Izbie Reprezentantów w czerwcu 1995 roku przy nieobecności 70 posłów z PLD i większości konserwatywnych parlamentarzystów opozycyjnych ${ }^{51}$. Z kolei w Izbie Radców Murakami Masa-

\footnotetext{
${ }^{45}$ Shimada Masao, Tian Jianong, op.cit., s. 439-441.

${ }^{46}$ Uozumi Akira, Shōgen Murakami Masakuni. Ware, kuni ni uragirareyōtomo, Kōdansha, Tokio 2007, s. 172-174.

${ }^{47}$ Zhong-Ri guanxi 30 nian..., s. 307.

${ }^{48}$ Nonaka Hiromu, Watashi..., s. 150-151.

${ }^{49}$ Shimada Masao, Tian Jianong, op.cit., s. 441.

${ }^{50}$ Kluczowy fragment rezolucji brzmiał: „Myśląc o licznych przypadkach dominacji kolonialnej czy aktach napaści we współczesnej historii świata, kraj nasz jest świadomy tych czynów dokonanych w przeszłości, jak też cierpienia zadanego innym narodom, w szczególności ludom Azji, i okazuje poczucie głębokiego żalu". Według Murakamiego bez konsultacji z nim w ostatniej chwili zostało dodane słówko „tych” ( $k \bar{o}$ shita) przed „,czynami”, które zupełnie zmieniło sens wypowiedzi, wskazując, że to Japonia była odpowiedzialna za „dominację kolonialną" (shokuminchi shihai) i ,akty napaści” (shinryakuteki kōi). Murakami Masakuni wspomina, iż po nieświadomej zgodzie na tę wersję, przewodniczący Komitetu Obrony Japonii, Kabashima Yūzō, jak też inni prawicowi aktywiści niemal rzucili się na niego ze złości, targając za krawat, gdyż uznali go za zdrajcę. Szerzej na ten temat: Uozumi Akira, op.cit., s. 176-178.

${ }^{51}$ Shimada Masao, Tian Jianong, op.cit., s. 442.
} 
kuni, czując się oszukanym przez Katō Kōichiego, użył swoich wpływów, by zablokować przegłosowanie tej, i tak mocno już zmodyfikowanej, uchwały ${ }^{52}$.

Zamiast stać się okazją do pojednania japońsko-chińskiego, rocznica zakończenia II wojny światowej przerodziła się w kolejny problem historyczny w relacjach między oboma krajami. Sun Pinghua, przewodniczący Stowarzyszenia Przyjaźni Chińsko-Japońskiej, skrytykował niejasne sformułowania, zawarte $\mathrm{w}$ rezolucji by rozmyć odpowiedzialność za zbrodnie popełnione $\mathrm{w}$ czasie wojny $^{53}$. Na dodatek na początku sierpnia 1995 roku japoński minister edukacji Shimamura Yoshinobu z frakcji Watanabe poddał w wątpliwość sens kolejnych przeprosin i zasugerował, że Japonia nie była agresorem w czasie wojny $^{54}$. W dniu 15 sierpnia 1995 roku premier Murayama Tomiichi wyraźnie przeprosił za kolonializm i ekspansjonizm w osobistym oświadczeniu, jednak nie posiadało ono równej wagi, co uchwała parlamentarna. Na dodatek, tego samego dnia grupa 59 posłów, w tym aż 9 ministrów z PLD, odwiedziła świątynię Yasukuni ${ }^{55}$. Było wyraźnie widać, że Kōno Yōhei nie potrafił przeforsować swojego stanowiska w partii.

\section{Zawieszenie pomocy finansowej dla Chin}

W październiku 1993 roku ChRL dokonała podziemnego testu nuklearnego, co spotkało się z ostrą krytyką ze strony Japonii ${ }^{56}$. Ponieważ próby były kontynuowane w 1994 roku, w PLD, która wówczas właśnie powróciła do władzy w koalicji z socjalistami, rozpoczęła się dyskusja na temat ewentualnych sankcji wobec Chin. W szczególności obóz ,jastrzębi” domagał się wyraźnej reakcji na ignorowanie przez ChRL wezwania do zaprzestania testów. Co ważne jednak, tym razem również koalicyjni partnerzy PLD, Japońska Partia Socjalistyczna z premierem Murayamą na czele i Nowa Partia Zwiastun, dążyli do ukarania Chin. Socjaliści od lat głosili hasła rozbrojenia, pacyfizmu i rezygnacji z broni atomowej na świecie. Na dodatek japońska opinia publiczna zdecydowanie negatywnie przyjęła chińskie próby nuklearne, co nie pozostało bez wpływu na zachowanie polityków, dbających o swój wizerunek wśród elektoratu ${ }^{57}$.

\footnotetext{
${ }^{52}$ Uozumi Akira, op.cit., s. 178-179.

${ }^{53}$ Shimada Masao, Tian Jianong, op.cit., s. 443.

${ }^{54}$ Hwei-ling Huo, Japan and China: Collaborators or Rivals [w:] Japan's Quest. The Search for International Role, Recognition, and Respect pod red. Warrena S. Hunsbergera, M. E. Sharpe, Armonk 1997, s. 158.

${ }^{55}$ Shimada Masao, Tian Jianong, op.cit., s. 444-446.

${ }^{56}$ ChRL przeprowadzała próby nuklearne niemal corocznie od 1964 roku, jednak w 1991 roku Japonia zmodyfikowała wytyczne w sprawie przyznawania ODA. W nowych uregulowaniach podkreślono m.in., że przy udzielaniu pomocy rozwojowej należy zwrócić szczególną uwagę na to, czy państwo-beneficjent nie rozwija broni masowego rażenia bądź technologii rakietowych. Szerzej na ten temat: Okada Minoru, op.cit., s. 154-155.

${ }^{57}$ Tsukasa Takamine, A New Dynamism in Sino-Japanese Security Relations: Japan's Strategic Use of Foreign Aid, „The Pacific Review” 2005, vol. 18 no. 4, s. 445-448; Hiramatsu Shigeo, Chūgoku, kaku misairu no hyōteki, Kadokawa Shoten, Tokio 2006, s. 231-233.
} 
Jedynie biurokraci z Ministerstwa Spraw Zagranicznych pod kierownictwem Kōno Yōheia sprzeciwiali się sankcjom wobec ChRL. Sam Kōno jednak, chociaż był politykiem propekińskim, nie mógł w nieskończoność opierać się presji zarówno z lewej (socjaliści), jak i z prawej (,jastrzębie” w PLD) strony japońskiej sceny politycznej ${ }^{58}$. W grudniu 1994 roku Japonia przyznała co prawda ChRL czwartą ratę pożyczki w jenach na lata 1996-2000, ale ogłosiła jednocześnie, iż w przeciwieństwie do poprzednich rat, które były wypłacane z góry za cały okres, będzie ona przyznana w dwóch transzach, za pierwsze trzy, a potem następne dwa lata. Kiedy jednak Chiny dokonały kolejnych próbnych detonacji w maju i sierpniu 1995 roku, stało się jasne, że nie obejdzie się bez bardziej zdecydowanych działań. Partie koalicyjne groziły wręcz Ministerstwu Spraw Zagranicznych, iż w razie braku sankcji wobec Chin nie przegłosują budżetu tego resortu na następny rok $^{59}$.

Obóz ,jastrzębi” z PLD wywierał coraz większą presję na przewodniczącego partii. Na przykład na posiedzeniu parlamentarnej Komisji Spraw Zagranicznych pod koniec maja 1995 roku Abe Shinzō podkreślał, że nie przystoi, by pomoc rozwojowa ze środków japońskich podatników była przekazywana krajowi, który rozwija broń zagłady. Kōno Yōhei jednak do samego końca starał się bronić ChRL, mówiąc: „Wielokrotnie wyrażałem wielki żal z powodu testów nuklearnych Chin, jednakże sądzę, że musimy także myśleć o tym, iż Chiny i Japonia, to znaczy relacje japońsko-chińskie są niezwykle ważnymi stosunkami. Uważam także, że należy zdać sobie sprawę z faktu, iż myśląc o przyszłości Japonii, obecność Chin w Azji oraz stosunki japońsko-chińskie są bardzo istotne. Ponad wszystko jesteśmy świadomi, że stosunki japońsko-chińskie, ustanowione poprzez Wspólną deklarację japońsko-chińską w niezwykle trudnych warunkach przez naszych starszych kolegów, są sprawą wielkiej wagi. Z drugiej strony, także na arenie międzynarodowej z pewnością będzie słychać silny głos opinii publicznej $\mathrm{w}$ sprawie testów nuklearnych. Wobec tego sądzę, że istnieje potrzeba jasnego stwierdzenia, iż z punktu widzenia doznań narodu Japonii, jako jedynego kraju będącego ofiarą bomb atomowych, domagamy się zaprzestania testów nuklearnych"60. Wypowiedź ta dobrze oddaje mieszane uczucia Kōno Yōheia. Z jednej strony starał się on zachować jak najlepsze relacje $\mathrm{z}$ władzami w Pekinie, $\mathrm{z}$ drugiej zaś bliskie mu były hasła rozbrojenia nuklearnego.

Ostatecznie, pod koniec sierpnia 1995 roku, niedługo po obchodach 50. rocznicy zakończenia II wojny światowej, Japonia zamroziła bezzwrotną pomoc finansową dla Chin w ramach ODA z wyjątkiem pomocy humanitarnej ${ }^{61}$. Były to sankcje na tyle poważne, że zadowoliły polityków partii koalicyjnych, a

\footnotetext{
${ }^{58}$ Michael Jonathan Green, op.cit., s. 81.

${ }^{59}$ Sekiyama Takashi, op.cit., s. 85-87.

${ }^{60}$ Posiedzenie Komisji Spraw Zagranicznych Izby Reprezentantów (Shūgiin Gaimu Iinkai) z 26 V 1995 roku, nr 18, Archiwum Obrad...

${ }^{61}$ Sekiyama Takashi, op.cit., s. 87.
} 
równocześnie na tyle łagodne, że Ministerstwo Spraw Zagranicznych mogło, choć niechętnie, je zaaprobować. Inaczej niż w 1989 roku, zamrożenie środków nie dotyczyło wszakże najważniejszej części ODA, czyli pożyczki w jenach. Z drugiej strony, o ile po masakrze na placu Tiananmen Japonia wydała decyzję o sankcjach dopiero po presji ze strony państw Zachodu, tym razem to ona stała $\mathrm{w}$ forpoczcie krajów pragnących ukarać Chiny. Z tego powodu ta unilateralna decyzja Japonii była znacznie większym zaskoczeniem dla ChRL niż analogiczny krok w 1989 roku $^{62}$.

Tymczasem zbliżał się koniec dwuletniej kadencji Kōno Yōheia jako przewodniczącego PLD. Kōno chciał ubiegać się o reelekcję, jednak wewnątrz partii narastał ruch żądający wzięcia przez niego odpowiedzialności za słaby wynik PLD w wyborach do Izby Radców w lipcu 1995 roku $^{63}$. Ostatecznie Kōno postanowił nie kandydować, gdy jeden z najbardziej wpływowych polityków frakcji Miyazawy, Katō Kōichi, ogłosił, że zamierza wesprzeć w wyborach nie swojego frakcyjnego kolegę, tylko Hashimoto Ryūtarō z frakcji Obuchiego ${ }^{64}$. Kōno przyznaje, iż obawiał się, że wraz z jego odejściem obóz „gołębi” zostanie osłabiony, jednak był już zmęczony wewnątrzpartyjną rywalizacją ${ }^{65}$. Zadanie zniesienia sankcji wobec Chin miało przypaść następnemu przewodniczącemu PLD.

$$
* * *
$$

Chociaż Kōno Yōhei to bardzo umiarkowany i propekiński polityk, w okresie piastowania przez niego funkcji przewodniczącego PLD nastąpiło pewne ochłodzenie w stosunkach między Japonią a ChRL. Można to wytłumaczyć zarówno tym, że uwarunkowania zewnętrzne (testy nuklearne ChRL) nie sprzyjały kontaktom na linii Tokio-Pekin, jak też faktem, iż Kōno miał znacznie mniejsze możliwości kształtowania dyplomacji Japonii niż poprzedni szefowie partii. Przez pierwszy rok jego urzędowania PLD była w opozycji, gdy zaś powróciła do władzy, musiała polegać na wsparciu Japońskiej Partii Socjalistycznej, której odstąpiła stanowisko premiera. Paradoksalnie, zazwyczaj propekińscy socjaliści ze względu na swoje pacyfistyczne przekonania okazali się jedną z sił dążących do zawieszenia pomocy rozwojowej dla ChRL z powodu chińskich testów nuklearnych. Niemniej jednak jako minister spraw zagranicznych Kōno starał się, by sankcje nałożone na władze w Pekinie czy coraz śmielsze inicjatywy ,jastrzębi” w PLD nie naruszyły nadmiernie przyjaźni japońsko-chińskiej.

\footnotetext{
${ }^{62}$ Tsukasa Takamine, op.cit., s. 447-449.

${ }^{63}$ Nonaka Hiromu, Watashi..., s. 196-198.

${ }^{64}$ Tazaki Shirō, op.cit., s. 377-397.

${ }^{65}$ Kōno Yōhei, Kōno Tarō, Ketsudan - Kōno fushi no seitai kan ishoku, Asahi Shinbubsha, Tokio 2004, s. 30.
} 


\section{HASHIMOTO RYŪTARŌ (1995-1998)}

Rządy Hashimoto Ryūtarō były okresem dalszej eskalacji napięcia w relacjach pomiędzy Japonią a ChRL. Chociaż Hashimoto trudno nazwać politykiem o skrajnie prawicowych poglądach, nie był także „gołębiem” pokroju Kōno Yōheia. Jego kadencja przypadła zaś na okres obfitujący w kryzysy w stosunkach z ChRL, wywołane rosnącą asertywnością władz w Pekinie po zakończeniu zimnej wojny. Uwarunkowania te sprzyjały nasileniu działalności obozu protajwańskiego w PLD i wykorzystaniu sprawy chińskiej w rywalizacji wewnątrzpartyjnej.

\section{Nastawienie Hashimoto Ryūtarō wobec Chin i historii Japonii}

Hashimoto Ryūtarō został nowym przewodniczącym PLD na początku października 1995 roku, zaś w styczniu 1996 roku także premierem, kiedy Murayama Tomiichi podał się do dymisji. W ten sposób PLD w pełni powróciła do władzy, choć nadal musiała polegać na koalicji z Japońską Partią Socjalistyczną (od 1996 roku Partia Socjaldemokratyczna) i Nową Partią Zwiastun. Kiedy jednak socjaliści i Nowa Partia Zwiastun ponieśli klęskę w wyborach parlamentarnych w październiku 1996 roku, przeszli do współpracy pozarządowej $^{66}$. Z kolei PLD zdołała wówczas uzyskać połowę mandatów w Izbie Reprezentantów i zdawało się, że po trzech latach osłabienia zaczynała odbudowywać swoją dawną dominującą pozycję. Coraz wyraźniej było także widać powrót do polityki frakcyjnej ${ }^{67}$.

Co charakterystyczne dla członka dawnej frakcji Satō, Hashimoto Ryūtarō był politykiem stosunkowo umiarkowanym i $\mathrm{w}$ miarę elastycznym pod względem ideologii. Jak sam przyznawał: „Warunki prowadzenia polityki, takie jak sytuacja międzynarodowa czy środowisko społeczne, ulegają ciągłym zmianom. Poszczególne sposoby myślenia niekoniecznie zawsze podążają tą samą ścieżką"68. Po ojcu, Hashimoto Ryōgo, przejął specjalizację w dziedzinie opieki społecznej $^{69}$. Od początku swojej kariery politycznej Hashimoto należał do zoku socjalnego w PLD i wykazywał zainteresowanie raczej polityką wewnętrzną niż zagraniczną. Jako przedstawiciel młodszego pokolenia niż Takeshita Noboru, Hashimoto nie zdążył wykształcić równie silnych związków personalnych z przywódcami KPCh, jak jego starsi koledzy ${ }^{70}$, ale można go nazwać politykiem

\footnotetext{
${ }^{66}$ Lee Kiwan, Ilbon-ui jeongdang-gwa jeongdang jeongchi, Doseo Chulpan Maebong, Seul 2006, s. 40.

${ }^{67}$ Bae Jeongho, Talnaengjeon sidae jeonhwangi-ui Ilbon-ui kungnae jeongchi-wa daeoe jeollyak, Tong-il Yeonguwon, Seul 2005, s. 15-18.

${ }^{68}$ Hashimoto Ryūtarō, Seiken..., s. 44.

${ }^{69}$ Okada Satoshi, Ryū-chan ryū. Hashimoto Ryūtarō atarashii seiji sutairu [w:] Ryū-chan ryū. Hashimoto Ryūtarō atarashii seiji sutairu no jituzō pod red. Tamury Shigenobu, KK Besutoserāzu, Tokio 1998, s. 24.

${ }^{70}$ Michael Jonathan Green, op.cit., s. 83.
} 
umiarkowanie propekińskim. Był jednym z pierwszych wysokich urzędników japońskich, którzy odwiedzili Pekin po masakrze na placu Tiananmen w 1989 roku. Jak wspominał: „Częste dochodzenie do tego typu incydentów byłoby kłopotliwe, jednak przekonałem się, że w przypadku powstania jakichś problemów, to Japonia powinna wykazać inicjatywę udania się do Chin",71.

Tabela 5.2 Rozkład sił pomiędzy frakcjami PLD oraz partie koalicyjne w czasie przewodnictwa Hashimoto Ryūtarō w latach 1995-1998.

\begin{tabular}{|l|l|}
\hline \multicolumn{1}{|c|}{ Cechy i liczebność frakcji PLD } & \multicolumn{1}{c|}{ Partie koalicyjne } \\
\hline Obuchi (L) 83 & Partia Socjaldemokratyczna (G, P) 31 \\
Mitsuzuka (D, J, T) 85 & Nowa Partia Zwiastun (G, P) 5 \\
Miyazawa (L, G, P) 70 & \\
Watanabe (D, J) 47 & \\
Kōmoto (D, G, P) 21 & \\
Bezfrakcyjni 28 & 36 \\
\hline 334 & \\
\hline
\end{tabular}

L- dawni członkowie Partii Liberalnej, główny nurt konserwatywny, D- dawni członkowie Partii Demokratycznej, boczny nurt konserwatywny, G- gołębie, J- jastrzębie, P- obóz propekiński, Tobóz protajwański.

Liczebność frakcji (podana przy poszczególnych frakcjach) po wyborach do Izby Reprezentantów w październiku 1996 roku. Uwzględniono członków frakcji z obu izb parlamentu. Liczebność Partii Socjaldemokratycznej podana w przybliżeniu.

Opracowanie własne na podstawie: Fukunaga Fumio, Habatsu..., s. 80; Hoshi Hiroshi, op.cit., s. $176-181$.

Z drugiej strony, do 1995 roku Hashimoto Ryūtarō był przewodniczącym skrajnie prawicowej organizacji Nihon Izokukai, co pośrednio rzutowało na jego politykę wobec Chin. Co prawda sam podkreślał, że nie należał do zwolenników nietolerancyjnej odmiany nacjonalizmu ${ }^{72}$, jednak jego podejście do historii Japonii było nieco problematyczne. Gdy w 1993 roku Hosokawa Morihiro powiedział, iż udział Japonii w II wojnie światowej był wojną napastniczą, Hashimoto uważał, że premier przesadził: „Nie da się zaprzeczyć, iż Japonia po części z pewnością dokonała także aktów agresji, na przykład wobec Półwyspu Koreańskiego czy Chin kontynentalnych. Poza tym przyznaję, że z obecnej perspektywy historycznej należy przyjąć krytykę, iż Półwysep Koreański czy dawne Państwo Mandżurii były koloniami. (...) Jednak jakże można twierdzić, że poprzednia wojna i całość ówczesnych działań Japonii były «inwazją»? Jeśli chodzi o tak zwaną wojnę na Pacyfiku, nie uważam, by Japonia dokonała aktów agresji w walce z Ameryką, Anglią, Francją i Holandią. (...) Co więcej, objąłem obecnie stanowisko przewodniczącego Nihon Izokukai i jestem wspierany przez osoby osierocone, z których niemal wszyscy wysłali na pole walki swoje dzieci, mężów czy ojców, wierząc, że uczynili to dla swojego kraju. Cóż sobie pomyślą

${ }^{71}$ Hashimoto Ryūtarō, Seiken..., s. 277.
${ }^{72}$ Idem, Vision of Japan. Waga kyōchū ni seisaku arite, KK Besutoserāzu, Tokio 1993, s. 30. 
ludzie nadal żyjący wspominając krewnych, którzy nie powrócili, gdy usłyszą: «ostatecznie tamta wojna była agresją»?",73

Jak widać, Hashimoto uznawał wojnę napastniczą i japoński kolonializm przynajmniej wobec Chin i Korei, więc trudno nazwać go radykałem. Według Nonaki Hiromu, wbrew opinii części mediów Hashimoto nie był ,jastrzębiem”, tylko politykiem potrafiącym dostosowywać się do zmieniającej się sytuacji ${ }^{74}$. Paradoksalnie, wieloletnia działalność w Nihon Izokukai dała Hashimoto szansę na gruntowne zapoznanie się $\mathrm{z}$ historią swojego kraju. Od lat 60 . XX wieku był on zaangażowany w ruch odszukiwania szczątek japońskich żołnierzy w krajach wschodnioazjatyckich, dzięki czemu wielokrotnie widział na własne oczy uczucia antyjapońskie wśród ludności na prowincji. Jak przyznaje: „Dzięki temu odczułem na własnej skórze, że choćby spór był rozwiązany na poziomie rządowym, wcale nie oznacza to, by zakończył się na poziomie zwykłego ludu. (...) W pamięci narodów Azji rany pozostawione przez II wojnę światową nadal się nie zagoiły. Głęboko odczuwam potrzebę dostosowania przyszłych działań Japonii do tej rzeczywistości”, ${ }^{, 7}$. Z drugiej strony, Hashimoto musiał wziąć pod uwagę stanowisko swoich wyborców z Nihon Izokukai, co niekoniecznie współgrało z jego propekińskimi przekonaniami. Jednym z kluczowych celów tej organizacji od lat było wszakże doprowadzenie do oficjalnej wizyty premiera $\mathrm{w}$ kontrowersyjnej świątyni Yasukuni w Tokio. Sam Hashimoto przed 1996 rokiem pełnił funkcję przewodniczącego Zgromadzenia Parlamentarzystów Odwiedzających Razem Świątynię Yasukuni (Minna de Yasukuni Jinja ni Sanpai Suru Kokkai Giin no Kai).

\section{Dalsza eskalacja napięcia w relacjach japońsko-chińskich}

Zadanie zniesienia sankcji wobec ChRL okazało się trudne do wykonania ze względu na liczne problemy, które powodowały dalszą eskalację kryzysu w relacjach z Chinami pod koniec 1995 i szczególnie w 1996 roku. W 1995 roku protajwańscy politycy z PLD, m.in. Murakami Masakuni, Fujio Masayuki, Satō Shinji i Hiranuma Takeo, kilkakrotnie próbowali zaprosić do Japonii Li Denghuia, zwłaszcza że w czerwcu 1995 roku zdołał on odwiedzić Stany Zjednoczone. Kolejna poważna inicjatywa pojawiła się we wrześniu 1995 roku, tuż przed objęciem stanowiska szefa partii przez Hashimoto. Do Japonii przybyła wówczas delegacja wysokich rangą polityków tajwańskich z $\mathrm{Wu}$ Boxiongiem i sekretarzem generalnym Guomindangu Xu Shuide na czele. Oprócz uczestnictwa w pogrzebie Fukudy Takeo, spotkali się oni z ministrem transportu Hiranumą Takeo ${ }^{76}$. Niedługo potem prasa podała, iż Hiranuma znajduje się wśród osób domagających się uczestnictwa prezydenta Tajwanu w

\footnotetext{
${ }^{73}$ Idem, Seiken..., s. 98-99.

${ }^{74}$ Nonaka Hiromu, Watashi..., s. 190.

${ }^{75}$ Hashimoto Ryūtarō, Vision..., s. 105-106.

${ }^{76}$ Zhong-Ri guanxi 30 nian..., s. 307-308.
} 
spotkaniu $\mathrm{APEC}^{77} \mathrm{w}$ Osace. Hiranuma Takeo oświadczył jednak, iż zrezygnował z promocji wizyty w chwili objęcia resortu ${ }^{78}$. Ostatecznie Kōno Yōhei, który do stycznia 1996 roku sprawował funkcję ministra spraw zagranicznych, nie dopuścił do wizyty Li Deghuia w październiku 1995 roku. W ten sposób dotrzymał swojej wcześniejszej obietnicy złożonej ChRL.

W 1996 roku miało jednak dojść do dalszego wzrostu napięcia w kontaktach japońsko-chińskich. Jeszcze w lipcu i sierpniu 1995 roku ChRL przeprowadziła testy rakietowe w Cieśninie Tajwańskiej na znak protestu przeciw podróży Li Denghuia do Stanów Zjednoczonych w czerwcu 1995 roku. Szczyt kryzysu przypadł na marzec 1996 roku, gdy Chińska Armia Ludowo-Wyzwoleńcza zorganizowała manewry wojskowe i kolejne próby rakiet balistycznych, by wywrzeć nacisk na Tajwan w samym środku prowadzonej tam kampanii przed pierwszymi demokratycznymi powszechnymi wyborami prezydenckimi ${ }^{79}$. ChRL chciała nie dopuścić do reelekcji Li Denghuia, oskarżając go o dążenie do ogłoszenia niepodległości Tajwanu ${ }^{80}$. Stany Zjednoczone wysłały wówczas w pobliże Tajwanu dwa lotniskowce, z których jeden, „USS Independence”, przybył z bazy Yokosuka w Japonii ${ }^{81}$.

„Dyplomacja rakietowa” ChRL zszokowała japońską opinię publiczną. Szantaż militarny wobec Tajwanu groził destabilizacją sytuacji w całym regionie i dotykał żywotnych interesów Japonii. Jedna z chińskich rakiet spadła zaledwie $60 \mathrm{~km}$ od japońskiej wyspy Yonaguni, zaś całe manewry wojskowe zakłóciły japoński ruch powietrzny i morski w pobliżu Tajwanu. Ponieważ Chiny zdecydowały się na ten krok pomimo wcześniejszych ostrzeżeń ze strony władz w Tokio, Japonia musiała podjąć zdecydowane działania. Tym razem za sankcjami byli nawet biurokraci z Ministerstwa Spraw Zagranicznych ${ }^{82}$. W PLD szczególnie ,jastrzębie” żądali wyraźnego ostrzeżenia Chin. Przez styczeń i luty 1996 roku tacy prawicowi politycy, jak Machimura Nobutaka z frakcji Mitsuzuki, aktywnie podnosili sprawę manewrów wojskowych na forum parlamentu ${ }^{83}$. Również znany z protajwańskich sympatii sekretarz gabinetu, Kajiyama Seiroku, domagał się od Chin odwołania prób rakietowych. Nawet tak

\footnotetext{
77 APEC (Asia-Pacific Economic Cooperation) to utworzone w 1989 roku forum współpracy gospodarczej państw basenu Oceanu Spokojnego. Szerzej na ten temat: Funabashi Yōichi, Nihon no taigai kōsō, Iwanami Shoten, Tokio 1993, s. 52- 73.

${ }^{78}$ Ri Taiwan sōtō hōnichi kōkoku - Hokki jinmei keisai no Hiranuma un'yushō ga shakumei, „Yomiuri Shinbun” z 22 IX 1995, s. 2.

${ }^{79}$ Andrew Scobell, Show of Force: Chinese Soldiers, Statesmen, and the 1995-1996 Taiwan Strait Crisis, „Political Science Quarterly” 2000, vol. 115, no. 2, s. 231-232.

${ }^{80}$ Matsuda Masaharu, Taiwan, Chūgoku, Nihon. Taiwan o meguru shomondai to Nihonjin no Chügoku ninshiki, Keiseisha, Tokio 1999, s. 108-110.

${ }^{81}$ Michael Jonathan Green, op.cit., s. 90-91.

${ }^{82}$ Tsukasa Takamine, op.cit., s. 450-451.

${ }^{83}$ Posiedzenie Komisji Bezpieczeństwa Izby Reprezentantów (Shūgiin Anzen Hoshō Iinkai) z 23 II 1996 roku, nr 3, Archiwum Obrad...
} 
umiarkowany i propekiński polityk, jak sekretarz generalny PLD Katō Kōichi, ostrzegał ChRL, że „kryzys może mieć wpływ na interes bezpieczeństwa samej Japonii" ${ }^{\prime \prime}$.

Po zignorowaniu przez Chiny japońskich ostrzeżeń, Hashimoto Ryūtarō zdecydował się w marcu 1996 roku na zawieszenie rozmów z ChRL w sprawie wypłaty pierwszej porcji czwartej raty pożyczki w ramach ODA, wartej $580 \mathrm{mld}$ jenów. Były to sankcje poważniejsze od tych nałożonych w 1995 roku, gdyż dotyczyły znacznie większych kwot, jednak nie przyniosły oczekiwanych rezultatów. W sprawie Tajwanu bardzo trudno było wpływać na Chiny za pomocą presji z zewnątrz ${ }^{85}$. W 2002 roku w Tajpej ujawniono materiały na temat funduszy używanych przez tajwańskie lobby w Stanach Zjednoczonych i Japonii. Wynika $\mathrm{z}$ nich, że premier Hashimoto odegrał znacznie bardziej aktywną rolę w kryzysie tajwańskim niż wcześniej uważano. Li Denghui miał nawiązać kontakt z premierem Japonii m.in. poprzez członka Izby Radców Shiinę Motoo ${ }^{86}$, syna Shiiny Etsusaburō. Hashimoto zgodził się wywrzeć presję na Amerykanów, by wysłali flotę w region Tajwanu ${ }^{87}$.

Kryzys w Cieśninie Tajwańskiej stał się dla obozu protajwańskiego dobrą okazją do nasilenia działalności i przekonania do swoich poglądów dużej części opinii publicznej. Shiina Motoo podkreślał: „W latach 70. wiele krajów nawiązało oficjalne stosunki dyplomatyczne z Chinami, ale nadchodzą zupełnie inne czasy. Wówczas także rząd Tajwanu nie był rządem demokratycznym. Guomindang rywalizowała z Partią Komunistyczną. Wszyscy myśleli, że taka sytuacja będzie trwała. Jednakże zbudowano gospodarkę i przy okazji obecnych wyborów zakończono demokratyzację. Czyż (podejście do Tajwanu) nie stanie się jednym z zadań społeczności międzynarodowej?" ${ }^{88} \mathrm{~W}$ maju 1996 roku w parlamencie przyjęto Uchwałę na temat sytuacji w Chinach i na Tajwanie (Chūgoku, Taiwan jōsei ni kan suru ketsugi), w której zaapelowano o pokojowe rozwiązanie sporu, przywitano z zadowoleniem powszechne wybory prezydenta Tajwanu oraz wyrażono nadzieję na dalszy rozwój demokracji na Tajwanie i w Chinach. Była to pierwsza od 1972 roku japońska rezolucja odnosząca się do Tajwanu $^{89}$. W tym samym miesiącu wizytę w Tajpej złożyła delegacja japońskich parlamentarzystów na czele z byłym marszałkiem Izby Reprezentantów,

\footnotetext{
${ }^{84}$ Tsukasa Takamine, op.cit., s. 451.

${ }^{85}$ Ibidem, s. 450-451.

${ }^{86}$ Co prawda Shiina Motoo w 1993 roku opuścił PLD, ale nadal pełnił rolę pośrednika w kontaktach między Tajwanem a japońskimi politykami konserwatywnymi. Przyznawał też, że pomimo zaproszeń nigdy nie udał się do ChRL. Szerzej na ten temat: Shiina Motoo, Shiina Motoo kaikoroku: Fuki fuhon, Tōshindō, Tokio 2006, s. 14-30.

${ }^{87}$ Honda Yoshihiko, op.cit., s. 125-126; Zhong-Ri guanxi 30 nian..., s. 329-330.

${ }^{88}$ Yamasaki Taku, Ajia Taiheiyō jidai to nichibei anpo, Sandokē Shuppankyoku, Tokio 1996, s. $128-129$.

${ }^{89}$ Matsurigoto. Dai 7 bu „,kuni” no sugata (4). Shinchū shintai shiru doryoku ga fusoku, „Yomiuri Shinbun" z 26 VII 1996, s. 1.
} 
Tamurą Hajime z PLD. Politycy pogratulowali Li Denghuiowi zwycięstwa w wyborach prezydenckich, zaś Tamura podkreślił, że premier Hashimoto też cieszył się, że doszło do tej wizyty ${ }^{90}$. Z kolei w czerwcu 1996 roku na przyjęciu powitalnym nowego tajwańskiego przedstawiciela $\mathrm{w}$ Tokio zjawili się tacy wpływowi politycy, jak Obuchi Keizō i Mitsuzuka Hiroshi ${ }^{91}$. Było wyraźnie widać, że władze w Tajpej zdołały utrzymać bliskie związki z liderami dwóch spośród trzech największych frakcji w PLD, w tym z przywódcą grupy, do której należał premier Hashimoto.

Gdy w styczniu 1996 roku Hashimoto Ryūtarō objął stanowisko szefa rządu, nie było pewne, czy jego powiązania $\mathrm{z}$ prawicowymi organizacjami nie wywrą negatywnego wpływu na relacje japońsko-chińskie. Już w maju 1996 roku pojawił się pierwszy problem związany z pamięcią historyczną. Wdowa po Mikim Takeo, Miki Mutsuko, zrezygnowała z działalności w organizacji zajmującej się odszkodowaniami dla „kobiet pocieszycielek”, ponieważ Hashimoto okazał bierną postawę wobec planów rozesłania wszystkim kobietom poszkodowanym $\mathrm{w}$ tym procederze listu $\mathrm{z}$ przeprosinami. Sprawa uzyskała jednak taki rozgłos, że pod wpływem krytyki mediów premier zgodził się na ten symboliczny gest ${ }^{92}$. Wkrótce potem, pod koniec lipca 1996 roku, Hashimoto Ryūtarō, jako pierwszy urzędujący premier od 1985 roku, złożył wizytę w świątyni Yasukuni. Nie było to dziwne, biorąc pod uwagę jego powiązania z Nihon Izokukai. Podobnie jak 11 lat wcześniej, wizyta w Yasukuni spotkała się z protestami w Chinach ${ }^{93}$. Hashimoto tłumaczył, że odwiedził kontrowersyjną świątynię z powodu przysięgi złożonej jako dziecko w czasie wojny wujowi oraz nauczycielowi ze szkoły podstawowej ${ }^{94}$.

W 1996 roku powrócił także zawieszony w latach 70. XX wieku spór o zwierzchność terytorialną nad bezludnymi wyspami Senkaku/Diaoyutai. W lipcu 1996 roku działacze jednej ze skrajnie prawicowych grup japońskich zbudowali na archipelagu małą latarnię morską i złożyli podanie do Morskiej Agencji

\footnotetext{
${ }^{90}$ Chōtōha giindan ga Taiwan hairi. Ri sōtō kei no shukufuku no i tsutaeru, „Yomiuri Shinbun” z 20 V 1996, s. 2.

${ }^{91}$ Matsurigoto. Dai 7 bu..., s. 1.

${ }^{92}$ W 1995 roku władze Japonii ustanowiły Narodową Fundację Pokoju Azjatyckiego na Rzecz Kobiet (Josei no tame no Ajia Heiwa Kokumin Kikin), która miała zająć się zbieraniem funduszy od osób prywatnych i instytucji, jak też rozdzielaniem odszkodowań dla „,kobiet pocieszycielek” z Tajwanu, Korei Południowej, Indonezji, Filipin i Holandii. Władze ChRL nie przystąpiły do tego programu, podkreślając, że zrzekły się wszelkich reparacji wojennych od Japonii w 1972 roku. Szerzej na ten temat: Ōnuma Yasuaki, op.cit., s. 18-37.

${ }^{93}$ Edo Yūsuke, Senkaku shotō. Dō suru Nihon, Kōyū Shuppan, Tokio 2005, s. 60.

${ }^{94}$ Hashimoto wspomina, że gdy odprowadził powołanego do wojska nauczyciela na dworzec kolejowy, usłyszał od niego: „Z pewnością powrócę do świątyni Yasukuni, więc proszę cię Ryūtarō, przyjdź”. Szerzej na ten temat: Sugiyama Toshiyuki, Tsuitō - Hashimoto Ryūtarō-shi (moto shushō). Nitchū no kakehashi wa mikan, „Nikkei Business” z 10 VII 2006, s. 13.
} 
Obrony Japonii o jej oficjalną rejestrację ${ }^{95}$. Wywołało to falę protestów wśród społeczności chińskiej w ChRL i na Tajwanie. Pod koniec września 1996 roku doszło do wyprawy na sporne wyspy działaczy z Tajwanu ${ }^{96}$ i Hongkongu, w czasie której utonął jeden z jej uczestników. Incydent wywołał dalszą eskalację antyjapońskich nastrojów wśród Chińczyków na całym świecie ${ }^{97}$. Władze w Tokio konsekwentnie unikały oceny działań podjętych przez japońskie prawicowe ugrupowanie, podkreślając jednocześnie, że nie ma powodu do negocjacji w sprawie zwierzchności nad archipelagiem. Na dodatek, pod koniec września 1996 roku PLD zawarła w swoim programie przed nadchodzącymi wyborami parlamentarnymi obietnicę kontynuacji oficjalnych wizyt w Yasukuni oraz obrony zwierzchności nad wyspami Senkaku/Diaoyutai. Był to sposób na pozyskanie głosów członków Nihon Izokukai i innych prawicowych organizacji ${ }^{98}$.

Tymczasem minister spraw zagranicznych Ikeda Yukihiko (adoptowany zięć premiera Ikedy Hayato) z umiarkowanej frakcji Miyazawy działał na rzecz wyciszenia kryzysu. Pod koniec września 1996 roku oświadczył, iż władze w Tokio nie planują oficjalnej rejestracji kontrowersyjnej latarni ${ }^{99}$. Chociaż strona japońska odmówiła demontażu latarni, napięcie zaczęło powoli opadać. W dużym stopniu przyczyniła się do tego elastyczność ideologiczna Hashimoto Ryūtarō, który przekazał stronie chińskiej, że nie zamierza dotrzymać złożonej przez PLD obietnicy kontynuacji oficjalnych wizyt w Yasukuni. Rzeczywiście, pomimo protestów prawego skrzydła partii, premier nie odwiedził kontrowersyjnej świątyni w trakcie obrzędów jesiennych w październiku 1996 roku, chociaż wypadały one tuż przed wyborami do Izby Reprezentantów ${ }^{100}$. W listopadzie 1996 roku Hashimoto Ryūtarō stwierdził w rozmowie z Jiang Zeminem w Manili, iż różnica zdań na temat przynależności wysp Senkaku/ Diaoyutai nie powinna stanowić przeszkody w przyjaznych stosunkach po-

\footnotetext{
${ }^{95} \mathrm{~W}$ sierpniu 1996 roku tajfun zniszczył latarnię, w wyniku czego podanie o jej rejestrację zostało chwilowo wycofane. Prawicowi działacze ponownie udali się na sporny archipelag we wrześniu 1996 roku, aby naprawić obiekt i znowu wystąpić o jego uznanie za oficjalny punkt nawigacyjny. Szerzej na ten temat: Chien-peng Chung, The Diaoyu/Tiaoyutai/Senkaku Islands Dispute: Domestic Politics and the Limits of Diplomacy, „American Asian Review” 1998, vol. 16, no. 3, s. 143.

${ }^{96}$ Tajwańskie ugrupowania opozycyjne wykorzystały spór o wyspy Senkaku/Diaoyutai w celu krytyki rządu Guomindangu, który według nich nie potrafił zadbać o interesy narodu chińskiego. Szerzej na ten temat: Phil Deans, Contending Nationalisms and the Diaoyutai/Senkaku Dispute, „Security Dialogue” 2000, vol. 31, no. 1, s. 126-128.

${ }^{97}$ Peter Hays Gries, op.cit., s. 122; Robert Jakimowicz, Chińsko-japoński spór o Wyspy Senkaku [w:] Wspótczesna Japonia - mocarstwo na rozdrożu pod red. Elżbiety Potockiej i Małgorzaty Pietrasiak, Wydawnictwo Uniwersytetu Łódzkiego, Łódź 2004, s. 120-122.

${ }^{98}$ Edo Yūsuke, op.cit., s. 61-63.

${ }^{99}$ Erica Strecker Downs, Phillip C. Saunders, Legitimacy and the Limits of Nationalism. China and the Diaoyu Islands, „International Security” 1998/1999, vol. 23, no. 3, s. 135-136.

${ }^{100}$ Edo Yūsuke, op.cit., s. 61-85.
} 
między Japonią a ChRL. Podkreślił również, że Japonia nie wspiera działań zmierzających do ustanowienia „dwóch Chin” czy niepodległego Tajwanu. Obaj politycy zgodzili się, iż należy usilnie pracować nad poprawą relacji bilateralnych. Premier zaprosił także Jianga do Japonii ${ }^{101}$. Jak widać, podobnie jak Nakasone, Hashimoto nie chciał dopuścić, by jego osobiste prawicowe przekonania wpłynęły negatywnie na relacje z ChRL.

Tymczasem nagły wzrost napięcia w stosunkach japońsko-chińskich w 1996 roku zaniepokoił stronnictwo propekińskie w PLD. Toida Saburō z frakcji Obuchiego z żalem przyznawał, że z powodu antychińskich nastrojów wśród społeczeństwa nawet politycy z Parlamentarnej Ligi Przyjaźni JapońskoChińskiej nie mieli ochoty na aktywną działalność ${ }^{102}$. Były jednak wyjątki. W połowie 1996 roku Chiny odwiedził Gotōda Masaharu, jeden z ostatnich przedstawicieli ,starej gwardii” z dawnej frakcji Tanaki, od lat 70. XX wieku aktywnie zaangażowanych w umacnianie przyjaźni z ChRL. Gotōda obawiał się wyraźnego wzrostu antychińskich nastrojów, szczególnie wśród młodszych polityków $\mathrm{PLD}^{103}$. W grudniu 1996 roku podkreślał na specjalnym spotkaniu dyskusyjnym na temat stosunków z Chinami, iż bez przyjacielskich relacji z ChRL Japonia nie jest w stanie zrealizować swoich interesów narodowych, ani zapewnić sobie bezpieczeństwa. Apelował także o intensyfikację wymiany kulturowej z Chinami i wzmocnienie wzajemnego zaufania na poziomie przywódców państw przy okazji zbliżających się obchodów 25. rocznicy ustanowienia stosunków dyplomatycznych oraz 20. rocznicy zawarcia Traktatu o pokoju i przyjaźni. Ostrzegł także, by w przyszłości w sprawie wizyt w świątyni Yasukuni brać pod uwagę uczucia narodów azjatyckich ${ }^{104}$. Gotōda był jednak wyjątkiem. Honzawa Jirō podkreśla, że w przeciwieństwie do tajwańskiego lobby, które wzmacniało swe wpływy w partii w drugiej połowie lat 90. XX wieku, dawni politycy propekińscy nie doczekali się równie zdeterminowanych następców ${ }^{105}$.

Ponowne zawieszenie sporu o wyspy Senkaku/Diaoyutai umożliwiło rządowi w Tokio rozważenie zniesienia sankcji nałożonych na ChRL. Jeszcze pod koniec lipca 1996 roku Chiny oficjalnie ogłosiły wstrzymanie dalszych prób nuklearnych. Ostatecznie w grudniu 1996 roku Japonia zadecydowała o przyznaniu ChRL pożyczki w jenach, zaś w lutym 1997 roku wznowiła bezzwrotną pomoc w ramach ODA dla tego państwa ${ }^{106}$.

\footnotetext{
${ }^{101}$ Zhong-Ri guanxi 30 nian..., s. 266-267.

${ }^{102}$ Matsurigoto. Dai 7 bu..., s. 1.

${ }^{103}$ Michael Jonathan Green, op.cit., s. 82.

${ }^{104}$ Zhong-Ri guanxi 30 nian..., s. 267-270.

${ }^{105}$ Honzawa Jirō, Taiwan..., s. 8.

${ }^{106}$ Sekiyama Takashi, op.cit., s. 88.
} 


\section{Kwestia nowych wytycznych sojuszu japońsko-amerykańskiego}

Ledwie rozwiązano jeden spór w kontaktach z ChRL, pojawiło się następne zarzewie konfliktu. Zakończenie zimnej wojny sprawiło, że japońskoamerykański traktat sojuszniczy pod wieloma względami nie przystawał do nowej rzeczywistości. Zniknięcie zagrożenia sowieckiego, destabilizacja sytuacji w regionie Azji Wschodniej i oczekiwanie przejęcia przez Japonię większej odpowiedzialności za utrzymanie światowego pokoju skłoniły obie strony do wypracowania nowych wytycznych sojuszu. O ile od lat 70. XX wieku władze w Pekinie akceptowały sojusz japońsko-amerykański jako pakt wymierzony w Związek Radziecki, o tyle w latach 90. XX wieku wyglądało na to, że to raczej szybko rozwijające się Chiny stają się globalnym rywalem Stanów Zjednoczonych. Podobnie jak kwestia „klauzuli dalekowschodniej” w 1960 roku, zmiana wytycznych sojuszu spotkała się z dużym zaniepokojeniem ze strony chińskiej.

Tymczasem obóz protajwański w PLD znacząco nasilił swoją działalność. W lutym 1997 roku Parlamentarne Zgromadzenie Stosunków JapońskoTajwańskich połączyło się z ligami parlamentarnymi innych partii konserwatywnych, promującymi kontakty $\mathrm{z}$ władzami w Tajpej, tworząc Parlamentarne Zgromadzenie Japońsko-Tajwańskie (Nikka Giin Kondankai). Jego przewodniczącym został Yamanaka Sadanori z frakcji Watanabe, zaś wiceprzewodniczącymi m.in. Hiranuma Takeo i Murakami Masakuni. Zgromadzenie liczyło około 300 członków ${ }^{107}$. W kwietniu 1997 roku połączyły się również ligi parlamentarne promujące wizyty w świątyni Yasukuni, ponownie tworząc zjednoczone Zgromadzenie Parlamentarzystów Odwiedzających Razem Świątynię Yasukuni. Skupiało ono około 180 parlamentarzystów z PLD, w tym wielu członków obozu protajwańskiego, zaś przewodniczącym został Obuchi Keizōos. Honzawa Jirō podkreśla, że wielu członków obozu protajwańskiego po prostu odziedziczyło powiązania $\mathrm{z}$ władzami w Tajpej po swoich ojcach bądź dziadkach, którzy byli niegdyś szefami frakcji w PLD. Można tu wymienić takich polityków w drugim lub trzecim pokoleniu, jak Satō Shinji (syn Satō Eisaku), Nakagawa Shōichi (syn Nakagawy Ichirō), Shiina Motoo (syn Shiiny Etsusaburō), Abe Shinzō (syn Abe Shintarō, wnuk Kishiego Nobusuke) czy Funada Hajime (wnuk Funady Naki) ${ }^{109}$.

W maju 1997 roku sekretarz generalny Izby Radców PLD, Murakami Masakuni, odwiedził Tajpej, gdzie za zasługi w krzewieniu stosunków bilateralnych otrzymał wysokie odznaczenie państwowe z rąk prezydenta Li

\footnotetext{
${ }^{107}$ Chōtōha no Nikka Giin Kon ga hossoku, „Yomiuri Shinbun” z 6 II 1997, s. 3; Gong Qian, Riben zhengjie de qin-Tai shili jiqi dui-Zhong-Ri guanxi de yingxiang, ,Riben Yanjiu” 2004, $\mathrm{nr} 4$, s. 69.

108 Ji-Shin giin, renkei. Yasukuni Jinja kyō shūdan sanpai. Han "ho-ho" ha wa keikaikan, „Yomiuri Shinbun” z 22 IV 1997, s. 5.

${ }^{109}$ Honzawa Jirō, Taiwan..., s. 149-150.
} 
Denghuia $^{110}$. Z kolei w lutym 1998 roku chińskie media skrytykowały wizytę na Tajwanie Kajiyamy Seiroku ${ }^{111}$. Według Honzawy Jirō innym przejawem działalności obozu protajwańskiego było umożliwianie Republice Chińskiej szeroko zakrojonych inwestycji na Okinawie oraz zabieganie o pozostawienie na tej położonej blisko Tajwanu wyspie baz amerykańskich. W działania te zaangażowani byli Yamanaka Sadanori i Kajiyama Seiroku ${ }^{112}$. Umocniony obóz protajwański miał odegrać istotną rolę $\mathrm{W}$ procesie ustanowienia nowych wytycznych sojuszu z USA.

Japonia po raz pierwszy użyła będącego później przedmiotem kontrowersji sformułowania „regiony wokół Japonii” w ogłoszonych jeszcze w listopadzie 1995 roku założeniach obronnych kraju. Z kolei w kwietniu 1996 roku Hashimoto Ryūtarō ogłosił razem z prezydentem USA Williamem Clintonem wspólną deklarację, w której zapowiedziano rewizję dyrektyw sojuszu z 1978 roku ${ }^{113}$. Ponieważ do zdarzenia tego doszło bezpośrednio po chińskim szantażu rakietowym wobec Tajwanu, władze w Pekinie od razu oskarżyły Japonię o kierowanie ostrza sojuszu przeciwko ChRL. W tekście nowych wytycznych miano zawrzeć m.in. plany współpracy w razie ,sytuacji na obszarach otaczających Japonię, które mają istotny wpływ na pokój i bezpieczeństwo Japonii"114. Stwierdzenie ,sytuacje na obszarach otaczających Japonię" (Nihon shūhen chiiki ni okeru jitai, w skrócie shūhen jitai) budziło najwięcej kontrowersji. Rząd w Pekinie był zaniepokojony, że to niejasne sformułowanie mogłoby obejmować również sytuacje kryzysowe w Cieśninie Tajwańskiej. Według Honzawy Jirō, dyskurs o nowych wytycznych sojuszu japońskoamerykańskiego stworzył wręcz wrażenie, że świadomość strony japońskiej na temat sprawy chińskiej cofnęła się do stanu z 1969 roku, gdy premier Satō przyznał $\mathrm{w}$ rozmowie $\mathrm{z}$ prezydentem USA Richardem Nixonem, że bezpieczeństwo Tajwanu jest niezwykle ważne dla bezpieczeństwa Japonii ${ }^{115}$.

Spór o interpretację geograficznego zasięgu „obszarów otaczających Japonię” pojawił się w samej PLD. Sekretarz generalny partii, Katō Kōichi, w trakcie wizyty w Chinach w lipcu 1997 roku miał stwierdzić, że termin ten w szczególności odnosi się do Półwyspu Koreańskiego, a nie do Tajwanu. Kiedy jednak po powrocie do kraju został skrytykowany przez reprezentantów prawego skrzydła PLD, zaprzeczył, by złożył stronie chińskiej jasną deklarację na temat

${ }^{110}$ San'in Jimintō no Murakami kanjichō asu hōtai, „Yomiuri Shinbun” z 15 V 1997, s. 5.

${ }^{111}$ Kajiyama zen-kanbōchōkan no hōtai o Chūgokushi ga hihan, „Yomiuri Shinbun” z 12 II 1998, s. 2.

${ }^{112}$ Honzawa Jirō, Taiwan..., s. 45-50.

${ }^{113}$ Noda Mineo, Shühen jitai. Nichibei „shin gaidorain” no kyojitsu, Daisan Shokan, Tokio 1998, s. 11.

${ }^{114}$ Nichibei shin gaidorain to shūhen jitai hō pod red. Yamauchiego Toshihiro, Hōritsu Bunkasha, Tokio 2000, s. 324.

${ }^{115}$ Honzawa Jirō, Taiwan..., s. 18. 
wytycznych sojuszu ${ }^{116}$. Również dziś Katō Kōichi twierdzi, że cały czas próbował uczynić kwestię zawarcia Tajwanu w „obszarach otaczających Japonię" dwuznaczną ${ }^{117}$. Nie da się jednak ukryć, iż w PLD doszło do wyraźnej konfrontacji między dwoma obozami. Spór pomiędzy zwolennikami koalicji z umiarkowanymi partiami (socjaldemokratami i Nową Partią Zwiastun) a promotorami sojuszu z prawicowymi ugrupowaniami wywodzącymi się z PLD ciągnął się praktycznie od chwili powołania rządu Murayamy w 1994 roku. Katō pragnął utrzymania koalicji z socjaldemokratami, którzy domagali się wyraźnego wykluczenia Tajwanu $\mathrm{z}$ nowych wytycznych sojuszu. Zresztą sam był politykiem propekińskim i starał się poprzez ustępstwo wobec ChRL doprowadzić do wygaszenia sporu $\mathrm{w}$ relacjach $\mathrm{z}$ władzami w Pekinie przed planowaną na wrzesień 1997 roku wizytą premiera Hashimoto w Chinach. Głównymi sojusznikami Katō byli przewodniczący Rady Badań Politycznych PLD Yamasaki Taku z frakcji Watanabe oraz Nonaka Hiromu z frakcji Obuchiego $^{118}$.

$\mathrm{Na}$ czele przeciwnego obozu stanął sekretarz gabinetu Kajiyama Seiroku z frakcji Obuchiego, od dawna znany z sympatii protajwańskich. Wspierał go m.in. Kamei Shizuka z frakcji Mitsuzuki, a także były premier Nakasone Yasuhiro. Chociaż Nakasone był politykiem propekińskim, od lat dążył do zwiększenia roli Japonii w utrzymaniu bezpieczeństwa w regionie i nie chciał nakładać na nowe wytyczne sojuszu z USA żadnych ograniczeń. Prawe skrzydło PLD pragnęło na dobre odejść od koalicji $\mathrm{z}$ socjaldemokratami i wejść w porozumienie z inną partią konserwatywną, Nową Partią Postępu (Shinshintōo ${ }^{119}$. Obrona Tajwanu mogła być użytecznym środkiem demonstracji różnic programowych z lewicą i stać się spoiwem nowej prawicowej koalicji ${ }^{120}$. Zarówno Kajiyama, jak i przewodniczący Nowej Partii Postępu, Ozawa Ichirō, wywodzili się z dawnej frakcji Takeshity. Honzawa Jirō podkreśla, że na początku lat 90. XX wieku obaj byli, obok Kanemaru Shina, politykami o protajwańskich przekonaniach w tej tradycyjnie propekińskiej frakcji ${ }^{121}$.

Na przełomie lipca i sierpnia 1997 roku doszło do starcia obu obozów na posiedzeniu Rady Koalicyjnej ds. Problemu Wytycznych (Yotō Gaidorain Mondai Kyōgikai). Ostatecznie przewodniczący Rady Badań Politycznych PLD Yamasaki Taku wyraził kompromisowe stanowisko. Powiedział, iż nie uważa, by na Tajwanie doszło do zdarzeń odpowiadających nowym dyrektywom

116 „Shūhen jitai” de yotō kyōgi. Katō Jimintō kanjichō ga hōshin teigi, kenkai matomeru, „Yomiuri Shinbun” z 30 VII 1997, s. 5.

${ }^{117}$ Wywiad autora z Katō Kōichim...

${ }^{118}$ Shimizu Masato, Kantei shudō, Nihon Keizai Shinbunsha, Tokio 2005, s. 63-87.

${ }^{119}$ Yang Kiho, Ilbon-ui seongeo-wa jeongdang [w:] Ilbon jeongchi-ui ihae pod red. Hanguk Ilbon Hakhoe, Sisa Ilboneosa, Seul 1998, s. 95-96.

${ }^{120}$ Nichibei bōei hōshin „shūhen” chūtai atsukai ga hidane. Hohoha to Jishasaha ga tairitsu, „Yomiuri Shinbun” z 7 VIII 1997, s. 5.

${ }^{121}$ Honzawa Jirō, Taiwan..., s. 22. 
sojuszu, jednak terminu „obszary otaczające Japonię” nie da się jasno zdefiniować pod względem geograficznym ${ }^{122}$.

Oba obozy starały się zadbać, by zbliżająca się wizyta premiera Hashimoto w Pekinie przebiegła po ich myśli. Na początku sierpnia 1997 roku jeden z przywódców obozu protajwańskiego w PLD, Hiranuma Takeo, spotkał się z Kajiyamą Seiroku. Ostrzegł go, iż trzeba zwrócić szczególną uwagę, by w czasie wizyty władze KPCh nie wymogły na premierze deklaracji, że nowe wytyczne nie obejmują Tajwanu ${ }^{123}$. Kajiyama zrobił znacznie więcej, wyraźnie oświadczając w połowie sierpnia 1997 roku, że także Tajwan jest zawarty w terminie „obszary otaczające Japonię" ${ }^{124}$. Jego wypowiedź wywołała zdecydowany protest władz w Pekinie, w tym premiera Li Penga.

Protajwańska postawa Kajiyamy, jednego z najważniejszych członków frakcji Obuchiego, pokazała jak bardzo zmieniła się dawna frakcja-hegemon, która niegdyś stała na straży „propekińskiego konsensusu”. Kajiyama Seiroku nie należał jednak do najbardziej radykalnych prawicowych polityków w PLD. Jego protajwańska postawa $\mathrm{w}$ dużym stopniu wynikała $\mathrm{z}$ racjonalnej oceny sytuacji pozimnowojennej. Podkreślał, że o ile jeszcze w latach 80. XX wieku Chiny zgadzały się na obecność amerykańskiego wojska w Japonii, gdyż służyło ono powstrzymaniu remilitaryzacji Japonii, ostatnio znacząco rozwinęły się gospodarczo i zaczęły aspirować do roli mocarstwa światowego. ChRL poczuła się na tyle silna, by negować sojusz japońsko-amerykański. Według Kajiyamy Japonia nie powinna ulegać presji z zagranicy, tylko oprzeć swoją dyplomację na wyraźnych zasadach ${ }^{125}$. Swoje stanowisko w sprawie wytycznych tłumaczył następująco: „W żadnym razie nie uznaję «dwóch Chin» i wiem, że problem Tajwanu jest sprawą do rozwiązania poprzez negocjacje pomiędzy obiema stronami chińskimi, jednakże dopóki Chiny nie zrezygnują z alternatywy wojskowego wyzwolenia Tajwanu, Japonia za nic nie może wysłać wiadomości: «proszę bardzo, zróbcie to». Ileż było przypadków, że błędna wiadomość spowodowała konflikt, którego, gdy się później pomyśli, można było uniknąć" 126 .

W przeciwieństwie do członków obozu propekińskiego czy protajwańskiego, Hashimoto Ryūtarō trzymał się kompromisowego stanowiska wypracowanego przez Yamasakiego Taku. W trakcie wizyty premiera Japonii w Pekinie na początku września 1997 roku, premier Li Peng powtórzył żądanie jasnego wykluczenia Tajwanu z ,sytuacji na obszarach otaczających Japonię”. Hashi-

\footnotetext{
${ }^{122}$ Nichibei bōei hōshin..., s. 5.

${ }^{123}$ Nichibei bōei gaidorain minaoshi. Hiranuma-shi shūhen yūji de yōsei, „Yomiuri Shinbun” z 1 VIII 1997, s. 5.

${ }^{124}$ Taiwan Kaikyō mo „shūhen yūji” no han'i-nai. Kajiyama kanbōchōkan ga kenkai, „Yomiuri Shinbun" z 18 VIII 1997, s. 2.

${ }^{125}$ Kajiyama Seiroku, Hakai to sōzō - Nihon saikō e no teigen, Kōdansha, Tokio 2000, s. 203-208.

${ }^{126}$ Ibidem, s. 259.
} 
moto nie zmienił jednak zdania w tej sprawie, powtarzając, że termin ten nie ma znaczenia geograficznego. Szef japońskiego rządu przyznał, że z powodu różnic historycznych i ustrojowych w stosunkach japońsko-chińskich może dochodzić do sporów, ale wyraził też nadzieję, iż uda się wzmocnić wzajemne zaufanie pomiędzy oboma narodami. Dowodem na stopniowe polepszanie się relacji bilateralnych były wizyty w Japonii premiera Li Penga w listopadzie 1997 roku oraz wiceprzewodniczącego ChRL Hu Jintao w kwietniu 1998 roku $^{127}$.

Tymczasem pomimo różnic zdań zarówno wewnątrz PLD, jak wśród partii koalicyjnych, pod koniec września 1997 roku w Nowym Jorku ostatecznie przyjęto nowe wytyczne bez dodatkowych wyjaśnień na temat statusu Tajwanu. $\mathrm{Na}$ początku października 1997 roku premier Hashimoto tłumaczył na posiedzeniu Izby Radców: „Sytuacje w okolicznych obszarach nie są koncepcją geograficzną. Termin ten zwraca uwagę na naturę sytuacji. Przy osądzie, czy odnosi się on do danej sytuacji, należy wziąć pod uwagę całość takich czynników, jak jej uwarunkowania czy skala. Wobec tego trudno jest geograficznie wyznaczyć region, w którym może dojść do [tak zdefiniowanych - przyp. aut.] sytuacji w okolicznych obszarach. Co do problemu Tajwanu, po raz kolejny podkreślam, że nasz kraj ma głęboką nadzieję, iż dojdzie do jego pokojowego rozwiązania przez strony sporu" ${ }^{28}$.

Kiedy we wrześniu 1997 roku Hashimoto Ryūtarō został wybrany na następną kadencję jako szef partii, wydawało się, że ma szansę na dłuższe rządy. Zwycięstwo PLD w wyborach do Izby Reprezentantów w październiku 1996 roku zdawało się świadczyć o odbudowie hegemonicznej pozycji tej partii. Jednakże już w lipcu 1998 roku PLD poniosła dotkliwą porażkę w wyborach do Izby Radców i premier Hashimoto musiał podać się do dymisji.

$$
\text { * * * }
$$

Trudno jest jednoznacznie ocenić kadencję Hashimoto Ryūtarō. Był to polityk o silnych związkach ze skrajnie prawicowymi organizacjami, ale obawy związane $\mathrm{z}$ jego postawą wobec problemów historycznych nie sprawdziły się w pełni. W 1996 roku premier odwiedził świątynię Yasukuni, jednak zrezygnował z wizyt w następnych latach swojego urzędowania. Więcej problemów wynikło z czynników pozapartyjnych, które wpłynęły na pogorszenie się relacji japońskochińskich w 1996 roku (dyplomacja rakietowa ChRL wobec Tajwanu, spór o wyspy Senkaku/Diaoyutai). Chociaż Hashimoto daleko było do pojednawczej postawy Kōno Yōheia wobec Chin, nie należał też do obozu najbardziej radykalnych ,jastrzębi”. Nie przystał ani na wyraźne wykluczenie, ani włączenie Tajwanu w zakres terminu ,sytuacje na obszarach otaczających Japonię" z nowych wytycznych sojuszu z USA. Kadencja Hashimoto pokazała jednak, że

\footnotetext{
${ }^{127}$ Zhong-Ri guanxi 30 nian..., s. 273-278.

${ }^{128}$ Posiedzenie plenarne Izby Radców (Sangiin honkaigi) z 3 X 1997 roku, nr 3, Archiwum Obrad...
} 
wpływy obozu protajwańskiego uległy wzmocnieniu, podczas gdy tradycyjne stronnictwo propekińskie było już tylko cieniem dawnej potęgi z lat 80 . XX wieku.

\section{OBUCHI KEIZŌ (1998-2000)}

Kadencja Obuchiego Keizō przypadła na okres względnego polepszenia relacji japońsko-chińskich, zapoczątkowany jeszcze pod koniec rządów Hashimoto Ryūtarō. Jako że nowy premier pochodził z tej samej frakcji co poprzednik, polityka Japonii wobec Chin nie uległa większym zmianom. Protajwańskie sympatie Obuchiego oraz konieczność utrzymania równowagi w partii między jej prawym i lewym skrzydłem stanowiły jednak istotne ograniczenia polityki PLD wobec Chin.

\section{Wewnątrzpartyjne uwarunkowania polityki Obuchiego Keizō wobec Chin}

Po dymisji Hashimoto Ryūtarō frakcja Obuchiego zdecydowała się wystawić swojego lidera jako kandydata $\mathrm{w}$ wyborach na przewodniczącego partii. W lipcu 1998 roku Obuchi Keizō pokonał Koizumiego Jun'ichirō oraz Kajiyamę Seiroku, zostając kolejnym premierem Japonii. Przy okazji tych wyborów potwierdziło się, że solidarność członków frakcji uległa daleko idącemu osłabieniu. Kajiyama rzucił wyzwanie swojemu frakcyjnemu koledze, uzyskując dobry wynik, zaś na Koizumiego nie zagłosowali nawet wszyscy członkowie frakcji Mitsuzuki, do której należał.

W 1998 roku nastąpiły duże przetasowania w systemie frakcyjnym wewnątrz PLD. We wrześniu 1998 roku frakcję Mitsuzuki opuściła grupa Kameia Shizuki, niezadowolonego z wystawienia Koizumiego Jun'ichirō jako kandydata frakcji na szefa partii. Kamei założył nową frakcję, którą nazwał Towarzystwem Podstawowych Problemów Państwa, tak samo jak skrajnie prawicową grupe polityczną, której przewodził w drugiej połowie lat 80. XX wieku. Przywództwo nad większością frakcji Mitsuzuki przejął Mori Yoshirō. Jednocześnie frakcję zmarłego jeszcze w 1995 roku Watanabe Michio opuściła grupa Yamasakiego Taku. Jedynie część posłów pozostała wierna swojemu poprzedniemu oyabunowi, Nakasone Yasuhiro, który w grudniu 1998 roku powierzył fotel przewodniczącego Murakamiemu Masakuniemu ${ }^{129}$. W tym samym miesiącu przywództwo we frakcji Miyazawy przejął Katō Kōichi, jednak grupę opuścili politycy związani z Kōno Yōheiem. Nowa frakcja Kōno stanowiła mozaikę polityków „głównego” i „bocznego nurtu konserwatywnego”, jak też mieszankę reprezentantów różnych stronnictw ideologicznych. Mimo że sam Kōno Yōhei był „gołębiem” i politykiem propekińskim, w jego grupie znalazło się wielu protajwańskich ,jastrzębi”, jak Etō Seishirō, Kamei Hisaoki czy wnuk Yoshidy

\footnotetext{
${ }^{129}$ Murakami Masakuni, Hirano Sadao, Fudesaka Hideyo, Sangiin nanka iranai, Gentōsha, Tokio 2007, s. 108-112.
} 
Shigeru, Asō Tarō. Ponieważ jednak Kōno nie zamierzał rezygnować ze swoich propekińskich poglądów, szeregi jego frakcji stopniowo topniały.

Tabela 5.3 Rozkład sił pomiędzy frakcjami PLD oraz partie koalicyjne w okresie rządów Obuchiego Keizō w latach 1998-2000.

\begin{tabular}{|l|l|}
\hline \multicolumn{1}{|c|}{ Cechy i liczebność frakcji PLD } & \multicolumn{1}{c|}{ Partie koalicyjne (od 1999) } \\
\hline Obuchi (L) 95 & Partia Liberalna (J) 41 \\
Mori (D, J, T) 65 & Kōmeitō (G, P) 53 \\
Katō (L, G, P) 69 & \\
Murakami (D, J, T) 39 & \\
Yamasaki (D, J) 30 & \\
Kamei (D, J, T) 23 & \\
Kōmoto (D, G, P) 17 & \\
Kōno 17 & \\
Bezfrakcyjni 18 & \\
\hline 373 & 75 \\
\hline
\end{tabular}

L- dawni członkowie Partii Liberalnej, główny nurt konserwatywny, D- dawni członkowie Partii Demokratycznej, boczny nurt konserwatywny, G- gołębie, J- jastrzębie, P- obóz propekiński, Tobóz protajwański.

Liczebność frakcji (podana przy poszczególnych frakcjach) po wyborach do Izby Radców z lipca 1998 roku. Liczebność partii koalicyjnych w 2000 roku. Uwzględniono członków frakcji z obu izb parlamentu. Liczebność Partii Liberalnej podano w przybliżeniu.

Opracowanie własne na podstawie: Tsuchiya Shigeru, op.cit., s. 108-180; Fukunaga Fumio, Habatsu..., s. 80; Hoshi Hiroshi, op.cit., s. 176-181.

Po porażce w wyborach do Izby Radców w lipcu 1998 roku PLD musiała znaleźć partnera koalicyjnego, aby zapewnić sobie możliwość uchwalania nowych ustaw. Tuż przed wyborami koalicję ostatecznie opuścili socjaldemokraci i Nowa Partia Zwiastun. Pomimo dawnych animozji, PLD zawarła pod koniec 1998 roku porozumienie z Ozawą Ichirō, ówczesnym przewodniczącym Partii Liberalnej (Jiyūtō), na mocy którego przystąpiła ona do koalicji w styczniu 1999 roku. W połowie 1999 roku Ozawa zaprosił do wejścia do koalicji także Kōmeitō, partię będącą polityczną przybudówką buddyjskiej sekty Sōka Gakkai. Ostatecznie Kōmeitō dołączyła do koalicji w październiku 1999 roku ${ }^{130}$. Partia Liberalna skupiała zarówno polityków propekińskich, jak protajwańskich, a także wielu ,jastrzębi”, głównie dawnych członków PLD. Z kolei Kōmeitō była ugrupowaniem pacyfistycznym $\mathrm{i}$ od dawna miała silne powiązania $\mathrm{z}$ władzami w Pekinie. Z drugiej strony, Honzawa Jirō podkreśla, że w latach 90. XX wieku część członków Kōmeitō w wyniku współpracy z Ozawą Ichirō

\footnotetext{
${ }^{130}$ Partia Liberalna powstała w styczniu 1998 roku, skupiając część polityków konserwatywnych z Nowej Partii Postępu, która uległa rozpadowi w 1997 roku. Nonaka Hiromu przyznaje, że PLD pragnęła przede wszystkim zawiązać koalicję z Kōmeitō, ale sojusz z tą buddyjską partią byłby bardzo źle przyjęty przez wyborców. Wobec tego postanowiono wejść w porozumienie z Kōmeitō pośrednio, poprzez koalicję z Partią Liberalną Ozawy. Szerzej na ten temat: Nonaka Hiromu, Rōhei wa shinazu. Nonaka Hiromu zenkaikoroku, Bungei Shunjū, Tokio 2005, s. 81-83.
} 
nawiązała także kontakty $\mathrm{z}$ władzami $\mathrm{w}$ Tajpej. Tendencja ta uległa jednak osłabieniu po rozpadzie Nowej Partii Postępu ${ }^{131}$. Chociaż wewnątrz PLD Obuchiego wspierało wielu umiarkowanych polityków, nowy premier musiał także liczyć się ze zdaniem prawego skrzydła, aby nie doprowadzić do następnego rozłamu w partii.

Podobnie jak Hashimoto Ryūtarō, Obuchi Keizō nie należał do polityków najbardziej radykalnych pod względem ideologii w PLD. Z jednej strony miał prawicowe poglądy, o czym świadczy choćby fakt, że przejął po Hashimoto Ryūtarō funkcję przewodniczącego Zgromadzenia Parlamentarzystów Odwiedzających Razem Świątynię Yasukuni, z drugiej zaś, podobnie do poprzednich przewodniczących potężnej dawnej frakcji Satō, był osobą stosunkowo elastyczną ideologicznie. Od Hashimoto różnił się jednak pod jednym względem, miał silniejsze powiązania z Tajwanem. Kiedy w 1967 roku Wydział Młodzieżowy PLD (Jimintō Seinenkyoku) rozpoczynał współpracę z młodzieżówką Guomindangu, Obuchi Keizō, wówczas mało doświadczony członek protajwańskiej frakcji Satō, został przewodniczącym Młodzieżowego Stowarzyszenia Przyjaźni Japońsko-Tajwańskiej (Nikka Seinen Shinzen Kyōkai). Dzięki podróżom na Tajwan Obuchi nawiązał bliskie kontakty z parlamentarzystami Guomindangu $^{132}$. W latach 90. XX wieku już jawnie spotykał się z wysokimi urzędnikami reprezentującymi władze w Tajpej.

\section{0. rocznica podpisania Traktatu o pokoju i przyjaźni z ChRL}

Jednym z pierwszych zadań nowego rządu było przygotowanie obchodów 20. rocznicy podpisania Traktatu o pokoju i przyjaźni z ChRL. Planowana wizyta przewodniczącego Jiang Zemina w Japonii miała stać się okazją do potwierdzenia wzajemnej przyjaźni i ostatecznego zatarcia złego wrażenia po kryzysie 1996 roku. Kiedy jednak pod koniec listopada 1998 roku Jiang przyjechał do Tokio, nie uzyskał od premiera Japonii żadnych ustępstw w kwestii Tajwanu. Chociaż nawet prezydent USA William Clinton przystał wcześniej na tzw. „trzy nie" ${ }^{133}$ w tej sprawie, Obuchi zgodził się tylko na jedno „nie” - nie wspierać niepodległości Tajwanu ${ }^{134}$. Fakt, że Chiny otrzymały od Japonii mniej niż od innych państw wskazywał, jak bardzo zmienił się stan stosunków japońsko-

\footnotetext{
${ }^{131}$ Honzawa Jirō, Taiwan..., s. 154-155.

132 Tamura Shigenobu, Tomashima Norio, Koeda Yoshito, op.cit., s. 19-20; Gong Qian, op.cit., s. 71 .

133 “Trzy nie” to: „1) nie wspierać niepodległości Tajwanu, 2) nie wspierać idei dwóch Chin ani jednych Chin i jednego Tajwanu, 3) nie twierdzić, że Tajwan powinien uczestniczyć w organizacjach międzynarodowych skupiających tylko suwerenne państwa”. Szerzej na ten temat: Tamura Shigenobu, Tomashima Norio, Koeda Yoshito, op.cit., s. 207-208.

${ }^{134}$ Zhong-Ri guanxi 30 nian..., s. 279.
} 
chińskich ${ }^{135}$. Również problem historyczny nie został rozwiązany. Ciągła krytyka przez Jianga braku wyraźnych przeprosin za zbrodnie z czasów II wojny światowej jedynie rozdrażniła stronę japońską. Przewodniczący ChRL spodziewał się, iż otrzyma od premiera Obuchiego przeprosiny na piśmie, podobnie jak prezydent Korei Południowej miesiąc wcześniej. W przygotowanym tekście wspólnej deklaracji Japonia co prawda po raz pierwszy przyznała się na piśmie do agresji, jednak kolejny już raz nie pojawiło się słowo ,przepraszam”. Premier Obuchi zaoferował stronie chińskiej jedynie ustne przeprosiny ${ }^{136}$.

W przeciwieństwie do władz w Seulu, które przed otrzymaniem przeprosin na piśmie obiecały, że nie będą już przywoływać „karty historycznej” w przyszłości, KPCh zdawała się używać antyjapońskiego nacjonalizmu do legitymacji swojej władzy wśród chińskiego społeczeństwa. Prawe skrzydło PLD podkreślało tę różnicę, sprzeciwiając się jakimkolwiek daleko idącym ustępstwom wobec Chin. Poza tym premierowi Obuchiemu Keizō zależało wówczas na zdobyciu poparcia w partii takich ,jastrzębi”, jak Murakami Masakuni i Kamei Shizuka ${ }^{137}$. Wszakże Kamei zaledwie dwa miesiące wcześniej założył nową prawicową frakcję, zaś Murakami od dawna był nazywany „cesarzem Izby Radców” (Sangiin no tennō) ze względu na szerokie wpływy wśród parlamentarzystów PLD z izby wyższej ${ }^{138}$. Cieszący się niskim poparciem społecznym premier Obuchi starał się uniknąć nowych sporów wewnątrz partii i nie antagonizować wobec siebie nacjonalistycznych środowisk, które i tak nie były zadowolone z wcześniejszych przeprosin złożonych Korei Południowej.

Chociaż wizytę Jiang Zemina w Japonii trudno uznać za udaną, obie strony wydały wspólną deklarację - Partnerstwo przyjacielskiej współpracy na rzecz pokoju i rozwoju. Określono również 33 sfery wzajemnej współpracy, mające stanowić nowe ramy wspólnych działań. Jiang Zemin podziękował także za dotychczasową pomoc rozwojową przyznaną Chinom przez Japonię ${ }^{139}$. W stosunkach bilateralnych pozostawało jednak mnóstwo nierozwiązanych problemów. Jednym z nich była kwestia budowy przez Japonię razem z USA tarczy antyrakietowej, która mogłaby objąć także Tajwan. Dla kierownictwa KPCh przedsięwzięcie to potwierdzało jedynie, że ostrze sojuszu japońskoamerykańskiego skierowało się przeciw umacniającym swoją pozycję międzynarodową Chinom $^{140}$. Obuchi Keizō starał się uspokoić stronę chińską, kiedy w

\footnotetext{
${ }^{135}$ Wang Jianwei, Nihon no Ajia seisaku ni tai suru Chūgoku no senryaku [w:] Nihon no Ajia seisaku - Ajia kara mita fushin to kitai pod red. Inoguchiego Takashiego, NTT Shuppan, Tokio 2003, s. 160.

${ }^{136}$ Lam Peng Er, The Apology Issue: Japan's Differing Approaches Toward China and South Korea, „American Asian Review” 2002, vol. 20, no. 3, s. 48-50.

${ }^{137}$ Zhong-Ri guanxi 30 nian..., s. 284.

${ }^{138}$ Murakami Masakuni, Hirano Sadao, Fudesaka Hideyo, Sangiin..., s. 86.

${ }^{139}$ Okada Minoru, op.cit., s. 158.

${ }^{140}$ W październiku 1998 roku Japonia i USA ogłosiły deklarację w sprawie wspólnej budowy systemu obrony antyrakietowej. Bezpośrednią przyczyną było zaniepokojenie władz w Tokio
} 
lipcu 1999 roku odwiedził ChRL. Premier Japonii powtórzył, że Chiny zajmują jedno z najważniejszych miejsc w japońskiej dyplomacji. Ponownie podkreślił, że nie wspiera niepodległości Tajwanu. Oświadczył także, iż władze w Tokio nadal trzymają się uregulowań pacyfistycznej konstytucji, zaś Japonia nie ma zamiaru zostać mocarstwem militarnym ${ }^{141}$.

Tymczasem doszło do istotnych przemian wewnątrz PLD. W marcu 1999 roku frakcje Murakamiego i Kameia połączyły się pod przewodnictwem Murakamiego Masakuniego ${ }^{142}$. Obie grupy dobrze się uzupełniały, gdyż o ile do frakcji Murakamiego należało wielu doświadczonych, starszych polityków, frakcja Kameia składała się głównie z młodszych parlamentarzystów. Wkrótce Murakamiego zastąpił Etō Takami i odtąd mówiono o frakcji Etō/Kameia. Nowa grupa była jedną z największych w partii. Należeli do niej liczni prawicowi i protajwańscy politycy, jak Hiranuma Takeo, Murakami Masakuni czy były członek Seirankai, Etō Takami ${ }^{143}$. Z kolei we wrześniu 1999 roku liderzy dwóch ważnych frakcji, Katō Kōichi i Yamasaki Taku, rzucili wyzwanie premierowi, kandydując w wyborach na stanowisko szefa PLD. Wygrał Obuchi, zaś Katō i Yamasaki utracili wpływy w jego rządzie. Zamiast nich do kręgu ścisłej władzy dostała się frakcja Etō/Kameia ${ }^{144}$, wobec której premier zrobił gest dobrej woli już rok wcześniej, nie zgadzając się na „trzy nie” wobec Tajwanu. Równolegle PLD zawiązała koalicję z nacjonalistyczną Partią Liberalną oraz z Kōmeitō.

Wszystkie te przemiany wywołały duży „skręt w prawo” japońskiej polityki. Dzięki ustanowieniu koalicji z ugrupowaniem Ozawy Ichirō, w maju 1999 roku Obuchiemu udało się w końcu ratyfikować $w$ parlamencie nowe wytyczne sojuszu z USA ${ }^{145}$. Jeszcze jako minister spraw zagranicznych w rządzie Hashimoto, Obuchi Keizō podkreślał, iż „sytuacje na obszarach otaczających Japonię" nie mają znaczenia geograficznego, kontynuując kompromisową interpretację tego terminu. Innym owocem współpracy PLD z prawicową Partią Liberalną i zepchnięcia na boczny tor umiarkowanej frakcji Katō była ustawa o

zagrożeniem ze strony Korei Północnej po próbnym wystrzeleniu przez ten kraj rakiet Taepo-dong w sierpniu 1998 roku. Szerzej na ten temat: Michael Jonathan Green, op.cit., s. 92-93; Kawasaki Jirō, Hitasura anzen ni kaketa jōnetsu, Kawasaki Jirō Shuppan Jikkō Iinkai, Tokio 1999, s. 42-51; Liu Qingcai, Gao Ke et al., Dongbeiya diyuan zhengzhi yu Zhongguo diyuan zhanlüe, Tianjin Renmin Chubanshe, Pekin 2007, s. 185; 21 shiji de Zhong-Ri..., s. 396; Edward Haliżak, Regionalny kompleks bezpieczeństwa Azji Pótnocno-Wschodniej, Wydawnictwo Naukowe Scholar, Warszawa 2004, s. 101-102; Michał Łuszczuk, Stosunki chińsko-japońskie [w:] Chiny w stosunkach międzynarodowych pod red. Krzysztofa Iwańczuka i Agaty Ziętek, Wydawnictwo UMCS, Lublin 2003, s. 174.

${ }^{141}$ Zhong-Ri guanxi 30 nian..., s. 279-280.

${ }^{142}$ Uozumi Akira, op.cit., s. 185-187.

${ }^{143}$ Murakami Masakuni, Hirano Sadao, Fudesaka Hideyo, Sangiin..., s. 112-114.

${ }^{144}$ Tsuchiya Shigeru, op.cit., 229-232.

${ }^{145}$ Zhong-Ri guanxi 30 nian..., s. 374. 
fladze Hi no Maru i hymnie Kimi ga Yo, przegłosowana w sierpniu 1999 roku $^{146}$. Oficjalne zatwierdzenie dawnych imperialnych symboli jako znaków państwowych stanowiło kolejny dowód na wzrost popularności poglądów nacjonalistycznych na japońskiej scenie politycznej ${ }^{147}$. Z kolei w styczniu 2000 roku w obu izbach parlamentu powołano do życia Komisję Badań Konstytucyjnych, która miała przygotować plany rewizji pacyfistycznej ustawy zasadniczej ${ }^{148}$. Wydarzenia te nie sprzyjały atmosferze przyjaźni w relacjach japońskochińskich. Na dodatek w 1999 roku w Japonii została wydana książka pt. Stanowisko Tajwanu autorstwa Li Denghuia. Okazała się ona bestsellerem, zaś nostalgia, z jaką prezydent Tajwanu opisywał swoje nastawienie wobec Japonii, zjednała mu sympatię jeszcze większych rzesz Japończyków ${ }^{149}$. Li Denghui podkreślał, że władze w Tokio powinny mniej bać się reakcji ChRL i działać na rzecz pogłębienia relacji z Tajwanem ${ }^{150}$. Na wezwanie to odpowiedział m.in. Murakami Masakuni, który w listopadzie 1999 roku odwiedził Tajwan, po raz kolejny próbując zaprosić Li Denghuia do Japonii ${ }^{151}$.

Tymczasem na początku kwietnia 2000 roku premier dostał udaru mózgu, wywołanego m.in. przepracowaniem i stresem związanym ze spodziewanym opuszczeniem koalicji rządowej przez Partię Liberalną Ozawy Ichiró ${ }^{152}$. Obuchi zapadł w śpiączkę i zmarł już po wyborze nowego szefa partii, w maju 2000 roku. O przyjazd na pogrzeb tego protajwańskiego polityka zabiegał prezydent Tajwanu Chen Shuibian, jednak strona japońska nie zgodziła się na wydanie wizy żadnemu wysokiemu urzędnikowi Republiki Chińskiej ${ }^{153}$.

\footnotetext{
${ }^{146}$ Obuchi Keizō no 615-nichi pod red. KOK, Kōshinsha, Tokio 2000, s. 212-219; Wang Xiliang, op.cit., s. 143.

${ }^{147}$ Za promocją ustawy stała m.in. prawicowa organizacja Konferencja Japonii (Nippon Kaigi), która powstała w 1997 roku z połączenia Narodowej Rady Obrony Japonii (Nihon o Mamoru Kokumin Kaigi) i Komitetu Obrony Japonii (Nihon o Mamoru Kai), dwóch innych stowarzyszeń zrzeszających prawicowych polityków, przedsiębiorców, intelektualistów czy kapłanów. W Izbie Radców ustawę wspierał Murakami Masakuni. Szerzej na ten temat: Uozumi Akira, op.cit., s. 187197.

${ }^{148}$ Xu Wansheng, op.cit., s. 94

${ }^{149}$ Nagayama Hideki, Nihon no meiun wa Taiwan ni ari. Gunkaku Chūgoku ga aru Higashi Ajia de, Madoka Shuppan, Tokio 2008, s. 10.

${ }^{150}$ Li Denghui, op.cit., s. 166-192.

${ }^{151}$ Li Jianmin, op.cit., s. 329.

152 Ozawa co jakiś czas podawał nowe warunki pozostania Partii Liberalnej w koalicji, np. obniżenie liczby ministerstw. PLD spełniała je, gdyż bez wsparcia Partii Liberalnej koalicja nie miałaby większości mandatów w izbie wyższej. Kiedy jednak na początku 2000 roku Ozawa zażądał, by Obuchi rozwiązał PLD i dokonał fuzji z Partią Liberalną tworząc nowe ugrupowanie, premier nie zamierzał przystać na tę propozycję. Szerzej na ten temat: Nonaka Hiromu, Rōhei..., s. $101-158$.

${ }^{153}$ Nagayama Hideki, op.cit., s. 180.
} 
* * *

Za rządów Obuchiego Keizō nie nastąpił pozytywny przełom w relacjach z ChRL, choć nie doszło także do wzrostu napięcia porównywalnego z kryzysem 1996 roku. Ponieważ Obuchi od dawna utrzymywał bliskie relacje z politykami Guomindangu, a także starał się nie antagonizować prawego skrzydła PLD, w trakcie wizyty Jiang Zemina w Japonii w 1998 roku nie zgodził się ani na ,trzy nie" wobec Tajwanu, ani na wyraźne przeprosiny na piśmie za japońskie zbrodnie z czasów II wojny światowej. Nie znaczy to jednak, by nie doceniał wagi relacji z władzami w Pekinie. Podobnie jak Hashimoto Ryūtarō, Obuchi podkreślał znaczenie przyjaznych kontaktów z ChRL. Z drugiej strony, obóz protajwański w PLD umocnił się po powstaniu w 1999 roku dużej frakcji Etō/Kameia. Również w następnych latach inicjatywy polityków tej grupy miały rzutować na stan relacji japońsko-chińskich.

\section{MORI YOSHIRŌ (2000-2001)}

Objęcie stanowiska szefa partii przez Moriego Yoshirō, polityka od lat znanego z protajwańskich i prawicowych poglądów, w pewnym stopniu stanowiło odzwierciedlenie wzrostu popularności idei nacjonalistycznych w PLD. Mori był pierwszym od ponad 20 lat premierem wywodzącym się $\mathrm{z}$ dawnej frakcji Kishiego Nobusuke. Miał radykalniejsze poglądy niż Hashimoto Ryūtarō i Obuchi Keizō. Za jego rządów obóz protajwański osiągnął apogeum wpływów w partii, choć z drugiej strony trudno odmówić Moriemu pewnej wrażliwości na sytuację międzynarodową i elastyczności ideologicznej, która ocaliła relacje japońsko-chińskie przed poważniejszym kryzysem.

\section{Mori Yoshirō i jego postawa wobec Chin}

Kiedy Obuchi Keizō zapadł w śpiączkę, odbyło się zakulisowe spotkanie tzw. „grupy pięciu” (go nin gumi), czyli wpływowych polityków piastujących ważne urzędy partyjne i państwowe. Brali w nim udział sekretarz generalny PLD Mori Yoshirō, sekretarz gabinetu Aoki Mikio z frakcji Obuchiego (Hashimoto), przewodniczący Izby Radców PLD Murakami Masakuni z frakcji Etō/Kameia, zastępca sekretarza generalnego PLD Nonaka Hiromu z frakcji Obuchiego (Hashimoto) oraz przewodniczący Rady Badań Politycznych PLD Kamei Shizuka. Jak widać, wszyscy oni wywodzili się z trzech wpływowych frakcji Obuchiego (Hashimoto), Moriego oraz Etō/Kameia. Wśród uczestników spotkania zabrakło natomiast przewodniczącego Rady Generalnej PLD, Ikedy Yukihiko, który reprezentował jedną z największych wówczas grup w partii, frakcję $\mathrm{Kato}^{154}$. W trakcie narady Murakami zaproponował, by nowym przewod-

\footnotetext{
${ }^{154}$ Według Moriego Yoshirō spotkanie „grupy pięciu” zostało zwołane w zupełnie innej sprawie i tylko przypadkowo, w wyniku nagłej śpiączki premiera Obuchiego, zajęło się dyskusją na temat wyboru jego następcy. Szerzej na ten temat: Mori Yoshirō. Jimintōo..., s. 225-226.
} 
niczącym mianować Moriego Yoshirō ${ }^{155}$. Chociaż Mori został później oficjalnie wybrany przez zgromadzenie parlamentarzystów z PLD, decyzja o tym, kto zostanie następcą Obuchiego, tak naprawdę zapadła już na potajemnym spotkaniu „grupy pięciu”. Nieobecność na tej naradzie reprezentanta frakcji Katō, największej z umiarkowanych, propekińskich grup wewnątrz PLD, miała się później okazać brzemienna w skutkach dla stosunków japońsko-chińskich.

Tabela 5.4 Rozkład sił pomiędzy frakcjami PLD oraz partie koalicyjne w okresie rządów Moriego Yoshirō w latach 2000-2001.

\begin{tabular}{|l|l|}
\hline \multicolumn{1}{|c|}{ Cechy i liczebność frakcji PLD } & \multicolumn{1}{c|}{ Partie koalicyjne } \\
\hline Mori (D, J, T) 60 & Kōmeitō (G, P) 54 \\
Hashimoto (L) 96 & Partia Konserwatywna (P) 13 \\
Katō (L, G, P) 62 & \\
Etō/Kamei (D, J, T) 56 & \\
Yamasaki (D, J) 23 & \\
Kōmoto (D, G, P) 13 & \\
Kōno 11 & \\
Bezfrakcyjni 14 & 67 \\
\hline 335 & \\
\hline
\end{tabular}

L- dawni członkowie Partii Liberalnej, główny nurt konserwatywny, D- dawni członkowie Partii Demokratycznej, boczny nurt konserwatywny, G- gołębie, J- jastrzębie, P- obóz propekiński, Tobóz protajwański.

Liczebność frakcji (podana przy poszczególnych frakcjach) po wyborach do Izby Reprezentantów z czerwca 2000 roku. Uwzględniono członków frakcji z obu izb parlamentu.

Opracowanie własne na podstawie: Kokkai binran - Heisei 12 nen 8 gatsu shinpan pod red. Yoshidy Nobuko, Nihon Keizai Shinbunsha, Tokio 2000, s. 418-441.

Po zapadnięciu w śpiączkę Obuchiego Keizō, przywództwo nad jego frakcją objął były premier Hashimoto Ryūtarō. Chociaż Partia Liberalna Ozawy Ichirō zerwała porozumienie z PLD, ugrupowania koalicyjne zachowały większość mandatów w obu izbach parlamentu. Stało się tak dzięki pozostaniu w koalicji Kōmeitō, jak też dzięki rozłamowi, do jakiego doszło w Partii Liberalnej. Parlamentarzyści pragnący kontynuować sojusz z PLD opuścili ugrupowanie Ozawy, zakładając Partię Konserwatywną (Hoshutō) z Ōge Chikage jako przewodniczącą. W nowej partii znalazło się wielu polityków propekińskich, na czele z byłym premierem Kaifu Toshikim, Nikaiem Toshihiro wywodzącym się z dawnej frakcji Takeshity oraz Nodą Takeshim, który niegdyś należał do frakcji Nakasone.

Mori Yoshirō miał wyraźnie prawicowe poglądy. Został posłem w 1969 roku dzięki wsparciu w kampanii wyborczej udzielonemu mu przez Kishiego Nobusuke. Aby zwrócić ten dług wdzięczności, od początku należał do frakcji Fukudy Takeo, służąc jako jeden $\mathrm{z}$ jego najwierniejszych przybocznych

${ }^{155}$ Nonaka Hiromu, Rōhei..., s. 164-166. 
polityków w okresie „wojny Kaku-Fuku” w latach 70. XX wieku ${ }^{156}$. Będąc wpływowym członkiem zoku edukacyjnego, od lat domagał się reformy szkolnictwa, by promować tradycyjne wartości, moralność i patriotyzm. Pragnął m.in., by $\mathrm{w}$ szkołach przywrócono naukę religii shintoistycznej $\mathrm{w}$ celu zwalczania materializmu i komunizmu. Postulował powrót do lektury mitów shintoistycznych, które miały ponownie natchnąć Japończyków duchem ich przodków $^{157}$.

Mori posiadał silne powiązania z Tajwanem. Nie był typem inteligenta, dostał się na prestiżową uczelnię Waseda $\mathrm{w}$ Tokio jedynie dzięki osiągnięciom sportowym jako zawodnik rugby ${ }^{158}$. Kontakty z czasów studenckich okazały się później czynnikiem umacniającym związki Moriego z władzami w Tajpej, gdyż Uniwersytet Waseda skończył również przedstawiciel Tajwanu w Japonii, Lin Jinjing ${ }^{159}$. W latach 70 . XX wieku Mori należał do aktywnych członków skrajnie protajwańskiej grupy Seirankai. Będąc ministrem transportu w rządzie Miyazawy w 1993 roku złamał długo utrzymywane tabu i jako pierwszy członek japońskiego rządu od 1972 roku spotkał się z odwiedzającym Japonię tajwańskim urzędnikiem wysokiego szczebla ${ }^{160}$. W trakcie wyborów prezydenckich w 1996 roku Mori wspierał Li Denghuia, ale nawiązał kontakty również z opozycją tajwańską. W lipcu 1999 roku spotkał się np. z Chen Shuibianem, zaś w marcu 2000 roku z innym wysłannikiem Demokratycznej Partii Postępu ${ }^{161}$.

Chociaż Mori niewątpliwie był ,jastrzębiem” i członkiem obozu protajwańskiego, trudno go nazwać politykiem równie radykalnym w poglądach, jak Fujio Masayuki czy Murakami Masakuni. Mori wiele razy udowodnił, iż był zdolny do kompromisów ideologicznych. Wszakże kiedy piastował stanowisko sekretarza generalnego PLD w 1994 roku stał się jednym z głównych autorów historycznego porozumienia koalicyjnego z Japońską Partią Socjalistyczną, zaś w 1995 roku wykazywał większe zrozumienie dla konieczności uchwalenia rezolucji z okazji 50. rocznicy zakończenia II wojny światowej niż Murakami Masakuni. Wyraźnie widać, że podobnie do wielu innych dawnych członków Seirankai, jego poglądy na politykę zagraniczną Japonii uległy złagodzeniu w latach 80. XX wieku, razem z awansem wewnątrz PLD. Od 1998 roku Mori był już liderem jednej z największych frakcji w partii i, podobnie jak Fukuda Takeo w latach 70. XX wieku czy Abe Shintarō w latach 80. XX wieku, musiał złagodzić ton swoich wypowiedzi na temat Chin.

\footnotetext{
${ }^{156}$ Mori Yoshirō, Anata ni oshierare, hashiri tsuzukemasu, Hokkoku Shinbunsha, Kanazawa 1999, s. $140-178$.

${ }^{157}$ Idem, Kyōiku ni „kokoro” o torikaesō [w:] Nakagawa Ichirō, Ishihara Shintarō et al., op.cit., s. $127-132$.

${ }^{158}$ Mori Yoshirō, Anata ni..., s. 67-70.

${ }^{159}$ Zhong-Ri guanxi 30 nian..., s. 329.

${ }^{160}$ Nittai jitsumu..., s. 4.

${ }^{161}$ Zhong-Ri guanxi 30 nian..., s. 330.
} 
Poza tym Yakushiji Katsuyuki podkreśla, że Mori nie był typem „polityka walczącego" (tōsōgata no sejika), tylko „polityka koordynującego” (chōseigata no seijika $)^{162}$. Oprócz specjalizacji w dziedzinie edukacji, Mori Yoshirō miał także doświadczenie długiej pracy w Komisji Strategii Parlamentarnej, odpowiedzialnej za kontakty z partiami opozycyjnymi ${ }^{163}$. Nauczyło go to ugodowości. Sam Mori podkreśla, iż od Fukudy Takeo przejął zasadę, że „należy walczyć o rzeczy wielkie, a nie o rzeczy małe”164. Ta elastyczność w podejściu do ideologii była czynnikiem łagodzącym politykę rządu Moriego wobec Chin i nadającym jej stosunkowo mało podatny na osobiste emocje, racjonalny charakter.

\section{Problem wizyty Li Denghuia i chińskich statków badawczych}

W marcu 2000 roku w wyborach prezydenckich na Tajwanie zwyciężył Chen Shuibian z Demokratycznej Partii Postępu. Jeszcze przed wyborami Li Denghui rozpoczął starania o wizytę w Japonii już jako osoba prywatna po zakończeniu swojej kadencji. Chiny od razu zareagowały, ostrzegając, że nawet ustąpiwszy z funkcji prezydenta Li nie powinien otrzymać japońskiej wizy. Władze w Pekinie groziły m.in. odwołaniem planowanej na 2000 rok wizyty w Tokio premiera Zhu Rongjiego. Protajwańscy politycy z PLD nasilili jednak kampanię na rzecz nieoficjalnego przyjazdu Li Denghuia do Japonii. Jeszcze w marcu 2000 roku Murakami Masakuni zaprosił gubernatora Tokio, byłego członka PLD, Ishiharę Shintarō do udziału w promocji tego przedsięwzięcia ${ }^{165}$. Kiedy miesiąc później Murakami został w trakcie potajemnego spotkania „grupy pięciu” głównym inicjatorem objęcia władzy przez Moriego, było wyraźnie widać, jak bardzo zwiększyły się wpływy obozu protajwańskiego w partii. Tymczasem Ishihara Shintarō odpowiedział na prośbę Murakamiego i w trakcie wizyty na Tajwanie w maju 2000 roku obiecał wsparcie dla pomysłu przyjazdu Li Denghuia do Japonii. Nie omieszkał przy tym zaznaczyć: „Jeśli Jiang Zemin spróbuje dokonać aneksji Tajwanu siłą, będzie taki sam jak Hitler" ${ }^{\text {"166 }}$.

Widać było, że dawne środowisko Seirankai z lat 70. XX wieku (Ishihara Shintarō) i Towarzystwa Podstawowych Problemów Państwa z lat 80. XX wieku (Murakami Masakuni) połączyły siły w celu przeforsowania wizyty Li Denghuia w Japonii. Obóz propekiński na czele z Kōno Yōheiem, który wówczas znowu piastował stanowisko ministra spraw zagranicznych, był poddany coraz większej presji wewnątrz partii. Pamiętając o swojej obietnicy z 1994 roku, Kōno starał się jednak nie dopuścić do wizyty Li Denghuia, argumentując, że nawet po

\footnotetext{
${ }^{162}$ Mori Yoshirō. Jimintō..., s. 189

${ }^{163}$ Mori Yoshirō, Anata ni..., s. 201-203.

${ }^{164}$ Ibidem, s. 176.

${ }^{165}$ Ri Tōki-shi rainichi de junbii kessei e. Murakami San'in kaichō ga Ishihara tochiji ni sanka yōsei, ,Yomiuri Shinbun” z 7 III 2000, s. 2.

${ }^{166}$ Ishihara-shi no „Hitorā hatsugen”. „Rei o shissuru Kōno gaishō ga hihan”, „Yomiuri Shinbun" z 23 V 2000, s. 2.
} 
złożeniu przez niego urzędu prezydenta takie wydarzenie miałoby wyraźny wymiar polityczny. Minister spraw zagranicznych krytykował także Ishiharę za porównanie Jiang Zemina do Hitlera ${ }^{167}$. Kōno Yōhei przyznaje, że zdecydowanie sprzeciwiał się wizycie byłego prezydenta Tajwanu, jednak w inicjatywę tę zaangażował się sam premier Mori ${ }^{168}$.

Tymczasem zbliżała się kolejna, 55. rocznica kapitulacji Japonii po II wojnie światowej. Zaraz po objęciu stanowiska premiera, Mori dokonał kilku nietaktownych wypowiedzi w sprawie historii, np. w kwietniu 2000 roku podkreślił, że istnieją różne poglądy na temat, czy Japonia prowadziła wojnę napastniczą ${ }^{169}$. Nie sprzyjało to atmosferze przyjaźni $w$ relacjach japońsko-chińskich, ale największe znaczenie miała kwestia ewentualnej wizyty premiera w Yasukuni. Mori Yoshirō przyznaje, że jego ojciec, który w czasie wojny służył jako żołnierz, na łożu śmierci miał tylko jedno życzenie - aby jego syn kontynuował tradycję odwiedzania kontrowersyjnej świątyni. Przed 15 sierpnia 2000 roku premier musiał podjąć niezwykle trudną decyzję. Stanął przed wyborem dotrzymania przysięgi złożonej ojcu lub poszanowania uczuć narodów azjatyckich, które padły niegdyś ofiarą japońskiego ekspansjonizmu. Jak wspomina: „W tym czasie myślałem, by zabiegać o wizytę w Japonii byłego prezydenta Tajwanu Li Denghuia. Gdybym w takich okolicznościach odwiedził świątynię Yasukuni, sprawa Li Denghuia stałaby się trudna do załatwienia. Chodzi o to, że ciężko jest kontynuować działania, których nie lubią Chiny" ${ }^{\text {"170. }}$. Mori przyznaje, że zamiast odwiedzić 15 sierpnia samą świątynię Yasukuni, uciekł się do sprytnego wybiegu. Podjechał w pobliże świątyni samochodem i poprosił młodszego kolegę, by stanął przed Yasukuni, po czym złożył mu pokłon. Jak wyjaśnia: „Oczywiście tak naprawdę oddałem hołd duszom poległych żołnierzy czczonym w świątyni Yasukuni, jednak patrząc z boku wyglądało, jakbym pokłonił się młodszemu koledze. Gdy później otworzyłem drzwi wsiadając do samochodu, jeszcze raz złożyłem pokłon w kierunku Yasukuni. Potem przejeżdżaliśmy samochodem przy świątyni Yasukuni. Z wnętrza samochodu pokłoniłem się kolejny raz. Można pomyśleć, że było to śmieszne przedstawienie, ale to potrzeba serca"171. Postawa Moriego pokazuje, że pomimo swoich prawicowych przekonań jako premier potrafił przedłożyć interes państwa nad własne uczucia.

$\mathrm{W}$ międzyczasie pojawił się jednak inny poważny problem $\mathrm{w}$ stosunkach $\mathrm{z}$ ChRL. Od 1999 roku nasiliła się aktywność chińskich statków badawczych i wywiadowczych na Morzu Wschodniochińskim, zwiastując wznowienie zawieszonego w latach 70. XX wieku sporu o zasoby naturalne akwenu. Przeciwko

\footnotetext{
${ }^{167}$ Ibidem.

${ }^{168}$ Wywiad autora z Kōno Yōheiem...

${ }^{169}$ Li Jianmin, op.cit., s. 304.

${ }^{170}$ Mori Yoshirō. Jimintō..., s. 279.

${ }^{171}$ Ibidem, s. 280-281.
} 
tym działaniom protestował jeszcze premier Obuchi, jednak ChRL nie zaprzestała badań. Miarkę przebrały wydarzenia z maja 2000 roku, kiedy chiński okręt wojenny opłynął Japonię, zbierając dane na temat cieśnin Tsushima i Tsugaru. Protesty ,jastrzębi”, szczególnie z zoku obrony, były tak silne, że nawet Kōno Yōhei musiał zareagować zdecydowanie. W sierpniu 2000 roku Japonia zawiesiła wypłatę Chinom dwóch specjalnych pożyczek wartych 17,2 mld jenów. W tym samym miesiącu Kōno spotkał się w Pekinie z przewodniczącym Jiang Zeminem, premierem Zhu Rongjim i ministrem spraw zagranicznych Tang Jiaxuanem. Ostrzegł ich, że brak transparentności w chińskich wydatkach wojskowych sprawia, iż japońska opinia publiczna podchodzi coraz bardziej krytycznie do udzielania ChRL pomocy rozwojowej. Władze w Pekinie zareagowały ze zrozumieniem i zgodziły się na rozpoczęcie rozmów w sprawie ustalenia systemu oficjalnych powiadomień o planowanych badaniach morskich. Deklaracja ta starczyła do wznowienia pożyczek w jenach dla Chin w październiku 2000 roku ${ }^{172}$. Cały incydent pokazał jednak, że nakładanie na Chiny sankcji gospodarczych stawało się coraz bardziej powszednim środkiem wywierania presji na władze w Pekinie.

Jednocześnie w zaawansowaną fazę weszły rozmowy na temat wizyty byłego prezydenta Tajwanu w Japonii. Li Denghui pragnął przyjechać na japońskotajwańskie sympozjum w Nagano w październiku 2000 roku, jednak we wrześniu 2000 roku dziewięcioosobowa delegacja parlamentarzystów PLD z Murakamim Masakunim na czele odwiedziła Tajwan, prosząc o przełożenie wizyty na następny rok. Murakami podkreślał, że warunki jeszcze nie sprzyjały przyjazdowi ${ }^{173}$. Wszakże wydanie wizy Li Denghuiowi niosło za sobą ryzyko odwołania przez ChRL zaplanowanej na październik 2000 roku wizyty premiera Zhu Rongjiego w Japonii. Przyjechawszy do Tokio premier ChRL podkreślił jeszcze raz, że Li Denghui nie jest zwykłym obywatelem i jego wizyta w Japonii wpłynęłaby negatywnie na stosunki japońsko-chińskie. Przypomniał także, iż Japonia nadal nie przeprosiła Chin na piśmie za zbrodnie z czasów II wojny światowej, ale jednocześnie stwierdził, że ChRL wysoko ocenia deklarację premiera Murayamy z 1995 roku $^{174}$. W rozmowie z gościem Mori Yoshirō podkreślił, iż Japonia żałuje za wydarzenia z przeszłości ${ }^{175}$.

\section{„Bunt Katō” i dalsze osłabienie obozu propekińskiego}

Przez cały okres swoich rządów Mori był ostro krytykowany przez media, które przedstawiały go jako osobę bez kompetencji do piastowania urzędu premiera ${ }^{176}$.

\footnotetext{
172 Tsukasa Takamine, op.cit., s. 454-455.

${ }^{173}$ Ri zen Taiwan sōtō no hōnichi no miokuri e. Murakami-shi „kankyō totonowazu” Chin sōtō ni tsutaeru, ,Yomiuri Shinbun” z 16 IX 2000, s. 2.

${ }^{174}$ Shu Yōki Chūgoku shushō no kaiken yōshi, ,Yomiuri Shinbun” z 17 X 2000, s. 6.

${ }^{175}$ Zhong-Ri guanxi 30 nian..., s. 281-282.

176 Opinia publiczna bardzo źle przyjęła już sam zakulisowy sposób wyboru Moriego na przewodniczącego partii, później zaś popularność rządu ciągle spadała w wyniku skrupulatnie
} 
Zdawało się, że opinia publiczna wesprze pomysł odsunięcia od władzy mało popularnego szefa rządu. Widząc szansę na przejęcie władzy, w listopadzie 2000 roku Katō Kōichi ogłosił na konferencji prasowej, iż zamierza poprzeć lub być nieobecnym na głosowaniu złożonego przez opozycję wniosku o wotum nieufności wobec rządu. Był to początek tzw. „buntu Katō” (Katō no ran). Przyłączył się do niego bliski przyjaciel Katō, Yamasaki Taku. Ponieważ frakcje Katō i Yamasakiego łącznie liczyły wystarczającą liczbę posłów, by w sojuszu z ugrupowaniami opozycyjnymi przegłosować wniosek, usunięcie od władzy premiera Moriego wydawało się jak najbardziej realne.

Przeciwko działaniom buntowników aktywnie wystąpiła jednak „grupa pięciu”, zwłaszcza zaś sekretarz generalny PLD, Nonaka Hiromu z frakcji Hashimoto. Politykom skupionym wokół premiera Moriego udało się wykorzystać fakt, że po zmianie ordynacji wyborczej w 1994 roku solidarność frakcyjna znacząco osłabła. Dzięki perswazji ze strony zarządu PLD większość posłów należących do dwóch nieposłusznych frakcji zdecydowała się nie brać udziału w „buncie”. Co istotne, obóz Katō opuścił nawet jego dawny oyabun, Miyazawa Kiichi. Nastąpił wówczas rozłam we frakcji. Od grupy Katō oddzieliło się grono polityków pod kierownictwem Horiuchiego Mitsuo i Kogi Makoto. Frakcja Horiuchiego zagłosowała pod koniec listopada 2000 roku za odrzuceniem wotum nieufności wobec rządu, ratując gabinet premiera Moriego $^{177}$. Wydarzenie to pokazało, jak bardzo osłabły więzy lojalności pomiędzy szefami frakcji a ich kobunami ${ }^{178}$.

Katō Kōichi był jedną z głównych postaci obozu propekińskiego i dawnym zaufanym politykiem Ōhiry Masayoshiego ${ }^{179}$. Wywodził się z biurokracji Ministerstwa Spraw Zagranicznych, gdzie specjalizował się w problematyce chińskiej. Znał biegle język chiński i bardzo dobrze orientował się w historii, kulturze i polityce Chin. Studiował na Tajwanie, zaś w latach 60. XX wieku pełnił funkcję wicekonsula w Hongkongu ${ }^{180}$. W latach 90. XX wieku niejednokrotnie wchodził w spór z prawicowymi i protajwańskimi politykami w PLD,

notowanych przez media gaf. Na przykład premier miał powiedzieć, iż Japonia jest „krajem bogów z cesarzem w centrum”. Szerzej na ten temat: Mori Yoshirō. Jimintō..., s. 232-236.

${ }^{177}$ Nonaka Hiromu przyznaje, że nie czuł wrogości do Katō Kōichiego, ale nie chciał dopuścić do rozpadu partii i utraty przez nią władzy. Nonace udało się przekonać do swoich argumentów takich wpływowych członków frakcji Katō, jak Miyazawa Kiichi i Koga Makoto. Szerzej na ten temat: Nonaka Hiromu, Rōhei..., s. 202-223.

${ }^{178}$ Do klęski Katō przyczyniła się m.in. niechęć polityków PLD do wewnątrzpartyjnych rewolt po opuszczeniu partii przez Ozawę Ichirō w 1993 roku. Panowała obawa, iż kolejny rozłam w ugrupowaniu może znowu doprowadzić do utraty władzy w państwie. Szerzej na ten temat: Karol Żakowski, Bunt Katō a bunt Ozawy. Analiza porównawcza przesileń w japońskiej Partii Liberalno-Demokratycznej [w:] Japonia: Historia i wspótczesność pod red. Joanny MarszałekKawy, Wydawnictwo Adam Marszałek, Toruń 2008, s. 212-213.

${ }^{179}$ Honzawa Jirō, Taiwan..., s. 24; Kurokawa Kotarō, Katō Kōichi (naikaku kanbōchōkan), „Nikkei Business” z 25 XI 1991, s. 85.

${ }^{180}$ Katō Kōichi, Atarashiki..., s. 58-59. 
starając się nie dopuścić do pogorszenia relacji z władzami w Pekinie. Starczy tylko przypomnieć rolę, jaką odegrał w 1995 roku forsując w parlamencie przeprosiny za zbrodnie japońskie z czasów II wojny światowej czy w 1997 roku, starając się wyłączyć Tajwan z działań objętych nowymi wytycznymi sojuszu z USA. Katō przyznaje, że w okresie zimnej wojny podstawą polityki dawnej frakcji Ikedy było łagodzenie napięć międzynarodowych bez nadmiernego podkreślania jakiejkolwiek ideologii, w tym antykomunizmu. Zauważa także, iż już dawno przewidział, że system komunistyczny załamie się w Chinach ${ }^{181}$. Według Katō trójkąt w stosunkach japońsko-amerykańskochińskich powinien być jak najbardziej równoboczny ${ }^{182}$.

To umiarkowane podejście do dyplomacji stało się jednak trudne do utrzymania w wyniku radykalizacji nastrojów społecznych po upadku ZSRR. Według Katō Kōichiego wzrost popularności poglądów nacjonalistycznych wiąże się z rozmrożeniem ukrytych do tej pory sporów religijnych i narodowościowych. Także w Japonii takie prawicowe sekty religijne, jak Seichō no Ie, z której wywodził się np. Murakami Masakuni, przybrały na znaczeniu w erze pozimnowojennej ${ }^{183}$. Na przekór tym zmianom, Katō bronił pacyfistycznej konstytucji, ponieważ, jak twierdził: „Artykuł 9 jest deklaracją podstawowej polityki zagranicznej powojennej Japonii, został sformułowany w oparciu o refleksję na temat II wojny światowej i daje krajom ościennym wielkie poczucie bezpieczeństwa”" ${ }^{84}$. O sobie samym mówił: „Często nazywa się mnie gołębiem, ale jeśli to oznacza, iż jestem wrażliwy na sytuację międzynarodową i kładę nacisk na współpracę z państwami na świecie, to mogę tak być nazywany. Co więcej, jestem raczej $\mathrm{z}$ tego dumny. Niebranie pod uwagę środowiska międzynarodowego wokół Japonii czy podnoszenie w kraju epickiej dyskusji w celu uzyskania emocjonalnego poparcia opinii publicznej jest czynem niegodnym polityka"185.

Chociaż Katō Kōichi był dotąd uważany za jednego z najbardziej obiecujących kandydatów na stanowisko szefa partii, w wyniku „buntu” z 2000 roku utracił wszelkie poparcie w PLD. Nawet główny sprawca jego klęski, Nonaka Hiromu, przyznaje: „Pan Katō miał niezwykłą wartość jako ostatni pozostały kandydat na premiera $\mathrm{z}$ frakcji liberalnej. Było mi bardzo przykro, że go zniszczyłem" ${ }^{186}$. Jednakże nie tylko sam Katō Kōichi poniósł klęskę, ale także cała dawna frakcja Ikedy. Rozpad tej umiarkowanej, liberalnej i tradycyjnie propekińskiej grupy oznaczał dalsze osłabienie nurtu Yoshidy, który od

\footnotetext{
${ }^{181}$ Wywiad autora z Katō Kōichim...

${ }^{182}$ Katō Kōichi, Ima seiji wa nani o subeki ka - Shin seiki Nihon no sekkeizu, Kōdansha, Tokio 1999, s. 230.

${ }^{183}$ Wywiad autora z Katō Kōichim...

${ }^{184}$ Katō Kōichi, Ima seiji..., s. 221.

${ }^{185}$ Ibidem, s. 233-234.

${ }^{186}$ Nonaka Hiromu, Rōhei..., s. 210.
} 
lat 70. XX wieku stanowił główną siłę stojącą za poprawą relacji japońskochińskich. Jego miejsce $\mathrm{w}$ partii stopniowo zajmowała prawicowa frakcja Moriego, której udało się uniknąć większych podziałów w latach 90. XX wieku.

Również sojusznik Katō Kōichiego, Yamasaki Taku, poniósł klęskę w „buncie”, jednak zdołał zachować jedność swojej frakcji. Yamasaki reprezentował inną opcję ideologiczną niż Katō. Należał do zoku obrony i do obozu ,jastrzębi”,"187. Uważał, iż „dyplomacja przeprosin” (shazai gaikō) tylko narusza zaufanie państw regionu do Japonii ${ }^{188}$. Niepokoił go także wzrost wydatków ChRL na zbrojenia ${ }^{189}$. Z drugiej strony, Yamasaki nie był radykalnym przedstawicielem prawego skrzydła PLD i prowadził stosunkowo wyważoną politykę ${ }^{190}$. W latach 70. XX wieku należał do skrajnie protajwańskiego Seirankai, ale szybko zniechęcił go radykalizm tej grupy. Pomimo podpisania paktu krwi, wystąpił z Seirankai, gdy tylko jego działacze zaczęli głosić w przemówieniach ulicznych, że komuniści zasługują na śmierć ${ }^{191}$.

Realistyczną postawę Yamasakiego wobec Chin najlepiej widać na przykładzie problemu nowych wytycznych sojuszu z USA w latach 90. XX wieku. Yamasaki zaproponował kompromisową interpretację terminu „sytuacje na obszarach otaczających Japonię", która stała się oficjalnym stanowiskiem japońskiego rządu. Podkreślał, że w celu prowadzenia samodzielnej polityki wobec Chin Japonia musi zachować możliwość powiedzenia „nie” wobec ewentualnych żądań użycia przez Stany Zjednoczone ich sił zbrojnych z baz na Okinawie. Przekonywał: „W Japonii są zarówno osoby po stronie Chin, jak i po stronie Tajwanu, więc $\mathrm{w}$ rzeczywistości jesteśmy zapewne neutralni. Jednakże z dyplomatycznego punktu widzenia wspieramy Chiny. $\mathrm{Z}$ zasady oficjalne stanowisko Japonii brzmi, iż są jedne Chiny, zaś władze w Pekinie są prawowitym rządem, jednak w społecznej mentalności jesteśmy neutralni. (...) Utrzymujemy stosunki dyplomatyczne z Chinami, a nie z Tajwanem. Na podstawie japońskoamerykańskiego traktatu sojuszniczego Japonia nie może bronić kraju, z którym nie ma stosunków dyplomatycznych"192. Podobnie jak Katō, Yamasaki uważał, że relacje w trójkącie Japonia-USA-Chiny powinny być jak najbardziej stabilne $^{193}$. Jak widać, podejście Yamasakiego do problemu chińskiego było

${ }^{187}$ Działalność polityczna Yamasakiego Taku nawiązywała do tradycji dwóch prawicowych polityków z Fukuoki: Nakano Seigō i Ogaty Taketory. Rozmowa autora z sekretarzem Yamasakiego Taku, Fukuoka, 20 XII 2008.

${ }^{188}$ Yamasaki Taku, 2010 nen Nihon jitsugen, Daiyamondosha, Tokio 1999, s. 37.

${ }^{189}$ Idem, Ajia Taiheiyō..., s. 53-55.

${ }^{190} \mathrm{~Np}$. na początku lat 80 . XX wieku Yamasaki Taku uważał, że z powodu pacyfistycznych nastrojów społecznych nie należy nadmiernie zwiększać wydatków na obronę. Szerzej na ten temat: idem, Tenki ni tatsu Nihon no bōei, Rīburu Shuppan Kikaku, Fukuoka 1982, s. 80-81.

${ }^{191}$ Idem, 2010 nen..., Daiyamondosha, Tokio 1999, s. 247-248.

${ }^{192}$ Idem, Ajia Taiheiyō..., s. 224-225.

${ }^{193}$ Idem, Naze ima „Kinmirai Kenkyūkai” ka - Maguma shūdan ga Nihon o kaeru [w:] Nihon no kinmirai pod red. Yamasakiego Taku, Daiyamondosha, Tokio 1998, s. II. 
wyważone i nie można go zaliczyć ani do obozu propekińskiego, ani protajwańskiego.

Tymczasem popularność premiera Moriego ciągle spadała. Po incydencie ze statkiem „Ehime Maru” w lutym 2001 roku osiągnęła rekordowo niski poziom poniżej 10 proc. ${ }^{194}$ Wewnątrz PLD narastał ruch domagający się ustąpienia Moriego ze stanowiska. Premier nie miał wyboru i w kwietniu 2001 roku musiał podać się do dymisji. Nie mając już nic do stracenia, Mori postanowił w końcu przeforsować wizytę Li Denghuia w Japonii. Osłabienie stronnictwa propekińskiego po „buncie Katō” sprzyjało owej inicjatywie. Również stronie tajwańskiej zależało na załatwieniu tej sprawy póki rządził przychylny jej premier, tym bardziej że najsilniejszym kandydatem na jego następcę zdawał się umiarkowanie propekiński Hashimoto Ryūtarō ${ }^{195}$. W sprawie wizyty Li Denghuia Mori już kilka miesięcy wcześniej poradził się zresztą zarówno Hashimoto, jak i innego byłego propekińskiego premiera, Nakasone Yasuhiro. Obaj przestrzegli Moriego, by postępował z najwyższą ostrożnością, aby nie pogorszyć stosunków $\mathrm{z}$ Chinami, ale w sumie zareagowali pozytywnie. Podkreślili również, że kluczowy będzie dobór odpowiedniego ambasadora Japonii w Pekinie. Mori posłuchał tych rad i specjalnie w celu negocjacji w sprawie wizyty Li Denghuia mianował w styczniu 2001 roku ambasadorem w ChRL Anamiego Koreshige, znanego dyplomatę specjalizującego się w relacjach z Chinami ${ }^{196}$. Strona chińska jednak do końca wyrażała sprzeciw. Wewnątrz PLD oprócz ministra spraw zagranicznych Kōno Yōheia wizycie próbował zapobiec także sekretarz gabinetu, znany z propekińskich sympatii syn Fukudy Takeo, Fukuda Yasuo ${ }^{197}$.

Ostatecznie Ministerstwo Spraw Zagranicznych musiało ugiąć się pod presją opinii publicznej oraz obozu protajwańskiego w PLD i 20 kwietnia 2000 roku wydało wizę Li Denghuiowi. W ostatniej chwili doszło jednak do ostrego sporu pomiędzy ministrem spraw zagranicznych a premierem. Kōno Yōhei pamiętał o swojej obietnicy z 1994 roku i groził, że poda się do dymisji, jeśli Mori będzie naciskał na wizytę Li Denghuia. Według Kōno, w stosunkach z ChRL i tak panowała napięta atmosfera z powodu kolejnego kryzysu podręcznikowego ${ }^{198} \mathrm{i}$

\footnotetext{
194 Japoński statek „Ehime Maru” zderzył się z amerykańską łodzią podwodną na Oceanie Spokojnym w okolicach Hawajów. Chociaż były ofiary śmiertelne, premier Mori nie przerwał nawet gry w golfa, by zająć się tym wypadkiem, co zostało skrytykowane przez media. Szerzej na ten temat: Mori Yoshirō. Jimintō..., s. 265; Wang Zhensuo, op.cit., s. 431-434.

${ }^{195}$ Ri Tōki-shi biza mondai. Shushō kōkei nirami „Ima ga kōki” to mo, „Yomiuri Shinbun” z 14 IV 2001, s. 3.

${ }^{196}$ Mori Yoshirō. Jimintō..., s. 279-280.

${ }^{197}$ Ri Taiwan zen sōtō no hōnichi biza shinsei. „Jindō” hakkyū to tai-Chū kōryo. Nihon seifu, kenkai wareru, „Yomiuri Shinbun” z 11 IV 2001, s. 2.

${ }^{198}$ Na początku kwietnia 2001 roku japońskie Ministerstwo Edukacji zatwierdziło kontrowersyjny Nowy podręcznik do historii (Atarashii rekishi kyōkasho), ukazujący zniekształconą wersję historii. Przygotowała go prawicowa organizacja Stowarzyszenie Stworzenia Nowego Podręcznika
} 
nie należało jej jeszcze pogarszać. Również koalicyjny partner PLD, Kōmeitō, a także przedstawiciele frakcji Hashimoto dawali do zrozumienia, że decyzję w tej sprawie lepiej odłożyć do czasu powołania nowego rządu. Chcąc uniknąć dymisji Kōno, Mori zgodził się na symboliczne ustępstwo wobec polityków propekińskich $^{199}$. Na działalność byłego prezydenta Tajwanu w Japonii nałożono liczne nadzwyczajne ograniczenia, zabraniając mu wypowiedzi w sprawach polityki oraz ściśle określając regiony, do których mógł się udać. Li Denghui odwiedził Japonię dosłownie w ostatnich dniach rządów Moriego Yoshirō (22-26 kwietnia 2001). Głównym celem wizyty była kuracja choroby serca w szpitalu w mieście Kurashiki. Władze ChRL nie wierzyły jednak w humanitarny wymiar wizyty i zgłosiły przeciw niej zdecydowany protest. Odwołały także przewidzianą na maj 2001 roku wizytę w Tokio przewodniczącego Stałego Komitetu Ogólnochińskiego Zgromadzenia Przedstawicieli Ludowych Li Penga $^{200}$.

Incydent z wizytą Li Denghuia pokazał, jak wiele zmieniło się 30 lat po „szoku Nixona”. Tym razem obiektem krytyki mediów stały się władze w Pekinie, uparcie trwające przy zakazie prywatnej wizyty w Japonii człowieka chorego na serce. Opinia publiczna sprzyjała wizycie ${ }^{201}$. Przy takich nastrojach społecznych obóz protajwański zyskiwał na znaczeniu, zaś politycy propekińscy zaczęli być postrzegani jako nadmiernie ulegli wobec żądań ChRL. Nie mogło to jednak pomóc samemu Moriemu, który nie cieszył się sympatią opinii publicznej i pod koniec kwietnia 2001 roku ustąpił ze stanowiska premiera.

$$
* * *
$$

Mori Yoshirō był jedynym dawnym członkiem Seirankai, który został premierem. Pomimo przynależności do obozu ,jastrzębi”, Mori okazał się politykiem na tyle racjonalnym i elastycznym, by powstrzymać się od wizyty $\mathrm{w}$ świątyni Yasukuni w trakcie pełnienia urzędu. W większym stopniu ujawniły się za to jego sympatie protajwańskie. Dzięki determinacji Moriego Japonię odwiedził w końcu, choć już nie jako prezydent, Li Denghui. Co ważne, w wyniku „buntu Katō” w 2000 roku doszło do rozpadu dawnej frakcji Ikedy, która od dziesięcioleci reprezentowała umiarkowane skrzydło PLD. Utrata przez

do Historii (Atarashii Rekishi Kyōkasho o Tsukuru Kai), powołana do życia na przełomie 1996 i 1997 roku. Jej działania wspierała grupa prawicowych posłów z PLD, na czele z Nakagawą Shōichim i Abe Shinzō. Zatwierdzenie podręcznika spotkało się z protestami ze strony Chin i Korei Południowej. Kryzys trwał do lipca 2001 roku, kiedy podręcznik został wydany pomimo sprzeciwu państw ościennych. Szerzej na ten temat: Zhong-Ri guanxi 30 nian..., s. 346-350; Caroline Rose, Sino-Japanese..., s. 60-65; Mōri Kazuko, op.cit., s. 171-172.

${ }^{199}$ Taiwan Ri Tōki-shi ni biza hakkyū. Kōno gaishō to Mori shushō, hibana no hantsuki, „Yomiuri Shinbun" z 20 IV 2001, s. 3.

${ }^{200}$ Zhong-Ri guanxi 30 nian..., s. 310-312.

${ }^{201}$ Ri Tôki Taiwan zen sōtō Nihon no haru ni kanmuryō. 16 nen buri no asa, „Yomiuri Shinbun” z 23 IV 2001, s. 1. 
Katō Kōichiego, znanego specjalistę w sprawach chińskich, szansy na zostanie premierem była poważnym ciosem dla obozu propekińskiego w partii.

\section{KOIZUMI JUN'ICHIRŌ (2001-2006)}

Gdy Koizumi Jun'ichirō obejmował stanowisko szefa rządu niewiele zapowiadało, że jego kadencja będzie obfitować w tak wiele kryzysów w relacjach japońsko-chińskich. Na atmosferę w stosunkach z władzami w Pekinie ogromny wpływ miała jednak wywrzeć nieustępliwa postawa premiera $\mathrm{w}$ sprawie problemów historycznych. Koizumi zerwał $\mathrm{z}$ wieloma tradycyjnymi zasadami rządzącymi procesem decyzyjnym $\mathrm{w}$ partii $\mathrm{i}$ w pełni wykorzystał nowe uprawnienia instytucjonalne nadane premierowi. Opierając się na wysokim poparciu wśród społeczeństwa osłabił jeszcze bardziej wpływy frakcji w PLD, narzucając partii swoją własną politykę. Przy takiej „odgórnej” metodzie sprawowania władzy osobiste przekonania premiera stały się czynnikiem o kluczowym znaczeniu dla zrozumienia wewnątrzpartyjnych uwarunkowań polityki PLD wobec Chin.

\section{Poglądy polityczne Koizumiego Jun'ichirō i plany reformy strukturalnej}

Kiedy Mori Yoshirō podał się do dymisji, wyglądało na to, że najpoważniejszym kandydatem na jego następcę jest Hashimoto Ryūtarō, który pragnął powrócić na fotel premiera. Kiedy jednak pod koniec kwietnia 2001 roku zorganizowano prawybory na stanowisko przewodniczącego partii, zdecydowanym zwycięzcą okazał się Koizumi Jun'ichirō z frakcji Moriego. Koizumi wygrał rywalizację w niemal wszystkich prefekturalnych oddziałach partii. Zawdzięczał to nie frakcyjnym powiązaniom, ale poparciu szeregowych członków PLD, którzy postrzegali w nim polityka „poza układami”. Na ostatecznym głosowaniu parlamentarzyści z PLD ugięli się pod presją opinii publicznej i Koizumi pokonał Hashimoto pomimo znacznie słabszej bazy poparcia wewnątrz partii ${ }^{202}$. $\mathrm{Z}$ drugiej strony, również tym razem nie obyło się bez „zagrywek" międzyfrakcyjnych. Koizumi zwyciężył także dzięki rezygnacji w ostatniej chwili Kameia Shizuki i wsparciu uzyskanemu ze strony jego frakcji ${ }^{203}$. Niemniej jednak w chwili powołania rządu cieszył się on rekordowym wskaźnikiem poparcia społecznego na poziomie $80-90$ proc. $^{204}$

Do 2001 roku zaszły pewne zmiany w systemie frakcyjnym wewnątrz PLD. W wyniku „buntu Katō” od byłej frakcji Ikedy odłączyła się grupa pod przewodnictwem Horiuchiego Mitsuo, która w styczniu 2001 roku oficjalnie powołała do życia nową frakcję $e^{205}$. W tym samym czasie zmarł Kōmoto Toshio,

\footnotetext{
${ }^{202}$ Bae Jeongho, op.cit., s. 33-35.

${ }^{203}$ Nonaka Hiromu, Rōhei..., s. 235-240; Cheol Hee Park, op.cit., s. 458-459.

${ }^{204} 21$ shiji de Zhong-Ri guanxi pod red. Jin Xide, Chongqing Chubanshe, Chongqing 2007, s. 87.

${ }^{205}$ Ōshita Eiji, Koga Makoto no shin seikai hana to ryū, Bīsuto, Tokio 2007, s. 255.
} 
który przeszedł na emeryturę jeszcze w 1996 roku, ale do śmierci pozostał honorowym przewodniczącym dawnej frakcji Mikiego. Przewodnictwo nad jego grupą przejął w 2000 roku Kōmura Masahiko. Rząd Koizumiego utrzymał koalicję z Kōmeitō i Partią Konserwatywną. Kōmeitō była ugrupowaniem pacyfistycznym i z niechęcią podchodziła do wizyt premiera $\mathrm{w}$ Yasukuni, ale $\mathrm{w}$ wyniku trwającej już kilka lat współpracy z PLD stawała się coraz bardziej zależna od partii rządzącej.

Tabela 5.5 Rozkład sił pomiędzy frakcjami PLD oraz partie koalicyjne w okresie rządów Koizumiego Jun'ichirō w latach 2001-2005.

\begin{tabular}{|l|l|}
\hline \multicolumn{1}{|c|}{ Cechy i liczebność frakcji PLD } & \multicolumn{1}{c|}{ Partie koalicyjne } \\
\hline Mori (D, J, T) 69 & Kōmeitō (G, P) 57 \\
Hashimoto (L) 90 & Partia Konserwatywna (P) 13 (do 2003) \\
Etō/Kamei (D, J, T) 50 & \\
Horiuchi (L, G, P) 46 & \\
Yamasaki (D, J) 28 & \\
Kōmura (D, G, P) 16 & \\
Katō-Ozato (L, G, P) 15 & \\
Kōno 9 & \\
Bezfrakcyjni 30 & 70 \\
\hline 353 & 70 \\
\hline
\end{tabular}

L- dawni członkowie Partii Liberalnej, główny nurt konserwatywny, D- dawni członkowie Partii Demokratycznej, boczny nurt konserwatywny, G- gołębie, J- jastrzębie, P- obóz propekiński, Tobóz protajwański.

Liczebność frakcji (podana przy poszczególnych frakcjach) po wyborach do Izby Reprezentantów z listopada 2003 roku. Uwzględniono członków frakcji z obu izb parlamentu.

Opracowanie własne na podstawie: Kokkai binran - Heisei 15 nen 12 gatsu rinjihan pod red. Kikuoki Nobuko, Nihon Keizai Shinbunsha, Tokio 2003, s. 398-425.

Przed objęciem urzędu premiera Koizumi Jun'ichirō nie był postrzegany jako prawicowy radykał. Należał do zoku finansowego, szczególnie zaś bankowego $(\text { ginkō zoku })^{206}$ i wykazywał ograniczone zainteresowanie polityką zagraniczną. Chociaż w 2001 roku poparł wizytę Li Denghuia w Japonii, tak naprawdę nie utrzymywał bliskich kontaktów ani z rządem w Pekinie, ani z władzami w Tajpej $^{207}$. Od lat 60 . XX wieku jego głównym konkurentem w okręgu wyborczym w Yokosuce był Tagawa Seiichi ${ }^{208}$, członek dawnej propekińskiej grupy Matsumury, co nie sprzyjało angażowaniu się Koizumiego w promocję relacji z ChRL. Jednakże w przeciwieństwie do swojego starszego kolegi frakcyjnego, Moriego Yoshirō, Koizumi Jun'ichirō w latach 70. XX wieku nie należał do

\footnotetext{
${ }^{206}$ Nonaka Hiromu, Rōhei..., s. 243-246.

207 Jimin shinsōsai ni senshutsu no „Koizumi gaikō” sekai ga chūmoku. „, Kyōkō na seisaku o suishin ka”, „Yomiuri Shinbun” z 25 IV 2001, s. 6.

${ }^{208}$ Asakawa Hirotada, Ningen Koizumi Jun'ichirō. Sandai ni wataru „, henkaku” no chi, Kōdansha, Tokio 2001, s. 144-146.
} 
Seirankai, ani nie kojarzono go $\mathrm{z}$ obozem protajwańskim. Kluczem do zrozumienia wewnątrzpartyjnych uwarunkowań polityki PLD wobec Chin w latach 2001-2006 była za to nieustępliwa postawa premiera w sprawie corocznych wizyt w świątyni Yasukuni.

Od samego początku kariery politycznej Koizumi co roku dwukrotnie odwiedzał świątynię Yasukuni jako wyraz wdzięczności za wsparcie udzielone mu przez wyborców pokolenia jego ojca. Mimo to nie był znany jako ,jastrząb” i przy poprzednich wyborach na przewodniczącego PLD, w których kandydował, nie składał obietnicy regularnych wizyt w Yasukuni jako szef rządu. Jednakże w kwietniu 2001 roku sytuacja się zmieniła. Aby zdobyć głosy 100 tys. członków PLD należących do Nihon Izokukai, frakcja Moriego wysłała faksem do każdego regionalnego przedstawicielstwa tej organizacji oficjalną przysięgę, że Koizumi będzie bezwzględnie odwiedzał świątynię Yasukuni jako premier. Był to także sposób na odróżnienie się od głównego kontrkandydata, Hashimoto Ryūtarō, który zawiódł zaufanie Nihon Izokukai, rezygnując z dalszych wizyt po jednej próbie w 1996 roku $^{209}$. W trakcie debaty przedwyborczej Koizumi wyraźnie zadeklarował: „Jeśli zostanę premierem, niezależnie z jaką krytyką bym się nie spotkał, będę koniecznie odwiedzał świątynię Yasukuni w święto poległych żołnierzy 15 sierpnia" ${ }^{\text {210. }}$. Strategia ta okazała się owocna i przyczyniła się do powiększenia skali zwycięstwa Koizumiego w prawyborach.

Według Shimizu Masato, ważnym czynnikiem wpływającym na posunięcia premiera było „DNA przeciwnego nurtu” (hanshuryū no DNA), które posiadał. Ojciec Koizumiego Jun'ichirō, Koizumi Jun'ya, należał do frakcji Fujiyamy Aiichirō, która przez cały okres swojego istnienia znajdowała się z dala od ścisłego kręgu władzy w partii. Kiedy Koizumi Jun’ya zmarł w latach 60. XX wieku, jego syn odziedziczył okręg wyborczy, jednak przegrał w swoich pierwszych wyborach parlamentarnych. Koizumi Jun'ichirō został posłem dopiero dzięki wsparciu Fukudy Takeo w 1972 roku. Odtąd cały czas należał do frakcji Fukudy, a potem Abe, Mitsuzuki i Moriego. W latach 70. XX wieku obserwował nierówną walkę Fukudy Takeo z Tanaką Kakueiem, zaś w latach 80. i na początku lat 90. XX wieku bezowocne starania Abe Shintarō o objęcie stanowiska przewodniczącego partii. Shimizu Masato uważa, iż doświadczenia te nauczyły Koizumiego, że jedynie wyjście poza ramy rywalizacji międzyfrakcyjnej i ,polityki pieniądza”, utożsamianej ze stworzoną przez Tanakę frakcją-hegemonem, umożliwi środowisku dawnej grupy Fukudy dojście do władzy ${ }^{211}$.

W przeciwieństwie do Moriego, który utrzymywał dobre kontakty z politykami z byłej frakcji Tanaki, Koizumi raczej nie przyjaźnił się z przedstawicielami tej grupy. O ile Mori Yoshirō i Mitsuzuka Hiroshi należeli niegdyś

\footnotetext{
${ }^{209}$ Yomiuri Shinbun Seijibu, op.cit., s. 222-223.

${ }^{210}$ Uchiyama Yū, Koizumi seiken, Chūō Kōron Shinsha, Tokio 2007, s. 135.

${ }^{211}$ Shimizu Masato, op.cit., s. 354-359.
} 
razem z Takeshitą Noboru do sławnego koła oratorskiego w czasie wspólnych studiów na Uniwersytecie Waseda, o tyle Koizumi nie posiadał takich powiązań z liderem frakcji-hegemona. Przez całą swoją polityczną karierę przeciwstawiał się frakcji Tanaki-Takeshity-Obuchiego-Hashimoto. W 1976 roku zbuntował się nawet przeciwko swojemu oyabunowi Fukudzie Takeo, gdy ten wszedł w sekretne porozumienie z Tanaką Kakueiem i Ōhirą Masayoshim. Koizumi uważał, że należy do końca wspierać premiera Mikiego oraz jego plany odnowy partyjnej i walki z korupcją. Z kolei na początku lat 90. XX wieku zawiązał razem z Yamasakim Taku z frakcji Watanabe i Katō Kōichim z frakcji Miyazawy nieformalny ,triumwirat” zwany potocznie YKK od pierwszych liter nazwisk tworzących go polityków ${ }^{212}$. Głównym celem trzech posłów było usunięcie $\mathrm{z}$ partii wpływów dawnej frakcji Tanaki. Koizumi poświęcił temu zadaniu dużo energii i nawet pomimo braku szans na zwycięstwo zgłaszał swoje kandydatury na szefa partii w 1995 i 1998 roku, rzucając wyzwanie Hashimoto Ryūtarō i Obuchiemu Keizō ${ }^{213}$.

Czynnikiem, który wzmacniał niechęć Koizumiego do frakcji TanakiTakeshity-Obuchiego-Hashimoto była uprawiana przez nią ,polityka pieniądza”. Wielu parlamentarzystów dawnej frakcji Tanaki należało do zoku pocztowego i budowlanego, dających olbrzymie możliwości pozyskiwania funduszy oraz mobilizacji poparcia wyborczego wśród pracowników firm budowlanych i lokalnych oddziałów poczty ${ }^{214}$. Z kolei Koizumi, jako członek zoku bankowego, zabiegał o prywatyzację nieefektywnie zarządzanej poczty i utworzonych przez Tanakę Kakueia firm z sektora budowlanego. W szczególności prywatyzacja poczty, do której dążył jeszcze dziadek premiera, minister poczty Koizumi Matajirō, stała się głównym celem Koizumiego Jun'ichirō. Sam przyznaje, że już od lat 70. XX wieku nieustannie podkreślał konieczność przeprowadzenia gruntownej reformy sektora pocztowego ${ }^{215}$. Nic dziwnego, prowadzenie przez pocztę kont oszczędnościowych stało $\mathrm{w}$ jawnej sprzeczności z interesami zoku bankowego i Ministerstwa Finansów, gdyż nie podlegało ich kontroli ${ }^{216}$. Jednakże determinacja, z jaką nowy przewodniczący PLD dążył do prywatyzacji

\footnotetext{
${ }^{212}$ Katō Kōichi przyznaje, że solidarność triumwiratu YKK zaczęła słabnąć już od 1995 roku, gdy razem z Yamasakim nie poparł Koizumiego w wyborach na przewodniczącego PLD. Szerzej na ten temat: Katō Kōichi, Atarashiki..., s. 155-162.

${ }^{213}$ Shimizu Masato, op.cit., s. 317-357; Yayama Tarō, op.cit., s. 12-13.

${ }^{214}$ Koizumi zdawał sobie sprawę, że w niektórych okręgach wyborczych osoby zatrudnione na poczcie potrafiły zapewnić wsparcie nawet 10-tysięcznego elektoratu, którego politycy nie mogli zignorować. Mimo to był zdeterminowany, by sprywatyzować pocztę. Szerzej na ten temat: Yūsei min'eika ron. Nihon saisei no daikaikaku pod red. Koizumiego Jun'ichirō i Matsuzawy Shigefumiego, PHP Kenkyūjo, Tokio 1999, s. 211-212.

${ }^{215}$ Koizumi Jun'ichirō, Koizumi Jun'ichirō no bōron - seiron, Shūeisha, Tokio 2001, s. 11.

${ }^{216}$ Sam Koizumi zaprzecza jednak, by dążył do prywatyzacji poczty w celu promocji interesów zoku finansowego, do którego należał. Podkreśla, że głosił hasła usunięcia wpływu na proces ustawodawczy wszystkich biurokratów, również tych z Ministerstwa Finansów. Szerzej na ten temat: idem, Kanryō ōkoku kaitairon. Nihon no kiki o sukuu hō, Kōbunsha, Tokio 1996, s. 5.
} 
poczty, była czymś nietypowym w świecie polityki. Koizumi przyznawał, że niezależnie od okoliczności polityk powinien dążyć do spełnienia swoich obietnic wyborczych ${ }^{217}$. Nieustępliwość i niechęć do ulegania wpływom z zewnątrz były dominującymi cechami charakteru nowego szefa partii, które ujawniły się także w sferze dyplomacji. Uchiyama Yū nazywa wręcz Koizumiego Jun'ichirō ,patetycznym premierem” (patosu no shushō), ponieważ przedkładał on własne przekonania, osobiste cele i ,politykę idei” (aidia no seiji) nad rację stanu i ,politykę interesu” (rieki no seiji) ${ }^{218}$.

Jak widać, chociaż Koizumi nie posiadał jasno określonych poglądów na temat polityki wobec Chin, jego cechy charakteru, powiązania personalne oraz przekonania na temat polityki wewnętrznej pośrednio warunkowały dyplomację Japonii wobec krajów Azji Wschodniej. W szczególności zapowiedź corocznych wizyt w świątyni Yasukuni miała się okazać głównym czynnikiem wpływającym na atmosferę w relacjach japońsko-chińskich. Koizumi nie byłby jednak w stanie skutecznie narzucać swojej woli partii, gdyby nie reforma instytucjonalna, którą przygotowano jeszcze za kadencji Hashimoto Ryūtarō. Szczególnie utworzenie Biura Gabinetu (Naikakufu) wyposażyło premiera w nowe instrumenty władzy, które $\mathrm{w}$ połączeniu $\mathrm{z}$ jego popularnością medialną i nietuzinkowym charakterem stworzyły idealne warunki do dalszego osłabienia wpływów frakcji w PLD. Koizumi musiał się opierać na takich metodach, gdyż spośród wewnątrzpartyjnych grup wspierały go tylko frakcje Moriego i jednego z członków dawnego triumwiratu YKK, Yamasakiego Taku ${ }^{219}$.

Zachowanie Koizumiego odbiegało od sposobu rządzenia poprzednich przewodniczących PLD. O ile dotychczasowi szefowie partii poświęcali wiele energii utrzymywaniu równowagi pomiędzy frakcjami, Koizumi zdawał się w ogóle lekceważyć istnienie tych grup ${ }^{220}$. W przeciwieństwie do Moriego, nigdy nie przykładał wagi do rekrutacji własnych kobunów $w^{221}$. Objąwszy stanowisko premiera odmówił uwzględnienia frakcyjnych rekomendacji przy formowaniu gabinetu i na wiele urzędów mianował młodych, bezfrakcyjnych polityków. Wyróżnione w ten sposób osoby były lojalne bezpośrednio wobec szefa rządu, a nie swoich oyabunów $w^{222}$. Zamiast dbać o wewnątrzpartyjną harmonię, Koizumi zadeklarował, iż doprowadzi do gruntownej reformy PLD, choćby to miało oznaczać zniszczenie tego ugrupowania ${ }^{223}$. Nie będąc ograniczanym koniecz-

\footnotetext{
${ }^{217}$ Koizumi Jun'ichirō, Koizumi..., s. 34-35.

${ }^{218}$ Uchiyama Yū, op.cit., s. 176-182.

${ }^{219}$ Honzawa Jirō, Habatsu no shüen..., s. 21.

${ }^{220} \mathrm{Z}$ drugiej strony, Nonaka Naoto podkreśla, że przed zostaniem premierem również Koizumi uprawiał politykę frakcyjną. Był lojalnym członkiem dawnej frakcji Fukudy, zaś hasło rozwiązania frakcji stanowiło jedynie środek walki z dawną frakcją Tanaki. Szerzej na ten temat: Nonaka Naoto, op.cit., s. 60-77.

${ }^{221}$ Honzawa Jirō, Habatsu no shūen..., s. 26.

${ }^{222}$ Uchiyama Yū, op.cit., s. 14-34.

${ }^{223}$ Shimizu Masato, op.cit., s. 243.
} 
nością szukania wewnątrzpartyjnego konsensusu, Koizumi nie zamierzał iść na kompromis także $\mathrm{w}$ sprawie swoich wyborczych obietnic, w tym wizyt w świątyni Yasukuni.

\section{Stosunki japońsko-chińskie w cieniu wizyt w świątyni Yasukuni}

Według Uchiyamy Yū, w przeciwieństwie do dobrze przemyślanej polityki wewnętrznej, polityka zagraniczna Koizumiego była pozbawiona wymiaru strategicznego. Osobiste przekonanie premiera, iż niezależnie od okoliczności należy spełniać obietnice wyborcze, jak też upór w dążeniu do celu, były konieczne do narzucenia partii prywatyzacji poczty, ale przyniosły tragiczne skutki w sferze dyplomacji. Obliczony na utrzymanie wysokiego poparcia opinii publicznej „patos” i populizm Koizumiego stanowiły olbrzymią przeszkodę w prowadzeniu racjonalnej polityki zagranicznej ${ }^{224}$. Wizyt w świątyni Yasukuni nie da się wytłumaczyć jedynie presją Nihon Izokukai, gdyż z powodu wymierania jej członków (głównie wdów po żołnierzach poległych w czasie wojny) wpływy tej organizacji były znacznie mniejsze niż np. za kadencji Nakasone ${ }^{225}$. Decydującym czynnikiem była raczej osobowość premiera.

Ministrem spraw zagranicznych w nowym rządzie została Tanaka Makiko, córka Tanaki Kakueia, która w trakcie kampanii wyborczej w kwietniu 2001 roku walnie przyczyniła się do zwycięstwa Koizumiego nad Hashimoto. Tanaka podzielała niechęć premiera do byłej frakcji Takeshity-Obuchiego, gdyż pamiętała zdradę, jakiej dopuścił się Takeshita Noboru wobec jej ojca w 1985 roku $^{226}$. Po ojcu odziedziczyła bardzo dobre relacje z władzami w Pekinie. W grudniu 2001 roku stwierdziła nawet, że Tajwan powinien podzielić los Hongkongu, co od razu spotkało się z pochwałą ze strony ChRL ${ }^{227}$. Jednakże ze względu na upór Koizumiego w sprawie świątyni Yasukuni, Tanaka Makiko nie była w stanie skutecznie działać na rzecz poprawy atmosfery w relacjach japońsko-chińskich.

W lipcu 2001 roku minister spraw zagranicznych ChRL Tang Jiaxuan w trakcie rozmów z sekretarzem generalnym PLD Yamasakim Taku oraz Tanaką Makiko przekazał stronie japońskiej, że wizyta premiera Koizumiego w kontrowersyjnej świątyni spotka się ze zdecydowaną reakcją narodu chińskiego. Kierownictwo KPCh weszło także w kontakt z innymi politykami PLD, którzy wykazywali zrozumienie dla wagi problemów historycznych. Na początku sierpnia 2001 roku Chiny odwiedziło dwóch wpływowych umiarkowanych posłów: Nonaka Hiromu z frakcji Hashimoto i Koga Makoto z frakcji Horiuchiego. Również oni usłyszeli od strony chińskiej zdecydowane żądanie rezygnacji premiera $\mathrm{z}$ wizyty $\mathrm{w}$ Yasukuni. W międzyczasie sekretarz gabinetu

\footnotetext{
${ }^{224}$ Uchiyama Yū, op.cit., s. 164-166.

225 shiji de Zhong-Ri..., s. 98.

${ }^{226}$ Asakawa Hirotada, op.cit., s. 28.

${ }^{227}$ Tanaka gaishō hatsugen o hyōka. Chūgoku gaimushō, „Yomiuri Shinbun” z 28 XII 2001, s. 2.
} 
Koizumiego, Fukuda Yasuo, skontaktował się z byłym ambasadorem Japonii w ChRL, Tanino Sakutarō. Tanino doradził, by premier odwiedził świątynię już po rocznicy kapitulacji Japonii w celu złagodzenia chińskiej reakcji. Za namową Fukudy, Koizumi przystał na tę propozycję i potajemnie przekazał władzom w Pekinie, że do wizyty w Yasukuni dojdzie 17 sierpnia 2001 roku $^{228}$.

Ponieważ jednak oficjalnie nadal podawano zamiar wizyty 15 sierpnia, dwóch dawnych najbliższych współpracowników Koizumiego, Yamasaki Taku i Katō Kōichi, postanowiło przekonać premiera do zmiany planów. Używając własnych kontaktów w Chinach Katō doszedł do wniosku, że przekładając wizytę na święto zmarłych 13 sierpnia 2001 roku da się władzom w Pekinie szansę na „zachowanie twarzy”. Co prawda Katō Kōichi po swoim buncie przeciw Moriemu w 2000 roku stracił wpływy w partii i znacząco pogorszył stosunki ze wspierającym Moriego Koizumim, ale poprzez pośrednictwo Yamasakiego starał się wykorzystać dawną przyjaźń w ramach triumwiratu YKK do promocji stosunków japońsko-chińskich. Za radą Katō i Yamasakiego, Koizumi nakazał Fukudzie zmianę daty wizyty z 17 na 13 sierpnia. Wywołało to pewne zamieszanie, gdyż już wcześniej przekazano stronie chińskiej, że premier odwiedzi Yasukuni dwa dni po rocznicy kapitulacji ${ }^{229}$.

Ostatecznie Koizumi złożył wizytę w kontrowersyjnej świątyni 13 sierpnia 2001 roku. Nie podał, czy dokonał tego oficjalnie, czy prywatnie. Po wizycie Fukuda Yasuo wydał oświadczenie, w którym m.in. ujawnił, że rząd bada możliwość budowy nowego miejsca żałoby po żołnierzach poległych w czasie II wojny światowej. Był to środek, by ChRL i Korea Południowa złagodziły swoje protesty. Jednakże władze w Pekinie zdecydowanie potępiły zachowanie premiera Japonii. Z drugiej strony, fakt że Koizumi zrezygnował z wizyty 15 sierpnia, częściowo łamiąc własną obietnicę wyborczą, umożliwił tymczasową poprawę w relacjach japońsko-chińskich ${ }^{230}$.

W październiku 2001 roku premier odwiedził ChRL. Symbolicznym gestem była wizyta w Muzeum Wojny Chińsko-Japońskiej przy Moście Marco Polo pod Pekinem. Koizumi przyznał wówczas: „Oglądałem wystawę z poczuciem żalu i szczerych przeprosin wobec ludzi, którzy stali się ofiarami dawnej wojny i agresji" ${ }^{231}$. Jednocześnie podkreślił, że Japonia zamierza odpowiedzieć na wyzwania terroryzmu po zamachach 11 września 2001 roku w USA z poszanowaniem dotychczasowych zasad nieuczestniczenia w konfliktach zbrojnych ${ }^{232}$.

\footnotetext{
${ }^{228}$ Yomiuri Shinbun Seijibu, op.cit., s. 223-227.

${ }^{229}$ Ibidem, s. 227-230.

${ }^{230}$ Ibidem, s. 231-233.

${ }^{231}$ Uchiyama Yū, op.cit., s. 137.

${ }^{232} \mathrm{~W}$ dniu 11 września 2001 roku terroryści z organizacji fundamentalistów islamskich Al-Kaida zorganizowali serię zamachów terrorystycznych na wielką skalę. Używając porwanych samolotów doprowadzili m.in. do zawalenia się dwóch wieżowców World Trade Center w Nowym Jorku, jak też częściowego zniszczenia siedziby sztabu amerykańskiej armii, Pentagonu. Japonia jeszcze w 2001 roku wysłała flotę Sił Samoobrony na Ocean Indyjski do logistycznego wspierania operacji
} 
Jiang Zemin wyraził zrozumienie dla pogłębienia japońsko-amerykańskiej współpracy w zwalczaniu terroryzmu ${ }^{233}$, ale ostrzegł też, że narody Azji są wrażliwe na zmiany w polityce obronnej Japonii ${ }^{234}$. Z kolei Koizumi wyraził nadzieję, iż stosunki japońsko-chińskie będą tak dobre, jak relacje między władzami w Tokio a innym państwem, które niegdyś toczyło wojnę z Japonią, Stanami Zjednoczonymi. Jiang jednak przypomniał o problemie wizyt $\mathrm{w}$ Yasukuni i japońskich podręczników do historii, które stanowią przeszkodę w stosunkach bilateralnych. Mimo wszystko, słysząc zapewnienia Koizumiego o pacyfistycznej polityce Japonii, przewodniczący ChRL nie zażądał explicite rezygnacji z wizyty w kontrowersyjnej świątyni w następnym roku i spotkanie zakończyło się $w$ przyjaznej atmosferze. Nie oznaczało to jednak, by strona chińska zmieniła stanowisko w sprawie Yasukuni. Władze w Pekinie oczekiwały, że Koizumi postąpi tak, jak przed laty Nakasone czy Hashimoto i powstrzyma się od dalszych wizyt w nacjonalistycznej świątyni ${ }^{235}$.

Dobrze układająca się współpraca bilateralna w następnych miesiącach zdawała się potwierdzać, że w relacjach między oboma krajami nastało odprężenie. W październiku 2001 roku Koizumi ponownie spotkał się z przewodniczącym Jiangiem na szczycie APEC w Szanghaju. Wyszedł wówczas z inicjatywą pogłębienia dwustronnej wymiany politycznej, gospodarczej, kulturalnej i gospodarczej przy okazji przypadających w następnym roku obchodów 30. rocznicy nawiązania stosunków dyplomatycznych. Równocześnie strona chińska zaczęła zabiegać o wizytę w ChRL japońskiego następcy tronu. Z kolei na forum gospodarczym na wyspie Hainan w połowie kwietnia 2002 roku Koizumi Jun'ichirō oświadczył, że chociaż istnieje tendencja postrzegania chińskiego wzrostu gospodarczego jako zagrożenia, jego zdaniem dla Japonii jest on raczej wyzwaniem i szansą. Wystąpienie to bardzo spodobało się premierowi Zhu Rongjiemu, który w dobrym humorze zaprosił Koizumiego do Pekinu we wrześniu 2002 roku $^{236}$.

Atmosfera odprężenia w relacjach japońsko-chińskich znikła nagle 21 kwietnia 2002 roku, kiedy Koizumi Jun'ichirō po raz drugi odwiedził świątynię Yasukuni. Uczynił to z zaskoczenia, bez żadnych wcześniejszych konsultacji z Ministerstwem Spraw Zagranicznych czy nawet z sekretarzem swojego gabinetu,

wojsk USA w Afrganistanie, zaś po obaleniu reżimu Saddama Husajna w 2003 roku zadecydowała o skierowaniu w 2004 roku sił lądowych do Iraku. Szerzej na ten temat: Li Jianmin, op.cit., s. 233-235; Liu Qingcai, Gao Ke et al., op.cit., s. 173-181.

${ }^{233}$ Chociaż Chiny zwykle spoglądały z zaniepokojeniem na zmiany w polityce bezpieczeństwa Japonii, w przypadku walki $\mathrm{z}$ międzynarodowym terroryzmem zachowały powściągliwość $\mathrm{w}$ krytyce władz w Tokio. Wynikało to z faktu, że także ChRL miała problem z terroryzmem islamskim. Szerzej na ten temat: Inoguchi Takashi, Kokusai seiji no mikata - 9.11 go no Nihon gaikō, Chikuma Shobō, Tokio 2005, s. 73.

${ }^{234}$ Uchiyama Yū, op.cit., s. 138.

${ }^{235}$ Yomiuri Shinbun Seijibu, op.cit., s. 236-237.

${ }^{236}$ Ibidem, s. 237-241. 
Fukudą Yasuo. Jak później tłumaczył, uważał, że to najlepszy moment, by dokonać wizyty w świątyni bez wzbudzania nadmiernych protestów za granicą. Jednakże strona chińska zdecydowanie potępiła jego zachowanie oraz odwołała wzajemne wizyty wysokich urzędników resortów obrony. Szczególnie premier Zhu Rongji „stracił twarz”, gdyż w KPCh obwiniano go o to, że nie postawił jasno sprawy Yasukuni w trakcie spotkania na wyspie Hainan. O gniewie Jiang Zemina przekonał się w trakcie wizyty w Pekinie pod koniec kwietnia 2002 roku Kanzaki Takenori, przewodniczący pozostającego w koalicji z PLD ugrupowania Kōmeitō ${ }^{237}$. Druga wizyta Koizumiego w kontrowersyjnej świątyni wyraźnie pokazała, że jego przypadek zdecydowanie różni się od zachowania Nakasone czy Hashimoto. O ile ci dwaj premierzy musieli dbać o delikatną równowagę wewnątrzpartyjną, Koizumi nie miał takich problemów. Deklarując, że dąży do zniszczenia PLD mógł ignorować głos obozu propekińskiego, jak też koalicyjnych partnerów, nie ponosząc przy tym poważniejszych konsekwencji. Na dodatek, w styczniu 2002 roku Tanaka Makiko została odwołana ze stanowiska ministra spraw zagranicznych. Zastąpiła ją była biurokratka Kawaguchi Yoriko, która nie miała równie dobrych relacji personalnych z władzami w Pekinie.

Jeszcze nie opadł głos krytyki po wizycie premiera Japonii w Yasukuni, a doszło do kolejnego incydentu w relacjach japońsko-chińskich. W maju 2002 roku chińskie służby porządkowe wtargnęły do japońskiego konsulatu w mieście Shenyang, by siłą wyprowadzić pięciu północnokoreańskich uchodźców. Chociaż po protestach rządu w Tokio władze KPCh pozwoliły uchodźcom udać się przez Filipiny do Korei Południowej, rozpoczęty drugą wizytą Koizumiego w Yasukuni stan napięcia między oboma krajami jeszcze się pogłębił. Uroczyście zapowiadane obchody 30. rocznicy nawiązania stosunków dyplomatycznych nie przyniosły poprawy sytuacji. Straciwszy zaufanie do japońskiego premiera, strona chińska cofnęła nawet zaproszenie dla niego na wrześniowe uroczystości w Pekinie. Aż do końca kadencji Koizumi miał już nie udać się do $\operatorname{Chin}^{238}$.

W październiku 2002 roku Koizumi Jun'ichirō spotkał się natomiast z Jiang Zeminem na szczycie APEC w Los Cabos w Meksyku. Przewodniczący ChRL przypomniał o japońskim ekspansjonizmie w czasie II wojny światowej i dał wyraźnie do zrozumienia, że rozwój przyjaznych stosunków chińsko-japońskich nie będzie możliwy w razie kontynuacji przez premiera Japonii wizyt w świątyni Yasukuni. Koizumi był jednak nieustępliwy, mówiąc: „Odwiedzam [Yasukuni przyp. aut.] w poczuciu, że nie można drugi raz doprowadzić do wojny, jak też

\footnotetext{
${ }^{237}$ Jiang Zemin nazwał wówczas postępowanie Koizumiego czynem „,nie do wybaczenia” (bu neng yuanliang), co w rozmowach dyplomatycznych jest bardzo silnym sformułowaniem. Szerzej na ten temat: Shimizu Yoshikazu, Chūgoku ga „hannichi” o suteru hi, Kōdansha, Tokio 2006, s. 93; Yomiuri Shinbun Seijibu, op.cit., s. 241-244.

${ }^{238}$ Uchiyama Yū, op.cit., s. 139-140.
} 
w celu wyrażenia żałoby po ludziach, którzy poszli na pole bitwy wbrew własnej woli" 239 . W grudniu 2002 roku okazało się także, że budowa nowego miejsca poświęconego pamięci poległych żołnierzy nie będzie łatwym zadaniem. Pomysł promowany przez Fukudę Yasuo napotkał na opór ze strony ,jastrzębi” z PLD, jak też Nihon Izokukai. Koga Makoto z frakcji Horiuchiego, który właśnie został przewodniczącym tej organizacji, apelował do premiera o porzucenie projektu budowy ośrodka mającego być substytutem kontrowersyjnej świątyni. Zresztą również Koizumi był zdania, że trudno jest zastąpić Yasukuni innym obiektem $^{240}$.

Do trzeciej wizyty Koizumiego w kontrowersyjnej świątyni doszło w połowie stycznia 2003 roku. Widać było, że premier wciąż poszukiwał daty, która by wywołała jak najmniejszy oddźwięk za granicą. Zresztą chciał odwiedzić Yasukuni jeszcze przed zapowiadanym na marzec 2003 roku objęciem stanowiska przewodniczącego ChRL przez Hu Jintao ${ }^{241}$. Zarówno Chiny, jak Korea Południowa zdecydowanie potępiły zachowanie japońskiego premiera ${ }^{242}$. Niemniej jednak przejęcie władzy w ChRL przez Hu Jintao stało się dobrą okazją do ocieplenia atmosfery w relacjach wzajemnych. Koizumi po raz pierwszy spotkał się z nowym przewodniczącym ChRL już w maju 2003 roku na szczycie w Sankt Petersburgu w Rosji. Hu Jintao nie wspomniał o problemie Yasukuni i zdawał się bardziej skupiać na przyszłości współpracy chińskojapońskiej niż na kwestiach historycznych. Obie strony zgodziły się na powołanie do życia Nowego Komitetu Chińsko-Japońskiej Przyjaźni w XXI wieku, nawiązując do inicjatywy Nakasone Yasuhiro i Hu Yaobanga z 1983 roku, która została przerwana pod koniec lat $80 . \mathrm{XX}$ wieku ${ }^{243}$.

Kolejnym dowodem na relatywne polepszenie atmosfery $w$ relacjach bilateralnych były obchody 25 . rocznicy podpisania Traktatu o pokoju i przyjaźni. W sierpniu 2003 roku do Pekinu przyjechali byli premierzy Hashimoto Ryūtarō i Murayama Tomiichi, jak też synowie premiera i ministra spraw zagranicznych sprzed 25 lat: sekretarz gabinetu Fukuda Yasuo z frakcji Moriego oraz Sonoda Hiroyuki z frakcji Ozato ${ }^{244}$. W oficjalnych przemówieniach uniknięto nawiązań do problemów historycznych, ale w rozmowie $\mathrm{z}$ Fukudą premier ChRL Wen Jiabao skrytykował upartą postawę Koizumiego w sprawie świątyni Yasukuni. Widać było, że strona chińska jest nastawiona pozytywnie do rozwoju współpracy z Japonią, ale m.in. ze względu na umacniające się uczucia antyjapońskie wśród społeczeństwa chińskiego nie

\footnotetext{
${ }^{239}$ Yomiuri Shinbun Seijibu, op.cit., s. 247.

${ }^{240}$ Ibidem, s. 248.

${ }^{241} \mathrm{~W}$ listopadzie 2002 roku Hu Jintao przejął od Jiang Zemina stanowisko sekretarza generalnego KPCh.

${ }^{242}$ Uchiyama Yū, op.cit., s. 140-141.

${ }^{243}$ Shimizu Yoshikazu, op.cit., s. 101-106.

${ }^{244}$ Fukuda chōkan ga hōchū - Heiwa yūkō jōyaku 25-shūnen, tasaina kaobure, Chūgoku gawa shōtai, ,Nihon Keizai Shinbun” z 10 VIII 2003, s. 2.
} 
mogła lekceważyć problemów związanych z pamięcią historyczną. W dniu 7 października 2003 roku Wen Jiabao spotkał się z Koizumim Jin'ichirō w trakcie szczytu przywódców Japonii, Chin i Korei Południowej na wyspie Bali w Indonezji. Politycy z trzech państw podpisali wówczas deklarację o rozwoju szeroko rozumianej współpracy trójstronnej. Stronę japońską zaskoczyła postawa premiera ChRL, który nie dość, że nie wspomniał o problemie Yasukuni, to nawet wyraził chęć wznowienia wzajemnych wizyt urzędników najwyższego szczebla ${ }^{245}$.

Atmosfera odprężenia zakończyła się jednak już następnego dnia. Koizumi Jun'ichirō w rozmowie z dziennikarzami 8 października 2003 roku powiedział, iż zamierza kontynuować coroczne odwiedzanie kontrowersyjnej świątyni. $\mathrm{Na}$ dodatek dodał: „To już zostało zrozumiane. Nie stanowi przeszkody dla

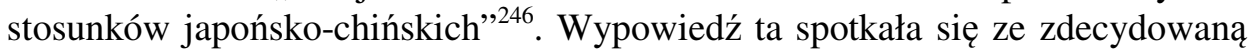
reakcją rządu w Pekinie, gdyż dawała do zrozumienia, że strona chińska zmieniła zdanie na temat wizyt w Yasukuni. Władze KPCh zaprzeczyły, by Wen Jiabao poszedł $\mathrm{w}$ rozmowie $\mathrm{z}$ Koizumim na jakiekolwiek ustępstwa $\mathrm{w}$ tej sprawie $^{247}$. Podobnie jak w kwietniu 2002 roku Koizumi wystawił na krytykę Zhu Rongjiego, tak teraz naraził następnego premiera ChRL na „utratę twarzy”. Po tym incydencie zarówno Wen Jiabao, jak i cała administracja Hu Jintao usztywniła stanowisko w sprawie problemów historycznych ${ }^{248}$.

Do czwartej wizyty Koizumiego w Yasukuni doszło w Nowy Rok 2004 roku. Jak zwykle, spotkało się to ze zdecydowanym protestem ChRL i Korei Południowej $^{249}$. Strona chińska odbierała kolejne wizyty japońskiego premiera $\mathrm{w}$ kontrowersyjnej świątyni jako prowokacje. Mimo że wzajemne stosunki gospodarcze rozwijały się bardzo dobrze, nieustępliwa postawa Koizumiego w sprawie problemów historycznych zaczęła negatywnie wpływać także na los japońskich inwestycji w ChRL. Najlepszym przykładem była kwestia budowy w Chinach sieci szybkiej kolei. Chociaż od 2002 roku władze w Pekinie skłaniały się ku technologii oferowanej przez Japonię (shinkansen), po trzeciej wizycie

\footnotetext{
${ }^{245}$ Yomiuri Shinbun Seijibu, op.cit., s. 252-253.

${ }^{246}$ Ibidem, s. 253-254.

${ }^{247}$ Ibidem, s. 254.

${ }^{248}$ Władze w Pekinie nie mogły pójść na kompromis w kwestii wizyt w świątyni Yasukuni ze względu na wzrost antyjapońskich nastrojów wśród społeczeństwa chińskiego, szczególnie wśród studentów. Symbolem wrogości Chińczyków wobec Japonii był sposób, w jaki publiczność potraktowała japońskich zawodników w trakcie meczów azjatyckich zawodów piłki nożnej w ChRL w 2004 roku. Piłkarze zostali wygwizdani i poniżeni przez chińską widownię. Coraz częściej dochodziło też do antyjapońskich demonstracji i zamieszek, wywołanych przez na pozór błahe incydenty. Shimizu Yoshikazu zwraca też uwagę, że chińska polityka wobec Japonii stała się jednym z narzędzi rywalizacji o władzę w KPCh. „Grupa szanghajska” związana z Jiang Zeminem miała wykorzystywać antyjapońskie nastroje do poddawania w wątpliwość autorytetu projapońsko nastawionego prezydenta Hu. Szerzej na ten temat: Shimizu Yoshikazu, op.cit., s. 118-222; Mōri Kazuko, op.cit., s. 189-190.

${ }^{249}$ Uchiyama Yū, op.cit., s. 142.
} 
Koizumiego w Yasukuni zaczęły dawać do zrozumienia, że będzie trudno usprawiedliwić wobec społeczeństwa chińskiego tak wielką inwestycję japońską, jeśli władze w Tokio nie zmienią podejścia do problemów historycznych ${ }^{250}$. Nie pomógł nawet lobbing w Pekinie ze strony Fukudy Yasuo czy Nonaki Hiromu. Koizumi był głuchy na głos japońskich przedsiębiorców i nie zamierzał zmieniać swojego postanowienia w sprawie wizyt w Yasukuni ${ }^{251}$.

Mori Yoshirō tłumaczy, że wizyty Koizumiego w Yasukuni wcale nie miały na celu pogorszenia stosunków japońsko-chińskich. Podkreśla, iż wszakże nie tylko znienawidzony przez Koizumiego propekiński Tanaka Kakuei, ale także dawny oyabun Koizumiego, Fukuda Takeo, był w latach 70. XX wieku współautorem zbliżenia z ChRL ${ }^{252}$. Z drugiej strony, nawet taki ,jastrząb” jak Mori nie mógł zrozumieć, dlaczego Koizumi tak bardzo uparł się, by corocznie odwiedzać Yasukuni. Według Moriego czym innym jest „potrzeba serca”, a czym innym konieczność elastycznego dostosowywania się do sytuacji międzynarodowej ${ }^{253}$. Podobne stanowisko reprezentował były premier Nakasone Yasuhiro, który do 2003 roku zachował mandat poselski. Według niego Japonia powinna nawiązać bliższy dialog z Chinami i dążyć do kompromisu z tym państwem w sprawie kontrowersyjnej świątyni. Nakasone ostrzegał także przed skrajnie nacjonalistycznymi przedsięwzięciami, podejmowanymi jedynie dla utrzymania się u władzy lub zdobycia poparcia społecznego ${ }^{254}$. Stanowisko Moriego i Nakasone, dwóch czołowych ,jastrzębi” w partii, pokazuje, jak bardzo nietypowe było zachowanie Koizumiego. Jego upór w kontynuacji wizyt w Yasukuni wywołał zaniepokojenie nawet u części prawego skrzydła PLD.

Tymczasem ponownie dał o sobie znać spór terytorialny na Morzu Wschodniochińskim. W sierpniu 2003 roku ChRL zaczęła planować budowę platform wiertniczych, z których jedna miała być położona zaledwie kilka kilometrów od linii środkowej, uważanej przez Japonię za granicę między wyłącznymi strefami ekonomicznymi obu państw. Japonia zareagowała bardzo stanowczo, żądając zaprzestania tego przedsięwzięcia ze względu na możliwość „wysysania” złóż z części szelfu kontynentalnego usytuowanej na wschód od mediany ${ }^{255}$. W marcu 2004 roku na wyspach Senkaku/Diaoyutai wylądowała grupa chińskich nacjonalistów. Zostali oni aresztowani przez japońską straż

\footnotetext{
${ }^{250}$ W 2003 roku prawicowa chińska organizacja Liga Patriotów (Aiguozhe Tongmeng) rozpoczęła akcję zbierania w Internecie podpisów pod petycją, w której żądano rezygnacji z oferty japońskiej. Szerzej na ten temat: Shimizu Yoshikazu, op.cit., s. 113.

${ }^{251}$ Yomiuri Shinbun Seijibu, op.cit., s. 254-258.

${ }^{252}$ Mori Yoshirō. Jimintō..., s. 206.

${ }^{253}$ Ibidem, s. 281-282.

${ }^{254}$ Nakasone Yasuhiro, Nishibe Susumu, Matsui Takafumi, Matsumoto Ken'ichi, op.cit., s. 126127.

${ }^{255}$ James C. Hsiung, Sea Power, the Law of the Sea, and the Sino-Japanese East China Sea “Resource War”, ,American Foreign Policy Interests” 2005, vol. 27, no. 6, s. 518.
} 
przybrzeżną, ale kilka dni później dokonano ich ekstradycji pod wpływem protestów władz w Pekinie ${ }^{256}$.

Coraz większa liczba incydentów na Morzu Wschodniochińskim skłoniła „jastrzębie” w PLD do nasilenia działalności. W październiku 2004 roku rozpoczęto rozmowy na temat ewentualnej wspólnej eksploatacji surowców energetycznych akwenu, jednak nie przyniosły one żadnych rezultatów. Minister gospodarki i przemysłu Nakagawa Shōichi skrytykował Chiny za ignorowanie głosu władz w Tokio w tej sprawie ${ }^{257}$. Z kolei w listopadzie 2004 roku japońska marynarka została postawiona $\mathrm{w}$ stan alarmu, gdy wody terytorialne Japonii naruszyła w pobliżu wysp Riukiu chińska atomowa łódź podwodna. ChRL oświadczyła, że okręt zabłąkał się na japońskie wody z powodu „błędu technicznego" i dopiero po zdecydowanym proteście ministra spraw zagranicznych Machimury Nobutaki wyraziła żal z powodu tego zdarzenia. Incydent spowodował dalszy spadek zaufania $w$ stosunkach wzajemnych, jak też osłabienie wpływów w PLD obozu propekińskiego, oskarżanego przez ,jastrzębi” o zbytnią uległość wobec prowokacyjnych inicjatyw ChRL ${ }^{258}$.

Jak widać, cztery kolejne wizyty Koizumiego w Yasukuni doprowadziły relacje japońsko-chińskie do stanu najgorszego od czasu normalizacji stosunków dyplomatycznych w 1972 roku. Chociaż nie wszystkie spory w relacjach bilateralnych zostały spowodowane problemem Yasukuni, kwestie historyczne uczyniły je trudniejszymi do rozwiązania i pobudziły do działania zarówno chińskich, jak japońskich nacjonalistów. Władze KPCh niejednokrotnie dawały do zrozumienia, że tę nienaturalną sytuację da się łatwo zażegnać, jeśli tylko premier Japonii zrezygnuje z odwiedzania kontrowersyjnej świątyni. Przyzwyczajony do nieulegania zewnętrznym wpływom Koizumi nie zamierzał jednak słuchać władz w Pekinie w sprawie, do której podchodził w bardzo osobisty i emocjonalny sposób. Kulminacja kryzysu wywołanego nieustępliwą postawą „patetycznego premiera” miała nastąpić w 2005 roku, na który przypadały obchody 60. rocznicy zakończenia II wojny światowej.

\section{Kryzys 2005 roku i zakończenie pomocy rozwojowej dla Chin}

Pod koniec 2004 roku władze w Pekinie i reprezentanci obozu propekińskiego w PLD nasilili działania $w$ celu przekonania japońskiego premiera do porzucenia zamiaru wizyty w Yasukuni w rocznicowym 2005 roku. Jeszcze w 2003 roku marszałkiem Izby Reprezentantów został Kōno Yōhei. Kōno przyznaje, że pomimo ciężkiego stanu zdrowia postanowił nie przechodzić jeszcze na emeryturę ze względu na konieczność walki z ,nagłym wzrostem popularności poglądów nacjonalistycznych w nurcie polityki krajowej, który byłby nie do

\footnotetext{
${ }^{256}$ Uchiyama Yū, op.cit., s. 142.

${ }^{257}$ Ibidem.

${ }^{258}$ Yomiuri Shinbun Seijibu, op.cit., s. 262-265.
} 
pomyślenia 10 lat wcześniej”,259. We wrześniu 2004 roku Kōno Yōhei spotkał się w Pekinie z przewodniczącym ChRL. Hu Jintao, po raz pierwszy w rozmowie z japońskim politykiem, wyraźnie odniósł się wówczas do problemu kontrowersyjnej świątyni ${ }^{260}$. W październiku 2004 roku Kōno spotkał się w tej sprawie z premierem. Argumentował, iż problem Yasukuni jest tak naprawdę jedyną poważną przeszkodą w poprawie relacji japońsko-chińskich i nie warto dla niego narażać na szwank stosunków z ChRL. Jednakże Kōno nie był w stanie nakłonić Koizumiego do zmiany stanowiska ${ }^{261}$.

W listopadzie 2004 roku Koizumi Jun'ichirō spotkał się z Hu Jintao na szczycie APEC w Santiago de Chile. Stosunki między oboma krajami znajdowały się $w$ tak złym stanie, że do ostatniej chwili nie było wiadomo, czy strona chińska w ogóle zgodzi się na tę rozmowę. Chiny obawiały się, iż znowu dojdzie do nieporozumienia podobnego do tego po spotkaniu na wyspie Bali rok wcześniej. W rozmowie z Koizumim przewodniczący ChRL przyznał, że współpraca gospodarcza między oboma krajami rozwija się bardzo dobrze, ale jednocześnie podkreślił, iż przyczyną zastoju w relacjach politycznych są wizyty w Yasukuni. Zwrócił przy tym uwagę, że nadchodzący rok 2005 będzie „wrażliwy” na problemy historyczne ze względu na 60. rocznicę zwycięstwa nad faszyzmem ${ }^{262}$.

Obawy Hu Jintao potwierdziły się. Jeszcze pod koniec 2004 roku doszło do incydentu, który miał okazać się początkiem całej serii wydarzeń niesprzyjających atmosferze przyjaźni w relacjach japońsko-chińskich. Japonię po raz drugi odwiedził Li Denghui. Li starał się o japońską wizę jeszcze w listopadzie 2002 roku, ale odmówiono mu jej wówczas decyzją premiera ${ }^{263}$. Widać było, że Koizumi miał zupełnie inne priorytety od Moriego, który wiele zrobił dla promocji wizyty Li Denghuia w Japonii w 2001 roku. Kiedy jednak w 2003 roku Yamasakiego Taku zastąpił na fotelu sekretarza generalnego PLD protajwańsko usposobiony Abe Shinzō, sytuacja zaczęła sprzyjać wydaniu wizy. W sierpniu 2004 roku presję na Abe w tej sprawie wywarł Hiranuma Takeo ${ }^{264}$. Ostatecznie wiza została wydana i były prezydent Tajwanu spędził w celach turystycznych w Japonii wraz z rodziną kilka dni na przełomie 2004 i 2005 roku. Sekretarz gabinetu Hosoda Hiroyuki oświadczył przy tym, że Japonia nie wspiera niepodległości Tajwanu, zaś minister spraw zagranicznych Machimura Nobutaka zakazał parlamentarzystom z PLD spotykania się z Li Denghuiem. Tym razem były prezydent Tajwanu miał więcej swobody w zwiedzaniu Japonii niż

\footnotetext{
${ }^{259}$ Kōno Yōhei, Kōno Tarō, op.cit., s. 115.

${ }^{260}$ Shimizu Yoshikazu, op.cit., s. 167.

${ }^{261}$ Yomiuri Shinbun Seijibu, op.cit., s. 258-260.

${ }^{262}$ Ibidem, s. 261-268.

${ }^{263}$ Ri-shi biza hakkyū mondai, Koizumi shushō ga fukyoka ketsudan. Nitchū kankei issō no akka kenen, „Yomiuri Shinbun” z 15 XI 2002, s. 4.

${ }^{264}$ Taiwan no Ri Tōki zen sōtō, raigetsu hōnichi o kibō Hiranuma Takeo-shi ga Abe kanjichō ni kyōryoku yōsei, ,Yomiuri Shinbun” z 25 VIII 2004, s. 7.
} 
poprzednio, ale nakazano mu powstrzymać się od wykładów, konferencji prasowych i rozmów z politykami. Jak zwykle jednak władze w Pekinie zdecydowanie zaprotestowały przeciw wydaniu wizy, zawieszając przy tym wzajemne wizyty urzędników państwowych wysokiego szczebla ${ }^{265}$.

W trakcie kadencji Koizumiego Jun'ichirō coraz więcej polityków z PLD zaczęło domagać się zaprzestania pomocy rozwojowej dla ChRL. Argumentowali to zarówno zwiększaniem przez Chiny budżetu wojskowego, jak i trudną sytuacją finansową Japonii. W październiku 2001 roku zmieniono wytyczne w sprawie pomocy rozwojowej dla ChRL. Podkreślono wagę takich celów, jak ochrona środowiska, oraz zmieniono dotychczasową metodę przyznawania pożyczek z góry na kilka lat na coroczne określanie wysokości pomocy. Skala pożyczek $\mathrm{w}$ jenach malała odtąd $\mathrm{z}$ roku na rok, ale głos niezadowolonych $\mathrm{w}$ PLD nie ustawat ${ }^{266}$. W 2002 roku przewodniczący jednej z prawicowych frakcji, Etō Takami, nazwał japońską dyplomację uległą wobec Chin, podkreślając, że ChRL uzbraja się za środki z Japonii, a sama jest już na tyle silna, by dostarczać pomoc gospodarczą innym państwom ${ }^{267}$.

Kiedy ministrem spraw zagranicznych został we wrześniu 2004 roku Machimura Nobutaka z frakcji Moriego, szybko zaczął dawać do zrozumienia, że Chiny dojrzały już do samodzielnego wspierania swojego wzrostu gospodarczego. Również premier Koizumi, starając się ograniczać wydatki państwowe $\mathrm{w}$ ramach reformy strukturalnej, wsparł pomysł generalnej rewizji zasad przyznawania ODA ChRL. Strona japońska była niezadowolona, że chińscy obywatele nie są informowani w wystarczający sposób o tym, iż wielkie projekty budowlane w Chinach, jak lotnisko w Pekinie, zostały w dużej części sfinansowane przez pożyczki w jenach. Widząc, iż pomoc rozwojowa wcale nie przyczynia się do hamowania wzrostu antyjapońskich nastrojów w chińskim społeczeństwie, coraz więcej polityków PLD sceptycznie spoglądało na konieczność jej kontynuacji. Ostatecznie w marcu 2005 roku Machimura Nobutaka przekazał stronie chińskiej decyzję o zakończeniu pożyczek w jenach do czasu rozpoczęcia Igrzysk Olimpijskich w Pekinie w 2008 roku $^{268}$. W ten sposób usunięto najważniejszy składnik pomocy rozwojowej dla Chin. Historyczna rola pożyczek w jenach, o których zadecydował ponad ćwierć wieku wcześniej Ōhira Masayoshi, dobiegła końca.

Według Sekiyamy Takashiego, w podjęciu decyzji o przerwaniu pożyczek w ramach ODA dla Chin duże znaczenie miał czynnik personalny. Poprzedniczki Machimury na stanowisku ministra spraw zagranicznych, Tanaka Makiko i Yamaguchi Yoriko, były zwolenniczkami kontynuacji pomocy rozwojowej dla ChRL. Tanaka należała do obozu propekińskiego, zaś Kawaguchi wywodziła się

\footnotetext{
${ }^{265}$ Yomiuri Shinbun Seijibu, op.cit., s. 269-270.

${ }^{266}$ Sekiyama Takashi, op.cit., s. 102-108.

${ }^{267}$ Okada Minoru, op.cit., s. 167.

${ }^{268}$ Sekiyama Takashi, op.cit., s. 109-128.
} 
ze świata biurokracji i nie posiadała wystarczających wpływów politycznych, by przeforsować tak trudną i ważną zmianę. W przeciwieństwie do Kawaguchi, Machimura Nobutaka należał do najważniejszych polityków potężnej frakcji Moriego (w 2006 roku przejął od Moriego przewodnictwo w tej grupie). Chociaż był synem Machimury Kingo, protajwańskiego parlamentarzysty z frakcji Ishiiego, który w latach 70. XX wieku sprzeciwiał się zacieśnianiu więzów z władzami KPCh, raczej nie odziedziczył po ojcu kontaktów z rządem w Tajpej. Można go nazwać politykiem propekińskim, pełnił nawet funkcję sekretarza generalnego Parlamentarnej Ligi Przyjaźni Japońsko-Chińskiej ${ }^{269}$. Niemniej jednak Machimura należał równocześnie do obozu ,jastrzębi”. Jako członek zoku edukacji od dawna postulował rozpowszechnianie w podręcznikach takiej wersji historii, „by można być dumnym z dokonań przodków”270. Widząc, że dyskurs na temat pomocy rozwojowej dla Chin jedynie przyczynia się do wzrostu uczuć antychińskich w Japonii i antyjapońskich w ChRL, Machimura doszedł do wniosku, iż należy ten problem ostatecznie usunąć. Nawet jeśli zakończenie pożyczek w jenach krótkoterminowo wpłynęłoby na wzrost napięcia w relacjach bilateralnych, stwarzało szansę na osiągnięcie naprawdę partnerskiej współpracy w przyszłości ${ }^{271}$. Stronnictwu propekińskiemu trudno było protestować przeciw tej argumentacji nie narażając się na krytykę ze strony coraz bardziej antychińsko nastawionej opinii publicznej.

Równolegle $\mathrm{z}$ decyzją o przerwaniu pożyczek w jenach doszło do wzrostu napięcia w relacjach bilateralnych na skalę niespotykaną od rządów Satō Eisaku. $\mathrm{W}$ ujawnionych $\mathrm{w}$ grudniu 2004 roku nowych japońskich ramach polityki obronnej odniesiono się do modernizacji armii chińskiej jako potencjalnego zagrożenia. Z kolei w lutym 2005 roku przedstawiciele resortów obrony Japonii i USA wymienili wśród wspólnych celów strategicznych „pokojowe rozwiązanie problemu Tajwanu”. Władze KPCh, wrażliwe na wszelką ingerencję z zewnątrz w kwestię Tajwanu, zareagowały zdecydowanym protestem ${ }^{272}$. $\mathrm{Na}$ dodatek powrócił problem podręczników do historii. W marcu 2005 roku japońskie media podały, że podobnie jak w 2001 roku, Ministerstwo Edukacji zamierzało zatwierdzić do użytku w szkołach kontrowersyjny Nowy podręcznik do historii ${ }^{273}$. Wszystkie te czynniki nałożyły się na problemy związane $\mathrm{z}$ rezygnacją Japonii z pomocy rozwojowej dla Chin, sporem terytorialnym na Morzu Wschodniochińskim, podróżą Li Denghuia i nieugiętą postawą Koizumiego w sprawie wizyt w Yasukuni, wywołując najpoważniejszy $\mathrm{z}$ kryzysów od 1972 roku.

\footnotetext{
${ }^{269}$ Ibidem, s. 158-173.

${ }^{270}$ Machimura Nobutaka, Hoshu no ronri. Rin to shite utsukushii Nihon o tsukuru, PHP Kenkyūjo,

Tokio 2005, s. 113

${ }^{271}$ Sekiyama Takashi, op.cit., s. 173-176.

${ }^{272}$ Shimizu Yoshikazu, op.cit., s. 48-49; 21 shiji de Zhong-Ri..., s. 107.

${ }^{273}$ Mōri Kazuko, op.cit., s. 186-187; Xu Wansheng, op.cit., s. 92.
} 
W ChRL doszło do antyjapońskich demonstracji w większych miastach, a nawet do aktów wandalizmu wobec japońskiej ambasady oraz japońskich firm i restauracji. Wielką popularność zdobył również ruch zbierania podpisów przeciw uzyskaniu przez Japonię stałego miejsca w Radzie Bezpieczeństwa ONZ oraz bojkot towarów japońskich ${ }^{274}$. Kiedy w połowie kwietnia 2005 roku minister spraw zagranicznych Machimura Nobutaka odwiedził ChRL, zażądał przeprosin za te incydenty, jednak usłyszał od strony chińskiej, iż problem leży w świadomości historycznej premiera Koizumiego. Wen Jiabao ostro skrytykował zarówno wizyty w Yasukuni, jak treść japońskich podręczników do historii i nie zamierzał przepraszać za akty przemocy wobec Japończyków w Chinach $^{275}$. Podobnie zakończyło się spotkanie Koizumiego Jun'ichirō z Hu Jintao na szczycie przywódców państw Azji i Afryki w Dżakarcie w drugiej połowie kwietnia 2005 roku. Obie strony usztywniły swoje stanowiska ze względu na nastrój wzajemnej antypatii między społeczeństwem japońskim a chińskim. Było to już ostatnie japońsko-chińskie spotkanie na szczycie za kadencji Koizumiego. Co prawda w maju 2005 roku chińska wicepremier Wu Yi, która przyjechała do Japonii na wystawę Expo w Aichi, planowała rozmowę z japońskim premierem, ale dostała nagłe polecenie powrotu do kraju. Powodem była kolejna wypowiedź Koizumiego, że nie zamierza zrezygnować z wizyt w Yasukuni $^{276}$.

Tymczasem zaostrzał się także spór o surowce energetyczne Morza Wschodniochińskiego. Japonia przeprowadziła serię badań geologicznych dna akwenu, których wyniki zawarto w raporcie z lutego 2005 roku. Potwierdzono wtedy wysokie prawdopodobieństwo rozciągania się eksploatowanych przez ChRL złóż także na wschód od mediany. W lipcu 2005 roku Japonia wydała pozwolenie na odwierty firmie Teikoku Oil ${ }^{277}$. Poprzez te posunięcia władze w Tokio pragnęły wywrzeć presję na rząd w Pekinie, jednak ChRL kontynuowała kontrowersyjną inwestycję. Podczas gdy kolejne rundy rokowań w sprawie wspólnej eksploatacji naturalnych złóż szelfu kontynentalnego nie przynosiły rezultatów, Chiny ukończyły w 2005 roku budowę pierwszych platform wiertniczych $^{278}$. Wizyty premiera Koizumiego w świątyni Yasukuni spowodowały tylko usztywnienie stanowiska chińskiego i uczyniły spór trudniejszym do rozwiązania.

\footnotetext{
${ }^{274}$ Shimizu Yoshikazu, op.cit., s. 50-60; Chügoku de no Nihon seihin boikotto, nikkei kakusha, taiō owareru, „Nihon Keizai Shinbun” z 5 IV 2005, s. 2.

${ }^{275}$ Yomiuri Shinbun Seijibu, op.cit., s. 280-284.

${ }^{276}$ Uchiyama Yū, op.cit., s. 144-145; Sawa Kishirō, Go Gi fukusōri no hirei to nitchū kankei no $a k k a$, ,Yamaguchi Keizaigaku Zasshi” 2006, vol. 54, no. 6, s. 77-98.

${ }^{277}$ Uchiyama Yū, op.cit., s. 145.

${ }^{278}$ Ueda Naruhiko, Takayama Masaji, Sugiyama Katsumi, Higashi Shina Kai ga abunai!, Kōjinsha, Tokio 2007, s. 104-106.
} 


\section{Obóz protajwański i propekiński za kadencji Koizumiego}

Ponieważ głównym celem Koizumiego Jun'ichirō była reforma strukturalna, dyskurs wewnątrzpartyjny skupił się na problemie prywatyzacji poczty i firm budowlanych. Premier celowo stworzył wyraźną linię podziału na zwolenników reformy i tzw. „siłę oporu” (teikō seiryoku), którą obciążył odpowiedzialnością za blokowanie zmian niezbędnych do wyjścia Japonii ze stagnacji gospodarczej. Podział na wszelkie inne obozy, w tym frakcje, zaczął odgrywać jedynie drugorzędną rolę. Kiedy w 2003 roku doszło do wyborów na stanowisko szefa partii, swoją kandydaturę zgłosił Fujii Takao z frakcji Hashimoto. Okazało się wówczas, że była frakcja Tanaki podzieliła się na dwie grupy. O ile Nonaka Hiromu chciał rzucić wyzwanie Koizumiemu, Aoki Mikio przewodził grupie, która zagłosowała na urzędującego premiera ${ }^{279}$. Był to już kolejny incydent, który pokazał, jak bardzo osłabła solidarność pomiędzy członkami frakcji. Również podział na obóz protajwański i propekiński w PLD zszedł na dalszy plan. Dobrze obrazuje to fakt, że propekiński Nonaka Hiromu wspierał przeciw Koizumiemu protajwańskiego Fujiiego Takao. Najważniejszą linią podziału stał się stosunek do reformy strukturalnej.

Wielu członków obozu protajwańskiego pragnęło zablokować prywatyzację poczty i firm drogowych. Niemal cała frakcja Etō/Kameia, w tym przewodniczący Parlamentarnego Zgromadzenia Japońsko-Tajwańskiego Hiranuma Takeo, sprzeciwiała się reformie strukturalnej. W 2003 roku Etō Takami przeszedł na emeryturę i jedynym liderem grupy został Kamei Shizuka. Kamei może nie wykazywał sympatii protajwańskich w równym stopniu, co Hiranuma Takeo, ale był ,jastrzębiem”. Miał też ambiwalentny stosunek do polityki Koizumiego. Z jednej strony przeciwstawiał się reformie strukturalnej, z drugiej zaś uważał wizyty premiera w świątyni Yasukuni za oczywistośćc ${ }^{280}$. Twierdził, że z powodu różnic historycznych, kulturowych i rozbieżności systemów wartości Japonii i Chin nigdy nie uda się w pełni zadowolić ChRL, zaś nadmierne ustępstwa władz w Tokio w sprawie Yasukuni i podręczników do historii byłyby tylko odłożeniem problemu na później ${ }^{281}$. Widać było, że Kamei nie zmienił swoich poglądów z połowy lat 80 . XX wieku, gdy jako lider Towarzystwa Podstawowych Problemów Państwa protestował przeciw uległości premiera Nakasone wobec Chin.

Honda Yoshihiko podkreśla, że na początku XXI wieku obóz protajwański utracił wielu wpływowych członków. W 2001 roku z powodu skandalu korupcyjnego zakończyła się polityczna kariera Murakamiego Masakuniego ${ }^{282}$, zaś w 2004 roku zmarł Yamanaka Sadanori ${ }^{283}$. Do tej listy można dodać

\footnotetext{
${ }^{279}$ Nonaka Hiromu, Rōhei..., s. 354-358.

${ }^{280}$ Murakami Masakuni, Hirano Sadao, Fudesaka Hideyo, Jimintō wa..., s. 266-267.

${ }^{281}$ Kamei Shizuka, Namikawa Eita, Han'ei no shinario, Chūkei Shuppan, Tokio 2003, s. 156-158.

${ }^{282}$ Hoshi Hiroshi, op.cit., s. 123.

${ }^{283}$ Honda Yoshihiko, op.cit., s. 120.
} 
Kajiyamę Seiroku, który umarł jeszcze w 2000 roku oraz Satō Shinjiego, który $\mathrm{w}$ tym samym roku przegrał $\mathrm{w}$ wyborach parlamentarnych, tracąc mandat poselski. Na dodatek, jak twierdzi były przedstawiciel Tajwanu w Japonii Lin Jinjing, przejście Guomindangu do opozycji było poważnym ciosem dla Parlamentarnego Zgromadzenia Japońsko-Tajwańskiego, gdyż przez lata utrzymywało ono bliskie relacje właśnie z tą partią. Główne ugrupowanie opozycyjne na Tajwanie w latach 90. XX wieku, Demokratyczna Partia Postępu, starało się raczej nawiązać współpracę z japońskimi opozycyjnymi partiami konserwatywnymi, w szczególności z Partią Demokratyczną (Minshutō) ${ }^{284}$. Kiedy więc prezydentem Tajwanu został w maju 2000 roku Chen Shuibian, niekoniecznie przejął wpływy w całym obozie protajwańskim w PLD $^{285}$.

Niemniej jednak, poprzez coraz częstsze spotkania z prezydentem Chen Shuibianem, w których pośredniczył także Li Denghui, protajwańscy politycy z PLD stopniowo nawiązali więź współpracy również z nowymi władzami w Tajpej $^{286}$. Hiranuma Takeo podkreśla, że obecnie politycy protajwańscy mają równe powiązania z Demokratyczną Partią Postępu, co z Guomindangiem ${ }^{287}$. Zresztą na miejsce członków obozu protajwańskiego starszego pokolenia pojawili się młodsi parlamentarzyści. Za kadencji Koizumiego nastąpił prawdziwy renesans tego stronnictwa. Młodsze pokolenie posłów protajwańskich założyło w maju 2001 roku Parlamentarną Ligę PLD Przyjaźni JapońskoTajwańskiej (Jimintō Nihon-Taiwan Yūkō Giin Renmei) pod przewodnictwem Kobayashiego Kōkiego z frakcji Etō/Kameia. Według Kobayashiego Parlamentarne Zgromadzenie Japońsko-Tajwańskie pełniło jedynie rolę ,tytularną” i było zbyt mało radykalne $\mathrm{w}$ działaniach. Podkreślał m.in., że to młodzi posłowie stanowili główną siłę, stojącą za promocją wizyty Li Denghuia w Japonii. Kobayashi twierdził, iż władze w Tokio muszą wzmocnić współpracę $\mathrm{z}$ Tajwanem, aby „,powstrzymać Chiny podążające ścieżką militarnej potęgi” ${ }^{288}$.

Po wizycie Li Denghuia w Japonii w kwietniu 2001 roku parlamentarzyści z PLD coraz chętniej wybierali się na Tajwan. W sierpniu 2001 roku Tajpej odwiedziła cała seria delegacji polityków protajwańskich, jak Etō Seishirō z frakcji Moriego, Kamei Hisaoki z frakcji Kōno czy Nakagawa Shōichi i Kobayashi Kōki z frakcji Etō/Kameia. Nawet propekiński poseł Katō Kōichi udał się na Tajwan, by wygłosić tam wykład na temat przyszłości Azji

\footnotetext{
${ }^{284}$ Partia Demokratyczna powstała w 1996 roku, a następnie powiększała się dzięki fuzjom z innymi ugrupowaniami konserwatywnymi. W 1998 roku utworzono nową Partię Demokratyczną jako związek starej i kilku mniejszych partii. W 2003 roku w jej skład weszła Partia Liberalna Ozawy Ochirō. Szerzej na ten temat: Ishikawa Masumi, op.cit., s. 191-209; I Sangbong, Poseuteu „jeonhu jeongchi”-ui Ilbon jeongchi, Hyeongseol Chulpansa, Seul 2002, s. 87-91.

${ }^{285}$ Honda Yoshihiko, op.cit., s. 130-131.

${ }^{286}$ Zhong-Ri guanxi 30 nian..., s. 313-325.

${ }^{287}$ Wywiad autora z Hiranumą Takeo...

${ }^{288}$ Kokkai giin, hōtai rasshu. Chin seiken yōjin to arata ni jinmyaku zukuri. Getsumatsu made ni 40 nin kosu, ,Yomiuri Shinbun” z 30 VIII 2001, s. 4.
} 
Wschodniej ${ }^{289}$. Świadczyło to o tym, że tradycyjny podział na stronnictwo propekińskie i protajwańskie ulegał stopniowemu zamazaniu. Nawet politycy blisko związani z ChRL przestali traktować kwestię w pełni demokratycznego już Tajwanu jak tabu. We wrześniu 2002 roku, równolegle z obchodami 20. rocznicy normalizacji japońsko-chińskich stosunków dyplomatycznych, pięciu młodych posłów protajwańskich odwiedziło Tajpej. Przewodniczący delegacji, Nakagawa Shōichi, podkreślił: „Stosunki z Tajwanem też są ważne dla Japonii. Mam zamiar zaproponować młodszym kolegom, by utrzymywali regularną wymianę z parlamentarzystami [tajwańskimi - przyp. aut.]"290. W listopadzie 2002 roku rząd japoński rozluźnił ograniczenia dotyczące wizyt na Tajwanie urzędników państwowych średniego szczebla ${ }^{291}$. W kwietniu 2003 roku Tajwan odwiedzili Fujii Takao z frakcji Hashimoto i Asō Tarō z frakcji Kōno. Asō, wówczas wiceprzewodniczący Parlamentarnego Zgromadzenia JapońskoTajwańskiego i przewodniczący Rady Badań Politycznych PLD, złożył wizytę u samego prezydenta Chen Shuibiana ${ }^{292}$. Jeszcze w tym samym roku, pod koniec grudnia, do Tajpej udał się były premier Mori Yoshirō ${ }^{293}$.

Po śmierci Yamanaki Sadanoriego w 2004 roku nowym przewodniczącym Parlamentarnego Zgromadzenia Japońsko-Tajwańskiego został Hiranuma Takeo $^{294}$. Losy tego polityka dobrze pokazują, jak wielką rolę w przynależności do obozu protajwańskiego odgrywały relacje interpersonalne. Hiranuma był adoptowanym synem premiera Hiranumy Kiichirō, który po II wojnie światowej został skazany na wyrok dożywotniego więzienia jako zbrodniarz wojenny klasy A. Pozostając pod wpływem tradycji ojca, jak i ideologii prawicowej sekty Seichō no Ie, Hiranuma Takeo od początku kariery politycznej należał do obozu „jastrzębi”. Członkiem stronnictwa protajwańskiego stał się poprzez znajomość z Kayą Okinorim, Satō Eisaku i Nakagawą Ichirō. W latach 70. XX wieku Hiranuma został sekretarzem byłego premiera Satō, zaprzyjaźnił się także z jego synem, Satō Shinjim. Największy dług wdzięczności odczuwał jednak wobec przewodniczącego Seirankai, Nakagawy Ichirō. Dzięki otrzymanemu od niego wsparciu zdołał po dwóch porażkach wyborczych wreszcie uzyskać upragniony mandat w Izbie Reprezentantów w 1980 roku $^{295}$.

\footnotetext{
${ }^{289}$ Ibidem.

${ }^{290}$ Chin sōtōra to kaidan, shintai-ha wakate giin, kyō Taiwan hōmon, „Nihon Keizai Shinbun” z 23 IX 2002, s. 2.

${ }^{291}$ Yang Xiaohua, Li Hongjin, Lengzhan-hou Riben dui-Tai zhengce de tiaozheng ji yuanyin, „Yan'an Jiaoyu Xueyuan Xuebao” 2008, vol. 22, no. 3, s. 26.

${ }^{292}$ Asō Seichōkaichō, Jimin san'yaku zaininjū ni irei no hōtai, „Yomiuri Shinbun” z 29 IV 2003, s. 4; Ding Zhaozhong, op.cit., s. 48.

${ }^{293}$ Li Jianmin, op.cit., s. 335.

${ }^{294}$ W marcu 2009 roku do Parlamentarnego Zgromadzenia Japońsko-Tajwańskiego należało około 240 parlamentarzystów. Wywiad autora z Hiranumą Takeo...

${ }^{295}$ Hiranuma Takeo, Seiji bushidō, PHP Fakutorī Paburishingu, Tokio 2007, s. 68-98.
} 
Hiranuma przeciwstawiał się reformie strukturalnej Koizumiego, ale zgadzał się z częścią jego posunięć politycznych. Uważał wizyty w Yasukuni za obowiązek szefa rządu, zaś chińskie protesty nazywał ingerencją w wewnętrzne sprawy Japonii ${ }^{296}$. Był zdania, że Japonia przeprosiła już za zbrodnie z czasów II wojny światowej i nie powinna iść na dalsze ustępstwa w sprawach historycznych $^{297}$. Nie bez zadowolenia obserwował również deregulację systemu frakcyjnego w PLD, działającą na niekorzyść ,głównego nurtu konserwatywnego”. Według niego dawne frakcje Ikedy i Tanaki „,nie tylko były propekińskie, ale stworzyły klimat ścisłego podążania za polityką Chin i dzięki swojej liczbie i sile (...) zniekształciły kurs Japonii”' ${ }^{298}$. Z drugiej strony, Hiranuma z goryczą zauważał, że większa niezależność od frakcji polityków wybieranych w okręgach jednomandatowych umożliwiła dojście do władzy takim parlamentarzystom o „unikalnej osobowości”, jak Koizumi Jun'ichirō ${ }^{299}$.

Hiranuma podkreślał, że nie czuje wrogości wobec Chin, ale jednocześnie przestrzegał przed prowokacyjnymi działaniami ChRL na Morzu Wschodniochińskim, które według niego były dowodem na to, że Chiny starają się powrócić do utraconej w XIX wieku pozycji regionalnego hegemona. Ostrzegał także, iż ChRL tylko czeka na odpowiednią okazję, aby dokonać zbrojnej aneksji Tajwanu. Przekonywał, iż został członkiem obozu protajwańskiego, by móc służyć jako arbiter w razie chińskiego ataku na tę wyspę. Uważał, że wzrost gospodarczy Chin ulegnie $\mathrm{w}$ końcu załamaniu $\mathrm{z}$ powodu niemożności pogodzenia autorytarnego reżimu z systemem kapitalistycznym. Twierdził, iż chociaż Chiny są najludniejszym krajem świata, to handel $\mathrm{z}$ posiadającym bogatsze społeczeństwo Tajwanem też jest bardzo intratny dla Japonii ${ }^{300}$. Podkreślał także, że dług wdzięczności wobec Jiang Jieshiego za jego wyrozumiałą postawę wobec Japonii po II wojnie światowej nadal pozostaje aktualny $^{301}$.

Hiranuma Takeo był również przewodniczącym innych prawicowych lig parlamentarnych, które krytykowały podejście Chin do problemów historycznych. Takie grupy, jak Zgromadzenie Parlamentarzystów Konferencji Japonii (Nippon Kaigi Kokkai Giin Kondankai) czy Zgromadzenie Utworzenia Właściwej Japonii (Tadashii Nihon o Tsukuru Kai) dbały o pochlebną dla Japonii wersję historii ${ }^{302}$. Inną ligą było liczące około 40 członków Zgromadzenie Parlamentarzystów Żądających Usunięcia Niewłaściwych Zdjęć z Chińskich Muzeów Japońskiej Agresji (Chūgoku no Kōnichi Kinenkan kara

\footnotetext{
${ }^{296}$ Idem, Shin kokka ron - Mattō na Nihon o tsukuru tame ni, Chūō Kōron Shinsha, Tokio 2005, s. 59-69.

${ }^{297}$ Ibidem, s. 174.

${ }^{298}$ Ibidem, s. 79.

${ }^{299}$ Idem, Seiji..., s. 96.

${ }^{300}$ Idem, Shin kokka..., s. 70-168.

${ }^{301}$ Wywiad autora z Hiranumą Takeo...

${ }^{302}$ Hiranuma Takeo, Seiji..., s. 207.
} 
Futōna Shashin no Teppai o Motomeru Kokkai Giin no Kai). Hiranuma przekonywał, że w ponad 200 chińskich muzeach upamiętniających konflikt z Japonią zawarte są zdjęcia zrobione przed wojną, a mające ukazywać japońskie zbrodnie. Nie godził się także na nazywanie masakry nankińskiej z 1937 roku „rzezią" $\left(\right.$ tosatsu) ${ }^{303}$.

Innym czołowym reprezentantem obozu protajwańskiego był Abe Shinzō, który pod koniec kadencji Koizumiego został przez niego wypromowany na przyszłego premiera. W przeciwieństwie do Hiranumy, Abe należał do grona zwolenników reformy strukturalnej. Jako wnuk Kishiego Nobusuke promował także ideę rewizji pacyfistycznej konstytucji i reformy systemu oświaty ${ }^{304}$. W sprawie wizyt w Yasukuni gorąco wspierał premiera, podkreślając, że nie tylko kwestia tej kontrowersyjnej świątyni, ale również szereg innych problemów, jak spór o surowce energetyczne Morza Wschodniochińskiego, jest przyczyną ochłodzenia $w$ relacjach bilateralnych ${ }^{305}$. W latach 90 . XX wieku Abe był przewodniczącym Wydziału Młodzieżowego PLD, który zajmował się m.in. kontaktami partii z Tajwanem ${ }^{306}$.

Abe przyznawał, iż relacje Japonii z ChRL są bardzo ważne, tym bardziej że w 2004 roku wartość handlu japońsko-chińskiego przewyższyła wartość handlu Japonii ze Stanami Zjednoczonymi. Z drugiej strony, Abe nie zamierzał iść na ustępstwa w sprawie problemów historycznych. Jak pisał: „W kwestii dawnych błędów Japonii często poddaje się w wątpliwość, czy przeprosiliśmy Chiny, ale tak naprawdę złożyliśmy już 20 oficjalnych przeprosin" ${ }^{307}$. Według Abe japońscy dziennikarze i naukowcy często byli nadmiernie propekińscy w opisie rzeczywistości. Przyznawał: „Kiedy antyjapońskie demonstracje przybrały niebezpieczne rozmiary, pojawił się dziennikarz, który nawoływał: «Japończycy muszą pozostać spokojni», ale ja chciałem powiedzieć: «To ty się ucisz»"308. Abe obawiał się jednak wpływu problemów historycznych na bilateralne kontakty gospodarcze i domagał się nowego „rozdziału polityki od gospodarki”, aby uniemożliwić Chinom wykorzystywanie antyjapońskich uczuć społecznych do nakładania ograniczeń na działalność japońskich przedsiębiorstw ${ }^{309}$.

\footnotetext{
${ }^{303}$ Wywiad autora z Hiranumą Takeo...

${ }^{304}$ Yamagiwa Sumio, op.cit., s. 53.

${ }^{305}$ Yasukuni dakai „Koizumi go” mo shiya. Ajia gaikō, shushō kōho no tairitsu jiku ni, „Asahi Shinbun" z 27 V 2005, s. 4.

${ }^{306}$ Syn Kōno Yōheia, poseł Kōno Tarō, przyznaje, że spytał kiedyś Abe Shinzō, czemu członkowie młodzieżówki PLD tak często jeżdżą na Tajwan, a jeszcze niegdy nie zorganizowali wizyty w ChRL. Abe odpowiedział mu wówczas, że Wydział Młodzieżowy jest „oknem na Tajwan” (Taiwan no madoguchi). Dopiero z inicjatywy Kōno Tarō młodzieżówka PLD po raz pierwszy odwiedziła ChRL. Wywiad autora z Kōno Tarō...

${ }^{307}$ Abe Shinzō, Utsukushii kuni e, Bungei Shunjū, Tokio 2006, s. 150.

${ }^{308}$ Ibidem, s. 155.

${ }^{309}$ Ibidem, s. 152-153.
} 
Pośrednie stanowisko wobec prywatyzacji poczty w obozie protajwańskim zajmował Asō Tarō z frakcji Kōno. Jako minister spraw wewnętrznych i komunikacji starał się bronić interesów swojego resortu, ale jednocześnie był zdolny do pójścia na kompromis w sprawie reformy strukturalnej ${ }^{310}$. Asō był wnukiem Yoshidy Shigeru, jednak przyznawał, że doktryna stworzona przez jego dziadka stała się już nieaktualna. Uważał, iż nadszedł czas na rewizję pacyfistycznej konstytucji, m.in. by móc zadbać o tak ważne dla bezpieczeństwa Japonii zadania, jak zapewnienie stabilności w Cieśninie Tajwańskiej ${ }^{311}$. Podkreślał przy tym, że Japonia nadal trzyma się zasady ,jednych Chin” i oczekuje pokojowego rozwiązania problemu Tajwanu ${ }^{312}$. Kiedy Asō został ministrem spraw zagranicznych w 2005 roku, zaczął podkreślać, iż „rozwój Chin nie przeszkadza niczyim interesom”, apelując jednocześnie do władz w Pekinie o większą transparentność wydatków na zbrojenia ${ }^{313}$. Nastawienie Asō wobec ChRL było ambiwalentne. $\mathrm{Z}$ jednej strony wraz $\mathrm{z}$ awansem $\mathrm{w}$ partii przyjmował coraz bardziej realistyczne stanowisko $\mathrm{w}$ sprawie Tajwanu, $\mathrm{z}$ drugiej zaś nie rezygnował ze swoich prawicowych poglądów w sprawie Yasukuni. Nazywał problem kontrowersyjnej świątyni wewnętrzną sprawą Japonii, lekceważąc jego międzynarodowe reperkusje. Sprzeciwiał się także budowie obiektu mającego być substytutem Yasukuni. Proponował nawet objęcie świątyni opieką państwa, by zapewnić jej stałe źródło finansowania ${ }^{314}$.

W stronnictwie propekińskim przeciwnicy reformy strukturalnej skupiali się szczególnie we frakcji Hashimoto. Wielu jej działaczy kontynuowało sposób uprawiania polityki zapoczątkowany przez Tanakę Kakueia i miało silne powiązania $\mathrm{z}$ sektorem pocztowym $\mathrm{i}$ budowlanym. Jeden $\mathrm{z}$ najbardziej wpływowych polityków tej grupy, Nonaka Hiromu, był wręcz zwany „lordem klanu pocztowego" (yūsei zoku no don $)^{315}$. Nonaka znany był ze swoich propekińskich sympatii i dobrych relacji z wiceprzewodniczącym ChRL Zeng Qinghongiem $^{316}$. Do „siły oporu” należy także zaliczyć Kōmurę Masahiko, przewodniczącego byłej frakcji Mikiego. Również wielu czołowych przedstawicieli frakcji Horiuchiego i Ozato sprzeciwiało się reformie.

\footnotetext{
${ }^{310}$ Nonaka Naoto, op.cit., s. 91-94.

${ }^{311}$ Asō Tarō, Asō Tarō no genten. Sofu Yoshida Shigeru no ryūgi, Tokuma Shoten, Tokio 2007, s. $168-169$.

${ }^{312}$ Idem, Jiyū to han'ei no ko, Gentōsha, Tokio 2008, s. 179.

${ }^{313}$ Idem, Watashi no gaikō senryaku, Asō Tarō to 21 Seiki no Kai, Iizuka 2006, s. 58-61.

${ }^{314}$ Idem, Totetsumonai Nihon, Shinchōsha, Tokio 2007, s. 139-152.

${ }^{315}$ Ōshita Eiji, op.cit., s. 342.

${ }^{316}$ Nonaka Hiromu krytykował postawę Koizumiego wobec problemów historycznych. W sprawie wizyt w Yasukuni podkreślał, że należy wziąć pod uwagę uczucia sąsiednich narodów. Nonaka przyznaje z goryczą, że w czasie swoich częstych wyjazdów do Chin zabierał ze sobą młodszych polityków, aby ich przedstawić władzom KPCh jako swoich następców w roli promotorów stosunków japońsko-chińskich, jednak później większość z nich okazała się zwolennikami polityki Koizumiego. Szerzej na ten temat: Nonaka Hiromu, Rōhei..., s. 413-415; Yayama Tarō, op.cit., s. 114-116.
} 
W przeciwieństwie do wzmacniającego swe wpływy w partii obozu protajwańskiego, stronnictwo propekińskie borykało się z coraz większymi problemami. W 2002 roku przewodniczący Stowarzyszenia Przyjaźni JapońskoChińskiej Noda Takeshi, wówczas także lider pozostającej w koalicji z PLD Partii Konserwatywnej, przyznał, że widać było wyraźną zmianę w podejściu polityków do kwestii chińskiej. Według niego, o ile starsze pokolenia parlamentarzystów miały poczucie winy z powodu II wojny światowej, o tyle ich młodsi koledzy pragnęli ostatecznie zamknąć okres powojenny ${ }^{317}$. Ciągłe przypominanie przez władze w Pekinie problemów historycznych jedynie zniechęcało młodych polityków do aktywnej działalności w obozie propekińskim. Tymczasem starsi członkowie obozu propekińskiego kończyli kariery polityczne. W 2003 roku na emeryturę przeszedł Miyazawa Kiichi. Miyazawa nie ukrywał niezadowolenia z polityki Koizumiego. Apelując o poszanowanie stosunków z ChRL cytował słowa Josepha Nye'a, iż Chiny „staną się wrogiem, jeśli będziemy je jako wroga postrzegać’318.

W 2003 roku Nowa Partia Konserwatywna ${ }^{319}$ przestała istnieć, zaś jej dawni członkowie wstąpili do PLD, tworząc niewielką frakcję Nikaia. Skupiała ona takich doświadczonych propekińskich parlamentarzystów, jak były premier Kaifu Toshiki. Sam Nikai Toshihiro miał wyraźne powiązania z władzami w Pekinie, przejęte jeszcze od swoich dawnych oyabunów, Tanaki Kakueia i Takeshity Noboru ${ }^{320}$. Od lat 90 . XX wieku przyjaźnił się z ówczesnym burmistrzem Dalian, Bo Xilaiem, który w 2004 roku został chińskim ministrem handlu. Równie dobre kontakty utrzymywał m.in. z ministrem spraw zagranicznych ChRL w latach 1998-2003, Tang Jiaxuanem ${ }^{321}$. Piastując stanowiska ministra transportu (1999-2000) czy ministra gospodarki, handlu i przemysłu (2005-2006), Nikai starał się promować japońsko-chińską wymianę kulturalną i turystyczną. Wielokrotnie odwiedzając Chiny aktywnie działał na rzecz utrzymania przyjacielskich więzi z politykami KPCh w trudnym dla stosunków z ChRL okresie rządów Koizumiego. Angażował się w promocję japońskich inwestycji w chińską infrastrukturę kolejową oraz w rozpoczęte w 2004 roku rozmowy na temat rozwiązania sporu o złoża naturalne basenu Morza Wschodniochińskiego ${ }^{322}$.

\footnotetext{
${ }^{317}$ Nitchū kokkō seijōka 30-shūnen zadankai. Hito, mono fukamaru kōryū. Masatsu koe sōgo rikai $o$, ,Yomiuri Shinbun” z 16 IX 2002, s. 12.

${ }^{318}$ Miyazawa Kiichi, Hato-ha no dengon - Miyazawa Kiichi shushō ga kataru, Chūgoku Shinbunsha, Hiroshima 2005, s. 23.

${ }^{319}$ Pod koniec 2002 roku Partia Konserwatywna zmieniła nazwę na Nową Partię Konserwatywną (Hoshu Shintō).

${ }^{320}$ Denggao wangyuan. Riben zhengzhijia Erjie Junbo pod red. Qiao Shenga, Shehui Kexue Wenxian Chubanshe, Pekin 2008, s. 150.

${ }^{321}$ Ibidem, s. 150-152.

${ }^{322}$ Ibidem, s. 79-106.
} 
Dobre kontakty z Nikaiem utrzymywał jeden z najbardziej wpływowych członków frakcji Horiuchiego, Koga Makoto. Koga był członkiem zoku drogowego (dōro zoku) w ramach zoku transportu i starał się powstrzymać prywatyzację autostrad, do której dążył Koizumi. Do obozu propekińskiego Kogę zaprosił Nonaka Hiromu, przedstawiając go czołowym chińskim politykom w czasie wizyty w Pekinie w sierpniu 2001 roku. Jednakże podejście Kogi do problemów historycznych miało złożony charakter. W 2002 roku Koga został przewodniczącym prawicowej organizacji Nihon Izokukai, która od lat domagała się oficjalnych wizyt premiera w Yasukuni ${ }^{323}$. Po wizycie w ChRL w 2001 roku Koga użył swoich wpływów, by zmienić stanowisko Nihon Izokukai (był wówczas wiceprzewodniczącym tej organizacji) tak, by nie żądać już od premiera wizyt $\mathrm{w}$ Yasukuni 15 sierpnia. Nadal wspierał jednak sam pomysł corocznych odwiedzin szefa rządu w tej kontrowersyjnej świątyni, jak też przeciwstawiał się budowie alternatywnego miejsca pamięci poległym żołnierzom ${ }^{324}$. $\mathrm{Z}$ jednej strony nie chciał drażnić Chin, z drugiej zaś był ograniczony w swoich działaniach przez własny prawicowy elektorat. Poza tym Koga przyjaźnił się z takimi protajwańskimi politykami, jak Hiranuma Takeo i Asō Tarō, należąc razem z nimi do nieformalnego Towarzystwa Trzech (San Nin no Kai) ${ }^{325}$.

Członkiem obozu propekińskiego, który wspierał reformę strukturalną był natomiast Fukuda Yasuo z frakcji Moriego. Co rzadkie, Fukuda nie przejął powiązań z Tajwanem po swoim ojcu, premierze Fukudzie Takeo. Był uważany za „gołębia”. Jako sekretarz gabinetu Koizumiego bezskutecznie starał się powstrzymać wizyty premiera w Yasukuni, jak też nie dopuścić do wydania wizy Li Denghuiowi. Ostrzegał, że władze w Tajpej powinny unikać prowokowania ChRL i powstrzymać się od ogłoszenia niepodległości Tajwanu, gdyż dla kierownictwa KPCh jest to kwestia najwyższej wagi ${ }^{326}$. Mimo że Fukuda był członkiem tej samej frakcji co Koizumi, zdobył zaufanie propekińskich polityków „głównego nurtu konserwatywnego”, którzy nawet planowali

\footnotetext{
${ }^{323}$ Na przełomie lat 60. i 70. XX wieku Koga Makoto był sekretarzem Onimaru Katsuyukiego, parlamentarzysty z frakcji Nakasone. Po jego śmierci przejął okręg wyborczy, jak też powiązania z Nihon Izokukai. Ponieważ ojciec Kogi zginął jako żołnierz w czasie II wojny światowej, zrzeszające wdowy i sieroty po poległych żołnierzach Nihon Izokukai stanowiło ważną bazę poparcia, dzięki której Koga uzyskał madat poselski w 1980 roku. Szerzej na ten temat: Ōshita Eiji, op.cit., s. 46-298.

${ }^{324}$ Ibidem, s. 284-301.

${ }^{325}$ W 2001 roku Towarzystwo Trzech zmieniło nazwę na Towarzystwo Czterech (Yo Nin no Kai), gdy dołączył do niego Kōmura Masahiko. Inicjatywa ta miała być alternatywą dla dawnego triumwiratu YKK. W 2002 roku ponownie zmieniono nazwę na Shishi no Kai. Szerzej na ten temat: ibidem, s. 190-310.

${ }^{326}$ Fukuda Yasuo, Etō Seishirō, Ikkoku wa hitori o motte okori, hitori o motte horobu, KK Bestoserāzu, Tokio 2007, s. 67-68.
} 
promować go na kontrkandydata Abe Shinzō w nadchodzących wyborach na przewodniczącego PLD.

Politykiem propekińskim, który miał ambiwalentny stosunek do reformy strukturalnej był Katō Kōichi. Jako zwolennik liberalizmu gospodarczego nie przeciwstawiał się samej prywatyzacji poczty czy autostrad, ale żywił wątpliwości co do szczegółów reformy ${ }^{327}$. Miał także za złe Koizumiemu, swojemu dawnemu koledze $\mathrm{z}$ triumwiratu YKK, jego sposób prowadzenia polityki wobec Chin. Katō utracił wpływy w partii po „buncie” z 2000 roku, ale nadal działał na rzecz przyjaźni japońsko-chińskiej. Przekonywał, że przyczyny kryzysu w relacjach bilateralnych w dużym stopniu leżą po stronie japońskiej. Podkreślał, iż wizyty japońskiego premiera w świątyni Yasukuni stanowią nie tylko wewnętrzny problem Japonii, ale też akt prowokacji wobec państw ościennych. Oskarżał Koizumiego o wykorzystywanie antychińskiego nacjonalizmu w celu kierowania uwagi społeczeństwa na zewnętrznego wroga. Ostrzegał, że nacjonalizm ,powraca jak bumerang” w postaci reakcji krajów sąsiednich $^{328}$. Wyrażał także zaniepokojenie z faktu, iż ,gdy się tylko w debacie na temat relacji japońsko-chińskich zabierze głos w obronie Chin, zaraz dostaje się mnóstwo listów z krytyką" ${ }^{329}$. Obrazowało to rosnącą niechęć, z jaką japońskie społeczeństwo postrzegało ChRL.

Jak widać, podział na zwolenników i przeciwników reformy strukturalnej przebiegał $\mathrm{w}$ poprzek podziału na obóz propekiński i protajwański w PLD. Prywatyzacja poczty stała się głównym przedmiotem sporu wewnątrz partii, zaś problemy wizyt w świątyni Yasukuni czy polityki wobec Tajwanu zeszły na dalszy plan. Nie oznacza to jednak, by politycy związani z ChRL zupełnie zrezygnowali z promocji przyjacielskich relacji z władzami w Pekinie.

\section{Polityka PLD wobec Chin na tle prywatyzacji poczty}

Kiedy na wiosnę 2005 roku doszło do kulminacji napięcia w relacjach japońskochińskich, obóz propekiński w PLD podjął próbę stworzenia wspólnego frontu przeciwko premierowi i kreowanemu na jego następcę Abe Shinzō. Był to także środek do zablokowania prywatyzacji poczty, na którą nie zgadzało się wielu polityków blisko związanych z ChRL. Przewodnią siłę stojącą za tą inicjatywą stanowiło środowisko ,głównego nurtu konserwatywnego”, zepchnięte na „boczny tor” za kadencji Koizumiego. W szeregach dawnych frakcji Satō i Ikedy można było znaleźć wielu parlamentarzystów niezadowolonych z reformy strukturalnej i „dyktatorskich” metod sprawowania władzy przez premiera. W czerwcu 2005 roku Koga Makoto z frakcji Horiuchiego oświadczył na zjeździe Nihon Izokukai, że w sprawie wizyt w świątyni Yasukuni premier powinien wziąć pod uwagę stanowisko sąsiednich krajów. Wypowiedź ta spotkała się z

\footnotetext{
${ }^{327}$ Katō Kōichi, Atarashiki..., s. 172-174.

${ }^{328}$ Ibidem, s. 87-95.

${ }^{329}$ Ibidem, s. 103.
} 
krytyką ze strony części członków tej prawicowej organizacji, jednak Koga nie zamierzał zrezygnować z rzucenia wyzwania Koizumiemu. Kilka dni później stwierdził: „Patrząc na historię PLD, w chwili gdy władza skłaniała się na prawo, wahadło nieco zawracało i zachowana była równowaga między obozem jastrzębi i gołębi. Powoli nadchodzi czas, by grupa polityczna głównego nurtu konserwatywnego, zwana Kōchikai [nazwa dawnej frakcji Ikedy - przyp. aut.], powróciła do źródeł i zderzyła się czołowo z reżimem Koizumiego"330. Koga zamierzał wypromować na następcę Koizumiego propekińsko nastawionego Fukudę Yasuo $^{331}$ lub byłą minister poczty, posłankę Nodę Seiko ${ }^{332}$.

Frakcja Horiuchiego nawiązała współpracę z innymi grupami wywodzącymi się z nurtu Yoshidy (frakcje Hashimoto, Ozato, częściowo Kōno), zaś głównym spoiwem jednoczącym ten sojusz okazała się sprawa chińska. Była to swoista próba wskrzeszenia propekińskiej „osi władzy” Tanaka-Ōhira z lat 70. XX wieku. W czerwcu 2005 roku ChRL odwiedzili Katō Kōichi i Hashimoto Ryūtarō. Katō zabrał ze sobą kilku posłów z frakcji Ozato, Horiuchiego i Hashimoto, aby pogłębić kontakty z Chinami na poziomie parlamenarzystów ${ }^{333}$. Również przewodniczący Parlamentarnej Ligi Przyjaźni Japońsko-Chińskiej, lider dawnej frakcji Mikiego, Kōmura Masahiko, jak też koalicyjny partner PLD, Kōmeitō, krytykowali bezkompromisową postawę premiera wobec $\mathrm{Chin}^{334}$. W lipcu 2005 roku umiarkowani politycy na czele z Kōmurą Masahiko zorganizowali specjalną konferencję poświęconą problemowi wizyt w Yasukuni. Głównym mówcą był Gotōda Masaharu, który ponownie wezwał premiera Koizumiego do nieodwiedzania kontrowersyjnej świątyni ${ }^{335}$.

Obozowi propekińskiemu nie udało się jednak uczynić z kwestii wizyt w Yasukuni głównej linii podziału wewnątrz partii. W sierpniu 2005 roku ustawa o prywatyzacji poczty została odrzucona przez Izbę Radców, wobec czego Koizumi rozwiązał Izbę Reprezentantów ${ }^{336}$. Posłowie, którzy głosowali wbrew decyzji partii, nie otrzymali oficjalnych nominacji na kandydatów PLD w wyborach. Przeciw prywatyzacji poczty oddali głos m.in. przewodniczący

\footnotetext{
${ }^{330}$ Hoshu honryū no Abe hōimō. Posuto Koizumi niramu Yasukuni batoru, „Asahi Shinbun” z 11 VII 2005, s. 28.

${ }^{331}$ Ōshita Eiji, op.cit., s. 384.

${ }^{332}$ Itagaki Eiken, op.cit., s. 224.

${ }^{333}$ Katō Kōichi-shi ga hatsuka kara hōchū. „Shinchūha” apīru, „Asahi Shinbun” z 9 VI 2005, s. 2.

${ }^{334}$ Yasukuni dakai..., s. 4.

${ }^{335}$ Li Xiushi, Riben xinbaoshouzhuyi zhanlüe yanjiu, Shishi Chubanshe, Pekin 2010, s. 233.

${ }^{336}$ Koizumi narzucił swoje zdanie Radzie Generalnej PLD, w której wbrew zwyczajowi poszukiwania konsensusu za wszelką cenę doszło do głosowania pomimo różnicy zdań. Niewielką przewagą głosów partia zatwierdziła ustawę o prywatyzacji poczty. Została ona następnie przegłosowana w Izbie Reprezentantów, ale odrzucona przez izbę wyższą. Premier nie ma prawa rozwiązać Izby Radców, a do odrzucenia veto izby wyższej potrzebne jest dwie trzecie głosów w izbie niższej. Aby je uzyskać Koizumi rozwiązał Izbę Reprezentantów. Szerzej na ten temat: Shimizu Masato, op.cit., s. 328-350.
} 
Parlamentarnego Zgromadzenia Japońsko-Tajwańskiego Hiranuma Takeo oraz przewodniczący Parlamentarnej Ligi PLD Przyjaźni Japońsko-Tajwańskiej Kobayashi Kōki. Z kolei przewodniczący Parlamentarnej Ligi Przyjaźni Japońsko-Chińskiej Kōmura Masahiko, jak też inni czołowi członkowie obozu propekińskiego, jedynie wstrzymali się od głosu, więc nie zostali usunięci z partii. Wybory do Izby Reprezentantów z września 2005 roku okazały się historycznym zwycięstwem PLD, która razem z Kōmeitō zdobyła dwie trzecie mandatów w Izbie Reprezentantów. Umocniwszy swoją pozycję, Koizumi ostatecznie przeforsował prywatyzację poczty.

Tabela 5.6 Rozkład sił pomiędzy frakcjami PLD oraz partie koalicyjne w okresie rządów Koizumiego Jun'ichirō w latach 2005-2006.

\begin{tabular}{|l|l|}
\hline \multicolumn{1}{|c|}{ Cechy i liczebność frakcji PLD } & \multicolumn{1}{|c|}{ Partie koalicyjne } \\
\hline Mori (D, J, T) 88 & Kōmeitō (G, P) 55 \\
Tsushima (L) 80 & \\
Koga/Niwa (L, G, P) 48 & \\
Yamasaki (D, J) 37 & \\
Ibuki (D, J, T) 33 & \\
Tanigaki (L, G, P) 16 & \\
Kōmura (D, G, P) 16 & \\
Kōno 15 & \\
Nikai (P) 15 & \\
Bezfrakcyjni 69 & 55 \\
\hline 417 & 55 \\
\hline
\end{tabular}

L- dawni członkowie Partii Liberalnej, główny nurt konserwatywny, D- dawni członkowie Partii Demokratycznej, boczny nurt konserwatywny, G- gołębie, J- jastrzębie, P- obóz propekiński, Tobóz protajwański.

Liczebność frakcji (podana przy poszczególnych frakcjach) po wyborach do Izby Reprezentantów z września 2005 roku. Uwzględniono członków frakcji z obu izb parlamentu.

Opracowanie własne na podstawie: Kokkai binran - Heisei 19 nen 2 gatsu shinpan pod red. Kikuoki Nobuko, Nihon Keizai Shinbunsha, Tokio 2006, s. 393-417.

W wyniku ,wyborów pocztowych” (yūsei senkyo) równowaga sił wewnątrz PLD została zachwiana. Frakcje Kameia i Hashimoto poniosły największe straty, gdyż wielu przeciwników prywatyzacji poczty wywodziło się z ich szeregów. Kamei Shizuka odszedł z PLD, zaś przywództwo nad resztkami jego grupy przejął Ibuki Bunmei ${ }^{337}$. Hashimoto Ryūtarō wycofał się z polityki ${ }^{338}$, zaś

\footnotetext{
${ }^{337}$ Ibuki Bunmei od początku rządów Koizumiego wykazywał większe zrozumienie dla potrzeby przeprowadzenia reformy strukturalnej niż Kamei Shizuka. Szerzej na ten temat: Ibuki Bunmei, Watanabe Yoshimi, Shinario. Nihon keizai to zaisei no saisei, Nikkan Kōgyō Shinbunsha, Tokio 2001, s. 9-40.

${ }^{338}$ Jeszcze w 2001 roku wykryto aferę korupcyjną, w którą zamieszany był Hashimoto, co zmusiło go do rezygnacji ze stanowiska przewodniczącego frakcji. Pozostało ono nieobsadzone aż do wycofania się Hashimoto z polityki. Szerzej na ten temat: Hoshi Hiroshi, op.cit., s. 124.
} 
po jakimś czasie nowym liderem grupy został Tsushima Yūji ${ }^{339}$. Z kolei Horiuchiego Mitsuo, który głosował przeciw prywatyzacji poczty, zastąpili na początku 2006 roku jako liderzy frakcji Koga Makoto i Niwa Yūya ${ }^{340}$. Również druga grupa wywodząca się z dawnej frakcji Ikedy zmieniła przewodniczącego. Ozato Sadatoshi przeszedł na emeryturę, przekazując przywództwo Tanigakiemu Sadakazu ${ }^{341}$. Jednakże największą zmianą było pojawienie się bardzo licznej, około 80-osobowej grupy posłów, nazywanych potocznie „dziećmi Koizumiego" (Koizumi chiruderen) ${ }^{342}$. Ci często młodzi i mało doświadczeni parlamentarzyści pierwszej kadencji zawdzięczali uzyskanie mandatu charyzmie i popularności premiera, więc nie czuli się lojalni wobec żadnych szefów frakcyjnych, a jedynie wobec centralnych organów partii. Chociaż część z nich rozproszyła się po różnych frakcjach, większość nie zrzeszyło się z żadną z grup $^{343}$. Szczególnie zyskała na sile prawicowa frakcja Moriego, stając się najliczniejszą grupą w PLD.

W ostatnim roku rządów Koizumiego jego popularność wśród społeczeństwa i pozycja w partii były tak silne, że obóz propekiński nie miał większej szansy na zawiązanie szerszego sojuszu przeciw premierowi. W marcu 2006 roku utworzono co prawda Grupę Badawczą Strategii Azjatyckich (Ajia Mondai Senryaku Kenkyūkai), w skład której weszły wszytkie frakcje dawnego nurtu Ikedy (Kogi/Niwy, Tanigakiego i Kōno) ${ }^{344}$, ale jej działalność nie przyniosła wymiernych rezultatów. Niemożność utworzenia wspólnego frontu przez liderów „głównego nurtu konserwatywnego" pokazywała, jak bardzo zmieniły się mechanizmy rywalizacji wewnątrz PLD od czasów dominacji „osi władzy” Tanaka-Ōhira. Wobec osłabienia solidarności wewnątrzfrakcyjnej i umocnienia władzy centralnych organów partyjnych, liderzy frakcji nie byli już w stanie dyktować, w jakim kierunku ma podążać polityka PLD. W połowie października 2005 roku Koizumi odbył piątą wizytę w Yasukuni. Tym razem nieco uprościł rytuały w świątyni, ale i tak jego postępowanie zostało krytycznie ocenione przez władze $\mathrm{ChRL}^{345}$. Na dodatek w tym samym miesiącu PLD ogłosiła projekt

\footnotetext{
${ }^{339}$ Matsuda Takakazu, Shiten 05 - konna hazu dewa... Jimintō habatsu, „Mainichi Shinbun” z 22 XII 2005, s. 5.

${ }^{340}$ Ōshita Eiji, op.cit., s. 373.

${ }^{341}$ Tanigaki był umiarkowanym politykiem, który zwracał uwagę na konieczność poprawy relacji z Chinami. Szerzej na ten temat: Tanigaki Sadakazu, Nihon keizai no genkyō to kadai [w:] Koizumi Jun'ichirō et al., Jimintō no sokojikara, Seikō Shobō, Tokio 2007, s. 132-134.

${ }^{342}$ Honzawa Jirō, Habatsu no shūen..., s. 113-114.

${ }^{343}$ Paradoksalnie, wspierając premiera grupa „dzieci Koizumiego” zachowywała się w partii w sposób podobny do frakcji. Jedna z członkiń tej grupy, minister równouprawnienia płci w rządzie Koizumiego, Inoguchi Kuniko, rzuciła nawet żartem: „Ja też należę do frakcji, do frakcji Koizumiego". Rozmowa autora z posłanką Inoguchi Kuniko, Uniwersytet Kwansei Gakuin w Nishinomiyi, 11 X 2008.

${ }^{344} 21$ shiji de Zhong-Ri..., s. 110-111.

${ }^{345} \mathrm{~W}$ przeciwieństwie do poprzednich wizyt, Koizumi nie podpisał się pod ofiarą dla świątyni jako premier, ani nie wszedł do jej głównego budynku. Oprócz wzięcia pod uwagę stanowiska
} 
rewizji konstytucji, w którym przewidywano zmianę pacyfistycznego artykułu $9^{346}$.

Wobec upartej postawy japońskiego premiera w sprawie Yasukuni, władze w Pekinie zdawały się już porzucić nadzieję co do możliwości zmiany jego nastawienia do problemów historycznych i czekać na objęcie władzy w Japonii przez następnego szefa rządu ${ }^{347}$. W ostatnim roku rządów Koizumiego dialog japońsko-chiński został niemal przerwany. Władze w Pekinie odmówiły spotkań z japońskim premierem zarówno na szczycie APEC w Korei Południowej w listopadzie 2005 roku, jak i na pierwszym Szczycie Azji Wschodniej ${ }^{348} \mathrm{w}$ Malezji w grudniu 2005 roku. Niezadowolenie ChRL z wizyt w Yasukuni było tak duże, że chińscy dyplomaci wysokiego szczebla unikali także rozmów z ministrem spraw zagranicznych Asō Tarō. Zresztą Asō w pełni zgadzał się z postawą premiera wobec problemów historycznych, a na dodatek był członkiem obozu protajwańskiego. W grudniu 2005 roku oświadczył, że z powodu posiadania broni nuklearnej i zwiększania wydatków na zbrojenia ChRL stanowi zagrożenie dla Japonii ${ }^{349}$. Kiedy zaś w lutym 2006 roku Asō powiedział, iż Tajwan stał się krajem o wysokim poziomie wykształcenia dzięki niegdysiejszej kolonialnej polityce Japonii, natychmiast został skrytykowany przez ChRL za zniekształcanie historii, jak też za nazwanie Tajwanu „krajem”350. Oprócz Asō, po ,wyborach pocztowych” Koizumi powołał na ważne stanowisko w swoim rządzie także innego znanego ,jastrzębia”, Abe Shinzō, który został sekretarzem gabinetu. Świadczyło to o tym, że premier nie miał zamiaru iść na żadne kompromisy w sprawie problemów historycznych ${ }^{351}$.

Po pięciu latach rządów, 15 sierpnia 2006 roku, Koizumi w końcu w pełni zrealizował swoją obietnicę wyborczą z 2001 roku i odwiedził Yasukuni w rocznicę kapitulacji Japonii. Po wizycie oświadczył na konferencji prasowej:

państw ościennych, jednym z powodów uproszczenia rytuałów był wyrok Sądu Osakijskiego z końca września 2005 roku, iż uczestnicząc $\mathrm{w}$ rytuałach religijnych premier nie może podkreślać funkcji, którą piastuje. Szerzej na ten temat: Shimizu Yoshikazu, op.cit., s. 14-15; Yomiuri Shinbun Seijibu, op.cit., s. 290-292.

${ }^{346}$ Miano stworzyć Armię Samoobrony zamiast Sił Samoobrony, jak też zalegalizować uczestnictwo wojska japońskiego w zagranicznych misjach pokojowych. Szerzej na ten temat: Toyoshita Narahiko, Shūdanteki jieiken to wa nani ka, Iwanami Shoten, Tokio 2007, s. 2; Karol Żakowski, Problem rewizji Konstytucji a japońska polityka bezpieczeństwa w XXI wieku [w:] Chiny $i$ Japonia. Dylematy mocarstw $w$ Azji Wschodniej pod red. Małgorzaty Pietrasiak i Dominika Mierzejewskiego, Wydawnictwo Uniwersytetu Łódzkiego, Łódź 2009, s. 71.

${ }^{347}$ Itagaki Eiken, op.cit., s. 222.

${ }^{348}$ Szczyt Azji Wschodniej (jap. Higashi Ajia Shunō Kaigi, ang. East Asia Summit, EAS) to ustanowione w 2005 roku coroczne spotkania na szczycie, w których biorą udział prezydenci lub premierzy krajów Azji Wschodniej. Uczestnicy omawiają szeroki wachlarz zagadnień, dotyczących np. współpracy gospodarczej.

34921 shiji de Zhong-Ri..., s. 405.

${ }^{350}$ Nagayama Hideki, op.cit., s. 227-228.

${ }^{351}$ Shimizu Yoshikazu, op.cit., s. 4-18. 
„Jestem zwolennikiem przyjaźni japońsko-chińskiej i japońsko-koreańskiej. Od chwili objęcia urzędu kontynuuję pogłębianie przyjacielskiej wymiany w różnych dziedzinach z Chinami i Koreą Południową. (...) W każdym kraju są różnice zdań czy spory. Czyż dla Japonii i innych krajów nie jest ważne przezwyciężenie takich problemów i rozwój przyjaznych stosunków zorientowanych na przyszłość? (...) Na początku wiele osób mówiło mi, bym tylko zrezygnował z [odwiedzin w Yasukuni - przyp. aut.] 15 sierpnia. Słuchając głosów tych ludzi, starałem się dokonywać wizyt unikając 15 [sierpnia - przyp. aut.]. Jednakże mimo iż rezygnowałem z 15 sierpnia, nie było żadnej różnicy w ciągłej krytyce, protestach i ruchach nadania temu problemowi wielkiej wagi. Kiedykolwiek bym nie poszedł, będzie tak samo. Skoro tak, to czyż dziś nie jest właściwy dzień?? ${ }^{352}$

Wkrótce potem kadencja Koizumiego jako przewodniczącego PLD dobiegła końca. We wrześniu 2006 roku bez większych głosów sprzeciwu premier przekazał władzę wnukowi Kishiego Nobusuke, Abe Shinzō, którego od lat przygotowywał do roli swojego następcy. W ten sposób zakończyła się era czwartego pokolenia przywódców PLD.

$$
* * *
$$

W czasie kadencji Koizumiego Jun'ichirō polityka zagraniczna, w tym też relacje z ChRL, zostały podporządkowane ważniejszym dla premiera celom, w szczególności zaś ogłoszonym przez niego planom reformy strukturalnej. W przeciwieństwie do przemyślanych działań w gospodarce, posunięcia w dziedzinie dyplomacji miały tylko doraźny, a z punktu widzenia realizmu politycznego nawet irracjonalny, charakter. „Patetyczny premier” zerwał z tradycyjnym japońskim stylem rządzenia. Przedkładając własne cele nad konieczność utrzymania wewnątrzpartyjnej równowagi, zastąpił poparcie szefów frakcji wysokim poparciem społecznym i był w stanie odgórnie narzucać swoją wolę całej partii. Przy takim podejściu do polityki czynnikiem o kluczowym znaczeniu okazały się jego osobiste przekonania i cechy charakteru. Na początku rządów Koizumi przyjął żelazną zasadę, iż spełni wszystkie obietnice wyborcze z 2001 roku, w tym obietnicę corocznych wizyt w Yasukuni. Rzeczywiście, premier uparcie kontynuował odwiedzanie kontrowersyjnej świątyni, nie bacząc na tragiczny wpływ tej postawy na relacje japońsko-chińskie. Jedyne ustępstwa dotyczyły daty $\mathrm{i}$ formy wizyt. Fakt, że nadal wpływowemu środowisku propekińskiemu w PLD nie udało się nakłonić premiera do rezygnacji z odwiedzin, wynikał $\mathrm{z}$ radykalnej zmiany równowagi sił wewnątrz partii. Dotychczasowe podziały na frakcje, jak też na obozy protajwański i propekiński, zeszły na dalszy plan, zaś Koizumiemu udało się skierować wewnątrzpartyjny dyskurs na problem reformy strukturalnej. Niemniej jednak siłą rzeczy na osłabieniu frakcyjności najbardziej skorzystała dawna grupa Kishiego, z której

${ }^{352}$ Iijima Isao, Koizumi kantei hiroku, Nihon Keizai Shinbunsha, Tokio 2006, s. 316-317. 
wywodził się premier. Wzrost wpływów prawicowej frakcji Moriego tylko pogłębiał stan napięcia w relacjach japońsko-chińskich.

\section{PODSUMOWANIE}

Ostatni $\mathrm{z}$ omawianych $\mathrm{w}$ pracy okresów znacząco różnił się od trzech poprzednich. Frakcje w PLD straciły na znaczeniu, zaś dotychczasowy podział na grupy „głównego nurtu” i poza ,głównym nurtem” uległ niemal całkowitemu zamazaniu. Doszedł za to nowy czynnik, jakim było stanowisko koalicyjnych partnerów PLD. W wyniku tych przemian wewnątrzpartyjne uwarunkowania polityki PLD wobec Chin stały się znacznie mniej przewidywalne i trudniejsze do naukowej analizy. Można powiedzieć, że lata 1993-2006 były dla stosunków japońsko-chińskich swoistą „równią pochyłą”. Okres ten zaczął się wyborem na stanowisko przewodniczącego PLD bardzo liberalnego i propekińskiego polityka, Kōno Yōheia. Następnie władzę przejęli Hashimoto Ryūtarō i Obuchi Keizō z frakcji środka, którzy charakteryzowali się ambiwalentnym, pragmatycznym nastawieniem wobec ChRL. Z kolei rządy Moriego Yoshirō i szczególnie Koizumiego Jun'ichirō z dawnej frakcji Kishiego zaznaczyły się skrajnym pogorszeniem atmosfery $\mathrm{w}$ relacjach $\mathrm{z}$ Chinami, głównie z powodu problemów historycznych i wizyt Li Denghuia w Japonii.

Pośredni wpływ na tę sytuację miała deregulacja systemu frakcyjnego w PLD. Po rozpadzie frakcji-hegemona zakwestionowany został utrzymywany przez nią w latach 80. XX wieku ,propekiński konsensus” w partii. Stronnictwo protajwańskie, które niemal zawiesiło swoją działalność w okresie hegemonii frakcji Tanaki, „obudziło się z letargu” tuż po zakończeniu zimnej wojny. Demokratyzacja Tajwanu oraz coraz bardziej agresywna polityka władz w Pekinie przysporzyły rządowi w Tajpej nowych zwolenników w PLD, zaś starym dodały pewności siebie. Co prawda dojście do władzy Demokratycznej Partii Postępu spowodowało chwilowe naruszenie kontaktów między tradycyjnym obozem protajwańskim w PLD a rządem w Tajpej, ale zostały one szybko odbudowane przez młodsze pokolenie polityków.

O ile deregulacja systemu frakcyjnego działała na korzyść obozu ,jastrzębi” i polityków protajwańskich, stronnictwo propekińskie napotykało na coraz większe przeszkody w promocji przyjaznych relacji z ChRL. W przeciwieństwie do poprzedniego okresu, nie mogło użyć dyscypliny frakcyjnej jako środka do tłumienia inicjatyw prawego skrzydła PLD. Na dodatek samo przeżywało kryzys tożsamości razem z odchodzeniem z polityki starszych parlamentarzystów, którzy byli autorami normalizacji chińsko-japońskich stosunków dyplomatycznych w latach 70. XX wieku. Dawna frakcja Tanaki, niegdyś główny obrońca „konsensusu propekińskiego”, stała się grupą o mieszanym nastawieniu wobec Chin, gdy w latach 90. XX wieku do kierowniczych stanowisk doszli w niej tacy protajwańscy politycy, jak Kajiyama Seiroku czy Obuchi Keizō. Hashimoto i 
Obuchi prowadzili pragmatyczną dyplomację jako premierzy, ale musieli także liczyć się ze zdaniem przybierającego na sile prawego skrzydła PLD. Również inna z frakcji ,głównego nurtu konserwatywnego", dawna grupa Ikedy, nie była w stanie skutecznie przeciwdziałać antychińskim nastrojom. Rywalizacja pomiędzy dwoma propekińskimi politykami, Kōno Yōheiem a Katō Kōichim, oraz rozpad frakcji Katō na przełomie 2000 i 2001 roku znacząco osłabiły wpływy umiarkowanych polityków w partii. Czynniki te sprawiły, że obozy „gołębi” i polityków propekińskich nie były w stanie skutecznie przeciwdziałać wizytom premiera Koizumiego w świątyni Yasukuni, które stały się jedną z głównych przyczyn eskalacji napięcia w relacjach japońsko-chińskich na początku XXI wieku. 


\section{PODSUMOWANIE I WNIOSKI}

Na politykę PLD wobec Chin zauważalny wpływ wywierały zarówno czynniki ideologiczne, osobowościowe i powiązania personalne, jak też pragmatyczne wykorzystanie sprawy chińskiej w rywalizacji o władzę, która bez przerwy toczyła się w partii rządzącej Japonią. Uwarunkowania te ulegały zmianie razem z ewolucją systemu wewnątrzpartyjnego, narzucającego ogólne ramy rywalizacji międzyfrakcyjnej. Podsumowania dokonano poprzez przedstawienie wniosków dotyczących trzech tez sformułowanych we wstępie pracy. Znalazły one odzwierciedlenie w uproszczonym modelu ukazującym, w jaki sposób kształtowane było stanowisko PLD wobec Chin.

\section{Ideologiczne, osobowościowe i personalne uwarunkowania polityki PLD wobec Chin}

$\mathrm{Na}$ gruncie teorii stosunków międzynarodowych szczególnie liberałowie podkreślają, że polityka zagraniczna państwa jest owocem rywalizacji pomiędzy jednostkami i grupami interesu reprezentującymi różnorodne opcje polityczne i osobowości, jak też posiadającymi powiązania personalne z innymi jednostkami i grupami. Ideologiczne uwarunkowania polityki PLD wobec Chin można rozważać na trzech poziomach: pojedynczych polityków, frakcji oraz całej partii. $\mathrm{O}$ ile na poziomie jednostki zabarwienie ideologiczne było dość wyraźnie widoczne, na poziomie partii jako całości ulegało daleko idącemu zamazaniu jako wypadkowa działań polityków i grup o sprzecznych poglądach i interesach.

\section{A. Poziom pojedynczych polityków}

Podejście polityków PLD do sprawy chińskiej było uwarunkowane ich nastawieniem do idei antykomunizmu, pacyfizmu czy azjanizmu. Chociaż wszyscy parlamentarzyści tej partii byli w mniejszym lub większym stopniu antykomunistami, w różny sposób interpretowali sytuację w Chinach. O ile Kishi Nobusuke, Ishii Mitsujirō, Funada Naka czy Nakagawa Ichirō nie potrafili przezwyciężyć zimnowojennych podziałów, tacy działacze jak Matsumura Kenzō, Fujiyama Aiichirō, Ōhira Masayoshi czy Katō Kōichi dostrzegali, że ChRL jest krajem komunistycznym jedynie powierzchownie i można dojść do porozumienia z jej przywódcami. Również politycy o silnych przekonaniach pacyfistycznych i snujący wizje solidarności państw azjatyckich, jak Ishibashi Tanzan czy Miki Takeo, sprzyjali porozumieniu z ChRL.

$\mathrm{Na}$ stosunek liderów PLD wobec Chin duży wpływ miały także ich doświadczenia z czasów wojny oraz osobiste relacje z ludźmi władzy na Tajwanie bądź w ChRL. Protajwańskie poglądy Kishiego Nobusuke były wzmacniane jego osobistą przyjaźnią z Jiang Jieshim, nawiązaną dzięki dawnym kontaktom z Armią Kwantuńską. Podobne relacje utrzymywał Mori Yoshirō z 
Li Denghuiem. Personalna zażyłość z chińskimi politykami grała istotną rolę również w stronnictwie propekińskim. Matsumura Kenzō nawiązał nić przyjaźni z Zhou Enlaiem, zaś Nakasone Yasuhiro z Hu Yaobangiem. Pielęgnowane przez lata znajomości $\mathrm{z}$ decydentami $\mathrm{z}$ ChRL lub Tajwanu $\mathrm{w}$ naturalny sposób umacniały ideologiczne nastawienie japońskich polityków wobec sprawy chińskiej. Pewną rolę odgrywały tu także doświadczenia z czasów studenckich. Mori Yoshirō utrzymywał kontakty z przedstawicielem Tajwanu w Japonii Lin Jinjingiem m.in. z powodu wspólnych powiązań z Uniwersytetem Waseda, podobnie zresztą jak Matsumura Kenzō z chińskim dyplomatą Liao Chengzhim.

Ważnym czynnikiem wpływającym na stosunek poszczególnych polityków do Chin były powiązania rodzinne. Pierwszy istotny przykład to wpływ Kishiego Nobusuke na protajwańską postawę jego brata, Satō Eisaku. Od lat 80. XX wieku coraz bardziej widocznym zjawiskiem stało się obejmowanie czołowych stanowisk w partii przez potomków polityków. Wielu parlamentarzystów w drugim czy trzecim pokoleniu odziedziczyło po swoich ojcach powiązania z władzami w Tajpej lub Pekinie. W obozie protajwańskim można wymienić np. Shiinę Motoo (syn Shiiny Etsusaburō), Abe Shinzō (wnuk Kishiego Nobusuke, syn Abe Shintarō) i Satō Shinjiego (syn Satō Eisaku), zaś w obozie propekińskim Tanakę Makiko (córka Tanaki Kakueia) i Sonodę Hiroyukiego (syn Sonody Sunao). Nie wszyscy potomkowie odziedziczyli jednak powiązania swoich ojców z rządem w Tajpej lub Pekinie, o czym świadczy np. propekińskie nastawienie Fukudy Yasuo, syna premiera Fukudy Takeo.

Kolejnym czynnikiem, który mógł wpływać na nastawienie niektórych polityków wobec sprawy chińskiej, była ich przynależność do klanów parlamentarnych (zoku). Klany edukacji i obrony w dużym stopniu składały się z reprezentantów obozu ,jastrzębi”, którzy nie zgadzali się na chińską ingerencję w takie wewnętrzne sprawy Japonii, jak zatwierdzanie kontrowersyjnych podręczników do historii, wizyty w świątyni Yasukuni czy zmiana dyrektyw sojuszu japońsko-amerykańskiego. Dobrymi przykładami są tu Mori Yoshirō, Fujio Masayuki czy Mitsuzuka Hiroshi. Znacznie mniej „nasycone ideologią” były zoku związane z polityką gospodarczą (budownictwa, finansów, poczty, opieki społecznej). Ich przedstawiciele zazwyczaj wykazywali ograniczone zainteresowanie polityką zagraniczną. $\mathrm{Z}$ jednej strony mogło to skutkować wyważonym, racjonalnym podejściem do dyplomacji (Hashimoto Ryūtarō), z drugiej zaś rodziło niebezpieczeństwo nadmiernego lekceważenia problemów międzynarodowych na rzecz polityki wewnętrznej (Koizumi Jun'ichirō). Unikalną rolę pełnił klan strategii parlamentarnej. Ponieważ jego członkowie specjalizowali się w negocjacjach z opozycją, byli przyzwyczajeni do szukania kompromisu i dbając o równowagę między frakcjami w PLD nie trzymali się swojego zdania za wszelką cenę. Jako przykład można podać Moriego Yoshirō, który pomimo swoich prawicowych poglądów zrezygnował z wizyty w świątyni Yasukuni w 2000 roku. Podobną ugodowość można zauważyć u Suzukiego 
Zenkō, który nauczył się jej dzięki wieloletniemu sprawowaniu funkcji przewodniczącego Rady Generalnej PLD. Jego nastawienie na szukanie kompromisu za wszelką cenę wydłużyło pierwszy kryzys podręcznikowy w 1982 roku.

Pomimo braku jednolitego klanu dyplomacji, za osobną kategorię można uznać liderów PLD, którzy posiadali doświadczenie kilkuletniego piastowania stanowiska ministra spraw zagranicznych (Miki Takeo, Ōhira Masayoshi, Kōno Yōhei, Miyazawa Kiichi). Na tle większości premierów, skupiających się głównie na problemach wewnątrzkrajowych, wyróżniali się oni większym zrozumieniem dla uwarunkowań zewnętrznych oraz lepszym przygotowaniem do formułowania dalekosiężnych strategii budowy mocarstwowej pozycji Japonii na arenie międzynarodowej. Jest to szczególnie widoczne na przykładzie Ōhiry Masayoshiego, który przed objęciem urzędu prezesa Rady Ministrów był ministrem spraw zagranicznych w sumie przez aż cztery lata. Nic dziwnego, że to właśnie on zauważył, jak wielką rolę odgrywać będą kontakty z ChRL w nieuchronnej, jego zdaniem, redefinicji nadmiernie pasywnej polityki Japonii w regionie Azji Wschodniej.

Równie istotne były związki poszczególnych polityków z organizacjami pozarządowymi. Szczególne znaczenie miały relacje z prawicowymi stowarzyszeniami, które stanowiły dla polityków ważne źródło głosów w wyborach parlamentarnych. Czasami więzi z grupami interesu okazywały się silniejsze niż członkostwo we frakcji (np. opuszczenie przez Tamakiego Kazuo propekińskiej frakcji Mikiego z powodu związków Tamakiego z protajwańską sektą Seichō no Ie). W szczególności należy wymienić takie wpływowe organizacje, jak Nihon Izokukai czy Nippon Kaigi. Promowane przez nie oficjalne wizyty premierów w świątyni Yasukuni negatywnie wpływały na relacje Japonii z ChRL.

\section{B. Poziom frakcji}

Frakcje z zasady były grupami opartymi na relacjach interpersonalnych, a nie na wspólnie podzielanej ideologii. Niemniej jednak, nawet jeśli ideologia nie odgrywała pierwotnie większej roli w ich powstaniu, poglądy charyzmatycznych liderów - założycieli frakcji wywarły wpływ na uformowanie się „etosu” poszczególnych grup. Młodzi parlamentarzyści byli wierni swoim oyabunom i z czasem przejmowali od nich polityczne nawyki. Kobuni odczuwali dług wdzięczności wobec przełożonych za pomoc w uzyskaniu mandatu poselskiego (np. Mori Yoshirō wobec Kishiego Nobusuke, Hiranuma Takeo wobec Nakagawy Ichirō) i pielęgnowali pamięć o nich, kontynuując ich linię polityczną. $\mathrm{W}$ ten sposób można wytłumaczyć, dlaczego niemal zawsze w chwili zmiany pokoleniowej we frakcji zachowywany był jej koloryt ideologiczny.

Tylko w niektórych przypadkach frakcja była na tyle niejednorodna ideologicznie, że nie dało się jej jednoznacznie zaliczyć do stronnictwa propekińskiego lub protajwańskiego. Najlepszy przykład stanowił nurt KōnoNakasone-Watanabe. Chociaż jego liderzy w większości byli politykami 
propekińskimi, wśród szeregowych członków można było znaleźć wielu posłów blisko związanych z reżimem Guomindangu. Ta niespójność ideologiczna wzięła się m.in. stąd, że w skład frakcji Kōno weszli kobuni aż trzech polityków: Hatoyamy Ichirō, Mikiego Bukichiego i Kitamury Tokutarō. Jeśli lider frakcji reprezentował inną opcję ideologiczną niż większość członków grupy, zaś członkowie ci nie byli jego bezpośrednimi kobunami, tylko zostali „przejęci” w wyniku fuzji kilku grup, solidarność frakcji była zagrożona. Jej przewodniczący nie mógł wówczas narzucać swojego zdania wszystkim podwładnym. Musiał postępować bardzo ostrożnie, by uniknąć rozłamu. O ile Kōno Ichirō się to powiodło (frakcja uległa rozpadowi dopiero po jego śmierci w 1965 roku), mniej szczęścia miał np. Fujiyama Aiichirō. Gdy frakcję propekińsko nastawionego Fujiyamy opuściła grupa protajwańska, frakcja straciła swoje wpływy i uległa szybkiemu zanikowi.

Pomijając stosunkowo nieliczne wyjątki, przypisanie frakcjom konkretnych opcji ideologicznych było możliwe dzięki temu, że lojalność wobec grupy decydowała o karierze polityków. W takich warunkach wewnątrzfrakcyjne podziały rzadko wychodziły na światło dzienne i przy pewnym uproszczeniu każdą z grup można było traktować jako monolit. Nawet jeśli dany poseł nie zgadzał się z decyzją swojego oyabuna, musiał ją respektować. Chociaż czasami zdarzały się przypadki nieposłuszeństwa wobec woli lidera grupy, były one na tyle nieliczne, że nie przeczyły ogólnej regule.

Dopiero po reformie systemu wyborczego w 1994 roku solidarność frakcji znacząco osłabła. Było to związane z utratą przez nie roli najważniejszych grup w partii. Ponieważ kariera polityków była coraz mniej zdeterminowana lojalnością wobec lidera frakcji, a coraz bardziej wiernością wobec naczelnych władz partii, parlamentarzyści nie musieli w każdej sprawie respektować woli oyabuna. W wyniku tego procesu wewnątrzfrakcyjne podziały stały się wyraźniej widoczne, zaś frakcje w dużym stopniu utraciły swój ideologiczny koloryt. Nawet jeśli w danej grupie przeważali zwolennicy określonej opcji politycznej i reprezentował ją także przewodniczący frakcji, nie byli oni w stanie narzucić swojego zdania reszcie grupy.

\section{Poziom całej partii}

Od samego początku istnienia PLD w jej skład wchodziły obozy o różnej ideologii. W przypadku polityki wobec Chin szczególną rolę odgrywał podział na stronnictwo propekińskie i protajwańskie oraz na „gołębie” i ,jastrzębie”. O ile pierwszy $\mathrm{z}$ nich był najważniejszy $\mathrm{w}$ pierwszych dwóch omawianych okresach (1955-1980), drugi przybrał na znaczeniu w dwóch ostatnich (19802006). Politycy obozu protajwańskiego w latach 80. XX wieku częściowo pogodzili się z nawiązaniem oficjalnych stosunków dyplomatycznych z ChRL i ich działalność stała się ponownie widoczna dopiero w latach 90. XX wieku. Nigdy jednak nie osiągnęła skali porównywalnej do okresu sprzed 1972 roku. Od lat 80. XX wieku przybierał za to na znaczeniu problem pamięci historycznej. 
Kryzysy związane z podręcznikami do historii, wizytami w świątyni Yasukuni, „kobietami pocieszycielkami” czy brakiem przeprosin za zbrodnie z czasów II wojny światowej sprawiły, że podział na „gołębie” i ,jastrzębie”, choć nie odnosił się bezpośrednio do sprawy chińskiej, stał się kluczowy dla zrozumienia wewnątrzpartyjnych uwarunkowań polityki PLD wobec Chin.

W celu dokładnego zbadania liczebności poszczególnych obozów ideologicznych $\mathrm{w}$ partii trzeba by przeanalizować poglądy polityczne wszystkich parlamentarzystów PLD na przestrzeni półwiecza stanowiącego ramy czasowe pracy. Takie zadanie byłoby niewykonalne technicznie z powodu braku źródeł dotyczących tysięcy polityków, których należałoby uwzględnić w badaniu. Zresztą tego typu dane nie byłyby zbyt przydatne do analizy wewnątrzpartyjnych uwarunkowań polityki PLD wobec Chin, a to z dwóch powodów. Po pierwsze, największy wpływ na proces decyzyjny w partii miał jej przewodniczący oraz ewentualnie nieliczne grono osób sprawujących najważniejsze urzędy partyjne. W większości rekrutowali się oni z ,głównego nurtu” w ramach PLD. Po drugie, podstawowymi jednostkami tworzącymi kolejne „główne nurty” były frakcje. Jak już zaś wcześniej wspomniano, przy pewnym uproszczeniu frakcje można traktować jako monolity pod względem ideologicznym. Dzięki temu, zamiast badać nastawienie wobec Chin wszystkich parlamentarzystów PLD, wystarczyła analiza poglądów politycznych przewodniczących partii oraz szefów frakcji.

Dopiero po przyjęciu powyższych założeń możliwe stały się rozważania na temat uwarunkowań ideologicznych na poziomie całej partii. Przy ich analizie brane były pod uwagę dwa kluczowe czynniki: przekonania przewodniczących PLD oraz spójność ideologiczna poszczególnych ,głównych nurtów”. Wielkość przeciwstawnych obozów w ,głównych nurtach” zmierzono poprzez ustalenie sumy parlamentarzystów z frakcji reprezentujących określone opcje ideologiczne. W sposób przeglądowy została ona ukazana na wykresach 6.1 i 6.2. Podstawowy wniosek, jaki się nasuwa po całościowej analizie danych jest taki, że im większa była spójność ideologiczna poszczególnych „głównych nurtów”, tym łatwiej decydentom przychodziło określenie jednolitej polityki PLD wobec Chin.

Wykres 6.1 przedstawia zmianę liczebności parlamentarzystów należących do frakcji propekińskich i protajwańskich w kolejnych „głównych nurtach”. Odległość pomiędzy dwiema liniami świadczy o spójności ideologicznej określonego „głównego nurtu” (jest do niej wprost proporcjonalna). Jak widać, obóz protajwański wyraźnie dominował w okresie rządów Kishiego Nobusuke (1957-1960), w drugim „głównym nurcie” Satō Eisaku (ok. 1967-1972) oraz za kadencji Mikiego Takeo (1974-1976). Pokrywa się to z okresami ochłodzenia relacji Japonii z ChRL. Kishi Nobusuke należał do liderów obozu protajwańskiego i był gotowy kontynuować pozarządowy handel z Chinami kontynentalnymi tylko $\mathrm{w}$ takim wymiarze, $\mathrm{w}$ jakim by nie zaszkodził relacjom z reżimem 
Guomindangu. Doprowadziło to do zerwania przez ChRL wszelkich kontaktów z Japonią w 1958 roku. Brat Kishiego, Satō Eisaku, charakteryzował się co prawda większą elastycznością ideologiczną, ale także on, nawet po „szoku Nixona" w 1971 roku, nie był gotowy do całkowitego zerwania oficjalnych stosunków z reżimem Guomindangu. Zresztą wewnątrz PLD, zwłaszcza w ostatnich latach swojej kadencji, był zależny głównie od poparcia skrzydła protajwańskiego. Ciekawym przypadkiem był okres rządów Mikiego Takeo. Premier należał do zdecydowanych zwolenników pogłębiania relacji z ChRL, ale ze względu na niechęć do „polityki pieniądza” utożsamianej z Tanaką Kakueiem, oprócz wsparcia własnej frakcji mógł liczyć jedynie na pomoc grup protajwańskich. Tłumaczy to, dlaczego nie potrafił doprowadzić do końca negocjacji w sprawie Traktatu o pokoju i przyjaźni z ChRL.

Wykres 6.1 Ewolucja liczebności parlamentarzystów PLD należących do frakcji propekińskich i protajwańskich $\mathrm{w}$,głównym nurcie”.

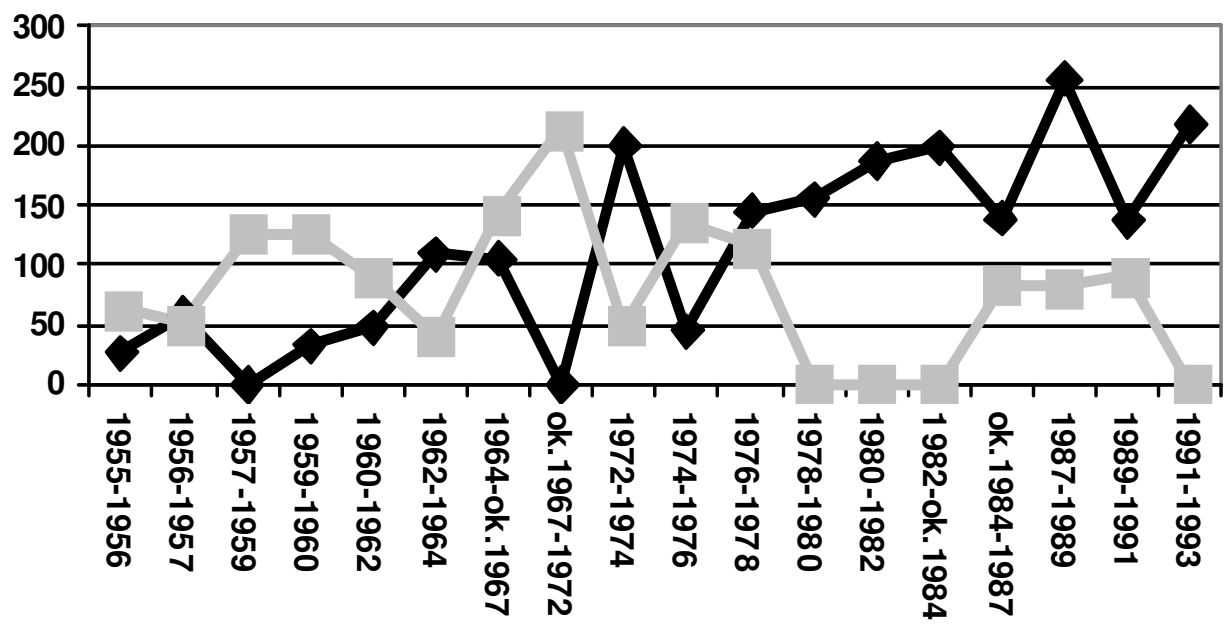

\section{Liczebność frakcji propekińskich w "głównym nurcie" \\ Liczebność frakcji protajwańskich w "głównym nurcie"}

Do 1962 roku uwzględniono tylko członków frakcji z Izby Reprezentantów.

Opracowanie własne na podstawie m.in.: Kitaoka Shin'ichi, op.cit., s. 334-336; Satō Seizaburō, Matsuzaki Tetsuhisa, op.cit., s. 241-243; Tsuchiya Shigeru, op.cit., s. 108-195; Fukunaga Fumio, Habatsu..., s. 80; Fukui Haruhiro, op.cit., s. 344-345; Iseri Hirofumi, op.cit., s. 109; Eguchi Nobuyuki, op.cit., s. 67; Asahi Shinbun Seijibu, op.cit., s. 131-171.

Z kolei za kadencji Hatoyamy Ichirō jako szefa PLD (1955-1956), jak też w pierwszych „głównych nurtach” Ikedy Hayato (1960-1962) oraz Satō Eisaku 
(1964-ok. 1967), obóz protajwański posiadał jedynie nieznaczną przewagę nad stronnictwem propekińskim. Hatoyama Ichirō był pozytywnie nastawiony do idei pogłębiania relacji z ChRL, co zaowocowało podpisaniem w 1955 roku trzeciej pozarządowej umowy z tym państwem. Niemniej jednak protajwańska baza poparcia wewnątrz partii uniemożliwiała mu normalizację stosunków dyplomatycznych $\mathrm{z}$ władzami $\mathrm{w}$ Pekinie. Podobna sytuacja panowała na początku rządów Ikedy Hayato. Premier wykazywał aktywną postawę wobec Chin, dzięki której ChRL zgodziła się na tzw. „handel przyjacielski” z Japonią. $\mathrm{Z}$ drugiej strony, dalsze pogłębienie wzajemnych relacji nie było możliwe, dopóki w „głównym nurcie” pozostawały protajwańskie frakcje Kishiego i Satō. Z kolei trzeci z przykładów różni się od dwóch poprzednich. Co prawda także w latach 1964-ok. 1967 obóz protajwański miał tylko niewielką przewagę nad stronnictwem propekińskim, ale w przeciwieństwie do Hatoyamy i Ikedy, Satō Eisaku zajmował raczej bierną postawę wobec Chin, co wyraźnie działało na korzyść reżimu Guomindangu.

Podobnie można przeanalizować wewnątrzpartyjne koalicje, w których dominowało stronnictwo propekińskie. Stosunkowo wysoką spójność ideologiczną wykazywał pod tym względem drugi ,główny nurt” Ikedy Hayato (19621964), a zwłaszcza okres rządów Tanaki Kakueia (1972-1974) oraz wszystkie „główne nurty” w latach 1978-1993. Po uwolnieniu się od wpływów Kishiego i Satō, Ikeda zyskał znacznie większą swobodę w formułowaniu polityki wobec Chin. Skutkowało to podpisaniem w 1962 roku umowy handlowej LiaoTakasaki. Jeszcze większą przewagą frakcji propekińskich charakteryzował się „główny nurt” Tanaki Kakueia. Pozwala to wytłumaczyć, dlaczego Tanace i Ōhirze udało się nawiązać stosunki dyplomatyczne z ChRL w 1972 roku. Z kolei po 1978 roku wszystkie ,główne nurty” były zdominowane przez frakcje propekińskie. Nawet jeśli dużą część wewnątrzpartyjnej koalicji stanowiły grupy protajwańskie, pod względem liczebności nie mogły się one równać z obozem związanym z władzami w Pekinie. Zresztą w latach 1978-1993 ani razu władzy nie objął premier mający silne powiązania z reżimem Guomindangu. Dzięki temu wszelkie zatargi $\mathrm{w}$ relacjach $\mathrm{z}$ władzami w Pekinie były stosunkowo szybko tłumione, nie przeradzając się w poważniejsze kryzysy.

Nieco inaczej wyglądała sytuacja, gdy obóz propekiński posiadał tylko niewielką przewage nad stronnictwem protajwańskim. Zdarzyło się tak w okresie rządów Ishibashiego Tanzana (1956-1957) oraz Fukudy Takeo (19761978). Ishibashi pełnił urząd premiera jedynie przez dwa miesiące, więc trudno jednoznacznie ocenić jego kadencję. Niemniej jednak z faktu, że w jego „głównym nurcie” obóz propekiński miał tylko minimalną przewagę nad protajwańskim można wnioskować, iż nawet silna wola Ishibashiego, by dokonać normalizacji stosunków dyplomatycznych z ChRL, mogłaby nie starczyć do realizacji tego trudnego zadania. Inna sytuacja panowała za kadencji Fukudy Takeo. Premier miał wyraźne powiązania $\mathrm{z}$ reżimem Guomindangu, ale 
doprowadził do podpisania Traktatu o pokoju i przyjaźni z ChRL. Można to wytłumaczyć m.in. faktem, że podlegał silnej presji środowisk propekińskich w „głównym nurcie”, zwłaszcza zaś „osi władzy” Tanaka-Ōhira.

Wykres 6.2 Ewolucja liczebności parlamentarzystów PLD należących do frakcji ,gołębi” i ,jastrzębi” w ,głównym nurcie”.

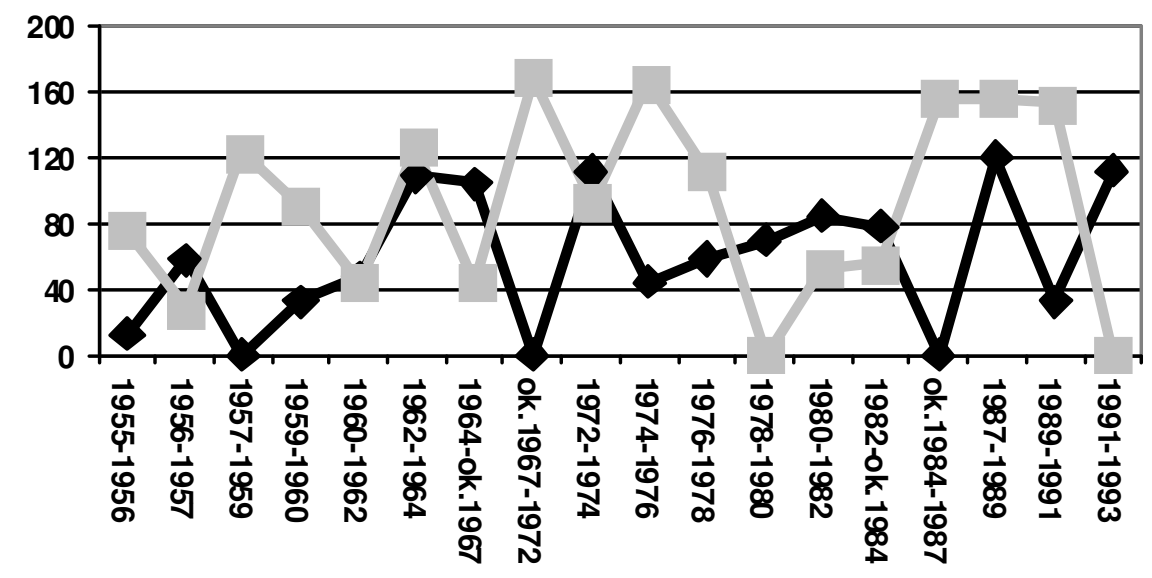

Liczebność frakcji "gołębi" w "głównym nurcie"

Liczebność frakcji "jastrzębi" w "głównym nurcie"

Do 1962 roku uwzględniono tylko członków frakcji z Izby Reprezentantów.

Opracowanie własne na podstawie m.in.: Kitaoka Shin'ichi, op.cit., s. 334-336; Satō Seizaburō, Matsuzaki Tetsuhisa, op.cit., s. 241-243; Tsuchiya Shigeru, op.cit., s. 108-195; Fukunaga Fumio, Habatsu..., s. 80; Fukui Haruhiro, op.cit., s. 344-345; Iseri Hirofumi, op.cit., s. 109; Eguchi Nobuyuki, op.cit., s. 67; Asahi Shinbun Seijibu, op.cit., s. 131-171.

W analogiczny sposób można zbadać wpływ na relacje z Chinami proporcji sił pomiędzy obozem ,jastrzębi” i „gołębi”. Był on znacznie mniej wyraźny niż efekt rywalizacji pomiędzy obozem propekińskim i protajwańskim, ponieważ tylko pośrednio dotyczył sprawy chińskiej. Prawe skrzydło jednoznacznie dominowało w partii za kadencji Kishiego Nobusuke (1957-1960) oraz w drugich „głównych nurtach” Satō Eisaku (ok. 1967-1972) i Nakasone Yasuhiro (ok. 1984-1987). Doszło wówczas do krytykowanego przez ChRL zacieśnienia sojuszu ze Stanami Zjednoczonymi (traktat z 1960 roku, wspólna deklaracja Satō i Nixona w 1969 roku) oraz pierwszej oficjalnej wizyty premiera w świątyni Yasukuni w rocznicę kapitulacji Japonii, 15 sierpnia 1985 roku. Wydarzenia te wywołały ochłodzenie w relacjach japońsko-chińskich. Również 
za rządów Mikiego Takeo (1974-1976) i Kaifu Toshikiego (1989-1991) w „głównym nurcie” dominowali ,jastrzębie”, ale sami premierzy byli zdeklarowanymi ,gołębiami” i hamowali przedsięwzięcia zmierzające do remilitaryzacji Japonii czy fałszowania historii.

Z kolei za kadencji Ishibashiego Tanzana (1956-1957), w pierwszym „głównym nurcie" Satō Eisaku (1964-ok. 1967) oraz za rządów Ōhiry Masayoshiego (1978-1980), Suzukiego Zenkō (1980-1982) i Miyazawy Kiichiego (1991-1993) zauważalną przewagę w ,głównym nurcie” posiadał obóz „gołębi”. Okresy te sprzyjały wyciszeniu inicjatyw związanych z remilitaryzacją Japonii lub fałszowaniem historii. Należy jednak zwrócić uwagę na dwa istotne wyjątki. Kryzys podręcznikowy w 1982 roku został wywołany przez dążenia polityków z zoku edukacji i pogłębiony przez ugodowość i niezdecydowanie premiera Suzukiego. Z kolei uchwalenie ustawy o misjach pokojowych ONZ za kadencji Miyazawy Kiichiego w 1992 roku trudno wytłumaczyć w ramach teorii liberalnej. W tym przypadku decydujący okazał się wpływ uwarunkowań międzynarodowych.

W dotychczasowej analizie pominięto rolę ,przeciwnego nurtu”. Frakcje znajdujące się z dala od władzy nie mogły ustalać kierunków polityki zagranicznej, ani blokować przedsięwzięć ,głównego nurtu”, ale były w stanie wymusić odroczenie pewnych decyzji. Wykorzystywały w tym celu m.in. niepisaną zasadę jednomyślności w Radzie Badań Politycznych i Radzie Generalnej PLD. Wystarczy przypomnieć sprzeciw obozu propekińskiego wobec nowego traktatu sojuszniczego z USA w 1960 roku czy stronnictwa protajwańskiego wobec umowy lotniczej z ChRL w 1974 roku. Niemniej jednak premier dysponował narzędziami, by przeforsować stanowisko „głównego nurtu" nawet pomimo tak ostrych protestów, jak te działaczy Seirankai w latach 70. XX wieku. Po pierwsze, mógł starać się złagodzić stanowisko niezadowolonych poprzez długotrwałe, zakulisowe negocjacje, by osiągnąć kompromis polegający np. na zawarciu niejasnych sformułowań w uchwale partyjnej. Tak uczynił Tanaka Kakuei, przekonując posłów protajwańskich do ugody w sprawie Podstawowych zasad normalizacji stosunków japońsko-chińskich w 1972 roku. Kompromis okazał się iluzoryczny, gdyż Japonia i tak zerwała stosunki dyplomatyczne z Tajwanem, ale umożliwił jednomyślne podjęcie decyzji partyjnej. Po drugie, jeśli perswazja nie pomagała, premier mógł się uciec do rozwiązań siłowych, np. łamiąc niepisaną zasadę konsensusu i przyjmując uchwałę partii pomimo głosów sprzeciwu w Radzie Generalnej. Tanaka użył także tej metody, forsując umowę lotniczą z ChRL w 1974 roku. Czasami posłowie ,przeciwnego nurtu” demonstrowali swoje niezadowolenie opuszczając głosowanie w parlamencie lub nawet głosując przeciw kontrowersyjnej ustawie, ale były to raczej tylko symboliczne gesty niż działania stwarzające realną szansę na zablokowanie już podjętej decyzji partyjnej. 
Osobnego omówienia wymagają ideologiczne, osobowościowe i personalne uwarunkowania polityki PLD wobec Chin w ostatnim z opisywanych okresów. Od chwili osłabienia frakcyjności po utracie władzy w 1993 roku i reformie systemu wyborczego w 1994 roku ,główne nurty" wewnątrz partii stały się na tyle niewyraźne, że metoda badawcza zastosowana do analizy sytuacji w latach 1955-1993 utraciła swoje walory naukowe. Razem ze wzrostem roli centralnych organów partii, potencjalnie jeszcze ważniejsze niż dotychczas stały się przekonania polityczne i osobowość poszczególnych przewodniczących PLD. Liderzy partii nie musieli już tyle uwagi co dawniej poświęcać zachowaniu równowagi pomiędzy słabnącymi frakcjami i zostali wyposażeni w instytucjonalne narzędzia narzucania swojej woli ugrupowaniu jako całości. Ta nowa tendencja nie ujawniła się jeszcze za kadencji Kōno Yōheia, gdyż nie piastował on funkcji premiera, co znacząco ograniczało jego wpływy w partii. Z kolei Hashimoto Ryūtarō, Obuchi Keizō i Mori Yoshirō byli politykami starego typu, przyzwyczajonymi do poszukiwaniu konsensusu pomiędzy rywalizującymi stronnictwami w PLD. Dopiero dzięki swojej nietuzinkowości Koizumi Jun'ichirō w pełni wykorzystał nowe ramy instytucjonalne do samodzielnego ustalania polityki partii. Chociaż głównym obiektem zainteresowań Koizumiego była polityka wewnętrzna, a nie zagraniczna, to jego osobowość wywarła olbrzymi wpływ na stan stosunków z Chinami. Trudno wytłumaczyć coroczne wizyty w świątyni Yasukuni, które stały w jawnej sprzeczności z interesem państwa, inaczej niż cechami charakteru premiera: uporem i niechęcią do ulegania naciskom z zewnątrz.

Nowym zjawiskiem w ostatnim $\mathrm{z}$ omawianych okresów była także konieczność dzielenia się przez PLD władzą z partnerami koalicyjnymi. Uwzględnianie stanowiska mniejszych ugrupowań komplikowało proces decyzyjny, wprowadzając do rywalizacji międzyfrakcyjnej dodatkowy czynnik pozapartyjny. W latach 1994-1996 koalicja z dwoma umiarkowanymi ugrupowaniami: Japońską Partią Socjalistyczną i Nową Partią Zwiastun, działała na korzyść stronnictwa „gołębi” i obozu propekińskiego. Można tym wytłumaczyć, dlaczego na początku czwartego z omawianych okresów relacje Japonii z Chinami były jeszcze relatywnie dobre. Dopiero gdy socjaldemokraci przeszli do współpracy pozarządowej z PLD, zaś ich wpływy zmalały w wyniku rozłamów i porażki wyborczej w 1996 roku, powstały warunki sprzyjające inicjatywom ,jastrzębi” i obozu protajwańskiego. Spór na temat nowych wytycznych sojuszu japońsko-amerykańskiego w 1997 roku zakończył się przyjęciem kompromisowej interpretacji terminu „obszarów otaczających Japonię", ale gdy na przełomie 1998 i 1999 roku PLD zawiązała koalicję z Partią Liberalną Ozawy Ichirō, przewaga prawego skrzydła była już bezsprzeczna. Świadczyło o tym uchwalenie ustawy o fladze i hymnie w 1999 roku oraz powołanie do życia Komisji Badań Konstytucyjnych w 2000 roku. Po opuszczeniu koalicji przez Ozawę w 2000 roku wpływ mniejszych partii na 
politykę PLD był już słabiej widoczny, szczególnie z powodu nietypowych metod sprawowania władzy przez Koizumiego.

Chociaż przedstawiony w pracy sposób badania wewnątrzpartyjnych uwarunkowań polityki PLD wobec Chin w latach 1955-1993 opiera się na pewnych uproszczeniach (np. na uznaniu frakcji za grupy jednolite pod względem ideologii, choć tak naprawdę sytuacja była znacznie bardziej skomplikowana), nie zniekształcają one rzeczywistości na tyle, by odmówić mu pewnych wartości eksplanacyjnych. Można zauważyć wysoką korelację pomiędzy składem „głównych nurtów” a polityką PLD wobec Chin i stanem relacji japońskochińskich. Chociaż nie jest to zależność funkcyjna, gdyż takie nie istnieją w naukach humanistycznych, wyraźnie widać znaczenie w procesie decyzyjnym uwarunkowań ideologicznych, osobowościowych i personalnych. Nie było obojętne, jakie poglądy polityczne, cechy charakteru czy powiązania personalne posiadały jednostki oraz grupy znajdujące się w ścisłym kręgu władzy w partii i w państwie. Kiedy zaś w latach 90. XX wieku „główne nurty” praktycznie przestały istnieć, wpływ na proces decyzyjny poglądów i cech charakteru poszczególnych przewodniczących partii jeszcze się uwydatnił. Równolegle pojawił się nowy czynnik w postaci opcji ideologicznych reprezentowanych przez ugrupowania koalicyjne.

\section{Sprawa chińska jako narzędzie rywalizacji wewnątrzpartyjnej}

Niezależnie od badanego okresu, na politykę PLD wobec Chin oddziaływały z zewnątrz zmiany zachodzące $\mathrm{w}$ otoczeniu międzynarodowym Japonii. Zgodnie $\mathrm{z}$ paradygmatem realistycznym i neorealistycznym, państwa są jednolitymi podmiotami stosunków międzynarodowych, które zachowują się w sposób racjonalny, dążąc do maksymalizacji własnej siły i bezpieczeństwa. W takim ujęciu kształt polityki zagranicznej narzuca struktura systemu międzynarodowego, zaś rola jednostki i wewnątrzpaństwowych, w tym wewnątrzpartyjnych, podziałów nie ma większego znaczenia. Pojedynczy politycy mogą co najwyżej wykorzystywać i tak nieuchronne z punktu widzenia racji stanu posunięcia dyplomatyczne do uzyskania i utrzymania władzy w partii i w państwie.

Polityka PLD wobec Chin nie była tylko mechaniczną wypadkową ideologii frakcji tworzących ,główny nurt”. Sprawę chińską wykorzystywano instrumentalnie jako wygodne narzędzie rywalizacji wewnątrzpartyjnej. Polityka Japonii wobec Chin była uwarunkowana kształtem systemu międzynarodowego i poważniejszych zmian można było $\mathrm{w}$ niej dokonać jedynie w przypadku ewolucji rozkładu sił w tym systemie. „Szok Nixona” w 1971 roku stanowił zwiastun przejścia systemu konfrontacji dwóch wrogich bloków (amerykańskiego i sowieckiego) w system równowagi sił pomiędzy USA, ZSRR oraz słabszym, ale stopniowo zyskującym na znaczeniu, mocarstwem, ChRL. Nowy układ sił został utrwalony dzięki wejściu Chin na drogę modernizacji w 1978 roku i nawiązaniu przez nie oficjalnych stosunków dyplomatycznych ze Stanami Zjednoczonymi w styczniu 1979 roku. Kolejna zmiana struktury systemu 
międzynarodowego nastąpiła w wyniku zakończenia zimnej wojny na przełomie lat 80. i 90. XX wieku oraz rozpadu Związku Radzieckiego. Kiedy zniknął wspólny wróg USA i ChRL, relacje pomiędzy tymi państwami uległy destabilizacji. Rosnąca potęga Chin zwiastowała okres poszukiwania nowej równowagi sił. Niezależnie od składu „głównych nurtów” w PLD, w celu maksymalizacji interesu narodowego japońska dyplomacja wobec Chin musiała ewoluować adekwatnie do zmian systemu międzynarodowego.

Yoshida Shigeru zawarł w 1952 roku traktat pokojowy z reżimem Guomindangu nie ze względu na sympatie protajwańskie, ale z powodu presji amerykańskiej. Dopóki ChRL była sojusznikiem ZSRR, nie było szans na zbliżenie na linii Tokio-Pekin. Obrazują to nieudane starania dwóch propekińskich przewodniczących PLD, Hatoyamy Ichirō i Ishibashiego Tanzana, o normalizację stosunków dyplomatycznych z komunistycznymi Chinami w latach 1955-1957. Z kolei zacieśniając sojusz ze Stanami Zjednoczonymi Kishi Nobusuke nie tyle kierował się pobudkami ideologicznymi, co po prostu dokonał racjonalnego wyboru $\mathrm{w}$ celu zapewnienia bezpieczeństwa swojemu krajowi. Również Ikeda Hayato musiał liczyć się z zimnowojennymi realiami. Chociaż udało mu się doprowadzić do wyraźnego ocieplenia w relacjach $\mathrm{z}$ ChRL w latach 1962-1964, nie był w stanie dokonać decydującego przełomu w stosunkach z tym państwem. Ikeda promował handel z ChRL, gdyż przynosił on zyski japońskiej gospodarce, ale dobrze wiedział, że ze względu na stanowisko Stanów Zjednoczonych nie może porzucić tajwańskiego sojusznika. Kiedy zaś po incydencie z Zhou Hongqingiem musiał zadbać o poprawę relacji z reżimem Guomindangu, przy okazji wykorzystał to do zdobycia poparcia przynajmniej części polityków prawego skrzydła partii przed wyborami na przewodniczącego PLD.

Niemniej jednak, kiedy w połowie lat 60 . XX wieku narastał kryzys w stosunkach chińsko-radzieckich i zdawało się, że KPCh odeszła od radykalnie lewicowych inicjatyw po klęsce ,wielkiego skoku”, dało się zauważyć zmianę nastawienia wobec ChRL niektórych członków obozu protajwańskiego. Satō Eisaku, pragnąc pokonać Ikedę Hayato w wyborach na stanowisko przewodniczącego PLD w 1964 roku, prezentował siebie jako męża stanu gotowego do daleko idących ustępstw wobec władz w Pekinie. Kiedy jednak został premierem, okazało się, że te deklaracje były tylko częścią marketingu politycznego. Zresztą uwarunkowania zewnętrzne (chińskie testy nuklearne, „rewolucja kulturalna” w ChRL, eskalacja wojny wietnamskiej) nadal nie sprzyjały normalizacji stosunków dyplomatycznych między Japonią a Chinami. Nowa sytuacja zaistniała dopiero w wyniku ,szoku Nixona” w 1971 roku.

Chyba najbardziej spektakularny przykład wykorzystania sprawy chińskiej w rywalizacji o władzę $\mathrm{w}$ PLD to użycie kwestii normalizacji stosunków dyplomatycznych z ChRL przez Tanakę Kakueia w celu pokonania Fukudy Takeo w wyborach na przewodniczącego partii w 1972 roku. Tanaka nie był 
specjalistą $\mathrm{w}$ sprawach dyplomacji, nie miał także wcześniej większych związków z problemem Chin, ale tuż po „szoku Nixona” w 1971 roku zmienił swoje nastawienie na aktywnie propekińskie. W ten sposób zbliżył się nie tylko do Ōhiry Masayoshiego, który od dawna był jego przyjacielem, ale również do Mikiego Takeo, który zapewne sprzymierzyłby się z Fukudą, gdyby nie deklaracje Tanaki o gotowości dokonania przełomu w relacjach z ChRL. Sojusz z Ōhirą i Mikim zapewnił Tanace też poparcie Nakasone Yasuhiro oraz szefów mniejszych frakcji, którzy po prostu chcieli znaleźć się w obozie zwycięzcy. Dzięki sprawnemu posłużeniu się problemem Chin, Tanaka Kakuei został premierem i złożył przełomową wizytę w Pekinie we wrześniu 1972 roku.

$\mathrm{W}$ połowie lat 70 . XX wieku otoczenie międzynarodowe Japonii nie sprzyjało dalszemu zacieśnianiu więzi między władzami w Tokio a rządem w Pekinie. Walka o władzę w ChRL i sprzeciw Związku Radzieckiego wobec „klauzuli antyhegemonistycznej" uniemożliwiały podpisanie Traktatu o pokoju i przyjaźni. Według realistycznej wizji stosunków międzynarodowych, Miki Takeo nie był w stanie dokonać przełomu w negocjacjach ze stroną chińską nie tyle z powodu presji protajwańskich polityków we własnym „głównym nurcie”, co raczej dlatego, że był ograniczany przez uwarunkowania międzynarodowe. Dopiero gdy w ChRL zwyciężył obóz umiarkowanych polityków, zaś rozmowy ze Związkiem Radzieckim na temat sporu terytorialnego nie przyniosły żadnych rezultatów, powstały warunki sprzyjające podpisaniu Traktatu o pokoju i przyjaźni. Nie miały przy tym żadnego znaczenia osobiste przekonania premiera Japonii, ani przewaga stronnictwa propekińskiego w jego „głównym nurcie”. Fukuda Takeo mógł podjąć tylko jedną racjonalną decyzję zgodną z interesem państwa i dlatego doprowadził negocjacje do końca, nakłaniając do ugody nawet protajwańskich parlamentarzystów z własnej frakcji. Przy okazji starał się instrumentalnie wykorzystać sukces dyplomatyczny w celu zwiększenia swoich szans na zwycięstwo w prawyborach na przewodniczącego PLD w 1978 roku.

Ponieważ w latach 80 . XX wieku ChRL porzuciła radykalne idee i rozpoczęła intensywną modernizację kraju, w interesie japońskiej gospodarki leżało aktywne włączenie się w ten proces. Na dodatek eskalacja napięcia w zimnej wojnie pomiędzy Stanami Zjednoczonymi a Związkiem Radzieckim zbliżyła do siebie USA i ChRL. Wszystkie te czynniki sprzyjały zgodnej współpracy rządów w Tokio i Pekinie, zaś okazjonalne kryzysy związane z problemami historycznymi nie miały większego znaczenia z punktu widzenia całokształtu polityki zagranicznej. Nie mogąc działać wbrew racji stanu, nawet dawni członkowie obozu protajwańskiego, jak Watanabe Michio i Mitsuzuka Hiroshi, włączyli się w umacnianie przyjacielskich relacji z Chinami komunistycznymi. Niewiele zmieniła też masakra na placu Tiananmen.

Dopiero upadek Związku Radzieckiego i koniec zimnej wojny przyniosły zmianę sytuacji. ChRL nie była już potrzebna Stanom Zjednoczonym jako potencjalny sojusznik w rywalizacji z ZSRR. Gwałtowny wzrost potęgi 
gospodarczej i militarnej Chin stanowił natomiast wyzwanie dla dominacji Stanów Zjednoczonych w Azji Wschodniej. Coraz większe zaniepokojenie Japonii budził wzrost chińskich wydatków na zbrojenia, „dyplomacja rakietowa” wobec Tajwanu oraz spór terytorialny na Morzu Wschodniochińskim. Nawet propekińsko usposobiony Kōno Yōhei musiał podjąć w 1995 roku decyzję o wstrzymaniu pomocy rozwojowej dla Chin po zignorowaniu przez nie żądań zaprzestania testów nuklearnych. Asertywność Chin na arenie międzynarodowej nasiliła się równolegle z poszukiwaniem przez japoński establishment nowej wizji politycznej po wyczerpaniu się ,doktryny Yoshidy” w jej pierwotnym kształcie. Idea „,normalnego kraju” zakładała dążenie do rewizji pacyfistycznej konstytucji, remilitaryzacji i zwiększenia zaangażowania Japonii w regionalną $\mathrm{i}$ globalną politykę bezpieczeństwa. Wzmocnienie sojuszu japońskoamerykańskiego, zwłaszcza w okresie kadencji premiera Koizumiego, stało się kolejnym źródłem napięć w relacjach między władzami w Tokio i Pekinie.

$\mathrm{Z}$ drugiej strony, $\mathrm{w}$ interesie Japonii nie leżała nadmierna eskalacja sporu $\mathrm{z}$ potężnym sąsiadem. Procesy globalizacji zwiększyły zależność japońskiej gospodarki od rynku chińskiego. Również takim protajwańskim premierom, jak Obuchi Keizō i Mori Yoshirō, racja stanu dyktowała powstrzymanie się od wyraźnego sprzyjania władzom w Tajpej. Nikt nawet nie myślał o ponownym nawiązaniu stosunków dyplomatycznych z Tajwanem, który dysponował znacznie mniejszym potencjałem ekonomicznym niż ChRL. Ogólne ramy japońskiej linii dyplomatycznej pozostawały racjonalne i niepodatne na emocjonalizm. Nawet jeśli pewną rolę w pogorszeniu relacji między władzami w Tokio i Pekinie odegrały wizyty premiera Koizumiego w świątyni Yasukuni, według realistów tak naprawdę decydujące znaczenie miały uwarunkowania międzynarodowe.

Jak widać, podejście realistyczne oferuje przynajmniej równie spójną interpretację ewolucji japońskiej polityki wobec Chin, jak teoria liberalna. Jeśli opisywać rzeczywistość w bardzo dużym uproszczeniu, państwa mogą być traktowane jako jednolite i racjonalne podmioty stosunków międzynarodowych. W tej wizji nie ma miejsca na oddziaływanie jakichkolwiek czynników wewnątrzpartyjnych. Wręcz przeciwnie, to struktura systemu międzynarodowego warunkuje sytuację wewnątrz partii. Podziały ideologiczne mają iluzoryczny charakter, gdyż politycy dbają przede wszystkim o uzyskanie i utrzymanie władzy w państwie i w partii. Mężowie stanu podkreślają swoje przekonania tylko wtedy, gdy działa to w ich interesie. Są zdeterminowani przez czynniki zewnętrzne i mogą co najwyżej wykorzystywać swoje sukcesy lub obietnice podjęcia konkretnych działań $\mathrm{w}$ polityce zagranicznej do rywalizacji $\mathrm{z}$ oponentami politycznymi w kraju. Sprawę chińską instrumentalnie wykorzystali lub usiłowali to zrobić m.in. Satō Eisaku, Tanaka Kakuei czy Fukuda Takeo. Z kolei tacy premierzy, jak Hatoyama Ichirō, Miki Takeo czy Mori Yoshirō, musieli zmodyfikować swoją pierwotnie aktywną postawę $\mathrm{w}$ promocji relacji z 
ChRL lub z Tajwanem, ponieważ nie mogli przezwyciężyć ograniczeń zewnętrznych. Poprzez badanie rozkładu sił na poziomie systemu międzynarodowego nie da się oczywiście wytłumaczyć wszystkich zjawisk zachodzących w skomplikowanej rzeczywistości (np. uparcie propekińskiej postawy Matsumury Kenzō i jego kobunów w trakcie „rewolucji kulturalnej” w ChRL czy irracjonalnych wizyt Koizumiego w świątyni Yasukuni). Dla realistów wyjątki te mają jednak tak małe znaczenie, że mogą być zupełnie pominięte przy ogólnej analizie polityki zagranicznej.

\section{Wpływ ewolucji systemu wewnątrzpartyjnego na politykę PLD wobec Chin}

Zarówno teoria liberalizmu, jak i realizmu/neorealizmu, oferuje w miarę spójną interpretację wewnątrzpartyjnych uwarunkowań polityki PLD wobec Chin. Podczas gdy pierwszy z nurtów przykłada do nich dużą wagę, drugi odmawia im większego znaczenia. Podejścia te zdają się wzajemnie wykluczać, jednak dopiero gdy się uwzględni czynniki wzięte pod uwagę w obu teoriach, można będzie stworzyć całościowy obraz wewnątrzpartyjnych uwarunkowań polityki PLD wobec Chin. Chociaż bodźce do zmiany ogólnych ram japońskiej polityki zagranicznej niemal zawsze przychodziły z zewnątrz, były następnie „filtrowane" przez wewnątrzpartyjne mechanizmy rywalizacji międzyfrakcyjnej. Choćby u zarania tego procesu politycy kierowali się własnym interesem i racją stanu, jak przewiduje realizm, długotrwała interakcja ze środowiskiem międzynarodowym mogła stworzyć fundamenty pod nową normę lub tożsamość w ujęciu konstruktywistycznym. Tożsamość ta stawała się z kolei integralną częścią konkretnego systemu wewnątrzpartyjnego i jako taka wpływała na proces decyzyjny.

Realizm zakłada, iż poczynania polityków nie były determinowane przez czynniki ideologiczne, osobowościowe czy personalne. Mężowie stanu mogli przedstawiać swoje decyzje jako wynikające z własnych przekonań, ale tak naprawdę kierował nimi tylko interes pojmowany w kategoriach siły. Ujęcie realistyczne pomija jednak istotny szczegół. Nawet jeśli politycy modyfikowali swoje poglądy według doraźnego interesu, jednym przychodziło to łatwiej niż innym. Ta swoista elastyczność ideologiczna odgrywała dużą rolę w rywalizacji o władzę w partii. Politycy cytowani w niniejszej pracy niejednokrotnie odwoływali się do abstrakcyjnego pojęcia „nurtu historii” (rekishi no nagare), który symbolizował zmiany zachodzące $w$ otoczeniu międzynarodowym. Jego umiejętne wykorzystanie mogło być nawet kluczem do osiągnięcia sukcesu w wyborach na przewodniczącego partii.

Opis czterech okresów przedstawionych w rozprawie rzeczywiście pokazuje pewien związek pomiędzy ewolucją systemu wewnątrzpartyjnego w PLD a zmianami międzynarodowego otoczenia Japonii. Trudno jest tu odróżnić czynnik sprawczy od skutku. System wewnątrzpartyjny w zasadzie kształtował się niezależnie od środowiska międzynarodowego, zaś sprawa chińska była tylko jedną z wielu kwestii spornych w PLD. Relacje Japonii z Chinami 
ewoluowały równolegle $\mathrm{z}$ rywalizacją międzyfrakcyjną $\mathrm{w}$ partii $\mathrm{i}$ były $\mathrm{z}$ nią związane jedynie w sposób pośredni. Dużą rolę odgrywała tu intersubiektywna struktura interesów i tożsamości, powstających w wyniku interakcji międzynarodowej. Nie wszyscy politycy tak samo pojmowali interes narodowy, gdyż na ich percepcję wpływały zinternalizowane, w pojęciu teorii konstruktywistycznej, normy i tożsamości. Protajwańska „oś władzy” Kishi-Satō (1955-1972), jak też propekińska oś Tanaka-Ōhira (1972-1980) oraz „ogólny główny nurt” (19801993) w pewnym sensie stały się nośnikami tożsamości PLD. Z kolei w wyniku osłabienia frakcyjności po 1993 roku wyróżnienie dominującego ośrodka władzy w partii stało się niemożliwe. PLD rozpoczęła proces poszukiwania nowej tożsamości, zaś jej polityka wobec Chin stała się mniej spójna.

Wykres 6.3 Ewolucja liczebności parlamentarzystów PLD należących do frakcji propekińskich, protajwańskich oraz o mieszanym nastawieniu wobec Chin.
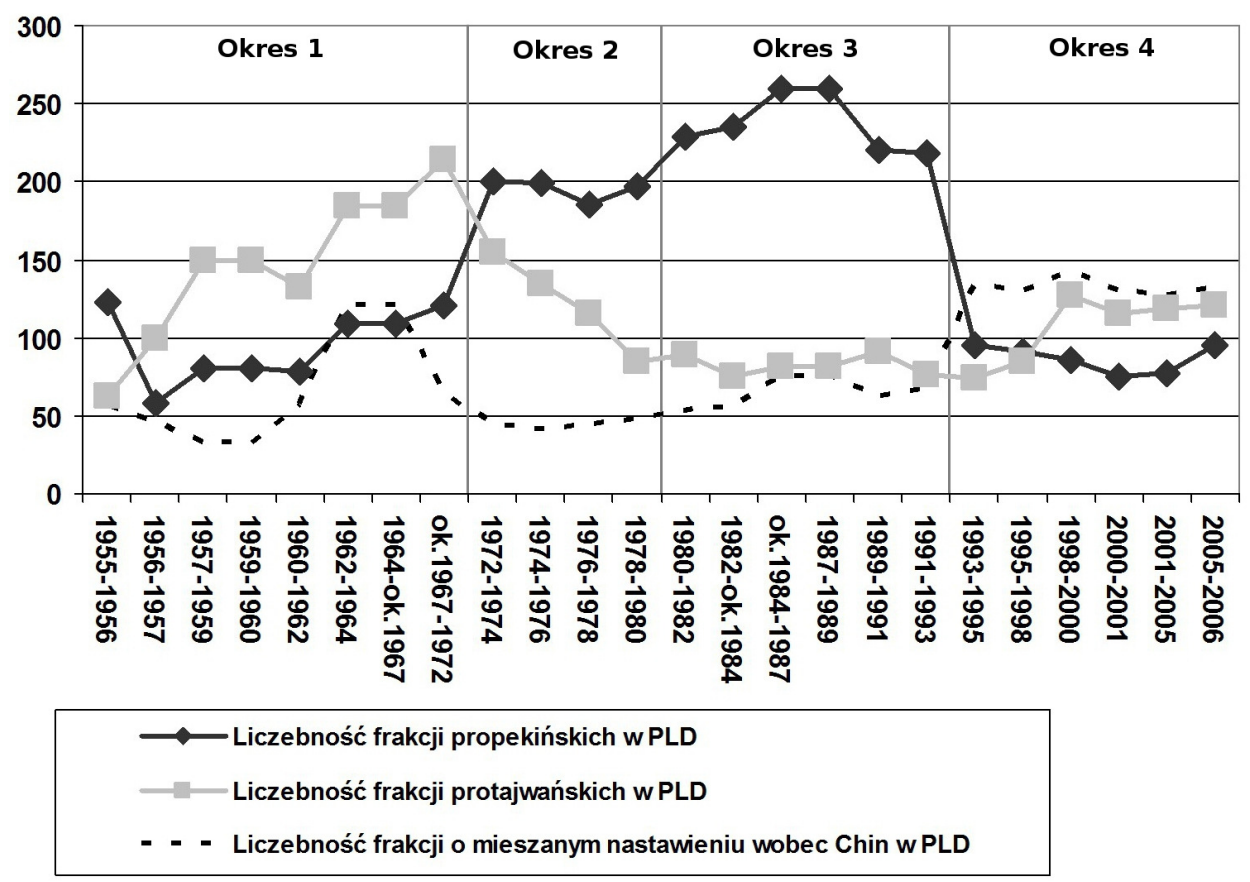

Do 1962 roku uwzględniono tylko członków frakcji z Izby Reprezentantów.

Opracowanie własne na podstawie m.in.: Kitaoka Shin'ichi, op.cit., s. 334-336; Satō Seizaburō, Matsuzaki Tetsuhisa, op.cit., s. 241-243; Tsuchiya Shigeru, op.cit., s. 108-195; Fukunaga Fumio, Habatsu..., s. 80.

Wykres 6.3 przedstawia ewolucję liczebności parlamentarzystów PLD z frakcji reprezentujących skrzydło propekińskie, protajwańskie oraz o mieszanym nastawieniu wobec Chin. Chociaż największy wpływ na proces decyzyjny wywierały frakcje należące do ,głównych nurtów”, również analiza PLD jako 
całości pozwala na wyciągnięcie pewnych wniosków dotyczących wewnątrzpartyjnych uwarunkowań polityki PLD wobec Chin. Na wykresie wyraźnie widać różnice pomiędzy czterema okresami omówionymi w pracy. W latach 1955-1972 dominował obóz protajwański, by w latach 1972-1980 stopniowo tracić na znaczeniu na rzecz stronnictwa propekińskiego, które gwałtownie zwiększyło swoją liczebność w 1972 roku. W trzecim z okresów (1980-1993) frakcje protajwańskie były już wyraźnie zmarginalizowane, zaś propekińskie uzyskały nad nimi ponad dwukrotną przewagę. Dane dotyczące lat 1993-2006 należy traktować w bardzo dużym przybliżeniu ze względu na wzrost znaczenia podziałów wewnątrzfrakcyjnych. Niemniej jednak da się zauważyć nagłe osłabienie skrzydła propekińskiego i dominację frakcji o mieszanym nastawieniu wobec Chin.

Należy zauważyć, że wszystkie kluczowe zmiany na wykresie 6.3 zostały spowodowane ewolucją ideologicznego kolorytu dawnej frakcji Satō. Na samym początku istnienia PLD przeważało stronnictwo propekińskie, ale już w 1956 roku sytuacja się odmieniła, gdy propekińska frakcja Yoshidy uległa rozpadowi na propekińską grupę Ikedy i protajwańską grupę Satō. Dominacja protajwańskiej „osi władzy” Kishi-Satō dobiegła końca dopiero w 1972 roku, gdy przywództwo nad większością grupy Satō przejął Tanaka Kakuei. Tanaka stworzył propekińską „oś władzy” razem ze swoim przyjacielem, Ōhirą Masayoshim. Po śmierci Ōhiry w 1980 roku frakcja Tanaki rozrosła się do rekordowych rozmiarów i uformowała propekiński „,ogólny główny nurt”. W 1987 roku przywództwo nad dawną grupą Satō przejął siłą Takeshita Noboru, ale nie naruszyło to jej hegemonicznej pozycji w partii. Dopiero gdy frakcja Takeshity uległa rozpadowi w 1992 roku, zaś zbuntowana grupa Ozawy opuściła PLD w 1993 roku, można było mówić o kolejnej zmianie systemu wewnątrzpartyjnego. Jak widać na wykresie 6.4, dawna frakcja Satō była częścią składową dwóch kolejnych „osi władzy”, jak też centralnym ośrodkiem „ogólnego głównego nurtu”. Dopiero w ostatnim okresie jej wpływy zmalały razem z ogólnym osłabieniem frakcyjności.

Wysoka elastyczność ideologiczna polityków nurtu Satō nie była przypadkowa. Kolejni liderzy tej frakcji (Satō Eisaku, Tanaka Kakuei, Takeshita Noboru, Obuchi Keizō, Hashimoto Ryūtarō) charakteryzowali się podobnym podejściem do polityki. Specjalizowali się zwłaszcza w problematyce resortów budownictwa, poczty czy transportu, gdyż przynosiły one najwięcej możliwości kontaktów z biznesem i zdobywania funduszy wyborczych. Wszyscy dobrze znali się na polityce wewnętrznej i posiadali umiejętności pozyskiwania poparcia w partii poprzez zakulisowe działania, ale wykazywali ograniczone zainteresowanie dyplomacją. Specjalizacja w polityce zagranicznej nie przynosiła wszakże ani pieniędzy, ani głosów elektoratu na poziomie okręgów wyborczych. Podobnym pragmatycznym nastawieniem charakteryzowali się także szeregowi członkowie dawnej frakcji Satō. Politycy, którzy chcieli zrobić 
szybkie kariery, wręcz garnęli się do tej grupy, ponieważ była ona najpotężniejsza, zaś jej liderzy potrafili zadbać o swoich kobunów. Niosło to za sobą dwie konsekwencje. Po pierwsze, nurt Satō stanowił zazwyczaj najliczniejszą grupę w PLD, po drugie zaś, była to frakcja o najmniej wyraźnym kolorycie ideologicznym. Dzięki temu zachowanie jej polityków było najbliższe realistycznej teorii stosunków międzynarodowych, gdyż najłatwiej dostosowywali się oni do zmian w otoczeniu międzynarodowym Japonii. $Z$ kolei ze względu na wielkość tej grupy, adaptacje te miały kluczowe znaczenie dla polityki PLD jako całości.

Wykres 6.4 Ewolucja systemu wewnątrzpartyjnego pod kątem nastawienia głównych frakcji wobec Chin.

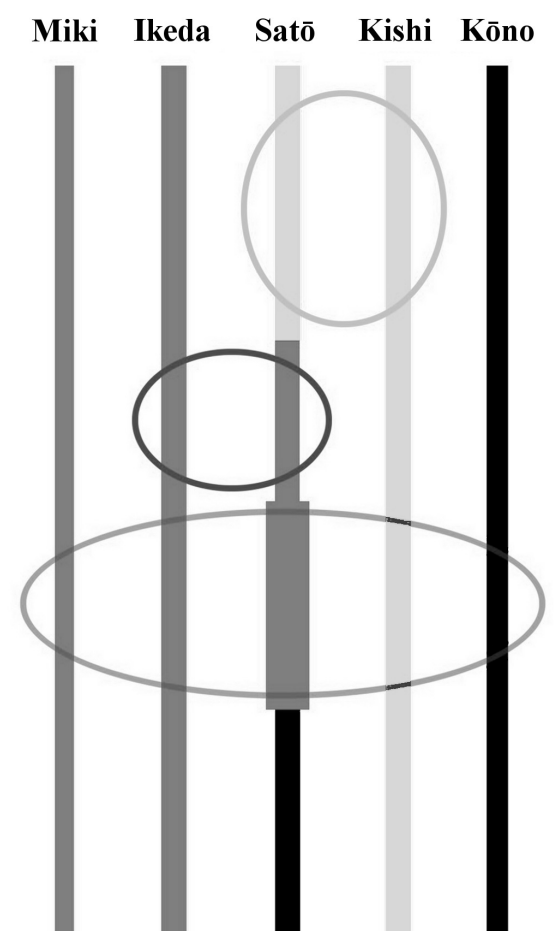

1955

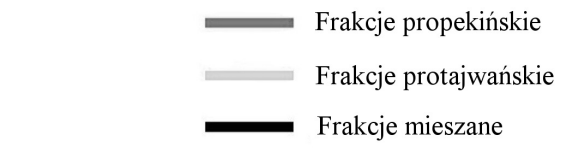

Protajwańska „oś władzy” Kishi-Satō

1972

Propekińska „oś władzy” Tanaka-Ōhira

1980

Propekiński „ogólny główny nurt”

1993

Deregulacja frakcyjności

2006

Opracowanie własne.

Protajwański charakter „osi władzy” Kishi-Satō wynikał przede wszystkim z sytuacji międzynarodowej w latach 1955-1972. Póki Stany Zjednoczone utrzymywały wrogie relacje $\mathrm{z}$ ChRL, Japonia nie mogła poważnie rozważać nawiązania stosunków dyplomatycznych z tym państwem. Na dodatek istniała groźba dalszego rozprzestrzeniania się komunizmu w krajach Azji Wschodniej. Spośród dwóch braci tworzących „oś władzy” to Kishi Nobusuke był zdeklarowanym antykomunistą i utrzymywał bliskie kontakty z reżimem Guomindangu. 
Bardziej elastyczny ideologicznie Satō Eisaku poszukiwał kontaktu z władzami w Pekinie. Chciał użyć sprawy chińskiej w rywalizacji międzyfrakcyjnej, ale ostatecznie dał za wygraną i przybrał bierną postawę wobec ChRL. Dominacja osi Kishi-Satō stabilizowała charakter japońskiej polityki zagranicznej. Nawet jeśli u źródeł protajwańskiego charakteru „osi władzy” leżała chęć realizacji japońskiej racji stanu, którą według Kishiego była obrona kraju przed zagrożeniem komunizmu, z czasem jej protajwańskie nastawienie umocniło się w wyniku długotrwałej interakcji pomiędzy władzami w Tokio a reżimem Guomindangu. Trudno jest powiedzieć, czy intersubiektywna tożsamość, będąca owocem tych relacji, istniała tylko na poziomie „osi władzy”, czy też całej partii. Oprócz Kishiego do obozu protajwańskiego należało wielu liderów mniejszych frakcji, jak Ishii Mitsujirō, Ōno Banboku czy Shiina Etsusaburō. Niemniej jednak przez cały pierwszy okres koncepcja antykomunistycznego sojuszu z „wolnym światem”, którego część stanowiły władze w Tajpej, była kontestowana przez frakcje propekińskie w PLD, na czele z Matsumurą Kenzō i Ishibashim Tanzanem. Poza tym trudno ją nazwać normą przyjętą przez całe społeczeństwo, o czym świadczyły choćby zamieszki przeciw rewizji traktatu sojuszniczego z USA w 1960 roku.

Nawet jeśli protajwańskie nastawienie nie było zinternalizowane przez wszystkie kręgi społeczne w Japonii, w wyraźny sposób wpływało na wzajemną percepcję rządów obu krajów. Pod koniec swojej kadencji Satō Eisaku intensywnie próbował nawiązać kontakt $\mathrm{z}$ władzami w Pekinie. ChRL nie odpowiedziała pozytywnie na to wezwanie, mimo że bardzo jej zależało na normalizacji stosunków dyplomatycznych z Japonią. Tego fenomenu nie da się $\mathrm{w}$ pełni wyjaśnić na gruncie teorii liberalizmu lub realizmu/neorealizmu. Przeszkodą we wzajemnych relacjach okazał się fakt, że obie strony przez długi czas wzajemnie postrzegały się jako wroga i nie miały do siebie zaufania. Chociaż Satō starał się wykorzystać „nurt historii” i nawiązać oficjalne stosunki dyplomatyczne z ChRL, do samego końca nie mógł się uwolnić od swojego wizerunku jako polityka protajwańskiego. Wizerunek ten został tak głęboko zapisany w świadomości przywódców KPCh, że nie byli oni gotowi do rozpoczęcia dialogu z bratem Kishiego.

Tanaka Kakuei wykorzystał tę sytuację, przejmując przywództwo nad większością frakcji Satō i dołączając do obozu propekińskiego. W nowej „osi władzy" to Ōhira Masayoshi pełnił rolę głównego promotora relacji z ChRL, zaś Tanaka po prostu użył sprawy chińskiej do zdobycia władzy w partii. Podobnie jak w pierwszym okresie, w latach 1972-1980 trudno powiedzieć, by polityka PLD wobec Chin została zinternalizowana pod postacią ogólnie przyjętej normy na poziomie całego ugrupowania. Chociaż politycy nastawieni na pogłębianie relacji z ChRL stanowili większość, w partii nadal istniał silny obóz protajwański. Działalność Seirankai pokazywała, że nie wszyscy parlamentarzyści jednakowo postrzegali japońską rację stanu. Dla polityków związanych z 
reżimem Guomindangu interes państwa nadal polegał na obronie „wolnego świata" przed zagrożeniem ze strony krajów komunistycznych. Do zbudowania nowej intersubiektywnej tożsamości potrzebna była długotrwała interakcja $\mathrm{z}$ ChRL i zwiększenie wzajemnego zaufania między rządami w Tokio i Pekinie.

Dopiero gdy Chiny jednoznacznie weszły na drogę reform wewnętrznych i modernizacji pod koniec lat 70. XX wieku, powstały warunki do dalszego zacieśnienia współpracy japońsko-chińskiej. Lata 1980-1993 były najspokojniejszym okresem w relacjach pomiędzy Japonią i ChRL. Propekiński „ogólny główny nurt", który w wyniku rozrostu frakcji Tanaki uformował się wówczas w PLD, mógł jedynie potęgować pewne zjawiska, a nie być ich siłą sprawczą. Dominacja frakcji Tanaki-Takeshity ułatwiała internalizację idei propekińskich na poziomie całego ugrupowania. Chociaż pierwotnym bodźcem do nawiązania stosunków dyplomatycznych z Chinami była zmiana systemu międzynarodowego w 1972 roku i chęć jej wykorzystania w rywalizacji międzyfrakcyjnej, w latach 80. XX wieku proces współpracy bilateralnej doprowadził do redefinicji tych egoistycznych powodów i sformułowania nowej intersubiektywnej tożsamości. Nawet członkowie obozu protajwańskiego złagodzili swoją postawę i przestali głośno bronić interesów reżimu Guomindangu.

Największym testem dla „konsensusu propekińskiego” w PLD była masakra na placu Tiananmen w 1989 roku. Japonia zareagowała na to zdarzenie w mniej zdecydowany sposób niż państwa Europy Zachodniej czy Stany Zjednoczone i nałożyła na Chiny sankcje ekonomiczne dopiero pod presją środowiska międzynarodowego. Fenomen ten można tłumaczyć na wiele sposobów, np. wysokim stopniem japońsko-chińskich powiązań gospodarczych, bliskością geograficzną czy czynnikami kulturowymi. Niemniej jednak jedną z interpretacji pozostaje stabilizujący wpływ propekińskiego „ogólnego głównego nurtu” na politykę PLD wobec Chin. Poprzez długotrwałą interakcję z ChRL wśród japońskich elit politycznych wytworzył się obraz Chin jako partnera, podobnie jak za rządów Satō były one postrzegane jako wróg. Wizerunek ten, jak też personalne powiązania pomiędzy politykami PLD i KPCh, utrudniał przyjęcie sankcji ekonomicznych wobec Chin.

Wraz z końcem zimnej wojny ChRL przestała być potencjalnym sojusznikiem USA w rywalizacji z ZSRR. Zwiększanie chińskiego budżetu wojskowego w latach 90. XX wieku zaczęło być postrzegane jako zagrożenie dla Japonii. Jednocześnie Stany Zjednoczone domagały się przejęcia przez władze w Tokio większej odpowiedzialności za utrzymanie bezpieczeństwa w regionie. Pojawiła się idea uczynienia z Japonii „,normalnego kraju” z wszystkimi atrybutami siły. Rozpoczął się proces odchodzenia od coraz bardziej kontestowanej „,doktryny Yoshidy" i poszukiwania nowej tożsamości społecznej. Równocześnie rozłamowi uległa frakcja Takeshity, zaś w 1993 roku PLD utraciła władzę. W ten sposób definitywnie zakończyła się era „ogólnego głównego nurtu”, a zaczął się proces deregulacji systemu frakcyjnego w partii. Frakcje stały się zbyt słabe, by stać się 
nośnikami nowych intersubiektywnych tożsamości. Do głosu doszły podziały wewnątrzfrakcyjne, zaś dawny nurt Satō, który dotąd wyznaczał kierunki polityki PLD wobec Chin, stał się niejednorodną grupą łączącą środowiska propekińskie i protajwańskie. Bez nowej ogólno przyjętej normy, mogącej wyznaczać granice dozwolonych zachowań i stabilizować politykę zagraniczną Japonii, możliwe stały się tak nieprzewidywalne incydenty, jak coroczne wizyty premiera Koizumiego w świątyni Yasukuni. Poważnym wyzwaniem dla propekińskiej polityki PLD stała się także demokratyzacja Tajwanu, dzięki której obóz protajwański uzyskał nowy argument do zacieśniania więzi z władzami w Tajpej. W wyniku tych procesów zmniejszył się poziom wzajemnego zaufania pomiędzy rządami Japonii i ChRL. O ile w 1989 roku władze w Tokio nałożyły sankcje na Chiny dopiero pod presją społeczności międzynarodowej, o tyle od połowy lat 90 . XX wieku robiły to już z własnej inicjatywy. Pokazuje to, jak bardzo zmienił się wizerunek ChRL wśród japońskich elit rządzących.

Jak widać, przedstawiona powyżej koncepcja nawiązuje do wszystkich trzech teorii stosunków międzynarodowych, które zostały opisane we wstępie książki. W każdym z czterech okresów ogólne ramy stosunków japońsko-chińskich były determinowane przez otoczenie międzynarodowe Japonii (rozkład sił w strukturze systemu międzynarodowego, stan relacji pomiędzy USA a ChRL), na analizę którego kładzie nacisk nurt realizmu/neorealizmu. Niemniej jednak da się też zauważyć postulowany przez teorię liberalną wpływ na politykę PLD wobec Chin rywalizacji międzyfrakcyjnej. Zależnie od okresu odbywała się ona w ramach innego systemu wewnątrzpartyjnego (dwie „osie władzy”, „ogólny główny nurt”, deregulacja frakcyjności). Łącznikiem pomiędzy uwarunkowaniami zewnętrznymi i wewnętrznymi są intersubiektywne tożsamości i normy w ujęciu konstruktywistycznym. Bodźcami do ich powstania były co prawda zmiany $w$ otoczeniu międzynarodowym, ale później internalizowano je jako integralne części kolejnych systemów wewnątrzpartyjnych.

\section{Model kształtowania stanowiska PLD wobec Chin}

Na podstawie przeprowadzonych badań można sformułować model, który w uproszczony sposób ukazuje czynniki wpływające na formułowanie stanowiska PLD wobec Chin. W celu zachowania przejrzystości pominięto w nim cały szereg uwarunkowań uznanych przez autora za mniej istotne w procesie decyzyjnym w sprawie chińskiej, np. rolę klanów parlamentarzystów czy biurokratów. Szczególny nacisk położono za to na rywalizację międzyfrakcyjną, będącą głównym przedmiotem analizy w niniejszej pracy. Należy przy tym zauważyć, że model ten w dużym stopniu stracił na aktualności po 1993 roku ze względu na zanik wyraźnych ,głównych nurtów” w partii.

Kolejni przewodniczący PLD, co jest naturalne, charakteryzowali się określonymi poglądami politycznymi, osobowościami i powiązaniami personalnymi. Teoretycznie dysponowali bardzo dużą władzą, zapisaną w statucie partii i 
konstytucji (jedynie Kōno Yōhei nie objął stanowiska premiera). W praktyce jednak procesem decyzyjnym w PLD rządził szereg nieformalnych zasad i mechanizmów, które ograniczały możliwości swobodnego formułowania polityki wobec Chin przez przewodniczących partii. Najważniejszą rolę w kształtowaniu linii dyplomatycznej odgrywał ,główny nurt”, będący wewnątrzpartyjną koalicją wspierającą premiera. Aby się utrzymać u władzy, należało dbać o jedność ,głównego nurtu”. Nie było to łatwe, gdyż zazwyczaj stanowił on zlepek frakcji o przeciwstawnych dążeniach. Na politykę wobec Chin w szczególności wpływała proporcja sił pomiędzy obozem protajwańskim i propekińskim oraz, w sposób pośredni, pomiędzy ,jastrzębiami” i ,gołębiami”. Im większa była spójność ideologiczna „głównego nurtu”, tym łatwiej przewodniczącym partii przychodziło ustalanie jednoznacznej linii dyplomatycznej. Frakcje poza „głównym nurtem” mogły dążyć do obalenia centralnych władz PLD, by zająć ich miejsce. Wówczas formował się ,,przeciwny nurt”, który wyraźnie kontestował politykę partyjną. Im bardziej nasilała się rywalizacja pomiędzy „głównym” a ,przeciwnym nurtem”, tym bardziej rosło prawdopodobieństwo posłużenia się w niej sprawą chińską. Członkowie „przeciwnego nurtu" nie mogli zablokować decyzji rządu, ale byli w stanie opóźnić pewne procesy w stosunkach japońsko-chińskich.

Wykres 6.5 Model kształtowania stanowiska PLD wobec Chin.

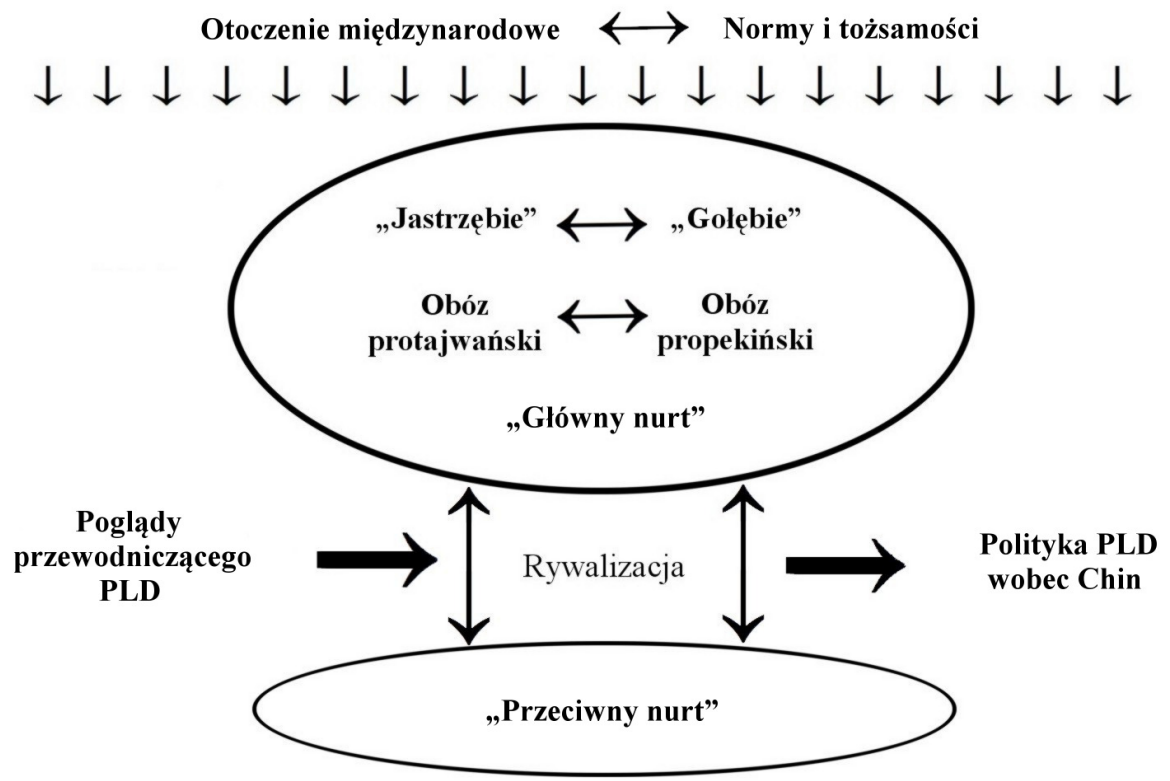

Opracowanie własne. 
Polityka PLD wobec Chin nie była jednak tylko mechaniczną wypadkową rywalizacji międzyfrakcyjnej. Ogólne ramy japońskiej dyplomacji tak naprawdę wyznaczała ewolucja otoczenia międzynarodowego Japonii. To ona determinowała zresztą dążenia poszczególnych stronnictw wewnątrz partii. O ile w okresie rządów Ikedy Hayato idea „dwóch Chin”, choć nieakceptowana przez żaden z rządów chińskich, była przywoływana jako metoda pogłębiania relacji z ChRL, o tyle pod koniec kadencji Satō została wykorzystana w próbie utrzymania członkostwa reżimu Guomindangu w ONZ. Politycy musieli ciągle redefiniować cele możliwe do osiągnięcia przy danym rozkładzie sił w systemie międzynarodowym. Mężowie stanu byli w dużym stopniu uwarunkowani koniecznością działania zgodnie z racją stanu i mogli co najwyżej wykorzystywać swoje decyzje w celu zdobycia oraz utrzymania władzy w partii i w państwie. Innymi słowy, japońscy politycy w pewnym stopniu wpływali na tempo i zakres przemian w relacjach ze stroną chińską, ale nie na ich kierunek.

Kolejnym czynnikiem, który musi być wzięty pod uwagę, są normy i tożsamości powstałe $\mathrm{w}$ wyniku długotrwałej interakcji $\mathrm{z}$ otoczeniem międzynarodowym. Choćby u źródeł kluczowych decyzji w polityce PLD wobec Chin leżały uwarunkowania zewnętrzne, współpraca z Tajwanem w latach 1955-1972 oraz z ChRL w latach 1972-1993 doprowadziła do powstania intersubiektywnych tożsamości, przynajmniej na poziomie dominujących środowisk wśród elit rządzących. Były one w organiczny sposób związane z systemami wewnątrzpartyjnymi w tych okresach: protajwańską osią Kishi-Satō, jak też propekińską osią Tanaka-Ōhira oraz propekińskim „ogólnym głównym nurtem”. Narzucone przez te systemy normy postępowania w relacjach z Chinami zostały w pewnym stopniu zinternalizowane na poziomie całej partii, zwłaszcza w latach 80 . XX wieku pod postacią „konsensusu propekińskiego”. Dzięki temu mogły oddziaływać stabilizująco na politykę zagraniczną Japonii. Z kolei brak wyraźniejszych norm zachowań $\mathrm{w}$ ostatnim $\mathrm{z}$ omawianych okresów pogłębił deregulację stosunków japońsko-chińskich na przełomie XX i XXI wieku.

Jak widać, polityka PLD wobec Chin kształtowała się przy bardzo skomplikowanych uwarunkowaniach wewnątrzpartyjnych, które ulegały ewolucji pod wpływem zmian otoczenia międzynarodowego. Chociaż realistyczna wizja stosunków międzynarodowych jest trafna przy daleko idących uproszczeniach, nie znaczy to, by wpływ czynników ideologicznych czy osobowościowych na dyplomację Japonii w ogóle nie istniał. Analiza dokonana w pracy pokazała, że przekonania polityczne i powiązania personalne głównych mężów stanu i grup w PLD miały pewne znaczenie przy formułowaniu polityki wobec Chin. Nawet jeśli wewnątrzpartyjne mechanizmy nie determinowały japońskiej linii dyplomatycznej, filtrowały bodźce nadchodzące $\mathrm{z}$ otoczenia międzynarodowego i nadawały im nowe znaczenia. Uwarunkowania wewnątrzpartyjne można porównać do pryzmatu, który jednocześnie przepuszcza światło, jak i je delikatnie załamuje. 



\section{INDEKS WYBRANYCH POLITYKÓW PLD}

Abe Shintarō (1924-1991): Zięć Kishiego Nobusuke, lider dawnej frakcji Kishiego w latach 1986-1991, minister spraw zagranicznych w latach 1982-1986, sekretarz generalny PLD w latach 1987-1989.

Abe Shinzō (1954- ): Syn Abe Shintarō, wnuk Kishiego Nobusuke, członek dawnej frakcji Kishiego, sekretarz generalny PLD w latach 2003-2004, sekretarz gabinetu w latach 2005-2006, przewodniczący PLD i premier w latach 2006-2007.

Aichi Kiichi (1907-1973): Członek frakcji Satō, sekretarz gabinetu w latach 1957-1958 oraz 1966, minister spraw zagranicznych w latach 1968-1971.

Aoki Mikio (1934- ): Członek dawnej frakcji Satō, sekretarz gabinetu w latach 1999-2000.

Ashida Hitoshi (1887-1959): Lider frakcji Ashidy w latach 1955-1956, przewodniczący Partii Demokratycznej w latach 1947-1948, minister spraw zagranicznych w latach 1947-1948, premier w 1948 roku.

Asō Tarō (1940- ): Wnuk Yoshidy Shigeru, lider dawnej frakcji Kōno Yōheia od 2006 roku, minister spraw zagranicznych w latach 2005-2007, przewodniczący PLD i premier w latach 2008-2009.

Etō Takami (1925-2007): Współprzewodniczący jednej z prawicowych frakcji w PLD w latach 1999-2003.

Fujinami Takao (1932-2007): Członek dawnej frakcji Kōno Ichirō, sekretarz gabinetu w latach 1983-1985.

Fujio Masayuki (1917-2006): Działacz protajwańskiej grupy Seirankai w latach 70. XX wieku, członek dawnej frakcji Kishiego, minister edukacji zdymisjonowany w 1986 roku za skrajnie nacjonalistyczne komentarze.

Fujiyama Aiichirō (1897-1985): Członek frakcji Kishiego do 1960 roku, lider frakcji Fujiyamy w latach 1960-1971, minister spraw zagranicznych w latach 1957-1960.

Fukuda Takeo (1905-1995): Lider byłej frakcji Kishiego w latach 1962-1986, sekretarz generalny PLD w latach 1959 i 1966-1968, minister spraw zagranicznych w latach 1971-1972, przewodniczący PLD i premier w latach 1976-1978.

Fukuda Yasuo (1936- ): Syn Fukudy Takeo, członek dawnej frakcji Kishiego, sekretarz gabinetu w latach 2000-2004, przewodniczący PLD i premier w latach 2007-2008.

Funada Naka (1895-1979): Lider frakcji Funady w latach 1965-1979, marszałek Izby Reprezentantów w latach 1963-1965 i 1970-1972, wiceprzewodniczący PLD w latach 19771978.

Furui Yoshimi (1903-1995): Członek frakcji Matsumury, promotor pozarządowego handlu z ChRL w latach 60. XX wieku, przewodniczący Parlamentarnej Ligi Przyjaźni JapońskoChińskiej w latach 1980-1983.

Gotōda Masaharu (1914-2005): Członek dawnej frakcji Satō, sekretarz gabinetu w latach 19821983 oraz 1985-1987.

Hamada Kōichi (1928- ): Członek frakcji Kawashimy, działacz Seirankai w latach 70. XX wieku.

Hashimoto Ryūtarō (1937-2006): Lider dawnej frakcji Satō w latach 2000-2004, sekretarz generalny PLD w 1989 roku, przewodniczący PLD w latach 1995-1998, premier w latach 19961998.

Hata Tsutomu (1935- ): Członek dawnej frakcji Satō, lider frakcji Haty w latach 1992-1993, przewodniczący Partii Odnowy w latach 1993-1994, wicepremier i minister spraw zagranicznych w latach 1993-1994, premier w 1994 roku, od 1998 roku w Partii Demokratycznej.

Hatoyama Ichirō (1883-1959): Lider frakcji Hatoyamy w latach 1955-1956, przewodniczący Japońskiej Partii Liberalnej w latach 1945-1946, przewodniczący Japońskiej Partii 
Demokratycznej w latach 1954-1955, przewodniczący PLD w 1956 roku, premier w latach 1954-1956.

Hatoyama Iichirō (1918-1993): Syn Hatoyamy Ichirō, minister spraw zagranicznych w latach 1976-1977.

Hatoyama Yukio (1947- ): Syn Hatoyamy Iichirō, wnuk Hatoyamy Ichirō, poseł PLD w latach 1986-1993, członek Nowej Partii Zwiastun w latach 1993-1996, członek Partii Demokratycznej od 1996 roku, przewodniczący Partii Demokratycznej i premier w latach 2009-2010.

Hiranuma Takeo (1939- ): Adoptowany syn premiera Hiranumy Kiichirō, członek frakcji Nakagawy, dawnej frakcji Kishiego oraz grupy Kameia, w latach 2005-2010 bezpartyjny, od 2010 roku lider partii Powstań Japonio, przewodniczący Parlamentarnego Zgromadzenia Japońsko-Tajwańskiego.

Hori Shigeru (1901-1979): Członek frakcji Satō, a od 1972 roku dawnej frakcji Kishiego, sekretarz gabinetu w latach 1951-1952 oraz 1968-1971, sekretarz generalny PLD w latach 19711972, marszałek Izby Reprezentantów w latach 1976-1979.

Horiuchi Mitsuo (1930- ): Członek dawnej frakcji Ikedy, lider frakcji Horiuchiego w latach 20002005.

Hosokawa Morihiro (1938- ): Członek dawnej frakcji Satō, gubernator prefektury Kumamoto w latach 1983-1991, przewodniczący Nowej Partii Japońskiej w latach 1992-1994, premier w latach 1993-1994.

Ibuki Bunmei (1938- ): Członek frakcji Watanabe, od 2005 roku lider dawnej frakcji Kameia, sekretarz generalny PLD w latach 2007-2008.

Ikeda Hayato (1899-1965): Lider frakcji Ikedy w latach 1956-1965, były biurokrata z Ministerstwa Finansów, przewodniczący PLD i premier w latach 1960-1964.

Ikeda Masanosuke (1898-1986): Członek frakcji Hatoyamy, a później Kishiego, promotor pozarządowych umów handlowych z ChRL w latach 50. XX wieku.

Ikeda Yukihiko (1937-2004): Adoptowany zięć Ikedy Hayato, członek dawnej frakcji Ikedy, minister spraw zagranicznych w latach 1996-1997.

Ishibashi Tanzan (1884-1973): Lider frakcji Ishibashiego w latach 1955-1963, liberalny dziennikarz w okresie przedwojennym, przewodniczący PLD i premier w latach 1956-1957.

Ishida Hirohide (1914-1993): Członek frakcji Ishibashiego, sekretarz gabinetu w latach 19561957.

Ishihara Shintarō (1932- ): Sławny powieściopisarz, lider dawnej frakcji Nakagawy w latach 1983-1984, działacz Seirankai w latach 70. XX wieku, gubernator Tokio od 1999 roku.

Ishii Mitsujirō (1889-1981): Lider frakcji Ishiiego w latach 1956-1978, marszałek Izby Reprezentantów w latach 1967-1969.

Itō Masayoshi (1913-1994): Członek dawnej frakcji Ikedy, sekretarz gabinetu w latach 19791980, minister spraw zagranicznych w latach 1980-1981.

Kajiyama Seiroku (1926-2000): Członek dawnej frakcji Satō, sekretarz generalny PLD w latach 1992-1993, sekretarz gabinetu w latach 1996-1997.

Kamei Shizuka (1936- ): Lider frakcji Kameia w latach 1998-2005, przywódca Towarzystwa Podstawowych Problemów Państwa w latach 80. XX wieku, w latach 2005-2012 w Nowej Partii Ludowej.

Kanemaru Shin (1914-1996): Członek dawnej frakcji Satō, oficjalny przewodniczący frakcji Takeshity w latach 1987-1992, sekretarz generalny PLD w latach 1984-1986, wiceprzewodniczący PLD w 1992 roku, w 1993 roku aresztowany w związku z aferą korupcyjną firmy Sagawa Kyūbin.

Katō Kōichi (1939- ): Lider dawnej frakcji Ikedy w latach 1998-2002, sekretarz gabinetu w latach 1991-1992, sekretarz generalny PLD w latach 1995-1998.

Kawasaki Hideji (1911-1978): Członek frakcji Matsumury, promotor pozarządowej wymiany handlowej z ChRL w latach 60. XX wieku. 
Kawasaki Jirō (1947- ): Syn Kawasakiego Hidejiego, członek dawnej frakcji Ikedy.

Kishi Nobusuke (1896-1987): Lider frakcji Kishiego w latach 1955-1962, sekretarz generalny PLD w latach 1955-1956, minister spraw zagranicznych w latach 1956-1957, przewodniczący PLD i premier w latach 1957-1960.

Kitamura Tokutarō (1886-1968): Lider frakcji Kitamury w latach 1955-1956, dawny członek Partii Reform.

Kobayashi Kōki (1944- ): Członek frakcji Etō/Kameia, w 2001 roku mianowany przewodniczącym Parlamentarnej Ligi PLD Przyjaźni Japońsko-Tajwańskiej, od 2005 roku poza PLD.

Koga Makoto (1940- ): Lider dawnej frakcji Ikedy od 2006 roku (do 2008 roku tylko nurtu Horiuchiego), sekretarz generalny PLD w latach 2000-2001, przewodniczący Nihon Izokukai w latach 2002-2012.

Koizumi Jun'ichirō (1942- ): Członek dawnej frakcji Kishiego, przewodniczący PLD i premier w latach 2001-2006.

Kōmoto Toshio (1911-2001): Lider dawnej frakcji Mikiego w latach 1980-1996, właściciel firmy Sankō Kisen.

Kōmura Masahiko (1942- ): Lider dawnej frakcji Mikiego od 2000 roku, minister spraw zagranicznych w latach 1998-1999 oraz 2007-2008.

Kōno Ichirō (1898-1965): Lider dawnej frakcji Hatoyamy w latach 1956-1965.

Kōno Kenzō (1901-1983): Brat Kōno Ichirō, marszałek Izby Radców w latach 1971-1977.

Kōno Tarō (1963- ): Syn Kōno Yōheia, wnuk Kōno Ichirō, członek dawnej frakcji Kōno (obecnie Asō).

Kōno Yōhei (1937- ): Syn Kōno Ichirō, lider frakcji Kōno w latach 1998-2006, przewodniczący Nowego Klubu Liberalnego w latach 1976-1979 oraz 1984-1986, sekretarz gabinetu w latach 1992-1993, przewodniczący PLD w latach 1993-1995, minister spraw zagranicznych w latach 1994-1996 oraz 1999-2001, marszałek Izby Reprezentantów w latach 2003-2009.

Kosaka Zentarō (1912-2000): Członek dawnej frakcji Ikedy, a później dawnej frakcji Kōno, minister spraw zagranicznych w latach 1960-1962 oraz 1976, przewodniczący Konferencji ds. Normalizacji Stosunków Japońsko-Chińskich w 1972 roku.

Machimura Kingo (1900-1992): Członek frakcji Ogaty i Ishiiego, gubernator Hokkaidō w latach 1959-1971.

Machimura Nobutaka (1944- ): Syn Machimury Kingo, lider dawnej frakcji Kishiego od 2006 roku, minister spraw zagranicznych w latach 2004-2005 oraz 2007.

Maeo Shigesaburō (1905-1981): Lider dawnej frakcji Ikedy w latach 1964-1970, sekretarz generalny PLD w latach 1961-1964, marszałek Izby Reprezentantów w latach 1973-1976.

Matsumura Kenzō (1883-1871): Współprzewodniczący frakcji razem z Mikim Takeo w latach 1955-1964 i lider frakcji Matsumury w latach 1964-1971, promotor pozarządowego handlu z ChRL w latach 60. XX wieku.

Miki Bukichi (1884-1956): Lider frakcji Mikiego Bukichiego w latach 1955-1956, bliski współpracownik Hatoyamy Ichirō.

Miki Takeo (1907-1988): Lider frakcji Mikiego w latach 1955-1980 (do 1964 roku razem z Matsumurą Kenzō), sekretarz generalny PLD w latach 1956-1957 oraz 1964-1965, minister spraw zagranicznych w latach 1966-1968, przewodniczący PLD i premier w latach 1974-1976.

Mitsuzuka Hiroshi (1927-2004): Lider dawnej frakcji Kishiego w latach 1991-1998, działacz Seirankai w latach 70. XX wieku, minister spraw zagranicznych w 1989 roku, sekretarz generalny PLD w 1995 roku.

Miyazawa Kiichi (1919-2007): Lider dawnej frakcji Ikedy w latach 1986-1998, minister spraw zagranicznych w latach 1974-1976, sekretarz gabinetu w latach 1980-1982, przewodniczący PLD i premier w latach 1991-1993. 
Mori Yoshirō (1937- ): Lider dawnej frakcji Kishiego w latach 1998-2006, sekretarz generalny PLD w latach 1993-1995 i 1998-2000, przewodniczący PLD i premier w latach 2000-2001.

Murakami Masakuni (1932- ): Lider frakcji Murakamiego w latach 1998-1999, działacz Towarzystwa Podstawowych Problemów Państwa w latach 80. XX wieku.

Nadao Hirokichi (1899-1994): Członek frakcji Ishiiego, pierwszy przewodniczący powstałego w 1973 roku Parlamentarnego Związku Stosunków Japońsko-Tajwańskich, marszałek Izby Reprezentantów w latach 1979-1980.

Nakagawa Ichirō (1925-1983): Były sekretarz Ōno Banboku, przywódca Seirankai w latach 1973-1979, lider frakcji Nakagawy w latach 1979-1983.

Nakagawa Shōichi (1953-2009): Syn Nakagawy Ichirō, członek frakcji Ishihary, dawnej frakcji Kishiego i frakcji Kameia.

Nakasone Yasuhiro (1918- ): Lider dawnej frakcji Kōno w latach 1965-1990, sekretarz generalny PLD w latach 1974-1976, przewodniczący PLD i premier w latach 1982-1987.

Nikai Toshihiro (1939- ): Lider frakcji Nikaia w latach 2003-2009, członek Partii Odnowy, Nowej Partii Postępu, Partii Liberalnej i Partii Konserwatywnej, od 2003 roku znowu w PLD.

Nikaidō Susumu (1909-2000): Lider dawnej frakcji Tanaki w latach 1987-1990, sekretarz gabinetu w latach 1972-1974, sekretarz generalny PLD w latach 1974 oraz 1981-1983, wiceprzewodniczący PLD w latach 1984-1986.

Niwa Yuya (1944- ): Współprzewodniczący dawnej frakcji Horiuchiego w 2006 roku.

Nonaka Hiromu (1925- ): Członek dawnej frakcji Satō, sekretarz gabinetu w latach 1998-1999, sekretarz generalny PLD w 2000 roku.

Ōasa Tadao (1889-1957): Lider frakcji Ōasy w latach 1955-1956, polityk dawnej Partii Reform.

Obuchi Keizō (1937-2000): Lider dawnej frakcji Satō w latach 1992-2000, sekretarz gabinetu w latach 1987-1989, sekretarz generalny PLD w 1991 roku, wiceprzewodniczący PLD w 1994 roku, minister spraw zagranicznych w latach 1997-1998, przewodniczący PLD i premier w latach 1998-2000.

Ogata Taketora (1888-1956): Lider frakcji Ogaty w latach 1955-1956, sekretarz gabinetu w latach 1952-1953, wicepremier w latach 1952-1954, przewodniczący Partii Liberalnej w latach 1954-1955.

Ōhira Masayoshi (1910-1980): Lider dawnej frakcji Ikedy w latach 1971-1980, sekretarz gabinetu w latach 1960-1962, minister spraw zagranicznych w latach 1962-1964 oraz 19721974, sekretarz generalny PLD w latach 1976-1978, przewodniczący PLD i premier w latach 1978-1980.

Okuno Seisuke (1913- ): Bezfrakcyjny poseł PLD o skrajnie nacjonalistycznych poglądach.

Ōno Banboku (1890-1964): Lider frakcji Ōno w latach 1955-1964, marszałek Izby Reprezentantów w latach 1952-1953, wiceprzewodniczący PLD w latach 1957-1959 oraz 19611964.

Ozawa Ichirō (1942- ): Członek dawnej frakcji Satō, sekretarz generalny PLD w latach 19891991, współzałożyciel Partii Odnowy w 1993 roku, przewodniczący Nowej Partii Postępu w latach 1995-1997, przewodniczący Partii Liberalnej w latach 1998-2003, przewodniczący Partii Demokratycznej w latach 2006-2009.

Sakurauchi Yoshio (1912-2003): Członek dawnej frakcji Kōno Ichirō, sekretarz generalny PLD w latach 1979-1981, minister spraw zagranicznych w latach 1981-1982, marszałek Izby Reprezentantów w latach 1990-1993.

Satō Eisaku (1901-1975): Lider frakcji Satō w latach 1956-1972, sekretarz gabinetu w latach 1948-1949, przewodniczący PLD i premier w latach 1964-1972.

Satō Shinji (1932- ): Syn Satō Eisaku, członek dawnej frakcji Satō, działacz Parlamentarnego Zgromadzenia Stosunków Japońsko-Tajwańskich. 
Shiina Etsusaburō (1898-1979): Lider dawnej frakcji Kawashimy w latach 1970-1979, sekretarz gabinetu w latach 1959-1960, minister spraw zagranicznych w latach 1964-1966, wiceprzewodniczący PLD w latach 1972-1976.

Shiina Motoo (1930-2007): Syn Shiiny Etsusaburō, poseł PLD, od 1993 roku bezpartyjny.

Sonoda Sunao (1913-1984): Lider dawnej frakcji Moriego Kiyoshiego w latach 1968-1972, zaś później członek byłej frakcji Kishiego, sekretarz gabinetu w latach 1976-1977, minister spraw zagranicznych w latach 1977-1979 oraz w 1981 roku.

Sonoda Hiroyuki (1942- ): Syn Sonody Sunao, członek dawnej frakcji Kishiego w latach 80. XX wieku, zaś od 1999 roku dawnej frakcji Ikedy, współzałożyciel Nowej Partii Zwiastun w 1993 roku, od 2010 roku w partii Powstań Japonio.

Suzuki Zenk̄̄ (1911-2004): Lider dawnej frakcji Ikedy w latach 1980-1986, sekretarz gabinetu w 1964 roku, przewodniczący PLD i premier w latach 1980-1982.

Takeshita Noboru (1924-2000): Lider dawnej frakcji Satō w latach 1987-1992, sekretarz gabinetu w latach 1971-1972 oraz 1974, sekretarz generalny PLD w latach 1986-1987, przewodniczący PLD i premier w latach 1987-1989.

Tamaki Kazuo (1923-1987): Członek frakcji Mikiego do 1972 roku, członek sekty religijnej Seichō no Ie, działacz Seirankai w latach 70. XX wieku.

Tanaka Kakuei (1918-1993): Lider dawnej frakcji Satō w latach 1972-1987, sekretarz generalny PLD w latach 1965-1966 oraz 1968-1971, przewodniczący PLD i premier w latach 1972-1974.

Tanaka Makiko (1944- ): Córka Tanaki Kakueia, minister spraw zagranicznych w latach 20012002, poza PLD od 2003 roku, członkini Partii Demokratycznej od 2009 roku.

Tanigaki Sadakazu (1945- ): Lider dawnej frakcji Ikedy (nurt Katō) w latach 2005-2008, przewodniczący PLD od 2009 roku.

Tsushima Yūji (1930- ): Lider dawnej frakcji Satō w latach 2005-2009.

Watanabe Michio (1923-1995): Lider dawnej frakcji Kōno Ichirō w latach 1990-1995, działacz Seirankai w latach 70. XX wieku, minister spraw zagranicznych w latach 1991-1993.

Yamanaka Sadanori (1921-2004): Członek dawnej frakcji Kōno Ichirō, przewodniczący Parlamentarnego Zgromadzenia Japońsko-Tajwańskiego w latach 1997-2004.

Yamasaki Taku (1936- ): Lider frakcji Yamasakiego od 1998 roku, sekretarz generalny PLD w latach 2001-2003, wiceprzewodniczący PLD w 2003 roku.

Yoshida Shigeru (1878-1967): Lider frakcji Yoshidy w latach 1955-1956, minister spraw zagranicznych w latach 1945-1947 oraz 1948-1952, przewodniczący Japońskiej Partii Liberalnej w latach 1946-1948, przewodniczący Partii Demokratyczno-Liberalnej w latach 1948-1950, przewodniczący Partii Liberalnej w latach 1950-1954, premier w latach 1946-1947 oraz 1948-1954. 



\title{
BIBLIOGRAFIA
}

\author{
Archiwalia
}

\section{Gaimushō Gaikō Shiryōkan [Archiwum Dyplomatyczne Ministerstwa Spraw Zagranicznych] w Tokio:}

Nichi-Chūka Minkoku kankei [Stosunki między Japonią a Republiką Chińską], A'1.2.1.7:

1. Chō Gun hishochōra to no kaidan no ken [W sprawie rozmowy z sekretarzem Zhang Qunem i in.] z 26 VII 1960.

2. Nikka Kyōryoku Iinkai kaigi ni kan suru ronpyō no ken [W sprawie komentarzy dotyczących konferencji Komitetu Współpracy Japońsko-Tajwańskiej] z 13 I 1961.

3. Sengo nikka kankei jūyō jikōshi [Zestawienie ważnych wydarzeń dotyczących powojennych stosunków japońsko-tajwańskich] z 9 XI 1963.

4. Kokufu Taiwan mondai kenkyū kadaian [Projekt badawczy zadań dotyczących problemu rządu na Tajwanie] z 28 I 1964.

5. Nikka kankei ni kan suru jakkan no kangaekata [Różne rozmyślania na temat stosunków japońsko-tajwańskich] z 2 III 1964.

6. Mōri Matsuhei, Hōka hōkoku [Raport z wizyty na Tajwanie] z 16 III 1964.

7. Kokufushi saikin no tai-Nichi ronpyō ni tsuite [W sprawie ostatnich komentarzy tajwańskich gazet na temat Japonii] z 22 V 1964.

8. Nikka kyōdō komyunike [Wspólny komunikat japońsko-tajwański] z 16 VIII 1965.

Honpō yōjin shogaikoku hōmon, Ajia Taiheiyō shokoku [Wizyty japońskich osobistości w różnych krajach, kraje Azji-Pacyfiku], A'1.5.1:

9. Kishi sōri Shō sōtō to kaidan no ken [W sprawie rozmowy pomiędzy premierem Kishim a prezydentem Jiangiem] z 4 VI 1957.

10. Chūka Minkoku seifu to hanashiau beki jikō, hatsugen yōshian [Sprawy, które należy omówić z rządem Republiki Chińskiej, projekt przemówienia] z 17 I 1964.

11. Chō Gun hishochō ni takushitaru „Shō sōtō yori Yoshida Shigeru sensei ni tai suru dengon” [,Wiadomość od prezydenta Jianga do pana Yoshidy Shigeru” powierzona sekretarzowi Zhang Qunowi] z 19 III 1964.

12. Yoshida Shigeru, Yoshida moto sōri kara Chō Gun hishochō ate henrin [Odpowiedź byłego premiera Yoshidy adresowana do sekretarza Zhang Quna] z 7 V 1964.

13. Satō-Shō kaidan gijiroku [Zapis rozmowy Satō-Jiang] z 12 IX 1967.

Kokki bujoku jiken zakken [Różne incydenty zniewagi flag państwowych], D2.3.0.8:

14. Nagasaki ni okeru Chūkyō hata hikikudashi jiken [Incydent opuszczenia flagi Chin komunistycznych w Nagasaki] z 7 V 1958.

15. Nagasaki no Chūgoku kokki jiken narabi ni Taiwan no naisei kanshō ni kan suru yōseisho [Petycja w sprawie incydentu z chińską flagą w Nagasaki oraz ingerencji Tajwanu w sprawy wewnętrzne] z 7 V 1958.

Kokkai Kaigiroku Kensaku Shisutemu [Archiwum Obrad Parlamentu Japonii], Kokkai Toshokan [Biblioteka Parlamentarna] w Tokio, dostępne na stronie internetowej: http://kokkai.ndl.go.jp/:

16. Posiedzenie Komisji Spraw Zagranicznych Izby Reprezentantów (Shūgiin Gaimu Iinkai) z 29 III 1956 roku, nr 24.

17. Posiedzenie plenarne Izby Radców (Sangiin honkaigi) z 6 II 1957 roku, nr 5 .

18. Posiedzenie Komisji Spraw Zagranicznych Izby Reprezentantów (Shūgiin Gaimu Iinkai) z 31 VII 1957 roku, nr 26. 
19. Posiedzenie Komisji Spraw Zagranicznych Izby Radców (Sangiin Gaimu Iinkai) z 1 VIII 1957 roku, nr 1.

20. Posiedzenie plenarne Izby Reprezentantów (Shūgiin honkaigi) z 21 X 1960 roku, nr 3.

21. Posiedzenie Komisji Sprawiedliwości Izby Reprezentantów (Shūgiin Hōmu Iinkai) z 17 XII 1963 roku, $\mathrm{nr} 4$.

22. Posiedzenie plenarne Izby Reprezentantów (Shūgiin honkaigi) z 21 XI 1964 roku, nr 3.

23. Posiedzenie Komisji Spraw Budżetowych Izby Radców (Sangiin Yosan Iinkai) z 9 XII 1964 roku, nr 3.

24. Posiedzenie plenarne Izby Reprezentantów (Shūgiin honkaigi) z 17 VII 1971 roku, nr 3.

25. Posiedzenie Komisji Rozrachunkowej Izby Radców (Sangiin Kessan Iinkai) z 18 VI 1987 roku, nr 4.

26. Posiedzenie plenarne Izby Reprezentantów (Shūgiin honkaigi) z 7 VI 1989 roku, nr 18.

27. Posiedzenie Komisji Spraw Zagranicznych Izby Reprezentantów (Shūgiin Gaimu Iinkai) z $26 \mathrm{~V} 1995$ roku, nr 18.

28. Posiedzenie Komisji Bezpieczeństwa Izby Reprezentantów (Shūgiin Anzen Hoshō Iinkai) z 23 II 1996 roku, nr 3.

29. Posiedzenie plenarne Izby Radców (Sangiin honkaigi) z 3 X 1997 roku, nr 3.

\section{Pozostałe teksty źródłowe}

1. Jiyū Minshutō tōsoku [Statut Partii Liberalno-Demokratycznej], Jiyū Minshutō, Tokio 2009.

2. Nihonkoku Kenрō o уоти [Czytając Konstytucję Japonii], Kashiwa Shobō, Tokio 1996.

3. Treaty of Mutual Cooperation and Security between Japan and the United States of America, dostępne na stronie internetowej: http://www.mofa.go.jp/region/n-america/us/q\&a/ref/1.html, uzyskane 27 VI 2008.

Nitchū kankei kihon shiryōshū 1949 nen - 1997 nen [Zbiór podstawowych dokumentów na temat stosunków japońsko-chińskich, lata 1949-1997], Zaidan Hōjin Kazankai, Tokio 1998:

4. Satō sōri to Jonson Bei daitōryō to no aida no kyōdō komyunike [Wspólna deklaracja premiera Satō i amerykańskiego prezydenta Johnsona] z 15 XI 1967, s. 299.

5. Satō sōri to Nikuson Bei daitôryō to no aida no kyōdō komyunike [Wspólna deklaracja premiera Satō i amerykańskiego prezydenta Nixona] z 21 XI 1969, s. 322.

6. Nihonkoku seifu to Chūka Jinmin Kyōwakoku seifu no kyōdō seimei [Wspólna deklaracja rządu Japonii i rządu Chińskiej Republiki Ludowej] z 29 IX 1972, s. 428-429.

7. Nitchū kōkū kyōtei chōin ni sai shite no Ōhira gaimu daijin danwa [Oświadczenie ministra spraw zagranicznych Ōhiry w chwili podpisania japońsko-chińskiej umowy lotniczej] z 20 IV 1974, s. 470-471.

8. Nihonkoku to Chūka Jinmin Kyōwakoku to no aida no heiwa yūkō jōyaku [Traktat o pokoju i przyjaźni pomiędzy Japonią a Chińską Republiką Ludową] z 12 VIII 1978, s. 514-516.

\section{Pamiętniki i książki programowe polityków}

1. Abe Shintarō, Nihon gaikō no shishin [Wytyczne japońskiej polityki zagranicznej], Shintarō Kai, Tokio 1984.

2. Abe Shintarō, Nagano Nobutoshi, Sōzōteki gaikō o mezashite [Ku twórczej dyplomacji], Gyōsei Mondai Kenkyūjo, Tokio 1984.

3. Abe Shintarō, Tanaka Yōnosuke, Shin seiki e no kakehashi [Most ku nowemu stuleciu], Raifusha, Tokio 1990.

4. Abe Shinzō, Utsukushii kuni e [Ku pięknemu krajowi], Bungei Shunjū, Tokio 2006.

5. Ashida Hitoshi, Ashida Hitoshi nikki [Pamiętnik Ashidy Hitoshiego], t. 6, Iwanami Shoten, Tokio 1986.

6. Asō Tarō, Asō Tarō no genten. Sofu Yoshida Shigeru no ryūgi [Punkt wyjścia Asō Tarō. Styl dziadka Yoshidy Shigeru], Tokuma Shoten, Tokio 2007. 
7. Asō Tarō, Jiyū to han'ei no ko [Łuk wolności i dobrobytu], Gentōsha, Tokio 2008.

8. Asō Tarō, Totetsumonai Nihon [Niesamowita Japonia], Shinchōsha, Tokio 2007.

9. Asō Tarō, Watashi no gaikō senryaku [Moja strategia dyplomatyczna], Asō Tarō to 21 Seiki no Kai, lizuka 2006.

10. Azumane Chimao, Hitoshikarazaru o ureeru. Moto shushō Suzuki Zenkō kaikoroku [Martwiąc się o nierówność. Pamiętnik byłego premiera Suzukiego Zenkō], Iwate Nippōsha, Morioka 2004.

11. Fujio Masayuki, Nomura Takuji et al., Gōchoku dotō no gendai seijika Fujio Masayuki sorekara no 100-nichi [Gwałtowny współczesny polityk o moralnej odwadze, Fujio Masayuki - następne 100 dni], Kindai Seikei Kenkyūkai, Tokio 1987.

12. Fujiyama Aiichirō, Seiji waga michi. Fujiyama Aiichirō kaisōroku [Polityka, moja droga. Pamiętnik Fujiyamy Aiichirō], Asahi Shinbunsha, Tokio - Osaka - Kitakiusiu - Nagoja 1976.

13. Fukuda Takeo, Kaiko 90 nen [Pamiętnik 90 lat], Iwanami Shoten, Tokio 1995.

14. Fukuda Yasuo, Etō Seishirō, Ikkoku wa hitori o motte okori, hitori o motte horobu [Kraj kwitnie dzięki jednostce i przez jednostkę jest niszczony], KK Bestoserāzu, Tokio 2007.

15. Funada Naka, Satō Kiichirō, Serizawa Kōjirō, Matsuda Tsuneji, Watashi no rirekisho. Dai 26 $s h \bar{u}$ [Mój życiorys. Zbiór 26], Nihon Keizai Shinbunsha, Tokio 1968.

16. Furui Yoshimi, Nitchū 18 nen. Ichi seijika no kiseki to tenbō [18 lat japońsko-chińskich. Kariera i przewidywania jednego polityka], Makino Shuppan, Tokio 1978.

17. Furui Yoshimi, Furui Yoshimi ibunshū [Zbiór pism Furuia Yoshimiego] pod red. Matsuo Takayoshiego, Nitchū Yūkō Kaikan, Tokio 1997.

18. Gotōda Masaharu, Sei to kan [Polityka i biurokracja], Kōdansha, Tokio 1994.

19. Gotōda Masaharu, Mikuriya Takashi, Jō to ri - Kamisori Gotōda kaikoroku [Uczucia a rozsądek - Pamiętnik brzytwy Gotōdy], t. 1-2, Kōdansha, Tokio 2006.

20. Hamada Kōichi, Nihon o dame ni shita 9-nin no seijika [Dziewięciu polityków, którzy zniszczyli Japonię], Kōdansha, Tokio 1993.

21. Hara Yoshihisa, Kishi Nobusuke shōgenroku [Świadectwo Kishiego Nobusuke], Mainichi Shinbunsha, Tokio 2003.

22. Hashimoto Ryūtarō, Seiken dakkai ron [Dyskurs o odzyskaniu władzy], Kōdansha, Tokio 1994.

23. Hashimoto Ryūtarō, Vision of Japan. Waga kyōchū ni seisaku arite [Wizja Japonii. Polityka w mojej piersi], KK Besutoserāzu, Tokio 1993.

24. Hatoyama Ichirō, Hatoyama Ichirō kaikoroku [Pamiętnik Hatoyamy Ichirō], Bungei Shunjū Shinsha, Tokio 1957.

25. Hayasaka Shigezō, Hayasaka Shigezō no „Tanaka Kakuei” kaisōroku [Pamiętnik „Tanaki Kakueia” Hayasaki Shigezō], Shōgakukan, Tokio 1987.

26. Hiranuma Takeo, Seiji bushidō [Polityczny kodeks wojownika], PHP Fakutorī Paburishingu, Tokio 2007.

27. Hiranuma Takeo, Shin rokka ron - Mattō na Nihon o tsukuru tame ni [Nowa teoria państwa Ku stworzeniu właściwej Japonii], Chūō Kōron Shinsha, Tokio 2005.

28. Hori Shigeru, Sengo seiji no oboegaki [Notatki na temat powojennej polityki], Mainichi Shinbunsha, Tokio 1975.

29. Ibuki Bunmei, Watanabe Yoshimi, Shinario. Nihon keizai to zaisei no saisei [Scenariusz. Regeneracja japońskiej gospodarki i finansów], Nikkan Kōgyō Shinbunsha, Tokio 2001.

30. Ikeda Hayato, Kinkō zaisei. Fu - senryōka 3 nen no omoide [Równowaga finansów. Dodatek - wspomnienia z trzech lat pod okupacją], Chūō Kōron Shinsha, Tokio 1999.

31. Ikeda Masanosuke, Chūgoku minzoku no tokusei [Charakterystyczne cechy narodu chińskiego], Naigai Jijō Kenkyūjo, Tokio 1975. 
32. Ikeda Masanosuke, Nazo no kuni - Chūkyō tairiku no jittai [Zagadkowy kraj - Rzeczywisty stan komunistycznych Chin kontynentalnych], Jiji Tsūshinsha, Tokio 1969.

33. Ikeda Masanosuke, Shina minzokusei no kaimei [Analiza narodowości chińskiej], Naigai Jijō Kenkyūjo, Tokio 1971.

34. Ishibashi Tanzan, Tanzan kaisō [Wspomnienia Tanzana], Iwanami Shoten, Tokio 2007.

35. Ishibashi Tanzan, Ishibashi Tanzan hyōronshū [Zbiór esejów Ishibashiego Tanzana] pod red. Matsuo Takayoshiego, Iwanami Shoten, Tokio 1984.

36. Ishida Hirohide, Watashi no seikai Shōwashi [Moja historia świata polityki ery Shōwa], Tōyō Keizai Shinpōsha, Tokio 1986.

37. Ishihara Shintarō, Morita Akio, „Nō” to ieru Nihon [Japonia mogąca powiedzieć „nie”], Kōbunsha, Tokio 1990.

38. Ishihara Shintarō, Tahara Sōichirō, Nippon no chikara [Siła Japonii], Bungei Shunjū, Tokio 2007.

39. Ishihara Shintarō, Watanabe Shōichi, Ogawa Kazuhisa, Sore demo „nō” to ieru Nihon [Japonia nadal mogąca powiedzieć „nie”], Kōbunsha, Tokio 1990.

40. Ishii Mitsujirō, Kaisō 88 nen [Wspomnienia z 88 lat], Karuchā Shuppansha, Tokio 1976.

41. Kaifu Toshiki, Kokorozashi aru kokka Nihon no kōsō [Scenariusz Japonii, kraju z ambicją], Tōyō Keizai Shinpōsha, Tokio 1995.

42. Kaifu Toshiki, Seiji to kane - Kaifu Toshiki kaikoroku [Polityka a pieniądze - Pamiętnik Kaifu Toshikiego], Shinchōsha, Tokio 2010.

43. Kajiyama Seiroku, Hakai to sōzō - Nihon saikō e no teigen [Zniszczenie i kreacja - Sugestie odnowy Japonii], Kōdansha, Tokio 2000.

44. Kamei Shizuka, Namikawa Eita, Han'ei no shinario [Scenariusz dobrobytu], Chūkei Shuppan, Tokio 2003.

45. Katō Kōichi, Atarashiki Nihon no katachi [Kształt nowej Japonii], Daiyamondosha, Tokio 2005.

46. Katō Kōichi, Ima seiji wa nani o subeki ka - Shin seiki Nihon no sekkeizu [Co powinna robić obecna polityka - Plan Japonii nowego wieku], Kōdansha, Tokio 1999.

47. Kawasaki Hideji, Nitchū fukkō-go no sekai. Gekidō no dorama 1 nen kara [Świat po przywróceniu stosunków japońsko-chińskich. Rok od dramatu nagłej zmiany], Nyū Saiensusha, Tokio 1972.

48. Kawasaki Jirō, Hitasura anzen ni kaketa jōnetsu [Szczery zapał zapewnienia bezpieczeństwa], Kawasaki Jirō Shuppan Jikkō Iinkai, Tokio 1999.

49. Kikigaki. Miyazawa Kiichi kaikoroku [Wywiad. Pamiętnik Miyazawy Kiichiego] pod red. Mikuriyi Takashiego i Nakamury Takafusy, Iwanami Shoten, Tokio 2007.

50. Kishi Nobusuke, Kishi Nobusuke kaikoroku - Hoshu gōdō to anpo kaitei [Pamiętnik Kishiego Nobusuke - Konserwatywna fuzja i rewizja traktatu o zapewnieniu bezpieczeństwa], Kōsaidō, Tokio 1983.

51. Kishi Nobusuke et al., Watashi no rirekisho. Hoshu seiken no ninaite [Mój życiorys. Osoby odpowiedzialne za politykę konserwatywną], Nihon Keizai Shimbun Shuppansha, Tokio 2007.

52. Koizumi Jun'ichirō, Kanryō ōkoku kaitairon. Nihon no kiki o sukuu hō [Dyskurs o zniszczeniu królestwa biurokratów. Prawo, które ocali Japonię z kryzysu], Kōbunsha, Tokio 1996.

53. Koizumi Jun'ichirō, Koizumi Jun'ichirō no bōron - seiron [Absurdalne - właściwe argumenty Koizumiego Jun'ichirō], Shūeisha, Tokio 2001.

54. Koizumi Jun'ichirō et al., Jimintō no sokojikara [Potencjał PLD], Seikō Shobō, Tokio 2007.

55. Kōmoto Toshio, Sekai no naka no Nihon. Dai 3 shū. 80 nendai seiji e no teigen [Japonia na świecie. Zbiór trzeci. Sugestie dla polityki lat 80.], Shin Seisaku Kenkyūkai, Tokio 1984.

56. Kōno Ichirō, Kōno Ichirō jiden [Autobiografia Kōno Ichirō], Tokuma Shoten, Tokio 1965. 
57. Kōno Kenzō, Gichō ichidai. Kōno Kenzō kaisōki [Życie marszałka. Wspomnienia Kōno Kenzō], Asahi Shinbunsha, Tokio - Osaka - Kitakiusiu - Nagoja 1978.

58. Kōno Tarō, Kōno Tarō no kokkai kōryaku hon [Książka o zdobyciu parlamentu przez Kōno Tarō], Eiji Shuppan, Tokio 2003.

59. Kōno Yōhei, Hakushu wa iranai - Atarashii seiji o motomete [Nie potrzebuję oklasków Dążąc do nowej polityki], Tōyō Insatsu, Kioto 1976.

60. Kōno Yōhei, Kōno Tarō, Ketsudan - Kōno fushi no seitai kan ishoku [Decyzja Transplantacja wątroby ojca i syna Kōno], Asahi Shinbunsha, Tokio 2004.

61. Li Denghui, Taiwan no shuchō [Stanowisko Tajwanu], PHP Kenkyūjo, Tokio 1999.

62. Liu Deyou, Toki wa nagarete - Ntchū kankei hishi 50 nen [Czas przemija - 50 lat sekretnej historii stosunków japońsko-chińskich], t. 1-2, Fujiwara Shoten, Tokio 2002.

63. Machimura Nobutaka, Hoshu no ronri. Rin to shite utsukushii Nihon o tsukuru [Logika konserwatyzmu. Stworzenie dostojnej i pięknej Japonii], PHP Kenkyūjo, Tokio 2005.

64. Maeo Shigesaburō, Gendai seiji no kadai [Zadania współczesnej polityki], Mainichi Shinbunsha, Tokio 1976.

65. Maeo Shigesaburō, Seijika no hōjōki [Zapis chaty polityka], Risōsha, Tokio 1981.

66. Matsumura Kenzō, Kakō getsuen. Matsumura Kenzō ibunshō [Kwitnący kwiat, pełen księżyc. Zbiór pism Matsumury Kenzō] pod red. Matsumury Masanao et al., Seirin Shoin Shinsha, Tokio 1978.

67. Minato Tetsurō et al., Seirankai kara no chokugen [Szczere przesłanie od Seirankai], Rōman, Tokio 1974.

68. Miyazawa Kiichi, 21 seiki e no ininjō [Mandat na 21 wiek], Shōgakukan, Tokio 1995.

69. Miyazawa Kiichi, Hato-ha no dengon - Miyazawa Kiichi shushō ga kataru [Przesłanie od frakcji gołębi - Opowiada premier Miyazawa Kiichi], Chūgoku Shinbunsha, Hiroshima 2005.

70. Miyazawa Kiichi, Tōkyō - Washinton mitsudan [Potajemne rozmowy Tokio-Waszyngton], Chūō Kōron Shinsha, Tokio 1999.

71. Miyazawa Kiichi, Kōsaka Masataka, Utsukushii Nihon e no chōsen [Wyzwanie stworzenia pięknej Japonii], Bungei Shunjū, Tokio 1984.

72. Miyazawa Kiichi. Hoshu honryū no kiseki [Świadectwo lat 90. Miyazawa Kiichi. Ścieżka głównego nurtu konserwatywnego] pod red. Iokibe Makoto, Itō Motoshige, Yakushijiego Katsuyukiego, Asahi Shinbunsha, Tokio 2006.

73. Mori Yoshirō, Anata ni oshierare, hashiri tsuzukemasu [Nauczywszy się od Ciebie, kontynuuję bieg], Hokkoku Shinbunsha, Kanazawa 1999.

74. Mori Yoshirō. Jimintō to seiken kōtai [Mori Yoshirō. PLD a zmiana władzy] pod red. Iokibe Makoto, Itō Motoshige, Yakushijiego Katsuyukiego, Asahi Shinbunsha, Tokio 2007.

75. Morita Hajime, Arai Shunzō, Bunjin saishō Ōhira Masayoshi [Premier literat Ōhira Masayoshi], Shunjūsha, Tokio 1982.

76. Morita Hajime, Saigo no tabi. Nokosareta yuiitsu no Ōhira saishō nikki [Ostatnia podróż. Jedyny pozostawiony dziennik premiera Ōhiry], Gyōsei Mondai Kenkyūjo, Tokio 1981.

77. Murakami Masakuni, Hirano Sadao, Fudesaka Hideyo, Jimintō wa naze tsuburenai no ka [Dlaczego PLD nie upadnie?], Gentōsha, Tokio 2007.

78. Murakami Masakuni, Hirano Sadao, Fudesaka Hideyo, Sangiin nanka iranai [Izba Radców nie jest potrzebna], Gentōsha, Tokio 2007.

79. Nakagawa Ichirō, Ishihara Shintarō et al., Seirankai - Keppan to yūkoku no ronri [Seirankai Pakt krwi i logika patriotyzmu], Rōman, Tokio 1973.

80. Nakasone Yasuhiro, Jiseiroku - Rekishi hōtei no hikoku to shite [Rachunek sumienia - Jako pozwany przez sąd historii], Shinchōsha, Tokio 2004.

81. Nakasone Yasuhiro, Nakasone Yasuhiro - Toppu daun gata seijika. Haisen ku no kokufuku kara sekai no Nihon e [Nakasone Yasuhiro - polityk typu odgórnego. Od przezwyciężenia 
trudności po przegranej wojnie ku Japonii globalnej], Nakasone Yasuhiro Jimusho, Tokio 1991.

82. Nakasone Yasuhiro, Nishibe Susumu, Matsui Takafumi, Matsumoto Ken'ichi, „Shōwa 80 nen” sengo no yomikata [Sposób czytania okresu powojennego „80 roku ery Shōwa”], Bungei Shunjū, Tokio 2005.

83. Nakasone Yasuhiro, Takemura Ken'ichi, Inochi no kagiri semi shigure. Nihon seiji ni senryakuteki tenkai o [Cykadowy deszcz przez całe życie. Ku strategicznej ewolucji japońskiej polityki], Tokuma Shoten, Tokio 2003.

84. Nihon no kinmirai [Bliska przyszłość Japonii] pod red. Yamasakiego Taku, Daiyamondosha, Tokio 1998.

85. Nonaka Hiromu, Rōhei wa shinazu. Nonaka Hiromu zenkaikoroku [Stary żołnierz nie umiera. Pełen pamiętnik Nonaki Hiromu], Bungei Shunjū, Tokio 2005.

86. Nonaka Hiromu, Watashi wa tatakau [Ja walczę], Bungei Shunjū, Tokio 2001.

87. Ōhira Masayoshi, Ōhira Masayoshi kaisōroku - Shiryōhen [Pamiętnik Ōhiry Masayoshi zbiór materiałów], Ōhira Masayoshi Kaisōroku Kankōkai, Tokio 1982.

88. Ōhira Masayoshi, Watashi no rirekisho [Mój życiorys], Nihon Keizai Shinbunsha, Tokio 1978.

89. Okushima Sadao, Jimintō Kanjichōshitsu no 30 nen [30 lat Biura Sekretariatu Generalnego PLD], Chūō Kōron Shinsha, Tokio 2005.

90. Ōno Banboku, Ōno Banboku kaisōroku [Pamiętnik Ōno Banboku], Kōbundō, Tokio 1962.

91. Ozawa Ichirō, Nihon kaizō keikaku [Plan przebudowy Japonii], Kōdansha, Tokio 2006.

92. Satō Akiko, Watashi no Tanaka Kakuei nikki [Mój dziennik Tanaki Kakueia], Shinchōsha, Tokio 1994.

93. Satō Eisaku, Satō Eisaku Nikki [Dziennik Satō Eisaku], t. 1-6, Asahi Shinbunsha, Tokio $1997 / 1998$.

94. Shiina Motoo, Shiina Motoo kaikoroku: Fuki fuhon [Pamiętnik Shiiny Motoo: Utrzymać wolność, nie spieszyć się], Tōshindō, Tokio 2006.

95. Sonoda Sunao, Sekai Nihon ai [Świat, Japonia, miłość], Dai San Seikei Kenkyūkai, Tokio 1981.

96. Tagawa Seiichi, Matsumura Kenzō to Chūgoku [Matsumura Kenzō a Chiny], Yomiuri Shinbunsha, Tokio 1972.

97. Tagawa Seiichi, Nitchū kōryū to Jimintō ryōshūtachi [Wymiana japońsko-chińska a liderzy PLD], Yomiuri Shinbunsha, Tokio 1983.

98. Takeshita Noboru, Seiji to wa nani ka - Takeshita Noboru kaikoroku [Czym jest polityka? Pamiętnik Takeshity Noboru], Kōdansha, Tokio 2001.

99. Takeshita Noboru, Shōgen. Hoshu Seiken [Świadectwo. Władza konserwatywna], Yomiuri Shinbunsha, Tokio 1991.

100. Takeshita Noboru, Subarashii kuni Nihon [Japonia, wspaniały kraj], Kōdansha, Tokio 1987.

101. Tanaka Kakuei, Nihon Rettō kaizōron [Dyskurs o przebudowie Archipelagu Japońskiego], Nikkan Kōgyō Shinbunsha, Tokio 1972.

102. Tanaka Rokusuke, Hoshu honryū no chokugen [Szczery dyskurs głównego nurtu konserwatywnego], Chūō Kōronsha, Tokio 1985.

103. Tanaka Rokusuke, Ōhira Masayoshi no hito to seiji [Ōhira Masayoshi jako człowiek i jego polityka], Asahi Sonorama, Tokio 1981.

104. Tsuisō. Hatoyama Iichirō [Wspomnienia. Hatoyama Iichirō] pod red. Hatoyama Kaikan, Kadokawa Shoten, Tokio 1996.

105. Watanabe Michio, Kakizawa Kōji, Ibuki Bunmei, Shin hoshu kakumei [Nowa konserwatywna rewolucja], Nesuko, Tokio 1994.

106. Watanabe Tsuneo kaikoroku [Pamiętnik Watanabe Tsuneo] pod red. Itō Takashiego, Mikuriyi Takashiego, Iio Juna, Chūō Kōron Shinsha, Tokio 2000. 
107. Yamasaki Taku, 2010 nen Nihon jitsugen [Realizacja Japonii 2010 roku], Daiyamondosha, Tokio 1999.

108. Yamasaki Taku, Ajia Taiheiyō jidai to nichibei anpo [Era Azji i Pacyfiku a sojusz japońskoamerykański], Sandokē Shuppankyoku, Tokio 1996.

109. Yamasaki Taku, Tenki ni tatsu Nihon no bōei [Japońska obrona w punkcie zwrotnym], Rīburu Shuppan Kikaku, Fukuoka 1982.

110. Yoshida Shigeru, Kaisō 10 nen [Wspomnienia z 10 lat], t. 1-4, Chūō Kōronsha, Tokio 1998.

111. Yoshida Shigeru, Sekai to Nihon [Świat i Japonia], Banchō Shobō, Tokio 1963.

112. Yūsei min'eika ron. Nihon saisei no daikaikaku [Dyskurs o prywatyzacji poczty. Wielka reforma odnowy Japonii] pod red. Koizumiego Jun'ichirō i Matsuzawy Shigefumiego, PHP Kenkyūjo, Tokio 1999.

\section{Wywiady}

1. Wywiad autora z Suzakim Shin'ichim, profesorem Uniwersytetu Kōbe, Wydział Kultury Międzynarodowej Uniwersytetu Kōbe, 27 XI 2008.

2. Wywiad autora $\mathrm{z}$ Fukunagą Fumio, profesorem Uniwersytetu Dokkyō w Saitamie, Nishinomiya, 27 XII 2008.

3. Wywiad autora z Nakatsu Nobuyoshim, radnym prefektury Hiroshima, byłym sekretarzem premiera Miyazawy Kiichiego, Fukuyama, 6 I 2009.

4. Wywiad autora z Kōno Tarō, posłem 4. kadencji, przewodniczącym Komisji Spraw Zagranicznych Izby Reprezentantów, Parlament Japonii, Tokio, 10 III 2009.

5. Wywiad autora $\mathrm{z}$ Hiranumą Takeo, posłem 9. kadencji, przewodniczącym JapońskoTajwańskiego Zgromadzenia Parlamentarnego, byłym minister transportu i gospodarki, Nagatachō Biru, Tokio, 12 III 2009.

6. Wywiad autora z Kōno Yōheiem, posłem 14. kadencji, marszałkiem Izby Reprezentantów, byłym przewodniczącym Nowego Klubu Liberalnego, byłym przewodniczącym Partii Liberalno-Demokratycznej, byłym ministrem spraw zagranicznych, byłym przewodniczącym frakcji Taiyūkai w PLD, Rezydencja Marszałka Izby Reprezentantów, Tokio, 13 III 2009.

7. Wywiad autora z Katō Kōichim, posłem 12. kadencji, przewodniczącym Stowarzyszenia Przyjaźni Japońsko-Chińskiej, byłym sekretarzem generalnym PLD, byłym sekretarzem gabinetu, byłym przewodniczącym Rady Badań Politycznych PLD, byłym dyrektorem Agencji Obrony, byłym przewodniczący dawnej frakcji Ikedy w PLD, Parlament Japonii, Tokio, 13 III 2009.

\section{Leksykony i słowniki}

1. Grzenia, Jan, Stownik nazw własnych, Wydawnictwo Naukowe PWN, Warszawa 2002.

2. Kajdański, Edward, Chiny - Leksykon, Książka i Wiedza, Warszawa 2005.

3. Kokkai binran - Heisei 12 nen 8 gatsu shinpan [Podręcznik parlamentarny - Nowe wydanie z sierpnia 12 roku ery Heisei] pod red. Yoshidy Nobuko, Nihon Keizai Shinbunsha, Tokio 2000.

4. Kokkai binran - Heisei 15 nen 12 gatsu rinjihan [Podręcznik parlamentarny - Specjalne wydanie z grudnia 15 roku ery Heisei] pod red. Kikuoki Nobuko, Nihon Keizai Shinbunsha, Tokio 2003.

5. Kokkai binran - Heisei 19 nen 2 gatsu shinpan [Podręcznik parlamentarny - Nowe wydanie z lutego 19 roku ery Heisei] pod red. Kikuoki Nobuko, Nihon Keizai Shinbunsha, Tokio 2006.

6. Obuchi Keizō no 615-nichi [615 dni Obuchiego Keizō] pod red. KOK, Kōshinsha, Tokio 2000.

7. Shushō retsuden. Itō Hirobumi kara Koizumi Jun'ichirō made [Biografie premierów. Od Itō Hirobumiego do Koizumiego Jun'ichirō] pod red. Ujiego Toshihiko, Tōkyō Shoseki, Tokio 2001. 


\section{Monografie i pozostałe druki zwarte}

1. 21 shiji de Zhong-Ri guanxi [Stosunki chińsko-japońskie 21 wieku] pod red. Jin Xide, Chongqing Chubanshe, Chongqing 2007.

2. Abe, Hitoshi; Hindō, Muneyuki; Kawato, Sadafumi; The Government and Politics of Japan, University of Tokio Press, Tokio 1994.

3. Adachi Toshiaki, Jimintō jinbutsu fūunroku, Yoshida Shigeru kara Ōhira Masayoshi made [Zapis wiatru i chmur PLD, od Yoshidy Shigeru do Ōhiry Masayoshiego], Shinsedai Shisutemu Sentā, Tokio 1983.

4. Amako Satoshi, Ribenren yanli de Zhongguo [Chiny w oczach Japończyków], Shehui Kexue Wenxian Chubanshe, Pekin 2006.

5. Asahi Shinbun Seijibu, Takeshita-ha shihai [Rządy frakcji Takeshity], Asahi Shinbunsha, Tokio 1992.

6. Asakawa Hirotada, Ningen Koizumi Jun'ichirō. Sandai ni wataru ,henkaku” no chi [Koizumi Jun'ichirō jako człowiek. Krew „reform” przez trzy pokolenia], Kōdansha, Tokio.

7. Azja Wschodnia na przełomie XX $i$ XXI wieku. Przemiany polityczne $i$ spoteczne pod red. Krzysztofa Gawlikowskiego, Wydawnictwo TRIO, Warszawa 2004.

8. Bae Jeongho, Talnaengjeon sidae jeonhwangi-ui Ilbon-ui kungnae jeongchi-wa daeoe jeollyak [Japońska polityka wewnętrzna oraz strategia zagraniczna przełomu po okresie zimnowojennym], Tong-il Yeonguwon, Seul 2005.

9. Barnett, A. Doak, China and the Major Powers in East Asia, The Brookings Institution, Washington 1977.

10. Bouissou, Jean-Marie; Gipouloux, François; Seizelet, Eric, Japon: le déclin?, Editions Complexe, Bruxelles 1995.

11. China and Japan. History, Trends, and Prospects pod red. Christophera Howe'a, Oxford University Press, New York 1996.

12. Chinese-Japanese Relations in the Twenty-first Century pod red. Marie Söderberg, Routledge, London - New York 2002.

13. Chiny i Japonia. Dylematy mocarstw w Azji Wschodniej pod red. Małgorzaty Pietrasiak i Dominika Mierzejewskiego, Wydawnictwo Uniwersytetu Łódzkiego, Łódź 2009.

14. Chiny $w$ stosunkach międzynarodowych pod red. Krzysztofa Iwańczuka i Agaty Ziętek, Wydawnictwo UMCS, Lublin 2003.

15. Chodubski, Andrzej Jan, Wstęp do badań politologicznych, Wydawnictwo Uniwersytetu Gdańskiego, Gdańsk 2006.

16. Civilisation of Evolution, Civilisation of Revolution: Metamorphoses in Japan 1900-2000 pod red. A. Jabłońskiego, S. Meyera, K. Mority, Manggha Museum of Japanese Art \& Technology, Kraków 2009.

17. Curtis, Gerald L., The Japanese Way of Politics, Columbia University Press, New York 1988.

18. Curtis, Gerald L., The Logic of Japanese Politics. Leaders, Institutions, and the Limits of Change, Columbia University Press, New York 1999.

19. Denggao wangyuan. Riben zhengzhijia Erjie Junbo [Wspinać się wysoko i patrzeć daleko. Japoński polityk Nikai Toshihiro] pod red. Qiao Shenga, Shehui Kexue Wenxian Chubanshe, Pekin 2008.

20. Destler, I. M.; Clapp, Priscilla; Sato, Hideo; Fukui, Haruhiro, Managing an Alliance: The Politics of U.S.-Japanese Relations, The Brookings Institution, Washington 1976.

21. Dobson, Hugo, Japan and United Nations Peacekeeping. New Pressures, New Responses, Routledge Curzon, London - New York 2003.

22. Edo Yūsuke, Senkaku shotō. Dō suru Nihon [Wyspy Senkaku. Co zrobi Japonia], Kōyū Shuppan, Tokio 2005.

23. Eguchi Nobuyuki, Habatsu saihen to nyūrīdā [Reorganizacja frakcji a nowi liderzy], Kyōikusha, Tokio 1985. 
24. Endō Kazuo, Matsumura Kenzō [Matsumura Kenzō], KNB Kōsan Kabushiki Gaisha Shuppankyoku, Toyama 1975.

25. Fenomen Chin. Wybrane problemy polityki wewnętrznej i zagranicznej Chińskiej Republiki Ludowej pod red. Małgorzaty Pietrasiak, Wydawnictwo Uniwersytetu Łódzkiego, Łódź 2007.

26. Finnemore, Martha, National Interests in International Society, Cornell University Press, Ithaca - London 1996.

27. Foreign Policy of the Republic of China on Taiwan: An Unorthodox Approach pod red. Yu San Wanga, Praeger Publishers, New York 1990.

28. Fujita Yoshirō, Shiina saitei [Nominacja przez Shiinę], Sankei Shuppan, Tokio 1979.

29. Fukui Haruhiro, Jiȳu Minshutō to seisaku kettei [Partia Liberalno-Demokratyczna a decyzje polityczne], Fukumura Shuppan, Tokio 1969.

30. Fukunaga Fumio, Sengo Nihon no saisei - 1945-1965 nen [Odbudowa powojennej Japonii lata 1945-1965], Maruzen, Tokio 2004.

31. Fukunaga Fumio, Ōhira Masayoshi. „Sengo hoshu” to wa nanika [Ōhira Masayoshi. Czym jest ,powojenny konserwatyzm”], Chūō Kōron Shinsha, Tokio 2008.

32. Funabashi Yōichi, Nihon no taigai kōsō [Ramy relacji Japonii z zagranicą], Iwanami Shoten, Tokio 1993.

33. Gotō Kenji, Takeshita seiken 576 nichi [576 dni rządów Takeshity], Gyōken Shuppankyoku, Tokio 2000.

34. Gotō Motoo, Uchida Kenzō, Ishikawa Masumi, Sengo hoshu seiji no kiseki [Ścieżka powojennej polityki konserwatywnej], t. 1-2, Iwanami Shoten, Tokio 1994.

35. Green, Michael Jonathan, Japan's Reluctant Realism. Foreign Policy Challenges in an Era of Uncertain Power, Palgrave Macmillian, New York 2003.

36. Haliżak, Edward, Polityka $i$ strategia Chin $w$ ksztattowaniu międzynarodowego bezpieczeństwa, Wydawnictwo Naukowe Scholar, Warszawa 2007.

37. Haliżak, Edward, Regionalny kompleks bezpieczeństwa Azji Pótnocno-Wschodniej, Wydawnictwo Naukowe Scholar, Warszawa 2004.

38. Hara Yoshihisa, Kishi Nobusuke. Kensei no seijika [Kishi Nobusuke. Wpływowy polityk], Iwanami Shoten, Tokio 2007.

39. Hara Yoshihisa, Yoshida Shigeru. Sonnō no seijika [Yoshida Shigeru. Polityk czczący cesarza], Iwanami Shoten, Tokio 2005.

40. Harada Nobuo, Senkaku shotō - Sappō Ryūkyū Shiroku o yomu [Wyspy Senkaku - Czytając kroniki Riukiu], Yōju Shorin, Ginowan 2006.

41. Hatakeyama Takeshi, Habatsu no uchimaku [Kulisy frakcji], Rippu Shobō, Tokio 1975.

42. Hatano Masaru, Shimizu Urara, Yūkō no kakehashi o yumemite - Nitchū kokkō seijōka e no kiseki [Marząc o przyjaznych stosunkach - Cud ku normalizacji japońsko-chińskich stosunków dyplomatycznych], Gakuyō Shobō, Tokio 2004.

43. Hayasaka Shigezō, Kenryoku no shisaitachi [Kapłani władzy], Asuka Shinsha, Tokio 1991.

44. Hayasaka Shigezō, Saishō no utsuwa [Zdolności premiera], Kuresutosha, Tokio 1992.

45. Hayasaka Shigezō, Seijika Tanaka Kakuei [Polityk Tanaka Kakuei], Shūeisha, Tokio 1993.

46. Hays Gries, Peter, China's New Nationalism. Pride, Politics, and Diplomacy, University of California Press, Berkeley - Los Angeles - London 2004.

47. Higuchi Tsuneo, Tamaki Kazuo no yuigon [Testament Tamakiego Kazuo], Asuka Shinsha, Tokio 1987.

48. Hiramatsu Shigeo, Chūgoku, kaku misairu no hyōteki [Chiny, cel rakiet nuklearnych], Kadokawa Shoten, Tokio 2006.

49. Hobson, John M., The State and International Relations, Cambridge University Press, Cambridge 2000. 
50. Honda Yoshihiko, Nitchūtai miezaru kizuna. Chūgoku shunō tsūyaku no mita gaikō hiroku [Niewidzialne więzi japońsko-chińsko-tajwańskie. Tajemny zapis dyplomacji widzianej przez tłumaczy na spotkaniach na szczycie z Chinami], Nihon Keizai Shinbunsha, Tokio 2006.

51. Honzawa Jirō, Habatsu no shüen to Nihon no shinro. Koizumi seiji no isan [Koniec frakcji a kurs Japonii. Dziedzictwo polityki Koizumiego], Nagasaki Shuppan, Tokio 2008.

52. Honzawa Jirō, Jimintō habatsu [Frakcje PLD], Piipurusha, Tokio 1990.

53. Honzawa Jirō, Taiwan Robī [Tajwańskie lobby], Dētahausu, Tokio 1998.

54. Horikoshi Sakuji, Sengo seiji rimenshi [Zakulisowa historia powojennej polityki], Iwanami Shoten, Tokio 1998.

55. Hoshi Hiroshi, Jimintō to sengo - Seikentō no 50 nen [PLD a okres powojenny - 50 lat partii władzy], Kōdansha, Tokio 2005.

56. Hoshu kaiki [Zwrot konserwatywny] pod red. Uchidy Kenzō, Shiratoriego Reia i Tomity Nobuo, Shinhyōron, Tokio 1981.

57. Hoshu seijika wa ureeru [Politycy konserwatywni się martwią] pod red. „Sekai” Henshūbu, Iwanami Shoten, Tokio 1986.

58. Hosoya Chihiro, Nihon gaikō no kiseki [Kurs japońskiej dyplomacji], Nihon Hōsō Shuppan Kyōkai, Tokio 2001.

59. Hosoya Chihiro, Nihon gaikō no zahyō [Współrzędne japońskiej dyplomacji], Chūō Kōronsha, Tokio 1979.

60. Huang Dahui, Riben dui-Hua zhengce yu guonei zhengzhi - Zhong-Ri fujiao zhengzhi guocheng fenxi [Polityka Japonii wobec Chin a polityka wewnętrzna - Analiza procesu przywrócenia chińsko-japońskich stosunków dyplomatycznych], Dangdai Shijie Chubanshe, Pekin 2006.

61. Hyeondae Ilbon Hakhoe, Ilbon jeongchi ron [Dyskurs na temat japońskiej polityki], Nonhyeong, Seul 2009.

62. I Sanghun, Ilbon-ui jeongchi kwajeong [Japoński proces decyzyjny w polityce], Doseo Chulpan Bogosa, Seul 2003.

63. I Sangbong, Poseuteu „jeonhu jeongchi”-ui Ilbon jeongchi [Japońska polityka po ,polityce powojennej"], Hyeongseol Chulpansa, Seul 2002.

64. Igarashi Akio, Nihon seijiron [Dyskurs na temat polityki Japonii], Iwanami Shoten, Tokio 2011.

65. Iijima Isao, Koizumi kantei hiroku [Sekretny zapis rezydencji Koizumiego], Nihon Keizai Shinbunsha, Tokio 2006.

66. Iio Jun, Nihon no tōchi kōzōo [Struktura rządów w Japonii], Chūō Kōron Shinsha, Tokio 2008.

67. Ikeda, Satō seikenki no Nihon gaikō [Dyplomacja Japonii w okresie rządów Ikedy i Satō] pod red. Hatano Sumio, Minerva Shobō, Tokio 2004.

68. Ilbon jeongchi-ui ihae [Rozumienie japońskiej polityki] pod red. Hanguk Ilbon Hakhoe, Sisa Ilboneosa, Seul 1998.

69. Inoguchi Takashi, Gendai Nihon seiji no kisō [Podstawy współczesnej polityki Japonii], NTT Shuppan, Tokio 2002.

70. Inoguchi Takashi, Kokusai seiji no mikata - 9.11 go no Nihon gaikō [Punkt widzenia polityki międzynarodowej - Japońska dyplomacja po 11 września], Chikuma Shobō, Tokio 2005.

71. Inoguchi Takashi, Iwai Tomoaki, „Zoku giin” no kenkyū [Badania nad „klanami parlamentarzystów"], Nihon Keizai Shinbunsha, Tokio 1987.

72. Inoue Yoshihisa, Habatsu to seisaku shūdan [Frakcje a grupy polityczne], Kyōikusha, Tokio 1979.

73. Iseri Hirofumi, Habatsu saihensei. Jimintō seiji no omote to ura [Reorganizacja frakcji. Wszystko o polityce PLD], Chūō Kōronsha, Tokio 1988.

74. Ishikawa Masumi, Sengo seijishi [Powojenna historia polityczna], Iwanami Shoten, Tokio 2004. 
75. Ishikawa Masumi, Hirose Michisada, Jimintō - Chōki shihai no kōzō [PLD - Struktura długotrwałej władzy], Iwanami Shoten, Tokio 1989.

76. Itagaki Eiken, Sengoku Jimintō 50 nen shi - Kenryoku tōsōshi [Historia 50 lat walczących królestw PLD - Historia walki o władzę], Kadensha, Tokio 2005.

77. Itō Hirotoshi, Kon-Chiku-Shō no kane to kenryoku [Pieniądze i władza trójkąta KanemaruTakeshita-Ozawa], Shakai Shinpō, Tokio 1993.

78. Itō Kiyoshi, Taiwan - 400 nen no rekishi to tenbō [Tajwan - 400 lat historii i perspektywy], Chūō Kōron Shinsha, Tokio 2003.

79. Itō Masaya, Ikeda Hayato to sono jidai [Ikeda Hayato i jego czasy], Asahi Shinbunsha, Tokio 1985.

80. Itō Masaya, Jimintō sengokushi - Kenryoku no kenkyū [Historia walczących królestw PLD Badania nad władzą], Asahi Sonorama, Tokio 1983.

81. Itō Masaya, Jimintō „Sonshi” - Sonshi riron ni yoru seijiryokugaku no kaimei [,,Sunzi” PLD - Analiza praw rządzących polityką na podstawie logiki Sunzi], Purejidentosha, Tokio 1989.

82. Itō Masaya, Nihon saishō retsuden 21 - Ikeda Hayato [Biografie japońskich premierów 21 Ikeda Hayato], Jiji Tsūshinsha, Tokio 1985.

83. Itō Masaya, Shin Jimintō sengokushi [Nowa historia walczących królestw PLD], Asahi Sonorama, Tokio 1983.

84. Itō Masaya, Tetsugaku no nai seijika ga kuni o horobosu [Pozbawieni filozofii politycy niszczą kraj], Takei Shuppan, Tokio 1989.

85. Iwanaga Kenkichirō, Sengo Nihon no seitō to gaikō [Partie i dyplomacja powojennej Japonii], Tōkyō Daigaku Shuppankai, Tokio 1985.

86. Iwase Tatsuya, Ware banshi ni ataisu. Dokyumento Takeshita Noboru [Jestem wart wielokrotnej śmierci. Dokument o Takeshicie Noboru], Shinchōsha, Tokio 1999.

87. Iyasu Tadashi, Aru hoshu seijika - Furui Yoshimi no kiseki [Pewien konserwatywny polityk Ścieżka Furuia Yoshimiego], Ochanomizu Shobō, Tokio 1987.

88. Iyasu Tadashi, Seitō habatsu no shakaigaku. Taishū minshusei no nihonteki tenkai [Socjologia frakcji politycznych. Japoński rozwój systemu demokracji mas], Sekai Shisōsha, Kioto 1983.

89. Jakimowicz, Robert, Stosunki japońsko-chińskie w latach 1949-2002. Aspekty polityczne i gospodarcze, Wydawnictwo Akademii Ekonomicznej w Krakowie, Kraków 2004.

90. Japan in International Politics. The Foreign Policies of an Adaptive State pod red. T. U. Bergera, M. M. Mochizukiego i J. Tsuchiyamy, Lynne Rienner Publishers, Boulder - London 2007.

91. Japan's Foreign Policy After the Cold War. Coping with Change pod red. G. L. Curtisa, M. E. Sharpe, Armonk-London 1993.

92. Japan's Quest. The Search for International Role, Recognition, and Respect pod red. Warrena S. Hunsbergera, M. E. Sharpe, Armonk 1997.

93. Japonia: Historia i wspótczesność pod red. Joanny Marszałek-Kawy, Wydawnictwo Adam Marszałek, Torun 2008.

94. Japonia na początku XXI wieku. Polityka, gospodarka, społeczeństwo i stosunki z Polska pod red. Krzysztofa Gawlikowskiego i Małgorzaty Ławacz, Wydawnictwo Adam Marszałek, Toruń 2008.

95. Jimintō Seichōkai [Rada Badań Politycznych PLD] pod red. Nihon Keizai Shinbunsha, Nihon Keizai Shinbunsha, Tokio 1983.

96. Johnson, Chalmers, Japan: Who Governs? The Rise of the Developmental State, W. W. Norton \& Company, New York - London 1995.

97. Karolczak, Krzysztof, System konstytucyjny Japonii, Wydawnictwo Sejmowe, Warszawa 1999. 
98. Katzenstein, Peter J., Cultural Norms and National Security. Police and Military in Postwar Japan, Cornell University Press, Ithaca - London 1998.

99. Kawachi Takashi, Chi no seiji - Seirankai to iu monogatari [Polityka krwi - Opowieść o Seirankai], Shinchōsha, Tokio 2009.

100. Kawashima Shōjirō [Kawashima Shōjirō] pod red. Kawashima Shōjirō Sensei Tsuisōroku Henshū Iinkai, Kōyū Kurabu, Tokio 1971.

101. Kawauchi Issei, Ōhira seiken 554 nichi [554 dni rządów Ōhiry], Gyōsei Mondai Kenkyūjo, Tokio 1982.

102. Kenpō [Konstytucja] pod red. Kurikiego Hisao i Tonamiego Kōjiego, Seirin Shoin, Tokio 1995.

103. Kerbo, Harold R.; McKinstry, John A., Who Rules Japan? The Inner Circles of Economic and Political Power, Praeger Publishers, Westport 1995.

104. Kikuchi Hisashi, Jimintō habatsu ura no ura ga wakaru hon [Książka, dzięki której się zrozumie tajemnice frakcji PLD], Piipurusha, Tokio 1987.

105. Kikuchi Hisashi, Sōri daijin Takeshita Noboru [Premier Takeshita Noboru], Piipurusha, Tokio 1987.

106. Kinjō Hiroyuki, Senkaku kaitei shigen wa Okinawa no zaisan [Surowce naturalne dna morskiego Senkaku bogactwem Okinawy], Bōdāinku, Naha 2005.

107. Kitaoka Shin'ichi, Jimintō - Seikentō no 38 nen [PLD - 38 lat partii władzy], Chūō Kōron Shinsha, Tokio 2008.

108. Kiyomiya Ryū, Fukuda seiken 714 nichi [714 dni rządów Fukudy], Gyōsei Mondai Kenkyūjo, Tokio 1984.

109. Kobayashi Hideo, Manshū to Jimintō [Mandżuria a PLD], Shinchōsha, Tokio 2005.

110. Kohno, Masaru, Japan's Postwar Party Politics, Princeton University Press, Princeton 1997.

111. Kong Uisik, Ilbon hyeondae jeongchi-ui ihae [Rozumienie współczesnej polityki japońskiej], Sejong Chulpansa, Busan 2003.

112. Kunihiro Masao, Sōshu aru hoshu seijika Miki Takeo [Konsekwentny polityk konserwatywny Miki Takeo], Tachibana Shuppan, Tokio 2005.

113. Kusano Atsushi, Seiken kōtai no hōsoku [Zasada zmiany władzy], Kadokawa Shoten, Tokio 2008.

114. Lawrance, Alan, China under Communism, Routledge, London 1998.

115. Lee Kiwan, Ilbon-ui jeongdang-gwa jeongdang jeongchi [Japońskie partie i polityka partyjna], Doseo Chulpan Maebong, Seul 2006.

116. Leng, Shao Chuan, Japan and Communist China, Doshisha University Press, Kioto 1958.

117. Li Enmin, Tenkanki no Chūgoku, Nihon to Taiwan - 1970 nendai Chūnichi minkan keizai gaikō no keii [Chiny, Japonia i Tajwan okresu przełomu - Przebieg chińsko-japońskiej pozarządowej dyplomacji gospodarczej w latach 70. XX wieku], Ochanomizu Shobō, Tokio 2001.

118. Li Jianmin, Lengzhan hou Riben de „putong guojiahua” yu Zhong-Ri guanxi de fazhan [,Budowa normalnego kraju” w Japonii po zimnej wojnie a rozwój stosunków chińskojapońskich], Zhongguo Shehui Kexue Chubanshe, Pekin 2005.

119. Li Xiushi, Riben xinbaoshouzhuyi zhanlüe yanjiu [Studium japońskiej neokonserwatywnej strategii], Shishi Chubanshe, Pekin 2010.

120. Lian Degui, Meiguo yu Zhong-Ri guanxi de yanbian, 1949-1972 [Stany Zjednoczone a ewolucja stosunków chińsko-japońskich, 1949-1972], Shijie Zhishi Chubanshe, Pekin 2006.

121. Lin Jinjing, Ume to sakura - Sengo no nikka kankei [Śliwa i wiśnia - Powojenne stosunki japońsko-tajwańskie], Sankei Shuppan, Tokio - Osaka 1984.

122. Liu Qingcai, Gao Ke et al., Dongbeiya diyuan zhengzhi yu Zhongguo diyuan zhanlüe [Polityka regionalna w Azji Północno-Wschodniej a chińska strategia regionalna], Tianjin Renmin Chubanshe, Pekin 2007. 
123. Marugame Hiroaki, Bōryaku no habatsu ningengaku [Spiskowe relacje interpersonalne frakcji], Keizaikai, Tokio 1983.

124. Masuda Hiroshi, Anadorazu, kanshō sezu, hirefu sezu - Ishibashi Tanzan no tai-Chūgoku gaikōron [Nie lekceważąc, nie ingerując, nie padając na kolana - Dyskurs Ishibashiego Tanzana na temat dyplomacji wobec Chin], Sōshisha, Tokio 1993.

125. Masuda Hiroshi, Ishibashi Tanzan. Riberarisuto no shinzui [Ishibashi Tanzan. Kwintesencja liberała], Chūō Kōron Shinsha, Tokio 1995.

126. Matsuda Masaharu, Taiwan, Chügoku, Nihon. Taiwan o meguru shomondai to Nihonjin no Chūgoku ninshiki [Tajwan, Chiny, Japonia. Problemy związane z Tajwanem i Chiny w świadomości Japończyków], Keiseisha, Tokio 1999.

127. Matsuzaki Tetsuhisa, Nihongata demokurashī no gyakusetsu - Niseigiin wa naze umareru no $k a$ [Paradoks demokracji w japońskim stylu - Czemu rodzą się parlamentarzyści w drugim pokoleniu], Tōjusha, Tokio 1991.

128. Meandry japońskiej polityki pod red. Joanny Marszałek-Kawy, Wydawnictwo Adam Marszałek, Toruń 2008.

129. Morgenthau, Hans J., Polityka między narodami. Walka o potęge i pokój, Difin, Warszawa 2010.

130. Mōri Kazuko, Nitchū kankei: Sengo kara shinjidai e [Stosunki japońsko-chińskie: Od okresu powojennego ku nowej epoce], Iwanami Shoten, Tokio 2006.

131. Mori Seiho, Hatoyama Yukio to Hatoyama-ke 4 dai [Hatoyama Yukio i 4 pokolenia rodu Hatoyamów], Chūō Kōron Shinsha, Tokio 2009.

132. Morita Minoru, Seikai tairan. Jimintō kaitai shintō sōsei [Wielki bunt świata polityki. Rozpad PLD i powstanie nowych partii], Tōyō Keizai Shinpōsha, Tokio 1993.

133. Mouton, Johann; Marais, HC, Basic Concepts in the Methodology of Social Sciences, HSRC Publishers, Pretoria 1996.

134. Murakawa Ichirō, Seisaku kettei katei [Proces decyzyjny w polityce], Shinzansha, Tokio 2000.

135. Murakawa Ichirō, Fukuoka Masayuki et al., Gendai no seiji katei [Współczesny proces polityczny], Gakuyō Shobō, Tokio 1982.

136. Muramatsu Michio, Itō Mitsutoshi, Tsujinaka Yutaka, Nihon no seiji [Polityka Japonii], Yūhikaku, Tokio 1999.

137. Nagamori Seiichi, Habatsu [Frakcje], Chikuma Shinsho, Saitama 2002.

138. Nagatachō kenbunroku [Informator o Nagatachō] pod red. Watanabe Tsuneo, Tōyō Keizai Shinpōsha, Tokio 1980.

139. Nagayama Hideki, Nihon no meiun wa Taiwan ni ari. Gunkaku Chūgoku ga aru Higashi Ajia de [Los Japonii jest na Tajwanie. W Azji Wschodniej ze zbrojącymi się Chinami], Madoka Shuppan, Tokio 2008.

140. Nakamura Katsunori, Huang Zhaotang, Asano Kazuo, Tokuoka Hitoshi, Zoku. Unmei kyōdōtai to shite no Nihon to Taiwan [Kontynuacja. Japonia i Tajwan jako wspólnota losu], Waseda Shuppan, Tokio 2005.

141. Nakane Chie, Tate shakai no ningen kankei [Relacje interpersonalne w społeczeństwie wertykalnym], Kōdansha, Tokio 2007.

142. Narai Shigeo, Saishō - Nakasone Yasuhiro [Premier - Nakasone Yasuhiro], Taishū Nihonsha, Tokio 1988.

143. Nichibei shin gaidorain to shūhen jitai hō [Nowe dyrektywy japońsko-amerykańskie a prawo sytuacji w okolicznych obszarach] pod red. Yamauchiego Toshihiro, Hōritsu Bunkasha, Tokio 2000.

144. Nihon no Ajia seisaku - Ajia kara mita fushin to kitai [Azjatycka polityka Japonii Nieufność i oczekiwania z punktu widzenia Azji] pod red. Inoguchiego Takashiego, NTT Shuppan, Tokio 2003. 
145. Nitchū kankei o dō kōchiku suru ka. Ajia no kyōsei to kyōryoku o mezashite [Jak zbudować stosunki japońsko-chińskie? Ku azjatyckiej symbiozie i współpracy] pod red. Mōri Kazuko i Zhang Yun-linga, Iwanami Shoten, Tokio 2004.

146. Noda Mineo, Shūhen jitai. Nichibei „shin gaidorain” no kyojitsu [Sytuacje w okolicznych obszarach. Prawda i fałsz na temat „,nowych wytycznych” japońsko-amerykańskich], Daisan Shokan, Tokio 1998.

147. Nonaka Naoto, Jimintō seiji no owari [Koniec polityki PLD], Chikuma Shobō, Tokio 2008.

148. Ogata, Sadako, Normalization with China: A Comparative Study of U.S. and Japanese Processes, Institute of East Asian Studies University of California, Berkeley 1988.

149. Okazaki Hisahiko, Taiwan mondai wa Nihon mondai [Problem Tajwanu problemem Japonii], Kairyūsha, Tokio 2008.

150. Ōkubo Denzō, Rekishi no shōgen. Nikka kankei - On o ada de kaeshite yoi no ka [Świadectwo historii - Czy godzi się odpłacać niewdzięcznością za przysługę?], Sankei Shinbunsha Shuppankyoku, Tokio - Osaka 1974.

151. Ōnuma Yasuaki, „Ianfu” mondai to wa nan datta no ka [Czym był problem „kobiet pocieszycielek"?], Chūō Kōron Shinsha, Tokio 2007.

152. Ōshita Eiji, Koga Makoto no shin seikai hana to ryū [Kwiat i smok nowego świata polityki Kogi Makoto], Bīsuto, Tokio 2007.

153. Pałasz-Rutkowska, Ewa; Starecka, Katarzyna, Japonia, Wydawnictwo TRIO, Warszawa 2004.

154. Powaski, Ronald E., The Cold War: The United States and the Soviet Union 1917-1991, Oxford University Press, New York 1998.

155. Rasmussen, Erik Stavnsager; Østergaard, Per; Beckmann, Suzanne C.; Essentials of Social Science Research Methodology, University Press of Southern Denmark, Odense 2006.

156. Rose, Caroline, Sino-Japanese Relations. Facing The Past. Looking to The Future?, Routledge Curzon, London - New York 2005.

157. Rosja, Chiny, Japonia w polityce globalnej pod. red. Małgorzaty Pietrasiak i Małgorzaty Rączkiewicz, Wydawnictwo Wyższej Szkoły Handlowej im. Króla Stefana Batorego, Piotrków Trybunalski 2008.

158. Rowiński, Jan, Morze Wschodniochińskie: region potencjalnego konfliktu $w$ Azji, PISM (wydane na prawach rękopisu), Warszawa 1990.

159. Rowiński, Jan, Problem wysp Senkaku (Tiaoyi Liedao) w stosunkach chińsko-japońskich, PISM (wydane na prawach rękopisu), Warszawa 1982.

160. Ryū-chan ryū. Hashimoto Ryūtarō atarashii seiji sutairu no jituzō [Styl Pana Ryū. Prawdziwy obraz nowego politycznego stylu Hashimoto Ryūtarō] pod red. Tamury Shigenobu, KK Besutoserāzu, Tokio 1998.

161. Satō Seizaburō, Matsuzaki Tetsuhisa, Jimintō seiken [Władza PLD], Chūō Kōronsha, Tokio 1986.

162. Scalapino, Robert A.; Masumi, Junnosuke, Parties and Politics in Contemporary Japan, University of California Press, Berkeley 1962.

163. Schaller, Michael, Altered States. The United States and Japan since the Occupation, Oxford University Press, New York 1997.

164. Seki Hei, „Nitchū yūkō” wa Nihon o horobosu! Rekishi ga oshieru „datsu Chūgoku” no hōsoku [„Przyjaźń japońsko-chińska” zniszczy Japonię! Zasada „rezygnacji z Chin”, którą naucza historia], Kōdansha, Tokio 2005.

165. Sekiyama Takashi, Nitchū no keizai kankei wa kō kawatta. Tai-Chū en shakkan no 30 nen no kiseki [Tak się zmieniły japońsko-chińskie stosunki gospodarcze. 30 lat pożyczki w jenach wobec Chin], Kōbunken, Tokio 2008.

166. Senda Hisashi, Satō naikaku kaisō [Wspomnienia rządu Satō], Chūō Kōronsha, Tokio 1987. 
167. Sengo Nihon no taigai seisaku [Polityka zagraniczna powojennej Japonii] pod red. Watanabe Akio, Yūhikaku, Tokio 1985.

168. Sengo Nihonjin no ishiki kōzō [Struktura świadomości powojennych Japończyków] pod red. Suzakiego Shin'ichiego, Azusa Shuppansha, Matsudo 2007.

169. Shen Haitao, Nitchü kankei shinka e no atarashii kokoromi [Nowa próba postępu w stosunkach japońsko-chińskich], Nihonkyō Hōsha, Kawaguchi 2004.

170. Shimada Masao, Tian Jianong, Sengo nitchū kankei 50 nen - Nitchū sōhō no kadai wa hatasaretaka [50 lat powojennych stosunków japońsko-chińskich - Czy zostały spełnione wzajemne zadania japońsko-chińskie?], Tōhō Shoten, Tokio 1997.

171. Shimizu Masato, Kantei shudō [Przywództwo pałacu], Nihon Keizai Shinbunsha, Tokio 2005.

172. Shimizu Yoshikazu, Chūgoku ga „hannichi” o suteru hi [Dzień, w którym Chiny odrzucą ,antyjapońskość”], Kōdansha, Tokio 2006.

173. Shinoda, Tomohito, Leading Japan. The Role of the Prime Minister, Praeger Publishers, Westport 2000.

174. Shioda Michio, Inochi moyuru seijika Tamaki Kazuo [Tamaki Kazuo, polityk o płomiennym życiu], Gurafusha, Tokio 1988.

175. Shioguchi Kiichi, Kikigaki: Ikeda Hayato [Spisana opowieść: Ikeda Hayato], Asahi Shinbunsha, Tokio - Osaka - Kitakiusiu - Nagoja 1975.

176. Sławiński, Roman, Historia Chin i Tajwanu, Wydawnictwo Naukowe ASKON, Warszawa 2002.

177. Sławiński, Roman, Historia Tajwanu, Dom Wydawniczy Elipsa, Warszawa 2001.

178. Soeya, Yoshihide, Japan's Economic Diplomacy with China, 1945-1978, Clarendon Press, Oxford 1998.

179. Stronach, Bruce, Beyond the Rising Sun. Nationalism in Contemporary Japan, Praeger Publishers, Westport 1995.

180. Suganuma, Unryu, Sovereign Rights and Territorial Space in Sino-Japanese Relations. Irredentism and the Diaoyu/Senkaku Islands, Association for Asian Studies, University of Hawai'i Press, Honolulu 2000.

181. Takahashi Tetsuya, Yasukuni mondai [Problem Yasukuni], Chikuma Shobō, Tokio 2005.

182. Tamaki Kazuo Kirokushū Hensan Iinkai, Seitō seijika Tamaki Kazuo [Partyjny polityk Tamaki Kazuo], Gakushū Kenkyūsha, Tokio 1988.

183. Tamura Shigenobu, Tomashima Norio, Koeda Yoshito, Nikka dankō to nitchū kokkō seijōka [Zerwanie stosunków japońsko-tajwańskich i normalizacja stosunków japońsko-chińskich], Nansōsha, Tokio 2000.

184. Tanaka Akihiko, Nitchū kankei 1945-1990 [Stosunki japońsko-chińskie 1945-1990], Tōkyō Daigaku Shuppankai, Tokio 1996.

185. Tanaka Zen'ichirō, Jimintō no duramatsurugī. Sōsai senshutsu to habatsu [Dramaturgia PLD. Wybory przewodniczącego a frakcje], Tōkyō Daigaku Shuppankai, Tokio 1986.

186. Tazaki Shirō, Kajiyama Seiroku. Shi ni gao ni emi o tataete [Kajiyama Seiroku. Z uśmiechem na pośmiertnej twarzy], Kōdansha, Tokio 2005.

187. The Foreign Policy of Modern Japan pod red. Roberta A. Scalapino, University of California Press, Berkeley 1977.

188. Togo, Kazuhiko, Japan's Foreign Policy, 1945-2009: The Quest for a Proactive Policy, Brill Academic Publisher, Leiden/Boston 2010.

189. Tominomori Eiji, Sengo hoshutōshi [Historia powojennych partii konserwatywnych], Iwanami Shoten, Tokio 2006.

190. Tomoda Seki, Nyūmon - Gendai Nihon gaikō [Wprowadzenie - Dyplomacja współczesnej Japonii], Chūō Kōronsha, Tokio 1988. 
191. Toyoshita Narahiko, Shüdanteki jieiken to wa nani ka [Czym jest prawo do kolektywnej samoobrony], Iwanami Shoten, Tokio 2007.

192. Tsuchiya Shigeru, Jimintō habatsu kōbōshi [Historia wzlotu i upadku frakcji PLD], Kadensha, Tokio 2000.

193. Uchiyama Yū, Koizumi seiken [Rządy Koizumiego], Chūō Kōron Shinsha, Tokio 2007.

194. Uchida Kenzō, Habatsu. Seiken kōsō no omote to ura [Frakcje. Kulisy rywalizacji o władzę], Kōdansha, Tokio 1983.

195. Uchida Kenzō, Gendai Nihon no hoshu seiji [Polityka konserwatywna współczesnej Japonii], Iwanami Shoten, Tokio 1989.

196. Uchida Kenzō, Sengo Nihon no hoshu seiji [Polityka konserwatywna powojennej Japonii], Iwanami Shoten, Tokio 1969.

197. Uchida Kenzō, Sengo saishōron [Dyskurs o powojennych premierach], Bungei Shunjū, Tokio 1994.

198. Ueda Naruhiko, Takayama Masaji, Sugiyama Katsumi, Higashi Shina Kai ga abunai! [Morze Wschodniochińskie jest niebezpieczne!], Kōjinsha, Tokio 2007.

199. Uji Toshihiko, Suzuki seiken 863 nichi [863 dni rządów Suzukiego], Gyōsei Mondai Kenkyūjo, Tokio 1983.

200. Unmei kyōdōtai to shite no Nihon to Taiwan. Posuto reisen jidai no kokka senryaku [Japonia i Tajwan jako wspólnota losu. Strategia państwowa okresu po zimnej wojnie] pod red. Nakamury Katsunoriego, Tendensha, Tokio 1997.

201. Uozumi Akira, Shōgen Murakami Masakuni. Ware, kuni ni uragirareyōtomo [Świadectwo. Murakami Masakuni. Choćbym miał być zdradzony przez kraj], Kōdansha, Tokio 2007.

202. Wang, Qingxin Ken, Hegemonic Cooperation and Conflict: Postwar Japan's China Policy and the United States, Praeger Publishers, Westport 2000.

203. Wang Xiliang, Zhanhou Riben zhengjie zhanzhengguan yanjiu [Studium poglądów powojennego świata japońskiej polityki na temat wojny], Shehui Kexue Wenxian Chubanshe, Pekin 2005.

204. Wang Zhensuo, Zhanhou Riben zhengdang zhengzhi [Polityka partyjna powojennej Japonii], Renmin Chubanshe, Pekin 2001.

205. Wendt, Alexander, Społeczna teoria stosunków międzynarodowych, Wydawnictwo Naukowe Scholar, Warszawa 2008.

206. Wspótczesna Japonia - mocarstwo na rozdrożu pod red. Elżbiety Potockiej i Małgorzaty Pietrasiak, Wydawnictwo Uniwersytetu Łódzkiego, Łódź 2004.

207. Wspótczesne Chiny. Kultura - Polityka - Gospodarka pod red. Małgorzaty Pietrasiak, Wydawnictwo Uniwersytetu Łódzkiego, Łódź 2005.

208. Xu Wansheng, Riben zhengzhi yu duiwai guanxi [Polityka japońska a stosunki z zagranicą], Renmin Chubanshe, Pekin 2006.

209. Yamada Eizō, Seiden Satō Eisaku [Prawdziwa biografia Satō Eisaku], t. 1-2, Shinchōsha, Tokio 1988.

210. Yamagiwa Sumio, Abe Shinzō monogatari [Opowieść Abe Shinzō], Kōbunsha 21, Tokio 2003.

211. Yamamoto Shichihei, Habatsu. Naze sō naru no ka [Frakcje. Czemu tak się dzieje], Nansōsha, Tokio 1985.

212. Yan Shengyi, Dangdai Zhongguo waijiao [Polityka zagraniczna współczesnych Chin], Fudan Daxue Chubanshe, Szanghaj 2009.

213. Yayama Tarō, Jimintō Hashimoto-ha no taizai [Wielki grzech frakcji Hashimoto z PLD], Fusōsha, Tokio 2004.

214. Yomiuri Shinbun Seijibu, Gaikō o kenka ni shita otoko. Koizumi gaikō 2000 nichi no shinjitsu [Mężczyzna, który prowadził kłótnie w sprawach dyplomacji. Prawda o 2000 dni dyplomacji Koizumiego], Shinchōsha, Tokio 2006. 
215. You Bo, Jueqi zhong de Zhong-Ri guanxi [Stosunki chińsko-japońskie w okresie wzrastania], Shijie Zhishi Chubanshe, Pekin 2009.

216. Yuasa Hiroshi, Kokkai „giin zoku” - Jimintō „Seichō” to Kasumigaseki [„Klany parlamentarzystów” - Kasumigaseki a „Rada Badań Politycznych” PLD], Kyōikusha, Tokio 1986.

217. Zhai Xin, Songcun Qiansan jituan he Zhongguo [Grupa Matsumury Kenzō a Chiny], Shehui Kexue Wenxian Chubanshe, Pekin 2007.

218. Zhao Quansheng, Nitchü kankei to Nihon no seiji [Stosunki japońsko-chińskie a polityka Japonii], Iwanami Shoten, Tokio 1999.

219. Zhong-Ri guanxi 30 nian 1972-2002 [30 lat stosunków chińsko-japońskich 1972-2002] pod red. Xu Zhixiana, Shishi Chubanshe, Pekin 2002.

\section{Artykuły naukowe}

1. Bettcher, Kim Eric, Factions of Interest in Japan and Italy: The Organizational and Motivational Dimensions of Factionalism, „Party Politics” 2005, vol. 11, no. 3, s. 339-358.

2. Browne, Eric C.; Kim, Sunwoong, Factional Rivals and Electoral Competition in a Dominant Party: Inside Japan's Liberal Democratic Party, 1958-1990, „European Journal of Political Research" 2003, vol. 42, s. 107-134.

3. Chao, K. T., East China Sea: Boundary Problems Relating to the Tiao-yu-t'ai Islands, „Chinese Yearbook of International Law and Affairs” 1982, vol. 2, s. 45-97.

4. Chen Fenglin, Chitian Yongren neige shiqi de Ri-Tai guanxi [Stosunki japońsko-tajwańskie w okresie gabinetu Ikedy Hayato], „Guoji Luntan” 2004, vol. 6, no. 6, s. 48-53.

5. Chen Fenglin, Shixi An Xinjie neige shiqi de Ri-Tai guanxi [Analiza stosunków japońskotajwańskich w okresie rządów Kishiego Nobusuke], „Dongbeiya Luntan” 2004, vol. 13, no. 1 , s. 88-93.

6. Chen Yongqin, Gaoqi Dazhizhu yu 20 shiji 40 niandai Liaoning diqu de tiemeiye [Takasaki Tatsunosuke a przemysł stalowo-węglowy w prowincji Liaoning w latach 40. XX wieku], „Nandu Xuetan” 2008, vol. 28, no. 5, s. 119-122.

7. Cheng, Joseph Y. S., Sino-Japanese Relations in Ikeda's Premiership, „China Report” 1977, vol. 13 , no. 2 , s. 44-60.

8. Christensen, Ray, The Effect of Electoral Reforms on Campaign Practices in Japan, „Asian Survey" 1998, vol. 38, no.10, s. 986-1004.

9. Chung, Chien-peng, The Diaoyu/Tiaoyutai/Senkaku Islands Dispute: Domestic Politics and the Limits of Diplomacy, „American Asian Review” 1998, vol. 16, no. 3, s. 135-164.

10. Cox, Gary W.; McCall Rosenbluth, Frances; Theis, Michael F., Electoral Reform and the Fate of Factions: The Case of Japan's Liberal Democratic Party, „British Journal of Political Science" 1999, nr 29, s. 33-56.

11. Deans, Phil, Contending Nationalisms and the Diaoyutai/Senkaku Dispute, „Security Dialogue" 2000, vol. 31, no. 1, s. 119-131.

12. Ding Zhaozhong, Zhong-Ri fujiao hou Riben zhengjie jijin qin-Tai shili de shanbian [Transformacja radykalnie protajwańskiego obozu na japońskiej scenie politycznej po przywróceniu stosunków chińsko-japońskich], „Guoji Luntan” 2008, vol. 10, no. 4, s. 46-49.

13. Dyson, Stephen Benedict; Preston, Thomas, Individual Characteristics of Political Leaders and the Use of Analogy in Foreign Policy Decision Making, „Political Psychology” 2006, vol. 27, no. 2, s. 265-288.

14. Fedorova, Maria, The Roots of Sino-Japanese Differences over the Senkaku (Diaoyudao) Islands, „Far Eastern Affairs” 2005, vol. 33, no. 1, s. 109-125.

15. Kazuo (John) Fukuda, Japan's Economic Advance into China: Meeting of Asia's Two Giants, „Journal of Marketing Management” 1997, no. 13, s. 219-228. 
16. Fukunaga Fumio, Habatsu kōzō kara mita Kōchikai - Soshiki, jinteki kōsei, rikurūtomento [Kōchikai widziane $\mathrm{z}$ perspektywy struktury frakcji - Organizacja, skład osobowy, rekrutacja], „Dokkyō Hōgaku” 2005, nr 67, s. 75-131.

17. Gong Qian, Riben zhengjie de qin-Tai shili jiqi dui-Zhong-Ri guanxi de yingxiang [Protajwański obóz w japońskich kręgach politycznych i jego wpływ na stosunki chińskojapońskie], „Riben Yanjiu” 2004, nr 4, s. 68-72.

18. Gregory, Paul, How the Soviet System Cracked, „Policy Review” 2008, nr 151, s. 45-60.

19. Guan Ying, Zhong,-Ri heping youhao tiaoyue dijie tanpan zhi yanjiu [Badania na temat rozmów w sprawie zawarcia Traktatu o pokoju i przyjaźni między Chinami a Japonią], „Zhejiang Daxue Xuebao (Renwen Shehui Kexueban)” 2003, vol. 33, no. 6, s. 133-141.

20. Kenji Hattori, Sino-Japanese Economic Relations, „The Japanese Economy” 2003-4, vol. 31, no. 3-4, s. 51-59.

21. He Yan, „Zhou Hongqing shijian” yu Mei-Ri-Tai sanjiao guanxi [Incydent z Zhou Hongqingiem a stosunki w trójkącie amerykańsko-japońsko-tajwańskim], „Dangdai Zhongguoshi Yanjiu" 2006, vol. 13 no. 5, s. 92-99.

22. Hsiung, James C., Sea Power, the Law of the Sea, and the Sino-Japanese East China Sea "Resource War”, „American Foreign Policy Interests” 2005, vol. 27, no. 6, s. 513-529.

23. Hagström, Linus, Quiet power: Japan's policy in regard to the Pinnacle Islands, „The Pacific Review" 2005, vol. 18, no. 2, s. 159-188.

24. Ijiri, Hidenori, Sino-Japanese Controversy since the 1972 Diplomatic Normalization, „The China Quarterly" 1990, nr 124, s. 639-661.

25. Jin Xide, ,Jue-Fu zhanzheng” de neihan, puxi jiqi xin taishi [Znaczenie „wojny Kaku-Fuku”, genealogia a nowa sytuacja], ,Ribenxuekan” 2008, nr 4, s. 39-50.

26. Kim, Hong N., The Tanaka Government and the Politics of the Sino-Japanese Civil Aviation Pact, 1972-1974, „World Affairs” 1975, vol. 137, no. 4, s. 286-302.

27. Köllner, Patrick, Factionalism in Japanese Political Parties Revisited or How do Factions in the LDP and the DPJ Differ?, ,Japan Forum”2004, vol. 16, no. 1, s. 87-109.

28. Chae-Jin Lee, The Making of the Sino-Japanese Peace and Friendship Treaty, „Pacific Affairs" 1979, vol. 52, no. 3, s. 420-445.

29. Liu Li, Daping Zhengfang yu dangdai Zhong-Ri guanxi [Ōhira Masayoshi a współczesne stosunki chińsko-japońskie], „Dongbeiya Luntan” 1999, nr 3, s. 21-26.

30. Moravcsik, Andrew, Liberalism and International Relations Theory, Center for International Affairs, Harvard University, Working Paper, no. 92-6; dostępne na stronie internetowej: http://www.princeton.edu/ amoravcs/library/liberalism_working. pdf, uzyskane 16 XI 2009.

31. Morris, David M., The Internal Roles and Functions of Kōmoto Faction Liberal Democratic Party Members, ,Japan Forum” 1989, vol. 1, no. 2, s. 151-159.

32. Nakajima Mineo, Dépasser la diplomatie de l'amitié, „Cahiers du Japon” 1993, nr 55, s. 2227.

33. Ni Zhimin, Ikeda naikaku ni okeru nitchū kankei to Ōhira Masayoshi, sono 1 [Ōhira Masayoshi a stosunki japońsko-chińskie w gabinecie Ikedy, cz. 1], „Ryūkoku Daigaku Keizaigaku Ronshū” 2005, vol. 44, no. 5, s. 73-111.

34. Ni Zhimin, Ikeda naikaku ni okeru nitchū kankei to Ōhira Masayoshi, sono 2 [Ōhira Masayoshi a stosunki japońsko-chińskie w gabinecie Ikedy, cz. 2], „Ryūkoku Daigaku Keizaigaku Ronshū" 2005, vol. 45, no. 2, s. 141-163.

35. Ni Zhimin, Ikeda naikaku ni okeru nitchū kankei to Ōhira Masayoshi, sono 3 [Ōhira Masayoshi a stosunki japońsko-chińskie w gabinecie Ikedy, cz. 3], „Ryūkoku Daigaku Keizaigaku Ronshū” 2005, vol. 45, no. 3, s. 35-66.

36. Ni Zhimin, Tanaka naikaku ni okeru nitchū kokkō seijōka to Ōhira Masayoshi, sono 1 [Ōhira Masayoshi a normalizacja stosunków japońsko-chińskich w gabinecie Tanaki, cz. 1], „Ryūkoku Daigaku Keizaigaku Ronshū” 2006, vol. 45, no. 5, s. 19-51. 
37. Ni Zhimin, Tanaka naikaku ni okeru nitchū kokkō seijōka to Ōhira Masayoshi, sono 2 [Ōhira Masayoshi a normalizacja stosunków japońsko-chińskich w gabinecie Tanaki, cz. 2], „Ryūkoku Daigaku Keizaigaku Ronshū” 2007, vol. 46, no. 5, s. 45-68.

38. Ni Zhimin, Tanaka naikaku ni okeru nitchū kokkō seijōka to Ōhira Masayoshi, sono 3 [Ōhira Masayoshi a normalizacja stosunków japońsko-chińskich w gabinecie Tanaki, cz. 3], „Ryūkoku Daigaku Keizaigaku Ronshū” 2007, vol. 47, no. 3, s. 33-68.

39. Nye, Joseph, Independence and Interdependence, „Foreign Policy” 1976, no. 22, s. 130-161.

40. Okazaki Yūji, Ikeda Masanosuke to sengo shoki nitchū bōeki, 1: Minkan bōeki kyōtei ni honsō - Shōnai shusshin seijika no ashiato [Ikeda Masanosuke a początek powojennego handlu japońsko-chińskiego, cz. 1: Starania o pozarządowe umowy handlowe - Ślad polityka z Shōnai], „Tōhoku Kōeki Bunka Daigaku Sōgō Kenkyūronshū” 2002, vol. 3, s. 85-105.

41. Okazaki Yūji, Ikeda Masanosuke to sengo shoki nitchū bōeki, 2: Minkan bōeki kyōtei ni honsō - Shōnai shusshin seijika no ashiato [Ikeda Masanosuke a początek powojennego handlu japońsko-chińskiego, cz. 2: Starania o pozarządowe umowy handlowe - Ślad polityka z Shōnai], „Tōhoku Kōeki Bunka Daigaku Sōgō Kenkyūronshū” 2002, vol. 4, s. 117-138.

42. Olsen, Edward A., Factionalism and Reform of Japan's Liberal Democratic Party, „World Affairs" Winter 1978/1979, vol. 141, no. 3, s. 257-268.

43. Park, Cheol Hee, Factional Dynamics in Japan's LDP since Political Reform. Continuity and Change, „Asian Survey” 2001, vol. 41, no. 3, s. 428-461.

44. Yung H. Park, The "Anti-Hegemony” Controversy in Sino-Japanese Relations, „Pacific Affairs" 1976, vol. 49, no. 3, s. 476-490.

45. Peng Er, Lam, The Apology Issue: Japan's Differing Approaches Toward China and South Korea, „American Asian Review” 2002, vol. 20, no. 3, s. 31-54.

46. Rose, Caroline, The Textbook Issue: Domestic Sources of Japan's Foreign Policy, „Japan Forum" 1999, vol. 11, no. 2, s. 205-216.

47. Sawa Kishirō, Go Gi fukusōri no hirei to nitchū kankei no akka [Niegrzeczność wicepremier Wu Yi a pogorszenie stosunków japońsko-chińskich], ,Yamaguchi Keizaigaku Zasshi” 2006, vol. 54, no. 6, s. 77-98.

48. Scobell, Andrew, Show of Force: Chinese Soldiers, Statesmen, and the 1995-1996 Taiwan Strait Crisis, „Political Science Quarterly” 2000, vol. 115, no. 2, s. 227-246.

49. Stockwin, J. A. A., Factionalism in Japanese Political Parties, „Japan Forum” 1989, vol. 1, no. 2, s. 161-171.

50. Strecker Downs, Erica; Saunders, Phillip C., Legitimacy and the Limits of Nationalism. China and the Diaoyu Islands, „International Security” 1998/1999, vol. 23, no. 3, s. 114-146.

51. Sun Hongyan, Zhong-Ri guanxi zhong de LT maoyi [Handel LT w stosunkach chińskojapońskich], „Changchun Daxue Xuebao” 2007, vol. 17, no. 3, s. 57-59.

52. Takahashi Shigeo, Rekishi ninshiki mondai to nitchū kankei [Problem świadomości historycznej a stosunki japońsko-chińskie], „Bunka Joshi Daigaku Kiyō. Jinbun-Shakai Kagaku Kenkyū" 2006, nr 14, s. 113-128.

53. Takamine, Tsukasa, A New Dynamism in Sino-Japanese Security Relations: Japan's Strategic Use of Foreign Aid, ,The Pacific Review” 2005, vol. 18 no. 4, s. 439-461.

54. Totten, George O.; Kawakami, Tamio, The Functions of Factionalism in Japanese Politics, „Pacific Affairs” 1965, vol. 38, no. 2, s. 109-122.

55. Tretiak, Daniel, The Sino-Japanese Treaty of 1978: The Senkaku Incident Prelude, „Asian Survey" 1978, vol. 18, no. 12, s. 1235-1249.

56. Utsunomiya Tokuma, Hoashi Kei, Iwamura Michio, Chūgoku kaku jikken-go no sekai no dōkō to nitch $\bar{u}$ kankei [Światowe trendy po chińskich testach nuklearnych a stosunki japońsko-chińskie], „Ajia Keizai Junpō” 1964, nr 594, s. 1-11.

57. Waltz, Kenneth N., Realist Thought and Neorealist Theory, ,Journal of International Affairs” 1990, vol. 44, no. 1, 21-37. 
58. Wang Zude, Daping Zhengfang yu Zhong-Ri youhao guanxi [Ōhira Masayoshi a przyjazne stosunki chińsko-japońskie], ,Jiangxi Shifan Daxue Xuebao” 1996, vol. 29 no. 4, s. 70-77.

59. Wendt, Alexander, Anarchy is what States Make of it: The Social Construction of Power Politics, „International Organization” 1992, vol. 46, no. 2, s. 391-425.

60. Xu Jianhua, Meiguo Dongya ezhi zhanlüe dui 20 shiji 60 niandai Zhong-Ri minjian maoyi de yingxiang [Wpływ amerykańskiej strategii powstrzymywania na chińsko-japoński handel pozarządowy w latach 60. XX wieku], „Wuhan Daxue Xuebao (Renwen Kexue Ban)” 2007, vol. 60, no. 1, s. 108-113.

61. Yamaoka Susumu, Kōkaryō soshō ni tsuite [O pozwie w sprawie Kōkaryō], „Daitō Bunka Daigaku Hōgaku Kenkyūjo Hō” 1988, nr 5, s. 1-7.

62. Yang Xiaohua, Li Hongjin, Lengzhan hou Riben dui-Tai zhengce de tiaozheng ji yuanyin [Rewizja japońskiej polityki wobec Chin po zimnej wojnie i jej powody], „Yan'an Jiaoyu Xueyuan Xuebao" 2008, vol. 22, no. 3, s. 26-28.

63. Yoda Hiroshi, Habatsu rengō soshiki, rīdāshippu, bunretsu kaihi no senjutsu. Jimintō no baai [Struktura koalicji frakcyjnych, przywództwo, strategie uniknięcia rozłamu. Przypadek PLD], „Shakai, Keizai Shisutemu” 1986, nr 4, s. 24-29.

64. Zang Peihong, Zuoteng neige shiqi „Ri-Tai” guanxi [Stosunki japońsko-tajwańskie w okresie rządów Satō], ,Riben Wenti Yanjiu” 2000, nr 4, s. 51-55.

65. Zhai Xin, Songcun Qiansan jituan he Zhong-Ri bangjiao zhengchanghua [Grupa Matsumury Kenzō a normalizacja stosunków chińsko-japońskich], „Ribenxuekan” 2008, nr 2, s. 29-38.

66. Zhai Xin, Zhanhou Riben de zhengjing fenli dui-Hua zhengce - Yi An Xinjie neige wei li [Polityka powojennej Japonii rozdziału polityki od gospodarki wobec Chin - Na przykładzie gabinetu Kishiego Nobusuke], „Shixue Jikan” 2008, nr 2, s. 68-74.

67. Zakowski, Karol, Kōchikai of the Japanese Liberal Democratic Party and Its Evolution After the Cold War, „The Korean Journal of International Studies” 2011, vol. 9, no. 2, s. 179-205.

68. Żakowski, Karol, Zniesienie frakcyjności w japońskiej Partii Liberalno-Demokratycznej. Stare zadanie $w$ nowych czasach, „Azja-Pacyfik. Społeczeństwo - Polityka - Gospodarka” 2008 , tom 11 , s. $26-40$.

\section{Periodyki (dzienniki i tygodniki)}

1. „Asahi Shinbun” z lat 1955-2006.

2. „Mainichi Shinbun” z lat 1955-2006.

3. „Nihon Keizai Shinbun” z lat 1988-2006.

4. „Nikkei Business” z lat 1972-2006.

5. „Pekin Shūhō” z 1972 roku.

6. „Renmin Ribao” z lat 1963-1964 oraz 1967.

7. „Yomiuri Shinbun” z lat 1980-2006. 


\section{SUMMARY IN ENGLISH}

\section{Intra-Party Determinants of the Policy of the Japanese Liberal Democratic Party towards China in the Years 1955-2006}

The book focuses on the problem of divisions inside the Liberal Democratic Party (LDP) and their influence on Sino-Japanese relations. In the analysis of decision making process in the LDP a special emphasis was put on ideological and personal factors, composition of successive mainstreams (intra-party coalitions comprising different factions) and evolution of factional system.

The main conclusion is that although LDP's China policy was determined mainly by the changes in the structure of international system, intra-party factors functioned as a filter for external stimuli, and to a certain degree influenced the diplomacy of Japan. The more coherent successive mainstreams were in regard to their composition of pro-Beijing or pro-Taiwan factions, the easier it was for the Japanese government to formulate a consistent policy towards China.

A pro-Taiwan alliance of Kishi and Satō factions dominated the decision making process in the LDP in 1955-1972, just as did pro-Beijing groups led by Tanaka and Ōhira in 1972-1980, as well as pro-Beijing Tanaka/Takeshita faction in 1980-1993. However, this mechanism stopped functioning together with the weakening of factions since the electoral reform in 1994. Destabilization of the LDP factional system coincided with the deterioration of SinoJapanese relations at the turn of the centuries.

Although it were international stimuli that determined the direction of changes in Sino-Japanese relations, intra-party factors could influence the intensity and velocity of foreign policy processes. 